Historic, Archive Document

Do not assume content reflects current scientific knowledge, policies, or practices. 



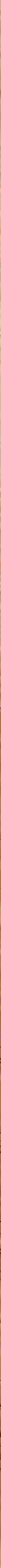




\section{C. MORSE \& CO. SEED GROWERS AND DEALERS}

\section{IMPORTANT DEPARTMENTS OF OUR BUSINESS}

\section{OUR RETAIL STORE}

125-127 Market Street, San Francisco

One and one-half blocks from the Ferry Building, on the South Side. Here we carry everything in the seed line, also tools, bulbs, and an assortment of plants. We keep a man in charge of our plant and tree department here, who is prepared to book any orders for nursery stock.

\section{OUR SEED FARMS-THE LARGEST AND MOST COMPLETE ON THE PACIFIC COAST Headquarters are at Carnadero, near Gilroy}

Here are our large seed farms or about 1,300 of our 2,000 acres. Here also are our Trial Grounds, Seed Testing Greenhouses and Farm Offices.

\section{OUR WHOLESALE COMMISSION BOX DEPARTMENTS AND GENERAL OFFICES}

Are at 48-56 Jackson street, in the building illustrated. Address all communications to us, here. Those interested in wholesale quantities should call at this address.

\section{OUR NURSERY SALESYARD AND GREENHOUSES \\ Glen and Eleth Avenues, Oakland}

All who are interested in plants, ornamental shrubs and trees and fruit trees, are cordially invited to visit our place here. You will find a valuable and interesting line of fine nursery stock. From San Francisco, take any Key Route boat (Leaving every twenty minutes) change to Piedmont train at the Mole and go to the end of the line. The nurseries are only one block up Glen avenue.

OUR NURSERIES

Are at Livermore

Two miles from the station. Here we grow some of our choicest ornamental stock, and fruit trees, roses, etc.

\section{OUR COVER ILLUSTRATIONS}

\section{FRONT-}

STRATAGEM PEA; re-selected strain. While this is not a new variety, we find it one of the best for market use. So many inferior stocks have been offered that we take pride in recommending our own strain, re-selected, pure and true. The beautiful illustration on the cover does not exaggerate in the least, its fine long pods, heavily filled and its deep rich green color. Per pound, 35c., postpaid. By express or freight, 1 lb. 25c., 10 lbs., $\$ 2.00,100$ lbs. $\$ 15.00$.

\section{BACK}

Three ABSOLUTELY NEW Colossal-Flowered SWEET PEAS, of the Spencer Type

ASTA OHN; ( Spencer ) - immense blossoms of beautiful mauve and lavender. Nothing has yet been introduced that compares with it and it should be in every garden. The standard and wings are not only large but wavy and fluffy. The sun does not discolor it and its long stems bear uniformly four blossoms, each one large and glorious. Pkts. of 25 seeds, 25c.; pkts. of 10 seeds, 15c.

AURORA SPENCER; One of the most pleasing and satisfactory novelties in Sweet Peas we have yet introduced. A bright orange-pink, striped, flaked and splashed on white, it has the effect of a soft delicate variety rather than that of a dazzling bright one. The stems are long and bear uniformly four blossoms, all of the immense wavy character, so much esteemed in the Spencer Sweet Pea. Pkt. of 25 seeds, 25c.; pkt. of 10 seeds, $15 \mathrm{c}$.

OTHELLO SPENCER ; For many years, we have longed to get a real good dark variety in the Spencers, and now we are able to offer the best color in the dark varieties, it being a deep rich maroon just the color we need to make a good collection of Spencers. If it were possible that one variety could be larger than another, it means that Othello Spencer is the very largest of all. A grand, bold flower with all the grace and beauty possible in a long-stemmed four-blossom Spencer. Pkt. of 10 seeds, 25c. 


\section{SAN FRANCISCO CAIIFORNIA U.S.A.}

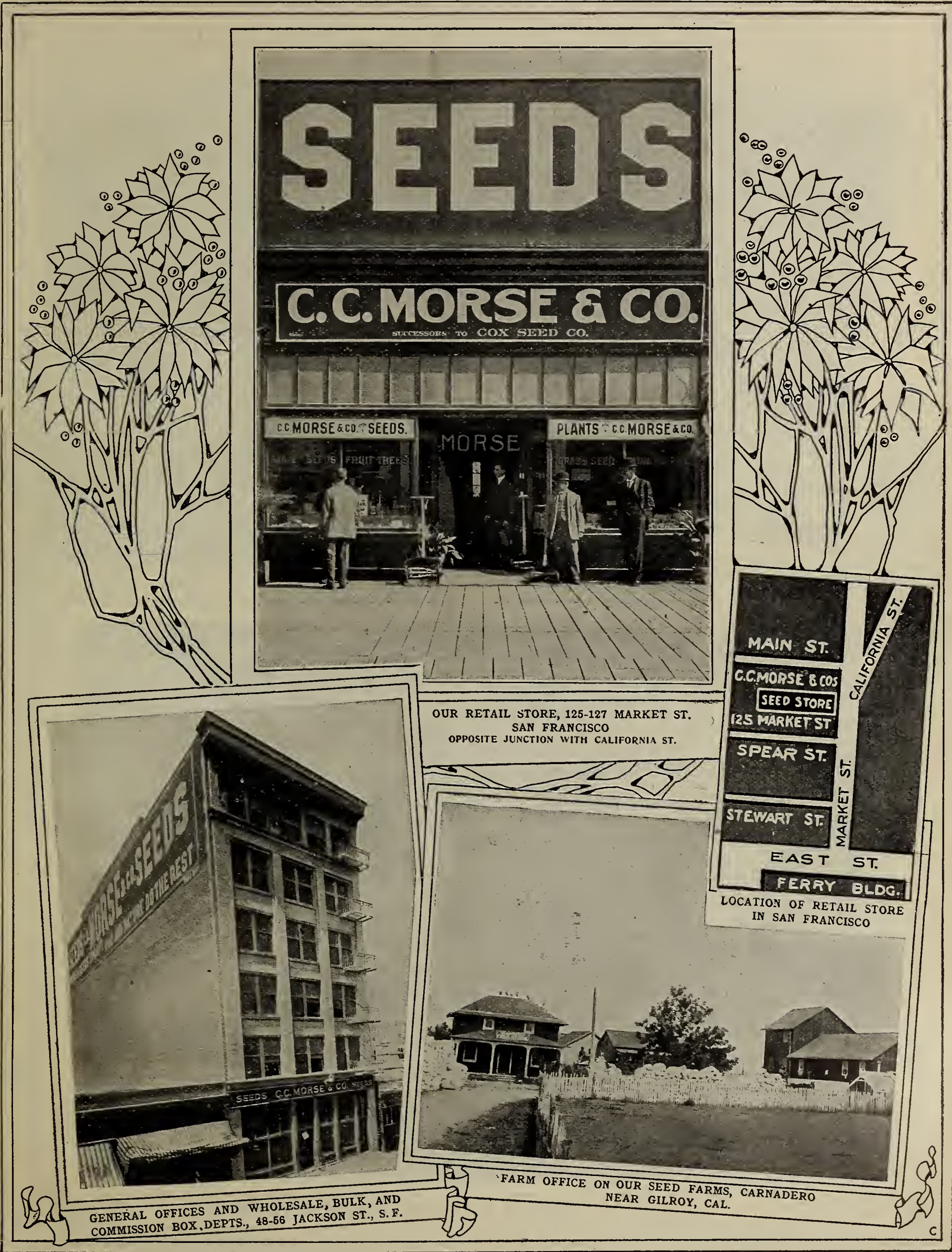


C.C.C.MORSE \& CO. VEGETABLE SEEDS ( 9

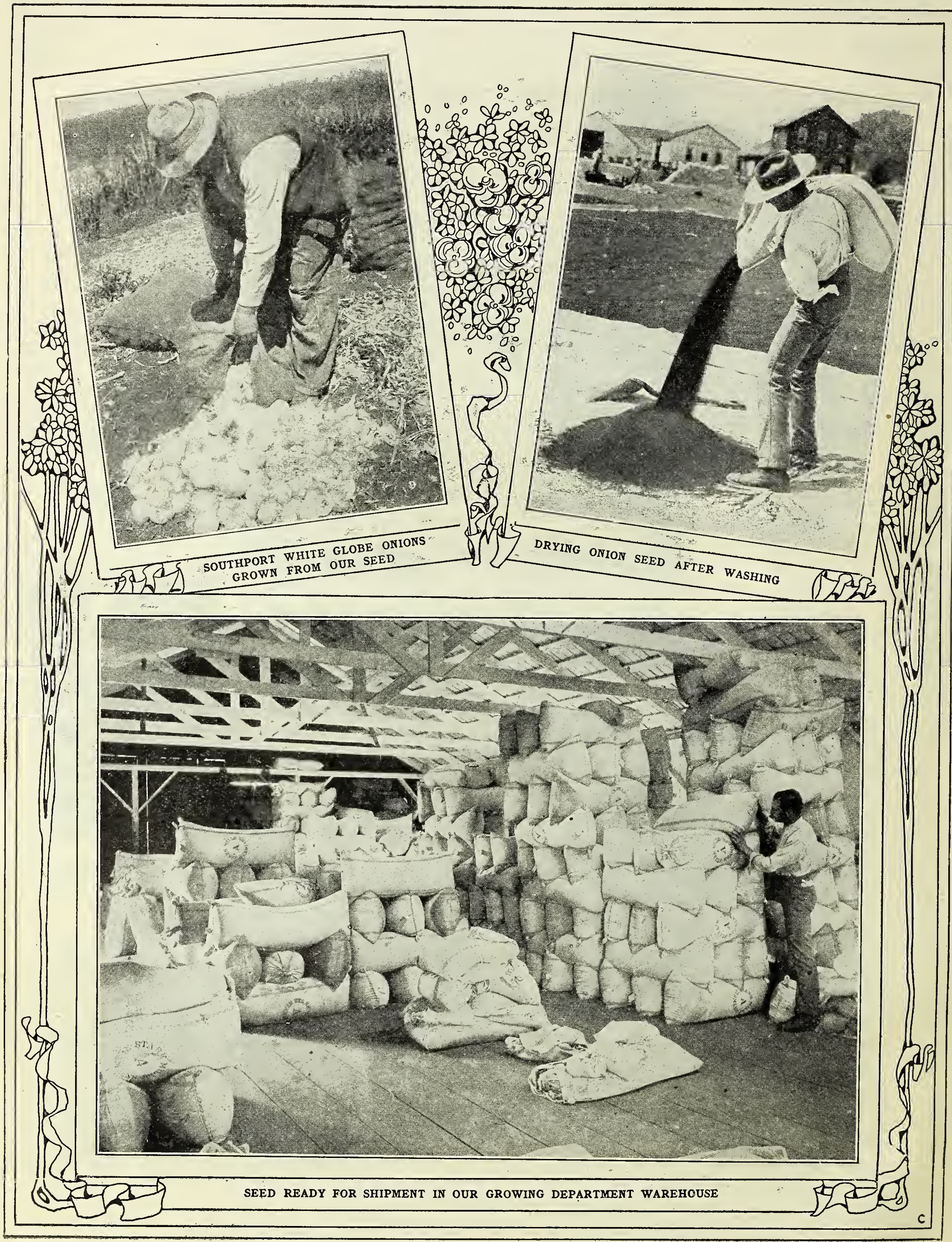




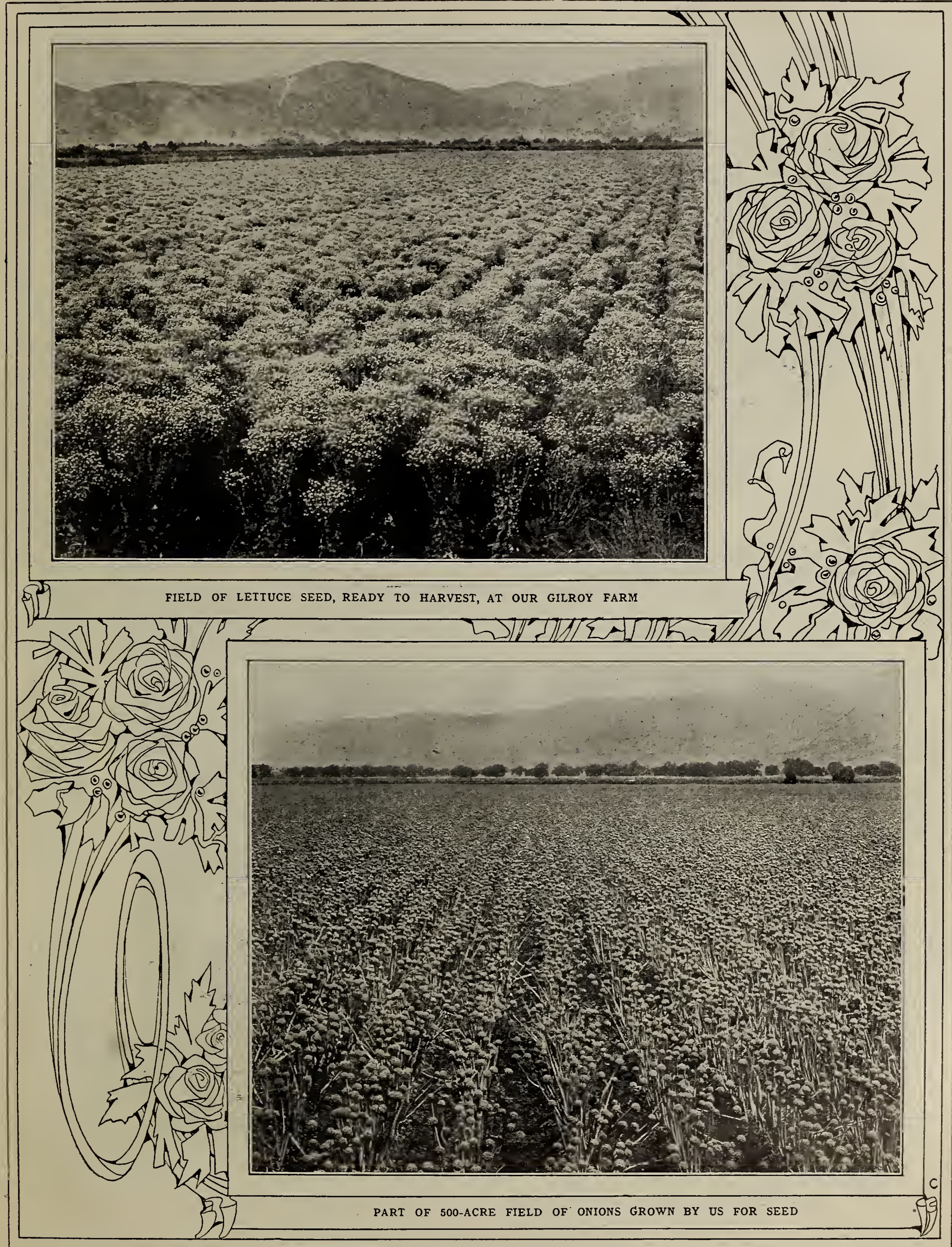




\section{CIC.C.MORSE \& CO. VEGETABLE SEEDS CP}

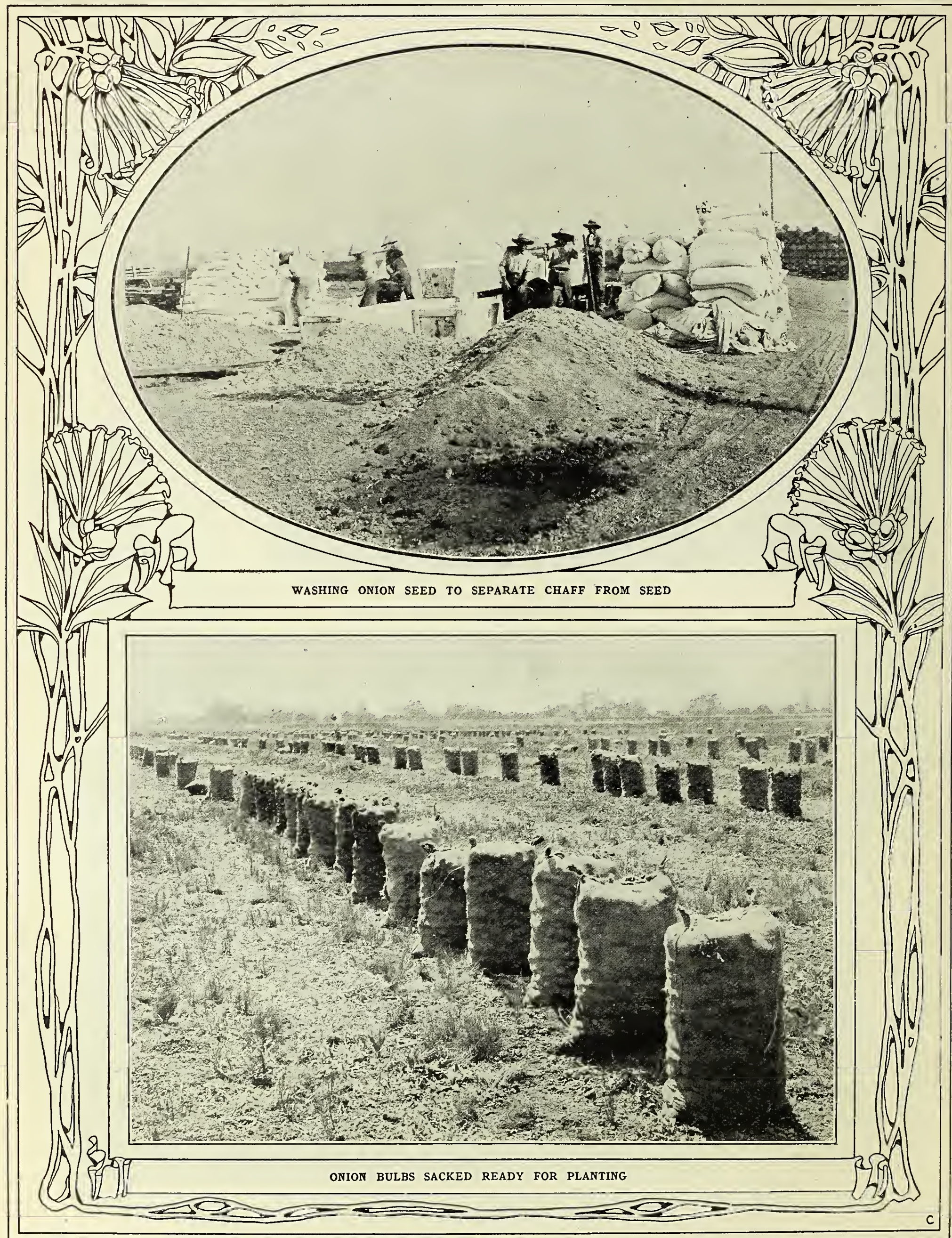




\section{SAN FRANGISCO CALIEORNIA U.S.A.}

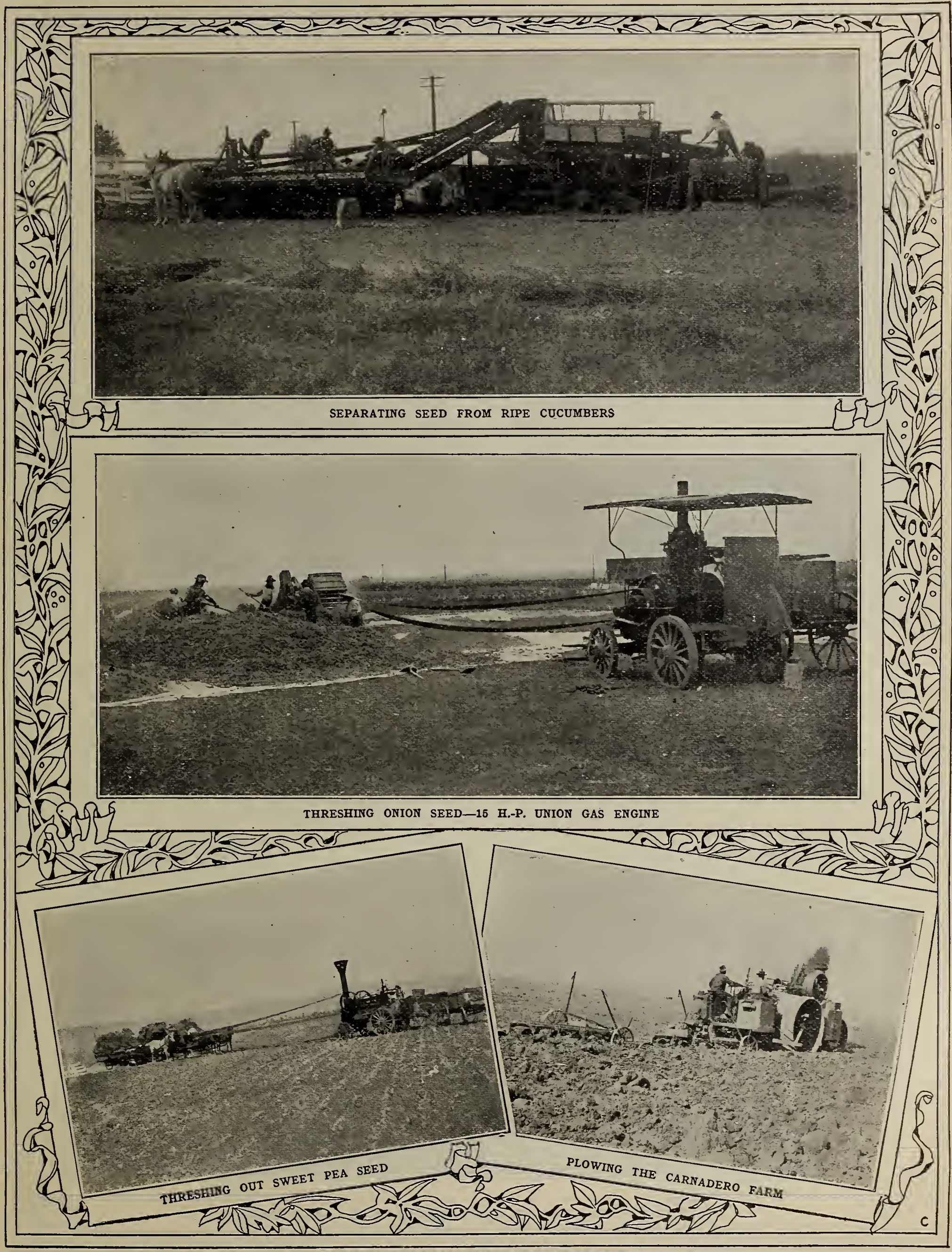




\section{C.C.MORSE \& CO. VEGETABLE SEEDS Sin}

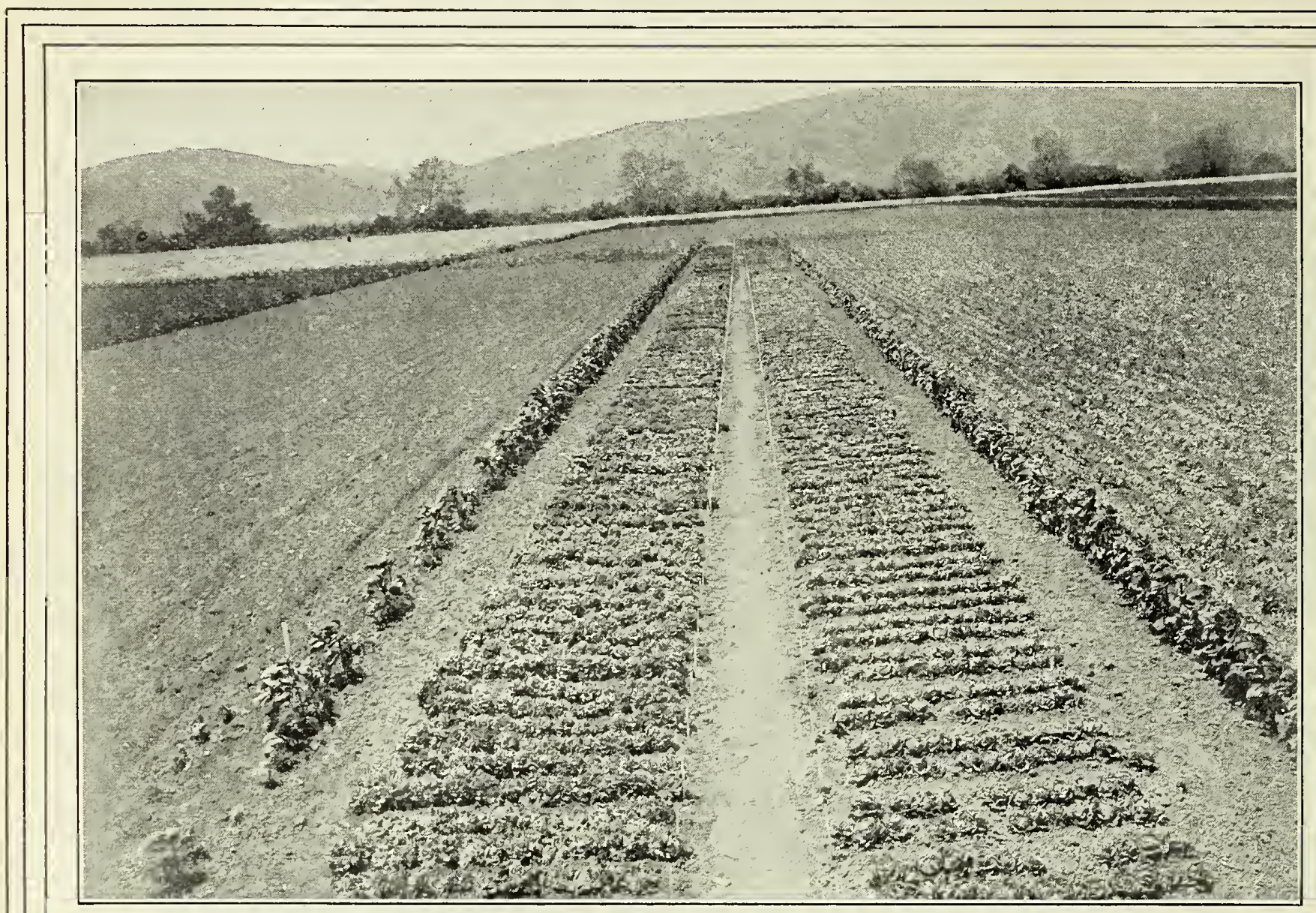

$2 \int^{2}$

LETTUCE TRIAL GROUNDS. WE TEST ALL OF OUR SEED IN THIS MANNER

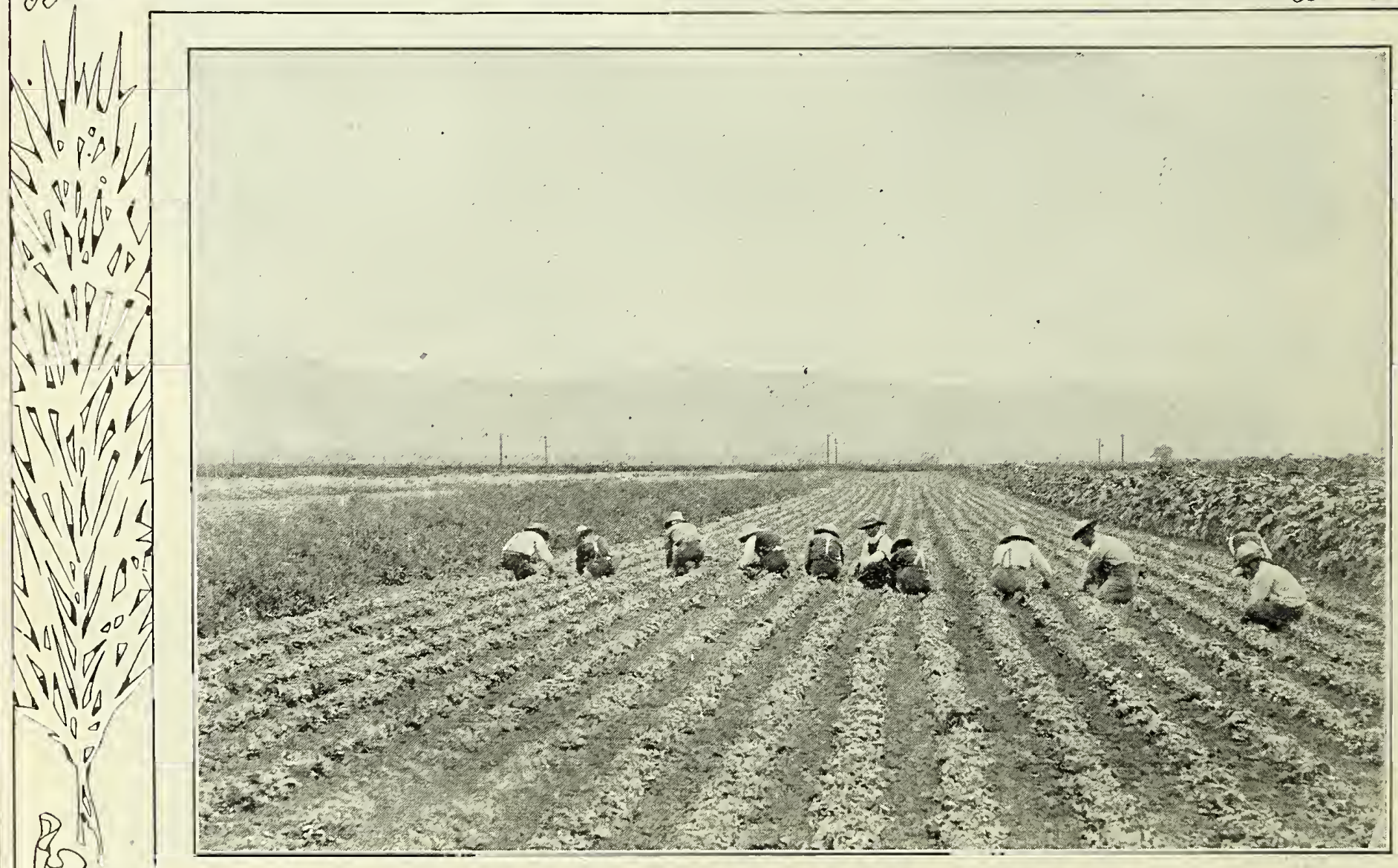

27.

$\sqrt{4} a_{1}^{1}$

CUTTING LETTUCE HEADS TO ALLOW SEED STALK TO COME THROUGH 


\section{SAN FRANCISCO CALIFORNIA U.S.A.}

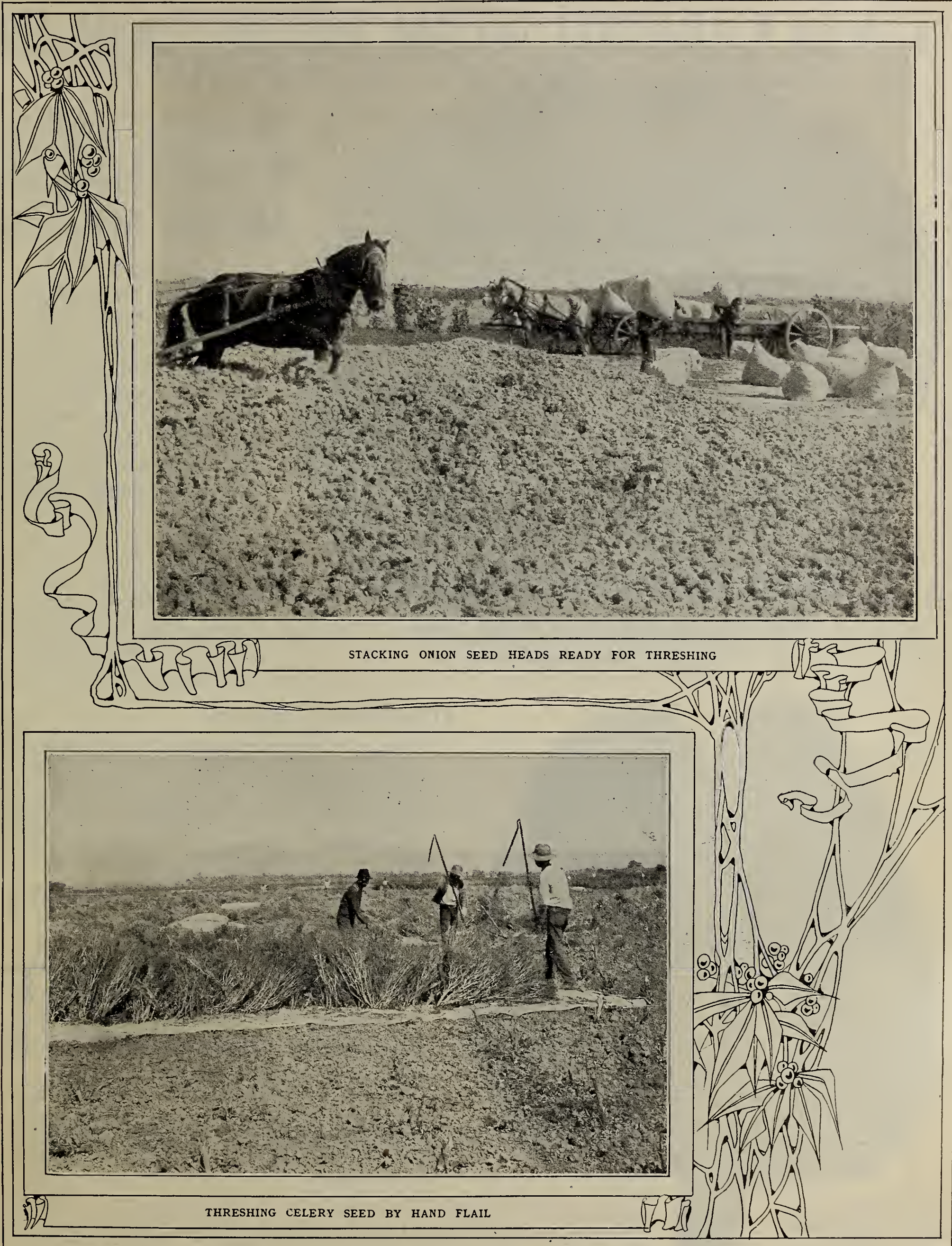




\title{
TWO GRAND NEW VEGETABLES
}

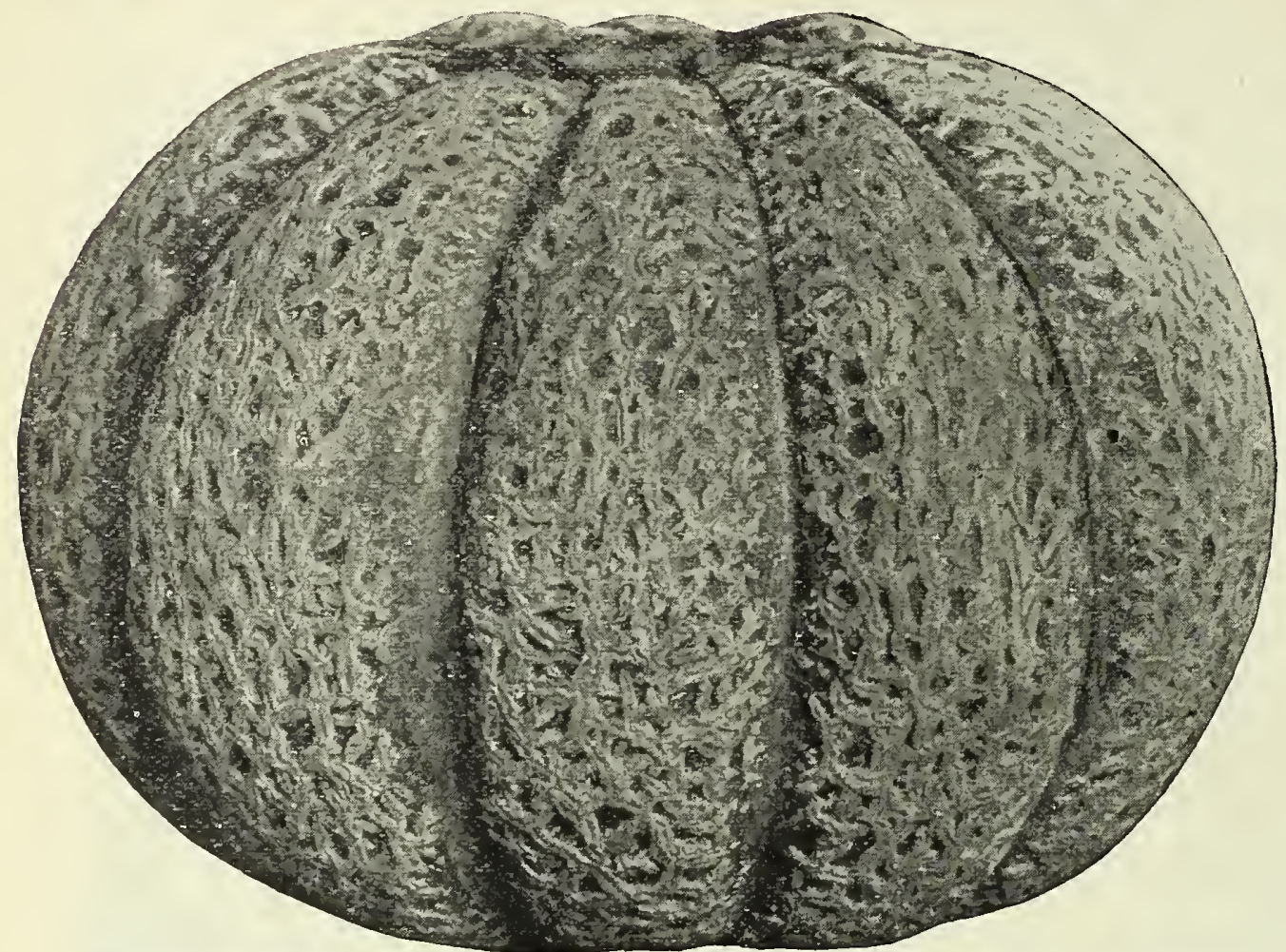

\section{BURPEE'S NEW "FORDHOOK" MUSK MELON}

\author{
Fully equals Emerald Gem \\ in delicious flavor. So firm \\ is the rough-netted skin, \\ and so solid the thick \\ salmon flesh, that the \\ melons carry to market \\ even better than do Bur- \\ pee's Netted Gem, the \\ f a mous "Rocky Ford" \\ Melon.
}

New Musk Melon-Burpee's "Fordhook"-Two-thirds size, from a photograph

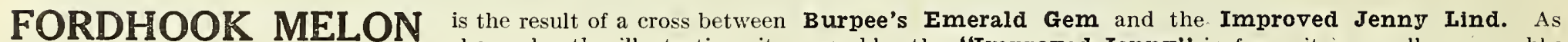
shown by the illustration, it resembles the "Improved Jenny" in form; it is equally as roughly

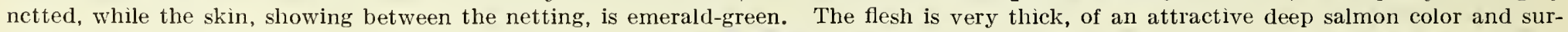

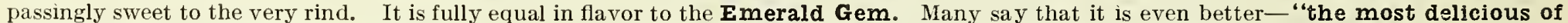

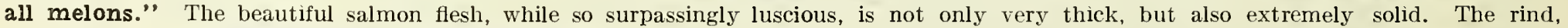

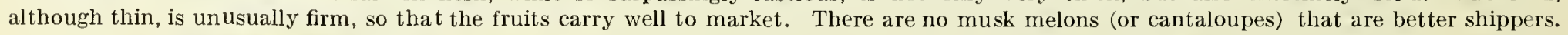

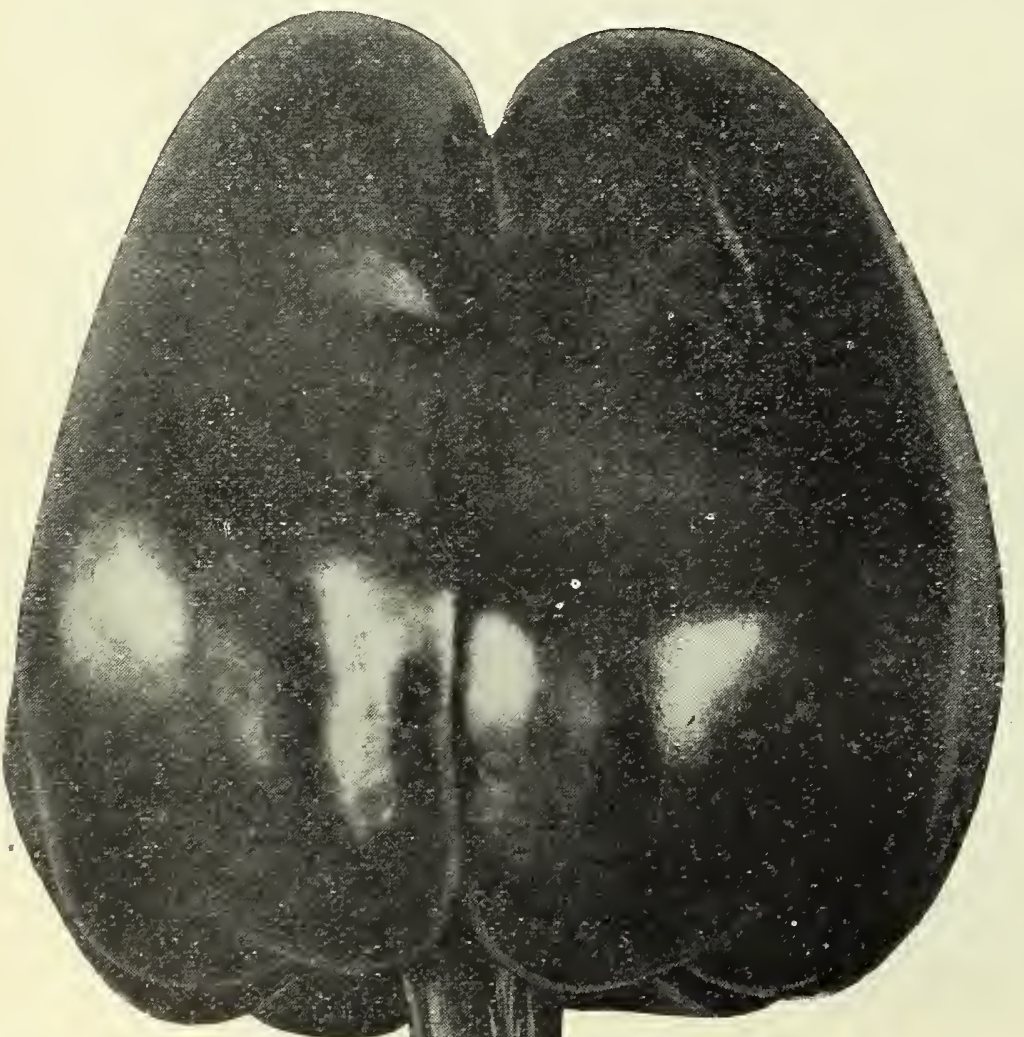

FORDHOOK MELON is most vigorous in growth very early and extremely prolific. The fruits are ready for market fully as early as the green-fleshed Early Jenny Lind. The vines grow vigorously and each vine sets from five to nine melons immediately around the stem; frequently the fruits touch one another. The melons are remarkably even in size, weighing from $1 \mathrm{lb} .8$ ozs. to two pounds each. They are always of the handsome form and attracive appearance illustrated above. "FonDHook" is so "thoroughbred" that there are practically no fruits unfit for market. Pkt. 10c; 0z. 30c; 1/4 1b. 85c; 1b. $\$ 3.00$.

\section{NEW PEPPER "SWEET UPRIGHT"}

The best Pepper for family gardens and almost unequaled for market. "SWEET UPRIG HT" produces fine large fruits of nearly square or blocky form, with exceptionally thick flesh of the very mildest and sweetest flavor.

The plants are of sturdy ercet growth. The fruits are borne stifly erect, and form at each fork of the branches; they are very broad, divided into four lobes, and when fully ripened are deeply indented at the blossom end. An average pepper measures three inches in length, two and three-quarter inches at the stem end and two inches across the blossom end, with a weight of seven ounces.

Natural Size of the New "Sweet Upright" Pepper
The color when ripe is rich glowing scarlet both in the thin tender skin and in the unusually thick sweet flesh. The thick flesh is as crisp, mild, and sweet as a fine apple. It is as early as the Sweet Bell or Bull-Nose, with heavier fruit, much thicker flesh and greatly superior in flavior. Pkt. 10c; oz. 65c; $1 / 41 \mathrm{~b} . \$ 1.75 ; 1 \mathrm{~b}$. $\$ 6.50$. 


\section{UNIQUE NEW TOMATO BURPEE'S DWARF-GIANT}

\section{BURPEE'S}

"DWARF - GIANT" is much the largest fruited of all dwarf Tomatoes! The fruits are truly gigantic in size, and are uniformly large throughout the season. In fact, no other tomatoes, excepting only the Ponderosa, which is one of its parents, are so large and heavy. The color is a rich purple-crimson and the depth of color is maintained throughout the entire fruit. The skin, while thin and easily removed in peeling, is so strong as to perfectly protect the fruit when shipped to distant markets.

\section{"DWARF - GIANT"}

is the most meaty of all Tomatoes! The flesh is so firm and the tomatoes so heary that they might be described "solid as a rock!" It is the most nearly seedless of all tomatoes. The very few seeds are contained in extremely small cells close to the outer margin. The firm, fine-grainęd flesh extends to the very center, with no trace whatever of a ccre.

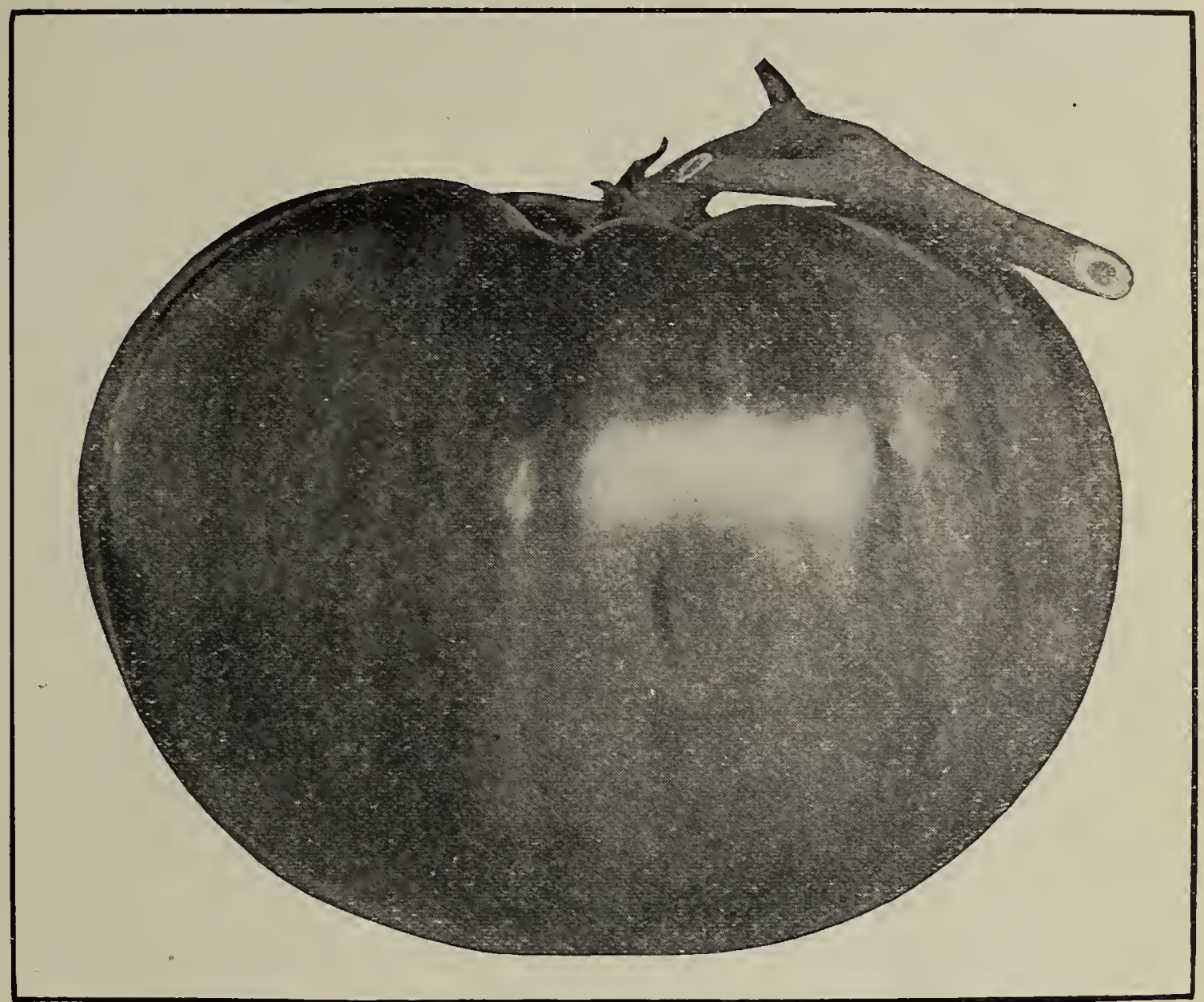

BURPEE'S "DWARF-GIANT" is unequaled in delicious flavor! This is saying a great deal, but a comparative trial will show that in rich, sweet flavor it surpasses even Matchless and Ponderosa. Eaten out of the hand, as gathered direct from the plants, its entire freedom from acidity and its luscious quality are most noticeable.

"DWARF-GIANT" is uniformly of compact bush-like growth. While of the true dwarf type, the plants, growing two feet high and well branched, are very strong and vigorous. The cut-leaf foliage is dark green and heavy-almost like leather. The thick stalks carry well the tremendous weight of fruits, which are produced in clusters of four to six and weigh from 12 to 16 ounces each.

BURPEE'S "DWARF.GIANT" is most productive and has only one fault! It originated with the well-known Tomato Specialist, Prof. E. G. Green, of Ohio, from a cross of the Dwarf Champicn and Ponderosa and naturally inherits to some extent the tendency of the latter parent to throw "ribbed" fruits. Even these are so meaty and delicious, however, that for family gardens this can hardly be counted a serious fault. "DWARF-GrANT" is a mid-season or main-crop variety. The first fruits ripen a week to ten days earlier than Ponderosa and the plants continue to mature the superb "solid-giant" tomatoes until frost. From an inspection of his crop in 1907, we believe that Prof. Greex (who has spent fifteen years' work on this tomato), is fully justified in writing that "this new Tomato possesses qualities never before known in the dwarf Tomatoes."

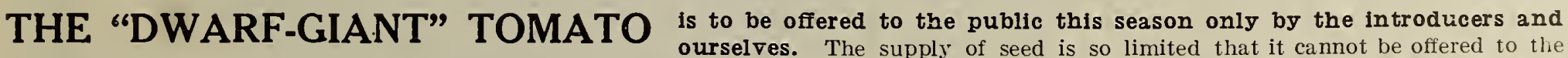
trade-hence this variety will not be found in any other catalogues for 1909 . Sold only in small sealed packets (of seventy seeds each), in the introducers' original packets. Pkt. $15 \mathrm{c} ; 2$ pkts. $25 \mathrm{c} ; 10$ pkts. $\$ 1.00$, net.

Prof. Green, of Ohio (who might well be called "The Burbank" of Tomato cross-breeding), writes in September, 1908, as follows, concerning this Tomato: "A new tomato that possesses qualities never before seen in the dwarf tomatoes. For the home garden the dwarf tomato has points of excellence that have made it a favorite; ever since the advent of the Dwarf Champion they have been growing in favor, for their compact and upright growth of plants makes them the very best for close planting as usually done in small gardens. But there has been a serious objection to the dwarfs, and that was their small size and seediness.

"But in Burpee's 'DWARF-Giant' or 'DWARF PoNderosa,' as I should call it, we have these defects remedied, for this tomato is of the largest size, very solid and meaty and of the very best quality. It is entirely free from the sharp acid taste usuallv found in the dwarf tomatoes. The growth of the plant, while dwarf, is very strong and vigorous; the color of the foliage is a dark healthy green." 


\section{C.C.MORSE \& CO VEGETABLE SEEDS Ci}

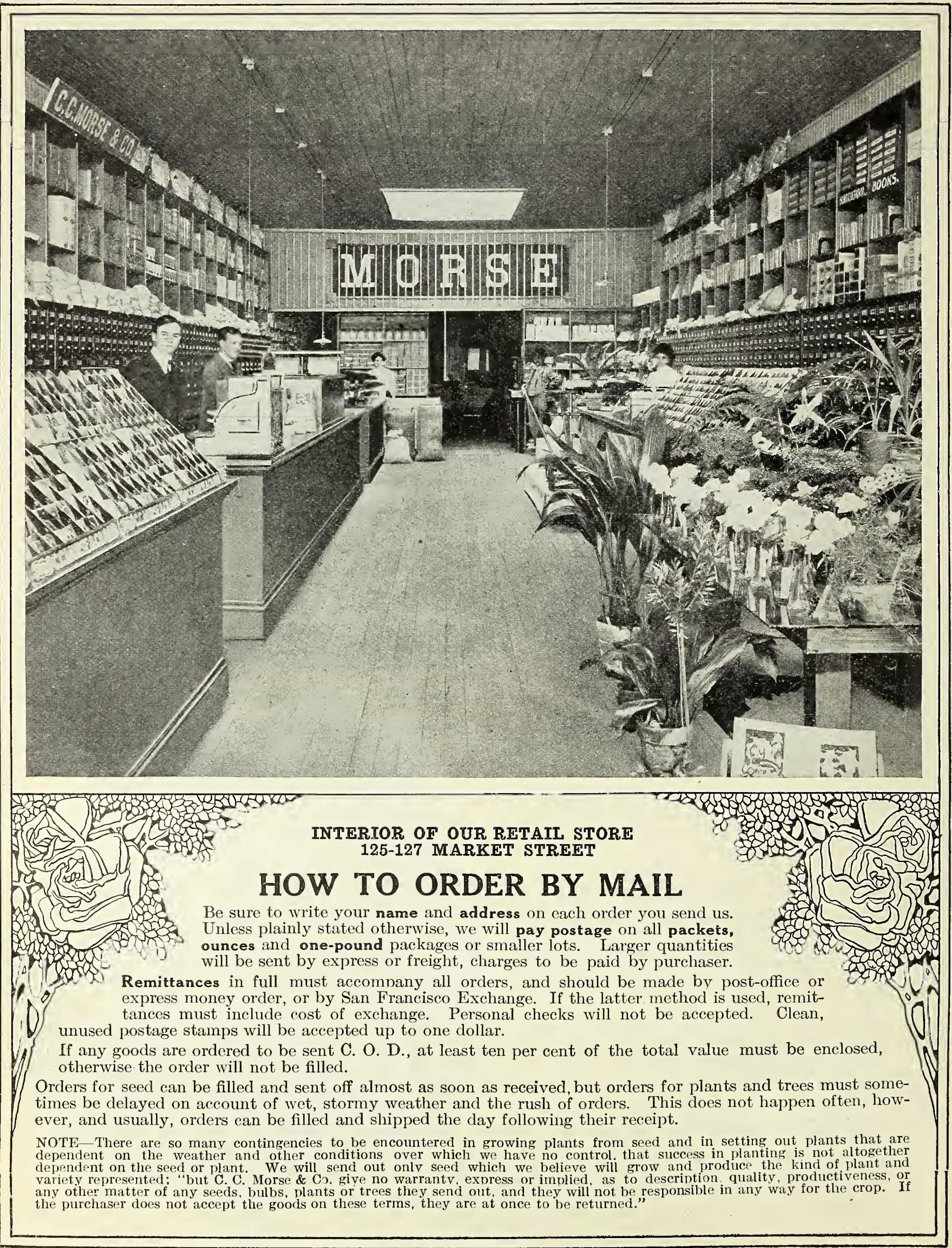




\section{VEGETABLE SEEDS}

We have aimed to catalogue only the very best varieties of vegetables, of both the newer and the older strains, and those which are

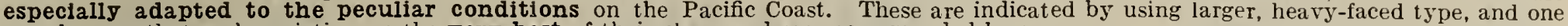
may be sure that such varieties are the very best of their class, and are recommended by us.

REMEMBER-We grow most of the seed we sell, ourselves, on our own Seed Farms, and know the difference between those

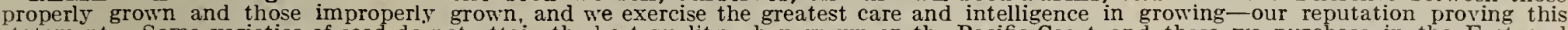

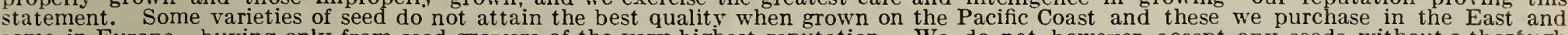

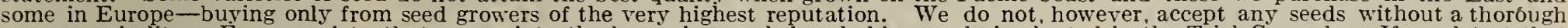

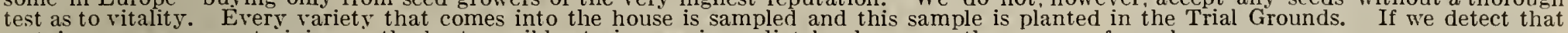
certain growers are not giving us the best possible strains, we immediately choose another source of supply.

TRIAI GROUNDS-We conduct an elaborate system of Trial Grounds on our Seed Farms at Carnadero where samples of everything

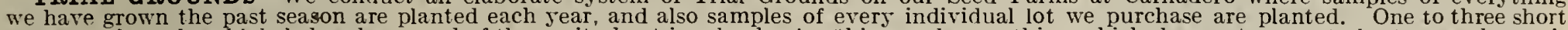

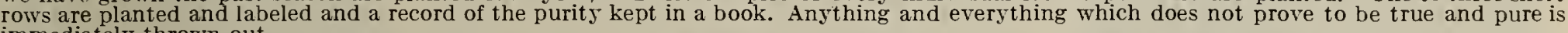
immediately thrown out.

This Trial Ground feature of a seed business is one of the necessities of a modern first-class house and represents an enormous outlay of expense to say nothing of care and attention.

EXPERIMENT GROUNDS-An important feature of our Seed Farms is what we locally style our "Work Shop" where new selections

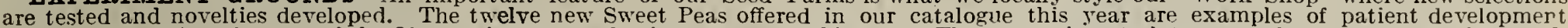

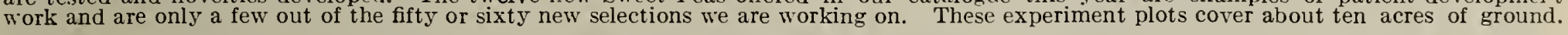

\section{ARTICHOKES}

Artichokes are cultivated for the edible bud, which resembles a giant thistle. The plants want a very rich soil and plenty of moisture. In

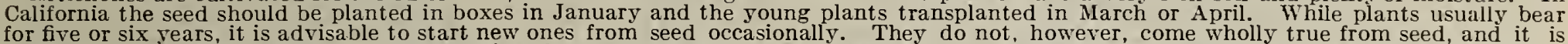

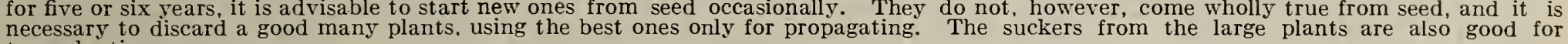
transplanting.

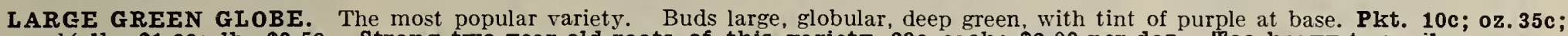
$1 / 4$ 1b. $\$ 1.00$; Ib. $\$ 3.50$. Strong two-year-old roots of this variety, 20c each; $\$ 2.00$ per doz. Too heavy to mail.

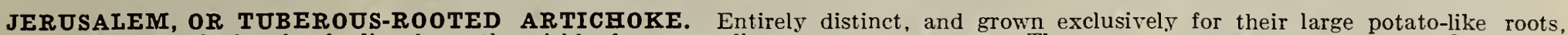
which are valuable for feeding hogs, the yield often exceeding two tons per acre. They condition until spring. The tubers are also edible, and are delicious when well cooked.

\section{ASPARAGUS SEED AND ROOTS}

It requires three or four years from the time of planting asparagus seed to the time that the plant produces shoots suitable for eating. To raise plants from seed about one pound per acre
is required, or one ounce for about 800 plants. Sow early in the Spring in drills 12 to 14 inches apart and thin to about 3 inches in the row. Allow the plants to grow two full seasons and then transplant to permanent beds. It requires plants to set an acre. When set out for crop, in in beds, they require plenty of room, since spread from the root, and therefore grow larger In the frold the root, and thould be from six to ten in the field the rows should be from six to ten A loose, porous soil is necessary for good asparathe flavor of the young shoots greatly depends character of the soil. The light, fibrous soils of
mento River Islands seem especially adapted asparagus.

In the house garden, the soil, if naturally heavy must be made porous and light by spading in amount of manure and sand. During the

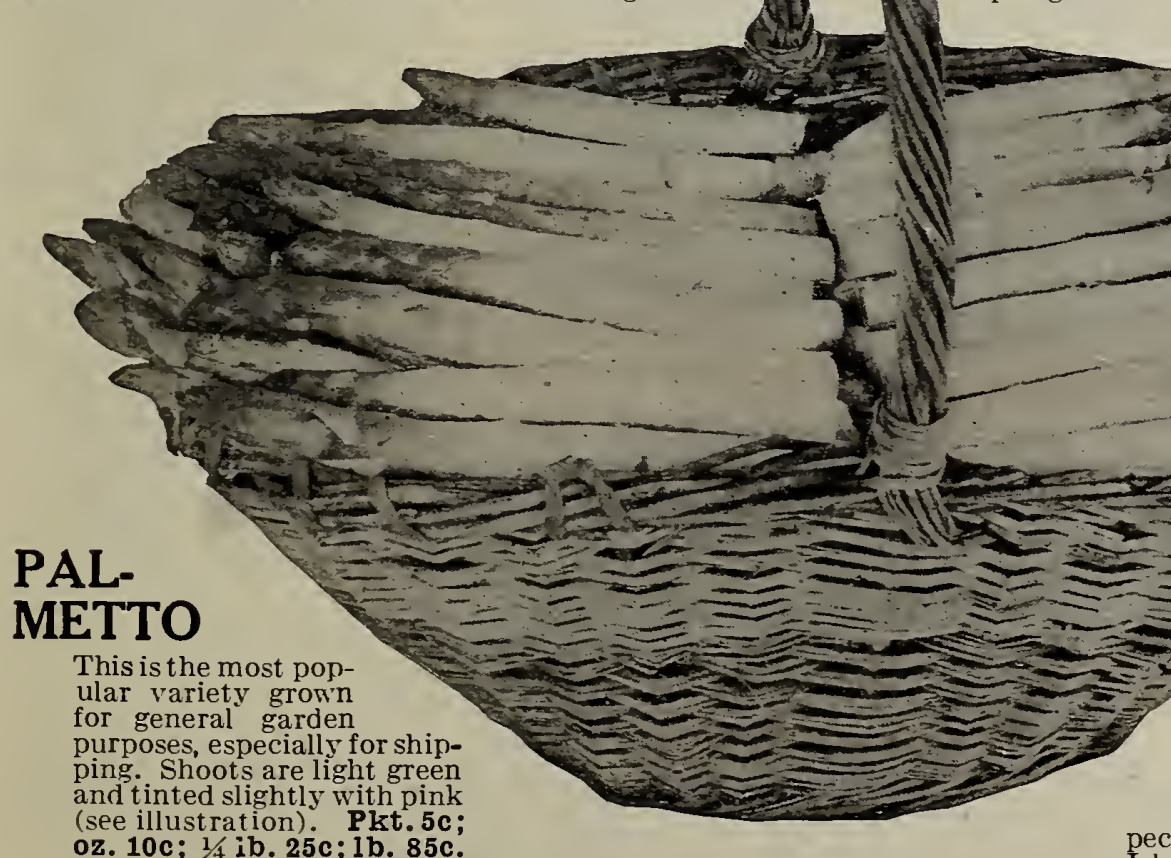

ASPARAGUS ROOTS Large vigorous roots of Paldoz., postpaid; $\$ 1.00$ per 100 , by express; $\$ 5.00$ per 1,000 . about 3000 the field or the plants each year. gus, and upon the for perfect or perfect and stiff, the proper
spring all

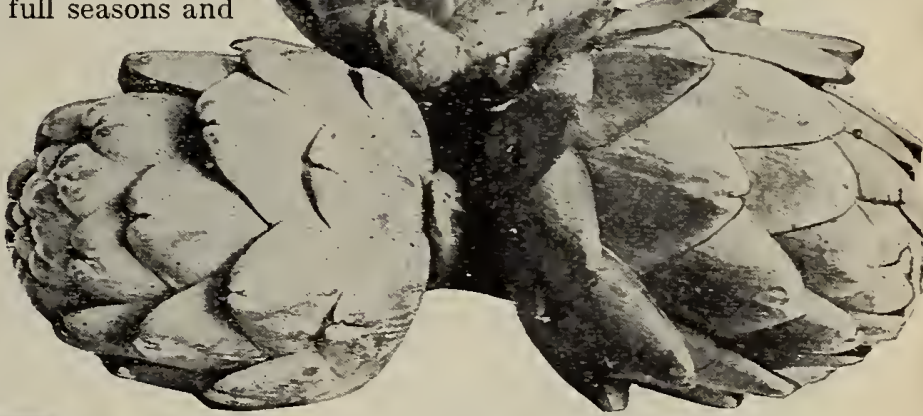

Artichoke-Large Green Globe Per Ib. $15 \mathrm{c}$; postpaid, $25 \mathrm{c}$ postpaid, 25c per Ib.; 100 ket rates. 
BEANS are naturally divided into several distinct classes, and each class is represented by a great number of varieties. You will find each class listed here, and we have chosen the best assortment of all varieties.

Beans require a light friable soil, with plenty of moisture, and they are very sensitive to frost. In California they should not be sown

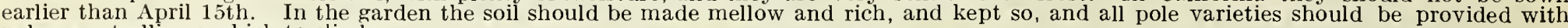
poles or a trellis on which to ciimb.

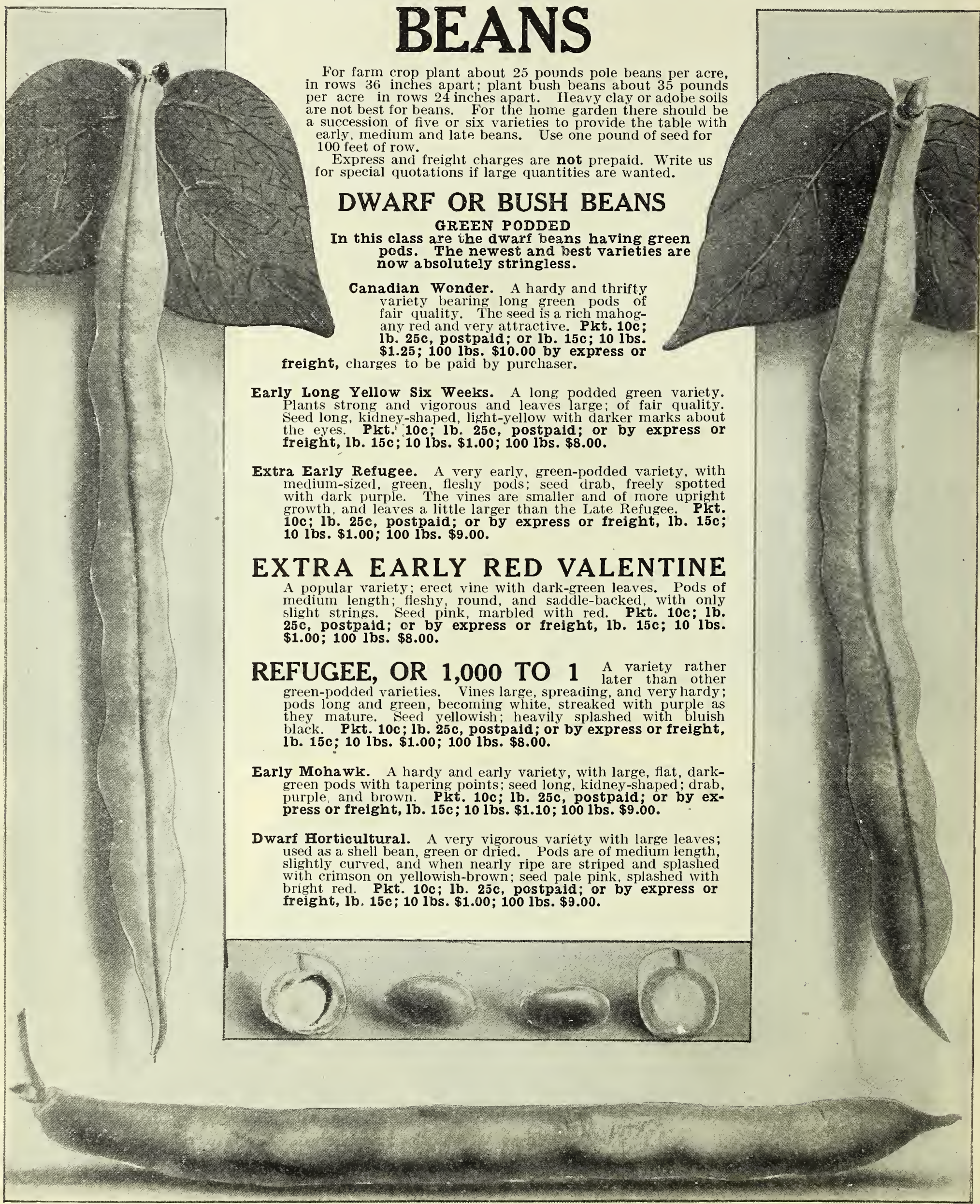




\section{SAN FRANCISCO CAIIFORNIA U.S.A. W:}

ENGLISH OR BROAD WINDSOR. This is not a string bean of any sort, but a very well-known popular variety with many farmers. Familiarly known as the Horse Bean. Pkt. 10c; $1 \mathrm{~b}$. 25c postpaid: or by express or freight, 1b. $15 \mathrm{c} ; 101 \mathrm{bs}$. $70 \mathrm{c} ; 100 \mathrm{lbs}$. $\$ 6.00$.

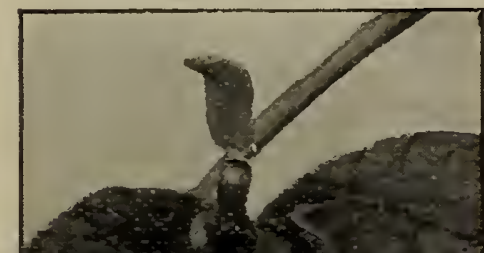

Round Yellow Six Weeks. A large, vigorous, productive bean, with long, straight, flat, light-green pods; seed light-yellow, with marks darker about the eyes. Pkt. 10c; 1b. 25c, postpaid; or by express or freight, 1b. 15c; $10 \mathrm{lbs} .90 \mathrm{c} ; 100 \mathrm{lbs}$. paid;

STRINGLESS GREEN POD A very valuable ety, absolutely free from strings. Is very early; pods are long, rather round, very fleshy and deeply saddle-backed; seed rich seal brown. Pkt. 10c; 1b. 25c, postpaid; or by express or freight, $1 \mathrm{~b} .15 \mathrm{c} ; 10 \mathrm{lbs}$. $\$ 1.10 ; 100 \mathrm{lbs} . \$ 9.00$.

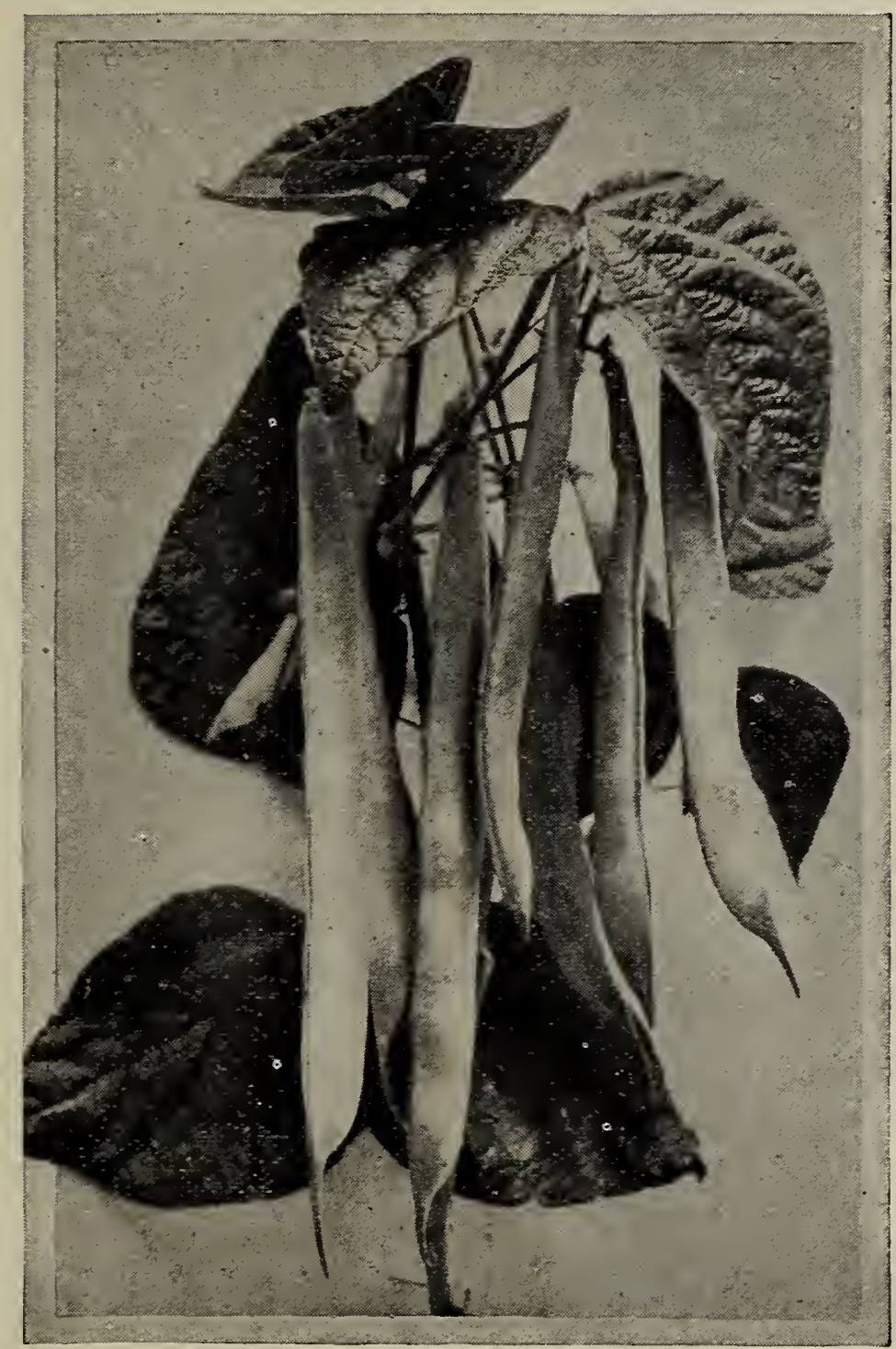

Davis White Wax

One of the best shipping varieties for market gardeners

\section{(}

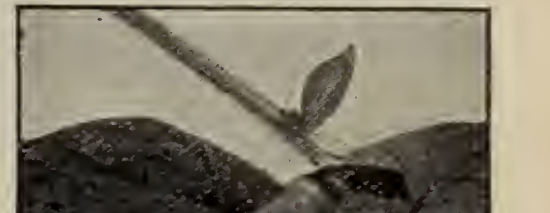

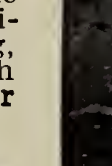


DWARF OR BUSH BEANS-WAX PODDED

In this class are the dwarf beans, having creamy white, yellow, and golden-yellow pods. Most of the varieties we list are

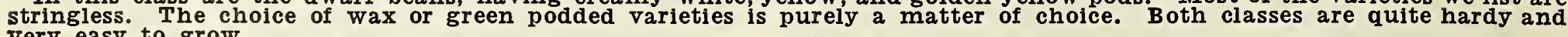
very easy to grow.

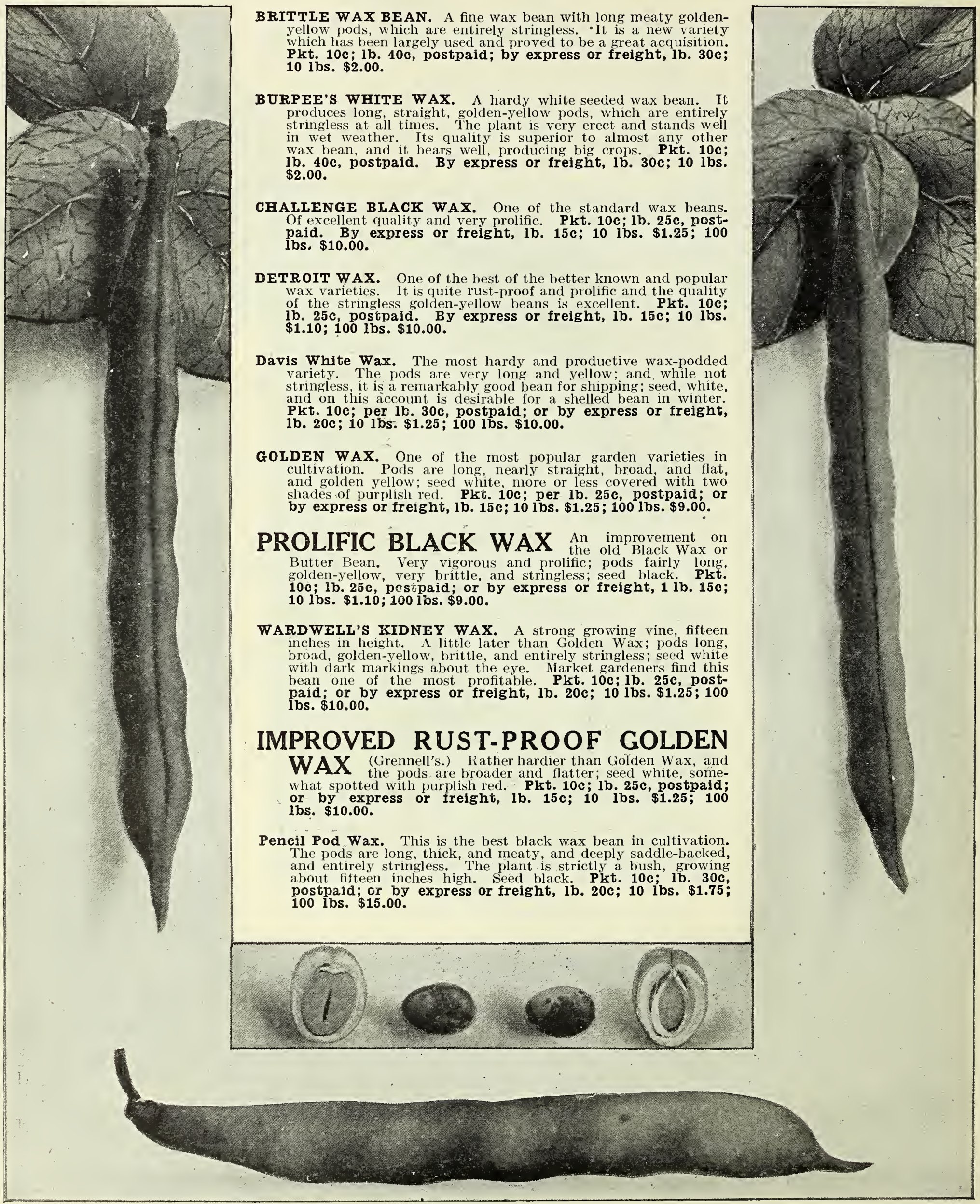




\section{POLE OR RUNNING BEANS GREEN AND WAX PODDED}

Tliese beans require a pole or trellis to climb on, if planted in the garden, although when raised as a seed crop in the open field they need no support whatever. Pole beans are usually very prolific, and bear longer pods and a great many more of them than the bush varieties.

Burger's Pole. A new pole variety of great merit. Bears long, brittle, stringless pods of excellent flavor. It rivals all other pole beans and is destined to become the most popular of all. Pkt. 10c; 1b. 30c, postpaid; or by express or freight, 1b. 20c; 10 ibs. $\$ 1.50 ; 100$ lbs. $\$ 13.00$.

Cut Short, or Corn Hill. A popular variety for planting among corn, since the vines climb the corn-stalks without the use of poles. Pods short and green; leaves deep green; seed white, spotted freely with reddish brown. Pkt. 10c; 1b. 25c, postpald or by express or frelght, 1b. $15 \mathrm{c} ; 10 \mathrm{lbs} .85 \mathrm{c} ; 100 \mathrm{lbs}$. $\$ 7.50$.

EARIY GOLDEN CLUSTER WAX. A very popular, early, and fine variety; pods six to eight inches long, wide and flat, borne in clusters, each containing from three to six pods, which are golden yellow. The pods are of fine quality and remain in condition to use for a long time; seed flat and dull white. Pkt. 10c lb. $40 \mathrm{c}$, postpaid; or by express or frelght, ib. $30 \mathrm{c} ; 10$ lbs. $\$ 2.00$.

Horticultural or Speckled Cranberry. An old favorite. Pods short, pale green, becoming splashed with brownish red. Seed blush pink, spotted with red Valuable either green or dry shelled. Pkt. 10c; 1b. 25c, postpaid; by express or freight 1b. $15 \mathrm{c} ; 10 \mathrm{lbs} .90 \mathrm{c} ; 100 \mathrm{lbs}$. $\$ 8.00$.

Indian Chief or Tall Black Wax. A black-seeded wax variety with thick, golden-yellow pods. Very hardy and prolific, and the most popular oi the pole wax beans. Pkt. 10c; 1b. 25c, postpaid; by express or freight, 1b. 15c; 10 lbs. 90c; 100 lbs. $\$ 10.00$.

\section{KENTUCKY WONDER, OR OLD} HOMESTEAD The most popular of the pole vari1. eties, and slould be in every garden where beans are planted. It grows luxuriantly and bears for long period. Pods are very long, very fleshy, and deeply creased or saddle-backed, green in color, and stringless. Seed light brown. Pkt. $10 \mathrm{c} ; 1 \mathrm{~b} ; 25 \mathrm{c}$, postpaid;
$1 \mathrm{~b} .15 \mathrm{c} ; 10 \mathrm{lbs}$. $\$ 1.25 ; 100 \mathrm{bs}$. $\$ 10.00$.

Kentucky Wonder Wax. An excellent variety, and one of the very best pole beans. The pods are long, very thick, meaty, deeply saddled-backed, entirely stringless, and bright yellow in color. The vine is thrifty and very prolific. Seed deep brown. Pkt. 10c; 1b. 30c, postpaid; by express or frelght, $1 \mathrm{~b}$ $20 \mathrm{c} ; 10$ lbs. $\$ 1.50$.

Lazy Wife. A green-podded variety bearing good, long pods in clusters; stringless and of peculiarly fine flavor, seed rather large, or freight, 1b. 20c;10 1bs. $\$ 1.50 ; 1001 \mathrm{bs}$. $\$ 11.00$.

Scarlet Runner. The well-known and old-fashioned climber having bright scarlet, pea-like flowers. It not only holds its place as a flower, but the pods when young are of fine quality for cooking. Seed large, bright scarlet, heavily blotched with purple. Pkt. 10c; 1b. 35c, postpaid; by express or frelght

White Creaseback. An early, green-podded variety. Pods five to six inches in length, deeply creased or saddle-backed, and borne in clusters. Are very fleshy and stringless; seed white and can be used as a shelled bean for winter use. Pkt. 10c; 1b. 25c, postpaid; by express or freight, 1b. 15c; 10 lbs. $\$ 1.10$; 100 lbs. $\$ 9.00$

White Dutch Case Knife. A climbing variety with long, flat, irregular pods, which become creamy white as they mature; seed
broad, flat and clear white. Pkt. 10c; 1b. 25c postpaid; by express or freight, $1 \mathrm{~b} .15 \mathrm{c} ; 10 \mathrm{lbs} . \$ 1.20 ; 100 \mathrm{lbs}$. $\$ 10.00$.

\section{BEANS-LIMA VARIETIES}

Lima beans are delicious when used green shelled, and can be grown for this purpose in any climate. The dry ripened bean is also staple article of food for winter use but in California these beans ripen only from San Luis Obispo County and south to Pasadena. The best territory for seed beans we believe to be Santa Barbara and San Buenaventura counties, where we grow our stock.

\section{BUSH VARIETIES}

BURPEE IMPROVED BUSH This is one of the ern vegetable introductions and we have secured for our customers

tomers some seed of it direct from the introducer. from five to six inches long by one and one-quarter inches wide from five to six inches long by one and one-quarter inches wide.
As compared with the original Burpee Bush Lima, both pods

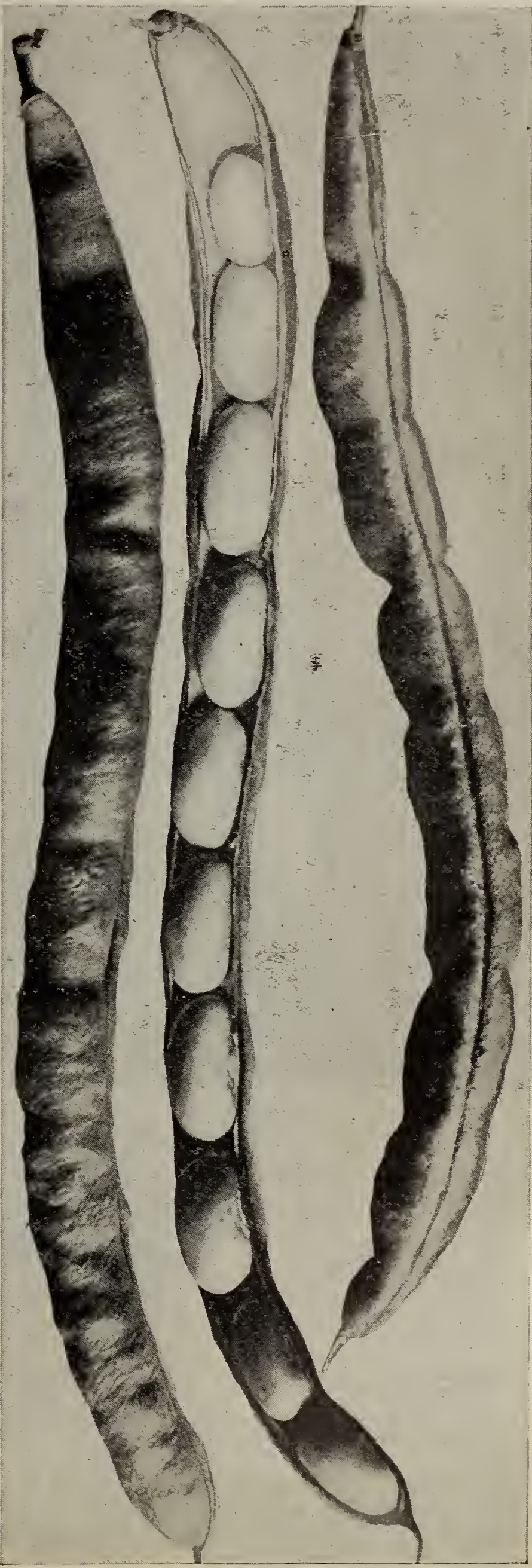

Kentucky Wonder Bean-Life-size average Pods Brittle, stringless, meaty, delicious flavor 


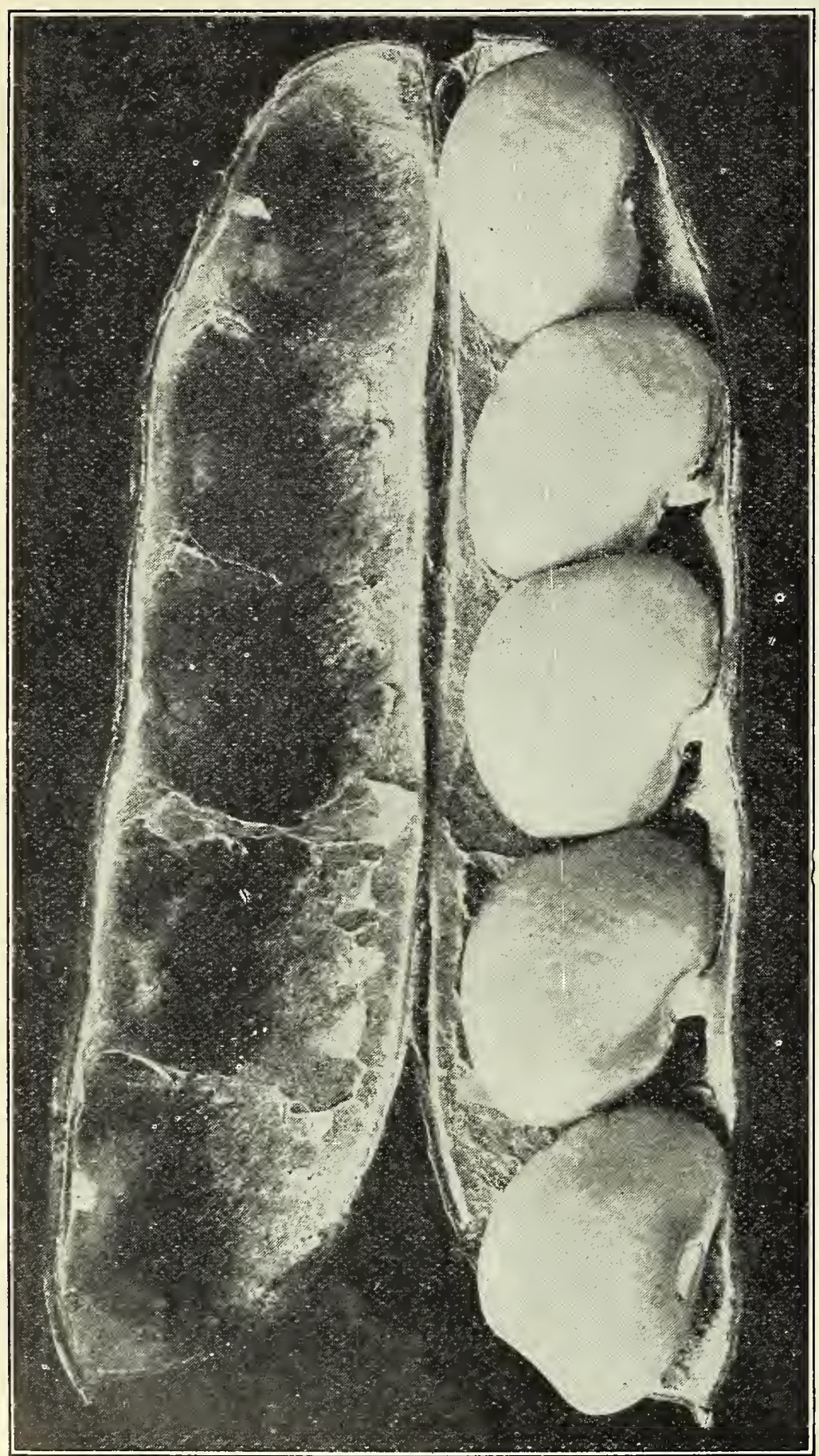

A Life-size Pod of

The Burpee Improved Bush Lima

\section{BUSH VARIETIES-Continued}

and beans are very much larger, while the beans, either green or dry, are nearly twice as thick. The beans have the same luscious flavor as the best flavored Limas, and are ready to use six to eight days earlier. It will outyield the Burpee Bush Lima by fully one-third, this greater yield being due to the increased size of both pod and beans. The dried beans are very handsome and generally show a greenish white coloring. Pkt. 15c; 1b. 60c, postpaid; by express or freight, 1 lb.50c; 10 lbs. $\$ 4.50$.

BURPEE'S BUSH. The best late dwarf variety. Plant eighteen to twenty-four inches high; very prolific. Pods large, and the by frost. Pkt. 10c; lb. 35c postpaid; by express or freight, lb. $25 \mathrm{c} ; 10$ lbs. $\$ 1.75 ; 100$ lbs. $\$ 15.00$.

Dreer's Bush or Kumerle. A very prolific variety, a little later than Burpee's and having short thick pods, closely filled with short, almost round, seed. The plant does not grow upright, Pkt. 10c; lb, 25c, postpaid; by express or freight, lb. 15c: 10 lbs. $\$ 1.25 ; 100$ lbs. $\$ 10.00$.
FORDHOOK BUSH This bean is of the type of Dreer's resembles. Its height is from twenty-two, which it most nearly and it bears its beans in clusters of two to five well out from the plant on long spikes. There are from three to five beans in each pod, with an average of four. The beans are round and thick, like those of Dreer's Bush, and have the same mild delicious flavor. This delicious bean is far ahead of anything which anybody has known in Lima Beans up to the present time. Pkt. 15c; $1 \mathrm{lb}$. 60c, postpaid; by express or freight, $1 \mathrm{lb}$. 50c; 10 ibs. $\$ 4.50$.

Henderson's Bush. The earliest variety we have, being fully two weeks earlier than any other variety. Plant about sixteen inches high and very prolific. Beans are small. Especially recommended where the season is short. Pkt. 10c; 1b. 25c, postpaid; by express or freight, $1 \mathrm{~b} .15 \mathrm{c} ; 10 \mathrm{lbs}$. $\$ 1.25$; 100 lbs. $\$ 10.00$.

\section{POLE VARIETIES}

Challenger, or Dreer's Pole. A splendid pole variety, quite early, very prolific, and of very fine quality. The pods are borne in clusters, and the beans are short and thick, almost round, and crowded so closely in the pod that the ends are flattened. A very popular variety with market gardeners. Pkt. 10c; 1b. 25c, postpaid; by express or freight, 1b. 15c; 10 lbs. $\$ 1.25 ; 100$ lbs. $\$ 10.00$.

EARLY LEVIATHAN. One of the newer varieties and the very best pole variety in cultivation. Vine very tall and strong; pods long and borne in clusters; beans large and white. Is early, strong-growing and prolific. Pkt. 10c; 1b. 30c, postpaid; by express or freight, 1b. 20c; 10 lbs. $\$ 1.50 ; 100 \mathrm{lbs}$. $\$ 12.50$.

KING OF THE GARDEN One of the best and crop varieties. It is medium early and has very long pods, $51 / 2$ to $61 / 2$ inches long, which are well filled with four or five goodsized beans. The pods are very straight and handsome, and the fine, hardy vines bear abundantly. Pkt. 10c; 1b. 25c, postpaid; by express or freight, $1 \mathrm{~b} .15 \mathrm{c} ; 10 \mathrm{lbs} . \$ 1.25 ; 100 \mathrm{lbs}$. $\$ 10.00$.

Large White. A very good variety of the pole or running type. Is very prolific and of good quality, but is now being superseded by Early Leviathan. Pkt. 10c; 1b. 25c, postpaid; by express or freight, 1b. 15c; $10 \mathrm{lbs}$. \$1.10; $100 \mathrm{lbs} . \$ 9.50$.

Siebert's Early. A standard early variety, with good sized pods and large beans Pkt, 10c: lb, 25c, postpaid; by express or freight, $1 \mathrm{~b}$. $15 \mathrm{c} ; 10 \mathrm{lbs}$. $\$ 1.25 ; 100 \mathrm{lbs} . \$ 10.00$.

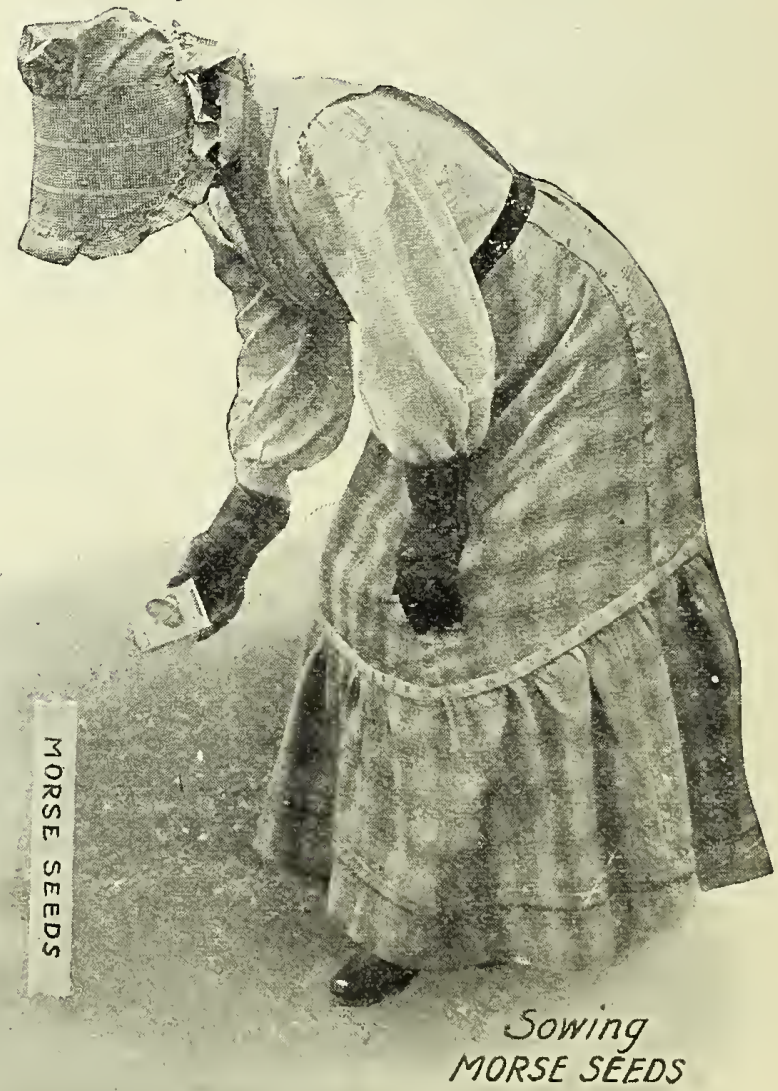




\section{SAN FRANCISCO CAIIFORNRA U.S.A.}

\section{BEETS-FOR TABLE AND FARM}

Beets are divided into three classes-TABLE, MANGELS or STOCK-FEEDING, and SUGAR.

For table use the seed can be sown in California any time after January 1st, and a light, sandy loam is preferable for good shaped roots of good color. The soil must be rich and moist to get a quick growth, which is essential to crisp, tender flesh.

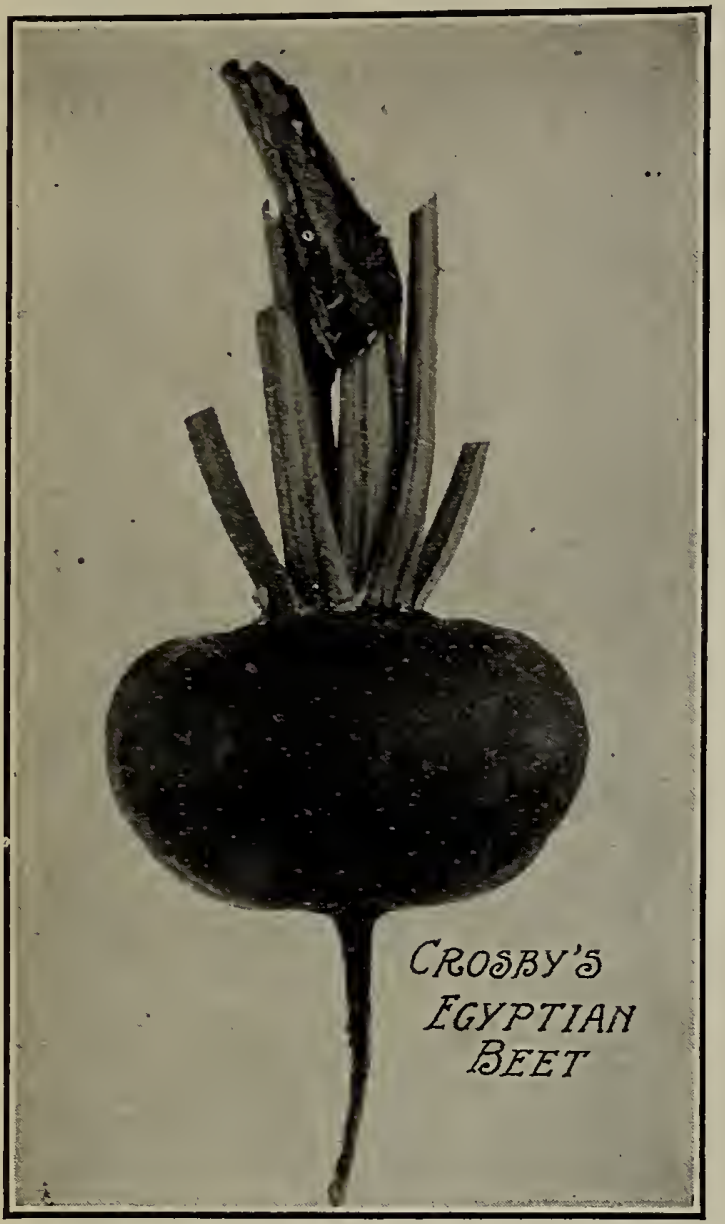

MANGEL WURZEL

OR STOCK FEEDING. For main crop, sow about March 1st in rows 22 inches a unt get good, large and uniform beets, the plants should be thinned get good, large and uniform beets, the plants should

If large lots of seed are wanted, write us for special prices. Champlon Yellow Globe. A large, round, orange-7ellow variety. Good for shallow soils. Lb. 35c, postpaid; or by freight or express, 1 b. 25c; 10 lbs. $\$ 2.00 ; 100$ lbs. $\$ 16.00$.

Glant Yellow Intermediate or Gate Post. A yellow-skinned variety with white flesh, zoned with yellow. Large and ovoid shape. Lb. 35c, postpaid; or by freight or express, 1b. $25 \mathrm{c} ; 10$ lbs. $\$ 2.00 ; 100$ lbs. $\$ 16.00$.

GOLDEN TANKARD YELLOW- Very large, FLESHED fleshed variety. Giant oval shape; small Lellow-stemmed top. Lb. 35c, postpaid; or by freight or express, lb. 30c; $10 \mathrm{lbs}$. $\$ 2.50 ; 100 \mathrm{lbs}$. $\$ 20.00$.

MAMMOTH LONG RED The largest of all the iest cropper. Skin is red; flesh white, zoned with red. This variety produces a larger amount of good feed than any other beet and is recommended as superior to all others. Lib. $35 \mathbf{c}$ postpald; or by freight or express, $1 \mathrm{~b}$. 25c; $10 \mathrm{lbs}$. $\$ 2.00$; $100 \mathrm{lbs}$. \$16.00. (See Illustration on page 18.)

Red Globe. A large globe-shaped variety with red skin. Flesh white, zoned with pink. Lb. 35c, postpaid; or by frelght or express, 1b. 25c; $10 \mathrm{lbs}$. $\$ 2.00 ; 100$ lbs. $\$ 18.00$

Yellow Leviathan. A large yellow olive-shaped variety, with clear, white, brittle flesh. The root grows partly out of ground, rendering it easy to dig. Lb. 35c postpaid; or by freight or express $1 \mathrm{~b} .25 \mathrm{c} ; 10 \mathrm{lbs}$. $\$ 2.00 ; 100 \mathrm{lbs}$. $\$ 18.00$.$$
\text { SUGAR BEETS }
$$

Giant Half Sugar for Stock-Feeding. (Green Top). A beet which is superior to mangels for stock-feeding purposes, as it is more nutritious, having a large amount of sugar. It is oval in shape and grows partly out of ground. Is of large size, and yields enormous crops. L b. 35c, postpaid; or by freight or express, 1b. 25c; 10 lbs. $\$ 2.00 ; 100$ lbs. $\$ 16.00$. Globe-shaped : bright, bu
$10 \mathrm{c} ; 1 / 4$ 1b. $30 \mathrm{c} ; 1 \mathrm{~b} .90 \mathrm{c}$.

\section{TABLE VARIETIES}

globe-shaped than Extra Early Egyptian, and the best known and most $y$ and of fine qualit RDD One of the best table varieties, and the one

Early Eclipse. A fine, early table variety, top-shaped or tapering globe-shaped. Flesh , top-shaped or tapering globe-shaped. Flesh
Crisp and sweet. Pkt. 5c; oz. 10c; 1/4 1b. A good variety for summer and autumn use. Is turnip-
showing zones. Pkt. 5c; 0z. 10c; $1 / 41 \mathrm{~b} .25 \mathrm{c} ; 1 \mathrm{~b} .75 \mathrm{c}$. lf Long Blood. A half-long variety about eight inches long and tapering abruptly.

Dark leaves: a good table variety and very early. Pkt. 5c A A very desirable variety for light soils, where ark brownish-red. Flesh deep blood-red. b. $25 \mathrm{c} ; 1 \mathrm{~b} .75 \mathrm{c}$.

OVD BLOOD TURNIP A turnip-shaped deep red flesh. Tops green. A fine selected strain and one
of the best varieties Pkt. 5c; 0z. 10c; $1 / \mathbf{4} \mathbf{1 b}$. 30c;1b. $\$ 1.00$.

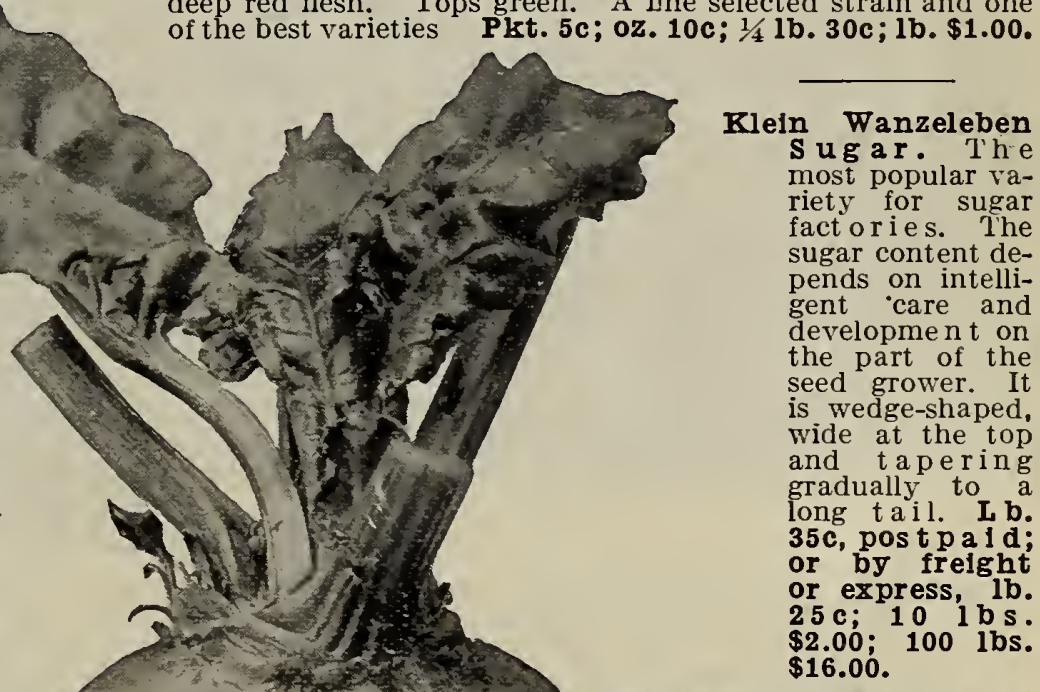
Sugar. Large, thick. tapering variety. Yields almost as much as mangels. Is sweet and rich and very desirable for stock. Ib. 35c, postpaid; or by freight or express, 1b. 25c; $101 \mathrm{bs}$ $\$ 2.00 ; 100$ lbs. $\$ 16.00$. Vilmorin's Improved Sugar. A little smaller than Klein Wanzeleben, but even richer in sugar and a valuable variety Grows entirely under ground, and yields good crops under ordinary conditions. I b. $35 \mathrm{c}$; postpaid; or by freight or express, $1 \mathrm{~b}$. 25c; 10 lbs. $\$ 2.00 ; 100$ lbs. $\$ 16.00$.

WHITE SUGAR $\underset{\text { For }}{\text { RED }}$ foeding stock. A very hardy variety, producing large crops with little care. The root is large and very rich in sugar and while not sufficiently so for sugar purposes, it makes a remarkably postpald; by freight or express, lb. $25 c ; 10$ lbs. $\$ 2.00 ; 100$ lbs. $\$ 16.00$. 


\section{C.C.MORSE \& CO. VEGETABLE SEEDS}

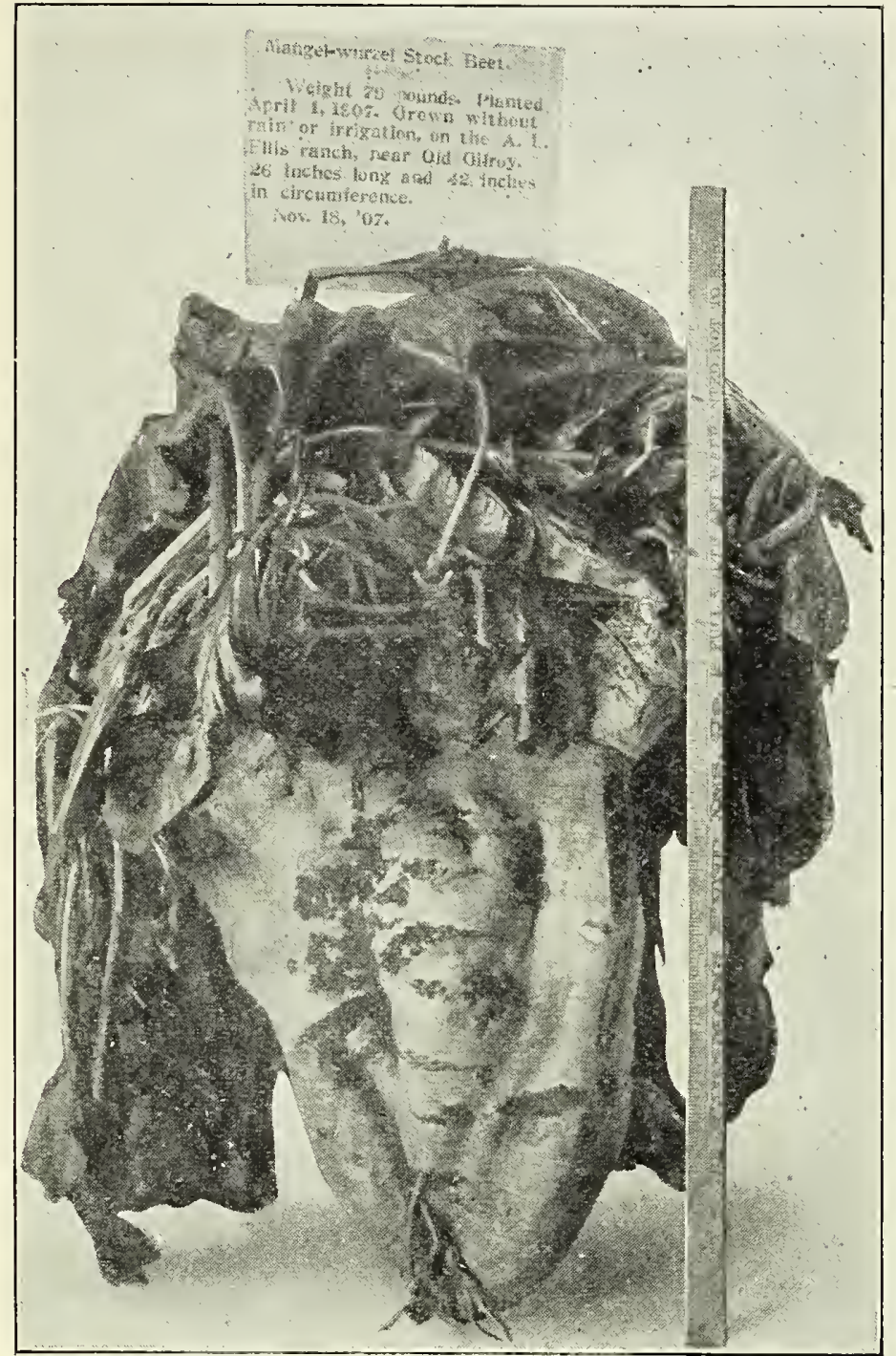

Mangel Wurzel Stock Beet. Mammoth Long Red
BEETS-Continued

The accompanying illustration of a Mammoth Long Red Mangel shows the immense size and irregular form these beets sometimes attain. The true shape is a long oval, tapering nicely at the top. But it is feed and lots of it the stockman wants and he will get it from this Mangel whether it spreads at the top or runs up regularly. See price on page 17 .

SWISS CHARD OR SEA KALE BEET

Used for greens by cutting the stem and leaf, which are also very ornamental. It resembles an ornamental beet top, but has no edible root. Pkt. 5c;0z. 10c; $1 / 4$ b.25c;1b. $75 \mathrm{c}$.

\section{BROCCOLI}

Should be treated the same as cauliflower, which it resembles. In fact, it is practically a coarse cauliflower, more divided in the head, Plant larger and taller, and is hardier and easier to grow.

EARLY ${ }^{\circ}$ LARGE WHITE. The best variety. Heads white and large. Pkt. 5c; 0z. 40c; $1 / 41$ b. $\$ 1.25 ; 1 b . \$ 4.00$.

Purple Cape. Good, large heads, which are tinged with purple. Pkt. 5c;0z. 35c; $1 / 4$ 1b. $\$ 1.00 ; 1 \mathrm{~b} . \$ 3.50$.

\section{BRUSSELS SPROUTS}

The plants are very hardy and grow from two to three feet high, bearing a large mass of leaves at the top. The sides of the main stem are covered with three or four dozen small cabbage heads, which are broken off and cooked the same as cabbage.

IMPROVED HALF DWARF. The standard variety. Grows two or three feet high, and the stem is well covered with small

firm, round sprouts. Pkt. 5c;0z. 15c; $1 / 4$ lb. 45c; lb. $\$ 1.50$.

OUR SEED FARMS. "It was in 1875 that R. W. Wilson of Rochester, Niw York came to Santa Clara and beran the wrowing of seeds for the New York, came to santa Clara and began the growing of seeds for the Eastern dealers. He was subsequently succeeded by . C. Morse \& Co. Valley have been one of the attractions of the county. Our principal farms are now at Gilroy where we moved them twelve years ago on account of our ability to get larger farmoved them twelve years ago on understands better than the market gardener thy superior lanerly grown seeds, or there is a tremendous difference in the manner of growin seed of all kinds. The fact that C. C. Morse \& Co. supply the most critical dealers in America, is evidence enough that their seed is carefully and properly and intelligently grown."

\section{CABBAGE}

It is difficult to give definite cultural directions for cabbage, since it is possible to have good cabbage at all seasons of the year in some

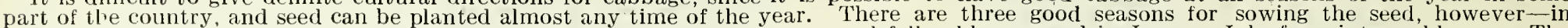

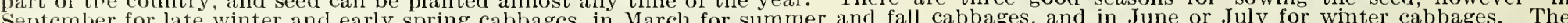

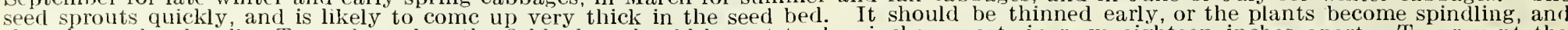
then do not head well. Transplanted to the field, they should be put twelve inches apart, in rows eighteen inches apart. To prevent the heads splitting open in the field before they are ready to be harvested, the plants should be loosened a little at the root. Cabbages require

\section{EARLIEST VARIETIES}

Early Baseball. One of the earliest varieties. Forms tight, solid. perfectly globular heads of rather small size. Pkí. 5c; oz. 30c; $1 / 41 \mathrm{~b} .90 \mathrm{9} ; 1 \mathrm{~b} . \$ 3.00$.

EARLY JERSEY WAKEFIELD $\begin{gathered}\text { One of the } \\ \text { best } \text { a n } \mathrm{d}\end{gathered}$ most popular early varieties. Forms round, pointed heads of good size. Is very hardy and on account of its thick outside great extent. Pkt. 5c;0z. 20c; $1 / 4$ 1b. 60c; $1 \mathrm{~b} . \$ 2.00$.

EARIY WINNIGSTADT A decidedly pointed fine quality - the most sharply pointed of all cabbages. One of the hardiest varieties, resists cold, wet, and insect pests to a dc gree which makes it very desirable; we recommend it as one of the

Early Spring. A very early flat-headed variety. Medium sized and good for summer use. Pkt. 5c;0z. 25c;1/4 lb. 75c; lb. $\$ 2.50$.

Large Early Wakefield (Charleston). Is very similar to Early 5c;0z. $40 \mathrm{c} ; 111 \mathrm{~b}$. 60c; $1 \mathrm{~b} . \$ 2.00$

\section{SECOND EARLY VARIETIES}

ALLHEAD EARLY. Probably the earliest of the large, flat-headed varieties. Is good for summer, autumn, and winter crop. Desirable for
$\mathbf{1 b} \$ \mathbf{\$ 2 . 0 0}$.

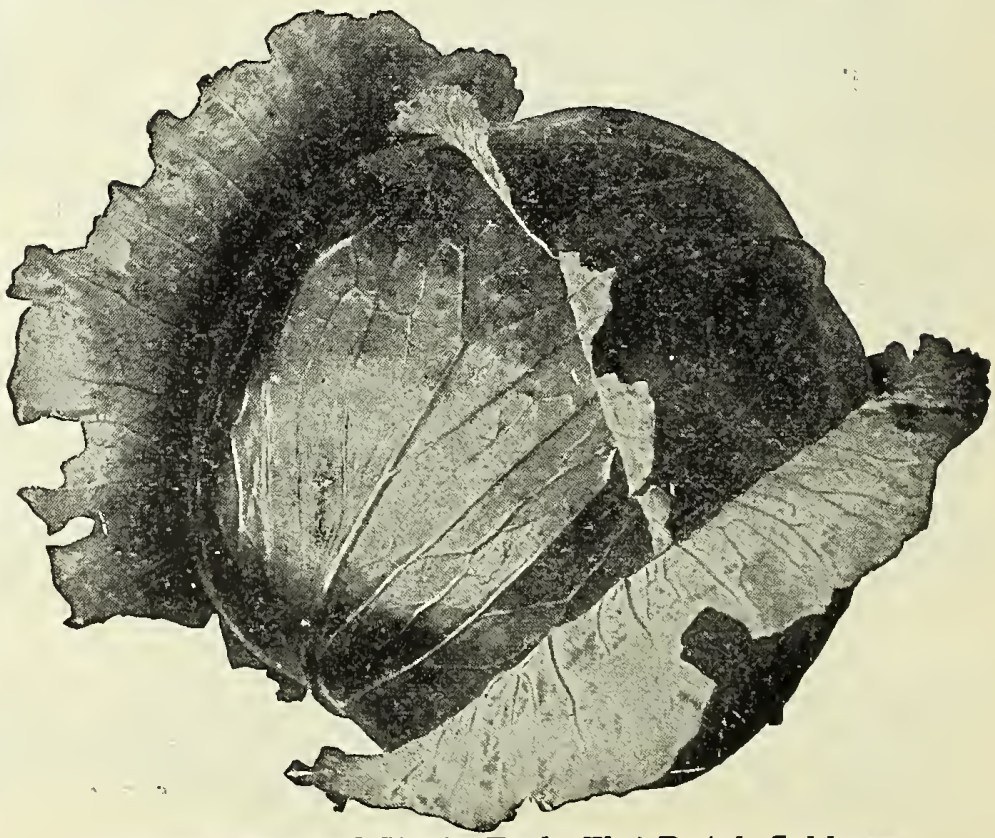

Morse's Selected Strain Early Flat Dutch Cabbage 


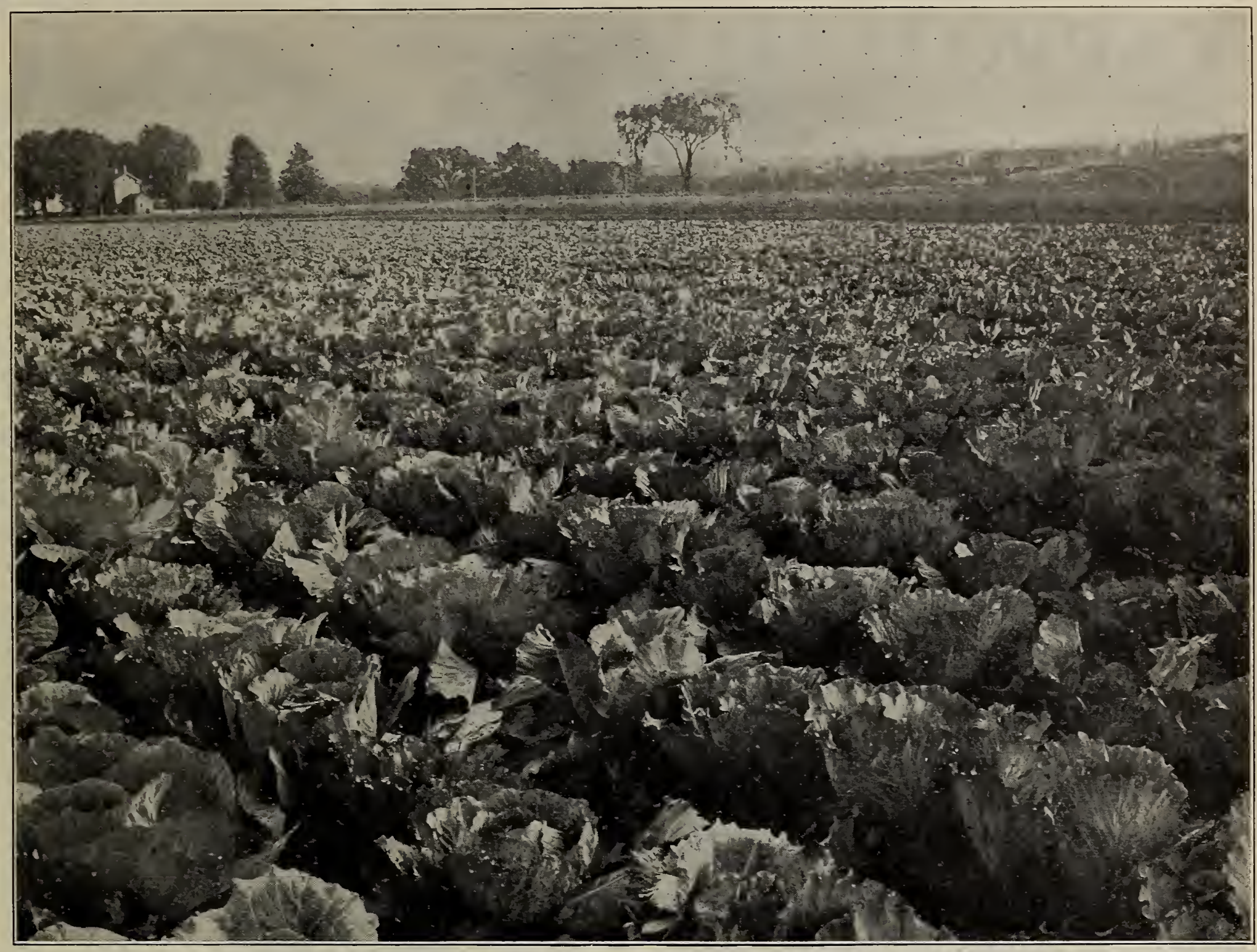

A fine field of marketable EARLY JERSEY WAKEFIELD Cabbages

EARLY DRUMHEAD. Second early; round, flat heads. Pkt. $5 \mathrm{c} ; 0 \mathrm{z} .15 \mathrm{c} ; 1 / 4 \mathrm{Ib} .60 \mathrm{c} ; 1 \mathrm{~b} . \$ 2.00$.

Early Dwarf Flat Dutch. A good flat-headed variety, with short stem and hard, firm head. Forms heads early and is valuable for summer. Pkt. 5c;0z. 20c; 1/4 1b. 60c; 1b. \$1.75.

Fottler's Brunswick. One of the most popular of the flat-headed types, especially with the home gardener. Best for autumn and winter use. Pkt. 5c; 0z. 20c; $1 / 41$ lb. 60c; 1b. $\$ 2.00$.

Henderson's Early Summer. A desirable medium sized, early, flat-headed variety. A good keeper and does well in summer and autumn. Pkt. 5c; 0z. 20c; $1 / 1$ ib. 60c; 1b. $\$ 2.00$.

Henderson's Succession. Is about ten days later than Early Plkt. 5c; oz. 20c; 1/4 1b. 60c; 1b. \$2.00.

MORSE'S SELECTED EARLY FLAT DUTCH A rery superior strain of this variety. An early

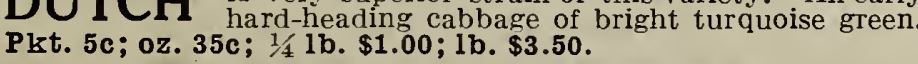

\section{WINTER VARIETIES}

Autumn King, or Worldbeater. A fine winter variety of vigorous growth. Large, well-formed globular heads of bluish green. Pkt. $5 \mathrm{c} ; 0 \mathrm{z} .25 \mathrm{c} ; 1 / 41 \mathrm{~b} .75 \mathrm{c} ; 1 \mathrm{~b}$. $\$ 2.50$.

Burpee's Surehead. One of the most popular varieties. Large, round, slightly flattened head; hard and firm. Pkt. 5c; oz. 20c;
$1 / 41 \mathrm{~b} .60 \mathrm{c} ; 1 \mathrm{~b} . \$ 2.00$.

\section{DANISH BALL HEAD, OR THE HOL-} LANDER A very late variety, forming globular heads: shipper. The color is bluish-green. Pkt. 5c; 0z. 30c; $1 / 1 \mathbf{l b}$. 90c; $1 \mathrm{~b} . \$ 3.00$.

Premium Flat Dutch. A well-known. large, late variety. Flattish, round heads, verv solid and firm: has rather tall, stout stem. Pkt. 5c; 0z. 20c; $1 / 4$ ib. 60c; 1b. \$2.00.
Stone-Mason Marblehead. Medium-sized, late, flat-headed variety, forming a good, solid head. The lea res are bright green.
with conspicuous veins. Pkt. $5 \mathrm{c} ; \mathbf{c z} .20 \mathrm{c} ; 1 / \mathrm{1b}$. 60c; $1 \mathrm{~b} . \$ 2.00$.

We carry Cabbage Plants at various seasons. page 43.

RED

CAB-

BAGE

Ma m moth $R$ ock Red. Best hardheaded red variety. Large heads, gl o b ular, and very deep red on top. Outer leaves greenused for pickling. Pkt. $5 \mathrm{c}$; oz. $20 \mathrm{c} ; 1 / 1 \mathrm{~b}$. $60 \mathrm{c} ; 1 \mathrm{~b} . \$ 2.00$.

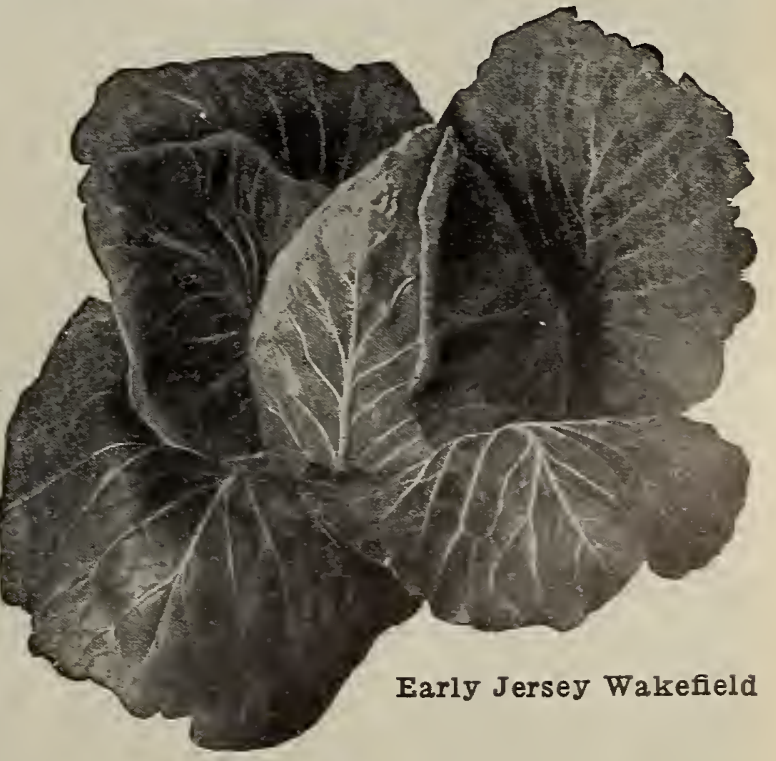

\section{CABBAGE-SAVOY}

Perfection Drumhead Savoy. A variety that is much prized in Europe and also by those who are familiar with it in this country It is rery sweet and crisp, and always tender. Heads mediun
sized and fairly compact. Pkt. 5c; oz. 20c; $1 / 41$ 1b. 60c;1b. $\$ 2.00$. 


\section{CARROTS}

FOR TABLE AND STOCK

Good, sandy loam is best adapted for carrots of all varieties. The shorter varieties, however, can be sown on heavier lands, with good results. For garden, sow the early and short varieties at any time after January 1st. For general crop sow in the.open field about April ist using two or three pounds per acre for rows sixteen to eighteen inches apart. While you get a good uniform root by thinning the young plants, it is not necessary to do so to get a crop of good, average carrots.

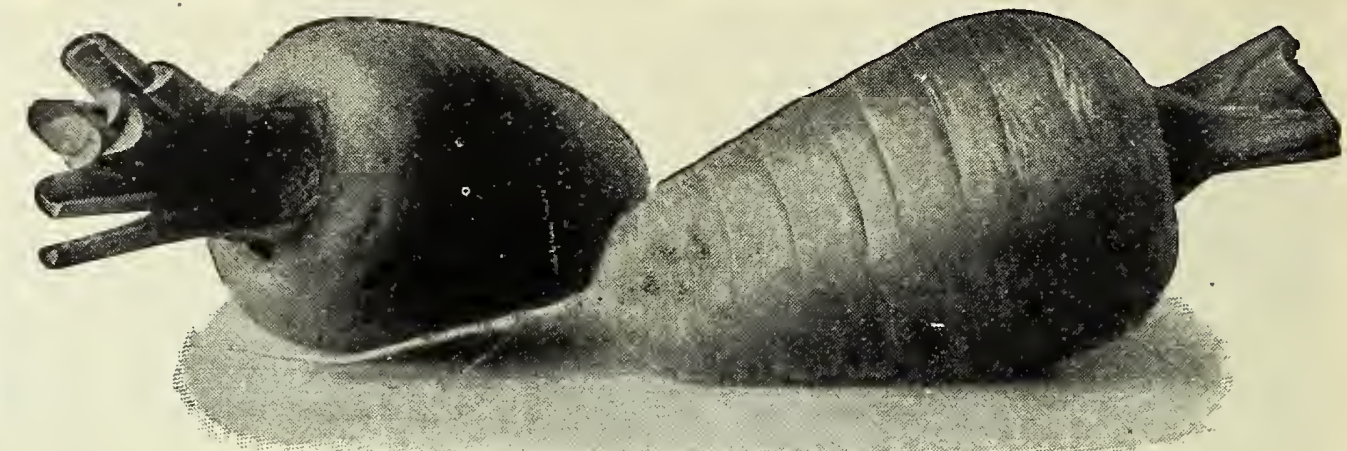

Oxheart, or Guerande Carrot

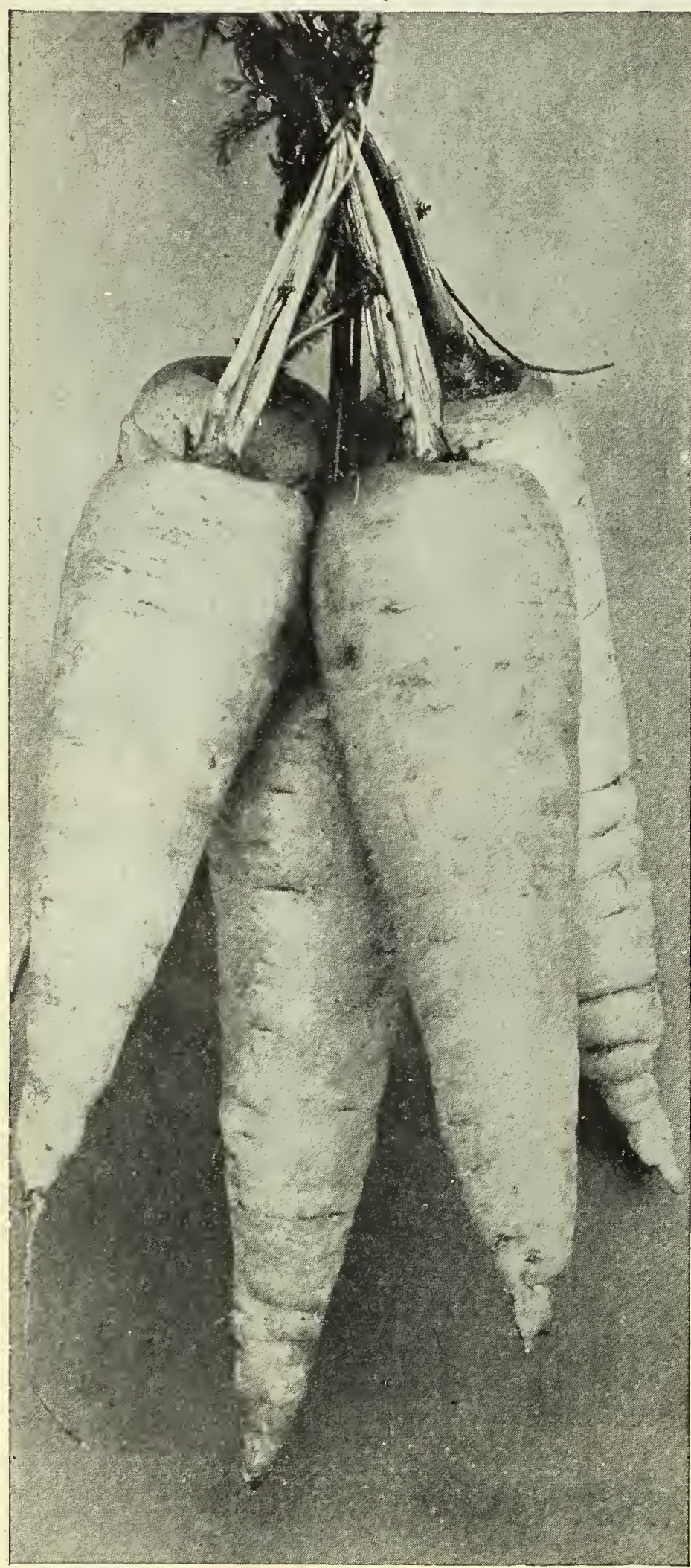

Chantenay, or Model. A very popular variety for general purposes five to six inches long; very stump-rooted; about three inches thick at shoulder; tapering slightly; bright orange-scarlet. Pkt. $5 \mathrm{c} ; 0 \mathrm{z} .10 \mathrm{c} ; 1 / 41 \mathrm{~b}$. $25 \mathrm{c} ; 1 \mathrm{~b} .80 \mathrm{c}$.

DANVER'S HALF-LONG The best variety for the most largely used, not only for stock raising, but for table the most largely used, not only for stock raising, but for table use as well. The perfect type is about eight inches long and about two and a half inches wide at the shoulder, tapering to a sort of
half-point at the bottom. Color is a bright orange-scarlet. It is a very heavy cropper. Pkt. 5c;0z. 10c; $1 / 41 \mathrm{~b} .25 \mathrm{c} ; 1 \mathrm{~b} .90 \mathrm{c}$.

French Forcing. A very popular variety for forcing. The root is globe-shaped, with distinct tap root. Color bright orangescarlet. Pkt. 5c; 0z. 10c; $1 / 41 \mathrm{lb} .30 \mathrm{c} ; \mathbf{1 b}$. $\$ 1.00$.

Half-Long Scarlet Stump-Rooted. A variety about as long as Danver's, but not so thick. It is of uniform thickness from shoulder to root, and very stump-rooted. Pkt. 5c; oz. 10c; 1/4 1b. $25 \mathrm{c} ; 1 \mathrm{~b} .80 \mathrm{c}$.

IMPROVED SHORT WHITE. The most popular of all white varieties, being a heavy cropper and of a desirable shape to allow easy digging in heavy soils. The true type is very thick in the middle and should not taper abruptly from the shoulder. Pkt. 5c; 0z. 10c; $1 / 4$ 1b. 20c; lb. 60c.

Large White Belgian. The best known and one of the oldest white varieties-is a long-pointed root, and should only be planted on light soils where roots are fairly easy to dig. The variety we offer does not grow above ground with a green shoulst rains. P k t. 5 ; oz. $10 \mathrm{co}:$ $1 / 41 \mathrm{~b} .20 \mathrm{c}$
1b. 50c.

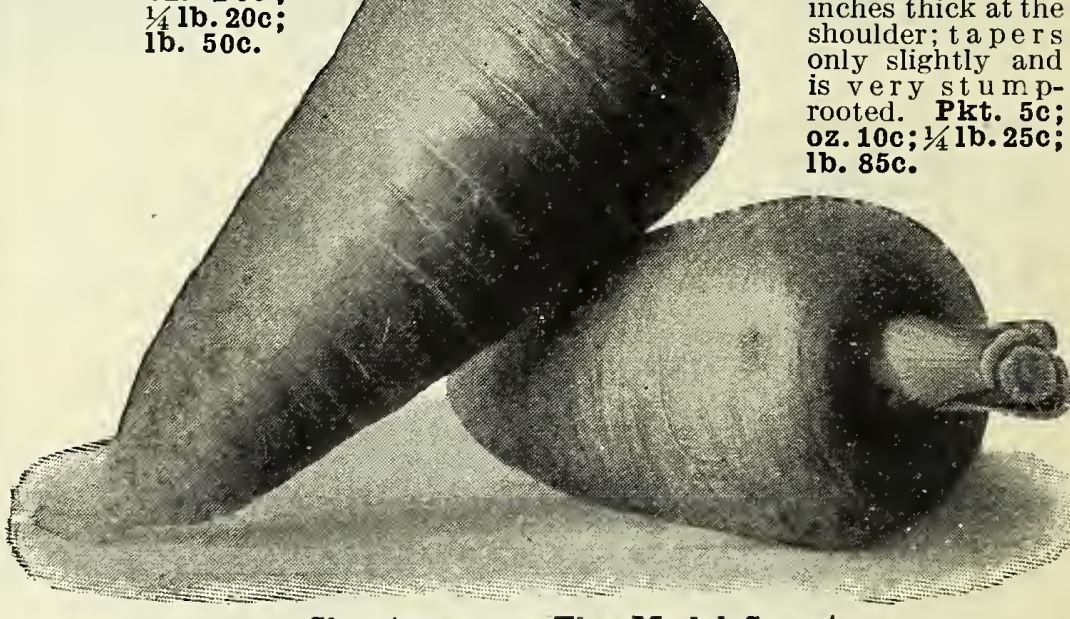

Chantenay, or The Model Carrot

LONG ORANGE The best long variety, and a good, roots can be easily dug. The strain we offer is a bright orangescarlet, and fairly thick, and grows entirely under ground, having Pkt. 5c;0z. 10c; $1 / 4$ 1b. 25c; 1b. 75c.

OXHEART, OR GUERANDE One of the and best croppers among the short carrots. The shape is particulary desirable for heavy soils. The true type is about $41 / 2$ inches long and $31 \%$ inches thick at the shoulder. It tapers slightly to the bottom, and is very stump-rooted. Pkt. 5c;oz. 10c; $1 / 4$ lb. 25c; 1b. $85 \mathrm{c}$.

Red Saint Valery, or New Intermediate. A little longer than Danver's, tapering abruptly, with pointed root. A very desirable, long variety, and rather preferable to Long Orange, being able, long variety, and rather preferable to Long Orange, being scarlet. Pkt. 5c; oz. 10c; $1 / 41 \mathrm{lb}, 25 \mathrm{c} ; 1 \mathrm{~b} .80 \mathrm{c}$. 


\section{CAULIFLOWER}

The culture of cauliflower is much the same as that of cabbage. It does not make a good summer crop, however, as it will not head up well in hot weather. It is especially popular as a fall and winter crop, and with market gardeners proves a profitable crop, owing to the
scarcity of good market vegetables when cauliflower is at its best. It is easy to grow in the garden, provicling the soil is made rich and porous.

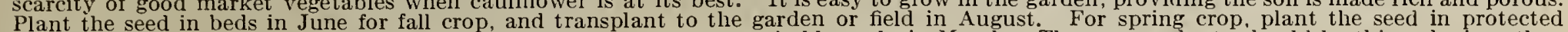

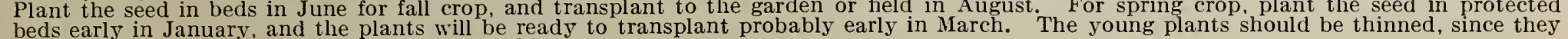
become very spindling if allowed to grow too thick.

Alglers. One of the best late varieties, forming good, large white heads, late in the fall. Pkt. 10c; $1 / 4$ oz. 25c; oz. $75 c ; 1 / 41 b$. $\$ 2.00$.

Dry Weather. A strain of the Early Snowball type, which is especially adapted to California. It is a Danish variety (the best Cauliflower comes from Denmark) and is destined to become very popular in our climate. Pkt. 20c; $1 / 4$ oz. 75c; oz. \$2.50; $1 / 4$ ìb. $\$ 8.00$.

CALIFORNIA WONDER A late variety, forming during the winter. This variety has given great satisfaction in California wherever tried. Pkt. 10c; $1 / 4$ oz. 25c; oz. 75c; $1 / 41$ b. $\$ 2.25 ; 1 b . \$ 6.50$.

Early Favorite. An early, hard-heading variety. It is quite hardy and a good market variety.

Pkt. 5c; $1 / 4$ oz. 35c; 0z. $\$ 1.00$; $1 / 4$ lb. $\$ 2.50$.

EARLY SNOWBALL The best and most popular is a vast difference in the strains of this variety offered, but what we offer is the best imported stock. Those who have had trouble with cauliflower should try this Snowball. It will make uniformly fine heads, even under adverse conditions. Pkt. 25c; $1 / 4$ Oz. 75c; oz. $\$ 2.50 ; 1 / 41$ b. $\$ 9.00$.

Extra Early Dwarf Erfurt. An early variety, forming good, solid white heads. Is very early and almost as good as the best quality of Snowball. Pkt. 20c; $1 / 40 z .65 \mathrm{c} ; 0 \mathrm{0z} . \$ 2.25 ; 1 / 4 \mathbf{l b}$. $\$ 8.00$.

Extra Early Paris. A hardy variety quite easy to grow, and forming good heads. Pkt. 10c; $1 / 4$ oz. 25c;0z. 75c; $1 / 41 \mathrm{~b}$. $\$ 2.50$.

Veitch's Autumn Giant. A large, late variety, very hardy, but especially desirable for the South. The heads are well protected by the foliage, enabling it to resist unfavorable climatic conditions oz. $50 \mathrm{c} ; 1 / 4 \mathrm{lb}$. $\$ 1.50$.

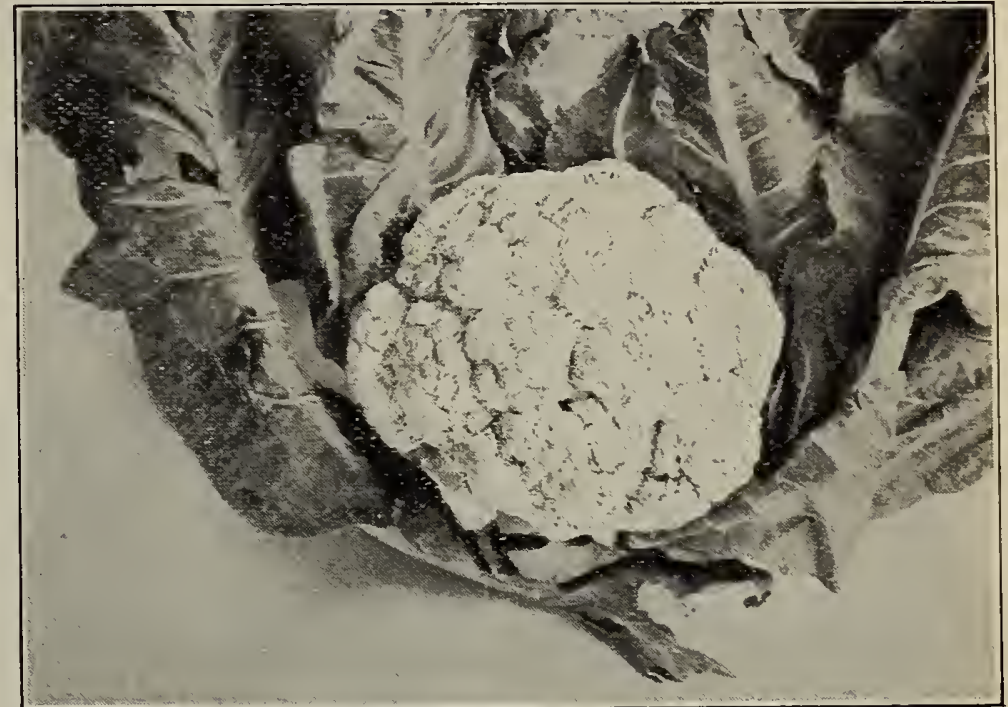

Cauliflower-California wonder

\section{CELERY}

Celery is essentially a market crop, and is not usually recommended for the home garden on account of the more than usual trouble required

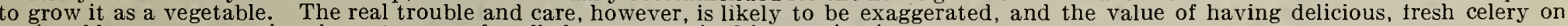
one's table compensates in a large measure for all the care required in growing it.

Celery requires water, and lots of it, from the time the seed is sown in boxes in March, until it is pulled in the autumn or winter. The seed

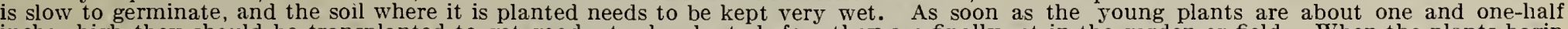

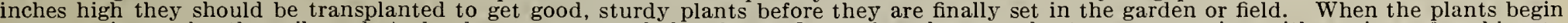

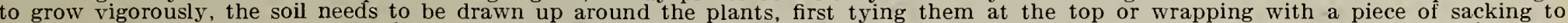

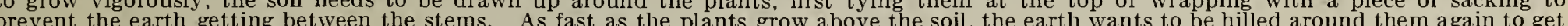

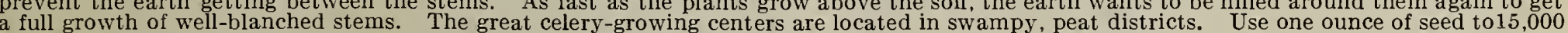
plants, or two ounces per acre.

Dwarf Golden Eeart. The most popular of the old green winter varieties. - Rather tall, forming a large bunch, and blanching white and crisp. Is hardy and a good shipper. Pkt. 5c; oz. $20 \mathrm{c} ; 1 / 41 \mathrm{~b}$. $75 \mathrm{c} ; 1 \mathrm{~b}$. $\$ 2.50$.

Evan's Triumph. A good, green, winter variety, very popular in the North. Forms a large bunch, blanches well, and is very hardy. Pkt. 5c; oz 20c; $1 / 4$ 1b. 75c; 1b. $\$ 2.50$.

Giant Pascal. The most popular of the newer green winter varieties. Rather tall with stems nearly round, and when blanched is white, brittle, and especially good flavor. Pkt. 5c; oz. 20c; $1 / 41 b .75 c ; 1 b . \$ 2.50$

Kalamazoo. A medium-short, dark green variety; very hardy; blanches easily, and ships well. Pkt. 5c;0z. 20c; 1/4 1b. 75c; 1b. $\$ 2.50$.

\section{GOLDEN SELF-BLANCHING, OR PARIS} GOLDEN The most popular market variety in use nOLDI L especially for early crop. The plant is blanched to make it brittle and fit for table use. Forms a rather small bunch.

It may seem incredible to some to know that there are several growers in California who plant 500 acres of this celery alone, and there are probably 5,000 acres of it grown as a market crop in Central and Southern California every year For some unknown reason, the imported seed of this variety is of much better quality and produces much better results $y$ is of much bet ter quality fact is peculiar to this variet it from Europe this variet $\mathrm{V}$ alone, and for this reason we import We think we have the best strain of seed it is possible to obtain We think we have the best strain of seed it is possible to obtain
and recommend it to all market planters. Imported-Pkt. and recommend it to all market plant

Perfection Heartwell. A good, green winter variety, rather tall, forming a large bunch. Pkt. 5c;0z. 20c; 1/4 1b. 75c; 1b. \$2.50.

WHITE PLUME This is one of the most popular of mostly for a very early crop. A comparatively easy variety to grow as it is fairly hardy, and being naturally white is easy to grow, as it is fairly hardy, and being naturally white is easy to Forms a medium-sized bunch and is fairly tall. Pkt. 5c;oz. 25c; $1 / 4$ lb. $75 \mathrm{c} ; 1 \mathrm{~b}$. $\$ 3.00$.

WINTER QUEEN One of the best winter varieties, and ket gardeners. It is tall and forms a large bunch. The leaves are light green. Pkt. 5c;0z. $25 \mathrm{c} ; 1 / 4 \mathbf{1 b}$. 75c; $1 \mathrm{~b} . \$ 2.50$.

New Rose. The best of the red celeries. The flavor is rather strong in red varieties, but we think is unappreciated by those who like winter varieties. It is tall forms a large bunch and blanches to a light-rose pink. Pkt.5c;0z. 20c; $1 / 41$ b. 75c;1b. $\$ 2.50$.

Celery Seed for Flavoring. (Soup Celery.) $1 / 2$ 1b. 20c; 1b. 30c.

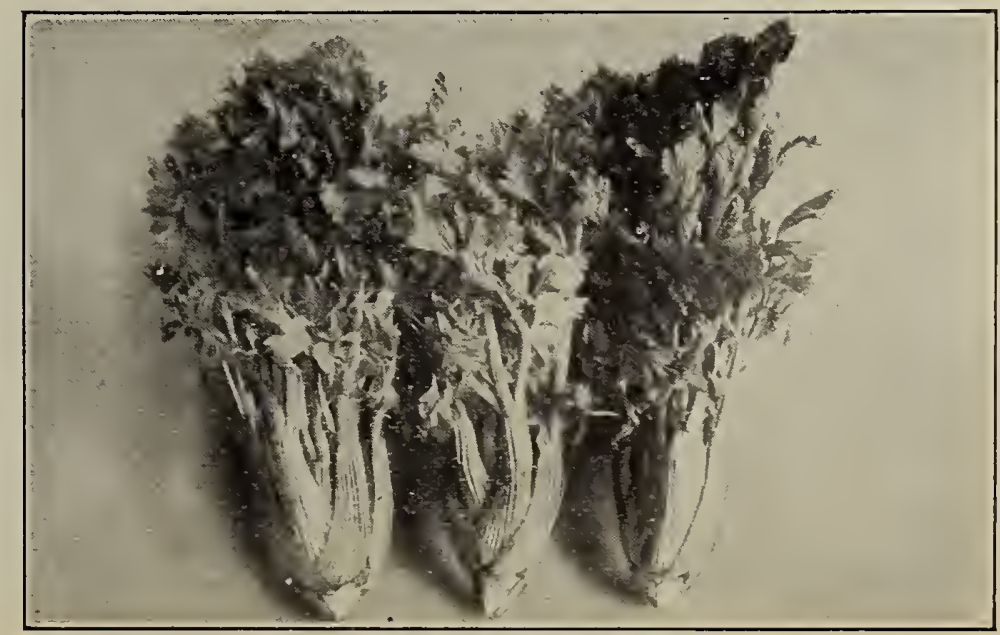

Golden Self-Blanching Celery 


\section{CORN-SWEET OR TABLE VARIETIES \\ EXTRA EASTERN GROWN STOCK-ESPECIALLY SWEET}

As corn is very sensitive to frost, it cannot be planted with any degree of safety until about the middle of April, except in sections that are

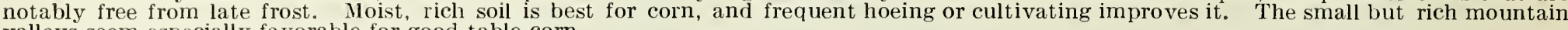
valleys seem especially favorable for good table corn.

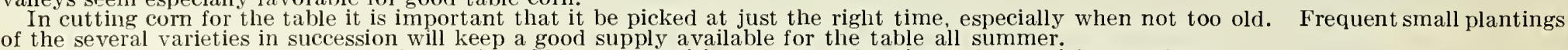
of the several varieties in succession will keep a good supply available for the table all summer.
Express or freight charges are not prepaid. If large quantities are wanted, write us for special quotations.

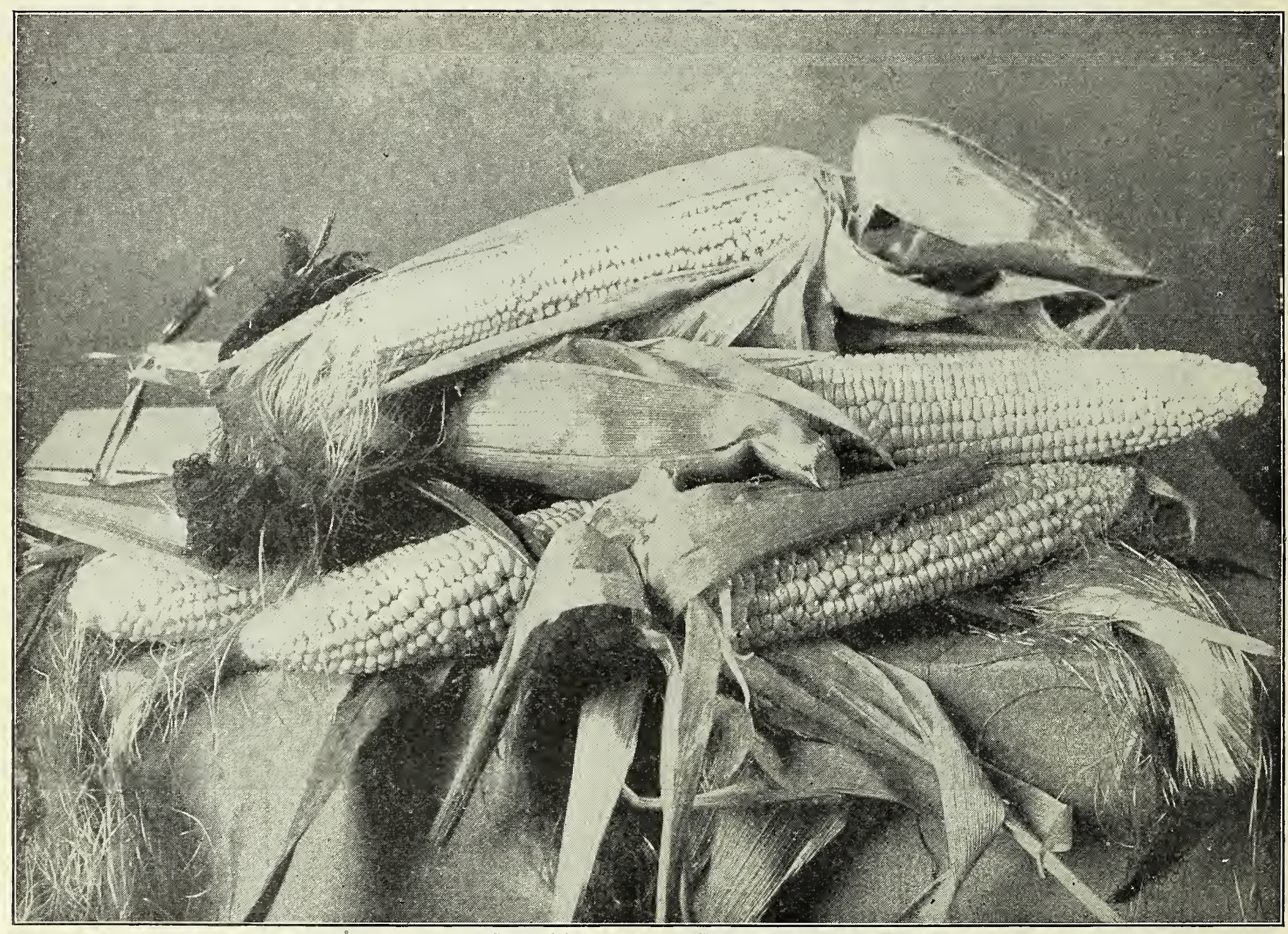

Stowell's Evergreen Sweet Corn

A main crop standard variety-one of the very best

Black Iiexican. One of the best medium early varieties. Although when ripe the seed is dark bluish or black, when ready for table use it is white. It is of especially fine, sweet flavor and very tender. Plkt. 10c; lb. 25c, postpaid; by express or freight, lb. $15 \mathrm{c} ; 10$ lbs. $\$ 1.00 ; 100$ lbs. $\$ 8.50$.

Golden Bantam. A very early variety. The ears are but medium size, but are thickly set with delicious yellow kernels. The quality of this variety is superb, and it has become a general favorite early sweet corn with all who have tried it. Pkt. 10c; 1b. 25c, postpaid; by express or freight, Ib. 15c; 10 lbs. $\$ 1.00 ; 1001 \mathrm{bs}$. $\$ 8.50$.

Crosby's Early. A fine, early variety, growing about 4 feet in height. Is twelve-rowed, and very popular. Pkt. 10c; Ib 25c, postbaid; by express or freight, $1 \mathrm{~b}$. 15c; 10 ibs. $\$ 1.00$; 25c, postpaid;

\section{COUNTRY GENTLEMAN OR SHOE}

PEG One of the best of the late varieties. Has a long, Is remarkably fine flavored and sweet, and is frequently used by canners. PKí. 10c; 1b.25c, postpaid; by express or freight, canners. Pkic. 10c; lb. 25c, postpaid;

Early Red Cob Cory. One of the best extra early varieties. Ears are about six inches long, and eight-rowed. Pkt. 10c; ib: 20c, ibs. $\$ 8.00$.
EARLY MINNESOTA The best early variety for Between Crosby's and Cory's in earliness. Stalks about five feet high; ears long, and eight-rowed. Pkt. 10c; 1b. 25c, postpaid; by express or freight, Ib. $15 \mathrm{c} ; 10 \mathrm{lbs} .90 \mathrm{c} ; 100 \mathrm{lbs} . \$ 8.00$.

Early White Cob Cory. An extra early variety with remarkably white grains, especially when cooked. Ears are six to seven inches long. Of good quality. Pkt. 10c; 1b. 25c, postpaid; by express or freight, $1 \mathrm{~b} .15 \mathrm{c} ; 10 \mathrm{lbs} . \$ 1.00 ; 100 \mathrm{Ibs}$. $\$ 8.00$.

\section{EARLY MAMMOTH, OR ALAMEDA} The very best variety for practically all California and the one most generally used here. Forms very large ears, which are quite sweet and of fair quality. It withstands our dry summers quite sweet and of fair quality. It withstands our dry summers Pkt. 10c; 1b. 25c, postpaid; by express or freight, 1b. 15c; $10 \mathrm{lbs}$. $\$ 1.00 ; 100 \mathrm{lbs}$. $\$ 8.00$.

Late Mammoth. A mammoth variety, with very long, thick ears, which are covered with very wide thick kernels. Has the largest ears of any variety. Is very late. Pkt. 10c; Ib. 25c, postpaid

Moore's Early Concord. A medium early variety. Ears ar rather short and well filled with 14 to 16 rows of kernels. A good variety for private garden or for canning. Pkt. 10c; 1b. $25 \mathrm{c}$, postpaid; by express or freight, Ib.15c; $10 \mathrm{Ibs} . \$ 1.00$ 100 lbs. $\$ 8.00$. 


\section{SAN FRANCISCO CALIFORNIA U.S.A.}

old Colony. A good late variety of rich, sweet flavor. Ears bear 16 to 20 rows of kernels, and are very heavy and solid. Pkt. 10c; $1 \mathrm{~b}$. 25c, postpaid; by express or freight, lb. 15c; $10 \mathrm{lbs}$. $\$ 1.00 ; 100$ lbs. $\$ 8.00$.

Perry's Hybrid. A good second early variety. Usually produces two good-sized ears, set low on the stalk. Of fine quality, sweet and tender. Pkt. 15c; 1b. 25c, postpaid; by express or freight, 1b. 15c; 10 lbs. $\$ 1.00 ; 1001 \mathrm{bs}$. $\$ 8.00$.

POTTER'S EXCELSIOR. A fine street variety for second-early Pkt. 10c; 1b. 25c, postpaid. By express or freight, lb. 15c; $10 \mathrm{lbs}$. 90c; $100 \mathrm{lbs}$. $\$ 8.00$.

ST ABLER'S EARLY. A very early variety with larger ears than most sorts. Fine white meaty kerncls. Pkt. 10c; 1b. 25c, postpaid. By express or freight, $1 \mathrm{~b} .15 \mathrm{c} ; 10 \mathrm{lbs}$. $\$ 1.00$;
$100 \mathrm{lbs}$ \$9.00.

STOWELL'S EVERGREEN The most popular and and the best all round table variety. Of good, strong growth, about 6 feet high. Ears keep in condition for boiling for a remarkably long time. The quality is excellent. Pkt. 10c; 1b. 25c, postpaid;

White Evergreen. Like Stowell's Evergreen, it is a good main crop variety, but has the remarkable quality of being snow-white. It is invaluable for canners, market gardeners, and all who desire or freight, 1b. $15 \mathrm{c} ; 10 \mathrm{lbs} . \$ 1.25 ; 100$ lbs. $\$ 10.00$.
Wisconsin White Dent. A tall-growing variety: large eared; 16 to 18 rowed; grains large and white ${ }^{2}$ L. 20 c postpaid; by Sweet Corn for Fodder. As this corn is always wanted in large quantites, write us for special quotations.

NOTE. Eastern Sweet Corn. Over a large area of our Pacific Coast, especially from Central California and south it is frequently impossible to grow good sweet corn of the more highly bred and sensitive varieties. This is largely due to our cool nights, and therefore the more hardy varieties do best-Early Vammoth for a really sweet variety and Early Adams and Extra Early Adams for medium sweet sorts. There is also a very decided opinion among some of the larger growers of corn that extreme eastern grown corn is better than that grown in the Middle West and to meet this demand we are now offering to our customers some of the choicest and most carefully eastern grown and we trust they will more than please our customers.

POP CORN, WHITE RICE The most popular Lb. 20c, postpaid; by express or freight, $1 \mathrm{~b} .10 \mathrm{c} ; 10$ lbs. $75 \mathrm{c} ; 100$ lbs. $\$ 6.00$.

\section{Kaffir Corn}

$\left.\begin{array}{l}\text { Egyptian Corn } \\ \text { Broom Corn }\end{array}\right\}$ See Field Seeds. Page 46.

Jerusalem Corn

\section{FIELD VARIETIES}

Extra Early Adams. The earliest of all corn and the first to make ears. Plant dwarf and stocky and grains of fair quality. Pkt. 10c; 1b. 20c, postpaid; by express or freight, $1 \mathrm{~b}$. $15 \mathrm{c} ; 10 \mathrm{lbs}$. 80c; $100 \mathrm{lbs}$. $\$ 7.00$.

Early Adams. Although not a sweet corn, can often be used as such on account of its fine, white kernels, which are quite sweet and tender. Is very hardy and can be planted earlier than the early varieties of sweet corn. Pkt. 10c; 1b. 20c, postpaid; by express or freight, 1b. $15 \mathrm{c} ; 10 \mathrm{lbs}$. 80c; $100 \mathrm{lbs}$. $\$ 7.00$.

Early Eight-Rowed Canada, also known as the Yellow Flint. A rapid growing, early variety, and for this reason largely used for reare short Lb. 20c postpald by express or freight, $1 \mathrm{~b}$. 10c; 10 lbs. $60 \mathrm{coc} ; 100 \mathrm{lbs}$. $\$ 5.00$.

King Phillip. An old New England favorite. The ears are long, and the variety is very early. express or freight, 1b. 10c; 10 lbs. 60c; 100 lbs. $\$ 5.00$.

Early Golden Dent, or Pride of the North. A very early dent variety, and especially valuable on account of its extreme earliness. Ears 8 to 10 inches long, with 10 to 16 rows of paid; by express or freight, $1 \mathrm{~b} .10 \mathrm{c} ; 10 \mathrm{lbs}$. $60 \mathrm{c} ; 100 \mathrm{lbs}$. $\$ 5.00$.

LEAMING A very popular, tall -growing are leafy, making excellent fodder. Stalks nels are long and deep golden yellow. It is the best yellow corn on the market. $L b$. 20c, postpaid; by express or freight, lb. $10 \mathrm{c} ; 10 \mathrm{lbs}$. 60c; $100 \mathrm{lbs}$. $\$ 5.00$.

White Cap Yellow Dent. An early and hardy variety, growing 6 to 7 feet in height. Ear are 8 to 10 inches in length. Cob small and 16 to 18 rowed. The outer end of the grain is white, while the inner portion is clear yellow. $10 \mathrm{c} ; 10 \mathrm{lbs} .60 \mathrm{c} ; 100 \mathrm{lbs}$. $\$ 5.00$.

SANFORD WHITE FLINT

An early, tall variety, bearing large ears which are well filled with long, pure white kernels. The very best white corn on the market. Lb. 20c, postpaid; by express or freight, lb. $10 \mathrm{c} ; 10 \mathrm{lbs} .60 \mathrm{c} ; 100 \mathrm{lbs}$. $\$ 5.00$.

\section{OUR NOVELTIES FOR 1909 :}

Stratagem Peas-re-selected strain,

Burpee's Fordhook Muskmelon,

Dwarf Giant Tomato,

Sweet Upright Pepper,

and the finest collection of 'Giant Spencer Sweet Peas ever offered by anyone anywhere.

Asta Ohn, Alurora Spencer, Othello Spencer, King Edward Spencer, Queen Victoria Spencer, Beatrice Spencer, Irs. Routzahn Spencer. Mrs Sankey Spencer, Flora Norton Spencer, Lovely Spencer, Tennant Spencer, Capt. of the Blues Spencer and Henry Spencer selections mixed Read all we say on pages 74 to 78 .

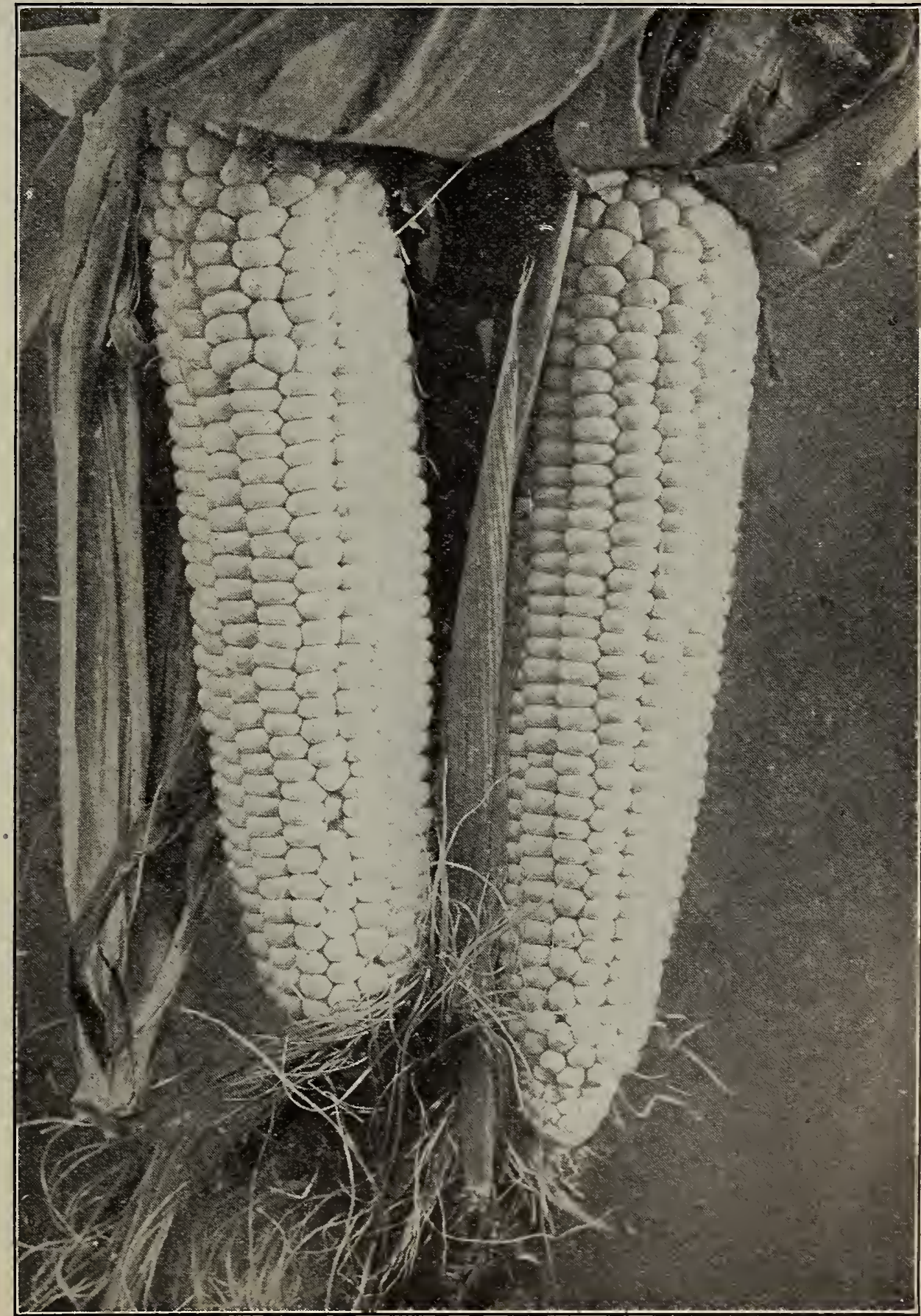

Early Mammoth, or Alameda Sweet The best adapted to our California Climate 


\section{CUCUMBERS}

Are sensitive to frost, and cannot be planted until the last of April. 'They require a great deal of water, and unless planted on very wet

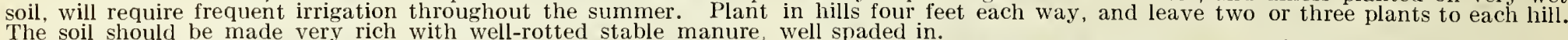

Cucumbers are very easy to grow, and a few hills will produce an abundance for an average family.

ARLINGTON WHITE SPINE A rich, dark-green white when ripened. The fruit is about 7 inches long when in marketable condition and very straight and even in shape. Is early, and good for forcing and out-of-door culture. Pkt. 5c;

Chicago Pickling. A mediumlong deep-green variety, turning yellow at maturity. The fruit is finely shaped being slightly blunt at both ends. It is the popular pickle ends. It is the popular pickle Pkt 5c: 0z, 10c; $1 / 1$ lb, 30c: lb. \$1.00.

Cool and Crisp. A fine garden variety, deep ree $\mathrm{n}$ and of the White Spine type, pure white when ri pe. Pkt. 5c; Oz. $15 \mathrm{c} ; 1 \mathrm{~b} 1 \mathrm{1b}$.
Cumberland Pickling. This variety is the result of a cross between Paris Pickling and White Spine, and retains the characteristics of the former in being thickly covered with small white spines. The vine is sturdy and very prolific. The mature fruits are from 9 to 10 inches in length. Pkt. 5c; oz. 10c; $1 / 41 \mathrm{~b} .30 \mathrm{c} ; 1 \mathrm{~b} . \$ 1.00$.

Early Cluster. A very productive variety, bearing its fruit in clusters of two or three. dark green. Pkt. 5c;0z. 10c: $1 / 4$ lb. 30c; $1 \mathrm{~b}$. $\$ 1.00$.

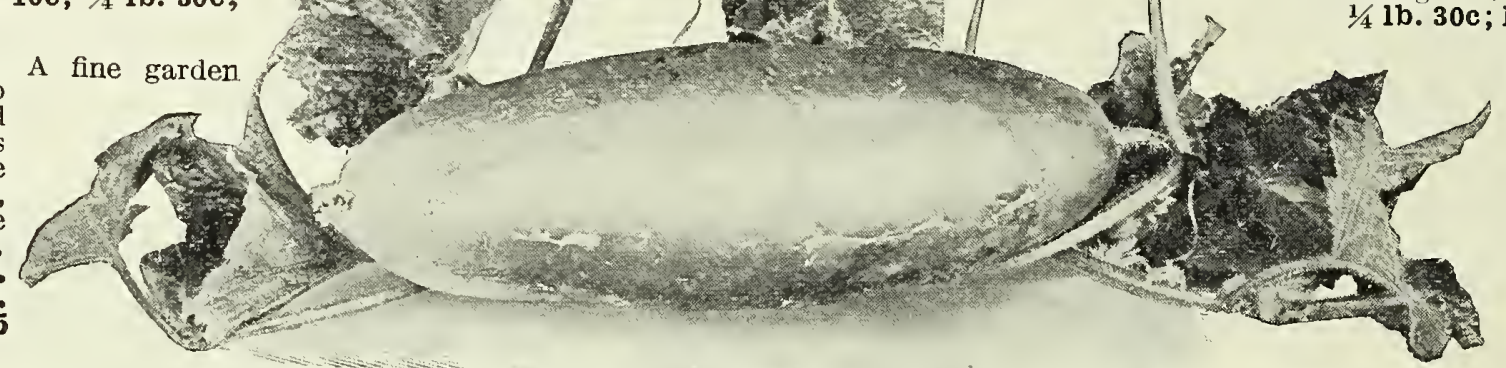

Arlington White Spine Cucumber

Early Short Green, or Early Frame. A very desireither pickling or table use Fruit straight: small at each end; bright end; bright oz. 10c; $1 / 4 \mathrm{lb}$. $30 \mathrm{c} ; 1 \mathrm{~b} . \$ 1.00$.

E ver b e a r ing. Very early and very prolific. Fruits 4 to 6 inches long; quite thick and blunt $1 / 41 \mathrm{~b}$. 30c; 1b. $\$ 1.00$.

Extra Early Green Prolific, or Boston Pickling. A very prolific variety, used principally for pickles. Fruit medium sized bright green, very even and symmetrical. Pkt. 5c; 0z. 10c; 1/4 1b. 30c; ib. $\$ 1.00$.

Extra Long White Spine, or Evergreen White Spine. A popular variety having long, rich dark-green fruits with very tender, white, and crisp flesh. Pkt. 5c; oz. 15c; $1 / 4$ 1b. 35c; 1b. $\$ 1.25$.

Fordhook Famous. A long White Spine variety, growing from 10 to 12 inches. Fulty as long as Long Green and of equally good quality. Pkt. 5c; oz. 15c; 1/4 1b. 40c; 1b. \$1.50.

Gherkin, or West India Gherkin. An extremely small fruited variety, grown exclusively for pickles. It has no value for slicing: is very prickly, but tender and crisp if picked when young. Seed germinates slowly. Pkt. 5c; 0z. 20c; 1/4 1b. 60c.

Japanese Climbing. A good variety for training to a trellis. Forms long fruit of rich, dark-green color. The flesh is white, crisp, and of good flavor. Pkt. 5c; oz. $15 \mathrm{c} ; 1 / 4 \mathrm{lb} .40 \mathrm{c} ; 1 \mathrm{~b}$. $\$ 1.50$.

LONG GREEN The best known and most popular variety tive, and forms fruit fit for use almost as early as the shorter varieties. The mature fruit is almost 12 inches long. The skin is of a deep green, and the flesh is solidh crisp, and of fine quality. is of a deepgreen, and the flesh is solid, crisp, and or hine quality. it as much the best cucumber of all, and the variety every one should plant. Pkt. 5c; oz. $15 \mathrm{c}$; $1 / 4$ lb. 35c; $1 \mathrm{~b} . \$ 1.25$.

\section{COLLARDS}

A plant bearing a large mass of leaves on the top of a stout stalk. It is a species of cabbage, and the flavor is the same. It bears leaves all through the winter, and is used especially in the South for cabbage greens. Young plants may be started in boxes in early spring, and the young plants transplanted, allowing plenty of room for each plant.

TRUE GEORGIA. The well known very large variety. Grows from four to five feet high, and forms a very large, loose head. Leaves are tinged with purple. Pkt. 5c: oz. 10c; 1/4 1b. 30c; lb. $\$ 1.00$.

\section{CORN SALAD OR FETTICUS}

A salad plant used as a substitute for lettuce in salads, or may be cooked like spinach for greens. It does well in winter and spring. On rich soil the leaves grow quickly and are excecdingly tender.

Large Leaved. Very tender leaves, which grow out rapidly after being cut. Pkt. 5c; oz. 10c; $1 / 4$ 1b. 20c; 1b.60c. 


\section{SAN FRANCISCO CAIIIFORNIA U.S.A.}

\section{CELERIAC}

This plant resembles celery in flavor, but the stems are very strong, and only the root is palatable. It should be treated much as celery, so far as planting the seed is concerned. The plant requires only a little hilling, however, to get a well-formed, good-sized root.

Giant Smooth Prague. The best variety. Forms a good, thick root as much as four inches in diameter and nearly globular. Pkt. $5 \mathrm{c}: 0 z .20 \mathrm{c} ; 1 / 41 \mathrm{~b}$. 50c;1b. $\$ 1.75$.

\section{CHERVIL}

Can be planted any time in the early spring. The leaves should be kept cut, and if not allowed to run to seed, will keep green for a long ime. Is more finely curled and handsome than parsley, and makes an excellent plant for garnishing.

Curled. Very finely curled, somewhat resembling parsley and used in same manner. Pkt. 5c;0z. 10c; 1/41b. 30c; 1b. \$1.00.

\section{CHICORY}

Used as a substitute for coffee when the roots are dried and ground. The roots are also used for cooking and are very palatable. Sow early in the sprillg, thin the young plants to six inches, and keep well hoed. The plant spreads from the root and is perennial.

Large Rooted, or Coffee. The largest rooted and best variety. Pkt. 5c; oz. 10c; 1/4 1b. 25c; 1b. 75c.

\section{CHIVES}

A plant resembling a tuft of grass, but the leaves have the flavor of onions. The leaves are used in Soups and Salads, giving a mild onion fla vor to same. Pkt. 10c; oz. 50c. See plants of chives listed under vegetable plants, page 43.

\section{CRESS}

There are two species of cress, as noted below. The first named should be sown in drills about sixteen inches apart in rich ground, early in the spring. Several sowings should be made at intervals to secure a succession. Watercress should be sowed along the banks of running water where there is good soil, and after the seed is up it needs no further cultivation, since the plants spread over the water and make a mass of fine, edible leaves.

Fine Curled (Pepper Grass). Leaves finely cut or curled like parsley. The leaves are pungent, and are used to mix with

True Water. Forms a plant, the leaves of which are used for salad or for garnishing. Thrives only when the roots and stems are

parsley. The leaves are pungent, and are used
lettuce. Pkt. 5c; oz. 10c; 1/4 1b. 20c; 1b. 50c. submerged in water. Pkt. 10c; oz. 35c: $1 / 1 / 1$ lb. $\$ 1.00 ; 1 b . \$ 3.50$.

\section{DANDELION}

An easily grown plant, now much esteemed for greens, which are cooked like mustard and spinach. Sow the seed in May or June on good rich soil, and thoroughly cultivate, when the leaves will be ready to cut the following spring. An ounce will sow 200 feet of row. Improved Large Leaved. The largest leaved and best cutting variety. Pkt.10c; oz. 75c; $1 / 4 \mathbf{1 b} . \$ 2.00$.

\section{EGG-PLANT}

The seed germinates slowly, and should be started under glass, with moderately high temperature, about March 1st. When about an inch high transplant carefully to the garden or field, but not until an inch high transplant carefully to the garden or field, but not until nights prevail as in places where the nights are warm. It needs a nights prevail, as in places where the nights are warm.
warm climate to insure quick and uninterrupted growth.

BLACK BEAUTY A very early variety; rich purple market variety. Pkt. $10 \mathrm{c} ; 0 \mathrm{z} .65 \mathrm{c} ; 1 / 4 \mathrm{lb} . \$ 2.00 ; 1 \mathrm{~b}$. $\$ 6.50$.

Early Long Purple. An early variety and also a very profitable one. The fruit is long and of a rich dark purple. Pkt. 5c; oz. 25c $1 / 41 b .75 c ; 1 b . \$ 2.50$.

NEW YORK IMPROVED The principal market ARGE PURPI LARGE PURPLE of deep rich purple. Pkt. 10c; oz. 30c; $1 / 41$ b. $\$ 1.00 ; 1 b . \$ 3.00$.

Black Pekin. An early, prolific variety, and valuable for market gardeners' use. Fruit is nearly round; skin smooth and black. Pkt. 10c; 0z. 35c; $1 / 4$ lb. $\$ 1.00 ; 1 \mathrm{~b}$. $\$ 3.50$.

White Pearl. A smooth-leaved variety with large, egg-shaped, pure white fruit. Pkt. 10c; 0z. 35c; $1 / 41$ b. $\$ 1.00 ; 1$ b. $\$ 3.50$.

\section{ENDIVE}

A salad vegetable which is becoming very valuable for winter use The seed should be sown in June or July in rows, and thinned to about six inches apart. When quite well grown, the outer leaves should be tied, thus blanching the inner leaves and the heart. It is hardly palatable until after frost, being rather bitter if used in summer.

\section{BROAD-LEAVED BATAVIAN, OR ES}

CAROLLE A variety having wide, thick leaves, straight Color dull green. Plt the edges and curved toward the center

GREEN CURLED A very curly variety, the midrib CURLD being wide and whitish and the ges very much indented and curled. A very attractive plant, and one of the very best varieties. Pkt. 5c; oz. 10c

Staghorn. A curly type, the lobes and divisions of the leaves being wider than in the curled varieties. Is a popular garden sort in San Francisco. Pkt. 5c; 0z. 15c; $1 / 4$ lb. 30c; 1b. $\$ 1.00$.

White Curled. A light yellowish-green variety; very curly and quite ornamental. A good variety for general use. Pkt. 5c oz. $15 \mathrm{c} ; 1 / 4 \mathrm{lb}$. 50c; $1 \mathrm{~b}$. $\$ 1.50$.

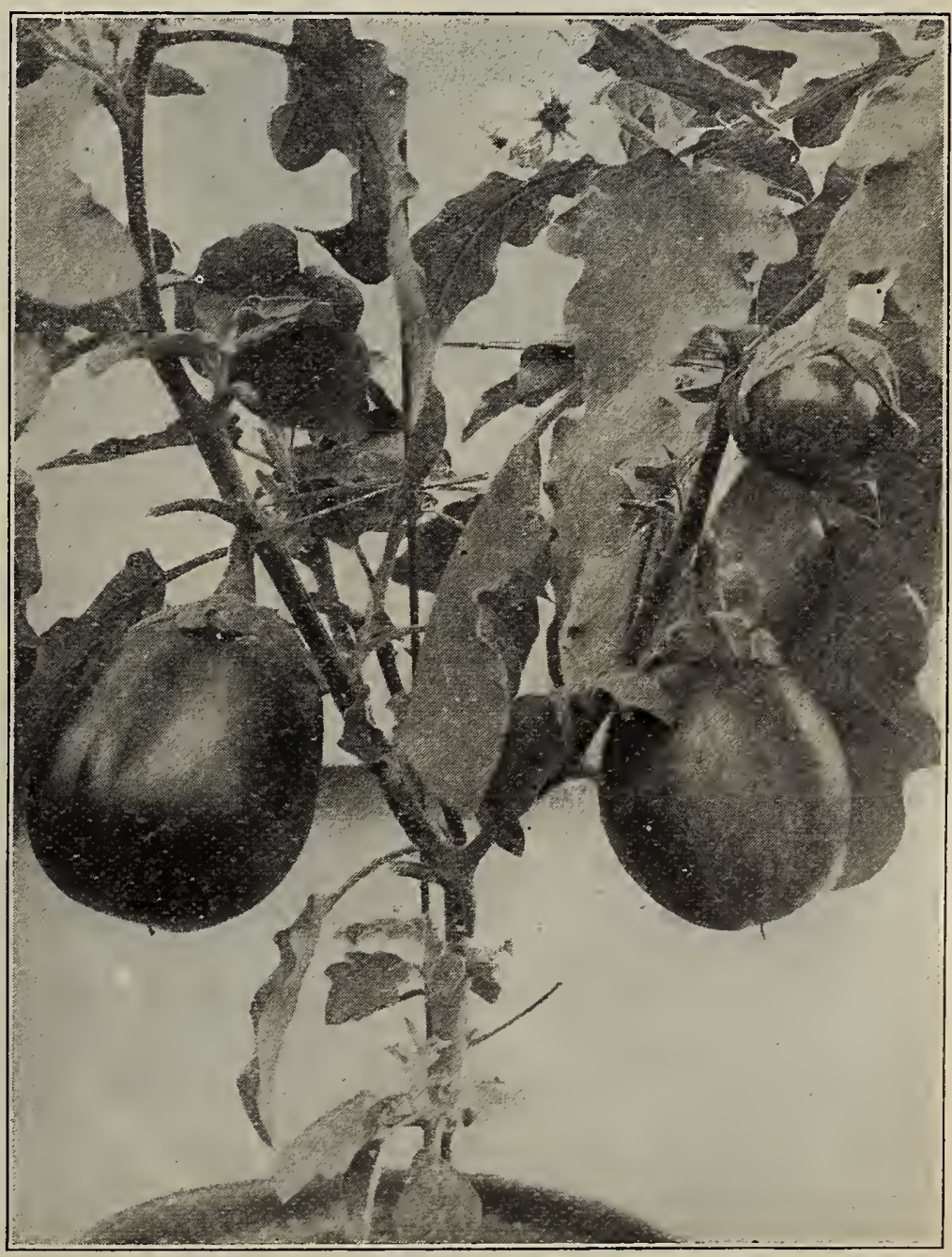

New York Improved Large Purple Egg Plant 


\section{KALE, OR BORECOLE}

A species of cabbage, forming a mass of leaves, some varieties being very beautiful and curly. The leaves are cooked as greens. The seed should be planted in September, and the plants will be ready to use in the winter. It is hardy and will withstand frost and snow.

DWARF CURLED SCOTCH The most popular The leaves are very curly and very tender. Color bright green.
Pkt. 5c; $\mathbf{0 z}$. 10c; $1 / \mathbf{1 b} \mathbf{1 b} \mathbf{2 5} ; \mathbf{1 b}$. $\mathbf{7 5 \mathbf { c }}$.

Green Curled Scotch, Tall. A very hardy variety, growing about $21 / 1$ feet high. Is very curly and makes a beautiful plant. Stands

Dwarf Purple German. Similar to Dwarf Curled Scotch, excepting the leaves are purple. Pkt. 5c; 0z. 10c; $1 / 41$ b. 30c; 1b. $\$ 1.00$.

JERSEY KALE A tall variety with smooth leaves. EsPkt. 5c; oz. 10c; 1/4 lb. 20c;1b. 60c.

Siberian. A plain-leaved variety, having very little curl to the large, green leaves, although the edges are cut and curled slightly. Pkt. 5c;0z. 10c; $1 / 4$ 1b. 25c;1b.75c.

\section{HORSE RADISH}

We carry roots of this popular root from January to May-see under Vegetable Plants, page 43.

GARIIC. See under Vegetable Plants and Roots, page 43.
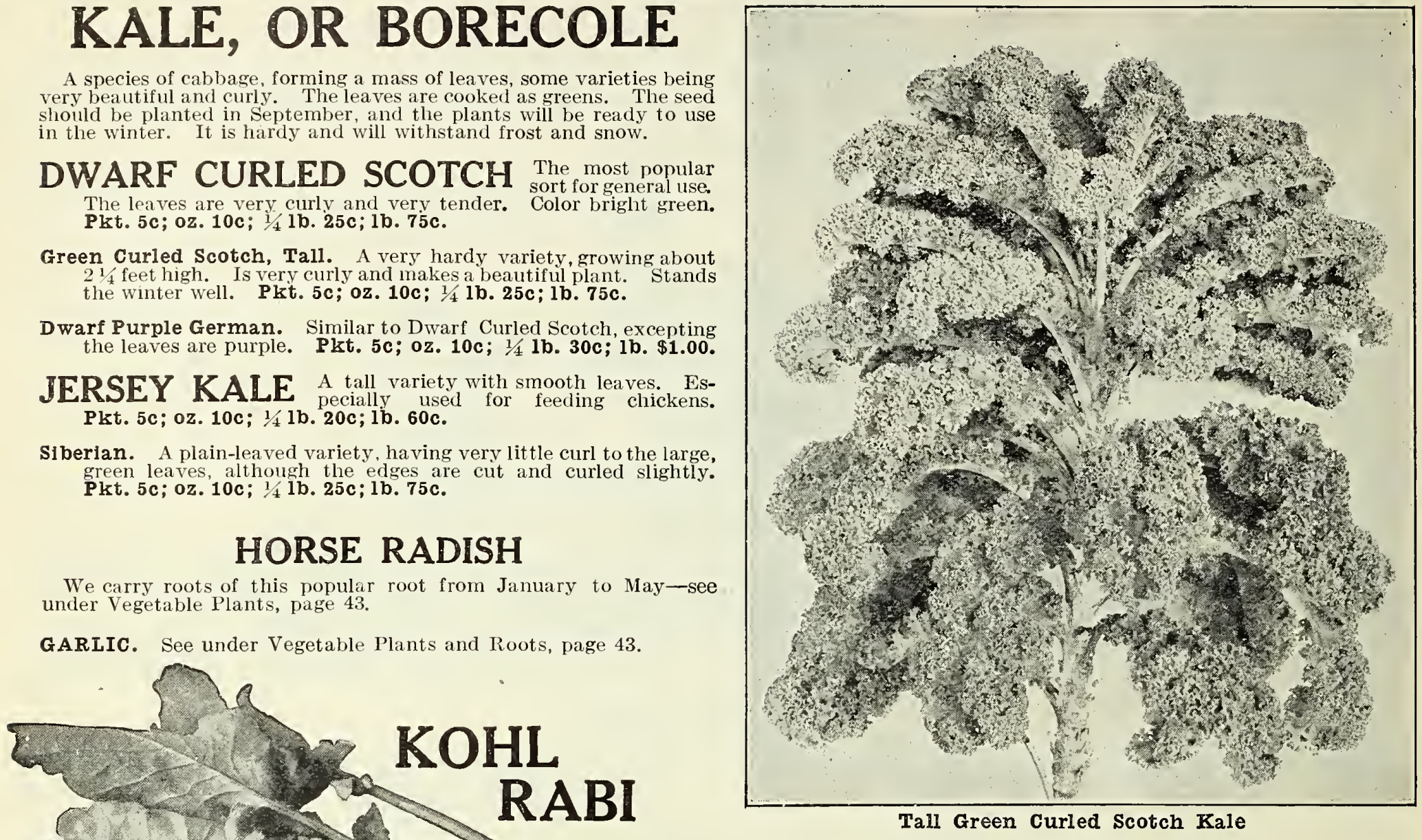

Tall Green Curled Scotch Kale

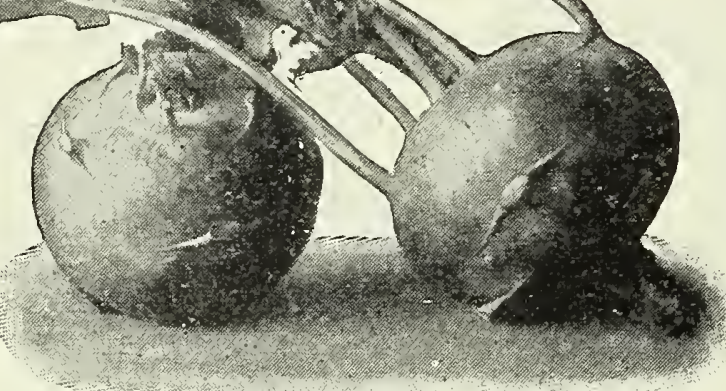

White Vienna, Kohl Rabl

\section{LEEK}

A species of onion which does not form a bulb, but is used for its mild and delicious root, stem, or neck. It can be planted in rows, and the young plants thinned to about four inches. When well grown, hill up with earth to get a long white stem. Seed should be planted in June for good plants in the fall and winter. Leek is a vegetable of unusual merit, and is not half appreciated by the American people. while it is regarded as a great favorite by many of our foreign population.

American Flag. A very good, strong-growing variety, forming large stems of good flavor. Pkt. 5c; oz. $10 \mathrm{c} ; 1 / 4 \mathrm{lb}$. 30c; 1b. $\$ 1.00$.

Carentan. The largest variety, though the stems are not so long as some other varieties. Leaves are very broad. Pkt. 5c;0z. 15c; $1 / 4 \mathbf{1 b}$. 40c; 1b. $\$ 1.50$

GIANT MUSSELBURGH The best variety, having good, thick vigorous and of sweet, mild flavor. Pkt, 5c; oz. 15c; $1 / 41 \mathrm{~b} .40 \mathrm{c} ; 1 \mathrm{~b}$. $\$ 1.25$.

\section{MARTYNIA, OR UNICORN PLANT}

The young pods are much esteemed for pickles, but must be picked young, since they becone very hard and flinty with age. Sow in hills after all danger of frost is
over. The plant grows to about five or six feet in diameter, and is very ornamental. Proboscidea. The common variety. Flowers creamy white with dark-purple throat. Pkt. 10c; 0z. 30c; $1 / 41 \mathrm{~b} .85 \mathrm{c} ; 1 \mathrm{~b} . \$ 3.00$.

NOTE-We have taken especial care to emphasize the best varieties of all vegetables for the Pacific Coast, and have indicated such by listing them in larger and heavier type. You will make no mistake in ordering these varieties.

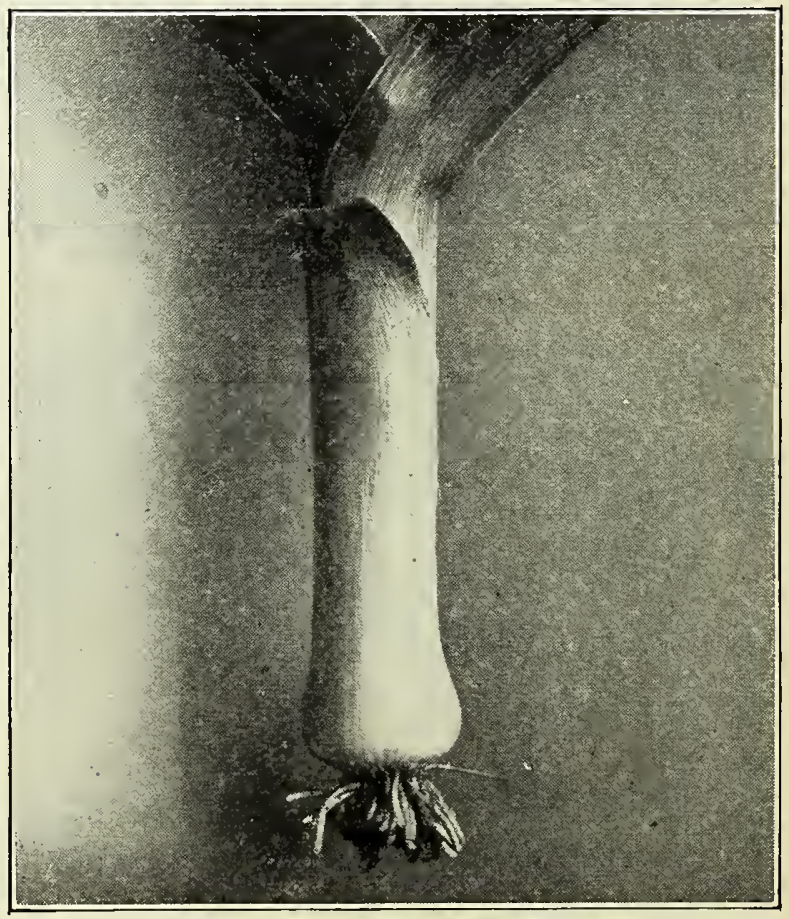

Leek-Giant Musselburgh 


\section{SAN FRANCISCO CALIFORNIA U.S.A.}

\section{LETTUCE}

Tettuce is represented by four distinct classes or types-by the thick-leaved, smooth-edged cabbage-heading type; the curly and

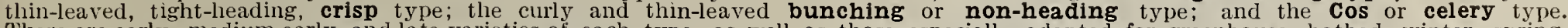

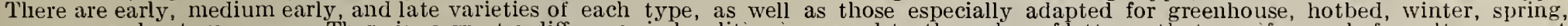
summer, and autumn uses. There is so great a difference in localities in regard to the value of lettuce, that a uniform rule for culture cannot

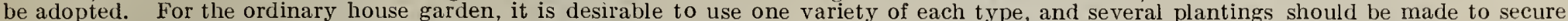

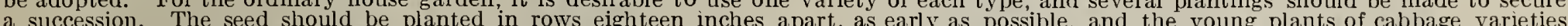
should be thinned to four inches apart. Varieties that do not head may be left quite thick, and when fairly well grown, those thinned out may be used.

BIG BOSTON A popular market variety, used largely in the South to grow winter lettuce for a light-green cabbage variety, slightly tinged with brown in the head. Has a particularly fine
buttery head. Pkt. 5c; oz. 15c; $1 / 41 \mathrm{~b} .40 \mathrm{4} ; 1 \mathrm{~b} . \$ 1.25$.

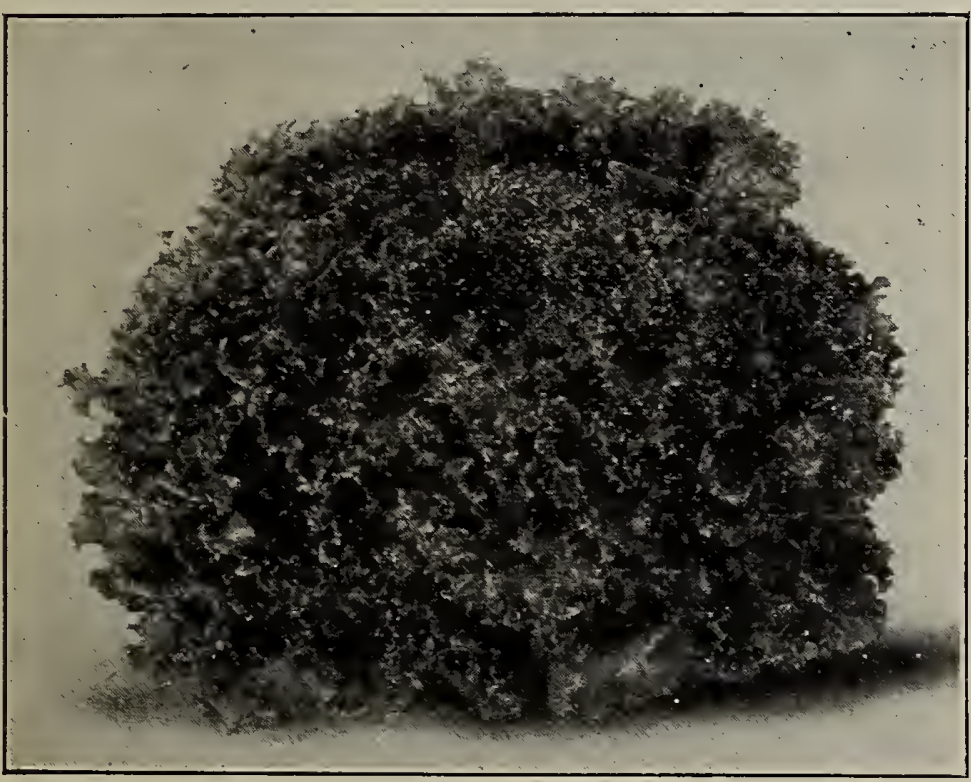

Grand Rapids

Black Seeded Simpson. A bunching variety, forming no definite head. It has a large mass of fine, brittle leaves of a light-green attractive color. Pkt. 5c; oz. $15 \mathrm{c} ; 1 / 4$ 1b. $40 \mathrm{c} ; 1 \mathrm{~b}$. $\$ 1.25$.

Black Seeded Tennisball. An old, well-known variety. Very desirable for hotbed culture in winter and for withstanding heat in summer. A light-green cabbage sort, forming hard heads. Pkt. $5 \mathrm{c}$; oz. $15 \mathrm{c} ; 1 / \mathrm{t} 1 \mathrm{~b} .40 \mathrm{c} ; 1 \mathrm{~b}$. $\$ 1.25$.

Boston Market. The well-known and popular hothouse variety of New England. Needs to be quickly grown to be of good flavor I ight-green cabbage variety, slightly tinged with brown on the head. Forms a compact, buttery head. Pkt. 5c; oz. 15c; $1 / 4$ lb. $40 \mathrm{c} ; 1 \mathrm{~b} . \$ 1.25$.

CALIFORNIA CREAM BUTTER or Rumal Cabbage. A very popular variety for autumn and winter use. Forms a very large head, which is very buttery, and of a rich golden-yellow inside. The leaves are thick and of bright green, slightly tinged with brown on top of head, and the outer leaves are slightly spotted with inconspicuous brown spots. Easy to grow and a good shipprow and a good ship-; oz. 15c; $1 / 4$ lb. $40 \mathrm{c}$; lb. $\$ 1.25$.

Deacon. A large cabbage variety having thick, bright green leaves; forms a large, buttery head; very brigh t golden-yellow inside. Pkt. 5c; oz. 15c; $1 / 4$ lb. 40c; ib. $\$ 1.25$.

Denver Market. A handsome variety, forming tight, conical heads, The leaves are very deeply savoyed, and even the outside leaves are tender and crisp. Color is light green. Pkt. 5c; oz. 15c; $1 / 4$ lb. $45 \mathrm{c} ; 1 \mathrm{~b} . \$ 1.50$.
Drumhead, or Malta. Sometimes called "Chinese" lettuce. A very large, tight-heading variety. Leaves are rather coarse, but very brittle and tender. Is dark green and slightly curled. Pkt. $5 \mathrm{c} ; 0 \mathrm{z} .15 \mathrm{c} ; 1 / 4 \mathrm{lb} .400 ; 1 \mathrm{~b}$. $\$ 1.25$.

Early Curled Simpson. A loose-bunching sort, forming no definite head. Is crisp and tender; light green in color. Is very hardy and easy to grow. Pkt. 5c; 0z. 15c; $1 / 4$ lb. 40c; $1 \mathrm{~b} . \$ 1.25$.

Grand Rapids. The well-known forcing variety for the middle West, where butter-headed or cabbage varieties do not grow well under glass. Is a loose-bunching variety, forming no definite head. Is extremely curly and its light yellowish-green color makes it very attractive. Pkt. 5c; 0z. 15c;1/41b.40c; 1 b. $\$ \mathbf{1 . 2 5}$.

HANSON A fine, large-heading variety. Leaves curled The on - the edges; light yellowish-green in color. The head is crisp and brittle, and flavor excellent. Is the very variety of its class. Pkt. 5c; 0z. 15c; 1/41b. 45c;1b. $\$ 1.50$.

Hubbard's Market. A large cabbage variety, forming a solid head, buttery, and yellow inside and of very fine flavor. Color light green. Is a favorite in some markets. Pkt. 5c; oz. 15c; $1 / 41 \mathrm{~b} .40 \mathrm{c} ; 1 \mathrm{~b}$. $\$ 1.25$.

Iceberg. A large-heading variety; crisp and brittle, and color bright green, lightly tinged with brown on top of the head: leaves curled on the edges. Pkt. 5c; 0z. 15c; $1 / 4$ 1b. $40 \mathrm{c} ; 1 \mathrm{~b}$. $\$ 1.25$.

Mammoth Black Seeded Butter. A very large, green cabbageheading variety similar to Salamander, but a third larger. Pkt. $5 \mathrm{c}$; 0z. $15 \mathrm{c} ; 1 / 4 \mathrm{lb}$. $45 \mathrm{c} ; 1 \mathrm{~b}$. $\$ 1.50$.

MAXIMUM, OR IMMENSITY A very large one of the lar larger than California Cream Butter, which it resembles in color and shape. It is especially adapted for planting in the fall and winter, and makes a fine tender buttery head. A number o our best local market gardeners have been growing it and find it unsurpassed for a fine heavy shipping variety.

Prof. R. E. Mansell of the Experiment Station at the University of California, who plants a very large number of samples annually, pronounces Maximum as entitled to lead
lettuces. Pkt. 5c;0z. $15 \mathrm{c} ; 1 / \mathbf{1 b} . \mathbf{4 0 c} ; \mathbf{1 b} \mathbf{\$ 1 . 2 5}$.

MAY KING A very early new variety, forming fine hard is medium sized, heads within a few weeks after planting. It There is just a faint tint of brown on the head.

There is just a faint tint of brown on the head. who have tried this variety. It is essentially a spring sort and does well all summer. Being of rapid growth and quick heading it is especially recommended for the home garden and is universally esteemed. It came to us from one of the leading growers in Germany and we are assured that it is as popular in Europe as America. Pkt. 5c; 0z. 15c; $1 / 1$ lb. 40c; 1b. \$1.50.

New York, or Wonderful. A large, crisp, tight-heading variety. Dark green, curly leaves; head large and of fine quality. Pkt. $5 c$; oz. 15c; $1 / 4$ lb. $40 c$; lb $\$ 1.25$

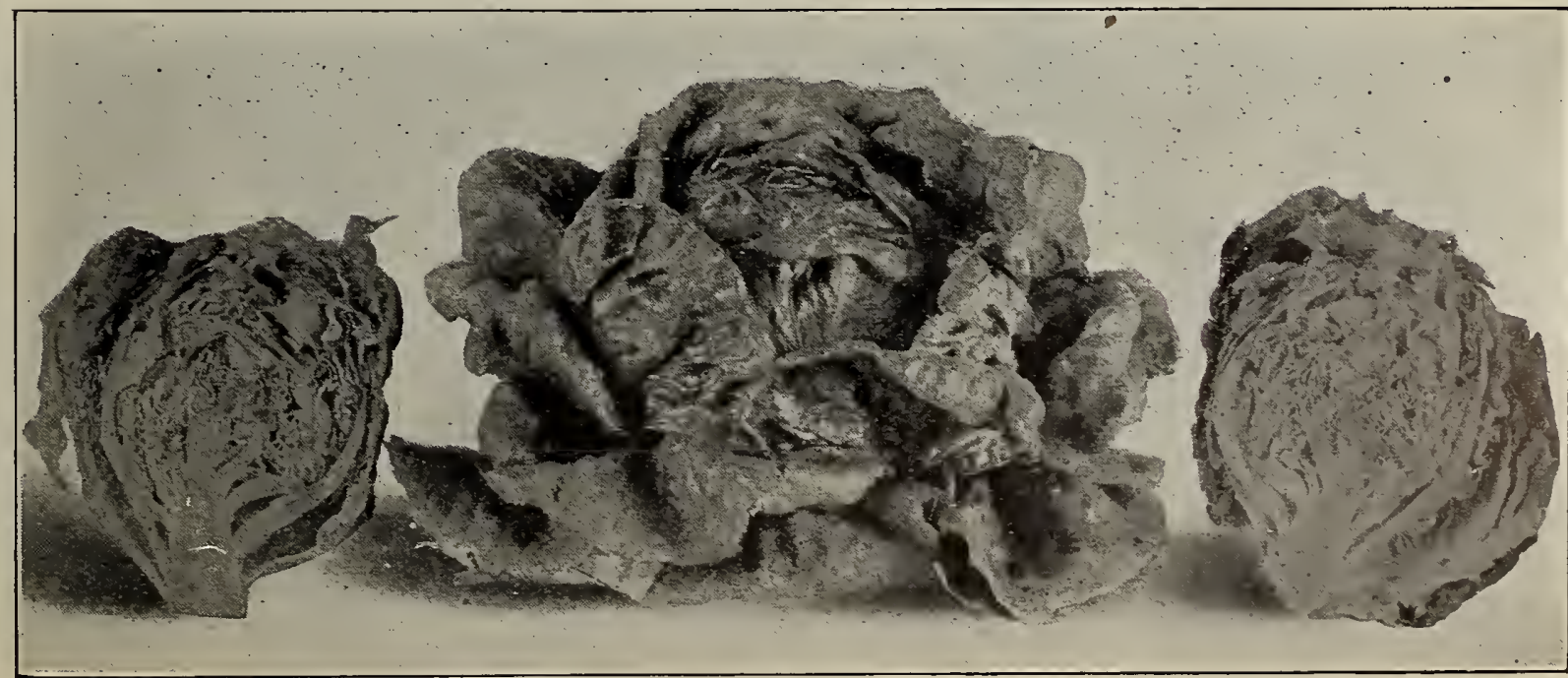

Maximum, or Immensity Lettuce-Immense Heads, very compact 


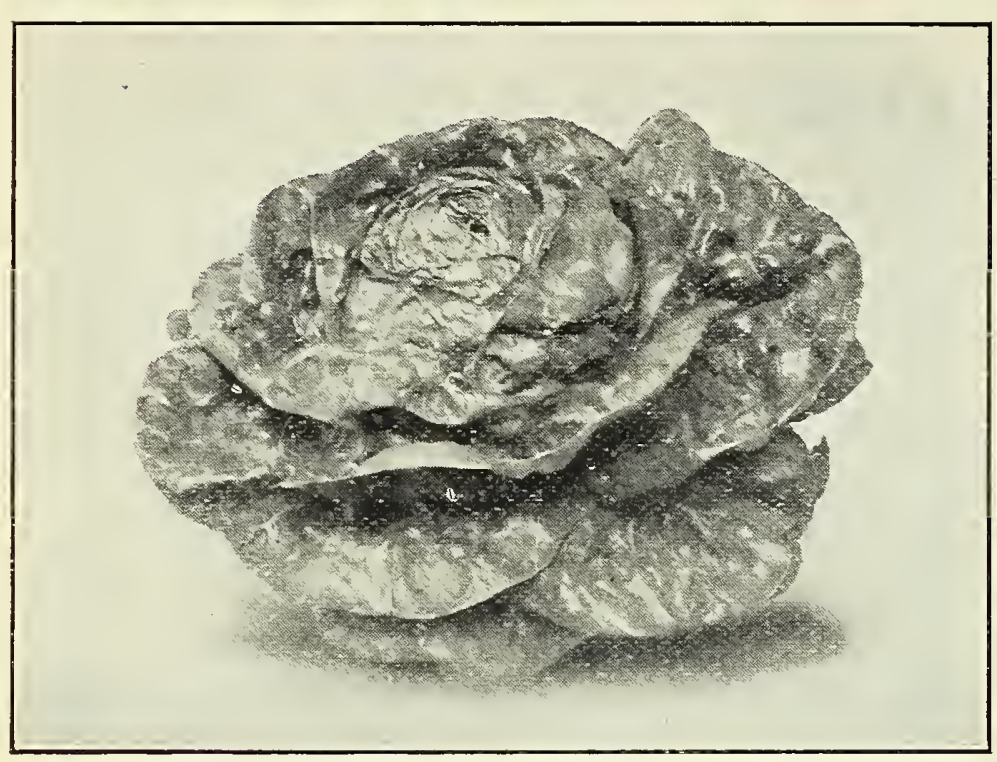

May King Lettuce-Very early and tender

PRIZE HEAD. One of the very best loose-bunching or non-heading varieties. Leaves brown, very curly, and of remarkably fine flavor. Grows quickly and all except the outer row of leaves are very brittle. It is probably the most easily grown lettuce in cultivation. Plkt. 5c; 0z. 15c; $1 / 4$ 1b. 40c; $1 \mathrm{~b}$. $\$ 1.25$.

Salamander. One of the most popular varieties for withstanding heat. Medium size, light green, and forms a hard, buttery head of fine quality. Pkt. 5c; 0z. 15c; 1/4 1b. 40c; 1b. \$1.25.

PASSION The most popular variety among California and New bage, butter-heading sort. We have the best and truest stock of this variety that can be obtained. It is especially recommended as a garden lettuce for our climate. It heads well, and bears shipping remarkably well, since it re1b. $45 \mathrm{c} ; 1 \mathrm{~b}$. $\$ 1.50$.

THE MORSE A large, loosenon-heading variet $y$,
forming a large bunch of leaves, which are very crisp and of fine flavor. and very a tractive. Pkt. $5 \mathrm{c}$; oz. 15c; $1 / 41 \mathrm{~b}$.

$$
\text { Plzt. 5c;0z. 15c; } 1 / 4
$$

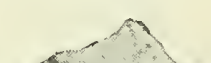

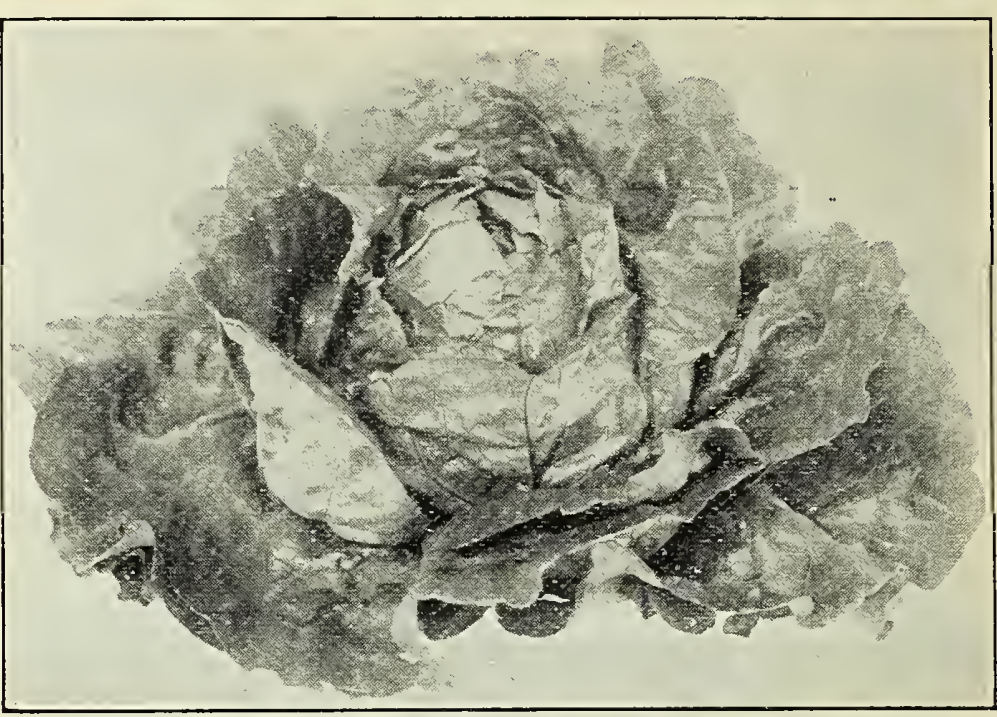

Big Boston Lettuce

Strawberry. Our last season's novelty. A medium-sized variety with hard, compact heads. Brownish-red on the surface and having pink colored heart. Pkt. 5c; oz. 20c.

White Seeded Tennis Ball. This variety is the same as Boston Market, which see for description. Pkt. 5c; oz. 15c; $1 / 41 \mathrm{lb} .40 \mathrm{c}$; lb. $\$ 1.25$.

White Summer Cabbage. The oldest and best known cabbageheading variety. Forms a medium-sized, hard head of fine quality. Pkt. 5c; 0z. 15c; $1 / 4$ 1b. 40c;1b. \$1.25.

WHITE PARIS COS. The best of the Cos or celery varieties. Forms a large, light-green plant, with the head well folded and quite
solid. Cos lettuce is also called Romaine, and is very popular with our foreign population, for it is highly prized in England and France, while little known to our own people. Pkt.5c; oz. 15c; $1 / 41 \mathrm{~b}$. 40c; $1 \mathrm{~b}$. $\$ 1.25$.

Our great LETTUCE FIELDS on our seed farms are almost world famous We exhibited some very large views of these fields at the World's Fair at St. Louis and they attracted more than usual attention. In miniature form these fields are now illustrated on pages 3
and 6 of this catalogue. Imagine these

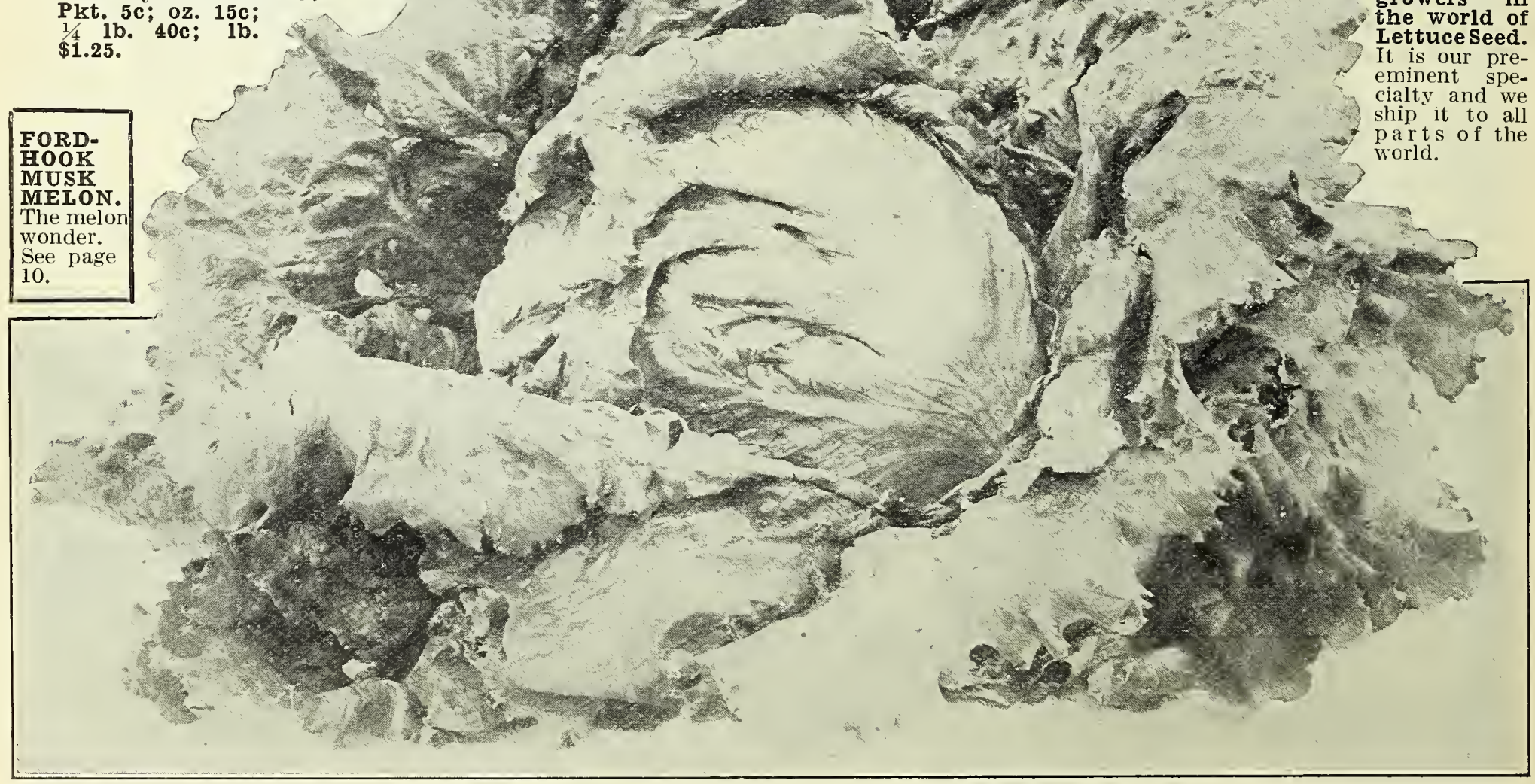

Hanson Lettuce-One of the very best garden varieties 


\section{SAN FRANCISCO CALIFORNIA U.S.A.}

\section{MUSKMELON OR CANTALOUPE}

Plant in hills in rich, moist land, using one ounce to 100 hills, or two to three pounds per acre. Sow the seed after all danger of frost is over

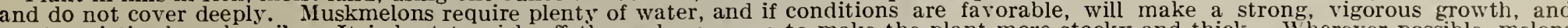

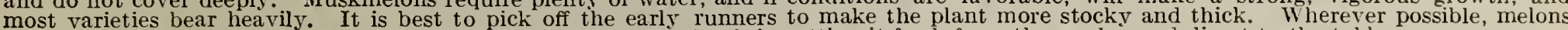
should be grown in the home garden, for the charm of a good melon is in getting it fresh from the garden and direct to the table.

Acme, or Early Baltimore. One of the best all-round melons in cultivation and recommended for its uniform shape and size and fine quality. Is slightly pointed at stem end; somewhat ribbed and coarsely netted. The flesh is thick, green, and very sweet. Pkt. 5c; oz. $15 \mathrm{c} ; 1 / 4$ Ib. $40 \mathrm{c} ; 1 \mathrm{~b}$. $\$ 1.25$.

Bay Vlew. A standard variety. Fruit large, oblong, heavily ribbed and netted. Flesh light green and of good flavor. Pkt. 5c;0z. 15c; $1 / 41 \mathrm{~b} .40 \mathrm{c} ; 1 \mathrm{~b}$. \$1.25.

BURRELL'S GEM A medium sized oval variety deeply flesh. It is larger than Rocky Ford and of an entirely distinct flavor. There is a growing demand for the fine grained, smooth salmon-red fleshed muskmelons and Burrell's Gem seems to be one of the best in cultivation. Pkt. 5c;0z. 20c; $1 / 41 \mathrm{~b} .60 \mathrm{c}$; Ib. $\$ 2.00$.

Extra Early Citron. A very early, medium-sized variety. Fruit ball-shaped, skin green, and flesh light green. Very productive $40 \mathrm{c} ; 1 \mathrm{~b}$. $\$ 1.25$

Emerald Gem. A salmon-fleshed variety of remarkably fine flavor and fine quality. Fruit medium sized, globular, slightly flat tened at the ends; skin only slightly netted; very thick, and wel ripened close to the rind. Pkt. 5c;0z. $15 \mathrm{c} ; 1 / 41 \mathrm{~b} .40 \mathrm{c} ; \mathrm{Ib} . \$ 1.50$.

Extra Early Hackensack. An early variety with almost globular fruit, which is heavily ribbed and heavily netted. Flesh thick,
and light green. Pkt. 5c;0z.15c;1/4 lb.35c;1b.\$1.25. (see cut)

Hackensack, or Turk's Cap. An excellent green-flesh variety with flattened ends, thick, irregular ribs, and coarse netting. The flavor is sweet and delicious. Pkt. 5c;0z. 15c; $1 / 41 \mathrm{lb} .40 \mathrm{c}$; 1b. $\$ 1.25$.

THE HOODOO Unlike its unpropitious name, this introductions. It is early and prolific. The fruit is of medium size; the seed cavity very small; the rind very thin indeed; and the edible fleshy part very thick and meaty. It is of orange or salmon color, the type much preferred now. But its great charm is its flavor. which is par excellence. We have seldom had such enthusiastic reports from any vegetable novelty as from the Hoodoo Muskmelon. It will pay jou to try it. Pkt. 10c; 0z. 35c;1b. $\$ 3.50$.

Jenny Lind. Very early and very prolific. Fruit is small, somewhat flattened, deeply ribbed and nctted. Flesh green and very sweet. Pkt. 5c; oz. 15c; $1 / 41 \mathrm{lb} .40 \mathrm{c} ; 1 \mathrm{~b}$. $\$ 1.25$.

Iarge Yellow Cantaloupe. Although there are several varieties frequently substituted for this sort, we have a distinct type, and find it very popular with all who have tried it. The fruit is large. oblong, slightly ribbed and coarsely netted. The flesh is light licious. PEt. 5c; oz. 10c; $1 / 4$ Ib. 35c; 1b. $\$ 1.10$.

Melrose. A fine shipping variety owing to the rather tough skin. Fruit is slightly oval, very much netted but not ribbed. Flesh light green, shading to salmon at seed center, and of $5 c ; 0 z$ 15c: $1 / 1$ ib $40 c$ : 1b. $\$ 1.25$.

Montreal Market. A large-fruited variet $\mathrm{v}$ nearly globular with flattened ends. $\mathrm{Sk}$ in dark green; heavily net ted. Flesh light green. Pkt. 5c; oz. 15c; $1 / 4$ Ib. $40 \mathrm{c}$; $1 \mathrm{~b}$. $\$ 1.50$.

Osage, or Miller's Cream. A salmon-flesh variety.

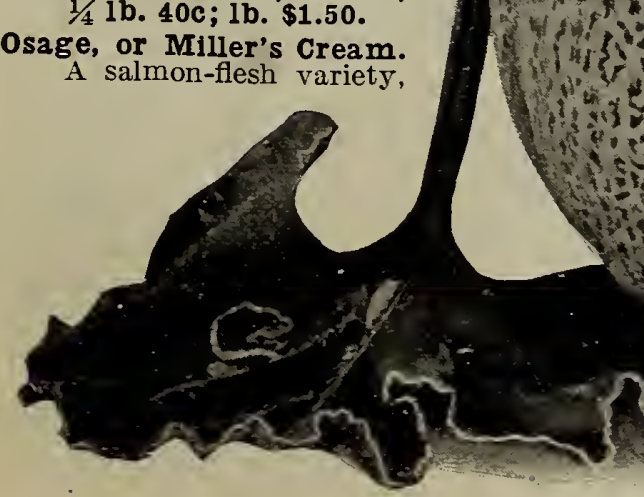

Extra Early Fackensack Muskmelon

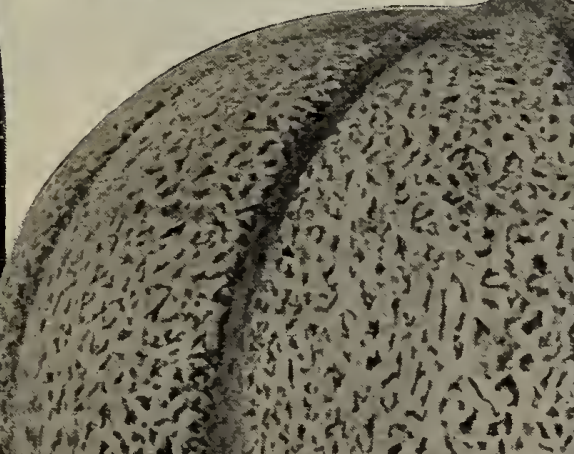
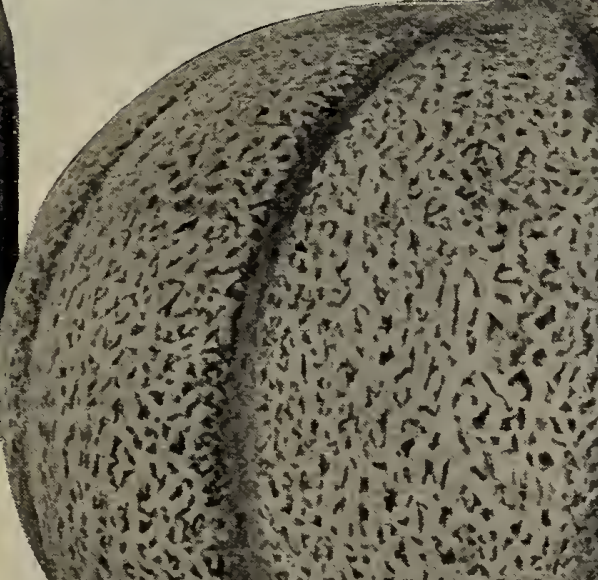

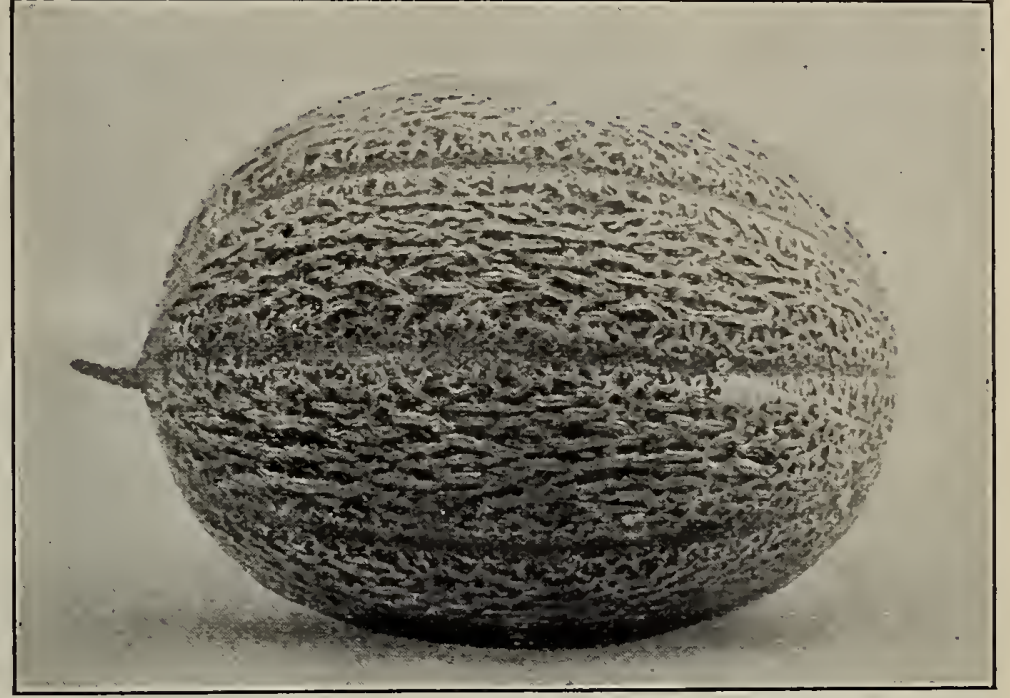

Rocky Ford-The most largely grown Muskmelon

larger than "Emerald Gem." Skin dark green, slightlv netted and ribbed. A favorite variety for the later markets. Pkt. 5c; Oz. $15 \mathrm{c} ; 1 / 4 \mathrm{~b}$. $40 \mathrm{c} ; 1 \mathrm{~b}$. $\$ 1.25$.

KRIS KRINGLE THE NEW WINTER MUSKMELON. vegetable world and is destined to become a standard vegetable just as much so as potatoes or onions. The seed should be sown late in the spring after all dan er frost is over on moist sandy loam. Do not pick until the light streaks become quite yellow. Stow away so they do not touch each other in a cool, dark place. When the rind becomes slightly softened and moist they are ready to eat. Some of the melons will actually keep until February. Pkt. 10c; 0z. 25c; $1 / 4$ Ib. 75c; 1b. \$2.50.

Petoskey, or Paul Rose. Excellent market variety with thick, firm, orange-colored flesh. Rather larger than Netted Gem; is slightly oval, ribbed, and heavily netted. Skin light green. $15 \mathrm{c} ; 1 / 4 \mathrm{lb}$. $45 \mathrm{c} ; 1 \mathrm{~b}$. $\$ 1.50$.

ROCKY FORD OR NETTED GEM. The riety in use. Grown in great quantities in Colorado. Fruit is slightly oval, finely netted, and slightly ribbed. Flesh thick, green, very sweet, and of fine areas of land devoted to the Rocky Ford or variety Melon, that there is but one variety in cultivation. In fact, there and it is this variety. It gives equally splendid results in the home garden and is the best all round variety to plant. Some of the best melons in the market the past season came from the Imperial Valley, a new and rapidly growing melon section of California and the best of them were the Rocky Ford variety. Pkt. $\$ 1.00$.

Large Green Nutmeg.

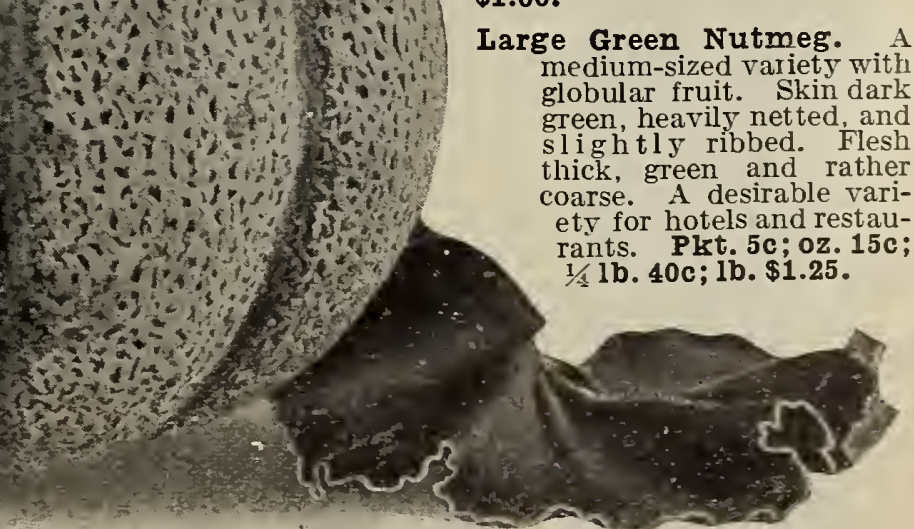




\section{C.C.MORSE \& CO VEGETABLE SEEDS}

\section{WATERMELON}

Light, sandy, or gravelly soil is necessary for the best watermelons. They seldom do well on heavy adobe or clay soils, and these lands

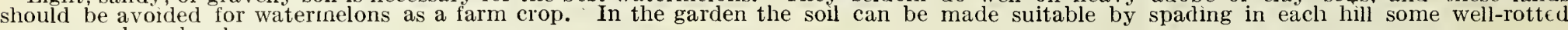

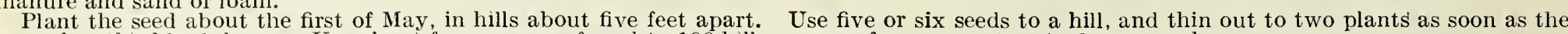
second or third leaf shows. Use about four ounces of seed to 100 hills, or as a farm crop, two to four pounds per acre.

There are five decidedly popular watermelons on the Pacific Coast, each very different and each of particularly fine quality and superlative

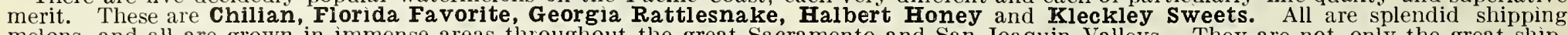

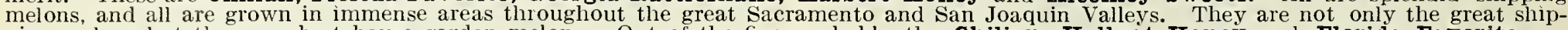

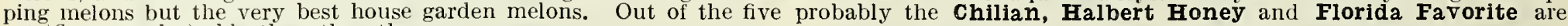
a trifle more desirable than the others.

EASTERN GROWN SEED-For some reason, not wholly understood, watermelon deteriorates if the seed is constantly grown in the

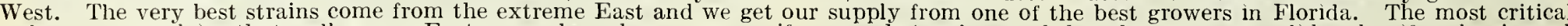

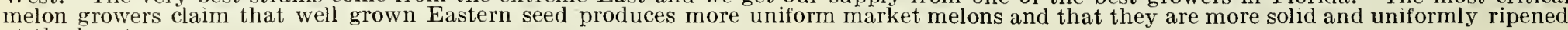
at the heart.

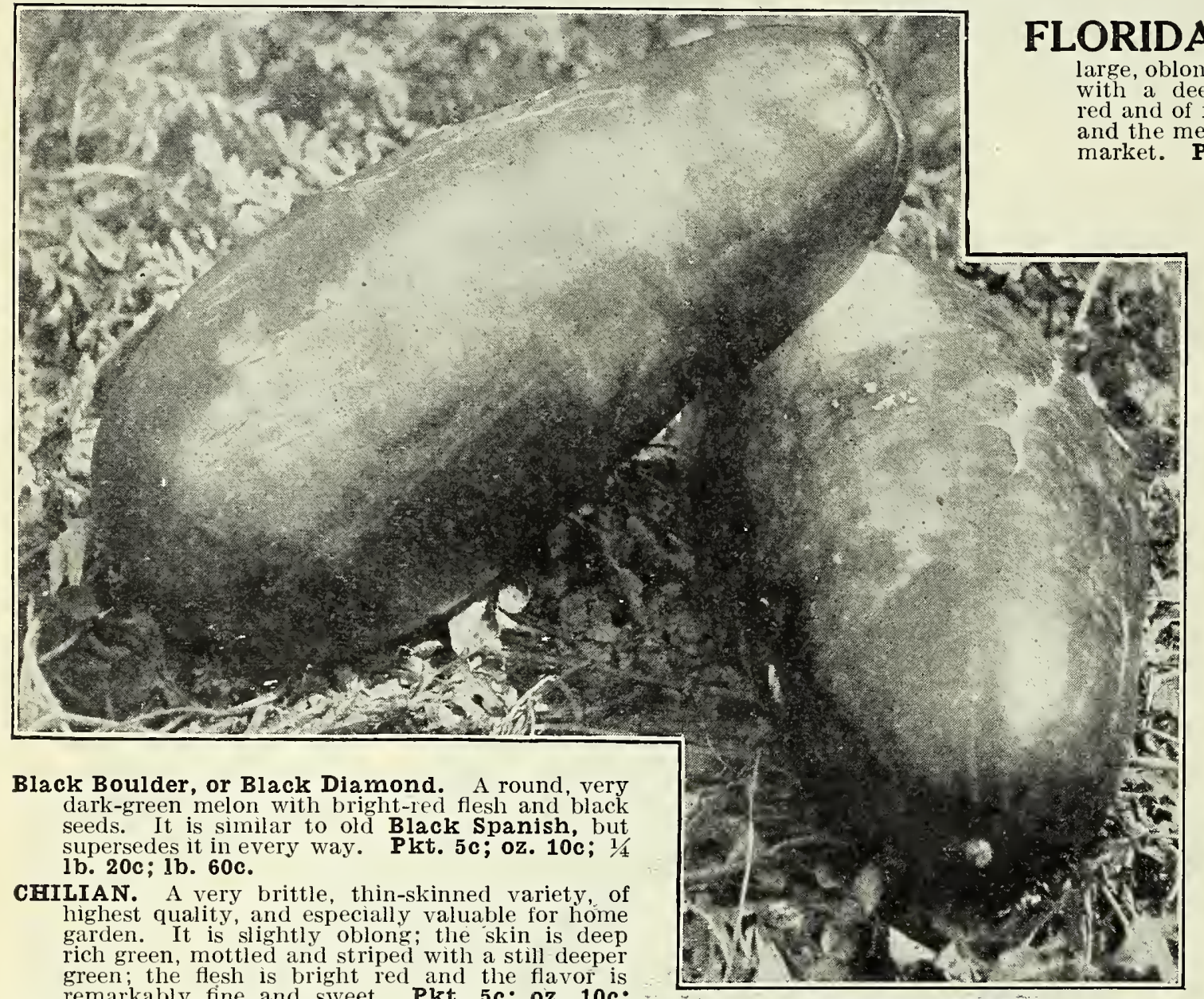
remarkably fine and sweet. Pkt. 5c; oz. 10c: $1 / 4$ lb. 30c; 1b. $\$ 1.00$.

Citron, Red Seeded. A small, globular variety, striped and marbled with light green. Flesh white and solid seeds red. Used exclusively for pickles and preserves. Pkt. 5c;0z. 10c; $1 / 41 \mathrm{~b} .25 \mathrm{c} ; 1 \mathrm{~b} .75 \mathrm{c}$.

Citron, Green Seeded or Colorado Preserving. A small ball shaped variety, brightly striped with light and deep green. The flesh is green with green seeds and is used largely for stock feed them to cattle in the field. Pkt. 5c; 0z. 10c; 1/4 1b. 25c; 1b. $75 \mathrm{c}$.

Cole's Early. A great favorite for a large area of different climates. Fruit medium sized, oblong, striped and mottled. Flesh, bright
red, solid, and of fine, sweet flavor. Pkt.5c;0z.10c;1/1 ib. 25c; red, solid,

Cuban Queen. An excellent shipping variety of medium to large size, and globular to oval shape. Rind quite thin, flesh bricht . Skin striped with light and dark green. Pkt. 5c oz. $10 \mathrm{c} ; 1 / 4$ ib. $25 \mathrm{c} ; 1 \mathrm{~b} .75 \mathrm{c}$.

Dark Icing. Fruit large, nearly globular. Skin dark-green, sort of mottled indistinctly with lighter green. Flesh deep pink and of fine flavor. Pkt. 5c; oz. 10c; $1 / 4$ lb. 25c; 1b. 75c.

Dixie. A good market variety with large, oblong fruit. Skin striped light and dark green. Rind thin but tough. Flesh bright red. Pkt. 5c;0z. $10 \mathrm{c} ; 1 / 4$ ib. $25 \mathrm{c} ; 1 \mathrm{~b} .75 \mathrm{c}$.

Fordhook Early. The earliest of all melons and of the finest quality. Fruit almost globular; color deep mottled green with occasional faint stripes of lighter green; flesh bright red and crisp; rind tough, which makes it a good shipping variety. Pkt. 5c; oz. $10 \mathrm{c} ; 1 / 4 \mathrm{lb} .25 \mathrm{c} ; 1 \mathrm{~b} .75 \mathrm{c}$. $25 \mathrm{c} ; 1 \mathrm{~b} .75 \mathrm{c}$.
Kleckley Sweets red and very sweet. It is the that makes it especially distinct Kolb's Gem. The well-known shipping variety. The fruit is large thick, and oval, with flattened ends. Skin striped with light and dark green. Flesh bright red. Pkt. 5c; oz. 10c; $1 / 41$ b. 25c; 1b. $75 \mathrm{c}$.

Mountain Sweet. A good home-garden variety and an old favorite. Fruit large and oval; skin green

Sweet Heart. A very productive and fine shipping variety. Fruit large, oval, with thin but firm rind. Ilesh bright red, solid, and sweet. Skin light mottled green. Pkt. 5c;0z. 10c; $1 / 41 \mathbf{b}$.

The Lodi, or San Joaquin. Well-known and popular California rariety on variety, grown on an immense scale in San Joaquin Valley and shipped to all parts of the Pacific Coast. Fruit large and oblong, red and sweet; seeds white. Pkt.5c;0z.10c; $1 / 41$ b. 25c;1b. 75c. NOTE.-Watermelon. There is a well established opinion among the larger watermelon growers throughout the San Joaquin valley that certain sections on the Atlantic Coast produce seed of very superior quality, in that the fruits are of even size, uniform shape and the heart more solid and firm and evenly ripened than western grown seed. The matter of growing good seed is always and anywhere a matter of honesty and intelligence and a certain section would have no preference except that the seed grower was a capable grower. We believe the watermelon we offer here is properly grown and it comes from the extreme Atlantic Coast in Florida. 


\section{GEORGIA}

RATTLESNAKE

One of the oldest and most popular sorts and freGuently. k llow $n$ a as variety with decided stripes, of liglit and deep green. Rind is tough but flesh is of good quality and bright red: a good shipping and market melon. Is quite as generally used by the large melon growers as Kleckley Sweets and is perhaps hardier and more profitable, being 5c; oz. 10c: $1 / 4$ lb. 25c; 1b. $75 \mathrm{c}$.

\section{NASTURTIUM}

The green seed of nasturtium has a sharp, pungent flavor, and when pickled makes an excellent condiment It is also valuable as a flower and serves a double purpose in the garden. Pkt. 5c; .oz. 10c; $1 / 4$ ib. 25c; 1b. 75 c.

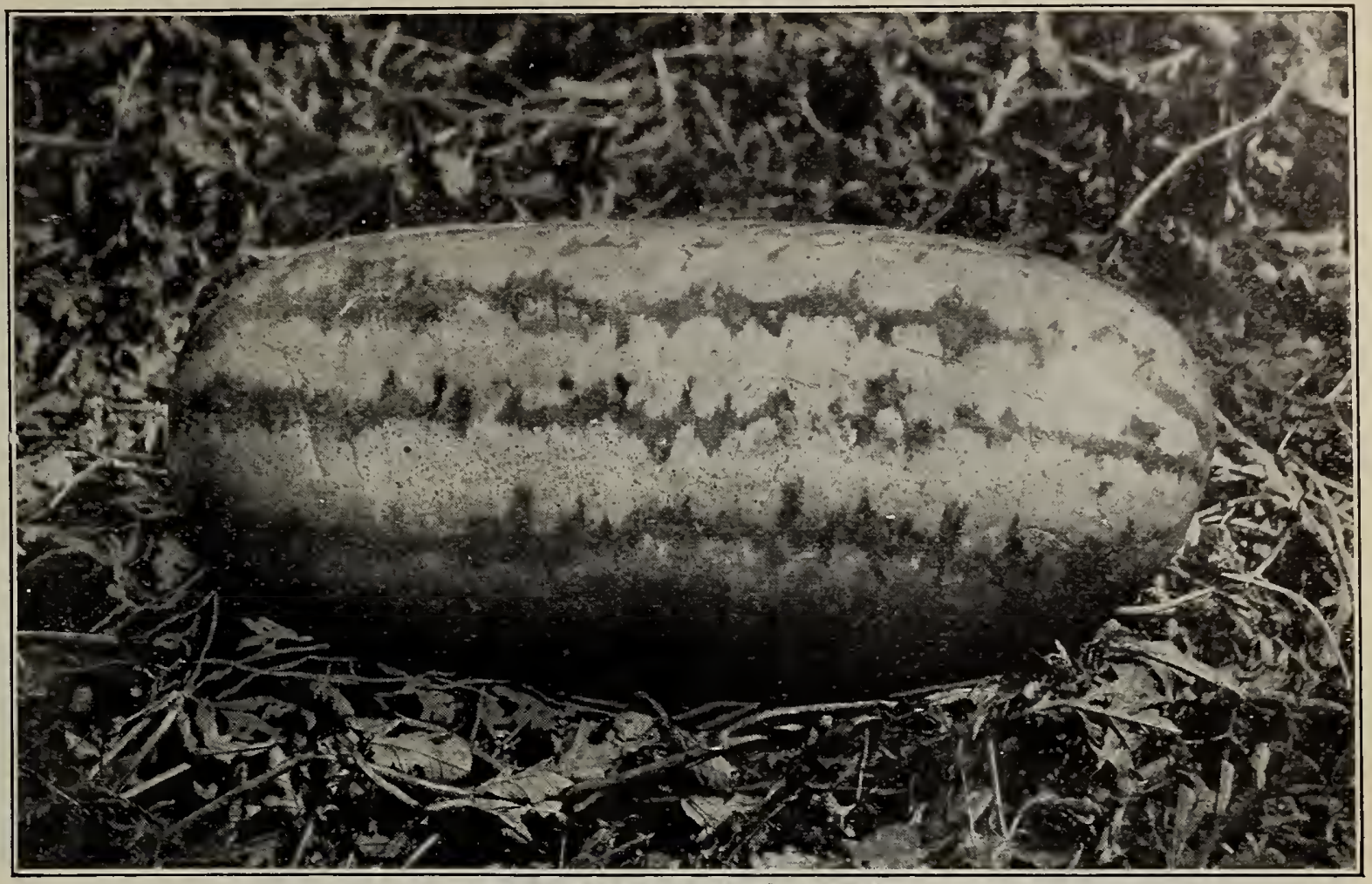

Georgia Rattlesnake Watermelon

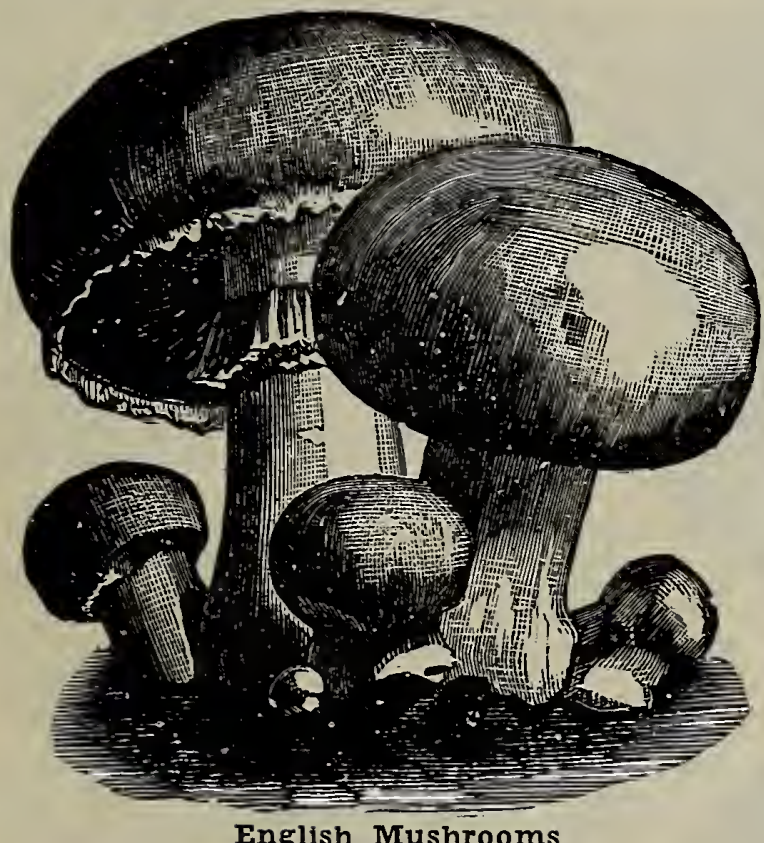

MUSHROOM SPAWN CULTURAL DIRECTIONS

Ten pounds will spawn about ten feet square. Mushrooms can be grown in any dark room or cellar where the temperature can be kept at from 50 to 70 degrees. From some old pasture procure good rich soil, and to every bushel of this soil add two bushels of fresh horse manure. Of this well-mixed compound prepare a bed, say four feet wide. Put down a thin layer and pound it down hard, and go on until you have a bed twelve
or eighteen inches thick. As soon as the temperature of the bed falls from 75 to 50 degrees, the spawn may be inserted in pieces about the size of a walnut about two inches deep and six inches apart. Cover with loamy soil about two inches deep and beat it down evenly and firmly. Finish off with a covering of clean hay, about a foot thick, and the work is done. If the temperature is right, in six or eight weeks you may ter the first crop is gathered spread over the bed an inch of fresh soil, moisten with warm water and cover with hay as before. The main conditions in mushroom-growing are proper and uniform temperature and very rich soil.

English Mushroom Spawn. It comes in pressed bricks weighing about twenty ounces. Brick, 35c, postpaid; by express, brick 20c; $10 \mathrm{lbs} . \$ 1.50$

\section{MUSTARD}

The leaves of these varieties of mustard, as here listed, make excellent greens of sharp, pungent flavor, and are cooked the same as spinach or beet leaves. Sow the seed in drills early in the spring and at frequent intervals throughout the summer to secure a constant supply of fresl greens. Mustard is hardy and is easily grown. One ounce will sow fifty feet of row.

Chinese. A very hardy, broad-leaved variety. Leaves are thick and deeply savoyed, with broad white midi

GIANT SOUTHERN CURLED

Large variety, forming a leaves, which are ruffled and finely curled on the edges. Hardy, vigorous, highly recommended. Pkt. 5c; 0z. 10c; $1 / 4$ lb. $15 \mathrm{c}$; 1b. 50c.

Fordhook Fancy. A very handsome variety with dark green foliage. Leaves very finely curled on the edges. Plant medium sized. Pkt. 5c; White English. Light-green variety; tender leaves.
oz. 15c; 1/1 1b. 25c; 1b. 90c.

\section{OKRA, OR GUMBO}

The long, tender pods of okra are very delicious when sliced and cooked in soups. While this is its chief use it is also boiled and served like other classes of vegetables. The tall sorts should be planted in hills about a foot apart, using about one ounce to 100 hills. The dwarf sorts may be planted in hills or in rows about three feet then very tender.

PERKINS MAMMOTH LONG

POD A dwarf-growing, very early and prolific

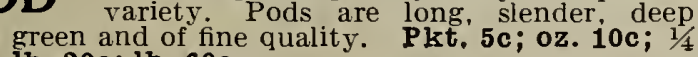
1b. $20 \mathrm{c} ; 1 \mathrm{~b} .60 \mathrm{c}$.
White Velvet. A medium-sized variety, bearing long, smooth, white pods, which are very tender. long, smooth, white pods, which are

DWARF GREEN. An early, dwarf, and prolific variety with thick, green pods. Pkt. 5c; oz. $10 c ; 1 / 11$ b. 20c; 1b. 60c.

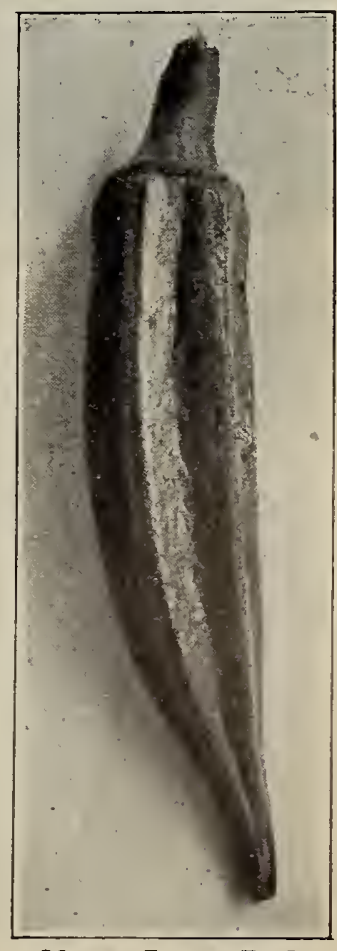

Okra-Long Pod 


\section{ONIONS}

\section{HOW TO GROW ONIONS FOR MARKET}

The most essential item in growing onions for market is good seed-seed that will come up and seed that will produce the variety you want-cheap seed is very poor economy.

For general crop, the seed must be sown during the month of January or before February 1st, and, if the location is a fairly dry one, it is best

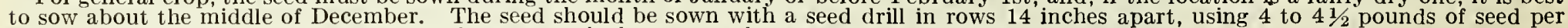
acre. In very weedy land the rows may be 18 or 20 inches apart when less seed is required.

For planting a single row of onions among strawberry plants about 2 pounds of seed per acre is sufficient.

The land must be thoroughly worked before planting, and usually two good plowings, a good disking, and a harrowing are necessary.

The crop must always be kept free from weeds, and it is usually necessary to weed out in the row by hand once or twice. Hoeing between

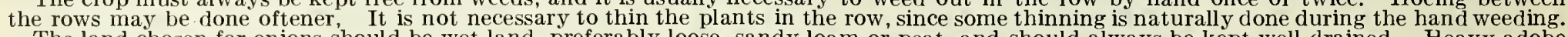
The land chosen for onions should be wet land, preferably loose, sandy loam or peat, and should always be kept well drained. Heavy adobe

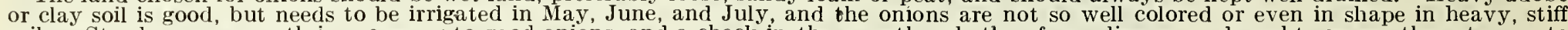

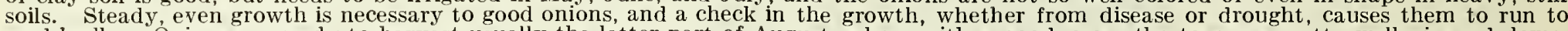

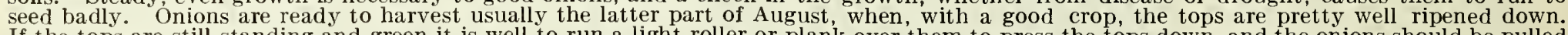

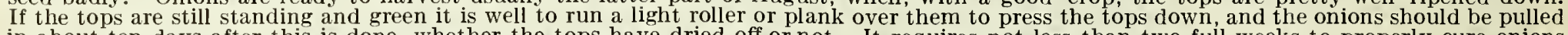

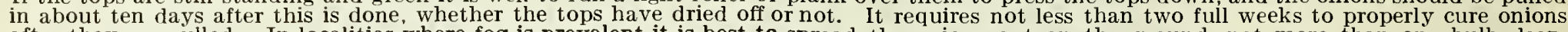

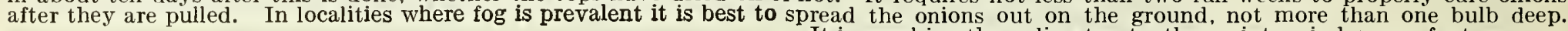

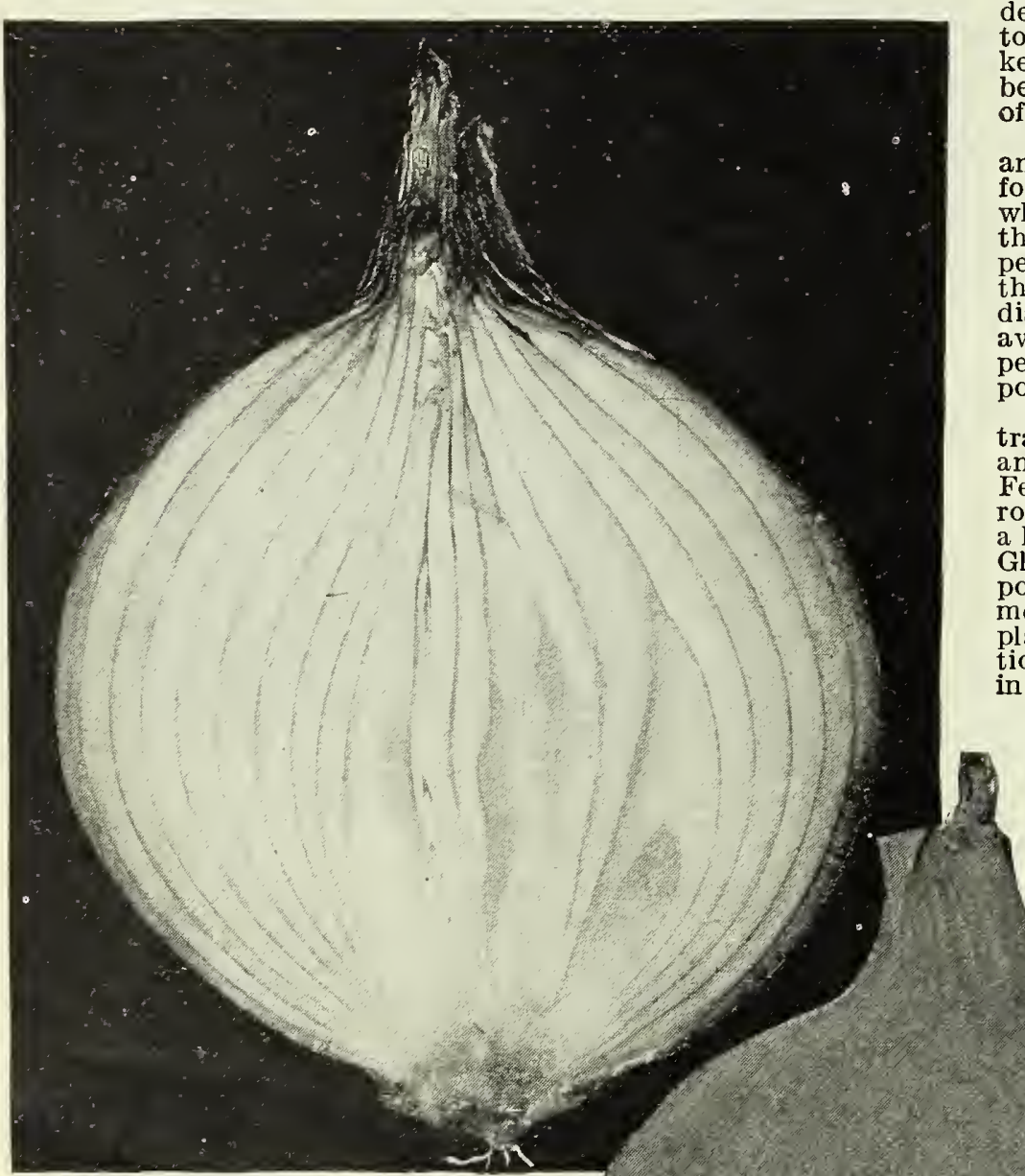

Prize Taker

Australian Brown. An early and very hardy variety which does especially well in the South. Should be planted early, on low, Wet grounds to get large bulbs. is a rich brown. Is especially is a rich brown. Is especially well into spring, and much longer than other varieties. Pkt. 5c;

California Early Red. A variety much used for very early onions. If the seed is sown in beds in August and set in the field in November or December, good market onions can be had in May. It is not a good-keeping variety, but is of very mild flavor and of fine quality. Is very much esteemed as a green onion before the bulb is formed. Pkt. 5c; oz. 15c: $1 / 41 \mathrm{~b} .45 \mathrm{c} ; 1 \mathrm{~b}$. $\$ 1.50$.

Crystal White Wax. A pure white variety, very flat and extremely early. Is of the Bermuda type and the It is usual in other climates to throw into windrows a foot or more deep and cover lightly with straw or dried tops. It is best not to top and sack until ready to ship to market, and if onions are to be top and sack until ready to ship to market, and if onions are to be be put under cover on a floor or in a bin with abundant circulation of air, and be kept absolutely dry.

The value of an onion crop is naturally dependent on the market and on the character of the land planted. Land that is very foul should usually be avoided as too expensive. Also avoid land which has just had a hay or grain crop, and if possible use land that has been planted to vegetables or some hoed crop, especially peas and beans. An onion crop should not be repeated-more than three times on the same land, and usually twice is best, since onion diseases (of which there are many) aprear very plentifully. An average crop runs from 150 to 200 centals $(15,000$ to $20,000 \mathrm{lbs}$.) per acre, and the cost represented by labor, rent, sacks, and transportation is estimated roughly at $\$ 75$ per acre

Another very good system of growing fancy market onions is by transplanting. By this method the seed is sown in beds in August and September, and the plants are pulled and transplanted about February 15th to March 1st. Put the plants 6 inches apart in lateral rows, 14 inches apart when they rake a uniform sized bulb and also a hard and firm one. This plan is especially recommended for the Globe varieties, since they do best under this treatment. About 2 method. The expense is considerably greater than by the ordinary plan, and should be roughly estimated at $\$ 100$ per acre. The additional cost is simply in labor in transplanting, for there is some saving in hoeing and hand weeding.

Unless the land is porous and friable and also very moist all through the summer, this method is usually unsuccessful and is not recommended. The seed should never be sown later than September $15 \mathrm{th}$, and the transplanting should never be done later than March 15 th.

best strains come from Teneriffe, Canary Islands, where we receive our supply. The beautiful clear white onion seen in our markets in crates, early in the spring, is this variety. Pkt. 5c; oz. 50c; $1 / 4$ ib. $\$ 1.50 ; 1 b . \$ 5.00$

El Paso. A large white globe Italian variety. The grain is rather coarse and the flavor mild. It is not a good winter sort, but is unsurpassed as a garden

Extra Early Pearl. A very early variety with white skin, rather coarse grain and mild flavor. In shape it is flat and is unsurpassed for early sets or home-made pickles. Pkt. 5c; oz. 25c; $1 / 41 \mathrm{~b} .65 \mathrm{c} ; 1 \mathrm{~b}$. $\$ 2.25$.

Extra Early Barletta. Extremely early variety. Seed planted in February will form ripe onions the last of July. Is a white onion. forming small bulbs about one inch in diameter. Valuable for home-made pickles. Pkt. 5c; oz. $25 \mathrm{c} ; 1 / 41 \mathrm{~b}$. 65c; 1b. $\$ 2.25$.

Extra Early Golden Globe, or Australian Extra Early Yellow Globe. A handsome and valuable yellow globe-shaped variety. It is very early and extremely hard and firm, and almost as good in long-keeping qualalmost as good in long-keeping qualvery uniform in shape, is of good average size, and perfectly globular. The skin is rich orange yellow and The skin is rich orange yellow and
the flesh is quite strong and fine
Pkt. 5c;0z. 25c;1/4 1 b. 75c; $1 \mathbf{b . ~} \mathbf{\$ 2 . 5 0}$. grained. Pkt. 5c; oz. 25c; $1 / 41$ 1b. 75c; 1b. $\$ 2.50$.

Extra Early Red Flat. A very early, flat varietv with dark purplish-red skin. Forms a hard bulb with good keeping qualities. Pkt. 5c; oz 20c; $1 / 41 \mathrm{lb}$. 60c; $1 \mathrm{~b}$. \$2.00.

NOTE-If in doubt about what variety to sow, make it Morse Brown Globe, and you will make no mistake. 


\section{WHITE PORTUGAL, OR SILVERSKIN}

The best-known and most largely used white onion. Is flat on the bottom and thick toward the top. Very hard and firm and an excellent keeper. Is largely used for white onion sets as well as for market onions and pickles. Pkt. 5c; 0z. 30c; $1 / 4 \mathbf{1 b}$. 90c; 1b. \$3.00. (See Cut, page 33.)

White Queen. A very early white onion. Rather small and does not keep well. Is of fine, mild flavor and largely used for homemade pickles. Pkt. 5c;0z. 25c; $1 / 4$ 1b. 65c;1b. \$2.25.

NOTE-The Yellow Danvers is frequently called Silverskin on the market, but this is an error, for the true Silverskin is a white, flat onion. We recommend as heavy croppers and adapted practically to all localities the Aust
low Danvers and Ohio Yellow Globe.

C. C. Morse \& Co., grow more acres and sell more seed of onions than any other seed establishment in the world, and we hold the highest reputation for supplying the best onion seed on the market.

\section{PARSNIPS}

A well-known vegetable for table use. It is also a very good stock food and quite as nutritious as carrots. It prefers very wet soil, and will thrive where the roots are very long, and are difficult to dig in stiff soil. Sow the seed in the spring in drills, using onefourth ounce to 100 feet. In the field sow in rows twelve inches apart, using three pounds per acre.

Early Short Round French. A flat, turnip-shaped variety. Of rather coarse grain, and not as good quality as the long varieties, but early and easy, 1b. $20 \mathrm{c} ; 1 \mathrm{~b}$. $50 \mathrm{c}$.

\section{HOLLOW CROWN}

A variety with a hollow or cup-shaped top, where the popular and best variety popular and best variety and white, and flesh tender, while the root grows eighteen to twenty inches long. The best part of it is coninches from the top. Our strain of Hollow Crown is the thick - shouldered type dealers. It is particularly Pkt. 5c; oz. 10c; $1 / 4$ lb. 20c; 1b. 50c.

Iong Smooth. A very long variety with

Pkt. 5c; oz. $10 \mathrm{c} ; 1 / 4$ lb. 20c; 1b. 50c.
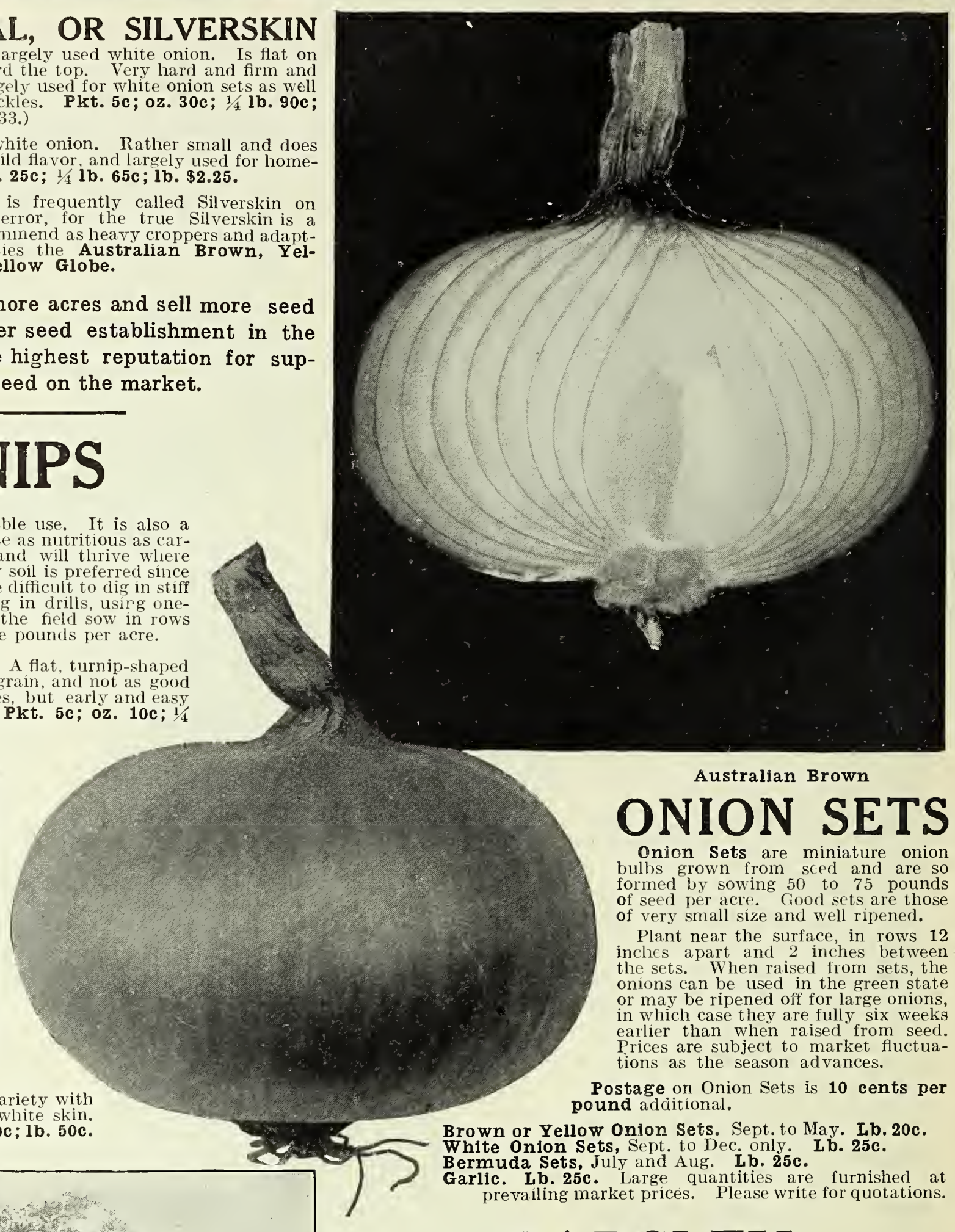

Onion Sets are miniature onion bulbs grown from sced and are so bulbs grown from sced and are so of seed per acre. Good sets are those of very small size and well ripened.

Plant near the surface, in rows 12 inches apart and 2 inches between the sets. When raised from sets, the onions can be used in the green state or may be ripened off for large onions, in which case they are fully six weeks earlier than when raised from seed. Prices are subject to market fluctuations as the season advances.

Postage on Onion Sets is 10 cents per pound additional.

Brown or Yellow Onion Sets. Sept. to May. Lb. 20c.

White Onion Sets, Sept. to Dec. only. Lb. $25 \mathrm{c}$

Bermuda Sets, July and Aug. Lb. $25 \mathrm{c}$

Garlic. Lb. 25c. Large quantities are furnished at prevailing market prices. Please write for quotations.

\section{PARSLEY}

Used for garnishing dishes of meat, or cooked in soups. A few plants in the garden will yield sufficient for a family, providing the leaves are cut oiten and the plant not allowed to seed. Sow the seed in drills early in spring, using one-fourth of an ounce to 100 feet.

Champion IMoss Curled. A very finely curled, bright-green and very ornamental variety. Pkt. 5c;0z. 10c; $1 / 41$ b. 20c;1b. 60c Hamburg, or Turnip Rooted. A plain-leaved variety, forming a long, thick, edible root. Pkt. 5c;0z. 10c; 1/4 1b. 20c;1b. 50c.

Plain or Single. A very hardy variety, resembling a wild plant The leaves are flat and not curled. Pkt. 5c; oz. 10c; $1 / 41$ 1b. 20c; 1b. 50c.

DOUBLE CURLED A curled variety very hardy and and by many preferred to the extremely curly varieties. Pkt. 5c; oz. 10c; $1 / 4$ 1b. 20c; 1b. 60c.

EXTRA TRIPLE CURLED Very finely curled green color. One of the best varieties for all purposes. Pkt. 5c;0z. 10c; $1 / 4$ 1b. 20c; 1b. 60c. 


\section{PEPPER}

There are varied uses for peppers, and while they are more popular in the Sourth among the Spanish and Mexican people, they are used

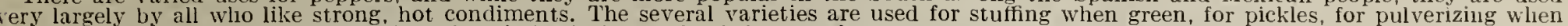
dry, and for soups, etc. Our selection of varieties includes all of the rery best.

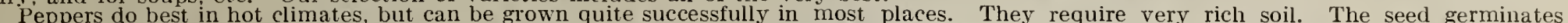
slowly and should be started in boxes, and the young plants transplanted after all danger of frost is over.
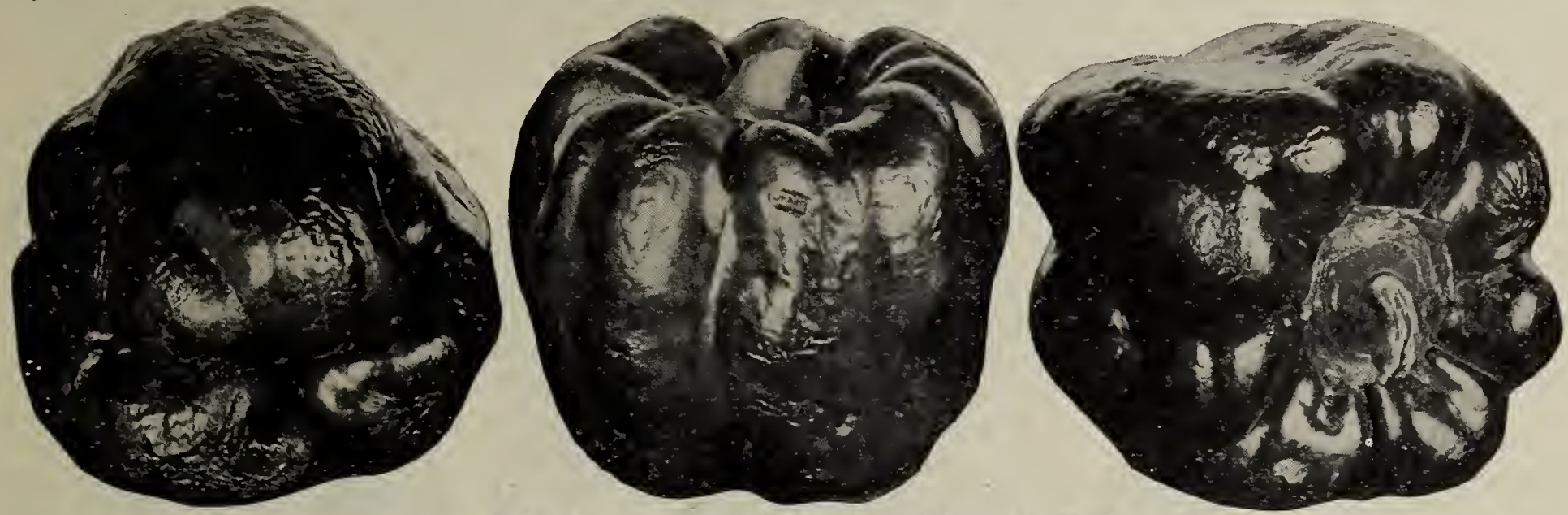

Iarge Bell or Bull Nose Peppers-best for stuffing

CHINESE GIANT A very large, deep-red variety, very as large as Large Bell, or Bull Nose, being four or five inches thick at the top and about six inches long. Pkt. 10c; oz. 50c; $1 / 4$ lb. $\$ 1.60 ; 1 \mathrm{~b}$. $\$ 5.50$.

Golden Dawn. A short, thick variety, similar to Large Bell, or Bull Nose, in sliape, but a rich golden yellow, with a mild sweet fla vor. Pkt. 5c;0z. 25c; $1 / 4$ 1b. 75c;1b. $\$ 2.50$.

Large Squash. An early variety, bearing large, flat, or tomato-

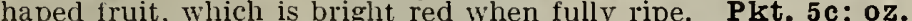
$25 \mathrm{c} ; 1 / 41 \mathrm{~b}$. $75 \mathrm{c} ; 1 \mathrm{~b}$. $\$ 2.50$.

\section{LARGE BELL, OR BULL NOSE} stuffing. Fruit large, round and blocky, and about three inches long and two inches thick. The color is deep green when fruit is young, but when fully ripened it is a rich, glossy blood-red. Plant grows about two feet high. Pkt. 5c; oz. 25c; 1/t 1b. 75c; 1b. $\$ 2.50$.

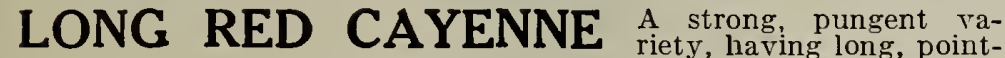

ed fruit. which is bright scarlet when ripe. A well-known and popular variety. Pkt. 5c; 0z. 25c; $1 / 41$ b. 75c; 1 b. $\$ 2.50$.

Red Cherry. An ornamental as well as useful variety, the plant being tail and bearing profusely, small, bright red fruit. The fruit is small, round, very hot, and is largely used for pickles. Pkt. 5c;0z. 25c; $1 / 41$ b. $75 \mathrm{c} ; 1 \mathrm{~b} . \$ 2.50$.

Red Chili. A rather small, bright-red variety about two inches long, and pointed. The pods are used in making chili sauce, and are very pungent and hot. Pkt. $5 \mathrm{c} ; \mathbf{0 z} .25 \mathrm{c} ; 1 / 1 \mathrm{lb} .75 \mathrm{c} ; 1 \mathrm{~b} . \$ 2.50$.

Ruby King. A popular variety of the Bell, or Bull Nose type. The fruit is large, bright, glossy-red, and the fla vor is mild and sweet. $5 \mathrm{c} ; 0 \mathrm{z}, 25 \mathrm{c} ; 1 / 1 \mathrm{~b} .85 \mathrm{c} ; 1 \mathrm{~b}$. $\$ 3.00$.

SWEET MOUNTAIN, OR SPANISH MAMMOTH A rery popular rariety with some marbearing large, thick fruit which is frequently eight inches long and two or three inches in diameter. When mature, it is a deep, glossy red, and the flavor is mild and sweet. Pkt. 5c; oz. 25c; $1 / 41 \mathrm{~b} .75 \mathrm{c} ; 1 \mathrm{~b} . \$ 2.50$.

\section{PUMPKIN}

While pumpkins are of strong growth, they will not stand frost, and cannot be planted until about April 15th. A moderately rich soil is

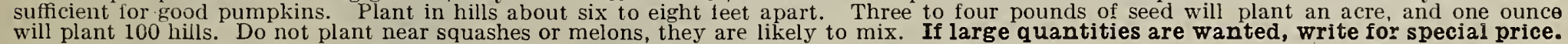
CONNECTICUT FIELD, OR NEW ENG- COMMON FIELD The well-known, ordinary pumpkins, LAND PIE A fine, large, orange-colored variety used LAND PIE for field culture and stock feeding. The skin is smooth and ribbed and the flesh is brittle and $1 / 4$ 1b. 20c; 1b. 50a, postpaid.

Large Cheese, or Kentucky Field. A very large, flattened variety, areraging When ripened the slin is a rich cream color. Flesh yellow and of fine quality. Pkt. $5 c ; 0 z .10 c ; 1 / 1$ 1b. 20c; $1 b$. $60 \mathrm{c}$, postpaid.

\section{MAMMOTH KING,} OR POTIRON

The best large pumpkin in use. Forms immense globula melons, flattened a little at the end. Skin reddish yellow in color and flesh rich orange. This is unquestionably the very best mammoth pumpkin we have. It runs rery uniform in shape and color and all are of 0z. $15 \mathrm{c} ; 1 / 1 \mathrm{tb} .45 \mathrm{c} ; 1 \mathrm{~b}$. $\$ 1.50$.

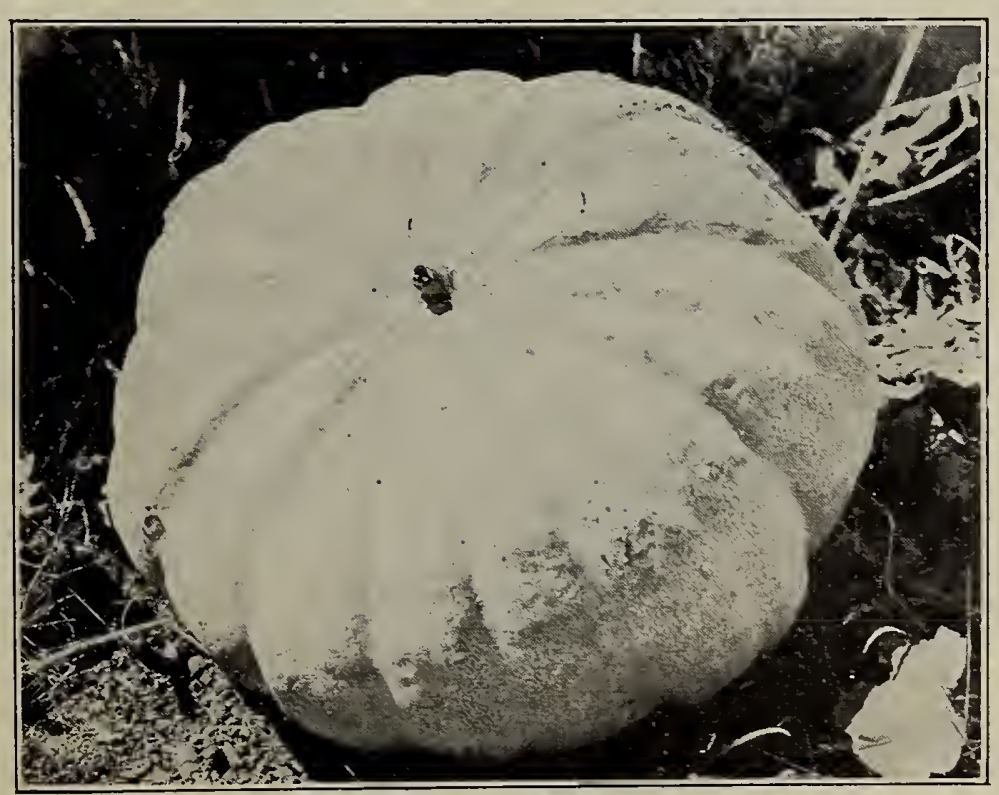

Mammoth King, or Potiron Pumpkin fruit is variously colored in yellow, drab, red, and orange, and fruit is variously colored in yellow, drab, red, and orange, and
varies also in size, but is usually very large. Is a heavy cropper ac; 1 b. $30 c$, postpaid. Pkt. express or freight, 1b. 20c; 10 lbs. $\$ 1.75 ; 100$ lbs. $\$ 15.00$.

Mammoth Golden Cushaw. One of the best stock-feeding varieties. Is a solid, yellow nearly all flesh, having a vkt. 5c;0z. 10c: 111 1b.30c: lb. $\$ 1.00$, postpaíd.

Pie Pumpkin. A small, round, isl netting. Flesh is thick, sitcet ant $5 \mathrm{c}: 10 \mathrm{c}: 11$ 1b.30c;1b. \$1.00, postpaid. SMALI SUGAR. quality. The flesh is rich yellow, rery thick and orange. TVe recommend this variet as the very best $1 / 41 \mathrm{~b}$. 30c; 1b: \$1.00, postpaid. 


\section{PEAS}

Peas are quite hardy, and for very early market can be planted in the fall in protected places, and ripe peas can be had in February. They

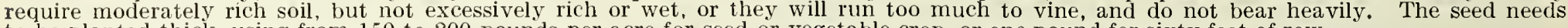
to be planted thick, using from 150 to 200 pounds per acre for seed or vegetable crop, or one pound for sixty feet of row.

The dwarf varieties can be planted in rows twelve to eighteen inches apart, and the tall ones three feet, By using the various classes of peas

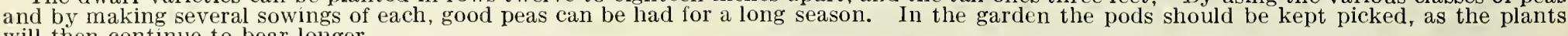
will then continue to b

Express or freight charges are not prepaid. Write us for special quotations on large quantities. Seed crop is very short this year.

\section{EXTRA EARLY} VARIETIES ALASKA, OR EARLIEST OF ALL. A very early, tall variety, with good quality, and short good-filled pods. Its well-filled pods. Its
fruit ripens practically all at one time, and is very popular with canners, who always desire to make but one cut25c, postpaid. $\mathrm{By}$ express or freight 1b. 15c; 10 lbs. $\$ 1.25$; 100 lbs. $\$ 10.00$.

\section{AMERICAN WONDER}

A dwarf or short-vine variety, bearing short, thick, well-filled pods
which are a rich dark green. It bears well, is easily grown, and very early. The peas flavor and it is the best dwarf variety for all purposes. The led. Pkt. 10c; 1b. 25c, postpaid. $\mathbf{B y}$ express or freight, 100 lbs. $\$ 10.00$.

First and Best. One of the earliest tall varieties, with s mooth, ripen almost at one time. Pods straight, short, and well filled. Of fair q uality.

postpaid. By express or freight, lb. $15 \mathrm{c} ; 10$ lbs. $\$ 1.25 ; 100$ lbs. $\$ 10.00$.

Gradus, or Prosperity. One of the very best early varieties. Is a tall variety, growing about three feet high and bears very long pods, which are pointed, and well filled with large, sweet, and very
fine wrinkled peas. The foliage and pods are light green, and the plant is not very hardy. Pkt. 10c; lb. 35c, lb. $25 \mathrm{c} ; 10 \mathrm{lbs}$. $\$ 2.00 ; 100 \mathrm{lbs}$. $\$ 15.00$.

\section{BURPEE'S BEST EXTRA}

EARLY $\begin{gathered}\text { We offer the intro- } \\ \text { ducer's }\end{gathered}$ This is very much the best early pea of the smooth-seed varieties, is very much sweeter than Alaska and also earlier. The vines make a very quick growth, about eighteen to twenty
inches in length, and the pods ripen inches in length, and the pods ripen lb. 30c, postpaid. By express or freight, lb. 20c; 10 lbs. $\$ 1.50 ; 100$ 1bs. $\$ 12.00$.

McLean's Little Gem. A good, dwarf, een inches high. Pods about three

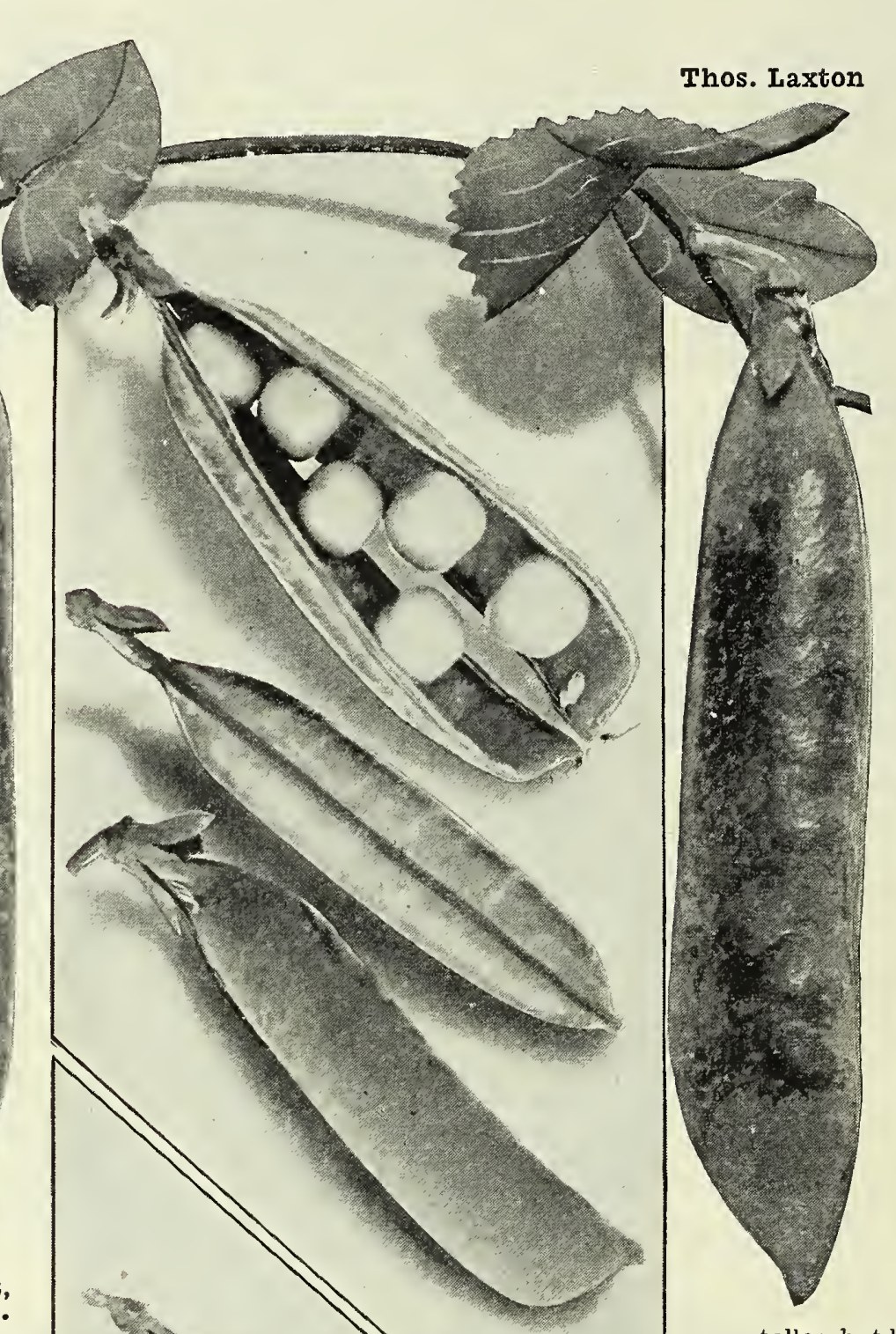

inches long and well filled with large peas. pkt. 10c; 1b, 25c, press or freight, lb. $15 \mathrm{c} ; 10$ lbs. $\$ 1.25$; 100 lbs. $\$ 10.00$.

Nott's Excelsior. The popular d w a r f , the home rarden the hor garden or vines are larger and more productive than American Wonder and the peas are of especially fine flavor and good quality. Some variety as the best for the home garden claiming it to be of peculiarly delicious flavor, of long continuous bearing quality and easy to grow. Pkt. $10 \mathrm{c} ; 1 \mathrm{~b} .30 \mathrm{c}$, postpaid. By express or freight, lb. 20c; 10 lbs. $\$ 1.75 ; 100$ lbs $\$ 15.00$.

\section{PREMIUM GEM}

The best and most popular dwarf, wrinkled variety, especially with market gardeners. It grows about fifteen inches high and bears good-sized pods, wears good-sized pods, six to eight peas of essix to eight peas of especially fine, sweet $25 \mathrm{c}$, postpaid. By express or freight. lb. 15c; 10 lbs. $\$ 1.25$. 100 lbs. $\$ 10.00$.

Thomas Laxton. A fine, early tall variety, similar to Gradus but more hardy and not quite so eary. Is also a little darker in color and taller, but has the same fine, large pods and fine color. Pkt. 10c; 1b. 35c, postpaid. By express or freight,
lb. $25 \mathrm{c} ; 10 \mathrm{lbs} . \$ 1.50 ; 100$ lbs. $\$ 12.50$.

\section{SECOND EARLY VARIETIES}

Abundance A tall branching variety bearing medium-sized pods with large peas of good quality. It ripens evenly. and is used largely by canners. Pkt. 10c; 1b. 30c, postpaid. By express or freight, 1b. 20c; 10 lbs. $\$ 1.50$; 100 lbs. \$12.00.

McLean's Advancer. A good, tall variety with wrinkled peas of very fine quality. Is especially productive and very popular with market gardeners. express or freight, lb. 20c; $10 \mathrm{lbs}$. $\$ 1.25 ; 100$ lbs. $\$ 12.00$.

Bliss's Everbearing. A tall, wrinkled variety bearing broad pods well filled 10c; lb. 30c postpaid. By express or freight, lb. 20c; 10 ibs. $\$ 1.25 ; 100$ lbs. $\$ 12.00$. 


\section{SAN FRANCISCO CALIFORNLA U.S.A.}

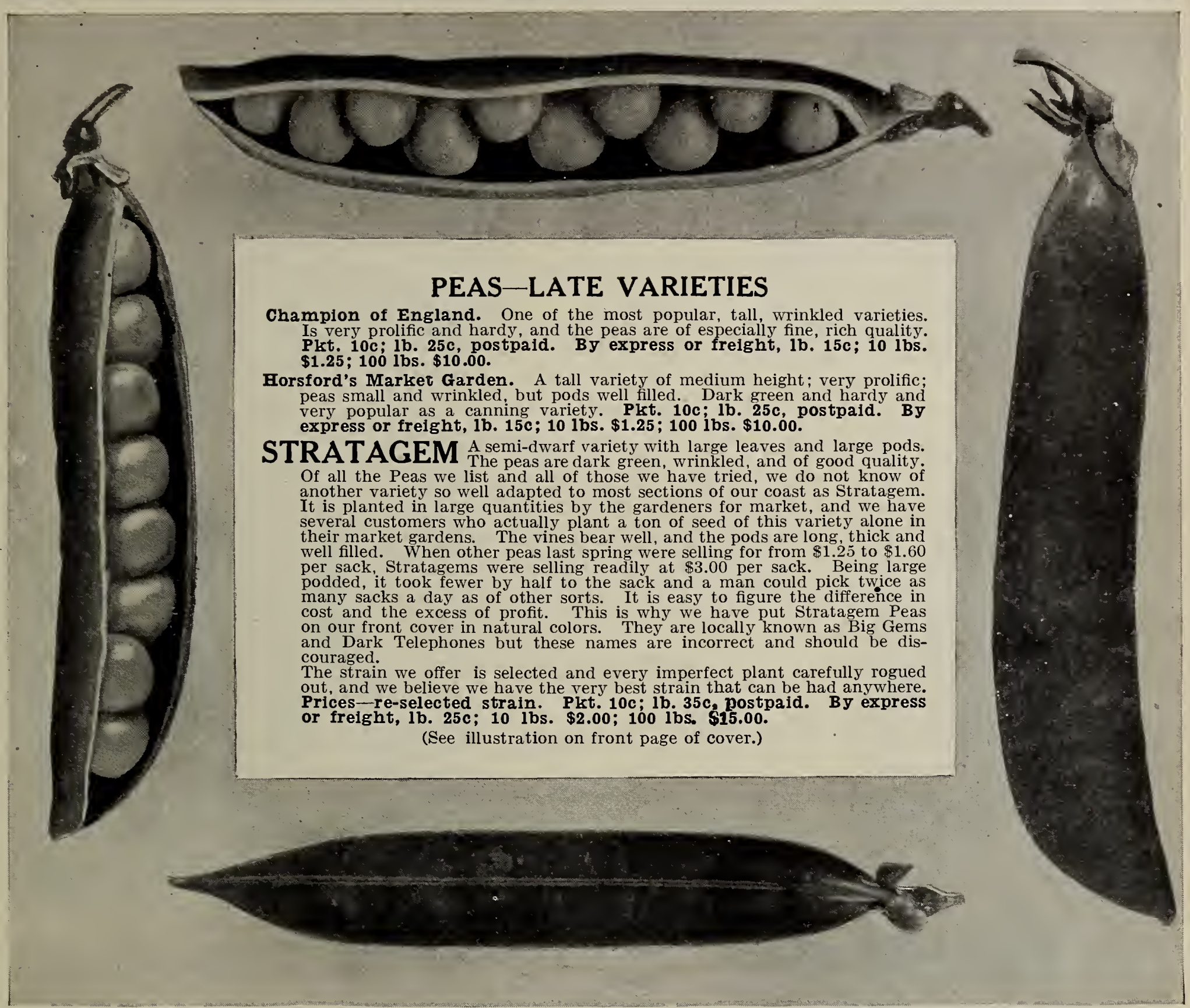

Telephone Peas. Long podded, delicious flavor, late bearing

Black-Eyed Marrowfat. The best of the marrowfat varieties. Tall, hardy, and productive. Pkt. 10c; 1b. 20c, postpaid. By express or freight, 1b. $10 \mathrm{c} ; 10 \mathrm{lbs} .80 \mathrm{c} ; 100 \mathrm{lbs}$. $\$ 7.00$.

Large White Marrowfat. A very tall hardy variety. Very productive, but of inferior quality. Pkt. 10c; 1b. 20c, postpaid. B y express or freight, $1 \mathrm{~b} .10 \mathrm{c} ; 10 \mathrm{lbs}, 80 \mathrm{c} ; 100 \mathrm{lbs} . \$ 7.00$.

Melting Sugar. A tall variety, bearing long, flat, brittle pods: which are cut or broken and cooked like string beans. Is a delicious vegetable, and should be better known and more generally used. Pkt. 10c; 1b. 35c, postpaid. By express or freight, $1 \mathrm{~b} .25 \mathrm{c} ; 10 \mathrm{ibs}$. $\$ 1.50$.
TELEPHONE One of the latest varieties. Is tall and large, wrinkled peas of remarkably fine quality. A popular home-garden and market variety. We have an especially fine pure stock this year. Pkt. 10c; lib. 30c, postpaid. By express or freight, lb. 20c; $10 \mathrm{lbs}$. $\$ 1.50 ; 100 \mathrm{lbs}$. $\$ 17.50$.

\section{YORKSHIRE HERO, OR ALAMEDA} SWEETS A very hardy and prolific, semi-dwarfed, SWEETS wrinkled variety. The peas are large and of fine quality and the pods, which are broad and medium sized, remain in condition for a long time. It bears immense crops, both of pods and dried peas, and is the variety most largely planted by gardeners Pkt. 10c; 1b. 25c, postpaid. By eXpress or freight, $1 \mathrm{~b} .15 \mathrm{c} ; 10 \mathrm{lbs} . \$ 1.00 ; 100 \mathrm{lbs}$. $\$ 8.00$.

NOTE.-We especially invite correspondence with farmers who grow produce for market, or who plant such things as mangel beets or stock carrots on a large scale for cattle feeding, or who plant large quantities of green manure plants, such as Vetches, Niles Peas, etc. We would esteem it a privilege to give what information we can to any large planters of anything we list and are always pleased to make special quotations when it is possible to do so.

Remember-A supply of seed is limited to the crop produced and we are likely to be sold out of many things as the season progresses. We cannot urge you too strongly to order early. 
Being a root crop, good brittle radishes require light, well-worked soil, made very rich and mellow to insure quick growth. If permitted

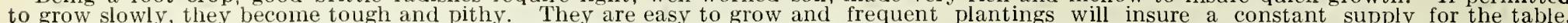

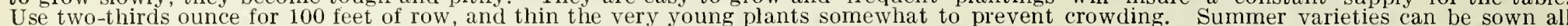

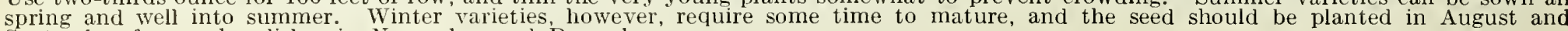
September for good radishes in November and December.

Brightest Long Scarlet. A very showy, long variety. Is thick at the shoulder and tapeling. Bright rose scarlet with distinct white tip. Plst.5c;oz.10c: $1 / 4$ lb. 25c; 1b. 75c.

chartier. A very long variety and larger in diameter and general size than Long Scarlet. Keeps hard and crisp longer than most varieties, and is an

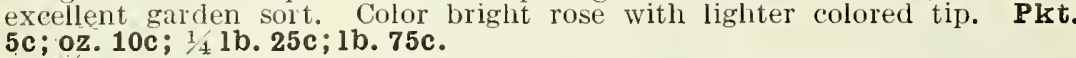

Cincinnati Market. An early and quick-growing long variety, which keeps hard and crisp for a long time. A favorite market garden variety. Color crimson. Pkt. 5c;0z. 10c; $1 / 4$ 1b. 25c; 1b. 75c.

Chinese Rose Winter. A bright scarlet winter variety. About 4 inches long and stump-rooted. Matures two or three weeks earlier than the Chimese

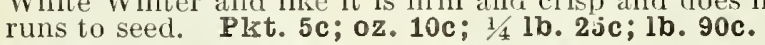

CHINESE WHITE WINTER, OR CELESTIAL (or Cal. Mammoin White Winter). The well-known and popular winter variety. Clear white, about 4 inches long and half stump-rooted. Keeps firm and crisp until it runs to seed. Is a good cooking variety, and when cooked the flavor resembles turnip. Pkt. 5c;0z.10c;1/41b. 25c;1b.90c. Crimson Giant Forcing. A new variety which will be a popular market and home garden variety, since it matures very early and remains firm and crisp,

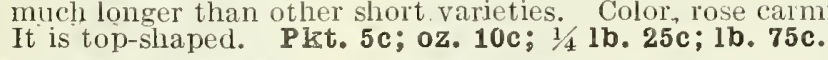

Early Round Dark Red, or Prussian Globe. A bright scarlet, turnip-shaped variety. Early, quick growing, and a handsome radisli. Pkt. 5c; oz. 10c $1 / 41 \mathbf{b} .25 \mathrm{c} ; 1 \mathbf{b} .75 \mathrm{c}$.

Early Scarlet Turnip. A valuable variety for forcing or outdoor culture. Is a $10 \mathrm{c} ; 1 / 4 \mathrm{~b}$. $25 \mathrm{c} ; 1 \mathrm{~b} .75 \mathrm{c}$

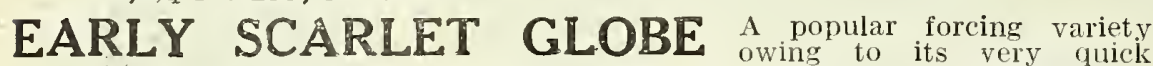
growth and fine bright scarlet color. Shape, a trifle oblong. Pkt. 5c;oz. $10 \mathrm{c} ; 1 / 4 \mathrm{lb} .2 \mathrm{jc} ; 1 \mathrm{~b} .75 \mathrm{c}$.

Early White Turnip. A very quick-growing, small, turnip-shaped variety. Color clear white; $10 \mathrm{c} ; 1 / 1 \mathrm{ib}$. $25 \mathrm{c}$; ib. $85 \mathrm{c}$.

French Breakfast. (See illustration page 39) A popular variety for market It is about two inches long and decidedly stump-rooter

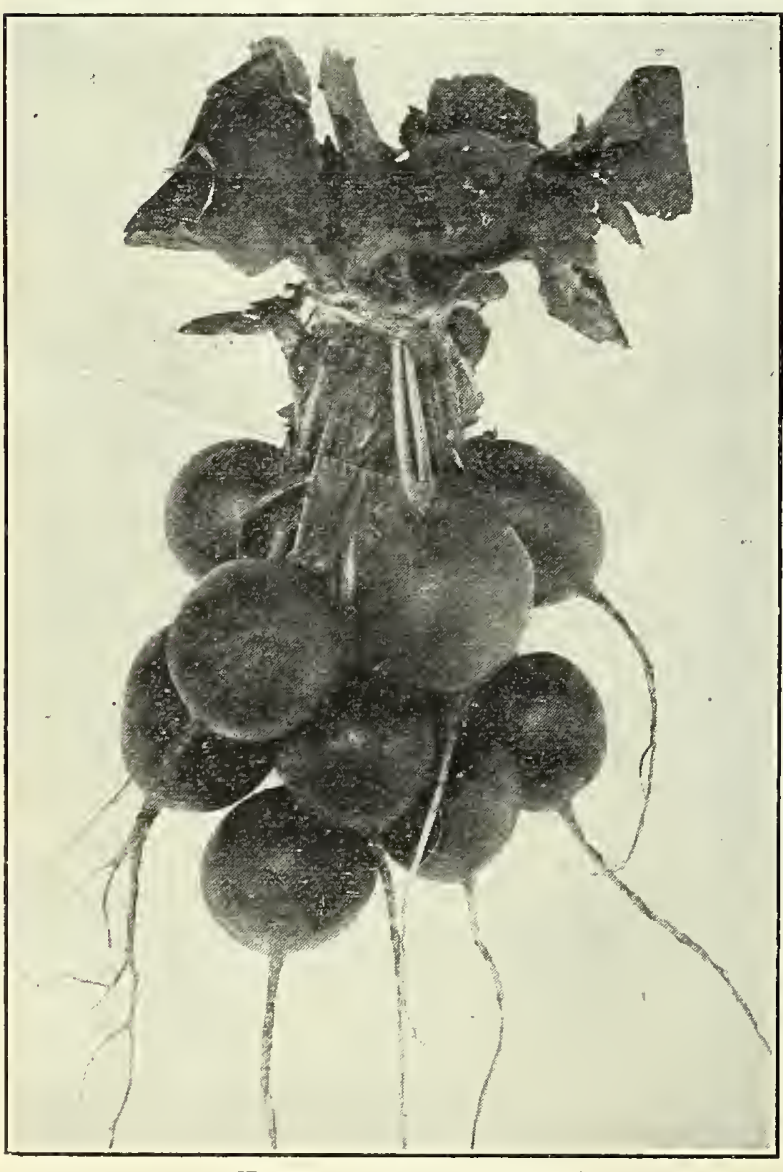

Early "Scarlet Globe" Color stump-rooted. bottom of root and the tail pure white. 1b. $25 \mathrm{c} ; 1 \mathrm{~b} .75 \mathrm{c}$.

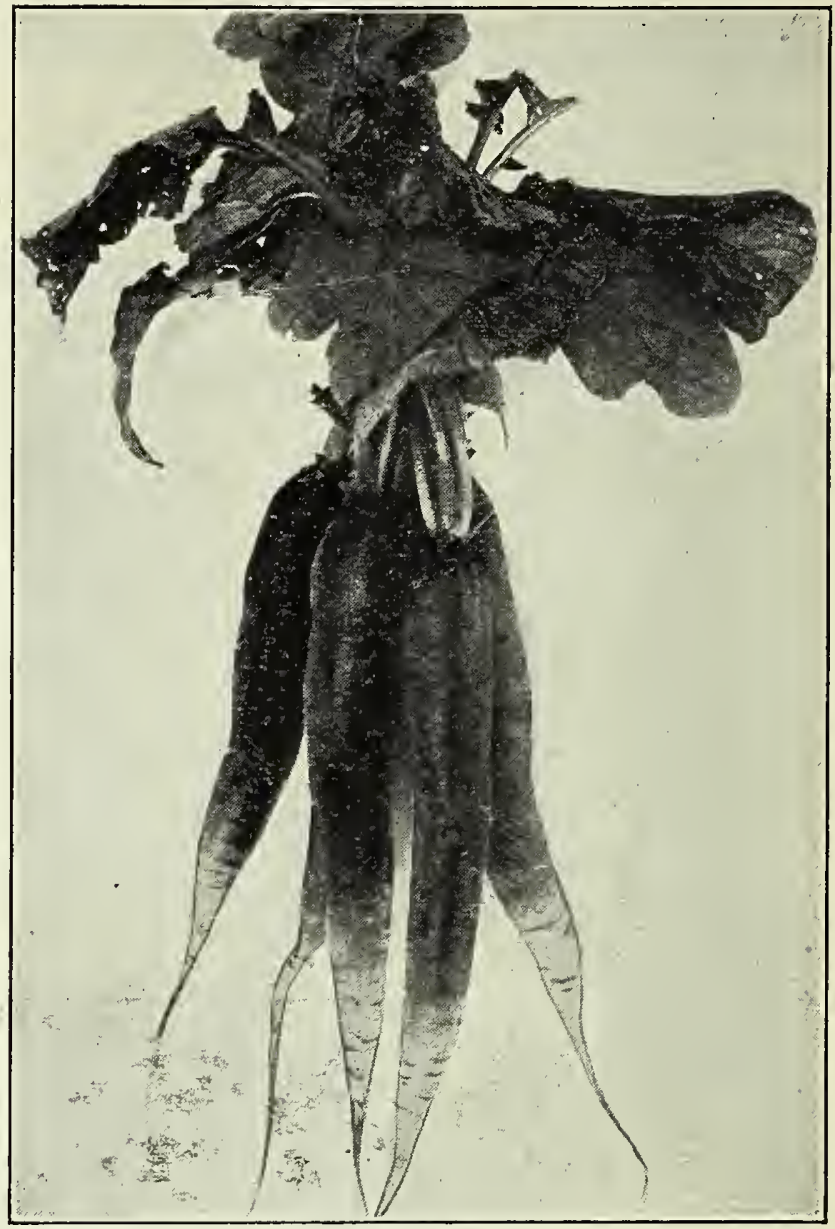

"Long Scarlet"

Golden Globe. Quite a large top-shaped variety with yellow skin, and solid, white flesh. Is not a quick-growing variet $y$ but retains its solidity a long time after naturity. Pkt. 5c;0z.10c; $1 / 4$ 1b. 25c; 1b. 75c.

Half Long, or Olive-Shaped. The variety most largely used by gardeners in California. It is about 3 inches long with half stump-root and sloping top. Color carmine. Quick growing and hardy Remains solid longer than any other variety. Pkt. 5c;0z, 10c; 1/4 1b. 20c; 1b.60c.

Half Long Deep Scarlet. A shorter, olive-shaped variety, with half stump-root 10c; $1 / 41 \mathbf{b}$. 25c; 1 b. $75 \mathrm{c}$.

ICICLE A handsome white variety, about 5 inches long, with sloping top and cz. $10 \mathrm{c} ; 1 / 4 \mathrm{lb} .25 \mathrm{c}$; $1 \mathrm{~b}$. $75 \mathrm{c}$.

Long Black Spanish. A winter variety with almost black skin and white flesh. Roots about six inches long. Pkt. 5c; oz. 10c; 1/4 1b. 25c;1b. 75c.

LONG SCARIET (short top). The best known and most popular brittle and firm. About 6 inches lollg, the top growing out of the ground about
bering one inch. Pkt. 5c; oz. 10c; 1/4 1b. 20c; 1b. 60c.

Long White Japanese. A winter variety, growing frequently 2 feet long and about 3 inches in diameter, Skin, white; flesh, solid and tender, and very pungent. A staple article of diet with the Japanese, who use it both green and dried. Our seed imported from Japan. Pkt. 5c; oz. 10c; $1 / 4$ 1b. 25c;1b. $\$ 1.00$.

Round Black Spanish. A winter variety, with black skin and white flesh. It is top-shaped or almost globular. Pki. 5c; oz. 10c; $1 / 41$ lb. 25c;1b. 75c.

SCARIET TURNIP, WHITE TIPPED (or Rosy Gem. Pkt. 5c; 0z. 10c; $1 / 4$ 1b. 25c; 1b. 90c.

White Strasburg. A large, white variety for late summer use. Rather thick at the shoulder and tapering to about 5 inches in length. Keeps firm and solid a long time. Pkt. 5c; oz. 10c; 1/4 1b. 25c;1b. 75c.

White Vienna (or Lady Finger). A very fine, long, white variety, quick growing and ready for use when very young. The flavor is mild and sweet. Pkt. 5c; oz. $10 \mathrm{c} ; 1 / 41 \mathrm{~b}$. 25c;1b. 75c. 


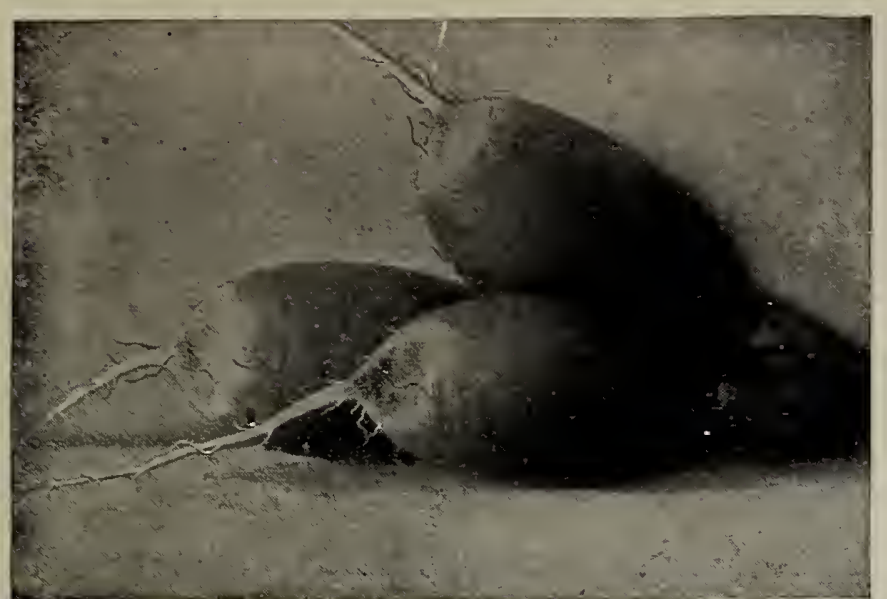

French Breakfast Radish-See page 38
RADISH

\author{
Continued
}

SCARLET TURNIP

WHITE TIPPED or R os y G e m. One of the most popular and attracive short varieties. It is globe-shaped. bright rose carmine with bottom and tip clear white. Stems and leaves small. Very valuable for foicing as well as for the house garden and oz. $10 \mathrm{c} ; 1 / 41 \mathrm{lb} .25 \mathrm{c}$; lb. $90 \mathrm{c}$.

\section{RHUBARB}

A rich, sandy soil, wet but well drained, is best for rhubarb. While it is frequently propagated from seed, only a percentage comes true, but it is cheaper to grow from seed and discard untrue plants. The popular method, however, is to use young plants propagated from the crown. Set plants three feet by six. The best stems are produced the second year, but it continues to produce plants three feet by six. The best stems are produced the second year, but it continues to pro
for several years. When the blossom stalk appears, it should be cut back well into the ground.

Myatt's Victoria. The variety most generally in use. It comes fairly true from seed.

Seed-Pkt. 5c; 0z. 15c; 1/: 1b. 40c; $1 \mathrm{~b}$. $\$ 1.50$.

Roots $-15 \mathrm{c}$ each, $\$ 1.50$ per dozen.

CRIMSON WINTER The new

which has become very popular and profit- able to the grower, is of delicious flavor extremely hardy, very prolific, and very quick growing. Produces good stems al winter and spring.

Seed-Pkt. 10c; oz. 65c; 1/4 lb. $\$ 2.00$; 1b. $\$ 6.50$.

Roots-25c each, 5 for $\$ 1.00$.

Add 10c per doz. for postage.

\section{SALSIFY, OR VEGETABLE OYSTER}

The salsify root, which grows about twelve inches long and one inch in diameter, is becoming a very popular vegetable. When cooked, it has a distinct flavor of the oyster, and may be served in a great variety of ways. A loose, light soil, especially sandy loam, is desirable for a long, smooth root. In stiff soils the roots are usually uneven and hard to dig. Use three-fourths ounce for 100 feet of row, and thin to one or two inches to prevent crowding.

MAMMOTH SANDWICH ISIAND. The improved, large-rooted variety, growing about 12 inches long and being from 1 to 2 inches thick. Pkt.5c;0z.20c; $1 / 41$ b. 50c;1b. $\$ 1.75$.

\section{SORREL}

The large leaves, when cookea like spinach, make a very palatable vegetable. In California it grows luxuriantly, spreads rapidly from the root, and becomes an obnoxious weed unless given attention. A confined location in the garden is therefore recommended.

Large Leaved French. The variety having the largest leaves, and therefore the most desirable. Pkt. 5c;0z. 15c; $1 / 41 \mathrm{~b} .40 \mathrm{c} ; 1 \mathrm{~b} . \$ 1.25$.

\section{SPINACH}

An easily grown plant, the seed of which may be planted in the fall to secure good spinach early in the spring or even throughout the winter. The better and richer the soil, the larger and more tender the leaves will be. As a field crop for the market garden, use 8 pounds of seed per acre. For the home garden use one-half ounce for 100 feet of row.

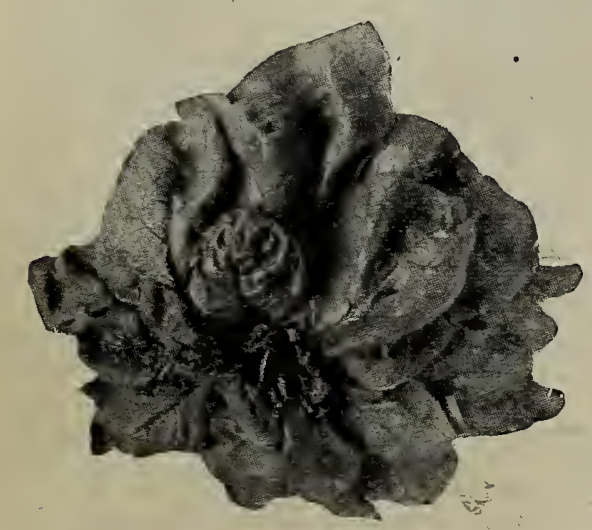

Prickly Spinach

\section{BLOOMSDALE SAVOY} The variety most generally used in the East, and especialty throughout the South for shipping. Leaves large, round, and thick, very much savoyed and rich deep green. " One of the earliest varieties. Pkt. 5c;0z. 10c; $1 / 41 \mathrm{~b}$ 1b. 35c.

Long Standing: A deep green variety with rather elongated smooth leaves. Seed round. Stands a long time without running to seed. Pkt. 5c; oz. 10c; $1 / 11 \mathrm{lb} .15 \mathrm{c}$; 1b. $40 \mathrm{c}$.

Victoria. A long-standing variety with round slightly savoyed leaves. Deep green and hardy. Forms good. edible leaves early hand continues to produce leaves for a long

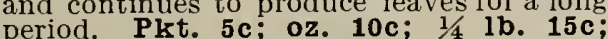
ib. $40 \mathrm{c}$.
New Zealand. A plant with thick, fleshy texture and soft crystatline leaves. Is not like the ordinary spinach in appearance but it is used in the same way. Pkt. 5c; oz. $10 \mathrm{c} ; 1 / 4 \mathrm{lb}$. 30c; 1b. $\$ 1.00$.

PRICKLY The variety commonly used very hardy and easily grown; bears large, smooth leaves, which are shaped like ar arrow point. Color, bright green. Seed,
irregular, with 3 or 4 sharp points. Pkt. 5c;0z. 10c; $1 / 41$ b. 15c;1b. 30c.

Round, Thick Leaved. A large-leaved, bright green variety. Leaves rather smooth and rounded at the top. A good variety for late spring and summer. Seed, round. Pkt. 5c; oz, 10c: $1 / 4$ 1b. $15 \mathrm{c}$ b. 40c. 


\section{SQUASH}

The summer varieties come into use early in the summer, but being sensitive to frost the seed cannot be sown until late in April. The

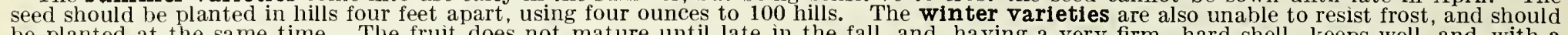

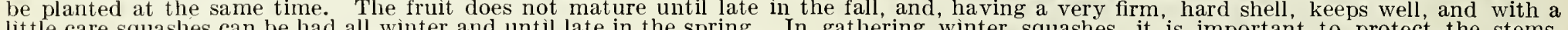

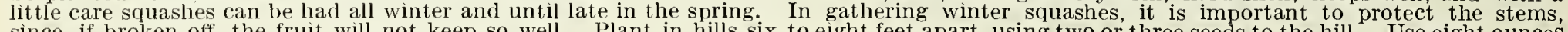

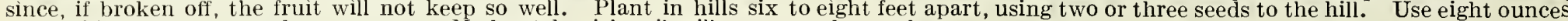
to 100 hills, or two pounds to an acre. Moderately rich soil will grow good squashes.

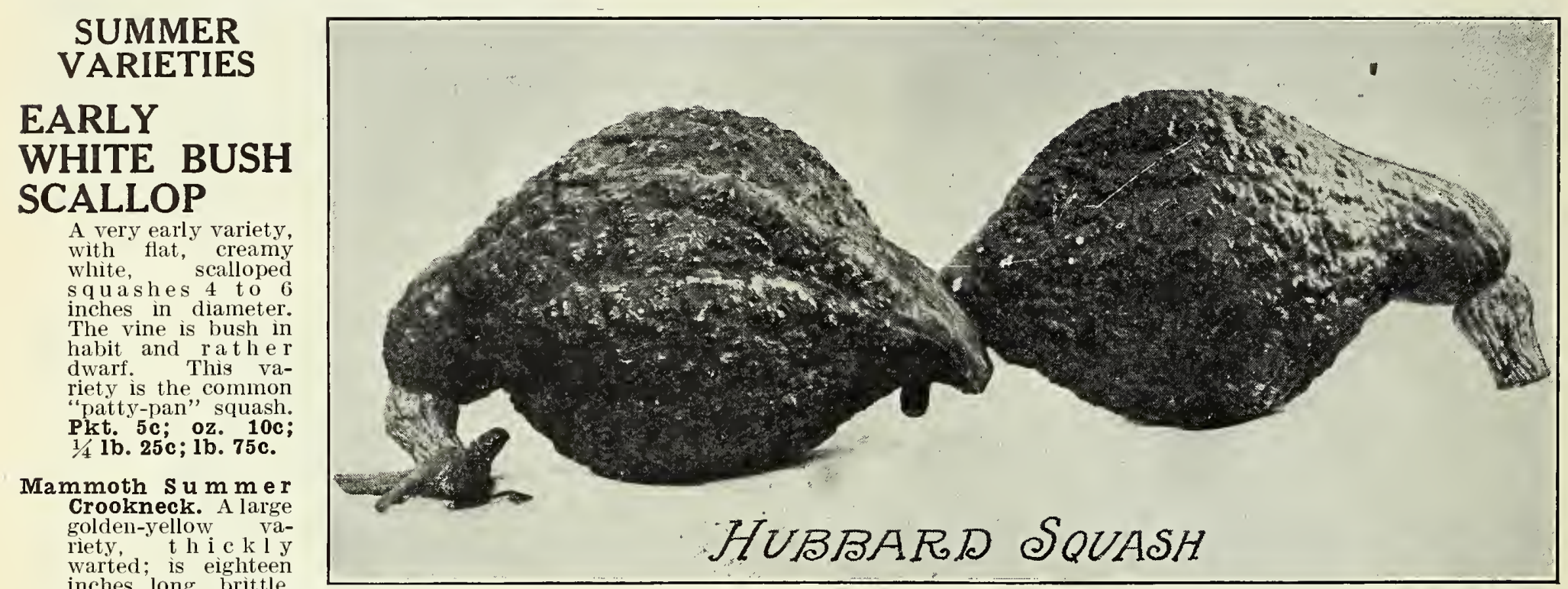
inches long, brittle, and tender Plants

are bush and very prolific. This is an improved strain of the old variety and considerably larger. Pkt. 5c; oz. 10c; 1/4 1b. 25c; 1b. $80 \mathrm{c}$.

Mammoth White Bush Scallop. A fine, large variety with round, scalloped fruit twelve to fourteen inches in diameter. Color,

VEGETABLE, OR ITALIAN MARROW A large, oblong variety, producing fruit which is dark green at
first becoming marbled and striped with yellow and lighter green as they mature. Pkt. 5c; oz. 10c; $1 / 4$ lb. 30c; 1b. $\$ 1.00$.

White summer Crookneck. Jong, crooknecked variety, similar to Summer Crookneck in size and shape, but it is pure white. Is
of especially fine quality. Pkt. 5c; oz. 10c; 1/4 1b. 25c;1b. 75c. Yellow Bush Scallop, or Custard. An early variety with flat, Pkt. 5c; oz. 10c; $1 / 41$ b. 25c; 1b. 75c.

YELLOW SUMMER CROOKNECK The known summer variety. Fruit long, skin very much warted, bright golden yellow. Pkt. 5c; 0z. 10c; 1/4 1b. 25c;1b. 75c.

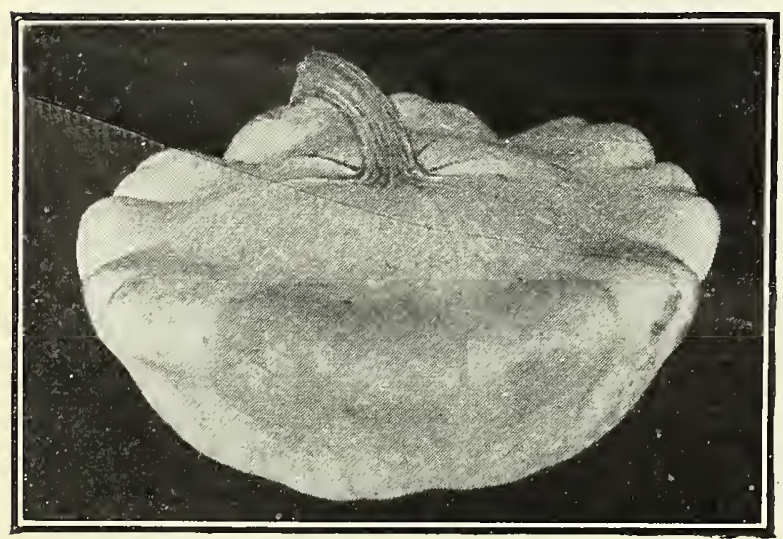

Early "White Bush Scallop" low outside and the flesh is of most delicious flavor. Is solid and hard and a oz.10c; $1 / 41 b .25 c ; 1 b .90 c$. Golden Hubbard. An exceptionally attractive variety of the true Hubbard type. At maturity the color is red, and the flesh bright orange. The vine is productive and the fruit is fit for use earlier than the Hubbard. Pkt. 5c; oz. $10 \mathrm{c} ; 1 / 4$ ib. $25 \mathrm{c} ; 1 \mathrm{~b} .75 \mathrm{c}$

HUBBARD The most and widely used of the winter squashes. Fruit is oblong and pointed, heavily warted, dark green in flesh. Is remarkable for its keeping qualities. Pkt. 5c; 0z. 10c; $1 / 4 \mathbf{1 b}$. 25c; 1 b. 85c. Perfect Gem or Cream. Long-keeping, winter squash, 4 to 6 inches in diameter; apple shaped; distinctly ribbed with smooth, cream-colored skin. It is solid and rather hard, but bakes to a delicious soft consistency on the inside. Although a small variety it is a great keeper and is used mostly in the winter. Pkt. 5c; oz. $10 \mathrm{c} ; 1 / 4 \mathrm{lb}$. $25 \mathrm{c} ; 1 \mathrm{~b} .85 \mathrm{c}$.

Mammoth Chili. A very large variety, with smooth, oblong fruit, flattened at both ends. Skin, rich orange yellow; flesh, orange, fine grained, and sweet. Pkt. 5c: $0 \mathrm{z} .15 \mathrm{c} ; 1 / 4$ ib. $45 \mathrm{c} ; 1 \mathrm{~b}$. $\$ 1.50$.

\section{WINTER VARIETIES}

MARROW A popular variety, with large oval fruit, Skin bright, reddish orange, with light cream netting. Flesh, orange. Fine grained, and of excellent quality. This is the most popular va-
riety for canning. The California canners plant several hundred acres annually and the fruit makes a rich orange-red, and delicious fish. Pkt. 5c;0z. 10c; $1 / 4$ 1b. 20c;1b. 60c. Xybrid, or Hard Shell Turban. An early, quick-growing variety, with, very hard shell. Is broad, with large neck or

Ahook. A good variety for early winter or even summer use

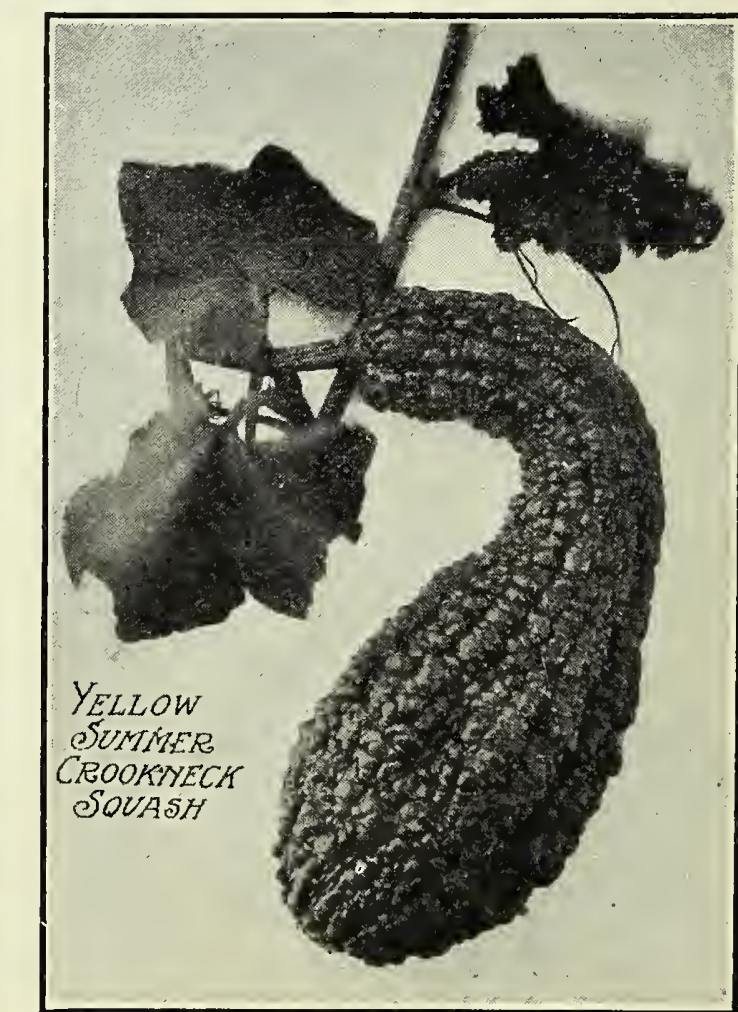




\section{TOMATO}

As tomatoes are very sensitive to frost, they cannot be set in the open field until about May 1st. The seed must be sown in well-protected

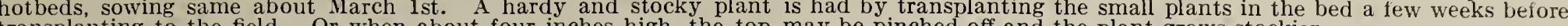
transplanting to the field. Or when about four inches high, the top may be pinched off and the plant grows stockier.

Sow the seed broadcast, using one ounce to about three square feet of area, which will yield plants enough to set an acre. In the field set

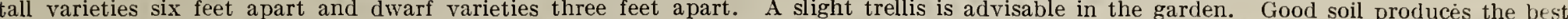

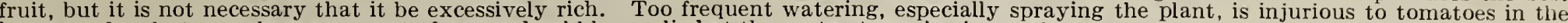
home garden, but a moderate amount of water should be applied at the roots at regular intervals.

Acme. A tall variety, medium early, bearing flat. tish globe fruit of a purplish-carmine color, and medium size. The fruit is smooth and uni

Beauty. A rather early, tall variety; very prolific, with good-sized, smooth fruit of a $25 \mathrm{c}$; $1 / 41 \mathrm{~b} .75 \mathrm{c} ; 1 \mathrm{~b}$. $\$ 2.25$.

\section{CHALK'S EARLY JEWEL} A wonderful new variety, in that it is early and bears continuously throughout the season. The fruit is large, smooth, uniform, and well ripened clear to the stem, and the flavor and quality to the stem, and the frovor and quality Pkt.10c;0z. 25c; 1/41b.85c; 1b.\$2.75.

Dwarf Champion. A dwarf variety, sometimes called th tree tomato on account of its upright growth and its bility to stand alone without trellising. Fruit, uniform, and of a pur-
MATCHLESS A tall-growing, prolific variety flattened smooth and uniform liuit, when is rather flattened, smooth and uniform. Color, bright scarlet. For canning and general main crop market, there is Extra selected strain, Pkt. 10c; oz. 40c; 1/4 Ib. $\$ 1.10 ; 1 \mathrm{~b}$. $\$ 4.00$.

Perfection. A tall variety, with medium-sized globular, uniform fruit, which is smooth and well

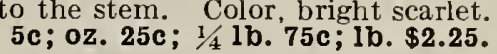

Ponderosa. An extremely large, irregularfruited variety. Vine tall, and fruit very solid and purplish-carmine in color Pkt. 10c, oz. 40c; $1 / 4$ Ib. $\$ 1.00 ; 1 b . \$ 3.50$.

Red Cherry. The fruit is small and globe shaped, about 1 to 2 inches in diameter. It is bright scarlet in cclor, and besides being ornamental, is very valuable for pre1b. \$2.50.

Red Pear Shaped. As the name implies, the fruit is shaped like a pear-small at the stem and enlarged at the top. It is

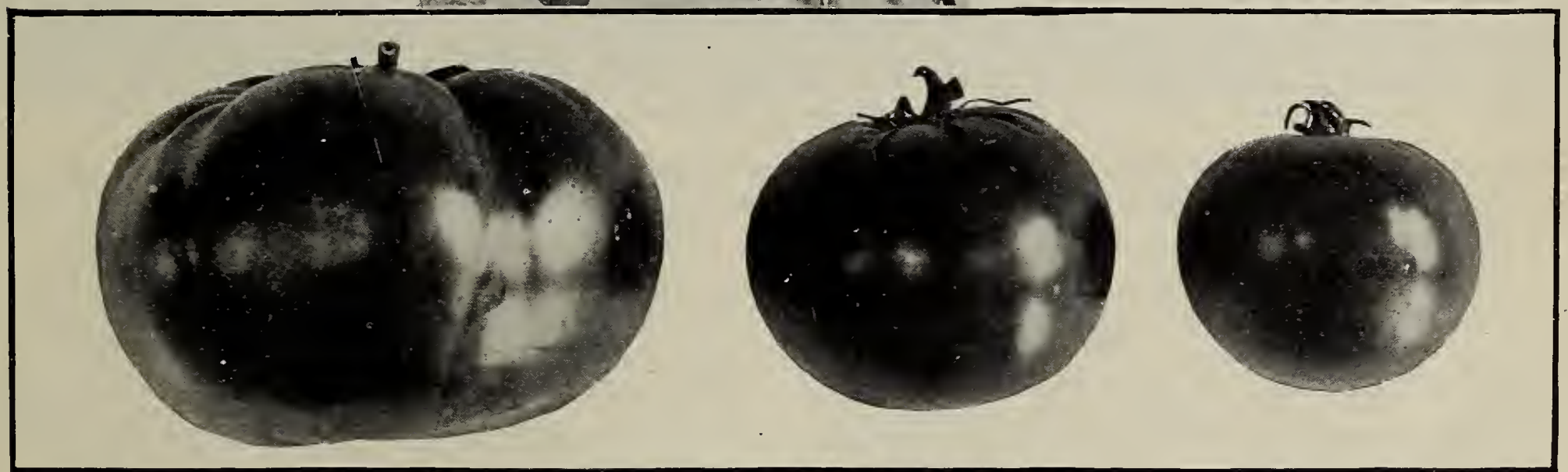

plish - carmine color. Pkt.5c; oz. 25c; 1/11b. $75 \mathrm{c} ; 1 \mathrm{~b} . \$ 2.50$.

Earliana (Sparks). The earliest tall variety forming ripe fruit much earlier than any other variety. The fruit is large, smooth, of a bright scarlet color, and of fine quality. Very valuable for early market use. Pkt. 10c $0 \mathrm{z} .25 \mathrm{C}$
$\mathbf{2 . 7 5}$.

Favorite. A tall variety, bearing globe-shaped, scarlet fruit. The fruit is smooth, and uniform, and well ripened to the stem. Pkt. 5c; oz. $25 \mathrm{c} ; 1 / 41 \mathrm{~b}$. $75 \mathrm{c} ; 1 \mathrm{~b}$. $\$ 2.25$.

Golden Queen. A large-fruited, tall variety, bearing smooth, bright yellow fruit of fine quality. Pkt. $5 \mathrm{c} ;$ oz. $25 \mathrm{c} ; 1 / 4$ 1b. $75 \mathrm{c} ; 1 \mathrm{~b}$. $\$ 2.50$.

Husk Tomato, or Ground Cherry. A variety that is covered by a loose covering or husk. The true edible variety is yellow and is used for preserves, and must not be confounded with the wild variety which resembles it in the husk but the fruit inside is black. Pkt. 5c; 0z. 25c; $1 / 4$ 1b. 90c; 1 b. $\$ 3.00$.

June Pink. A grand new extra early variety. One of the very earliest sorts we have-a little earlier than Earliana. The fruit is smooth and ripened to the stem and the plant bears well. Pkt. 10c; oz. 30c; $1 / 4$ Ib. 90c; Ib. $\$ 3.00$. Ponderosa-Stone-Dwarf Champion
Three of the most popular tomatoes

small, being about 2 or 3 inches long It is bright scarlet; is of fine flaver, and makes delicious preserves or salads. Pkt. 5c; oz. 25c $1 / 41 \mathrm{~b}$. 75c; Ib. $\$ 2.50$.

STONE The best main-crop poses, and largely or all purponning Vine, tall and procanning. vine, tall and proand uniform Color, bright scarlet. Pkt. 5c; oz. 25c; $1 / 4$ 1b. $75 \mathrm{c} ; 1 \mathrm{~b}$. \$2.25.

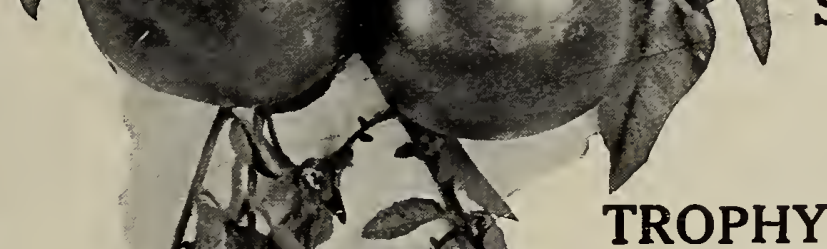

TROPHY

An old favorite and much ane quality, and is valuin color and the fruit shows a distinct navel at the blossom end. Pkt. $5 \mathrm{c} ; 0 z .20 \mathrm{c}$; $1 / 4$ 1b. 60c; Ib. $\$ 2.00$.

Yellow Cherry. A small-fruited, bright, goldenyellow variety; very attractive for salads or preserves. In all respects like the Red

Pkt. 5c; oz. 25c; 1/4 1b. 75c; Ib. $\$ 2.50$.

Yellow Pear Shaped. A small-fruited variety resembling the Red Pear Shaped, except in color, which is golden yellow. It is very useful for salads when the fruit is simply cut in two length-wise. It is also useful for preserves. Pkt. 5c; oz. $25 \mathrm{c} ; 1 / \mathrm{t}$ Ib. $75 \mathrm{c} ; 1 \mathrm{~b}$. $\$ 2.50$. 


\section{C.C.MORSE \& CO. VEGETABLE SEEDS}

\section{TURNIPS}

While turinips are a favorite fall and winter vegetable, they may also be had in spring by proper sowings. They are of easy culture, but need vell-worked, rich soil to insure a quick, uninterrupted growth, when they will be tender and free from woodiness. For fall and winter use sow the seed in August, using one ounce to 250 feet of row, thinning the plants when very young to three or four For field culture sow in rows about two feet apart, using one to three pounds of seed per acre.

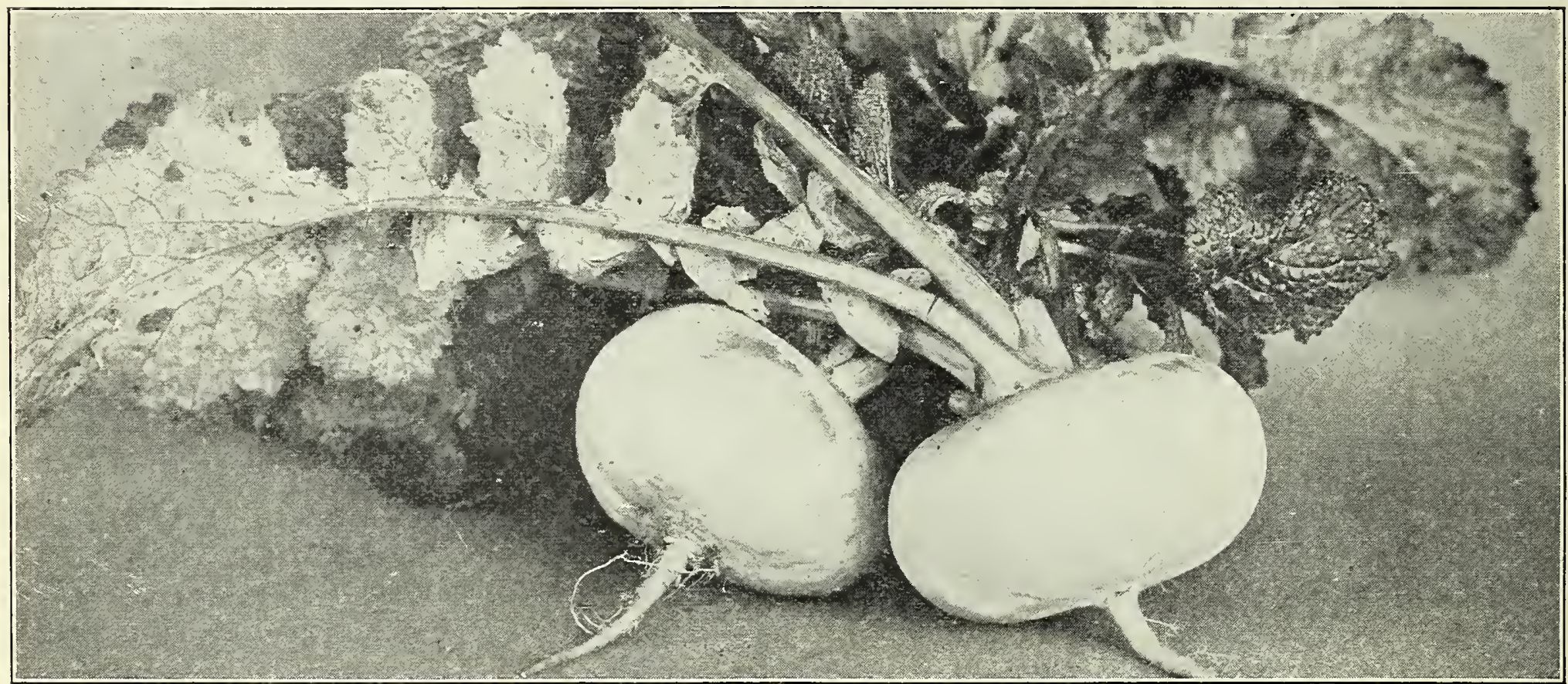

Whice Flat Dutch Turnips

Amber, or Yellow Globe. One of the best yellow-fleshed varieties. $5 \mathrm{c} ; 0 \mathrm{z}, 10 \mathrm{c} ; 1 /$ ib. 20c; $1 \mathrm{~b}, 50 \mathrm{c}$

Cow Horn. A long, pure white variety, resembling a white carrot more than a turnip. The flesh is tender and sweet, and it is quite popular as a market variety on this account. Pkt. 5c; Oz. $10 \mathrm{c} ; 1 / 41 \mathrm{~b}$. 20c; $1 \mathrm{~b} .50 \mathrm{c}$.

Early Snowball. A medium globe-shaped variety of pure white ery solid and of the best quality. $\mathbf{k} \mathbf{k} .5 \mathbf{c} ; \mathbf{c z} . \mathbf{1 0 c}$

\section{EARLY WHITE FLAT DUTCH (Strap} Leaf) A medium-sized, flat variety; clear white, early. 0z. 10c: $1 / 41 \mathrm{~b} .20 \mathrm{c}: 1 \mathrm{~b} .50 \mathrm{c}$.

Extra Early White Milan. A very early variety, medium sized, flat, and clear white. A fine home-garden variety. Pkt. 5c; oz. $10 \mathrm{c} ; 1 / 41 \mathrm{~b}$. $25 \mathrm{c} ; 1 \mathrm{~b} .75 \mathrm{c}$.

Extra Early Purple Top Milan. A very early variety, medium $1 / 1 b, 25 c ; 1 b .75 c$.

Orange Jelly, or Golden Globe. A globe-shaped, vellow variety 5c;0z, 10c; crisp vellow flest. A very fine table variety. Pkt.

\section{RUTA BAGAS, OR SWEDES}

These are grown very extensively for stock feeding and make an excellent and valuable crop. Treatment same as for winter turnips, but require a longer season to grow and the seed should be planted early in July. The rows should be at least two and one-half feet apart, and the plants thinned to eight or twelve inches. The roots frequently grow to an enormous size.

AMERICAN PURPLE TOP, or LONG ISLAND One of the best and most popular varieties, with purple top above, and the leaves are small. A good stockfeeding ol table variety. Pkt. 5c;0z. 10c; $1 / 4$ ib. 20c;1b. 50c.

Laing's Purple Top. A globe-shaped variety of good quality. 5c;0z. 10c; $1 / 41 \mathrm{~b} .20 \mathrm{c} ; 1 \mathrm{~b} .60 \mathrm{c}$.

\section{TOBACCO}

CONNECTICUT SEED LEAF. The best known and most widely used variety throughout the middle and northern States and $20 \mathrm{c} ; 1 / 1 \mathrm{~b} .60 \mathrm{c} ; 1 \mathrm{~b} . \$ 2.00$

Havana (Domestic). Pkt. $10 \mathrm{c} ; 0 \mathrm{z}, 25 \mathrm{c} ; 1 / 4 \mathrm{~b}$. 75c;1b. $\$ 3.50$.
LARGE WHITE, or SWEET GERIMAN. A very large variety. which is tender and sweet. Pkt. 5c;0z. 10c; $1 / 41 \mathrm{~b} .20 \mathrm{c} ; 1 \mathrm{~b} .50 \mathrm{c}$.

Monarch, or Tankard. Roots ovoid in shape and very large. Pkt. 5c;0z. 10c; $1 / 1$ 1b. 20c;1b. 50c.

Yellow Purple Top Swede. The well-known and most commonly used variety. Roots, globular; skín, yellow under ground and or stock feeding. Pkt. $5 \mathrm{c} ; 0 \mathrm{z} .10 \mathrm{c} ; 1 / 1 \mathrm{lb} .20 \mathrm{c} ; 1 \mathrm{~b} .50 \mathrm{c}$. Flesh, yeliow; skin, yellow below ground and purple above.
Vuelta de Abajo (Imported Havana). Pkt. 15c;0z. 50c. White Burley. Pkt. 5c; oz. 30c; $1 / 4$ lb. $\$ 1.00 ; 1 b . \$ 3.00$. Yellow Pryor. Pkt. 10c; oz. 25c; $1 / 4$ lb. 75c; lb. $\$ 2.50$. Kentucky Yellow. Pkt. 10c; oz. 25c; $1 / 4$ lb. 75c; 1b. $\$ 2.50$. 


\section{AROMATIC, MEDICINAL AND POT HERBS}

Anise. A hardy annual. The seed especially being used for seasoning :ood, also for flavoring liquors and for medicinal
purposes. Grows about two feet tall. Sow the seed where the plants are to stand. Pkt. 5c; 0z. 10c; $1 / 4$ lb. 25c;1b. 85c.

Balm. A perennial herb used for seasoning, especially in liquors. Has a lemon-like flavor. Thrives in any warm location, and is easy to gro

Basil, Sweet. A hardy annual, the leaves of which have a clovelike flavor. Used for seasoning soups, meats, and salads. Of the easiest culture; seed can be sown as early as the weather permits. Pkt. 5c; oz. $15 \mathrm{c} ; 1 / 41 \mathrm{lb} .40 \mathrm{c} ; \mathrm{lb} . \$ 1.50$.

Borage. The leaves are used for flavoring and the flowers furnish bee pasture. Pkt. 5c;0z. 10c; $1 / 41$ lb. 30c; 1b. $\$ 1.00$.

Caraway. A biennial herb, grown for its seeds, which are used for flavoring breads, cakes and cheese; also occasionally for the young shoots and leaves, which are eaten. Grows two feet high. Is of easy culture. Sow the seed in the spring for seed crop the following year. Pkt. 5c; oz. 10c; $1 / 41$ 1b. 25c; 1b. 75c.

Catnip. Practically a wild plant. Is a hardy perennial, the leaves of which are used for medicinal purposes. Pkt. 5c; oz. 40c; $1 / 4$ Ib. $\$ 1.25 ; 1$ b. $\$ 4.00$.

Coriander. An easily grown herb, the seeds of which are used for flavoring pastry, confectionery and liquors. Grows two to three feet high. Pkt. 5c; $1 / 4 \mathbf{1 b}$. 15c; lb. 45c.

Dill. An annual herb, the seeds of which are used for seasoning. The foliage is also used for flavoring as well as for medicinal purposes. Grows two to three feet high "Its largest use is 5c;0z. 10c; $1 / 4$ lb. 20c; 1b. 60c.

Fennel, Sweet. A hardy perennial, the leaves of which are used in soups, garnishes, and salads. The seed should be sown early and plants thinned to six or eight plants to foot of row. Pkt. 5c; oz. 10c; $1 / 4$ lb. 30c; 1b. $\$ 1.00$.

Horehound. A hardy perennial shrub, one to three feet high, with whitish, hairy leaves, which are used in confectionery, and in medicines for coughs and colds. Pkt. 5c;0z. 20c; $1 / 4$ ib. 60c.

Hyssop. A hardy perennial shrub, growing eighteen inches high. Used for medicinal purposes, both green and dried. Pkt. 5c; oz. $20 \mathrm{c} ; 1 / 4 \mathrm{lb}$. $60 \mathrm{c}$.
Lavender. A hardy perennial, growing two feet high and forming a bush about four feet in diameter. Used as a garden plant on stems are frequently used for fancy work when dried. Pkt. 5c; oz. $15 \mathrm{c} ; 1 / 4$ 1b. $40 \mathrm{c} ; 1 \mathrm{~b}$. $\$ 1.25$.

Sweet Marjoram. A half-hardy perennial, the leaves of which are used both green and dried tor

Rosemary. A hardy perennial shrub, the leaves of which are used for seasoning and medicinal purposes. Oil of rosemary is distilled from the leaves. Pkt. $5 \mathrm{c} ; 0 \mathrm{z} .35 \mathrm{c} ; 1 / 4 \mathrm{lb} . \$ 1.00$.

Rue. A hardy perennial, thriving on poor soil. Has a peculiar smell; leaves are bitter. Is used as a stimulant, but should be used with caution, since its use sometimes results in injury.
Pkt. 5c; oz. 15c; $1 / 4 \mathbf{l b}$. 40c.

Sage. A hardy perennial shrub, with whitish-green, oval, and very much wrinkled leaves, which have a yleasant smell and which are used for seasoning. It is easily grown and the seed can be sown almost any time. Its fragrant, purplish flowers are especially attractive to bees, and the finest white honey has its source in

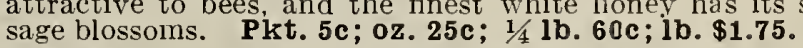

summer Savory. A hardy annual, the stems and leaves of which are used for flavoring dressings and soups. Pkt. $5 \mathrm{c} ; 0 \mathrm{oz} .10 \mathrm{c}$; $1 / 4$ lb. 30c.

Winter Savory. A hardy perennial, the leaves of which are used for seasoning. Pkt. 5c;0z. 20c; $1 / 41 \mathrm{lb}$. 60c.

Tansy. A very easily grown perennial plant, growing about three feet high. Its leaves are used for medicinal purposes, especially

Tarragon. The leaves are used for seasoning. The plants continue to bear leaves for a long period. Pkt. 10c.

Thyme. A low-growing, half-shrubby perennial, with fragrant leaves, having a mint-like odor, which are used for seasoning. Pkt. 5c; 0z. 25c; $1 / 4$ lb. 75c; 1b. $\$ 2.50$.

Wormwood. A hardy perennial, growing about four feet high. The leaves, which are greatly divided, have a strong, bitter flavor. They are gathered in the summer and dried, and are largely used in medicines for tonics and applications. Also used

\section{VEGETABLE PLANTS AND ROOTS}

We carry the following plants in the season shown and pack them very carefully for shipping. The purchaser takes the risk of their wilting or being damaged in transit.

Artichoke Plants. January to May. Doz. \$2.00. Too heavy to mail.

Asparagus Roots. 2 years old. January to April. Doz. 20c (postpaid 25c doz.); $100 \$ 1.00 ;$ special price per 1,000 .

Cabbage Plants. November to June. Doz. 15c; $10085 \mathrm{c} ; \mathrm{doz}$. 20c, postpaid.

Cauliflower Plants. November to June. Doz. 20c; $100 \$ 1.00$; doz. 25c, postpaid.

Celery Plants. March to May. Doz. 20c; $100 \$ 1.20 ;$ doz. 25c, postpaid.

Egg Plant. April to May 15th. Doz. 25c; doz. 30c, postpaid.

Garlic. November to May. 25c per 1 b.

Horse Radish Roots. January to May. Doz. 50c; doz. 55c, postpaid. Extra large roots, $15 \mathrm{c}$ each, or $\$ 1.00$ per 10 .

Pepper, Large Bell. April to May. Doz. 25c; $100 \$ 1.50 ;$ doz. 30c, postpaid.

Pepper, Cayenne. April to May. Doz. 25c; $100 \$ 1.50$; doz. 30c, postpaid.

Rhubarb Roots. December to May. Each 15c; doz. \$1.50; doz. $\$ 1.75$, postpaid.

Rhubarb Roots, Crimson Winter. Each 25c; 5 for $\$ 1.00, \$ 1.15$, postpaid.

Sweet Potatoes. April 15th to June. Doz. 20c; $100 \$ 1.00 ;$ doz. $25 \mathrm{c}$, postpaid.

Tomato, Extra Early Plants. April. Doz. 25c.

Tomato, Stone, etc. April to June. Doz. 20c; $100 \$ 1.25 ;$ doz. 25c, postpaid.

Herbs, Chives, Sweet Marjoram, Sage, Savory, Thyme, Tarragon. Two plants of any kind or assorted for $25 \mathrm{c}$; postpaid, 30c.

\section{SEASONS TO PLANT IN}

\section{CENTRAL CALIFORNIA}

Variety

Artichoke.

Asparagus...

Beans, Bush Lima.

Beans, Pole Lima..

Beans, Wax. ..

Beets.

Broccoli.

Brussels Sprouts

Cabbage

Carrot.... .

Cauliflower...

Celery...

Corn.

Corn Salad

Cucumber

Egg Plant.

Endive...

Kale......

Lettuce..

\section{When to Sow}

January to March.-Plant Roots

February to April.

January to May.

April to May.

April to August.

April to August.

All Year Round.

January to April.

January to April. - July to October.

January to April.- July to October.

January to Aprí

July to January.

September to January.

April 15th to July.

March to May.-August to October.

April 15th to June.

February to April.

July to October.

January to April.-July to October.

January to May.- July to October.

All Year Round.

\section{Variety}

Muskmelon

Watermelon.

Mustard....

Okra........

Onion....

Parsley

Parsnip

Pepper.

Pumpkin.

Radish...

Rhubarb

Rhubarb Roots

Salsify.

Spinach

Squash.

Tomato

Turnip.

Of the above all are planted out of doors except Egg Plant, Peppers

and Tomatoes, which should be started early in rame

When to Sow

April to June.

April to May.

February to May.

A pril to June.

All Year Pound.

July to October.-January to May.

All Year Round.

February to March.

April to June.

All Year Round.

February to May.

January to April.

August to February

April to June.

February to May.

August to April. 


\section{C.C.MORSE \& CO. FIELD SEEDS}

\section{WE ARE HEADQUARTERS IN CALIFORNIA FOR CLOVER AND GRASS SEEDS TO MAKE A GOOD LAWN}

The soil cannot be too well prepared. It does not need to be so very rich since a long growth of grass is not so necessary as a thick root

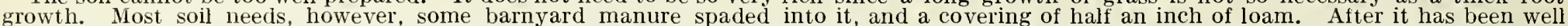

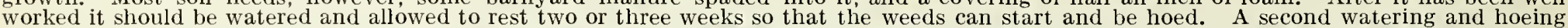

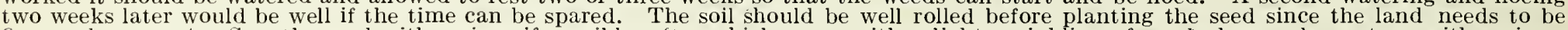

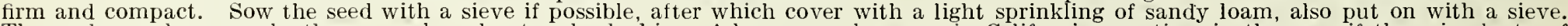

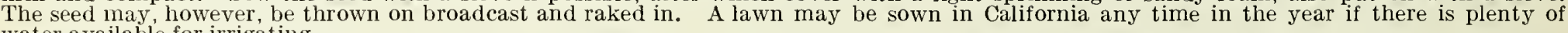
water available for irrigating.

Good Lawns are made from pure Kentucky Blue Grass, or Perennial Rye Grass or White Clover, but we recommend, as vastly superior to

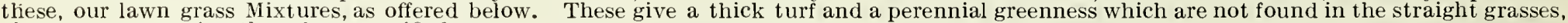
alone, as many using them have testified.

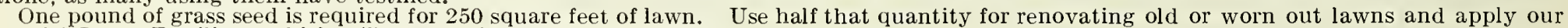
Special Lawn Fertilizer, which will greatly invigorate the growth.

\section{MORSE'S CALIFORNIA LAWN SEED}

A mixture of more than half a dozen good perennial lawn grasses, all of the heaviest recleaned seed. It gives the very best results in thick, deep green, sturdy lawns. Per lb. $45 \mathrm{c}$, postpaid, or by express or freight, lb. $35 \mathrm{c} ; 100 \mathrm{lbs}$. $\$ 30.00$.

our Golden Gate Park Lawn Mixture. We especially recommend this mixture for those requiring a quick-growing, thick, sturdy lawn which remains green all winter, as well as other seasons of the year; especially for sandy soils. This variety contains a small proportion of white clover, just enough to make it a thick mat. Per lb. 45c, postpaid, or by express or freight, $1 \mathrm{~b} .35 \mathrm{c} ; 100 \mathrm{ibs}$. $\$ 30.00$.

Morse's Velvet Lawn Mixture. A combination of soft, deep green

grasses, which form a thick mat especially in the summer. Is easy to cut and easy to grow in good, moist, rich soil, and is especially recommended for adobe soils. Per lb. 45c, postpaid, or by express or freight, 1b. 35c; $100 \mathrm{lbs}$. $\$ 30.00$.

Fancy Recleaned Kentucky Blue Grass. A great many still prefer the pure unmixed blue grass, of which we offer the finest and best seed. Per 1b, 35c, postpaid, or by express or freight, 1b. $25 \mathrm{c} ; 100 \mathrm{lbs}$. $\$ 17.50$.

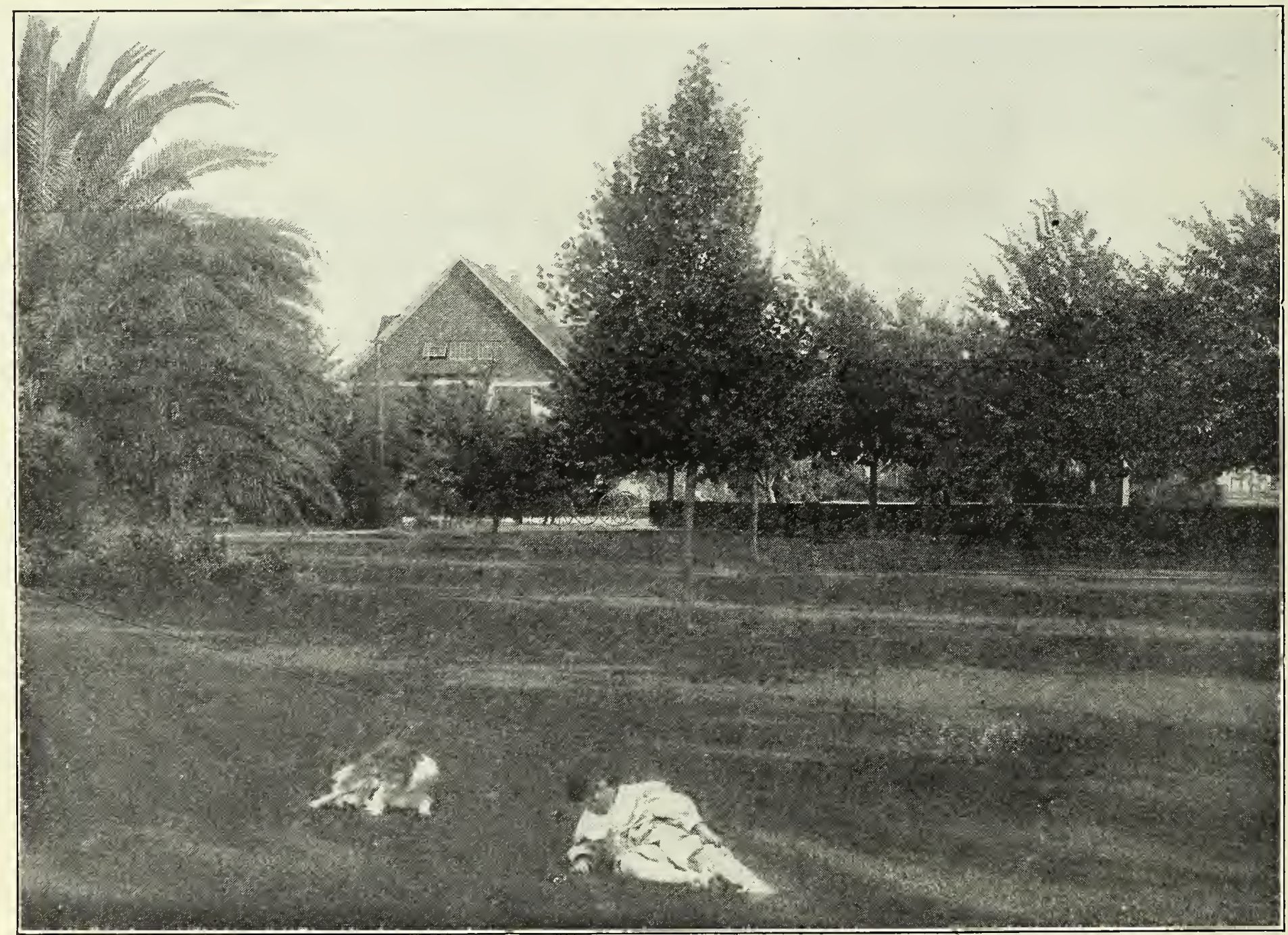

A Beautiful Lawn-Sown with Morse's California Lawn Mixture

Fertilizer. To insure a rapid growth of grass some kind of fertilizer is necessary, especially in lawns where the nourishment of the soil has been used up by continuously growing on the same place. We have a fertilizer especially prepared to invigorate the growth of grass and to keep it that dark green color. Use one and one-half pounds to one hundred square feet and make two applications each year. Special prices on lawn and field fertilizers upon application. By express or freight only. Lawn Dressing, 10 lbs. $65 \mathrm{c} ; 25$ lbs. $\$ 1.25 ; 50$ lbs. \$2.00. 
Australian Salt Bush (Atriplex semi-bacata). A valuable plant for poor soils, especially those containing alkali. Sow seed in the fall to get the benefit of early rains, using 1 to 2 pounds per acre. After the plant gets a good start, it will grow with very acre. After the plant gets a good start, it will grow with ver
little moisture. Oz. 10c; $1 / 4$ 1b. 30c; 1b. \$1.25, all postpaid.

Broom Corn (Improved Evergreen). Used for making brooms, and extensively used on account of its green color and long brush.

Buckwheat (Japanese). The best and most profitable variety. It is earlier than Silver Huller, and usually more productive. Is
also excellent for bee pasture. Lb. 20c, postpaid; $100 \mathbf{1 b s}$. $\$ 5.00$.

Buckwheat (Silver Hulled). A very good and popular variety. Grain is of a light color, rounder than the common variety;
has a much thinner husk, earlier, and yields more. Lb. 15c, postpaid; 100 1bs. $\$ \mathbf{4 . 5 0}$.

Canary. The seed is used for bird food. Is valuable also as an ornamental grass and has considerable merit as hay for feeding cattle. Lb. 20c, postpaid; $100 \mathrm{lbs}$. $\$ 6.00$.

Niles Peas. Used principally for green manure. Is a strong vigorous

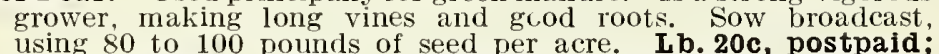
100 Ibs. \$5.00. Larger quantities on application.

Canada Field Peas. A standard variety, answering the same purpose as the above. Write for quotations.

Egyptian or Jerusalem Corn, or Dhoura. Belongs to nonsaccharine sorghums. It is considered a good grain for dry sec-
tions and seasons. It produces several small heads on side shoots, often as many as 8 heads on a stalk. The seed is small and makes excellent chicken food. Plant 3 lbs. per acre. L $\mathbf{b}$. 20c, postpaid; 100 lbs. $\$ 6.00$.

Cow Peas (Black Eye). Used largely for green manure. It is also valuable if allowed to mature the seed, when the dry vines can be plowed under and the seed used to grind as feed for stock. If for green manure, sow broadcast, using 80 pounds per acre. per acre. Lb. 20c, postpaid; $100 \mathrm{lbs}$. \$7.00.

Flax seed. Should be sown in the spring on moist land, using 30 pounds of seed per acre if grown for a seed crop, or twice that quantity if intended for a crop of fiber. Lb. 20c, postpaid; 100 lbs. $\$ 4.50$.

Hairy Vetch (Vicia Villosa). A pea-like plant growing about 4 feet high and doing well on dry, sandy soils for forage. Also a valuable green manure plant for sowing in the fall. Sow broad-
cast, 60 to 100 pounds per acre. Lb. 30c, postpaid; 100 1bs. cast, 60
$\$ 12.00$.

Hemp (Kentucky Hemp). A staple crop for manufacturing, sown broadcast, using 25 pounds of seed per acre. For a seed crop,
should be sown in hills 4 feet apart. Grows 12 to 14 feet high, should be sown in hills 4 feet apart. Grows 12 to 14 feet high, With deep cut, dark green leaves, which are rather fragrant. annual. The seed is used in birdseed mixtures. $\mathbf{L}$ b. 25c, postpaid; 100 lbs. $\$ 6.00$.

Jersey or Cow Kale. A tall-growing variety having a large bunch of cabbage-like leaves on the top of a stout stem. Pkt. 5c; oz. $10 \mathrm{c} ; 1 / 41 \mathrm{~b}$. 20c; 1b. 60c.

Paspalum Dilitatum. A new grass for hot, dry climates. A hardy perennial from Australia, growing 5 feet high, without getting tough, and seems to be particularly adapted for grazing dairy cattle. It stands drought remarkably well, and shoots rapidiy again with the first shower of rain, and is a splendid winter grass. Although it will stand a considerable degree of frost and even snow without harm, still it requires lot summer weather to grow it to perfection. The seed requires about 3 weeks of moist, genial weather to germinate it, but once established, it seems to stand anything. Oz. 10c; 1b. 75c.
Kaffir Corn. Grows from 6 to 10 feet high and thrives in hot, dry climates. Makes good fodder for cattle, and the seed is used for stock and chicken food. Sow in rows 3 feet apart, using 5 pounds per acre. Lb. 20c, postpaid; 100 lbs. $\$ 6.00$.

Rape (Dwarf Essex). A biennial crop, used principally for sheep pasture. Is usually sown broadcast on ranges, us
pounds per acre. Lb. 25c; postpaid; 100 lbs. $\$ 8.00$.

Soja Bean. Valuable as a forage crop or green manure. Also as

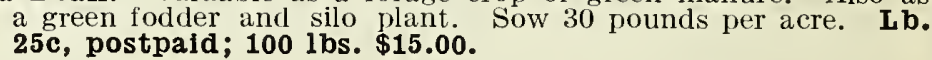

Spring Vetches, or Tares (Vicia Sativa). A plant resembling pea vines, and valuable for forage or green manure. It is usually sown with oats or wheat to hold them up. Sow 60 pounds per sown with oats or wheat to hold them up. Sow 60 pounds per
acre with grain, or 80 to 100 pounds if sown alone. Lb. 20c, postpaid. Larger quantities on application.

Sugar Cane (Sorghum), Early Amber. A good fodder if cut when 2 feet high. Is nutritious and yields a heavy crop. Sow late in
April, using 10 pounds seed per acre in drills, or 25 pounds broadApril, using 10 poinds seed per acre in drills
cast. Lb. 20c, postpaid; 100 lbs. $\$ 4.00$.

“ Early Orange. A strong, productive variety, either for fodder or for syrup. Lb. 25c, postpaid; 100 lbs. $\$ \mathbf{7 . 5 0}$.

Sunflower (Large Russian). A variety bearing large heads, frequently 12 to 20 inches in diameter and sometimes yielding 1,000 pounds of seed per acre. The seed is used for feeding chickens and parrots. Sow in the open field as soon as danger from frost is
over, using 3 pounds of seed per acre, sowing in rows 5 feet apart over, using 3 pounds of seed per acre, sowing in rows 5 feet apart
and thinning to 1 foot. Lb. 20c, postpaid; 10 lbs. $70 c ; 100$ lbs. $\$ 6.00$.

Speltz, or Emmer. A valuable grain from Russia. Grown in the United States for several years. It is adapted to a wide range of soil and climate, and is of superior feeding value, yielding much more heavily than oats and barley. This grain grows tall, like rye, and matures as early as barley, and yields trom 40 to 80 bushels to the acre, alld from 4 to 6 tons of straw hay. Tough and hardy, it stands the drought better than any other grain, making it a sure crop. Prepare your land as you would for wheat or oats, and sow at the rate of 75 r 100 pounds per acre. Sow very early in the spring or fall and do not let it stand until
it gets too ripe before cutting, as any grain that yields well shells it gets too ripe before cutting, as any grain that yields well shells
easily. In the green state it makes an excellent pasture. Lb. $\mathbf{1 5 c}$, postpaid; express or freight, $100 \mathrm{lbs}$. $\$ 4.00$.

Teosinte (Reana Luxurians). This plant grows quickly and produces a large quantity of forage in warm locations. It makes splendid dry fodder, yielding enormously, and being more nutritious and better relished by all stock than corn fodder. The seed should not be sown until all danger of frost is past. If cut for green forage, which can be done at any stage during growth, two or more joints should be left at the base of the stalk. These will sprout out quickly into fresh growth, making an even larger pounds of seed to an acre. Oz. 10c; $1 \mathbf{b}$. $75 \mathrm{c}$.

Velvet Bean. Used largely as a green-manure plant and also for forage. Grows taller and larger than any other soil plant, being sometimes 30 feet in length. Sow same as cow peas, in rows 5
feet apart and in hills 4 feet apart in the row. Lb. 25c, postpaid; $\mathbf{1 0 0}$ 1bs. $\$ 10.00$.

Whippoorwill Peas. This variety is a great favorite in the West and South as a green manure and fodder pea. Is early and grows close to the ground. Lb. 20c, postpaid; 100 lbs. $\$ 7.00$.

Wild Rice (Zizania Aquatica). A native plant, growing in shallow water with mud bottom. The seed is difficult to germinate, and should be kept moist several days before sowing. The plant makes an excellent shelter for wild fowl, and is much esteemed on game preserves.

NOTE.-We are usually prepared to quote Alfalfa, Clovers and Grasses by the carload and invite special correspondence for large quantities.

A word about Alfalfa. This is one of the items we handle more extensively than any other farm seed. It is not a plant we grow for seed ourselves, but we use the utmost care in purchasing our stock. Most of our seed comes from one of the best alfalfa growing sectious in Utah, where weeds and dodder do not infest the crops and we buy direct from the best farmers in this section. Before offering our seed, we submit samples to the United States Department of Agriculture for government test and use only such lots as pass satisfactorily.

Those buying Alfalfa seed from us can be assured that it is Government Tested. 


\section{CALIFORNIA TREE AND SHRUB SEEDS}

The vitality of tree and shrub seeds cannot be tested before the sale, but only such seeds are sent out as we believe will give complete satisfaction. No guarantee of genuineness or germination can be given, and we presume that parties ordertig liave rearl the above and agree to the conditions.

\section{Price per Packet, 10 cents, except where noted}

Abies Douglasii (Douglas Spruce). A very large and important tiniber tree 200 to 300 feet high; of pyramid shape. Found throughout the Rocky Mountains, from Oregon to Mexico. Very hardy. 0z. 30c; $1 \mathrm{~b}$. $\$ 3.00$.

Christmas Berry (Photinia Arbutifolia). A California Evergreen shrub, 10 teet high, bearing clusters of bright red berries. These are gathered for decorations at Christmas time and are familiar to nearly every one. Oz. 20c; 1 b. $\$ 1.50$.

Cupressus Goveniana (Goven's Cypress). 30 to 40 feet high; very ornamental; found in the Coast Ranges of Monterey. Oz. $40 \mathrm{c} ; 1 \mathrm{~b} . \$ 4.00$.

"Lawsoniana (Lawson's Cypress). A handsome tree, with white fragrant wood, free trom knots; easily worked and very durable. Oz. $40 \mathrm{c}$; 1 b. $\$ 4.00$.

Macrocarpa (Monterey Cypress). A tree 40 to 60 feet high, rough bark; spreading, horizontal branches, rich green toliage; rough bark; spreading, horizontal branches, rich green toliage; hedges. Oz. 15c;1b. $\$ 1.00$.

Pyramidalis (Italian Cypress). This variety is of upright pyramidal growth, and is much used in cemeteries. $\mathbf{0 z}$. 40c; Ib. $\$ 4.00$.

Libocedrus Decurrens (Thuya Craigiana). A fine, hardy timber tree; known as White Cedar of California. Oz. 40c; 1b. $\$ 4.00$

Madrone. A beautiful native tree of California. The foliage is a deep green and leathery; it attains a considerable size iflowers white. Pkt. 25c.

Manzanita. A low-growing tree or shrub, bearing attractive white biossoms and beautiful red berries. Pkt. $25 \mathrm{c}$.

Picea Grandis (Western Balsam Fir). Grows 200 to 300 feet ligh, 4 to 6 feet in diameter; grows rapidly in rich, moist soil; valuable timber tree. $0 z .40 \mathrm{c} ; 1 \mathrm{~b} . \$ 4.00$.

\section{AUSTRALIAN TREE AND SHRUB SEEDS}

SUITABLE FOR CULTURE ON THE PACIFIC COAST

Price per Packet, 10 cents, except where noted

ACACIA Baileyana. A handsome tree, with glaucous foliage; in great demand for street planting. One of the most beautiful of the Acacias. Oz. $40 \mathrm{c} ; 1 \mathrm{~b} . \$ 4.00$.

Decurrens (The Black Wattle of Australia). In California it has grown over 50 teet in eight years. Oz. 40c; 1b. $\$ 4.00$.

Lopantha. One of the rankest growing sorts, makes a bush 15 to 20 feet high with spreading leaves. Largely used in Golden Gate Park. Oz, 20c; 1b. $\$ 2.00$.

Melanoxylon. In irrigated glens of deep soil this tree will attain the height of 80 feet with a stem several feet in diameter. $\mathbf{0 z}$. $40 \mathrm{c} ; 1 \mathrm{~b} . \$ 4.00$.

Mollissima. A fine, erect, rapid-growing tree, with glaucous green, feathery foliage; flowers yellow, and borne in racemes. Oz. $40 \mathrm{c} ; 1 \mathrm{~b}$. $\$ 4.00$.

EUCALYPTUS Amygdalina (Giant Gum Tree). Is one of the best for subduing malarial effluvia in fever regions, although it does not grow with quite the same ease as the Eucalyptus globdoes not grow with quite the same
ulus. Pkt. 25c; oz. 75c; Ib. $\$ 750$.

Citriodora. The well-known lemon-scented gum; a popular favorite. Pkt. 50c; 0z. \$2.00.

Corynocalyx (Sugar Gum). This variety will stand more frost $\left(22^{\circ}\right)$ than any other Eucalyptus and will also stand more draught. Quick growing timber variety. $\mathbf{0 z}$. 75c; $1 \mathbf{b}$. $\$ 7.50$.

Ficifolia. Very ornamental for lawn or avenue planting; has beautiful crimson flowers. 50c per packet of 25 seeds.

Globulus (Blue Gum). A very rapid-growing tree, making valuable timber. The common variety - the one most generally planted. Oz. 50c; $1 \mathrm{~b} . \$ 5.00$.

Leucoxylon (Ironbark Tree). The culture of this variety is desirable on poor, stony land, where other Eucalypti would be unsatisfactory; flowers a re a beautiful cerise pink. Pkt. 15c; oz. $\$ 1.00$.
Picea IMagnifica. The Red Fir of the Sierras, found at an altitude of 7000 feet; very hardy. Oz. 50c; 1 b. $\$ \mathbf{5 . 0 0}$.

Date Palm (Phoenix Canariensis). A beautiful long-leaved variety growing to an immense height. 100 seeds for $25 \mathrm{c} ; 1000$ seeds for $\$ 1.50$.

Dracaena Indivisa (Dragon Palm). A handsome palm-like tree used for planting along avenues. The leaves are borne in a head at the top of a
$\mathbf{3 5 c} ; \mathbf{1 b} \mathbf{\$ 3 . 5 0}$.

Pinus Insignis (Monterey Pine). A very ornamental tree for parks and lawns; grows from 60 to 70 feet high; of rapid growth; has beautiful green foliage. $0 z .30 \mathrm{c} ; 1 \mathrm{~b} . \$ 3.00$.

Jeffreyi. A magnificent tree usually found at an elevation of 5000 feet; very hardy Oz. 35c; 1b. $\$ 3.50$.

Lambertiana (Sugar Pine). A hardy tree of gigantic dimensions; found on both slopes of the Sierras. The finest pine timber tree. Oz. 30c; 1b. $\$ 3.00$.

Ponderosa (Yellow Pine). One of the largest pines known. Found in Coast Range on the highest points. Very hardy. The most valuable timber variety. $0 z .30 c ; 1 b$. $\$ 3.00$.

Sabiniana (Nut Pine). Abundant over the dry and hot hills of the Coast Range. Very hardy. Oz. 20c; 1b. \$2.00.

Sequoia Gigantea (Wellingtonia Gigantea). The mammoth tree of Caliornia. This is the largest tree known to exist on the American continent. Pkt. 25c; oz. 70c; lb. $\$ 7.00$.

Sempervirens. Usually known as California Redwood. The most valuable timber of the California torests. Oz. 40c; Ib. $\$ 4.00$.

Wild Cherry. A native California hedge plant resembling holly. Oz. $25 \mathrm{c} ;$ ib. $\$ 2.50$.
EUCALYPTUS Marginata (Jarrah of Western Australia). A very excellent timber. Resists teredo, on which account it is largely used for piles. $\mathbf{0 z}$. $\mathbf{7 5 c}$.

“Robusta (Swamp Mahogany). Thrives best on low grounds, especially near the sea coast. Pkt. $25 \mathrm{c} ; 0 \mathbf{0 z} \mathbf{\$ 1 . 0 0}$.

“ Rostrata (Red Gum). A rapid-growing tree; stands heat and considerable cold without injury. Imported, oz. $75 \mathrm{c} ; 1 \mathrm{~b} . \$ 7.50$. Domestic, 0z. 50c; $1 \mathrm{~b}$. $\$ 4.00$.

" Stuartiana (Apple-Scented Gum Tree). Seems to do equally well on rather dry and sandy as on humid soils. The wood is of a handsome dark color and takes a good polish. Fkt. 15c; oz. $\$ 1.00$.

" Tereticornis (Gray Gum). A very hardy, quick-growing Eucalyptus; largely used for railroad ties, etc. One of the sorts most often planted for timber. Oz. 75c; 10. $\$ 7.50$.

Viminalis. In poor soil it grows to a moderate height; in rich soil it attains gigantic dimensions. $0 z .75 \mathrm{c} ; 1 \mathrm{~b}$. $\$ 7.50$.

We import seed of the following desirable varieties of Eucalypti, and offer at the uniform price of $15 \mathrm{c}$ per packet, $75 \mathrm{c}$ per ounce:

E. Cambagei. E. Hemiphloia. E. Polyanthema.

E. Coriacea. E. Mellodora. E. Resinifera.

E. Crebra. E. Obliqua. E. Rudis.

E. Gonicalyx. E. Platyphilla E. Piperita.

E. Gunnii. E. Saligna.

See under the head of Eucalypti-in our nursery department-for varieties we can furnish in plants.

Grevillea Robusta (Silk Oak of East Australia). Beautiful fernlike foliage; of rapid growth, flowering when about 20 leet in oz. $60 \mathrm{c} ; 1 \mathrm{~b} . \$ 6.00$.

Pepper Tree (Schinus Molle). Well known handsome shade tree. Oz. $15 \mathrm{c} ; 1 \mathrm{~b}$. $\$ 1.50$. 

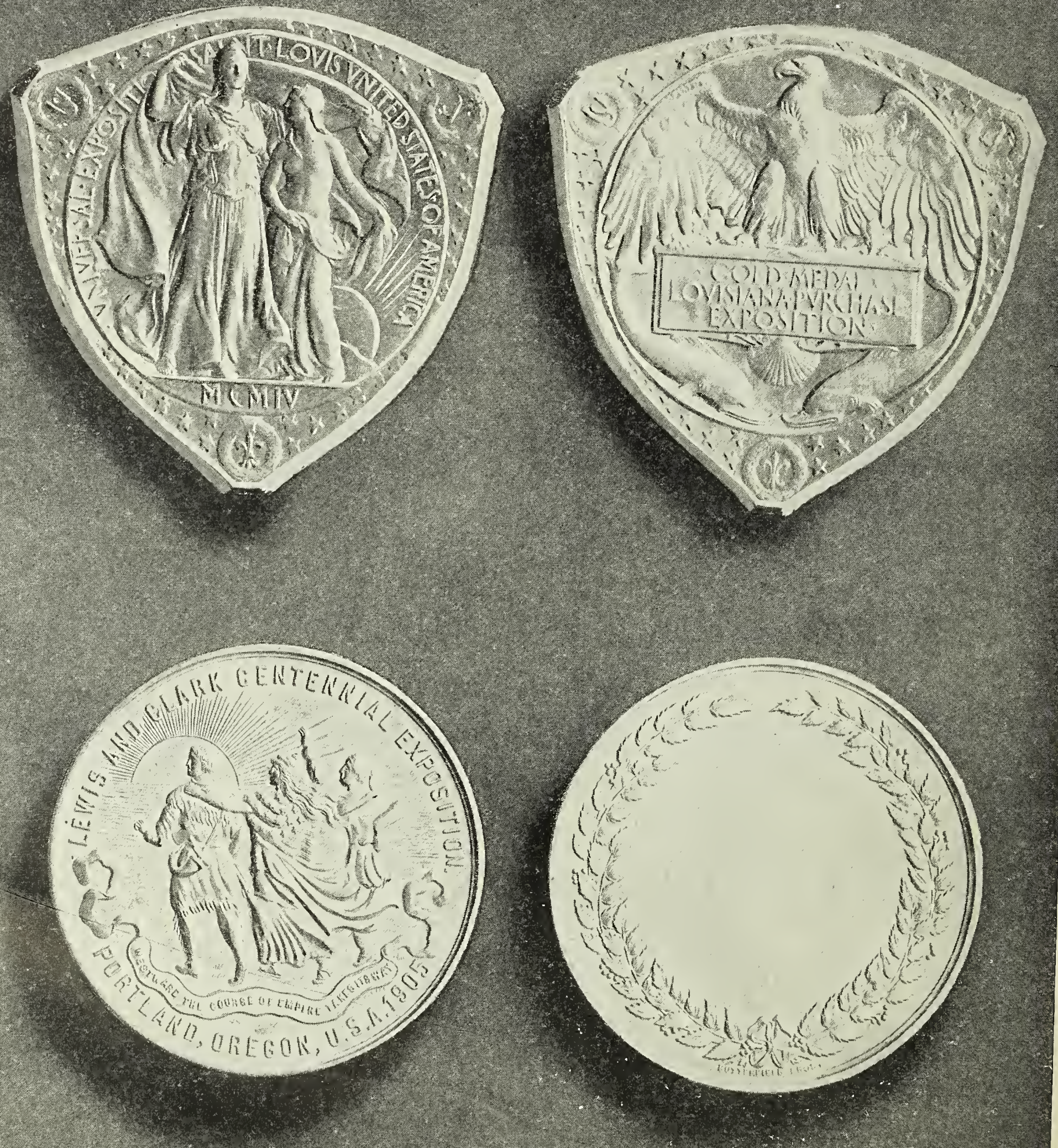


\section{OUR COMMISSION BOX SEEDS}

While our annual catalogue is our chief solicitor and we like very much to get your orders by mail, we are just as well pleased if you buy our seeds at the store where you do your trading. It used to be generally understood that seed sent out on commission by the large seed houses, was not of the best quality and that it was old and of doubtful germination. Whatever might have been true in the past, or whatever might even now be true of some seed houses, so far as Morse Seeds are concerned they are the best we know how to grow or how to produce, whether offered for sale in your town or in our store, providing they are in our sealed packets or packages and bear our name.

The name, C. C. Morse \& Co., on the package means the seed inside is the best to be had.

At the end of each planting season, every box and every unsold package and packet is collected by our representatives and sent back to us, and every paper and package torn. We do not use one of the same papers or packages the second season.

When it comes to the seed, it is a maxim in our establishment that "nothing is too good for our Commission Boxes." They are of the very best quality and at the time they are put up everything is tested and used only when of satisfactory germination, so that with reasonable care in planting our seeds should all grow.

Of course we cannot put every variety we handle in these assortments, but we do put in the staple articles and when you want something besides these, we are glad to have you send us your order direct by mail and it will receive our prompt attention.
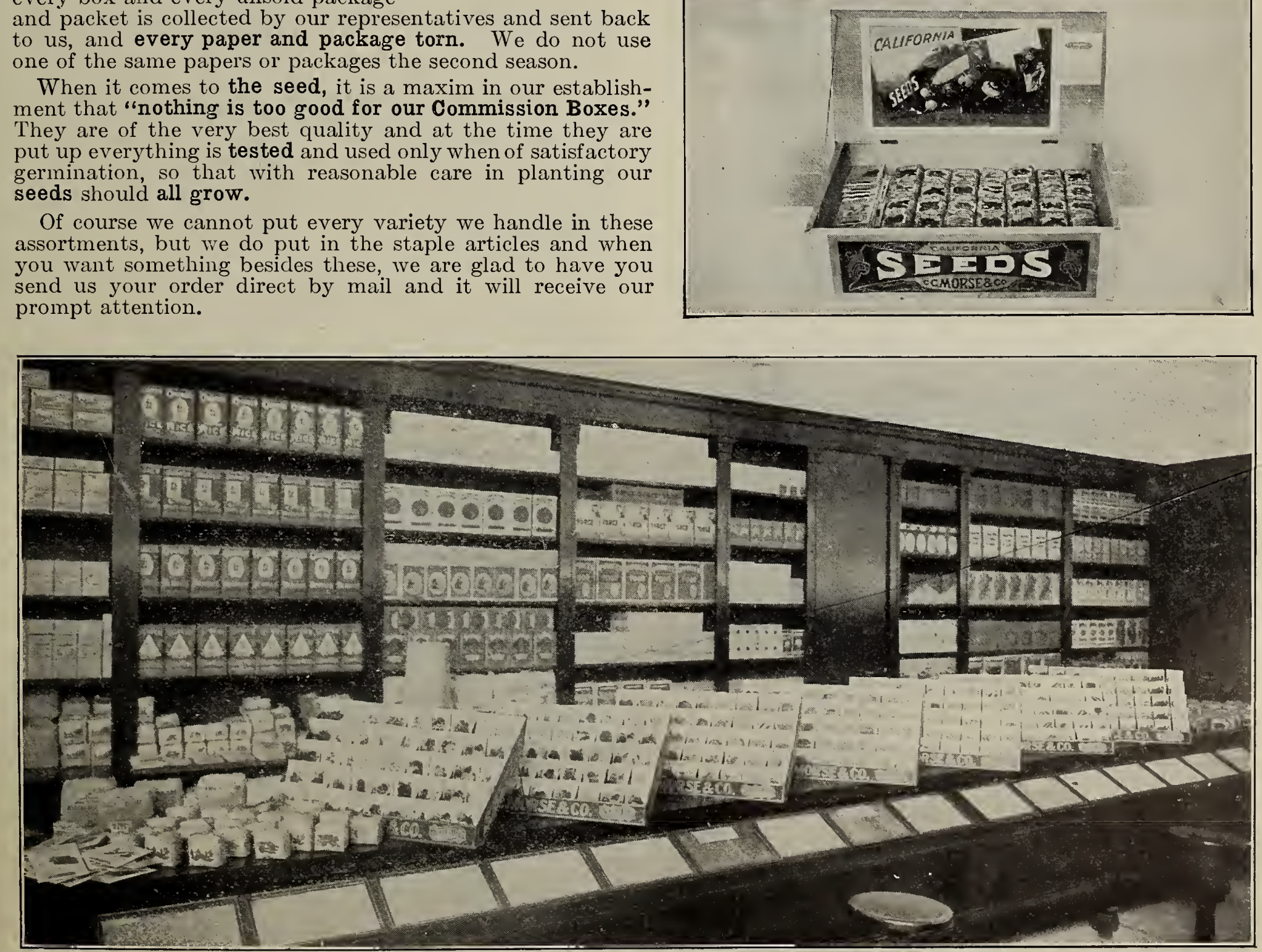

A photo of OUR SEEDS on sale in our regular patented METAL DISPLAY RACKS at "The Emporium," San Francisco 


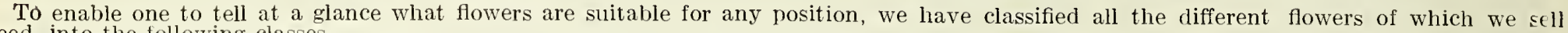
seed, into the following classes.

Perennials are separated from Annuals and Biennials are classed with the perennials. Plants which will do well in a shady location we have indicated by (s) after the name, and those that do well in a partially shaded location are indicated by (p s).

We think these lists will be of great service to every careful planter.

Asparagus Fern (s)

Begonia, Rex

Calceolaria (p s)

Cineraria (s)

\section{BEDDING PLANTS, PERENNIAL}

From 1 to 2 Feet High

Agrostema

Asperula Odorata

Begonia, Vernon Tuberous (p s)

Calceolaria Rugosa ( $\mathrm{p} s$ )

Candytuft, Perennial

Carnation

Cineraria (s)

Columbine

Daisy, Shasta

Linum. Blue Flax

Coleus

Cyclamen

Impatiens Sultani

Impatiens

Mimulus

Salvia

Senecio

Stevia

Stocks, Perpetual

Sweet William

Verbena

Viola (s)

Violet $(s)$

Wallflower (p s) Tuberous ( $\mathrm{p} \mathrm{s}$ )

Solanum or Jerusalem Cherry

Vinca or Madagascar Periwinkle

\section{ANNUAL BEDDING PLANTS}

or Tall Border Plants

1 to 2 Feet

Adonis

Ageratum, Tall

Amaranthus

Aster

Balsam

Bartonia Aurea

Browallia (s)

Cacalia

Calendula

Candytuft

Celosia

Centaurea

Centranthus

Chrysanthemum

Clarkia

Collinsia

Daffodils (see Fall Bulb Catalogue) (p s)

Dianthus

Eschscholtzia, or California

Poppy

Forget-me-not（s)

Four O'clock

Gaillardia

Gilia

Glaucum Luteum

Godetia (p s)

Gypsophila (for bouquets)

Grasses, Ornamental

Hunnemannia, or Bush Eschscholtzia

See page 111 for miscellaneous bedding plants, etc.

TALI GROWING SHRUB PIANTS, PERENNIAL For Grouping; from 2 $1 / 2$ Feet Up

Abutilon

Canna (s)

Chrysanthemum, White and

Yellow Marguerite ( $p s$ )

Coreopsis

Dahlia (s)

Digitalis

Fuchsia (s)

Geranium

Golden Rod

Golden Glow

Grasses, Pampas, etc.

Hollyhock

I pomopsis, or Tree Cypress

Larkspur, Formosum

Iyacinths (see Fall Bulb cata-

logue)
Iris (see Fall Bulb catalogue)

Leptosine Densiflorus

Linum, Scarlet Flax

Lupins

Lychnis, Haageana

Marigold

Nasturtiums, dwarf

Nige!la, or Love in a Mist

Pansy (p s)

Perilla Nankinensis

Petunia

Poppy

Portulaca

Pyrethrum Grandiflorum

Schizanthus

Snapdragon, dwar

Statice

Stock, Ten Weeks

Tulips (see Fall Bulb Catalogue)

Virginia Stock (s)

Viscaria

Whitlavia

Zinnia

Lavatera

Lemon Verbena

Oenelia, Cardinalis

Poppy, Oriental or Bracteatum

Platycodon or Wahlenbergia

Phlox, Perennial

Romneya Coulteri (Matilija Poppy)

Scabiosa Caucasia

Snapdragon, Tall (p s)

Stokesia Cornflower Aster

Sweet Rocket or Hesperis

Valerian

Wallflower (p s)

TALL GROWING PLANTS FOR GROUPING, ANNUAL From $21 / 2$ Feet Up

Amaranthus

Arctotis Grandis

Calliopsis

Castor Oil Bean

Cleome Pungens

Cosmos

Euphorbia

Honesty
Kochia Tricophylla

Larlispur

Lilies ( $\mathrm{p} s$ )

Lychnis Chalcedonica

Nicotiana

Salpiglosis

Scabiosa Grandiflora

Sunflower
LOW EDGING PLANTS, ANNUAL

6 to 12 Inches High

A geratum, dwarf Feverfew, or Pyrethrum Alyssum

Bulbs of All Sorts (see Special Fall Catalogue)

Brachycome

Candytuft

Celosia, dwarf

Centaurea, Dusty Miller

Dianthus Gypsophila

Limnanthes

Lobelia Compacta (very good) Mignonette (s)

Nemophila

Oxalis

Pansy (p s)

Sweet Peas, Cupids

LOW EDGING PLANTS, PERENNIAL

6 to 12 Inches High

Morning Glory, dwarf

Lemon Verbena
Poppy, Iceland

Primula, Vulgaris and P. Polyanthus (s)

Pyrethrum

Armeria Mariti

Daisy, English

Forget-me-not (s)

Viola (p s)

PLANTS FOR ROCKERIES, HANGING BASKETS, OR WINDOW BOXES

Abronia (Rockery)

Arabis, Alpina (Rockery)

Asparagus Fern (s)

Ice Plant (Rockery)

Kenilworth Ivy (s)

Iimnanthes Douglasii

Lobelia, Trailing

Maurandia (s)

\section{Mimulus}

Oxalis (s)

Portulaca (Rockery)

Sanvitalia (Rockery)

Sedum (Rockery)

Thumbergia

Torenia

Verbena (p s)

EVERIASTING FLOWERS

Acroclinium

Australian Star Flower

Gomphrena

Rhodanthe

Statice

Xeranthemum

Helichrysum

CLIMBING VINES, ANNUAL

7 to 25 Feet

Balloon Vine

Butterfly Runner Bean

Scarlet Runner Bean

Browallia

Calampelis

Canary Bird Vine

Clianthus Diampieri

Cobea Scandens

Cypress Vine

Convolvulus

Dolichos, or Hyacinth Bean

Echinocystis (Wild Cucumber Vine)

Ipomea, all kinds

Lophospermum

Mina Lobata

Momordica, or Balsam Apple Momordica, or Balsam Pear Moonflower

Morning Glory

Nasturtium, Tall

Sweet Peas

7 to 25 Feet

Adlumia Cirrhosa, or Mountain Heliotrope

Fringe IIumulus, or Japanese Hop

Aristolochia Sipho, Dutchman's

Pipe

Australian Pea Vine

Bignonia

Centrosema

Clematis

Lathyrus Latifolius

Lantana

Mandevilla Suaveolens

Sinilax

See page 101 for plants of climbing plants and vines.
Gourds, Ornamental

\section{CLIMBING VINES, PERENNIAL}

PACIFIC RYE GRASS-A brand new lawn grass which has never before been used in California. It is similar to Perennial or Australian Rye, but the seed is smaller. The leaf is much narrower, and almost as fine as Kentucky Blue Grass. But its chief merit is its great longevity-a place sown to it will last ten years without renovating, while ordinary Rye Grass should be resown every four or five years. Per lb. 35c, postpaid; by express or freight, 1 lb. $25 \mathrm{c} ; 10 \mathrm{lbs}$. $\$ 2.00 ; 100 \mathrm{lbs}$. $\$ 17.50$.

This beautiful new grass seed is obtainable only from C. C. Morse \& Co. 


\section{SAN FRANCISCO CALIFORNIA U.S.A.}

\section{A PAGE OF FLOWER NOVELTIES}

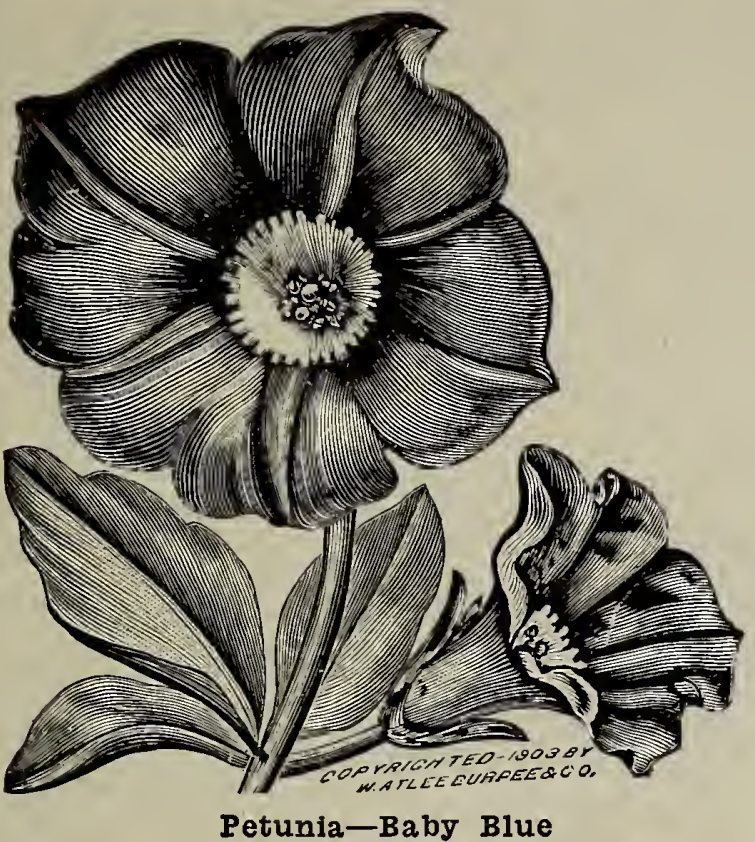

\section{CLIMBING DOLICHOS-IRIDESCENT}

This ornamental climber comes from the Island of Jamaica and is quite distinct from other varieties. The vines are of quick and strong growth. The pinkish lavender flowers come in quite large spikes and are succeeded by clusters of most showy pods which measure from 5 to 6 inches in length and about one inch in breadth. The pods are of a light green coloring, almost transparent with a dark line or margin of deep purple around the outer edge, and are heavily shaded with an iridescent tint of bright rose. The color effect of the pods resembles the fantastic shading of the interior of an abalone shell. Pkt. 10c.

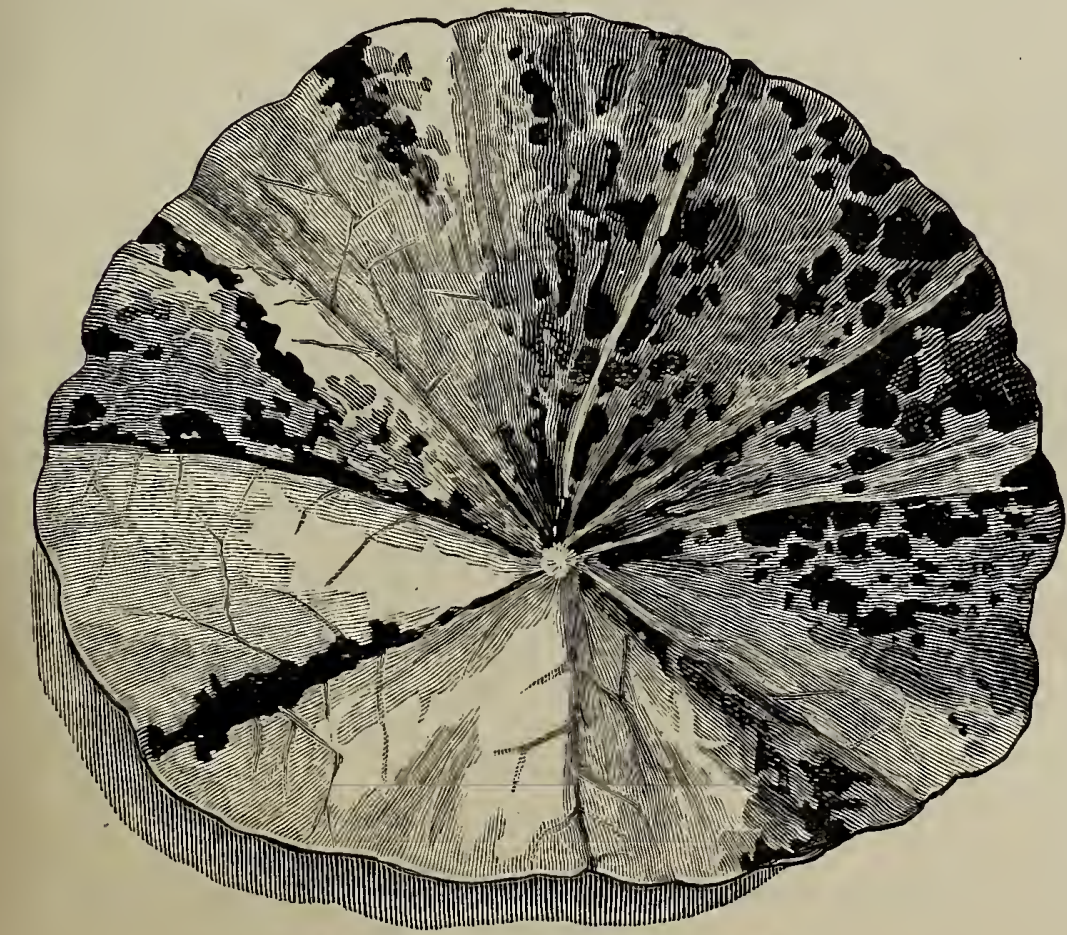

Nasturtium-Variegated Leaved

\section{PETUNIA-BABY BLUE} half inches across, and are a soft purplish blue. The general effect in bunch or when in full flower on the plant is that of a lovely blue without the suggestion of purple. It is a dainty border plant and so easily grown that the seed can be sown with success anywhere. Pkt. 10c.

\section{NICOTIANA AFFINIS}

Hybrids Mixed. This is a much finer strain of Nicotiana than the Sanderaea, the flowers being very much larger. The plants are compact, averaging two feet in height, pyramidal in form and bloom profusely. The flowers are large in size, have a short tube and are distinctly fragrant, resembling Jessamine. The colors range through creamy white and rose tints to bright red and crimson. Pkt. 10c.

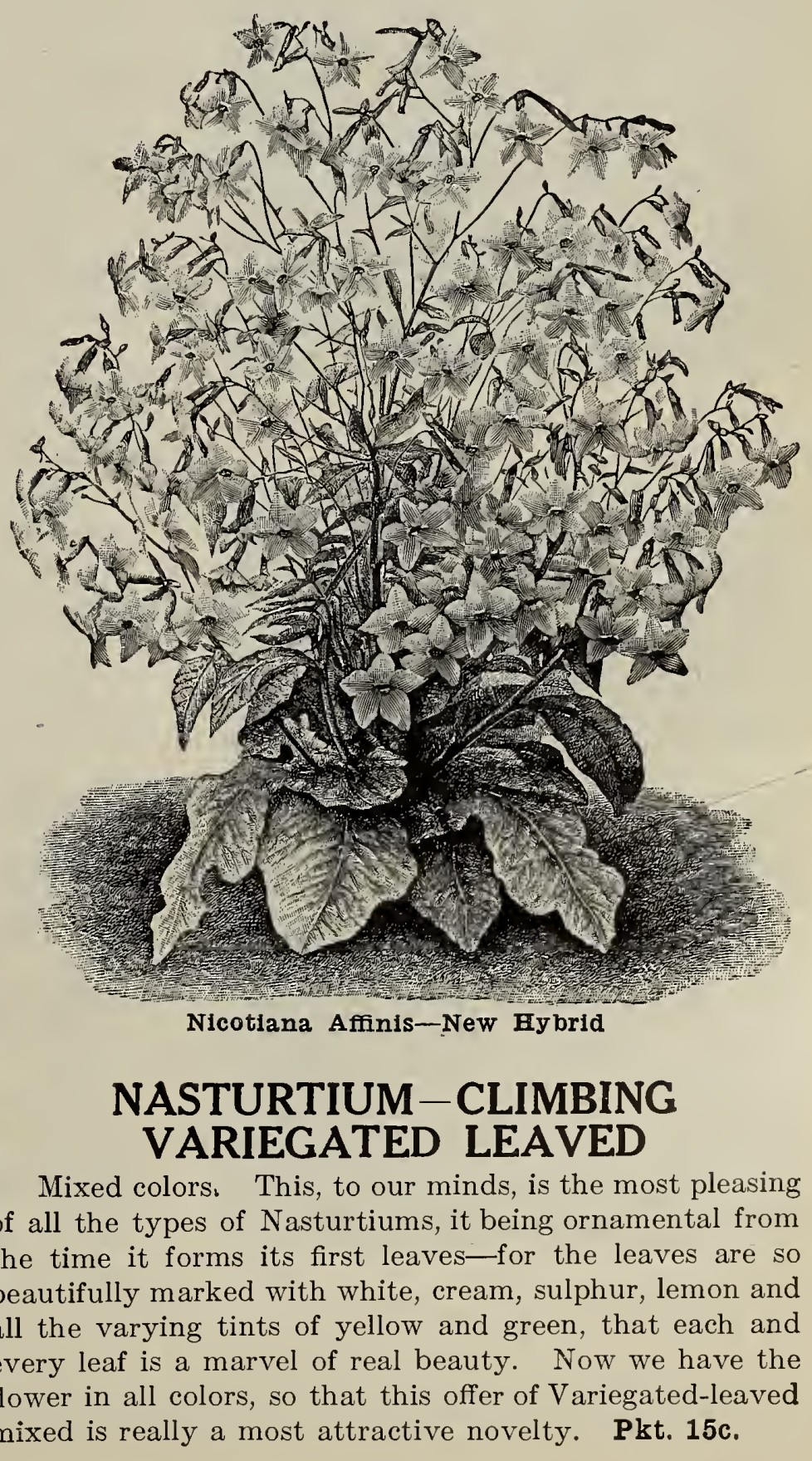




\section{[DC.C.MORSE \& CO. FLOWER SEEDS W. BURBANK'S SPECIALTIES}

We feel confident that nothing could please our friends and customers better than to have an opportunity of securing some of the choice

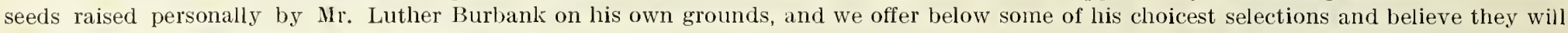
prove a delight to anyone who plants them in his garden.

These particular things are Mr. Burbank's own growing and should not be confused with the same varieties we offer elsewhere in this catalogue.

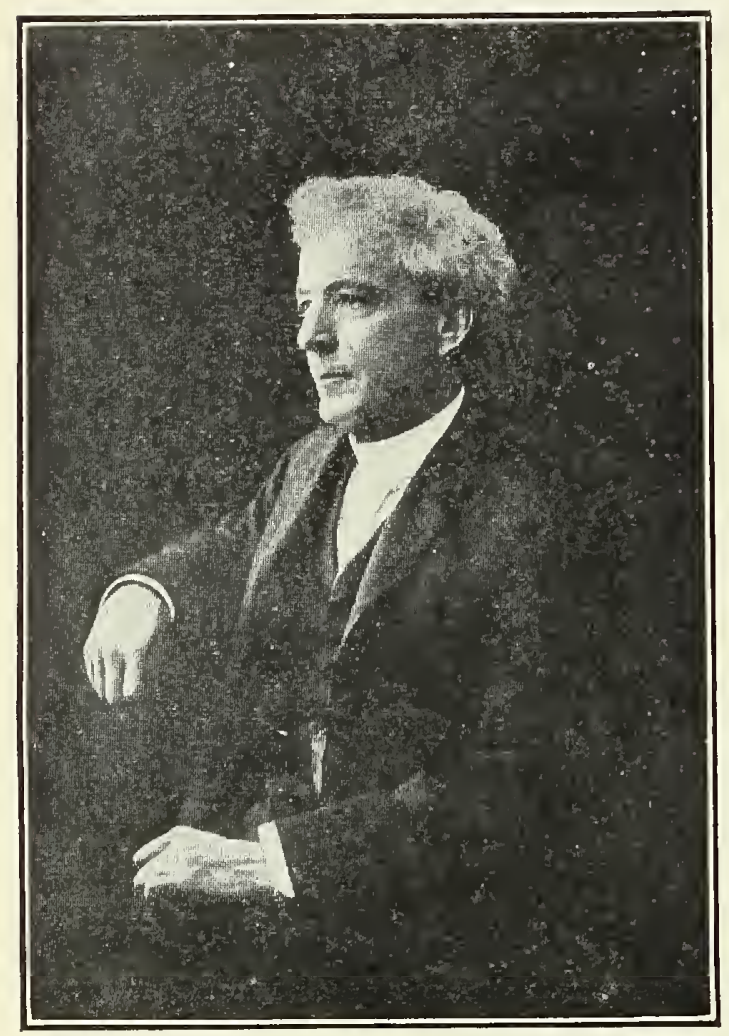

Luther Burbank

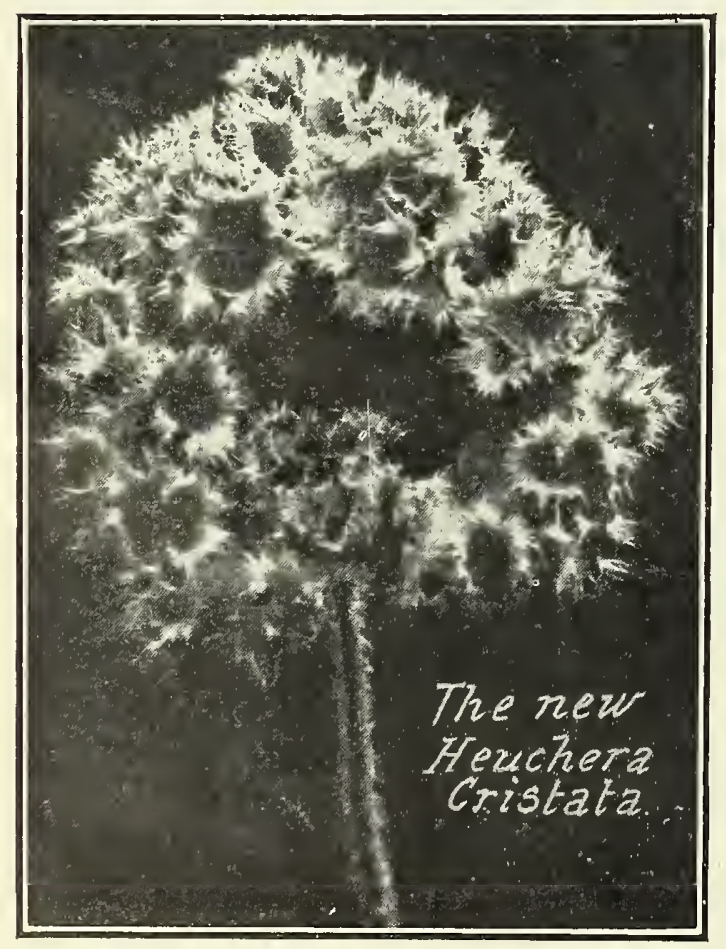

CARNATION MARGUERITE A superb strain of this delightful very double and containing a large assortment of colors. Among the colors are several shades of yellow, usually wanting in these mixtures. Pkt. $15 \mathrm{c}$.

LOBELIA Cardinalis. A magnificent flower that thrives best in moist soil. It flowers. Mr. Burbank tells us this is one of the most beautiful flowers he grows. Pkt. 15c.

SALPIGLOSIS Variabilis. In this strain Mr. Burbank has been working of tints and combination of colors. A beautiful flower at all times and especially so under Mr. Burbank's development. Pkt. 15c.

SCABIOSA One of our old fashioned favorites for slady locations and under lavender and pink shades and the blossoms are very large. Pkt. 15c.

CANNA-TARRYTOWN A giant flowered crimson, one of the most grand variety for growing in clumps on the lawn. Pkt. 15c.

ESCHSCHOLTZIA Crimson Gold. A strain of California Poppy that several sharles of crimson and bronzy yellow blossoms- This strain produces several shades of crimson and bronzy ye
attractive combination of colors. Pkt. $\mathbf{1 5 c}$.

SHASTA DAISY Alaska. As this is Mr. Burbank's original introduction more need be said of it. Pkt. 25c.

SCYPHANTHUS, ELEGANS A superior climbing vine, never an annual and thrives in any sunny location. Its large clear yellow blossoms usually measure 2 inches in diameter. This gorgeous flower deserves a larger notice and much more prominence than we are able to give it this year, but we hope our want of space will not prevent our customers from trying it. A rare vine from Chili. Pkt. 15c.

AUSTRALIAN GERANIUM A brand new Geranium-never ticular things on this pare which Mr. Burbank regards with peculiar pride. It is a low trowing, compact variety especially recommended for borders. It has very peculiar and interesting leaves and its foliage and blossoms are both very fragrant. It is an annual and grows readily from seed. Pkt. 25c.

HEUCHERA CRISTATA (Micrantha). A most surprising and crimped and crested in wonderful manner somial foliage plant. Leaves gracefully Begonia but far more beautiful. No plant possesses this peculiar cresting of the leaves to the same extent. Produced by years of selection from the ordinary plain leaved $H$, micrantha. Its great panicles, 2 to 3 feet long of small white flowers, are an added charm. Comes quite true from seed, but varies slightly in the amount of cresting. Pkt. 15c.

SHIRLEY POPPY "Santa Rosa" strain. Produced by years of rigid varied strain in existence. Unusually large flowers, remarkably clear colors, including new striped, new salmon shades and new bluish ones, all mixed. Pkt. 15c.

AUSTRALIAN STAR FLOWER New half hardy annual, $_{\text {everlang. }}^{\text {hale crims on }}$ and white, very graceful, abundant bloomer. Culture same as Petunias. Pkt. 15c.

SCHIZANTHUS WISETONENSIS Select mixed. B l o o m s a titudes of flowers of various pleasing shades. Pki. 15c.

PYRETHRUM, CRIMSON A large single flowering crimson flowered a large red daisy and is a fitting companion to the white Shasta Daisy. Pkc. 15c.

ALSTROEMERIA (Lily of the Incas) from Peru, A strong growing comes in a great variety of colors-red, yellow, lavender etc. and is especially ornamental for borders. The root in Peru is considered edible. Pkt. 15c.

CESTRUM Mixed. Semi-tropical shrub, bearing large panicles of orange, yellow, brown and crimson flowers. Hardy in CaliCOLLECTION of the above BURBANK STRAINS-(1 pkt. each 14 in all) for $\$ 1.75$.

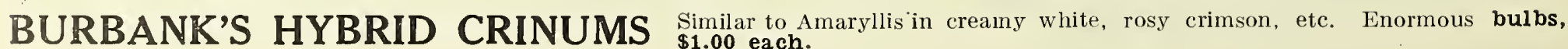




\section{FLOWER SEEDS}

There are no more satisfactory flowers in the garden than those grown from seed, especially the easily grown and brilliant flowered annuals.

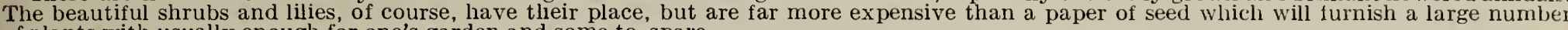
of plants with usually enough for one's garden and some to spare.

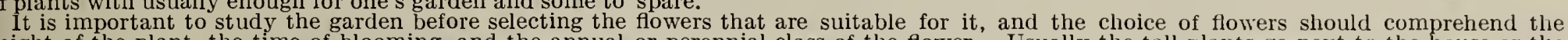

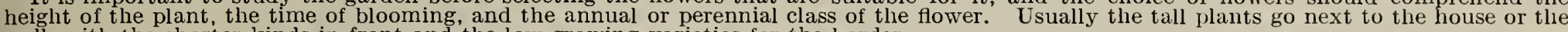
wall, with the shorter kinds in front and the low-growing varieties for the border.

While the old-fashioned flowers are still popular, new and improved varieties have been developed, with larger and finer blossoms.

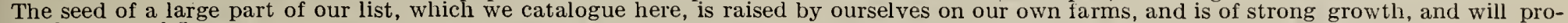
duce the best of flowers.

It is usually best to sow the seed of annuals early in the year, and the seed should be on hand in January or earlier.

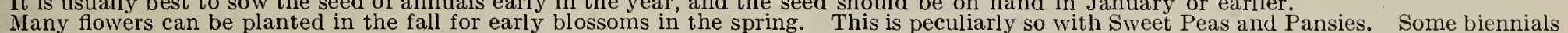

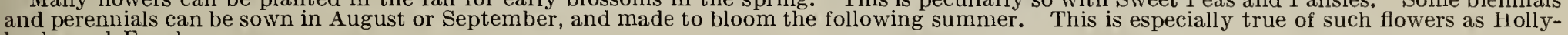
hocks and Foxgloves.

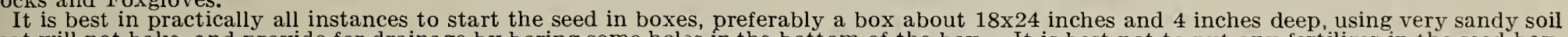

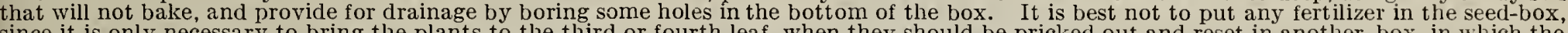

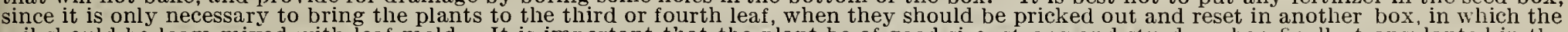

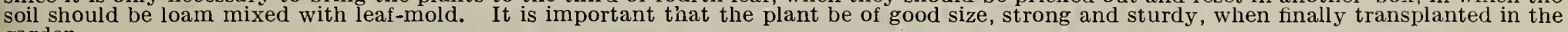
garden.

If the seed be sown directly in the garden, it should be sown in the spring after the soil is well worked and fertilized. A slight depression

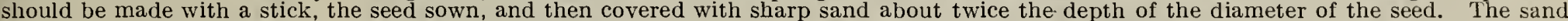
will prevent the crusting over of the soil after watering.

When up, the plants must be thinned from two to twelve inches, depending on the variety, atherwise they will be weak and spindling. It is

a common mistake in the garden to leave the plants altogether too thick. . Always keep the weeds out.

On account of the long, dry summers in California, it is necessary to apply water very often. Most of our gardens suffer for want of sufficient water. Where possible, it should be applied to the roots only, and after four o'clock in the afternoon.

With a little study of the garden and the colors and habits of the flowers, a beautiful garden can be had from the use of flower seeds at very little cost.

Annuals.-Bloom first year from seed and plant dies after one season.

Biennials. - Bloom second year from seed and plant dies after second year.

Perennials. - Bloom second year from seed and plant lives and blooms for several years.

Tender.-Means plant will not stand the least frost.

Half Hardy.-Means plant will stand a little frost and needs protection.

Hardy. - Means plants will stand considerable frost, or practically all we have on the Pacific Coast.

\section{HOT-BEDS}

Good hot-beds may be made by digging down about three feet and filling the excavation with rather fresh horse manure in which there is a

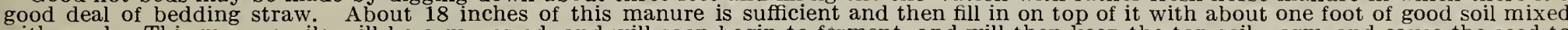

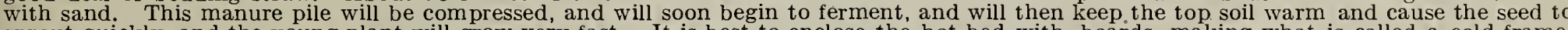

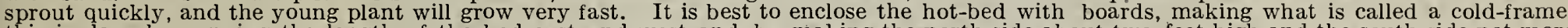

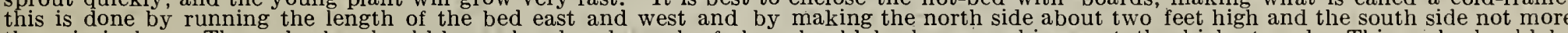

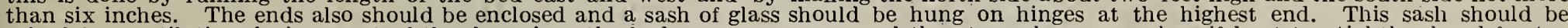

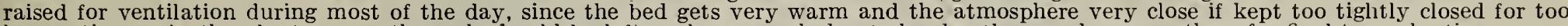
long a time. As the plants grow, the sash should be left up longer each day to harden them and prepare them for final transplanting.

The hot-bed should have a very sunny location near a hedge or some building, well-protected from the prevailing wind.

ime during the winter, and the plants can be ready to set out just as soon as danger of frost is over.

As the sun gets too hot it is necessary to shade the bed, and the glass should be white-washed or covered with sacking if necessary. Too much heat is fatal to the tender, young plants.

\section{SELECT LIST}

ABRONIA (Sand Verbena). A hardy annual, trailing in habit, about nine inches high, bearing verbena-like clusters of flowers which are very fragrant. A native of California. Thrives in dry situations, and is valuable for rock-work or hanging baskets.

Umbellata.' Rosy lilac. Pkt. 5c.

ABUTILON (Flowering Maple, or Chinese Bell-flower). A tender perennial shrub, used generally in greenhouses, but growing. into small trees in California. The flowers are beautifully bell-shaped and appear in white, yellow, rose and orange. Mixed colors, pkt. $10 \mathrm{c}$.

ACROCLINIUM. Very pretty annual, producing white and rosecolored daisy-like flowers in August and September. These are the "Immortelles," so desirable for wreaths and winter bouquets. One foot. - Double mixed, pkt. 5c; single mixed, pkt. $5 c$.

ADLUMIA CIRRHOSA (Mountain Fringe, or Allegheny Vine). An attractive and beautiful hardy climber, flowering the first season; clusters of small rosy-lilac flowers and pale green feathery foliage. Grows fifteen feet tall. Pkt. 10c.

ADONIS (Flos Adonis, or Pheasant's-Eye). A hardy annual of easy culture, growing about one foot high. Leaves fine-cut and feathery; flowers crimson. Seed should be sown in the autumn. Pkt. 5c.

AGERATUM (Floss Flower). A hardy annual of easy culture, especially valuable for bedding, as it is literally covered with blossoms all summer. Sow the seed early in the spring, either in boxes to transplant, or out of doors, and thin to four or six inches.

Blue Perfection. Deep blue, one foot high. Pkt. 5c. Mexicanum, Imperial Dwarf Blue. Eight inches high, flowers blue. Pkt. 5c.

Mexicanum, Imperial Dwarf White. Eight inches high, flowers white. Pkt. 5c.

Little Dorrit. A perfect mass of blue flowers; plant is six inches high and a foot through. Pkt. 10c.

"Little Blue Star." A very dwarf variety, densely covered with small, light-blue flowers, which are purplish-red at the center. Pkt. 15c.

AGROSTEMA (Rose of Heaven). A hardy perennial, blooming the first season if seed is sown in the autumn. Plant grows one to two feet high; flowers resemble Dianthus in bright colors; and are borne on long, slender stems. Mixed colors, pkt. 5c.

ALYSSUM (Maritimum). A fragrant, hardy annual, having the odor of honey, and bearing spikes of small. white flowers in great profusion throughout the summer and autumn. Useful for borders or early bedding flowers. Sow the seed early in spring.

Common Sweet Alyssum. One foot high, very sweet honey fragrance. Pkt. 5c; oz. 25c.

"Carpet of Snow." Pure white, very dwarf, sweet scented. Plkt. 5c.

Little Gem. Three to four inches high; fine for borders. Pkt. 5c; oz. 50c.

Saxatile. A. yellowish perennial variety. Pkt. 5c; oz. $50 \mathrm{c}$.

AMARANTHUS. Hardy annuals, grown especially for their brilliant foliage.

Caudatus (Love Lies Bleeding). Light yellowish-green foliage long drooping crimson flower spikes. Plant three to four long, drooping, crin

Cruentus. Tall spikes of red flowers. Three feet. Pkt. 5c. 
AMARANTHUS-Continued.

Tricolor (Joseph's Coat). Plant three feet ligh, with brilliant leaves in variegated, red, yellow, green, etc. Pkt. 5c.

ANGEL'S TRUMPET. See Datura.

ANTIRRHINUM. See Snapdiragon.

AQUILEGIA. See Columbine.

ARCTOTIS GRANDIS (The African Lllac Daisy). A remarkably handsome annual from Africa, forming branclied bushes two to two and a half feet in leight and breadth; are pure
white on the upper surface, reverse of petals pale lilac. Pkt. 10c. ARIST OLOCHIA SIPHO (Dutchman's Pipe). Strong-growing liardy climber, with large, thick, shining foliage
yellowish brown, pipe-shaped tlowers. Pkt. 10c.

ARMERIA MARITIMA (Thrift, Sea Pink). Pretty edging plant, bearing tuits of rosy-pink flowers; hardy perennial. One foot. Pkt. 10c.

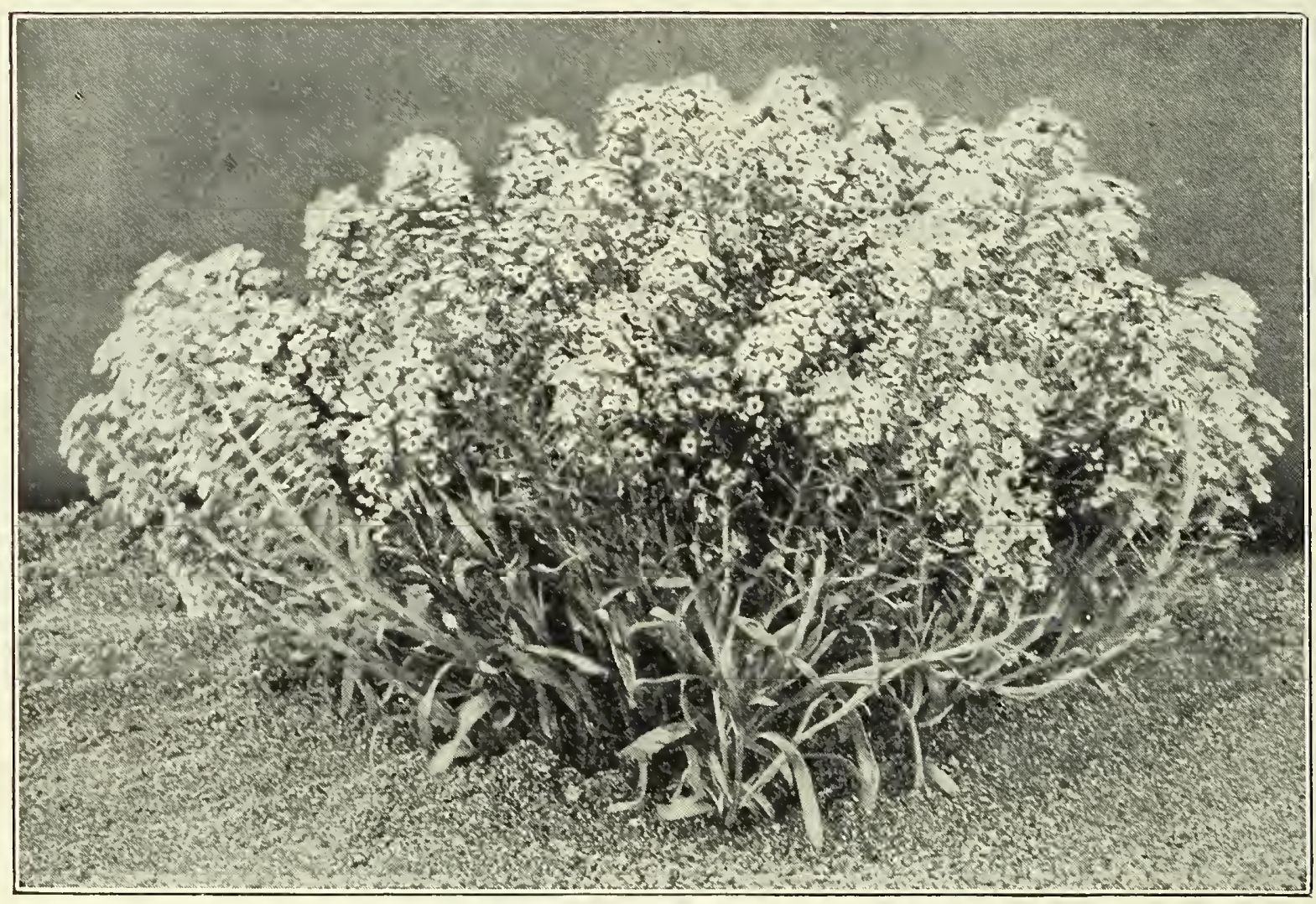

Sweet Alyssum

ASPARAGUS PLUMOSUS. A tender perennial for greenhouse or potted plant use, with long, fine feathery foliage. The sprays, when cut, retain their freshness in water from three to four weeks. Seeds start slowly, and should be soaked in water before sowing. Pkt. 10c; 100 seeds $75 \mathrm{c}$.

PLUMOSUS NANUS. A dwarf variety and sometimes preferred on account of its beautiful, dense sprays of feathery green. Pkt. 10c; 100 seeds 75c.

-SPRENGERI (Emerald Feather). An early, easily grown, feathery-leaved variety, with drooping branches. The best variety for hanging baskets. Pkt. 10c; 100 seeds 50c.

ASPERULA ODORATA (Sweet Woodruff). An old-fashioned favorite, grown for its fragrant leaves and stems, which, when
dried, have an odor not unlike new-mown hay, and are used for putting among clothes, etc. Used in Germany to flavor the "Naitrank," or May wine. Best grown in semi-shaded positions.
Flowers white. Pkt. 5c.

AURICULA (Primula auricula). A dwarf-growing plant, bearing umbels of fragrant flowers of many rich and beautiful colors. A great iavorite in England, where flower shows are held of this
plant alune. Extra choice mixed, from a prize collection. Pkt. 15c.

AUSTRALIAN PEA VINE (Dolichos Lignosus). A rapid-growing, climbing annual, flowering freely in large clusters of rose flowers. For covering arbors, trellises, etc., they have no superior. Pkt. 10c.
AUSTRALIAN STAR FLOWER. A very attractive, everlasting or straw-flower; introcluced into America by Luther Burbank. It is a hardy annual, easily grown, and prodnces beautiful clusters of small, light-pink, star-shaped flowers. The dwarf plant is the stems of the flower when dried are even more beactiful, and really bear out Mr. Burbank's description of them as a "fadeless flower." Pkt. 10c.

\section{ASTERS}

A popular half hardy ammal produced in a great variety of classes and an almost endless number of colors. The tallest varieties grow about two feet high, and some varieties of dwarfs are not over three
inclies high. The best methou of culture is to sow the seed in boxes about January 1st, and transplant about April 1st to 15th. The seed can be sown, however, in the row where the plants are to remain, thinning them from six to twelve inches apart, according to variety.

BOLTZE'S DWARF BOUQUET. An exceedingly Wwalf variety, grow ing only thrce to four inches gre a t variety of colors. Pkt. 15c.

COCARDEAU, OR CROWN. A tall variety, growing
14 to 16 inches high. Of 14 to 16 inches high. Of umlight liabit, with medicenter of the tolosson is usually white with it bright-colored outer rim. Mixed, pkt. 10c.

COMET. A good bedding variety, with large blossoms, the petals of which are long, na row, and curled backward. These colors are the best: Pink, light blue, pure lilac, 10c. II ixture of all colors, pkt. $10 \mathrm{c}$.

GIANT COMET. A taller growing variety of the Comet type, with brancling stems, which make Best colors: Crimson. dark violet, light blue, rose, white, The Bride (white changing to light rose). Pkt. 10c. Mix10c.

HOHENZOLLERN. A new variety of the Comet type, as large as the old variety. The petals are very long and curved as large as the old variety. The petals are very habit, about 16 inches high. Mixture, pkt. 15c.

TRUFFAUT'S PAEONY FLOWERED PERFECTION: This variety has the nllost brilliant and showy assortment of colors. Flowers, medium sized and almost globular. Plant, about 16 inches high, of upright growth, and flowers all borne on top. Mixture of all colors, pkt. 10c.

VICTORIA. One of the best bedding varieties, with medium-sized blossoms, which are borne in great profusion from the botton to the top of the plant. Grows 12 to 14 inclies higls. Best colors: ROSE, SNOW WHITE. Pkt. 10c. Mixture of all colors, pkt. 10c.

SEMPLES OR BRANCHING. The tallest and best florist's variety and we heartily recommend it as the very best type of aster we have. The plant grows 18 inches high and about 18 inches in width and the blossons. which are large and fullpetaled are borne on long stems or branches. The most satispetate tre bo all asters, since it is not only a showy bedding flower bue of an to its long stems and large blossoms, is fower, but owing to its long stems and large blossoms, is valuable for bouquets. Carmine, crimson, lavender, light blue, pink or rose, purple, white, Mary semple (very light blue, pink or rose, purple, white, Mary Semple (very light
pink), violet King. Pkt. 10c; oz. \$1.50. Mixture of above colors, pkt. 10c; oz. $\$ 1.25$.

OSTRICH PLUME. A medium tall variety of the Comet type. The petals are long, narrow, and curly, and the effect of
both individual blossoms and bunches is beautiful. Mixture of all colors, pkt. 10c.

QUEEN OF THE MARKET. One of the earliest blooming varieties, blossoming frequently in July. Of spreading habit, 8 to 10 inches high. Blossons medium sized, and the petals 
BACHELOR'S BUTTON. See Centaurea Cyanus.

BALLOON VINE, OR LOVE-IN-A-PUFF. Climbing annual, with small inferior flowers. The seed pods are curiously swelled or puffed, and are quite at tractive. Pkt. 5c.

BALSAM, OR LADY'S SLIPPER. A tender annual, with brittle stems and foliage. Grows about 12 inches high. Flowers both single and double, in bright colors and variations; are wax-like and very attractive. The individual blossoms floating in a dish of water exhibit their beaty to the best advantage. Camellia Flowered. Mixed; the largest double variety. Pkt. 5c.

Camellia Flowered. White; Pkt. 10c.

Dark Blood Red. Double. Pkt. 10c.

Peach Blossom. Doublc; shell pink. Pkt. 10c.

Red and White Spotted. Double. Pkt. 10c.

Snowball. Double; clear pearl white. Pkt. 10c.

Mixed Tall Doubles. Twelve inches high. Pkt. 5c; oz. $60 \mathrm{c}$.

Dwarf Double. Pkt. 5c.

BARTONIA AUREA (Golden Bartonia). A hardy annual, growing about two feet high and bearing golden-yellow flowers, which have a metallic luster when the sun shines on them. Is a native of California. Sow the seed where the plants are to remain, since it does not transplant easily. Prt. 5c.

BEAN. Butterfly Runner. A tall or climbing bean with beautiful red and white blossoms. Pkt. 10c.

Scarlet Runner. The popular climber. Pkt.10c.

BELLIS PERENNIS (Double Daisy). A hardy perennial, blossoming freely all spring and suminer. Plant is about four inches high and valuable for borders.

Extra Double White, or Snowball. A clear white variety. Pkt. 10c.

Extra Double. Mixed. Pkt. 10c.

German Double. Mixed; all colors mixed. Pkt. 5c.

Longfellow. Double dark rose. Pkt. 10c.

BEGONIA. Tender perennial, usually grown in the greenhouse. Some varieties are especially attractive on account of their

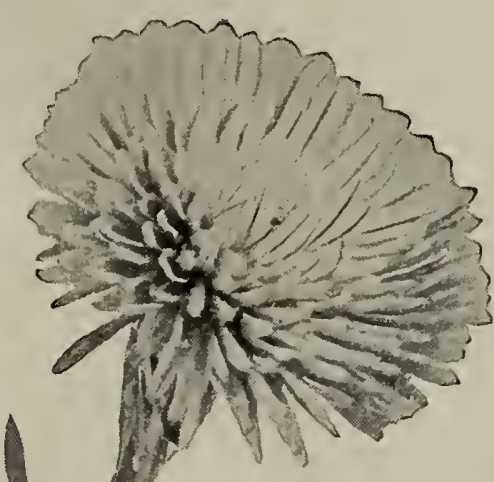

Branching Asters Vick's Violet King

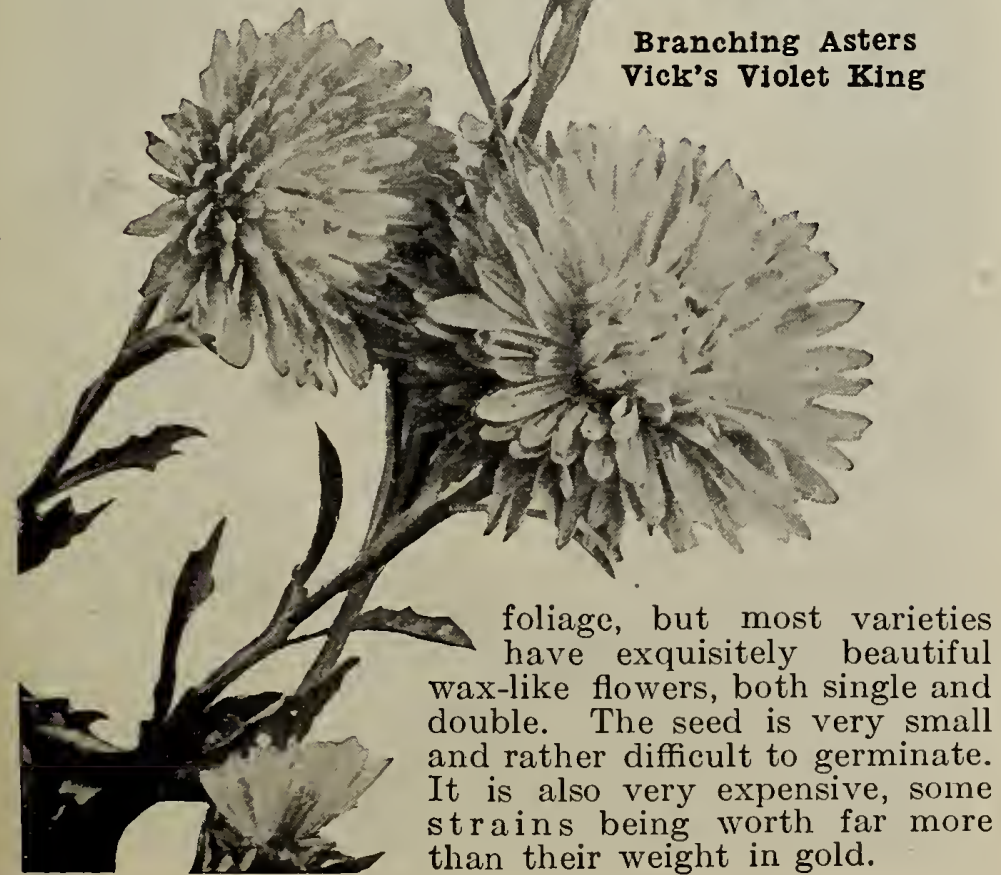

BEGONIA. FIBROUS-ROOTED VARIETIES. For outdoor culture, having beautiful leaves and bcaring clusters of small, waxy flowers.

Rex. A bcautifully marked, largc-lcaved varicty. Pkt. 25c.

Vernon. Decp-red flowers and dark-purple foliage. Pkt. 10c.

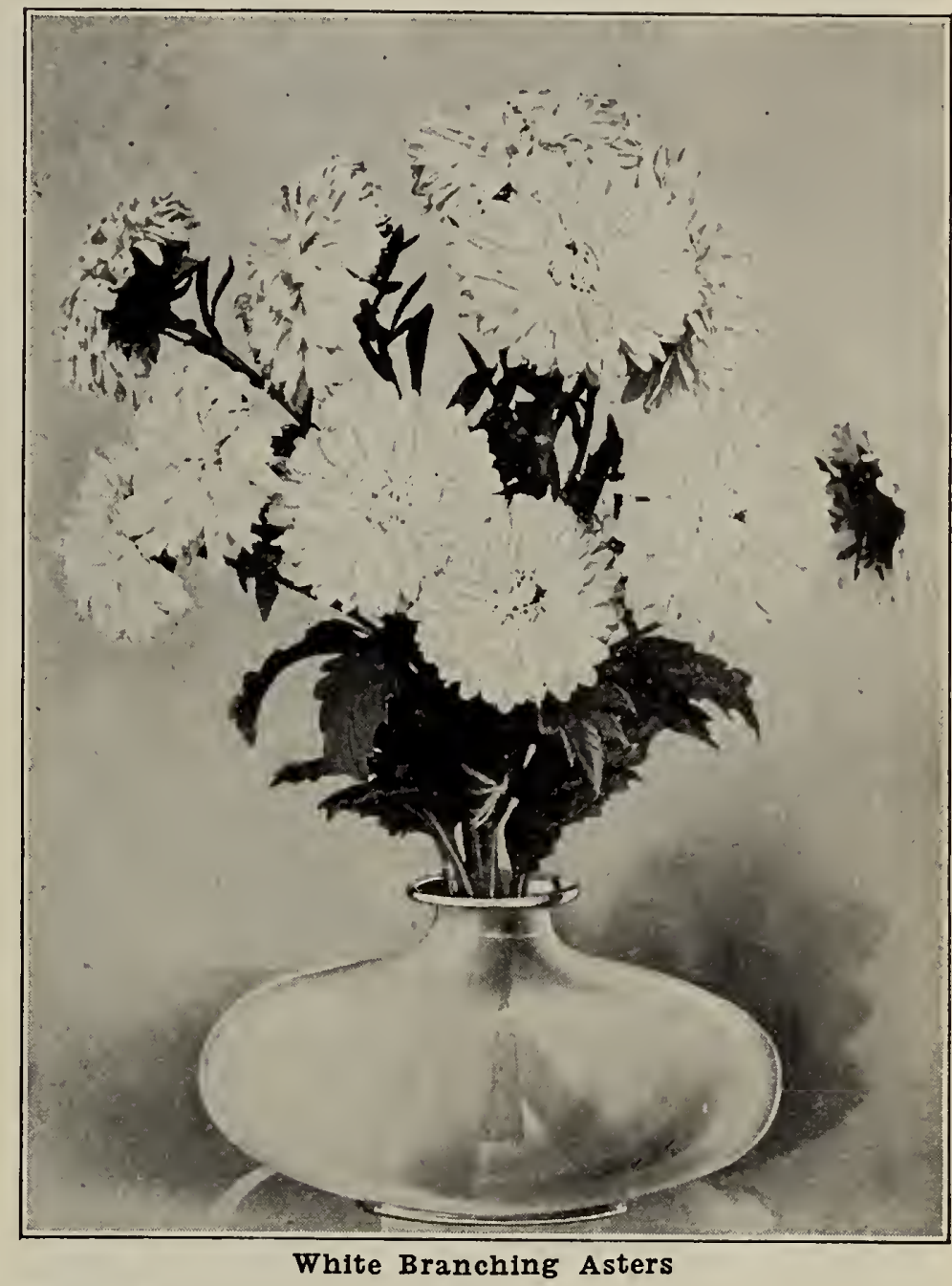

BEGONIA :

TUBEROUS-ROOTED VARIETIES. For greenhouse and pot culture, having large, waxy flowers in brilliant colors.

Double Varieties. Mixed. Pkt. 25c.

International Prize. The finest large flowered single mixture. Pkt. 35c.

Single Varieties. Mixed. Pkt. 25c.

BIGNONIA (Trumpet $\boldsymbol{\nabla i n e ) . ~ M a g n i f i c e n t , ~ h a r d y ~ p e r e n n i a l ~}$ climber, with brilliant scarlet flowers; a most ornamental and effective covering for walls, louses, etc. 30 feet. Pkt. 10c.

BRACHYCOME (Swan River Daisy). A hardy annual, growing from 6 to 10 inches high and producing an abundance of pretty blue and white flowers. Pkt. $\mathbf{5 c}$.

BROWALLIA. A half hardy annual, making a fine bedding plant. Blooms profusely. The flowers are bright ultramarine blue, and seed is sown in August. Mixed, pkt. 5c.

CACALrA (Tassel Flower). A beautiful and profuse flowering plant with tassel-shaped orange and scarlet flowers; fine for plant, with tassel-shaped orange and scan
mixed borders; hardy annual. Pkt. 5c.

CALAMPELIS (Bugle Vine). A well known beautiful annual climber; trained to a trellis or south wall, it is an ornamental object throughout the summer, its bright orange tubular flowers contrasting effectively with the delicate green of the foliage. Pkt. 10c. 
CALCEOLARIA. A tender perennial, used largely in greenhouses and conservatories. Is not of easy culture, but a very desirable flower. Bears a large profusion of small, pocket-shaped flowers, many of which are beautifully tigered or spotted. There is a great variety of shades and colors in various markings.

Grandiflora. Large-flowered, self-colored, profuse flowers. Pkt. 25c.

Tigered and Spotted. Mixed. Pkt. 25c.

Mixed. Grandiflora and Spotted. Pkt. 25c.

Rugosa Hybrid. A shrubby, profuse bloomer, and best for outdoor culture. Pkt. 25c.

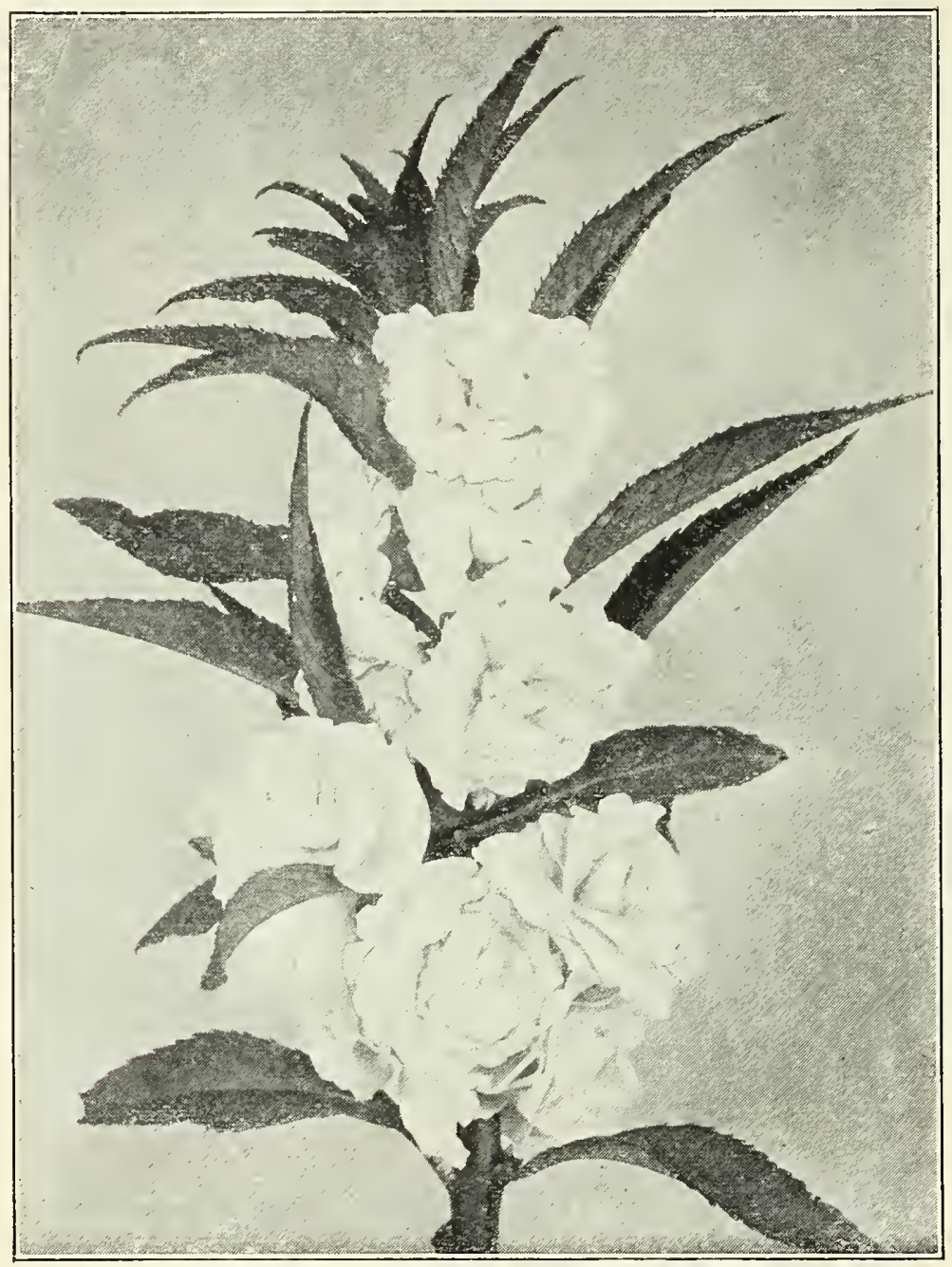

Balsam-Camellia Flowered, Double

CALENDUIA (Pot Marigold). Very hardy annual, one foot high, blooming freely practically the whole year round. Is of the easiest culture and is desirable for rather inferior soils, where less sturdy flowers do not thrive. A medicinal extract resembling arnica is made from the flowers.

Double Mixed. A good mixture of 8 or 10 different shades of yellow, some clear colors and some shaded and striped. Pkt. 5c; oz. 15c.

Lemon King. Plat. 5c.

Meteor. Large double yellow flowers, striped with orange. Pkt. 5c.

CALIFORNIA POPPY. See Eschscholtzia.

CALIIOPSIS. A half hardy annual, growing about three feet high, and valuable for bright bedding effects or for cutting. Leaves are narrow and stems slender. Blossoms single and about 2 to 4 inches in diameter.

Golden Wave. The largest-flowering variety. Clear yellow. Pkt. 5c; oz. 25c.
Drummondi. Mixed. A gorgeous mixture of golden yellow, brown, maroon, and other shades. Pkt. $5 c ; 0 z .25 c$.

Bicolor Hybrida Semiplena. Pkt. 5c; 0z. 25c.

Lanceolata. See Coreopsis.

CANARY BIRD FLOWER (Tropaeolum Canariense). A tender, climbing annual of the Nasturtium family. Blossoms have curiously winged petals and are light yellow. Pkt.5c.

CANDYTUFT (Iberis). A hardy annual, growing about 6 to 18 inches high, according to the variety. The blossoms are borne on variously long spikes, and the newer varieties are quite large flowering and very fragrant. Of easy culture and valuable for bedding or massing.

Common Sweet Scented. Small white flowers. Pkt. 5c; oz. 15c. Crimson, pkt. 5c. Purple, pkt. 5c.

Dwarf, or Tom Thumb. White. Plant very dwarf. Pkt. 10c.

Dwarf, or Tom Thumb. Mixed. Pkt. 10c.

White Rocket. Long spikes and large flowers. Pkt. 5c; oz. 20c.

Giant Hyacinth Flowered, or Improved Fmpress. Very large heads and long spikes of white flowers. An improved strain of Giant Empress and the best sort for cut flowers. Pkt. 10c; $1 / 4$ 0z. 25c; 0z. 75c.

Mixture of all colors. Pkt. 5c.

Perennial Lilac (Gibraltarica). Pkt. 10c.

Perennial White (Sempervirens). Pkt.10c.

CANNA. Mixture of the popular varieties. Pkt. 5c.

Crozy's Varieties. Mixed. Pkt. 10c.

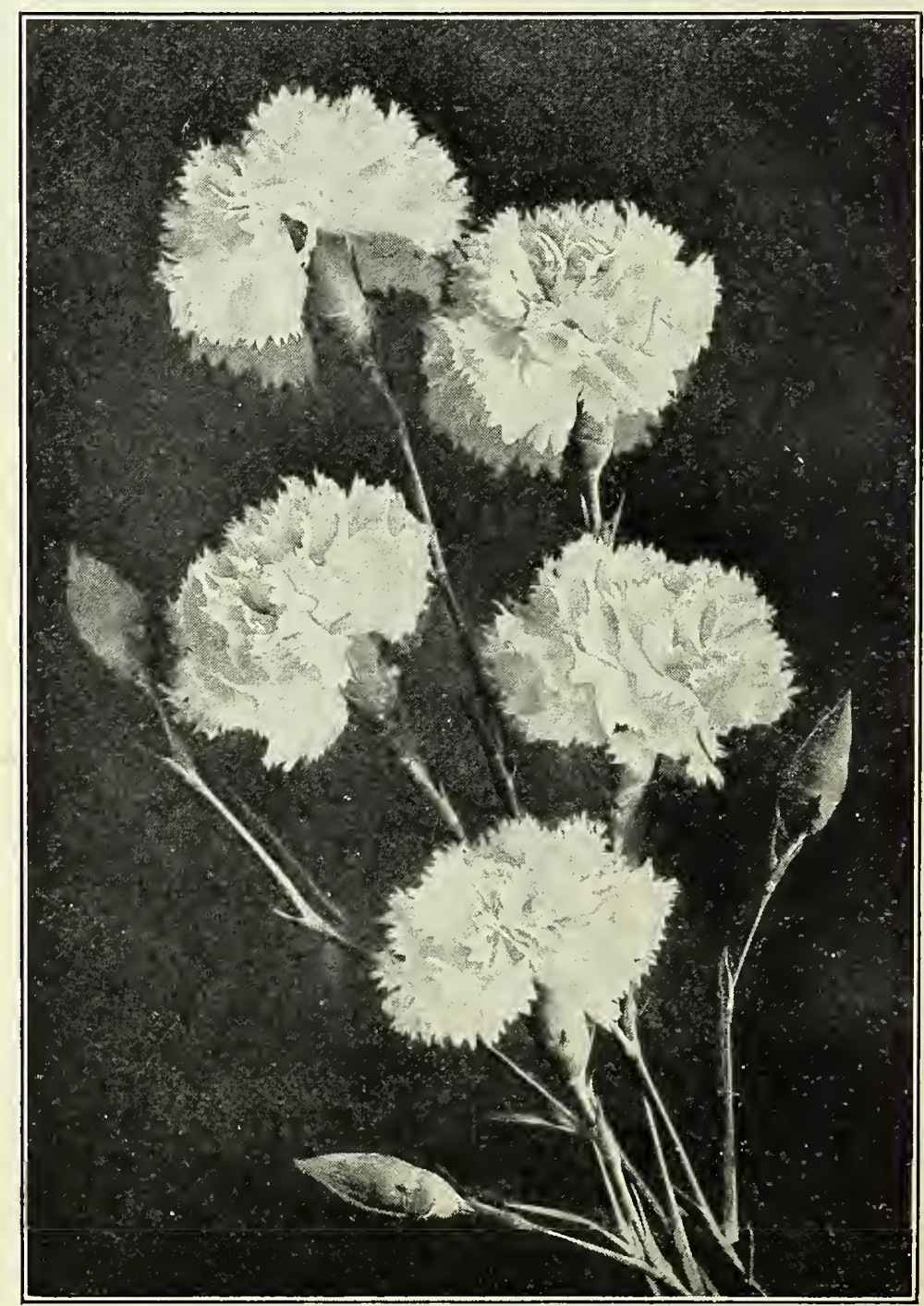

Carnation-Marguerite 
CANTERBURY BELLS

(Campanula). A hardy biennial, blooming the second year from seed. Of easy culture, but preferring rich, moist soil. Grows about three feet high, and bears double and single varieties of blue, white, purple, and red flowers. Si n g l e Mixed, pkt, 5c; Single White, pkt. 5c; Single Pink, 5c; Single Blue, pkt. 5c; Double Mixed, pkt. 5c.

Carpatica. Blue and white. Mixed. Pkt. 5c.

\section{CUP AND SAUCER}

TYPE. In this variety the outer petal forms a brim like a saucer. Light blue. Pink. Pure White. Pkt. 10c. Mixed, Pkt. 10c.

Persicifolia. Mixed, blue and white. Pkt.10c.

Pyramidalis. Blue and white. Pkt. 5c.

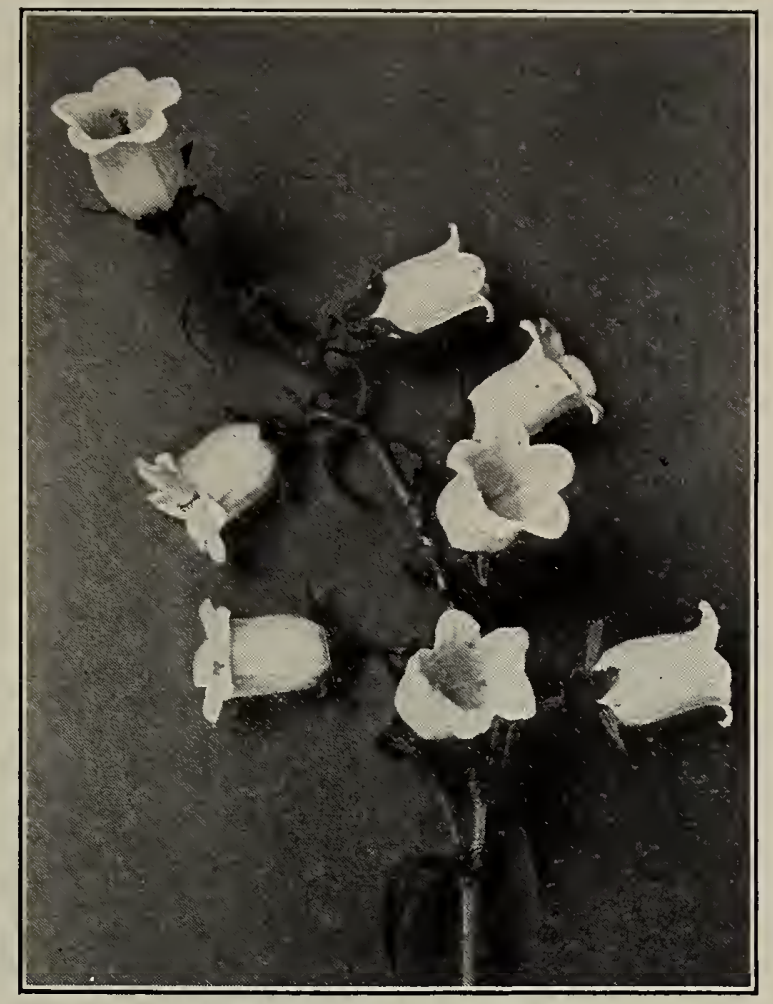

Canterbury Bells-Single

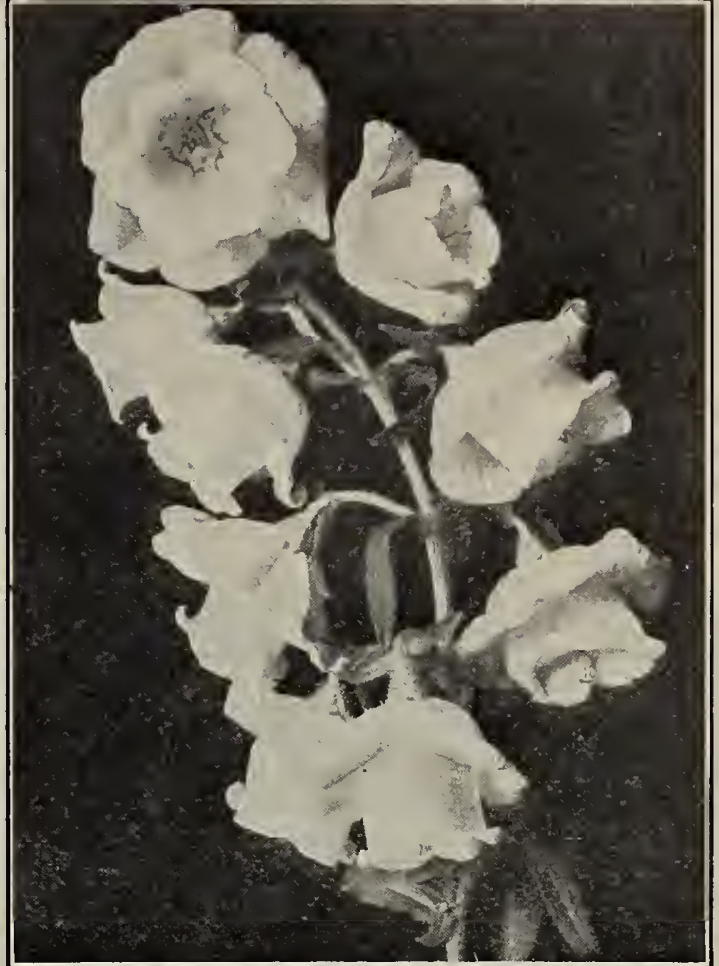

Canterbury Bells-Cup and Saucer Type
CARNATION. A half hardy perennial, used generally for greenhouse florist's trade in winter and for a garden favorite in summer. There are a large number of varieties and colors, but the early flowering mixtures are recommended for out-of-door culture. Sow the seed early in the year and transplant in March or April.

Chabaud's Everblooming. In mixed colors. Pkt. 15c. Choice Double Mixture. A fine mixture of various colors and types. Pkt. 15c.

German Extra Fine Double Mixed. A splendid strain. Pkt. 15c.

Marguerite. Mixed. The earliest, coming into bloom twelve weeks from seed. Pkt. 10c.

Picotee. Extra fine double mixed. White, edged with colors, or striped and splashed. Pkt. 25c.

Vienna Double Dwarf Mixed. Pkt. 10c.

Choice Double Perpetual. Mixed Colors. Pkt. 15c.

Double White. Marguerite Giant. Pkt. 10c.

CASTOR OIL BEAN (Ricinus). A tender annual, growing from 6 to 15 feet high and bearing large, green, deep purple, and brown resemble a prickly fruit. Of the easiest culture. Individual plants, with plenty of room, look best. (See cut page 58) Gibson's, dark red. Pkt. 5c; 0z. 15c.

Sanguineus. Tricolor. Has blood-red stocks and green leaves. with red veins. Pkt. 5c; oz. 15c.

Zanzibarensis. Mixed. A large-leaved variety, deep green and bronze, growing 10 to 15 feet high. Pkt. 5c; oz. 15c.

Mixture of all varieties. Pkt. 5c; 0z. 10c.

CELOSIA CRISTATA, or COCKSCOMB. A half hardy annual, growing 6 to 8 inches high, bearing a wide, wavy blossom that resembles a cock's comb. In brilliant colors, and fine for massing or border work.

Dwarf Mixed. Several shades of red and yellow mixed. Pkt. 15c.

Dwarf New Giant Empress. A rich, crimson variety, with dark foliage and very wide combs. Pkt. 10c.

Glasgow Prize. One of the best strains: Pkt. 10c.

PLUMOSIS, or Feathered Cockscomb. This species grows two or three feet high, and bears long, feathery plumes in brilliant colors. Mixed. Pkt. 5c.
Magnificent (Thompson's). A new variety, superior to the older sorts. Pkt. 10c.

Spicata. Ostrich plumes of pink shading to silver at tips. Pkt. 5c.

CENTAUREA. A hardy annual, embracing a number of species, some being grown only for their foliage. All varieties grow from $11 / 2$ to 2 feet high. Sow the seed early and transplant in March.

Cyanus (Bachelor's Button, or Bluebottle, or Corn Flower). Of easy culture. Sow the seed where it is to remain and thin to three or four inches. Mixed. Pkt. 5c;0z. 25c.

Emperor William (Large blue). Pkt. 10c; oz. 50c. Pink, pkt. 5c. White, pkt. 5c.

Imperialis. A beautiful, large-flowered type, resembling Sweet Sultan, but with a large-petaled margin around the blossom. In white, lavender, and purple shades. Mixed, pkt. 10c. Pure White, pkt. 10c. Purple Shades, pkt. 10c.

Marguerite. A large, white variety of the Imperialis class. Fragrant and pretty. Plst. 10c.

Moschata, or Sweet Sultan. A well-known type. In white, yellow, lavender, and purple. Blossoms very fragrant. Pkt. 5c.

Suavaelens. Yellow. Pkt. 10c.

Gymnocarpa. Called Dusty Miller. Pkt. 5c.

Candidissima, White Leaved, or Dusty Miller. Grown for its silvery, fine-cut leaves. Pkt. 10c.

Montana. Large blue. Pkt. 5c.

Catchily. See Silene.

CENTRANTHUS. The flowers are small, pink, salmon colored, or white, borne in clusters on light-green, almost transparent stems. Easy to raise from seed in open ground. Mixed, pkt. 5c.

CENTROSEMA, or Butterfiy Pea. A hardy perennial vine of rare beauty, which blossoms in July from seed sown in March, and bears in great profusion pea-shaped flowers, ranging in color from a rosy violet to a redolish-purple, with a feathery white marking through the center. Pkt. 10c. 
CHRYSANTHEMUM. There are many widely different classes of this flower represented in the hardy annual or garden varieties, both single and double, and the perennial varieties, chief of which is double or florist's varieties, so highly prized in the autumn and winter.

ANNUAL VARIETIES. Growing $1 \frac{1}{2}$ to 3 feet high Seeds should be planted early and the plants set out in April. Single varieties sometimes called "Painted Daisies." Very attractive. Mixed, pkt. 5c.

Coronarium, Double. Mixed. Pkt. 10c.

White. Beautiful for cut flowers. Pkt. 10c.

Yellow. Also fine for cut flowers. Pkt. 10c.

Eclipse. Pure golden, with a bright purplish scarlet ring, dark brown, disc; very striking. Pkt. 5c.
Hybrida Mixed. The best variety, having large flowers and brilliant colors. Pkt. 25c.

Grandiflora Dwarf. Mixed. Pkt. 25c.

Grandiflora Stella. Pkt. 25c.

Maritima Candidissima. Silvery foliage. Pkt. 5c.

CLARKIA. A hardy annual, of easy culture, growing about 18 inches high and bearing bright rose, white, or purple flowers in
great profusion: Native of California. Seed sown in the tall will give early blossoms in spring. Seed can be sown almost any time. Double Mixed, pkt. 5c; Single Mixed, pkt. 5c.

CLEMATIS. A popular hardy perennial climber. An old favorite and justiy so, for there are tew garden climbers that give more

Large Flowered Mixed. Pkt. 10c.

Virginiana (Virgin's Bower). Pkt. 10c.

Paniculata. Beautiful, small-flowered variety. Pkt. 5c.

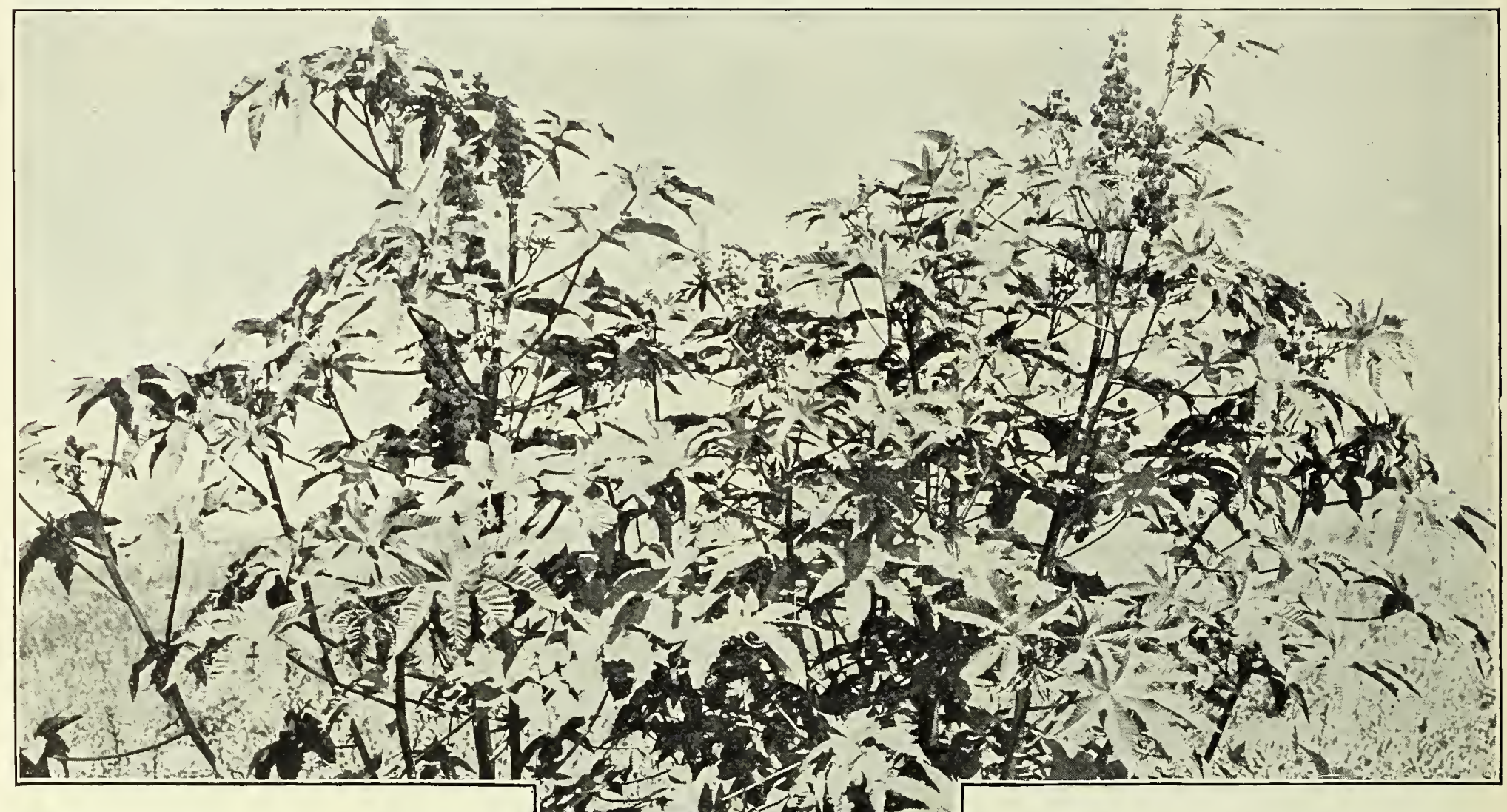

\section{CHRYSANTHEMUM:}

Tricolor Burridgeanum.

Single Mixed. Pkt. 10c.

White. Pkt. 10c.

Luteum, Carinatum. Pkt. 15c.

PERENNTAL VARIETIES. Growing $21 / 2$ to 3 feet high. Hardy and of easy culture. Frutescens, or "Marguerite"; also called "Paris White Daisy." White petals radiating from a goldenyellow eenter. Pkt. 10c.

Japanese Hybrids. A mixture of

the large-flowering florist's

varieties. These varieties are

the large, autumn flowers used in exhibitions and by florists. They are usually grown from cuttings, and do not come absolutely true from seed.

Pkt. 25c.

CINERARIA. A tender perennial, grown principally in the greenhouse, but can be grown safely in the garden in summer. Seed should be sown in summer, and the greenhouse requires only moderate heat. Plants grow from 1 to 2 feet high and bear clusters of large, single flowers of bright colors.
Jackmanil. Large blue. Pkt. 15c. Flammula. Feathery white. Pkt.10c. Coccinea. Scarlet. Pkt. 10c.

CLEOME PUNGENS, OR GIANT SPIDER PLANT. A hardy annual, growing 4 to 5 feet high and bearing in profusion rose-purple blossoms that are shaped something like a spider. Pkt. 5c.

CLIANTHUS DIAMPIERI (Glory Pea of Australia). One of the most gorgeous flowers in existence; the flowers are peashaped, of a brilliant scarlet color with intense black center; requires a dry. warm soil and little water. Pkt. 15c.

COBAEA SCANDENS. A half hardy, climbing annual, with large leaves and large trumpet-shaped flowers. Blossom is green until nearly grown, when it turns bright-purplish blue. Grows about 30 feet long, and is very desirable for covering a large lattice. A native of Mexico. Pkt. 10c.

COLEUS. A tender perennial, growing about 10 to 18 inches high, and grown for its beautiful, brightcolored, velvety leaves. Valuable for window garden or pots, and can also be grown out of doors if taken up in winter.

Extra Large Leaved Mixed. Pkt. 15c. 
Ornatus. The best large-leaved variety. Pkt. 15c. Morse's Exhibition. A beautiful and gorgeous strain. Pkt. 25c.

COLLINSIA. A free-flowering and easily grown annual, growing from 1 to 2 feet; flowers white, crimson, purple, etc. Mixed, pkt. 5 c.

COLUMBINE (Aquilegia). A hardy perennial, growing about 2 feet high and bearing an immense variety of colors on long, smooth stems.

Double Mixed. All colors. Pkt. 5c.

Long Spurred or Single Mixed. A large, single variety, with long spurs on back. A very showy and attractive type. Pkt. 100.

Chrysantha. Golden-yellow, single. Pkt. 10c.

Convolvulus. See Morning Glory.

\section{Cockscomb. See Celosia Cristata.}

CYCLAMEN. A tender, bulbous perennial, used in greenhouses and window-gardens. Is easily grown from seed. Sow in the fall or early spring.

Persicum Giganteum. Mixed. Very large flowers and very free blooming. Pkt. 25c.

Album. Pure white. Pkt. 25c.

Rubrum. Red. Pkt. 25c.

Crimson King. A new variety. Pkt. 25c.

Papilio. Butterfly type. Pkt. 25c.

CYPRESS VINE (Ipomoea Quamoclit). A tender, climbing red, pink, or white. Scarlet, pkt. 5c. White, pkt. 5c. Mixture red, pink, or white. Scarlet,
of several colors, pkt. 5 c.

COREOPSIS. A perennial with light, gracef ul foliage and beautiful golden and brown and gold flowers.

Lanceolata. Pkt. 10c.

Grandiflora Eldorado. Pkt. $10 \mathrm{c}$.

COSMOS. A tender annual, with fine-cut, feathery foliage and large, showy blossoms in rose, crimson, pink and white. The late flowering or giant type grows 5 to 6 feet high and its blossoms are larger than the early varieties, or about 4 to 5 inches in diameter. They bloom late in the fall or about November 1st, and rarely blossom very far north. The early varieties bloom in July. Sow about March 1st and transplant in May.

Early Flowering Dawn. White, slightly tinted with pink. Pkt. $10 \mathrm{c} ; 0 z . \$ 1.00$.

Early Flowering Mixed. The usual Cosmos colors in mixtures. Pkt. 10c; oz. $75 \mathrm{c}$.

Giants of California. Pink, pkt. 10c; oz. 75c. - White, pkt. 10c; oz. 75c. Crimson, pkt. 10c; oz. 75c. Mixed, pkt. 10c; oz. 50c.

Klondyke. A late blooming variety, with bright yellow blossoms. Pkt. 10c; oz. $\$ 1.00$.

LADY LENNOX. A g r a n d new variety which we have grown for a large New York seedman on our own farms. It is without question the finest Cosmos in existence. The plants are rather low growing (about $21 / 2$ feet high) and it bears profusely, the whole plant being a mass of bloom when in full flower. The blossoms are a bright rose pink and the petals are very large and wide, completely overlapping each other. It comes into its full perfection of bloom about October 1 to 15. Pkt. 10c.

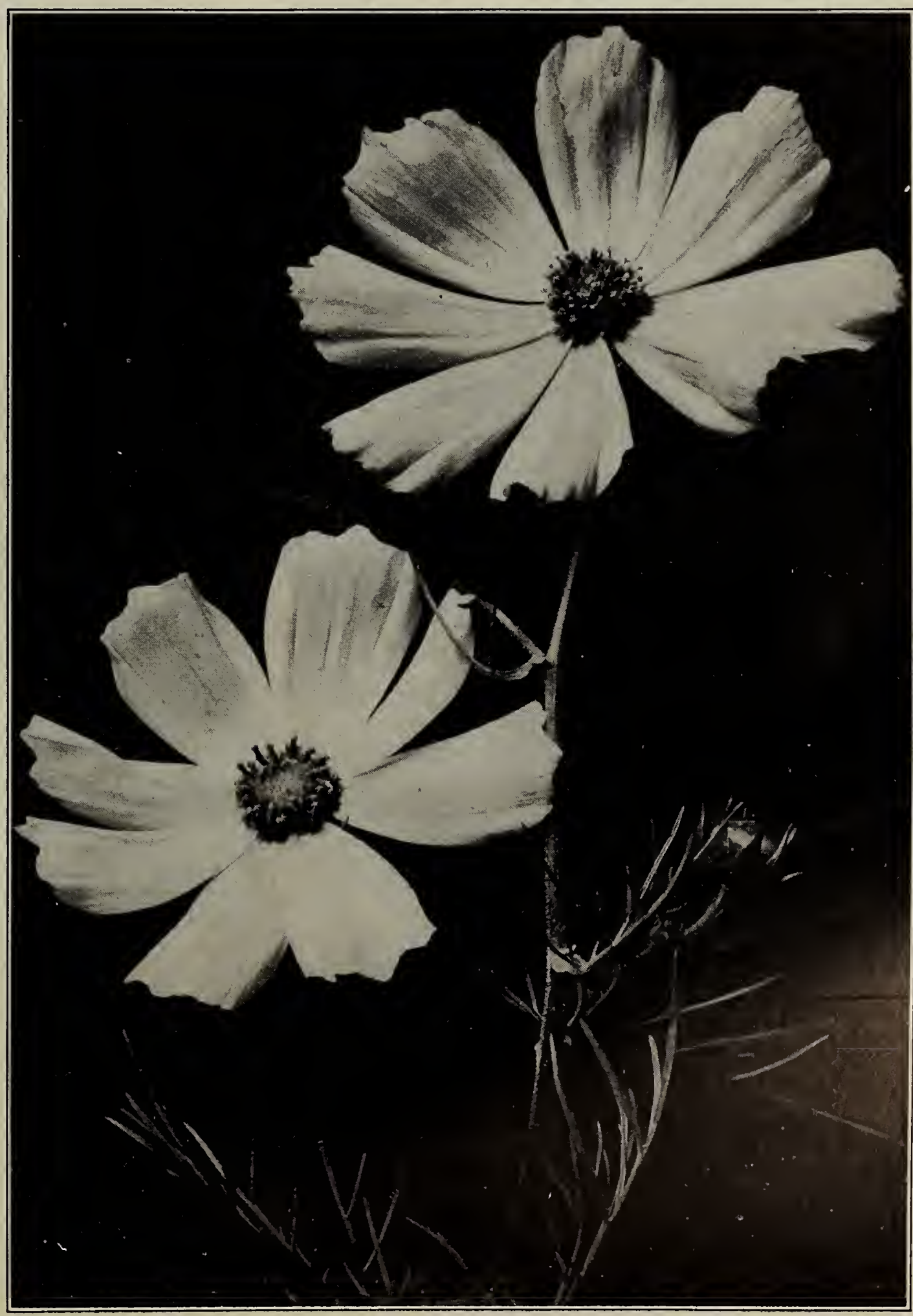




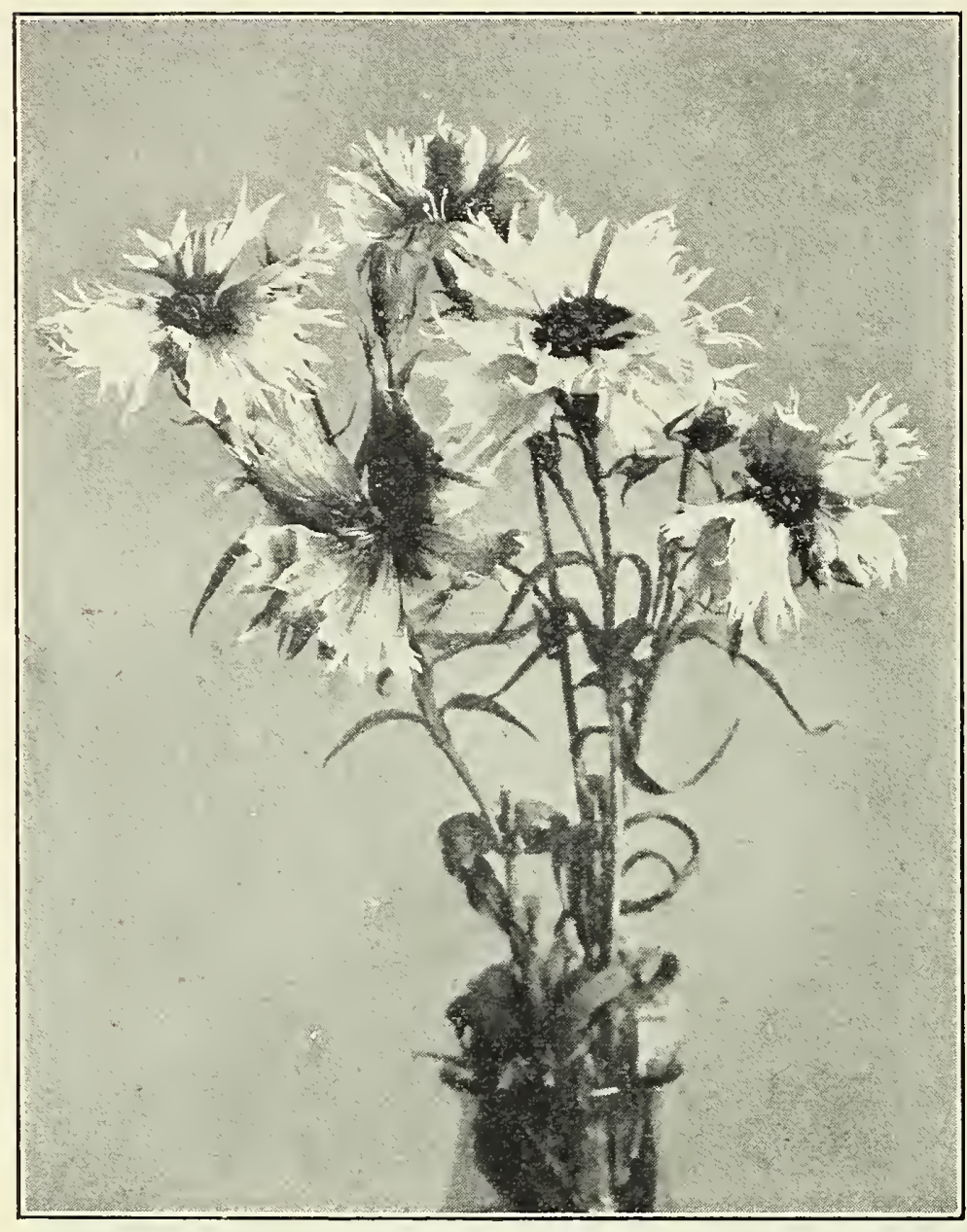

Dianthus Laciniatus

DAFILIA. A well-known and popular late summer and autumn flowering plant. Is. grown from seed or propagated from the bulbous roots. The seed may be planted early in the hotbed and
the plants set out in May after all danger of frost is over. By sowing the seed early the plants may be made to bloom the first year.

Cactus. Mixed, Double, with pointed petals. Pkt.10c.

Double. Mixed, pkt. 10c.

Single. Mixed. The most easily grown and also the most satisfactory frem seed. Plrt. 10c.

Daisy, Double. See Bellis Perennis.

DAISY, SHASTA DAISY. A fine perennial plant bearing large white single blossoms.

Alaska: One of Burbank's new selections. Pkt. 15c.

DATURA (Trumpet Flower, or Horn of Plenty). A tender annual, growing three feet high. Hlowers large and trumpetshaped.

“ (Chlorantha) F.Pl. Double golden-yellow blossoms. Pkt. 5c.

“ (Cornucopia). Blossoms single, white inside,'shading to purple. Pkt. 5 c.

Delphinium. See Larkspur.

Dianthus, Barbatus. See Sweet William.

Dianthus, Caryophyllus. See Carnation.

DIANTHUS, OR PINKS. Hardy annuals, about one foot high, and bearing beautifully colored, single and double blossoms in profusion all summer. Sow seed carly in boxes and transplant, or sow in rows where the plants are to remain, and thin.

Chinensis (China Pink). Double, White, pkt. 5c. Double Mixed, pkt. 5c.

Diadematis Fl. Pl. (Double Diadem Pink). Large, double flowers in many colors. Pkt. 5c.

Heddewigi (Japanese Pink). Finest single, mixed, pkt. 5c. Finest double, mixed, pkt. 5c.

Mourning Pink. Pkt. 5c.

Laciniatus. Single, fringed varieties. Pkt. 5c.
Mixture of all single varieties. Pkt. 5c; 0z. 50c. Imperiaiis. Very large. Pkt. 5c.

Plumarius, perennial. Double white, pkt. $10 c$. Double mixed, pkt. 10c.

DIGITALIS, OR FOXGLOVE. A hardy perennial, blooming the second year from seed. Grows usually about $31 / 2$ feet, although in very rich soil sometimes 6 feet. The bell-shaped flowers are borne on long spikes, and come in shades of purple, lavender, rose and white, all spotted lightly inside the blossom. Thrives best in cool, shady locations. Fine mixed, pkt. 5c; oz. 50c.

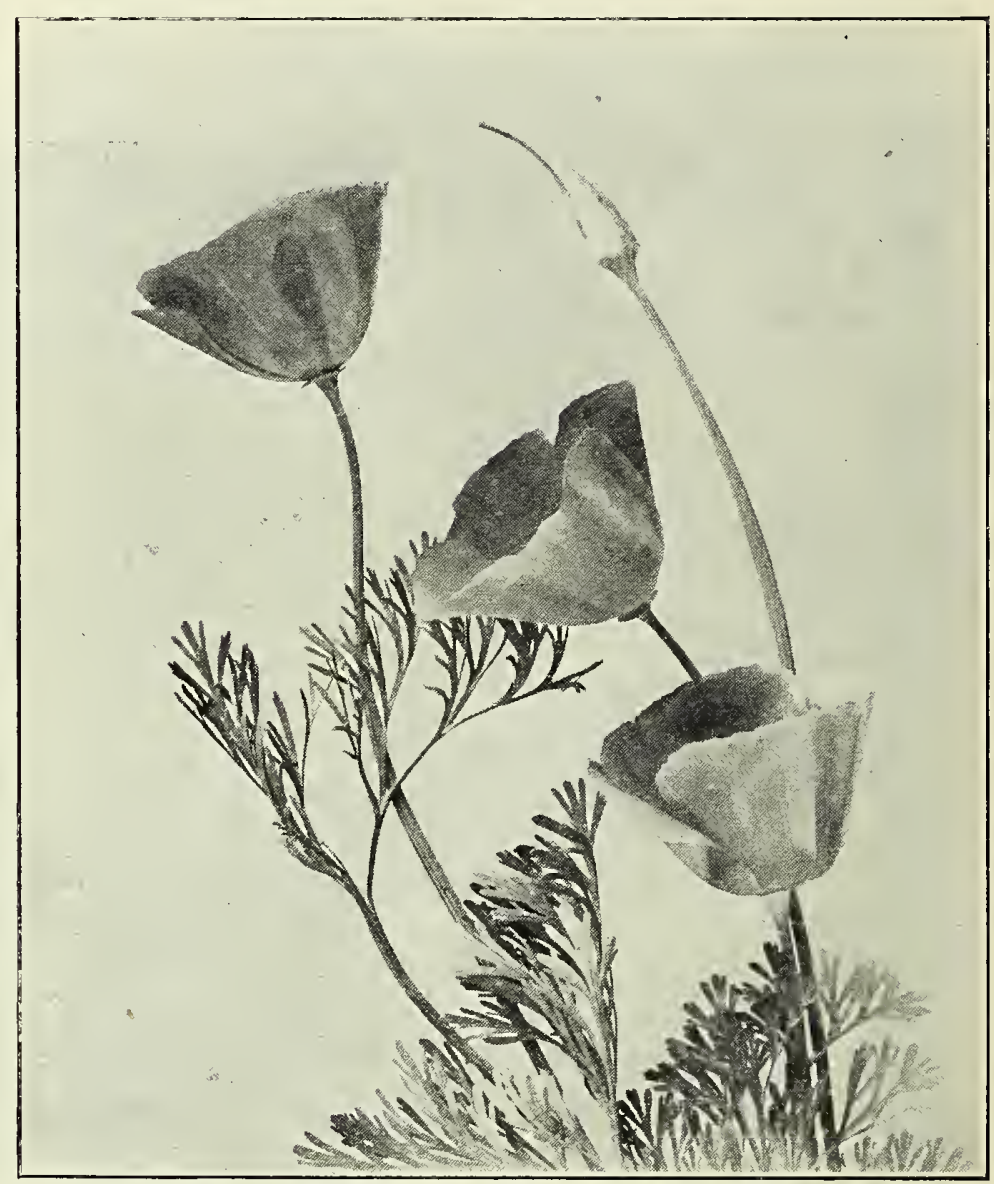

California Poppy-Eschscholtzia California

DOLICHOS, OR HYACINTH BEAN. A tender, climbing annual. Grows rapidly and is valuable for covering a trellis. Flowers in purple or white; are borne on long stems, the individual in purple or white; are borne on long stems, the individual blossoms resembling the bean flower, and the ornamental pods
resemble bean pods. Sow seed in open ground late in April.

Daylight. The best white. Pkt. 10c.

Darkness. The best purple. Pkt. 10c.

Lablab. Mixed. Pkt. 10c.

Dusty Miller. See Centaurea Candidissima.

ECHINOCYSTIS (Wild Cucumber Vine). One of the quickestgrowing vines we know of at taining a height of 30 feet in a seascn; growing vines we know of, at taining a height of 30 feet in a seascn; white, fragrant flowers, borne in great profusion, followed by an abundance of ornamental prickly seed pods; foliage very dense,
on which account it is most desirable where much shade is desired. Pkt. 5c.

ESCHSCHOLTZIA, OR CALIFORNIA POPPY. A hardy annual, with fine-cut, feathery foliage and beautiful velvety cup-shaped flowers. Grows from 1 to $11 / 2$ feet high, and blooms profusely. Seed may be sown in the fall and any time thereafter till April, and blossoms may be had from early in January till late in summer. Of the casiest culture. Any soil will do, but the better the soil, the larger the plants and blossoms. It is best to sow the seed in the garden, where the plants are to remain, as they do not transplant easily. 
Californicus. The bright, orange-yellow common variety. Pkt. 5c; oz. 15c; lb. $\$ 2.00$.

Burbank's Crimson Flowering. Pkt. 10c.

Crocea. Petals rose pink outside, white inside. Pkt. 5c; oz. 25c.

Double Rose. A semi-double blossom, rose colored outside and white inside the petal. Pkt. 5c; oz. 25c.

Erecta Mandarin. Brownish gold, erect growing plant. Pkt. 5c.

Golden West. Very large, orange-colored blossoms, shading to canary yellow at the edges. Pkt. 5c; 0z. 15c.

Mandarin. Blossoms are copper colored outside and bright-yellow inside the petals. Pkt. 5c; 0z. 25c.

Striata. Golden yellow, striped lightly with cream. Pkt. 5c; oz. 25c.

White. Large, ivory white. Pkt. 5c; 0z. 25c.

Mixed Yellows. A mixture of the popular orange and yellow varieties. Pkt. 5c; 0z. 15c.

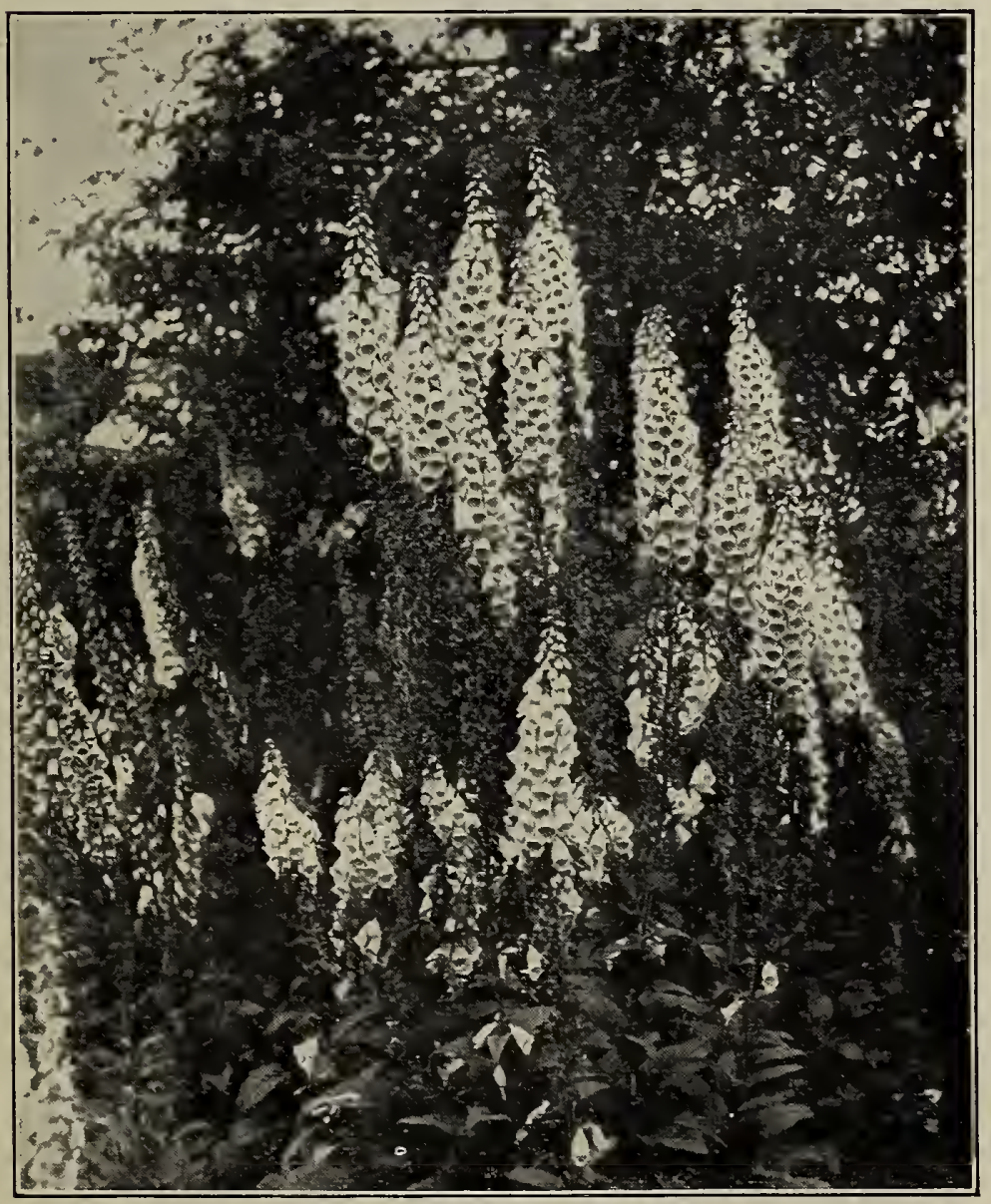

Foxglove, or Digitalis

Mixture of all varieties. Pkt. 5c; 0z. 20c; lb. $\$ 2.00$. Bush Eschscholtzia. See Hunnemannia.

EUPEORBIA. A hardy annual, growing four to s: $^{\circ}$ feet high, and esteemed for its beautiful foliage. The blossoms are inconspicuous.

Heterophylla. Called Mexican Fire Plant or Annual Poinsettia. Smooth, glossy leaves, turning scarlet late in the summer. Pkt. 10c.

Variegata. Called Snow on the Mountain. Leaves veined and margined with white. Pkt. 10c.

EVERLASTING FLoWERS. See Felichrysum, Gomphrena, Australian star Flower, Xeranthenum, Acroclinium, Rhodanthe.

Evening Primrose. See Oenothera.
Everlasting Pea. See Lathyrus Latifolius.

Flax. See Linium.

FEVERFEW. Matricaria Capensis. Called Double Feverfew. A plant growing 8 to 10 inclies high and bearing profusely pure white, very double flowers. Pkt. 5c.

See also Pyrethrum.

- Flowering Maple. See Abutilon.

Flowering Sage。 See Salvia.

FORGET-ME-NOT (Myosotis). A hardy percnnial, growing 6 to 12 inches high. Small star-like flowers are borne in clusters on long stems. The plant is of easy culture and blooms the first year if seed is sown early. Thrives best in a cool, moist, location.

Alpestris. Blue. Plkt. 5c; 0z. 75c.

White. Pkt. 5c.

Victoria. Pkt. 10c.

Dissitiflora Perfection. Pkt. 10c.

Perennial Semperflorens. Pkt. 10c.

FOUR O'CLOCK. A hardy annual, about two feet high Of the easiest culture. Seed should be sown in the open and thinned to one foot. Is free flowering, the blossoms in great variety of colors and stripes.

Mixture of all colors. Pkt. 5c.

Tom Thumb. Dwarf plant, mixed colors. Pkt. 5c. Variegated and striped colors. Mixéd. Pkt. 5c.

FOXGLOVE. See Digitalis.

FUCHSIA (Lady's Eardrop). A well known plant of easy culture in pots for the conservatory, parlor decoration, or the open 25c. Single mixed, pkt. 25c.

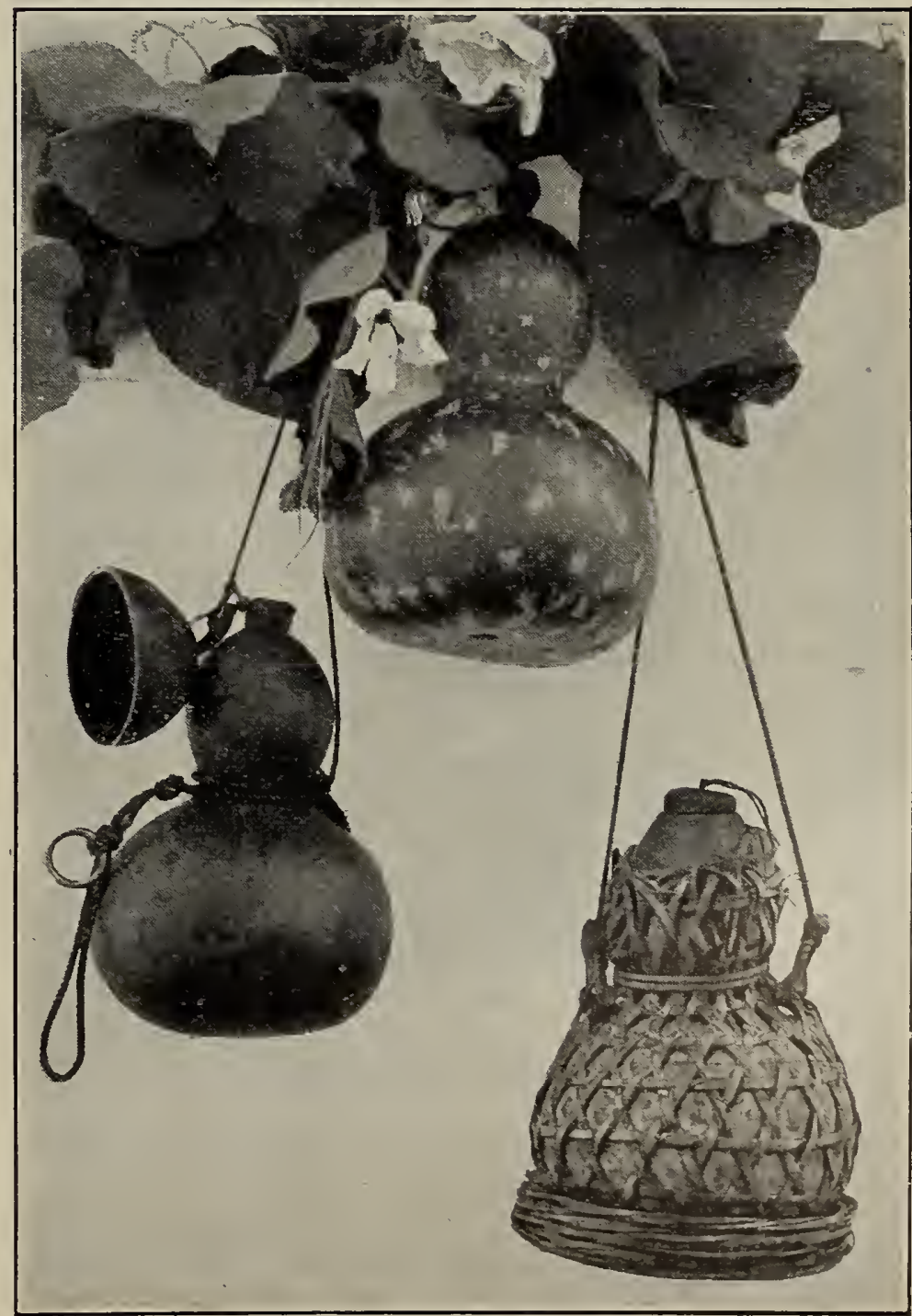

Gourds-Chinese Bottle 


\section{ORNAMENTAL GRASSES}

Ornamental grasses serve the double purpose of rendering the mixed flower-bed or border attractive during the summer, and for the use of the spikes or panicles in a dried state in winter bouquets. For large beds or groups on lawns nothing gives a finer effect.

AGROSTIS NEBULOSA. A very graceful and pretty grass-
charming ior borders. Annual. One and one-half feet. charming

AVENA STERILIS (Animated 0ats). Dlooping, very graceful. Annual. Two feet. Plit. 5c.

BRIZA AUSTRALIS. Lately discovered in Western Australia, much larger than the other brizas. The black spotted shoulders make it unusually ornamental. Pkt.25c.

BRIZA M AXIMA (Quaking Grass). Very pretty. Annual. One and one-lialf feet. Pkt. 5 c.

BRIZA GRACILIS (Small Quaking Grass). Very delicate and graceful. Annual. One toot. Pkt. 5c.

B ROMUS B RIZAEF ORMIS. An elegant Briza-like grass. Pkt. 5c.
COIX LACRYMA (Job's Tears). Grows two feet high. Pkt. 5c.

ERAGROSTIS ELEGANS (Love Grass). Very graceful and beautiful. Annual. One foot. Pkt. 5c.

EULALIA JAPONICA. One of the most beautiful of the tallgrowing grasses. Five feet. Pkt. 10c.

GYNERIUIM ARGENTEUM (Pampas Grass). The finest ornamental grass in cultivation. Half-hardy perennial. Ten feet. Pkt. 10c.

STIPA PENNATA (Feather Grass). One of the prettiest and most interesting. Perennial. Two feet. Pkt. 10c.

ZEA JAPONICA (Striped Japanese Maize). Pkt. 10c.
GAILLARDIA. A very showy garden plant, with brilliant flowers in scarlet and yellow, blended and shaded. Blooms freely from early summer till autumn. Grows one and one-half to two feet high, and the blossoms are borne on long, slender stems. Both single and double varieties are hardy. Fine Single Mixed, Pkt. 5c. Iarge Double Grandiflora (Perennial) Picta Lorenzianna, Mixed, Pkt. 5c. GERANIUM. A half hardy perennial, flowering the first year from seed if sown early. A popular flower in brilliant colors and

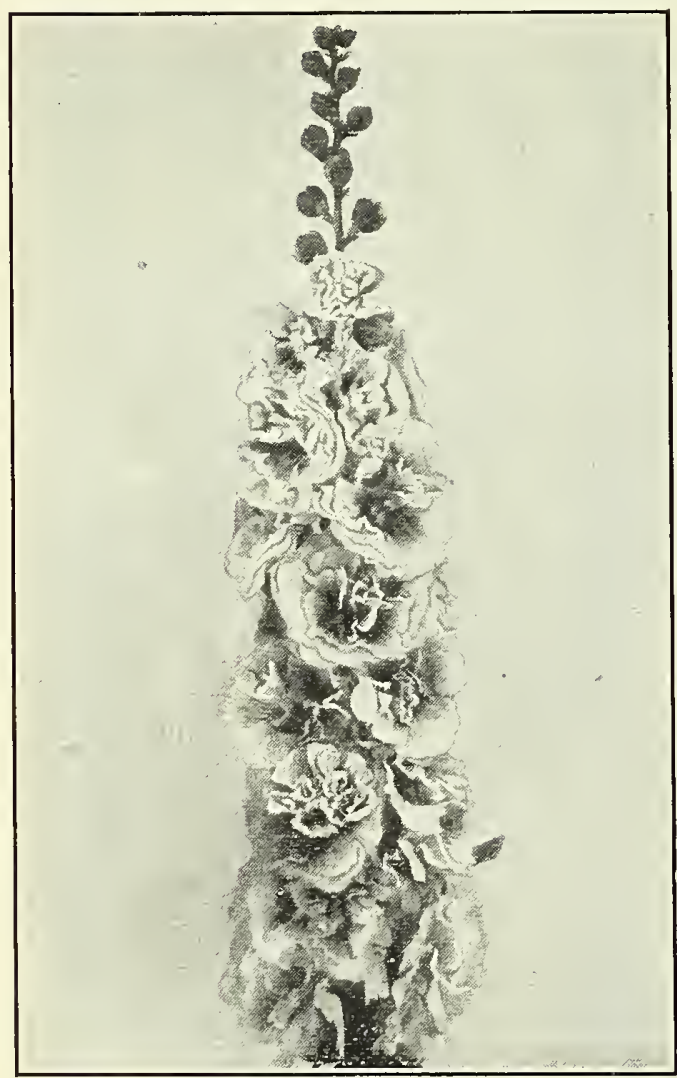

Hollyhock - Allegineny variously fra-
grant and ornagrant and ornaGrows easily from seed.

Apple scented. Very fragrant leaves. $\mathbf{P} \mathbf{k t}$ $25 \mathrm{c}$.

Fancy show, or Lady was hington. One of the most beau have; in rich have; in rich, beautiful markings. Fancy nixed. Pkt. $25 \mathrm{c}$.

zonale. Beautiful scarlet. Pkt. 10c.

GIIIA. A hardy an $n$ u a growing one foot high. with white, lilac or rose-colored flowers. A native of California. Valuable for rockwork or borders. Sow seed in the fall. Mixed. Pkt. 5c.

Gilliflower. See Ten We eks' Stocks.

G I A D I O I U S . Well-known magnificent $p l$ an $t s$, with sword - like leaves and long spikes of flowers of every conceivable color and Pliade. 10c.

GLACUM IUTEUM (Horn Poppy). A showy plant, with long silvery leaves, gracefully recurved and deeply cut and curled flowers bell-shaped, orange yellow. Pkt. 5c.

GLOXINIA. Beautiful hot-house plants, with large, bell-shaped blossoms, which come in rich, velvety-deep, and bright colors, pkt. 25c; tigered and spotted, Mixed, pkt. 25c.
GODETIA. A hardy annual, growing from six inches to ten inches high. Of compact growth, with a profusion of satiny cup-shaped flowers in deep red, pink, and white, shaded and blended. Valuable for tedding or massing. Sow seed early in the year. Smallflowered deep-red variety; grows wild in California. Tall Sorts. Fine Mixed. Pkt. 5c.

Tom Thumb, or Dwarf Varieties. Mixed. Pkt. 5c. Duchess of Albany. White. Pkt. 10c.

Lady Albemarle. Dark Crimson. Pkt. 10c.

GOLDEN-ROD (Solidago Canadenss̃s). Well-known golden-yellow hardy perennial. Three 1eê. Hkt. $5 \mathrm{c}$.

GOMPHRENA, OR GLOBE AMARANTH. A low-growing hardy annual, everlasting, or straw flower, about eight inches high, with globe-shaped flowers, in red or white. The plant makes a good border, and the flowers are very pretty, and are attractive, either while growing or dried. Mixed, Pkt. 5c. White, Pkt. 5c. Crimson, Fkt. 5c.

GOURDS. Some varieties, besides being odd, are very ornamental. IVixed ornamencal variecies. Fit. $5 c$.

Chinese $\mathbb{B}$ otcle. A usếul variety. Piź. Sc. (See cut, page 61.) Dish Cloth, or Lufia. The inside lining resembles a sponge. very useful. Pki. 5 c.

Dipper or Siphon. Can readily be made into a dipper. Pkt. 5c. Nest Egg. These resemble a hen's egg and are frequently used for nest eggs. Pkt. 5c.

Sugar Trough. Useful for baskets or buckets, holding from two to ten gallons each. Pkt.5c.

GYPSOPHILA (Baby's Breath). A hardy annual of easy culture Grows two to three feet high, and bears a profusion of small starshaped white and pink fiowers.

Muralis. An excellent border plant; pink flowers. Pkt. 5c. Paniculata. Fine for bouquets; white flowers. Pkt. 5c. Eilegans, annual white.

HELIANTHUS. See Sunflower.

HELICERYSUM. (Everiasting Flower). A free-flowering, hardy annual, growing four to five feet high and bearing beautiful, straw-like flowers in a great variety of shades and colors. The stems are long and the blossoms large. It is the best and most satisfactory of the everlasting flowers, and makes a very handsome dried bouquet. Mixed. Pkt. 5c.

HELIOTROPE. A half hardy perennial, growing four to eight feet high. Small flowers, borne in graceful clusters and very fragrant. Blooms the first season from seed if sown early. Forms a large plant, and requires a roomy situation. Can also be grown against a wall and made to assume the character of a climber.

King of the Blacks. Dark purple, almost black. Pkt. 10c. Queen Marguerite. Purple blue. Pkt. 10c.

White Lady. Pure White. Pkt. $10 \mathrm{c}$.

Finest Iixed. A mixture of the ordinary true types. Pkt. 10c. HESPERIS. See Sweet Rocket.

HONESTY (Satin Flower). The silvery seed pods are used for winter decoration. Very handsome, free-flowering. Two feet. Plt. 5c. 
HOLLYHOCK. A hardy perennial of upright, stately growth, five to eight feet high. The very doubie varieties are the most desirable, but the newer, semidouble, fringed types are also very popular. Hollyhocks make a fine row in the garden, or a fine background next to a building or high wall or fence.

DOUBLE VARIETIES. Mixed, pkt. 10c. oz. $\$ 1.50$. Black, Blood Red, Canary Yellow, Rose Pink, Salmon, Snow White. Pkt. 10c; 6 pkts. assorted, $40 \mathrm{c}$.

Allegheny. Mixed. The semi-double, fringed variety. An artistic and pretty sort. Pkt. 10c.

Henderson's Everblooming. An early-flowering gorgeous mixture of single and semi-double blossoms. Pkt. 5c.

SINGLES. Mixed. The old-fashioned blossoms in all colors. Pkt. 5c.

HUMULUS, OR JAPANESE HOP. A rapid-growing, hardy, climbing annual, with dense leaves. Will grow twenty to thirty feet in a season, and is very valuable for covering a trellis. Japonicus. Bright-green foliage. Pkt. 10c.

Japonicus variegatus. Bright, variegated yellow, white ano green leaves. Pkt. 10c.

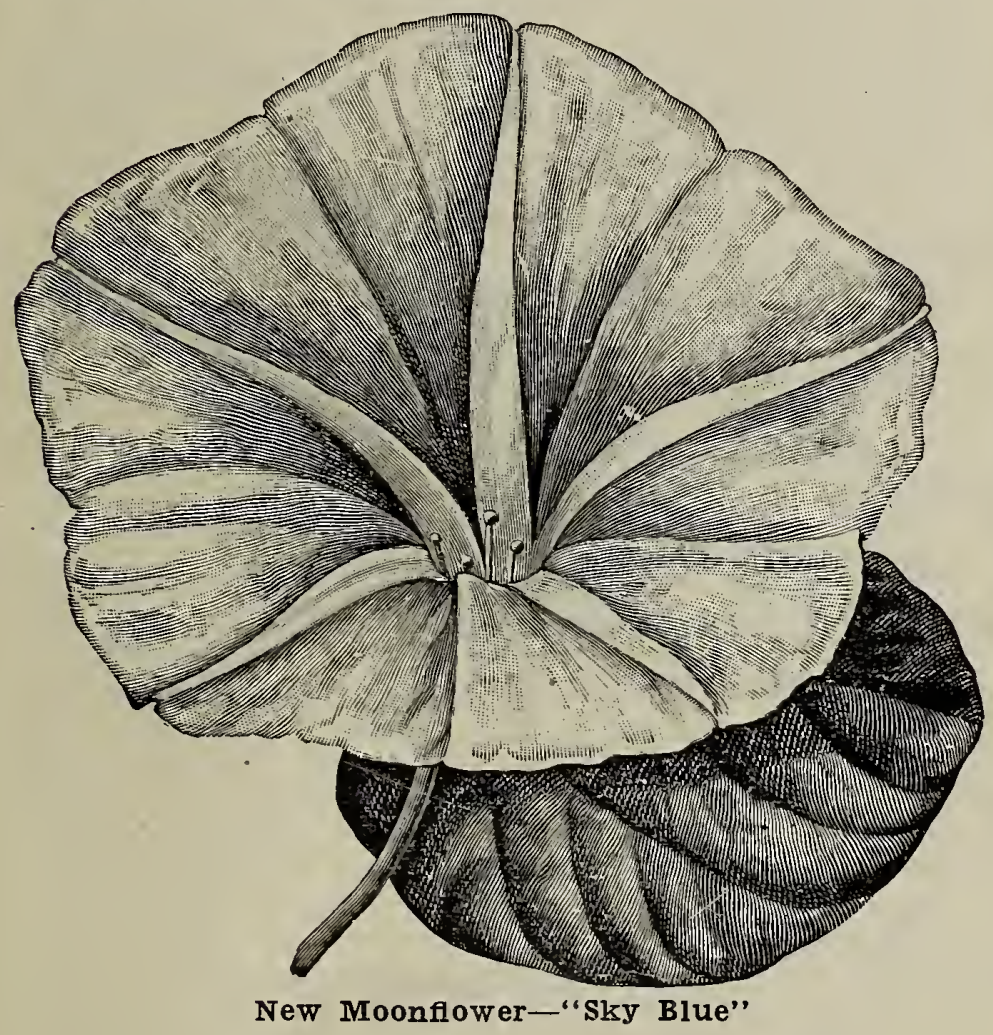

HUNNEMANNIA, OR BUSH ESCHSCHOLTZIA. Known also as the Santa Barbara Poppy. An erectgrowing, tender perennial, about two feet high. Foliage fine cut and feathery. Blossoms, beautifully cup-shaped, bright yellow, and about three to four inches across. Stems, long and smooth. There are few more satisfactory flowers in the garden than the Hunnemannia.

Fumariafolia. Pkt. 5c.

Hyacinth Bean. See Dolichos.

ICE PLANT (Mesembryanthemum Crystallinum). A lowgrowing and trailing tender annual. The thick leaves seem to be covered with crystals. Used for edging and box work. Pkt. 10c.

IMPATIENS SULTANI (Zanzibar Balsam). Much prized for window culture. The foliage is waxy green, and with the semi-transparent branches makes a plant in itself attractive. The bright rosy carmine flowers are very delicate and pretty. Pkt. 15c.

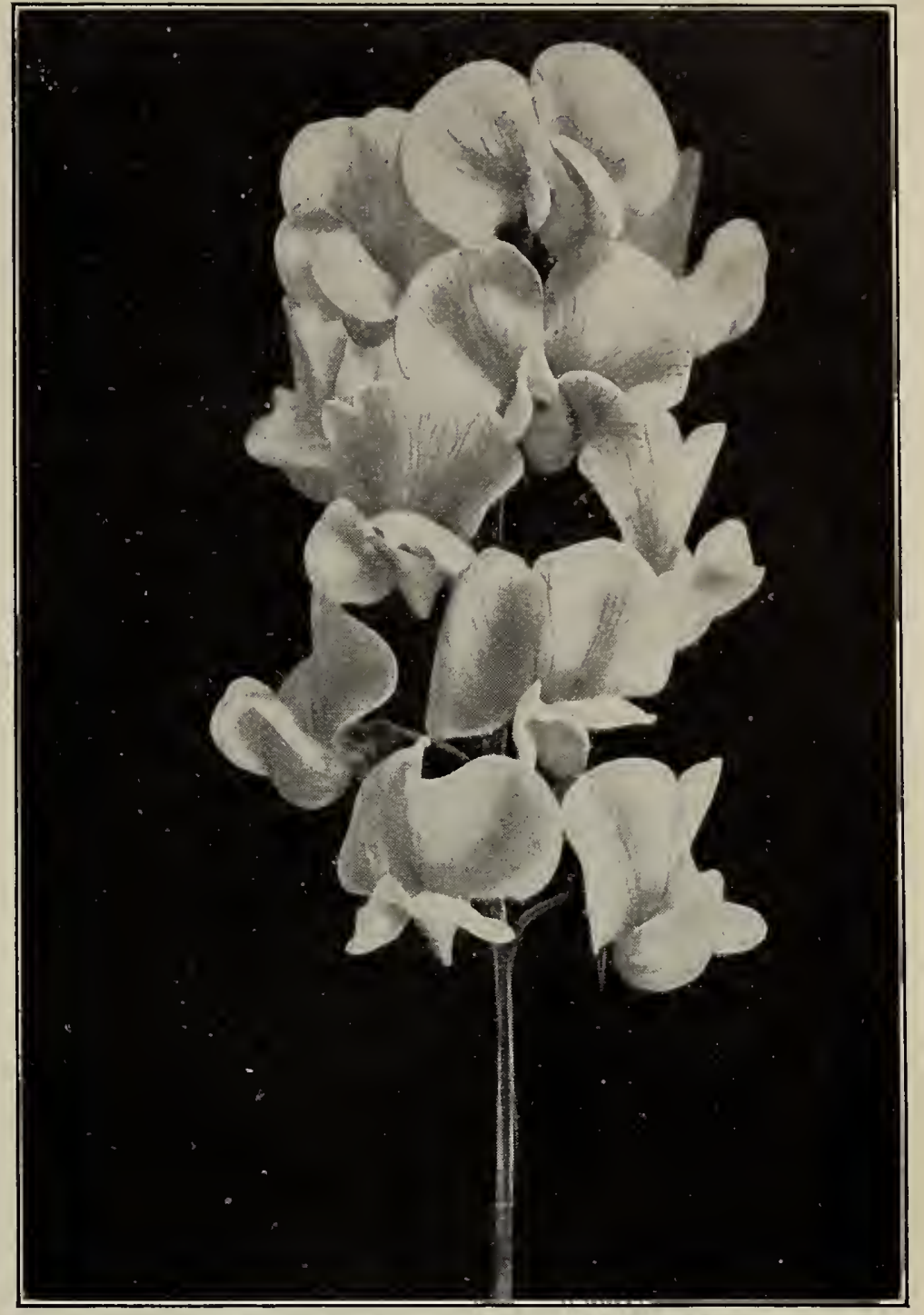

Lathyrus Latifolius-Pure White

IPOMOEA. An extensive genus, including many well. known garden flowers. Are tender climbing annuals, from five to ten feet long, and all classes are desirable. The seed of several varieties, especially the moonflower, should have the outer shell punctured and then soaked in water for twelve hours or more to germinate it.

Bona Nox (Evening Glory, or Good Night). Large, fragrant violet blossoms, expanding in the night. Pkt. 5c.

Coccinea, or Star Ipomea. Small scarlet blossoms. Pkt. 5c.

Grandiflora Alba (Moon Flower). Large, white blossoms, which expand only on dull days or at night. Pikt. 10c.

NEW MOON FLOWER. Sky Blue. Of strong, vigorous growth, the plants quickly attain a height of 12 to 15 feet. A dense mass of large, heart-shaped leaves forms a most appropriate setting for the large sky-blue flowers, which come in September in great profusion. The flowers measure nearly four inches across, and are surpassingly beautiful - of the softest cerulean blue, shading to white at the throat.

Plant two or three seeds in a flower pot (about four inches in diameter) during the fall or winter, and the dwarfed plants will produce these enormous flowers when only six to eight inches high, and continue to bloom freely for a long time. As easily grown as a Geranium in an ordinary room, these dwarf pot plants, covered with immense sky-blue flowers, are extremely attractive. Pkt. 10c. 


\section{NEW MOON FLOWER-Continued}

Heavenly Blue. A tall climber with large light blue flowers, yellow throated and measuring four to five inches across. Pkt. 10c.

Setosa, or Brazilian Morning Glory. Beautiful, rosecolored blossoms, three inches in diameter. Pkt. 10c.

Learii. Large, dark blue flowers. Pkt. 25c.

Lutea. Large yellow blossoms. Pkt. 10c.

Imperial Japanese. See list under Morning Glory.

Ipomea Quamoclit. See Cypress Vine.

Japanese Hop. See Humulus Japonicus.

KENILWORTH IVY. A hardy perennial, trailing plant, especially adapted for hanging-baskets. Pkt. 10c.

KOCHIA TRICOPHYLLA. A beautiful bush plant, forming a perfect sphere. The branches are covered with slender, light-green leavcs, and late in the fall the "plant is covered with sing
blossoms, when it resembles a "ball of fire." Pkt. 10c.

IANTANA. A tender perennial, two to three feet high, bearing verbena-like clusters of flowers, in orange, white, rose, and other colors. Blooms constantly all summer. Fine mixed. Pkt. 10c.

IARKSPUR (Delphinium). There are two well-known types, one being the single and double annual, and the other a very tall, hardy perennial. Both are of easy culture.

Hardy Annual Varieties. Grow about one and one-half to two feet high. A great variety of colors.

Dwarf Rocket. Mixed. Dwarf plant, double flowers. Pkt. 5c.

Emperor. Double Mixed. Pkt. 5c.

Single. Mixed. Pkt. 5c.

Hardy Perennial Larkspurs. Four to five feet high, with beautiful long spikes.

Formosum. The bright-blue variety, with white center. Pkt. 10c.

Formosum Coelestinum. The azure or very lightblue variety. Pkt. 10c.

LATHYRUS LATIFOLIUS. (Perennial or Everlasting Pea). A hardy perennial climber flowering the first year it seed is sown in the fall. Leaves and stems smooth. Flowers resemble sweet peas, but are borne on racemes, with eight to ten blossoms to the stem. Is not fragrant, but is hardy, and thrives in any good soil. Pink Beauty. The ground of the petals is white, edged and
shaded with pink. Pkt. 5c.

Crimson. Pkt. 5c.

White. The best variety for cutting, especially for florists' use. Pkt. 10c.

Splendens. Called the "Pride of California." Not as hardy as the ordinary class. Flowers bright crimson-scarlet.
Pkt. 10c.

LAVATERA. (Annual Mallow). A showy hedge plant, growing about six feet high and covered with shrimp-pink, cup-shaped flowers. Sow in May in the open ground and thin young plants to twelve inches apart. Pkt. 5c.

LAVENDER. Chiefly cultivated for the delicious and lasting fragrance of its flowers; succeeds in any common garden soil. Pkt. 5c.

LEMON VERBENA. The leaves of this fine old favorite are delightfully fragrant and refreshing. Grown easily from seed. Pkt. 10e.

LEPTOSINE DENSIFLORUS. Free-flowering, hardy annual, with large blue Coreopsis-like flowers on long stems; fine for cut flowers: One foot. Pkt. 5c.

LINUM, OR.SCARLET FLAX. A hardy annual, about one and one-half feet high. Of slender and graceful appearance, with smooth stems and bright-red flowers, which are borne in great profusion. Can be sown early out of doors, and thrives well in good soil.

Rubrum. Pkt. 5c.

Perennial Flax. Blue. Pkt. 5c.
LOBELIA. A half hardy annual and hardy perennial. The annual grows four to six inches high; is of compact growth, and literally covered with small, bright flowers. Used for ribbon work and borders or hanging baskets.

Crystal Palace Compacta. Bright blue. Pkt. 10c: Oz. \$2.50.

Emperor William. Pkt. 10c.

Golden Queen. Pkt. 10c.

White Gem (Compacta). White flowers. Pkt. 10c. Gracilis. Pkt. 5c.

Prima Donna. Maroon, with white eye. Pkt. 10c. Speciosa. Pkt. 10c.

Mixed annual varieties. Pkt. 5c.

Perennial Iobelias are hardy and three feet high. The blossoms are produced in spilies.

Cardinalis, or Cardinal Flower. Brilliant, scarlet flowers. Pkt. 10c.

Hybrids. Mixed. Large flowers, resembling Cardinalis. In shades of rose, red, lilac, purple, etc. Pkt. 10c.

LOPHOSPERIMUM SCANDENS. Tender climbing perennial, growing ten to twelve fect long, with showy purplish-rose blossoms something like Foxgloves. Pkt. 10c.

Love-in-a-Mist. See Nigella.

Love Lies Bleeding. See Amaranthus Caudatus.

LUPINUS, OR LUPINS. Hardy annuals, in great variety, growing from one to three feet high, and bearing spikes of pea-shaped flowers. Of the easiest culture. Sow in the open ground and thin to six inches apart.

Cruikshankii. Dark blue. Long racemes of beautiful, blue flowers. Pkt. 5c.

Mixture of all colors. Pkt. 5c.

LYCHNIS. Hardy perennial growing about three feet high and bearing bright-colored flowers in clusters. Of easy culture. Chalcedonica. Scarlet flowers. Pkt. 5c.

Haageana. Orange, crimson, and scarlet flowers. Pkt. 5c.

MANDEVILLA SUAVEOLENS. Fine summer climber with great clusters of large, waxy, stal-shaped yellow blossoms, exquisitely fragrant, resembling the single tuberose in shape. Pkt. 15c.

MARIGOLD. A hardy; annual, shrubby plant, in dwarf and tall varieties, growing from six inches to three feet high. Foliage, bright green, deeply cut, and graceful. The flowers are various shades of yellow and brown. The tall varieties are very valuable for large bedding or background work, and the dwarf varieties for borders.

Eldorado. Called "The African Marigold." The best tall variety, with large double blossoms. Mixed. Pkt. 5c; oz. 25c.

Dwarf French, Legion of Honor. Pkt. 5c. " " Striped. Pkt. 5c.

" " Mixed. Pkt. 5c: oz. 50c.

Tall French Mixture. A mixture of tall double, colors in yellow, brown and stripes. Mixed. Pkt. 5c.

Pot Marigold and Cape Marigold. See Calendula.

Marguerite. See Chrysanthemum frutescens.

Marvel of Peru. See Four O'clock.

Martynia. See Garden Seed List.

MATRICARIA. (Double White Feverfew). Bushy annual garden plant, bearing quantities of whitc double button-like flowers; useful for cutting. Pkt. 5c.

MAURANDIA (Giant-Flowering). Beautiful climber for either garden or greenhouse decoration and for hanging baskets; gemmed with Gloxinia-shaped flowers of rich purple, white, and rose, fully double the size of the older, well known sorts. The
plants from seed sown in spring will begin flowering by July and continue until frost. Mixed colors. Pkt. 10c. 
MIGNONETTE. A hardy annual, growing six to twelve inches high and bearing pyramidal-shaped flower spikes, made up of thickly-set flowerets, which are exceedingly fragrant. Grows easily from seed and can either be transplanted from boxes or sown out in the garden and thinned to four or six inches. Sow in the fall for early blossoms in the spring. Valuable for potting, or for bedding, or for border. The flowers are not attractive except for their fragrance.

Allen's Defiance. Long spikes of whitish flowers and compact growth. Pkt. 10c; oz. 50c.

Golden Machet. A compact-growing variety, with medium long, thick spikes of yellow flowers. Pkt. 5c; oz. 35c.

Parson's White. A tall variety, with long spikes with silver-white flowers. Pkt. 5c; oz. 50c.

Pure Machet. A compact-growing variety, with thick spikes and large flowerets of copper color. Pkt. $5 \mathrm{c} ;$ oz. $35 \mathrm{c}$.

Ruby Machet. A dwarf, compact variety, with large, stubby spikes covered with copper-red flowerets. Pkt. 10c.

Sweet Scented (Reseda Odorata). Pkt. 5c; 0z. 25c. Mixture of the best compact varieties. Pkt. 5c; oz. $25 \mathrm{c}$.

MIMULUS. A half hardy perennial, growing from six inches to one foot high. Blooms freely and exists in a large variety of colors. Useful for window-gardens and pot work or for garden in a moist, shady situation. Blooms first year from seed if sown early.

Moschatus, or Musk Plant. Fragrant plant, with small, yellow blossoms, spotted lightly with brown. Pkt. 5c.

Tigrinus, or Monkey Flower. Large flowers of several colors, and spotted. Pkt. 10c.

Cardinalis. Pkt. 10c.

MINA LOBATA. A half-hardy, annual climber, with orange-colored flowers, which are scarlet in the bud before opening. The plant blooms freely from base to top, and grows twenty to thirty feet long. Pkt. of 20 seeds, 10c.

MOMORDICA. Balsamina, or Balsam Apple. A climbing annual, growing about ten feet long. Has graceful and ornamental foliage, yellow flowers, and warted golden-yellow fruit. with large carmine-red seeds. Pkt. 5 c.

Charantia, or Balsam Pear. Same as the Balsam Apple, but fruit is pear-shaped. Pkt. 5c.
Moonflower. See Ipomea Grandiflora Alba.

MORNING GLORY (Convolvulus Major). A hardy climbing annual, growing about ten feet long. Flowers are well known and exist in a great variety of colors, tints, and markings. Fully expanded only in the mornings. Of easy culture, quick growth, and valuable in every garden.

Tall, or Climbing Varieties. Mixed. Pkt. 5c; oz. $15 \mathrm{c}$.

Imperial Japanese. Taller, larger leaved and larger flowered, with a greater variety of blossoms than the older type. Pkt. 10c; 0z. 20c.

Dwarf, or Bush Varieties (Convolvulus Minor). Plants grow ten to twelve inches high, and are hardy annuals. Mixed. Pkt. 5c.

Mourning Bride. See Scabiosa.

Musk Plant. See Mimulus Moschatus.

Myosotis. See Forget-me-not.

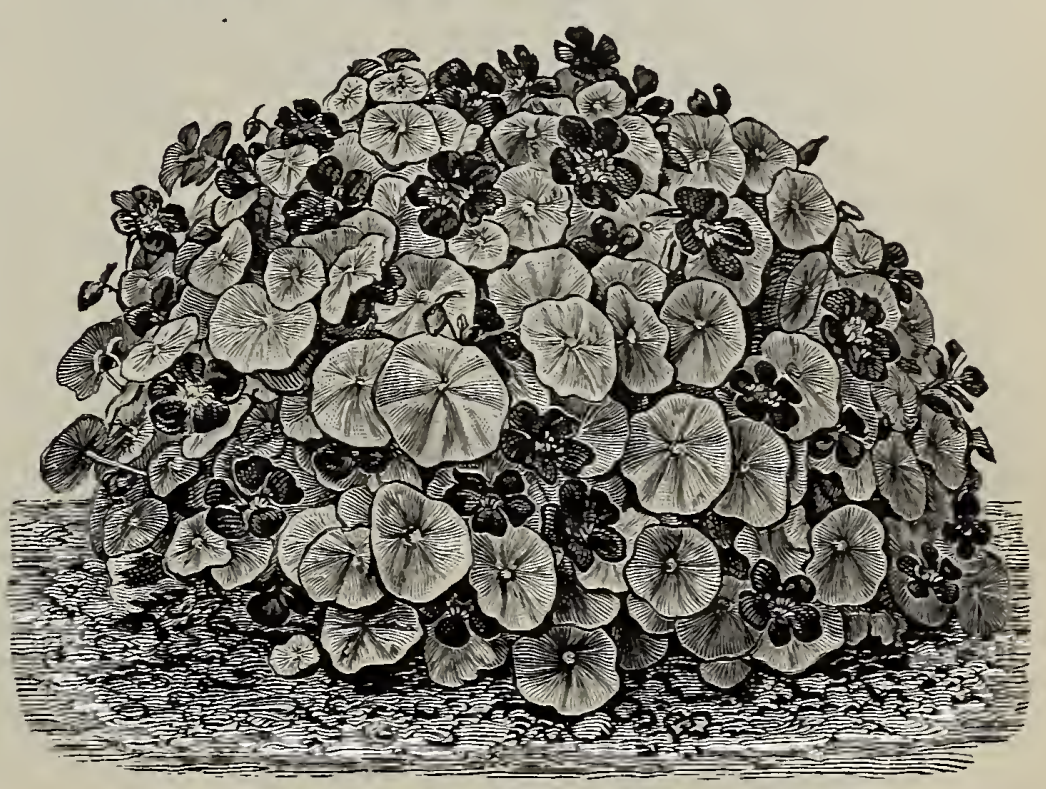

New Dwarf Nasturtium-"Golden Midnight"

\section{NASTURTIUM}

Tender annual, in two distinct classes-Dwarf, and Tall or Climbing

\section{DWARF VARIETIES}

The plant forms a small. round bush twelve to sixteen inches high. The foliage is pretty and the flowers very beautiful and contained in a

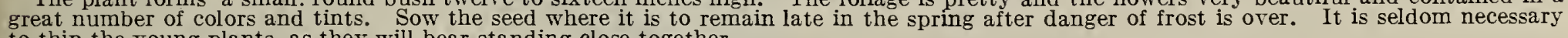
to thin the young plants, as they will bear standing close together.

Aurora. Yellow, veined carmine. Pkt. 5c; 0z. 10c; 1/4 1b. 30c.

Chameleon. Mixed. A dwarf mixture of blotched and inconstant shades. Plat. 5c; oz. 20c; $1 / 4$ 1b. 60c.

Crimson. Pkt. 5c; 0z. 15c; $1 / 41$ 1b. $45 \mathrm{c}$.

Crystal Palace Gem. Sulphur jellow, spotted with carmine. Pkt. 5c; oz. 10c; $1 / 41 \mathrm{~b}$. 30c.

Empress of India. Intense scarlet with dark brown and green foliage. Pkt. 5c; oz. 15c; $1 / 41 \mathrm{~b} .45 \mathrm{c}$.

Golden King. Rich golden sellow. Pkt. 5c;0z. 15c; 1/4 1b. 45c.

"Golden Midnight." The foliage is a light yellowish green, while the flowers are of such a dark maroon as to seem almost black. The artistic effect rendered by this contrast between leares and blossoms is unique and at the same time beautiful. Pkt. 15c.

King of Tom Thumbs. Dark scarlet and dark-green leaves. Pkt. 5c; 0z. 10c; $1 / 41$ b. 30c.

King Theodore. Deep crimson and dark foliage. Pkt. 5c; oz. $15 \mathrm{c} ; 1 / 4 \mathrm{lb} .45 \mathrm{c}$.

Rose. Pkt. 5c; 0z. 10c; $1 / 4$ 1b. 30c.

Ruby King. Bright red, tinted salmon. Pkt. 5c; oz. 10c; 1/4 lb. $30 \mathrm{c}$.

Queen of Tom Thumbs. Variegated foliage, crimson flowers. Pkt. 10c.
Scarlet. Pkt. 5c;0z, 10c; 1/4 1b. 30c.

White Pearl. Very light lemon or primrose. Pkt. 5c; oz. 10c; $1 / 4 \mathrm{lb} .30 \mathrm{c}$.

Yellow. Pkt. 5c;0z. 10c; 1/4 1b. 30c. Dwarf Varieties Mlxed. A splendid mixture of all the abore,
besides many other varieties. Pkt. 5c; oz. 10c; $1 / 41 \mathbf{b}$. 25c; lb. $85 \mathrm{c}$.

\section{TALL, OR CLIMBING VARIETIES}

Of quick growth, covering a wall, hedge, or trellis in a short time.

Butterffy. Light yellow, with blotch of deep red on lower petal. Pkt.5c;0z. 20c; $1 / 4$ 1b. 60c.

Chameleon. A mixture of changing or inconstant shades. Pkt. 5c; oz. 15c; $1 / 4$ lb. 35c; 1b. $\$ 1.20$.

Caprice. A mixture of light colors, spotted and shaded, with dark foliage. Pkt. 5c; oz. $15 \mathrm{c} ; 1 / 4 \mathrm{ib} .45 \mathrm{c}$.

Moonlight. Very light yellow. Pkt. 5c; oz. 15c; 1/4 1b. 40c.

Orange. Pkt. 5c; oz. $15 \mathrm{c} ; 1 / 41 \mathrm{~b} .40 \mathrm{c}$.

Pearl, or White. Light lemon or primrose. Pkt. 5c; oz. 15c; $1 / 4$ 1b. $40 \mathrm{c}$.

Rose. Pkt. 5c; oz. 15c; $1 / 41 \mathrm{lb} .40 \mathrm{c}$. 


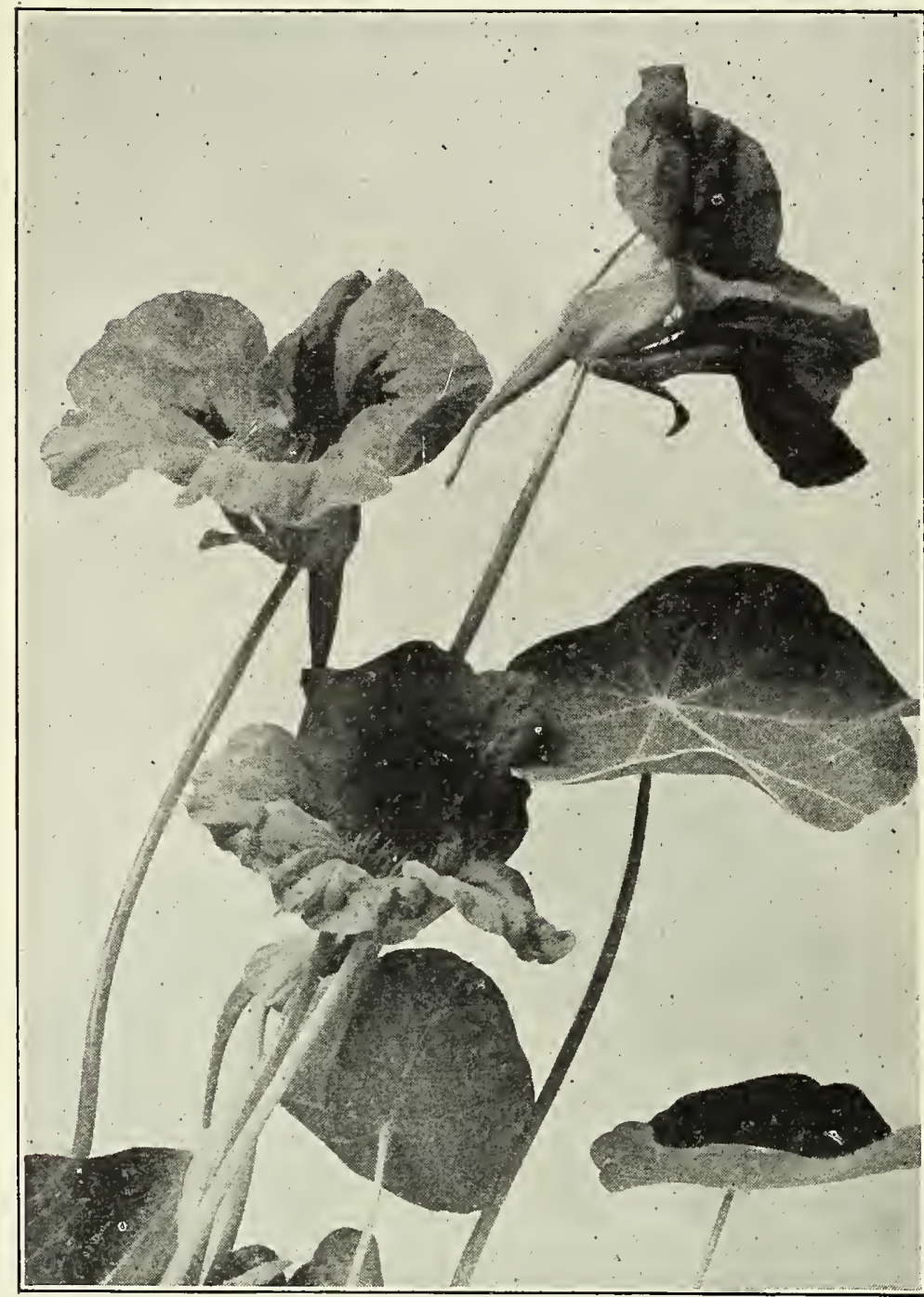

Nasturtium-Tall or Climbing

Red spurred. A mixture of light colors, all having a red back or spur. Foliage dark. Pkt. 5c; oz 15c; $1 / 41$ 1b. 50c.

Scarlet. Pkt. 5c; oz. 15c; 1/4 lb. 40c.

Twilight. Large blossoms of light salmon, suffused with rosy salmon. Pkt. 5c;0z. 15c; $1 / 4$ 1b. 40c.

Yellow. Pkt. 5c; 0z. 15c; 1/4 1b. 40c.

Tall Varieties Mixed. All the above varieties, besides many others, in a splendid mixture. Pkt. 5c; oz. 10c; 1/4 1b. 25c; 1b. $70 \mathrm{c}$.

VARIEGATED QUEEN-A TALL OR CLIMBING VARIETY While the leaves are not as large as those of the common Tall Nasturtium the plants are just as tall and equally vigorous in growth. Every leaf is variegated with yellow, white and green. Some of the leaves are one-half to two-thirds white and yellow while others are mostly green, but beautifully striped and blotched.

The flowers are rich scarlet maroon, deepest in color at base of petals. It comes entirely true from seed. Pkt. 10c; oz. 35c.

Ivy-leaved. A mixture of several colors; have lobed or scalloped leaves. The blossoms have narrow petals scalloped at the edges. Very pretty and attractive. Pkt. 5c; oz. 25c; $1 / 4$ lb. $75 \mathrm{c}$.

NEMOPHILA, OR LOVE GRASS. A hardy annual, growing about six inches high. Has small, cup-shaped blossoms about one inch in diameter, in white and shades of blue. Pkt. 5c.

INSIGNIS (Baby Blue Eyes). Sky blue, with white eyes. Pkt. 5c.

NICOTIANA, OR FLOWERING TOBACCO. A half hardy annual, growing three feet high. Belongs to the tobacco family. Has white blossoms. Requires plenty of room in the garden. Affinis. White. Pkt. 5c.

Colossea. Giant foliage plant of a dark glossy green with reddish ribs. Pkt. 10c.

sanderaea. A new, large, flowering type, with various brightcolored blossoms. Pkt. 10c.
Sunlight. Bright yellow, Pkt. 5c; 0z. 15c; 1/4 lb. 40c.

Dark Crimson. Pkt. 5c; 0z. 10c; $1 / 4$ lb. 30c.

Jupiter. Large, bright, golden yellaw. Pkt. 5c; oz. 20c; $1 / 4$ 1b. 60c.

Midnight. Flowers deep brownish red; foliage deep green. Pkt. 5c;0z. 20c; $1 / 4$ 1b. 60c.

\section{TROPAEOLUM LOBBIANUM OR LOBB'S VARIETIES}

A tall, or climbing class. The leaves are smaller and the flowers more numerous and prolific than the ordinary tall class.

Lobb's Varieties Mixed. Pkt. 5c; oz. 10c; $1 / 4$ lb. 30c; 1 b. $\$ 1.00$. Asa Gray. Light lemon or primrose. Pkt. 5c;0z. 15c; $1 / 41$ b. 45c. Crown Prince of Prussia. Blood red. Pkt. 5c; oz. 15c; $1 / 4$ lb. 45c.

Crystal Palace. Orange scarlet. Pkt. 5c; oz. 15c; 1/41b. 45c.

Giant of Battles. Sulphur yellow, blotched with red. Pkt. 5c; oz. $15 \mathrm{c} ; 1 / 4 \mathrm{lb} .45 \mathrm{c}$.

King of the Blacks. Dark-red flowers and dark foliage. Pkt. 5c;0z. 15c; $1 / 4$ lb. 45c.

Lucifer. Blossoms, deep crimson; leaves, brownish green. Pkt. 5c; oz. 15c; $1 / 4$ 1b. $45 \mathrm{c}$.

Regina. Salmon red, changing to almost cream color. Pkt. 5c; Oz. $15 \mathrm{c} ; 1 / 4 \mathrm{db} .45 \mathrm{c}$.

Spitfire. Brilliant scarlet. Pkt. 5c; oz. 15c; $1 / 4$ 1b. 45c.

Hybrids of Madam Gunter. Mixed. A splendid mixture of blotched, shaded, and variously marked petals in bright, glowing tints. Pkt. 5c; oz. 10c; $1 / 4$ 1b. 30c; 1 b. $\$ 1.00$.

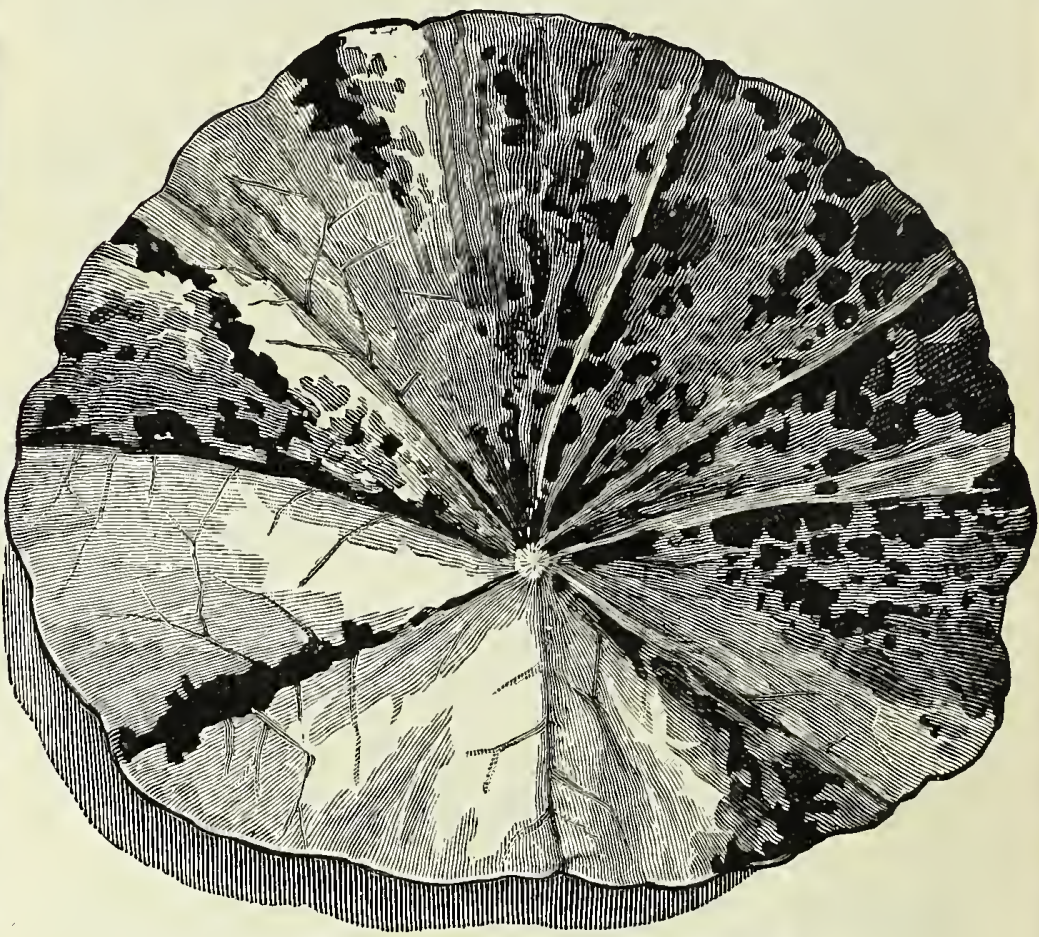

A Leaf of New Variegated Queen Nasturtium

NIGELLA, OR LOVE-IN-A-MIST. A hardy annual, one foot high, with finely cut foliage oddly shaped blossoms in blue and white, and curious seed pods. Of easy culture.

Damascena. Pkt. 5c.

OENOTHERA, OR EVENING PRIMROSE. A half hardy annual, and perennial, about six inches high, bearing bright, showy flowers in white, pale yellow, rose, etc. Of the easiest culture. The blossom is fully expanded only late in the afternoon. Annual Varieties. Mixed. Pkt. 5c.

oxALIS. A half hardy perennial, growing about nine inches high and suitable for greenhouse, rock-work, or out-door culture. Flowers, bright colored and showy. Mixed. ${ }^{2}$ Pkt. 10c. 


\section{MORSE'S SUPERB PANSIES}

All our Pansy seed is obtained from the most noted European specialists. They thrive best in a moist, shady location and in rich, loamy

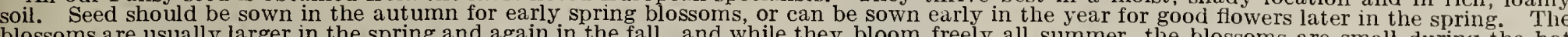

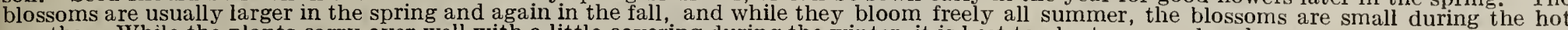
months. While the plants carry over well with a little covering during the winter, it is best to plant new seed each year.

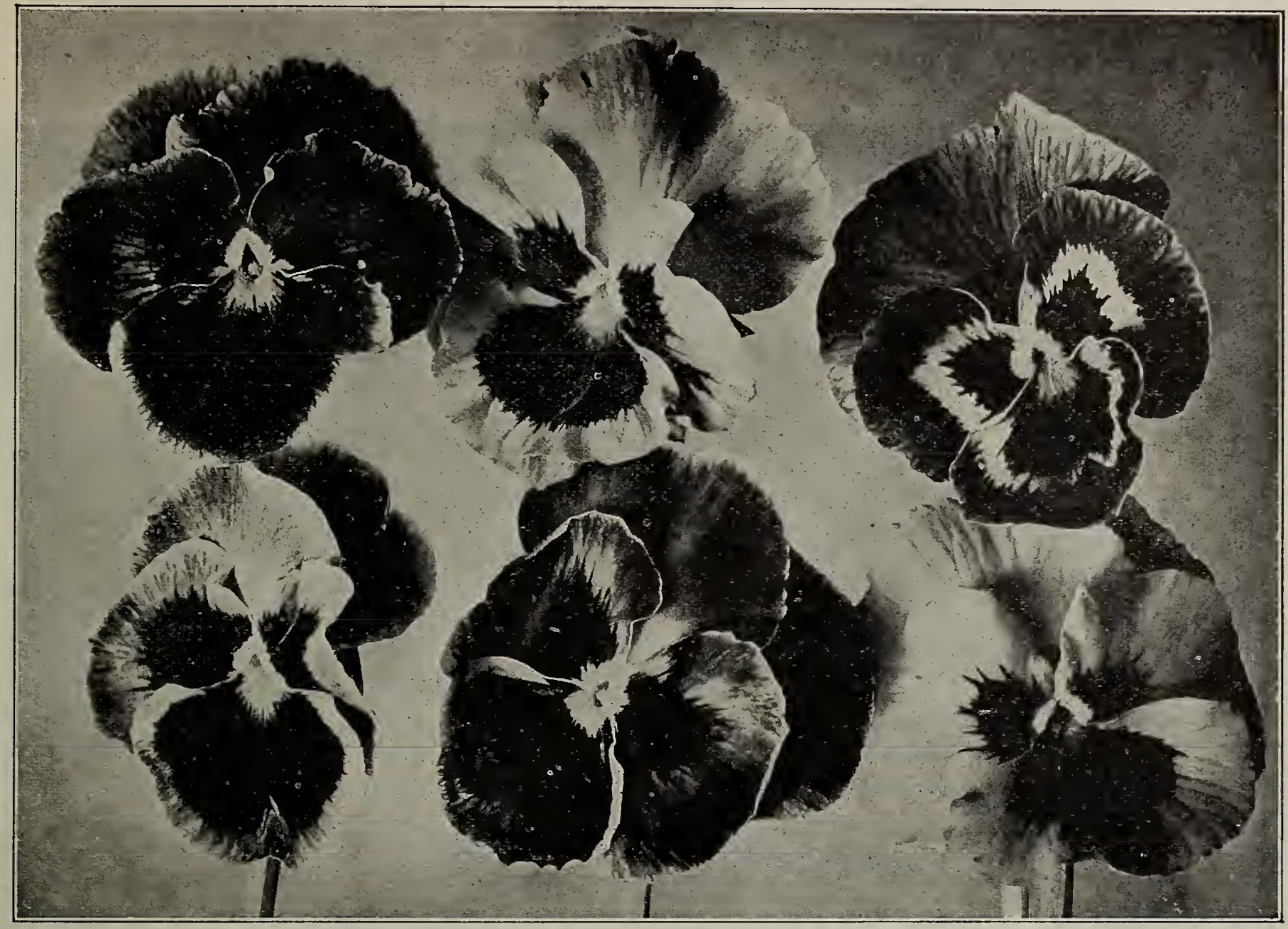

Morse's Prize Strain Pansies-About 1/2 natural size

We offer the following extra selected strains of superior large flowers especially for pansy fanciers, all at 25c per pkt.

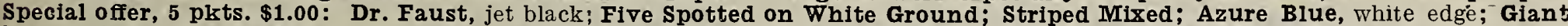
Fancy, light blue; Goldelse clear jellow; Cardinal, blood red; Emperor William, purple, violet shaded; Snow White.

\section{SPLENDID MIXTURES}

MORSE'S PRIZE STRAIN. The Seed of Morse's Prize Strain Pansy is grown for us by a noted specialist in Germany, and is saved from exhibition flowers, including almost every shade of color exquisitely spotted and blotched, veined, mottled of color, that mor dediption that nor do justice, being unsurpassed for rich and varied colors and immense size. Pkt. of
500 seeds, 50c. Morse's Imperial German Strains Mixed. A superfine Mixture of the choicest German varieties in all colors. Pkt. 25c.

Bugnot Mixed. A circular, ruffled, and five-petaled type, with soft, blended colors and tints, veined on the margins and with a dark blotch at the base of each petal. One of the finest varieties. Pkt. 25c.

Cassier's Giant, Mixed. A splendid mixture of various shades and markings. The blossoms are perfectly round and are blotched at the base of 3 to 5 of the petals. Pkt. 25c.

Giant Trimardeau, Mixed. The largest flowering type of pansies, called the French strain. The top petals are larger than the three lower ones and are beautifully marked. Pkt. 15c.

Giant Odier or Prize Blotched, Mixed. A large flowered type with round blossoms. The petals are all blotched at the base and distinctly margined on the edge. Pkt. 25c.

Giant Masterpiece. These new pansies have a most beautiful combination of rich velvety coloring and attractive wavy or ruffied petals. This wavy effect gives a graceful appearance rarely sec pansies, and while they are really very large, they appear larger on this account. Pkt. 25c.

Large Flowering Varieties. All Mixed. Pkt. 10c;0z. $\$ 2.00$.

Striped or Mottled. Mixed. Plrt. 10c.

\section{THE BEST SEPARATE COLORS OR NAMED VARIETIES}

Atropurpurea. Dark blue. Pkt. 10c; oz. \$2.50.

Auriculaeflora. Fine shades. Pkt. 10c; oz. \$2.50.

Azure Blue. Plzt. 10c; 0z. $\$ 2.50$.

Bronze. Pkt. 10c;0z. \$3.00.

Emperor William. Ultramarine blue. Pkt. 10c; oz. \$2.50.

Fairy Queen. Blue with azure margin. Pkt. 10c; oz. \$2.50.

Fire King. Crimson, yellow edge. Plit. 10c; oz. \$4.00.

Golden Gem. Pure yellow. Pkt. 10c; oz. $\$ 3.00$.

Gold Margined. Pkt. 10c; 0z. \$2.50.

Golden Yellow. Dark eye. Pkt. 10c; oz. $\$ 3.00$

King of the Blacks or Faust. Velvety black. Pkt. 10c; oz. $\$ 3.00$.

Lord Beaconsfield. Lavender, heliotrope and purple. Plat. 10c; oz. $\$ 2.50$.

Peacock. Peacock blue, white edge. Pkt. 10c; oz. $\$ 6.00$.

Prince Bismarck. Golden bronze. Pkt. 10c; oz. \$2.50.

Ouadricolor, or Pheasant's Eye. Pkt. 10c; 0z. \$2.50.

Ruby Red. Rich color. Pkt. 10c; oz. $\$ 6.00$.

Silver Edged. Extra fine. Pkt. 10c; 0z. $\$ 3.00$.

Snow Queen. Pure white. Pkt. 10c; oz. $\$ 3.00$.

victoria. Nearly scarlet. Pkt. 10c; oz. \$3.00.

violet. Fine violet, blue. Pkt. 10c; oz. $\$ 2.50$

White.' Pure white, dark eye. Pkt.10c; oz. \$2.50.

12 packets of any of the above 10 varieties for $\$ 1.00 ; 6$ for $50 \mathrm{c}$. 
PASSION FLOWER (Passiflora). A hardy perenníal climber, shedding its leaves in winter. Grows luxuriantly either from cuttings or seed. A very satisfactory climber for immense growth, as it will cover a porch or small cottage in one summer. Pink, Pkt. 10c; Purple, pkt. 10c; Scarlet, pkt. 10c; White Pkt. 10c.

Pelargonium. See Geranium.

PENTSTEMON. A hardy perennial, blooming first year from seed. Grows about 18 inches high, and its bright-colored and spotted blossoms are borne in spikes, somewhat like the Foxglove, but in a great variety of shades and colors. A decidedly beautiful and satisfactory flower. Mixed, pkt. 10c.

Perennial Pea. See Lathyrus Latifolius.
POPPY. A hardy annual, three to five feet high, and bearing single and large double blossoms in bright colors. Sow seed in open ground where plants are to remain, and thin to six or twelve inches. If left thick the plants will be weak and spindling and the blossoms inferior. To avoid getting the seed too thick, it can be mixed with dry sand before sowing. DOUBLE VARIETIES (POPPY)

Cardinal. A bright scarlet, fringed, double. Pkt. 5c; oz. 50c.

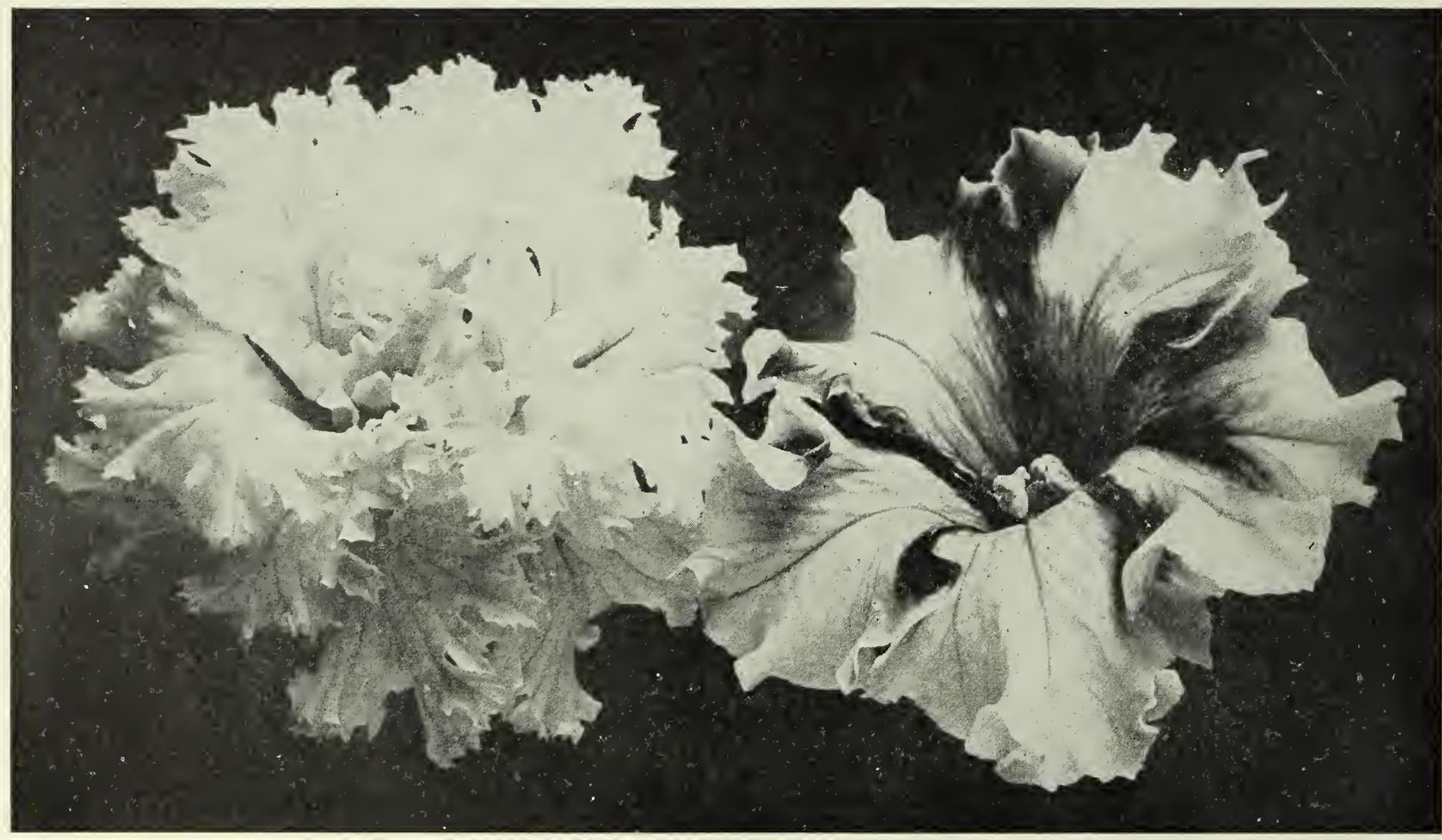

Strains of Giant Petunia-Single and Double Fringed

PERILLA NANKINENSIS. A half hardy annual, with very dark bronze, almestar to Coleus. Is of easy culture. Mixed, pkt. 5c.

Periwinkle. See Vinca.

PETUNIA. A tender perennial, of several distinct types, and variously adapted for greenhouse and pot culture, and for open air. The latter grows with little attention or care, and in any soil, and blooms profusely all spring and summer. The large, double varieties do not produce seed, but the pollen from them is artificially crossed on the large, single, and fringed plants, and the seed so produced will make double blossoms. The Giant Flowered types are in large single, plain edged, or fringed edged blossoms, or in very thickly double flowers.

Giant Flowered Varieties, all fertilized by hand-

Single. Deep throated, brilliantly blotched, plain edge, mixed. Pkt. 25c.

Single. Deep throated, brilliantly blotched, fringed, mixed. Pkt. 25c.

Double. White, blotched, and brilliantly colored, mixed, plain edged. Pkt. 25c.

Double. Striped, blotched, mixed, fringed. Pkt. 25c.

Small Flowered Varieties-

Dwarf Inimitable. Mixed. A very free-blooming, dwarf plant. Pkt. 10c.

Fine Mixed. Good mixture of small free-blooming colors. Pkt. 5c.
Double White, Paeony Flowered. Straight edges. Pkt. 5c;0z. 50c.

Fairy Blush. A large, double fringed white, with pink edges. Pkt. 5c; oz. 50c.

Shrimp Pink. Large double, straight edges. Pkt. 5c; 0z. 50c.

White Fringed, or Carnation Flowered. Large, double fringed. Pkt. 5c; 0z. 50c.

Large Double. Mixed. All colors. Pkt. 5c; oz. 40c.

\section{SINGLE VARIETIES (POPPY)}

Dannebrog. Scarlet, with white center. Pkt. 5c.

Tulip Flowered. Intense scarlet, single blossoms. Plant about two and one-half to three feet high. The brightest colored of all poppies. Pkt. 10c; oz. 60c.

Shirley. The most beautiful type of poppies, having soft, hairy foliage, and an immense variety of single blossoms in white, pink, lavender, purple, shades of red, and scarlet. Free blooming and fine for bedding or tall border. Mixed. Pkt. $10 \mathrm{c}$; 0z. 60c.

Umbrosum. Vermillion petals, with black spots on each. Pkt. 5c. 
PERENNIAL POPPIES. Hardy perennial, of easy culture; in bright, glowing colors. Blooms first year from seed.

Iceland. Mixed. A graceful, delicate variety, with white, orange, and yellow single blossoms, the petals resembling crumpled tissue paper. The plant is low-growing, but the stems are long and slender. Sow in the fall, where plants are to remain, and thin. Pkt. $10 \mathrm{c}$.

Orientale (the large Oriental Poppy). A hardy plant, bearing large, brilliant scarlet flowers, with a black blotch on each petal. Very showy and attractive. Pkt. 10c.

Orientale (Queen Alexandra). Pkt. 15c.

Bracteatum. Pkt. 10c.

Pinks. See Dianthus.

PHYSALIS, FRANCHETTI, OR CHINESE LANTERN PLANT. A showy annual, growing two feet high and esteemed for its seed pods, which in fall change from brilliant yellow to scarlet and which are round and pointed and resemble a small scarlet and which are round and pointed and resemble a small
lantern. The fruit inside the pod is sometimes made into prelantern. The fruit
serves. Pkt. 10c.

PLATYCODON GRANDIFLORA, OR JAPANESE BELL. A hardy perennial, growing $1 \frac{1}{2}$ feet high and bearing double, deep-blue blossoms in profusion all summer.

Japonicus. Pkt. 10c.

Polyanthus. See Primula.

PHLOX DRUMMONDII. A hardy annual, growing from six inches to one foot high and bearing beautiful, soft-petaled, and brilliantly colored flowers all spring and summer. Fine for bedding, and massing. Sow seed in the fall for early flowers.

Carnea. Pink, with chamois-rose center. Pkt. 10c.

Coccinea. Brilliant scarlet. Pkt. 10c.

Eclipse. Bright, rosy purple and violet. Pkt. 10c.

Kermisina. Vivid crimson. Pkt. 10c.

Large Blood Red. Pkt. 10c.

Pure White. Pkt. 10c.

Splendens. Bright red, with white eye. Pkt. 10c.

Yellow (Isabellina). Soft primrose. Pkt. 10c.

Fine Mixture of all colors of the larger types. Pkt. $5 \mathrm{c} ; 0 \mathrm{z} .50 \mathrm{c}$.

Dwarf Compact. Mixed. Low-growing plants, with good-sized flowers. Pkt. 10c.

Starred and Fringed. Mixed. A mixture of starshaped and pointed blossoms. Pkt. 10c.

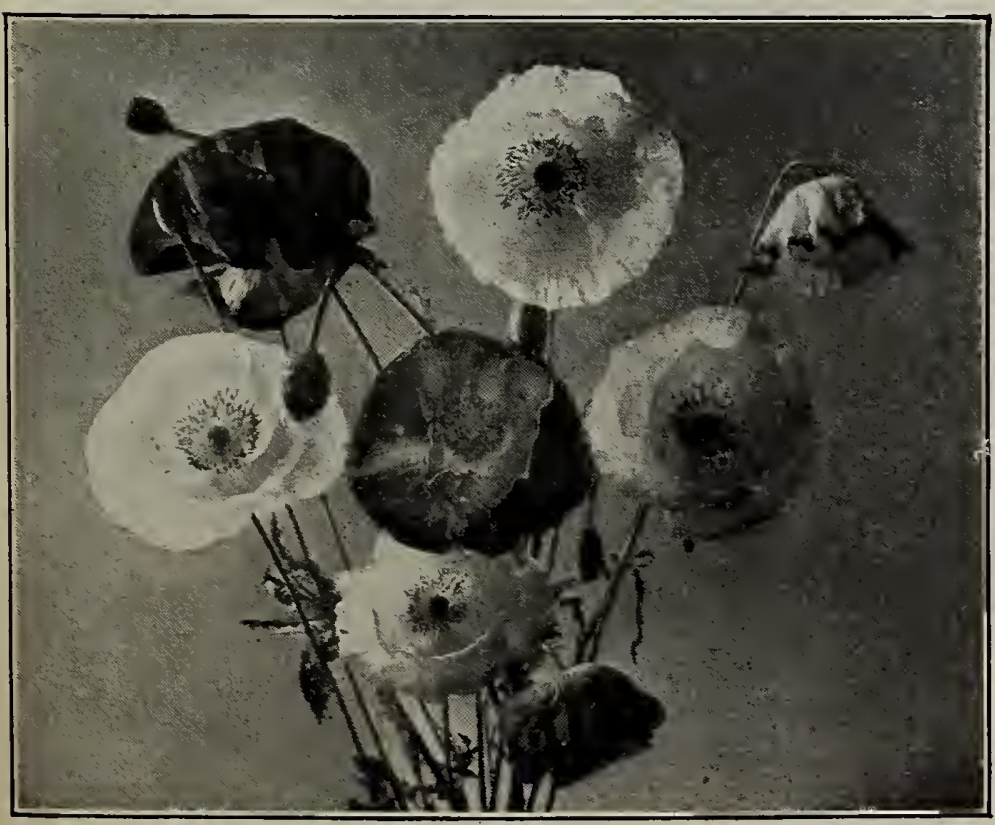

Shirley Poppies

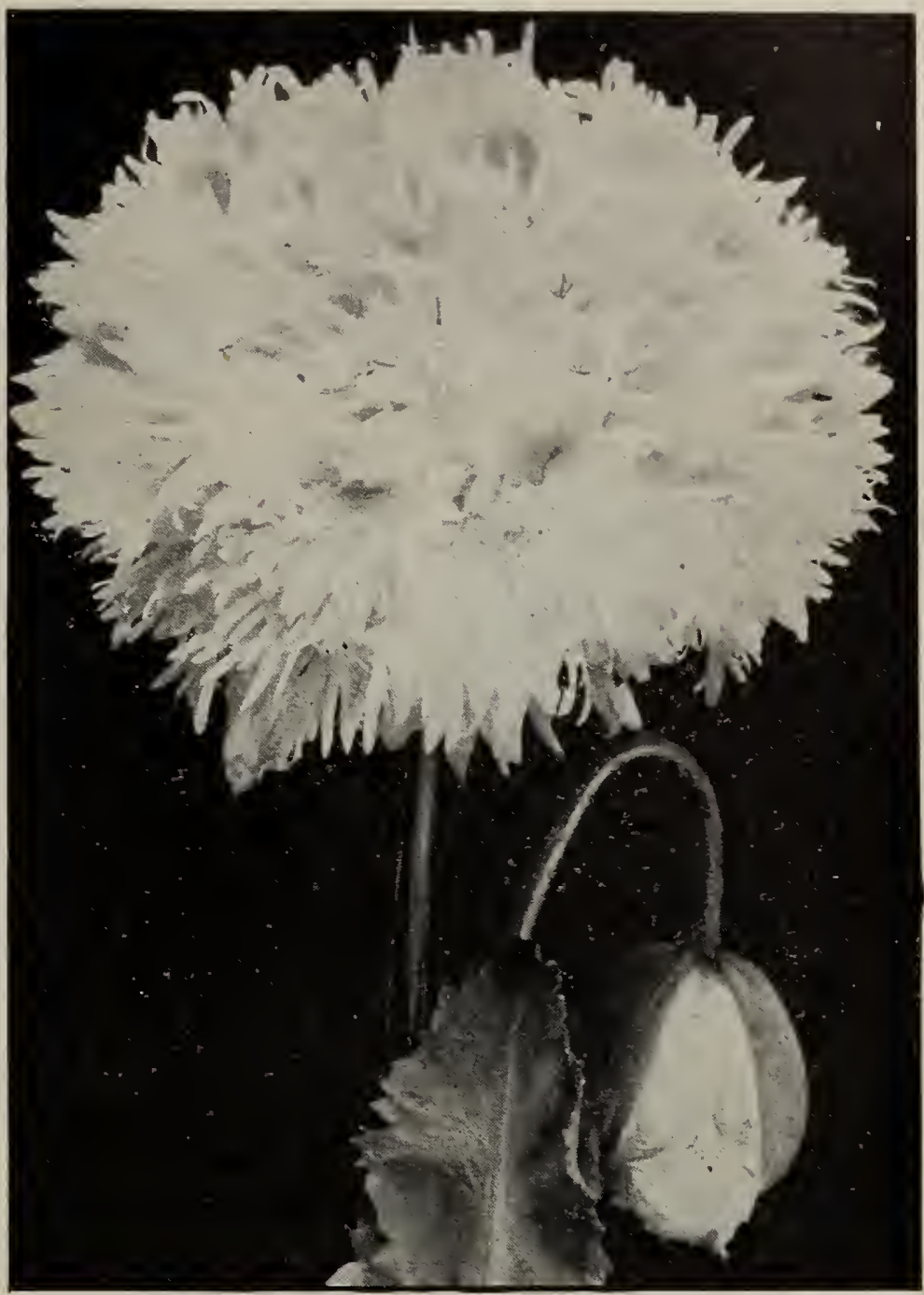

Double White Fringed Poppy

PERENNIAL HARDY PHLOX. A beautiful and easily grown perennial about three feet high and bearing clusters of bright-colored, phlox-like blossoms. There is no more satisfactory flower for the garden, and should be in far more general use than it is now.

Decussata Mixed. Pkt. 10c.

PORTULACA. Low-growing or creeping, tender annual, six to eight inches high and bearing glossy, cupshaped blossoms in very brilliant and gorgeous colors. The foliage and stems are thick. The seed germinates slowly and should be started under glass. The plants require a sunny location, and do best on rather dry ground.

Single. Large flowering, mixed. Pkt. 5c.

Double. Large flowering, mixed. Pkt. 10c.

Primrose, Evening. See Oenothera.

PRIMULA SINENSIS, OR CHINESE PRIMROSE. Greenhouse or pot plants, bearing large single $\mathrm{Ol}^{\circ}$ double blossoms in bright colors, as well as soft tints. Sow seed in April or May for winter blooming.

\section{SINGLE FRINGED VARIETIES}

Alba Magnifica. Pure white. Pkt. 25c.

Bright Blue. Pkt. 25c.

Bright Rose. Pkt. 25c.

Rosy Morn. Blush pink. Pkt. 25c.

Scarlet. Pkt. 25c.

Single Flowers. Choice mixed. Pkt. 25c. 
PRIMULA.-Continued.

Single Fringed Varieties. A splendid mixture. Pkt. 25c.

Double Fringed Flowers. Saved from the finest blossoms. Pkt. 50c.

Ficifolia, or Fern Leaved Varieties. Mixed. Pkt. 25c. Forbesi (Baby Primrose). Pkt. 15c.

Obconica Grandiflora. Pkt. 25c.

Vulgaris (True Yellow Primrose). Pkt. 10c.

Auricula. Extra fine quality, mixed. Pkt. 25c.

Veris Polyanthus. Pkt. 10c.

PYRETHRUM. A hardy perennial, with bright foliage, much used for edging and borders. Seed can be sown in the fall or spring and transplanted.

Parthenifolium Aureum, or Golden Feather. Small-cut leaves, bright golden yellow. Pkt. 5c.

Roseum, or Insect Powder Plant. A hardy perennial, with red-petaled flowers radiating from a golden-yellow center. Buhach, or insect powder, is made from the dry leaves. Pkt. 5c.

Grandiflorun. A large-flowered type, with bright-colored and attractive blossoms for cutting. Mixed. Pkt. 10c.

Seleginoides, Fern leaved edging plant. Pkt. 10c.

Red-Hot Poker Plant. See Tritoma.

Ricinus. See Castor Oil Bean.

RHODANTHE (Everlasting Flower). One of the finest and most beautiful of the many varieties of everlastings: for winter bouquets, the blossoms should be gathered before iuliy expanded, and if dried in the shade will retain their brilliancy for years. Rose and white mixed. Pkt. 5c.

ROMNEYA COULTERI (California Tree Poppy). Also well known as the Matilija Poppy. This fine perennial is of a supreme and stately beauty. It is of value as a cut flower, lasting well in water, and its delicate primrose-like perfume is most acceptable. The texture of the petals is extremely delicate, indeed, haif transparent. They never lose the crumpled folds that in the case of most poppies betoken newly opened state. The flowers are large, four to five inches across, pure white with a fine bunch of yellow stamens, resembling white, single with a fine bunch
peonies. Pkt. 15c.

RUDBECKIA IACINIATA F1. P1. (Golden Glow). Handsome perennial, six to eight feet high, covered with very double, golden-yellow flowers. Pkt. 10c.

SAIPIGLOSSIS. A half-hardy annual, growing about three feet high and bearing trumpet shaped blossoms of rich shades and colors, all beautifully veined. It is valuable for bedding and massing, and its long stems make it excellent also for cut flowers. Sow seed early in the year and transplant, or sow the seed where it is to remain, in April, and thin to six or eight inches. Extra Fine Mixed. Pkt. 10c.

SAIVIA OR FIOWERING SAGE. A tender perennial, blooming the first season from seed and growing two to three feet high. The blossoms are borne on long stems in racemes or spikes, and are fragrant. The plant forms a bunch and blooms profusely.

Patens. Bright blue flowers. Pkt. 15c.

Splendens. Bright scarlet flowers. Pkt. 10c.

Bonfire. A new dwarf Scarlet Sage, of dense compact growth, from 18 to 24 inches high; useful for bedding or borders. Flowers dark scarlet. Pkt. $10 \mathrm{c} ; 1 / 8$ oz. $75 \mathrm{c}$.

Dark Blood Red. A new variety with large flower spikes, much darker and richer than other scarlets. Dazzling and beautiful. Pkt. 10c.

Santo. A low growing plant of a gray color very largely used for edging and ribbon work; it trims well and has a narrow leaf. Pkt. 10c.

SANVITALIA. A hardy trailing annual, six inches high and bearing bright yellow blossoms resembling a miniature double Zinnia. Procumbens Fl. Pl. Plst. 5c.
SCABIOSA OR MOURNING BRIDE. Also called Sweet Scabious, Old Maid's Pincushion, etc. A hardy annual, growing eight inches to two feet high and bearing heads of bright flowers on long, slender stems. The seed pods are thimble-shaped and covered with stiff stamens. Very effective as a bedding plant or for cut flowers. While an old-fashioned flower, it is highly esteemed and very popular.

Mammoth Flowered, Double, or Maxima. Mixed. An improved strain, with large petals and beautiful colors. Pkt. 5c.

Dwarf Double Mixed. Pkt. 5c.

Tall Double Snowball. Pkt. 10c.

Tall Double Black Purple. Pkt. 10c.

Tall Double Azure Fairy. Pkt. 10c.

Tall Double Rose. Pkt. 10c.

Caucasia. A hardy perennial variety, with bluish lavender blossoms and long stems. Pkt. 10c.

Scarlet Flax. See Linum.

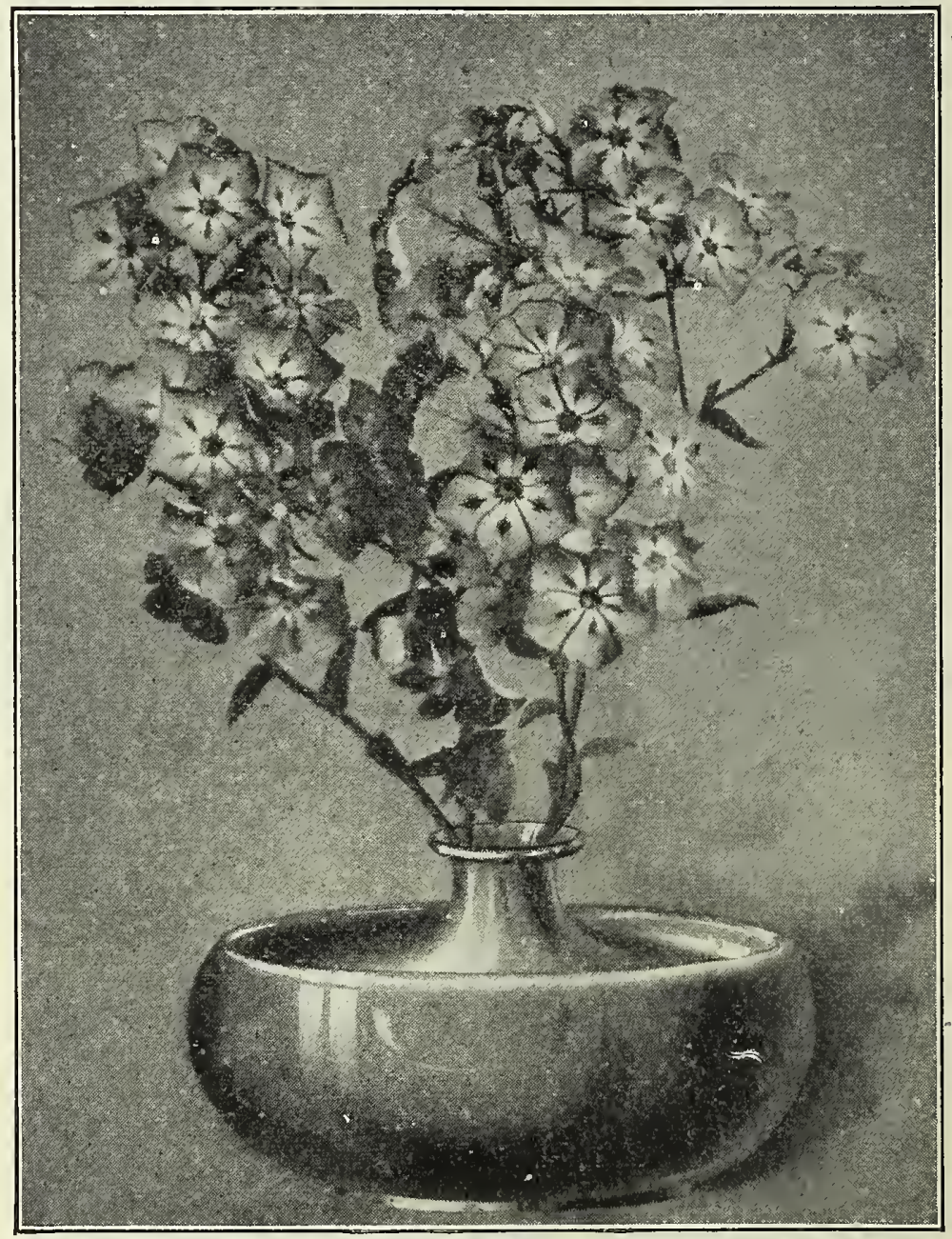

Phlox Drummondi

SCHIZANTHUS. Hardy annuals, growing one and onehalf to two feet high and covered with bright, showy, butterfly-like blossoms. Large flowering. Mixed. Pkt. 10c.

WISETONENSIS. Select mixed. Blooms a long season, producing multitudes of flowers of various pleasing shades. Pkt. 25c.

SENECIO (Tall Double Jacobea). A perennial plant, growing tuft-like on the ground, but bearing stems about two feet high with blooms of brilliant rose purple of good size. Blooms July to October. Elegans. Pkt. 10c.

SILENE, OR CATCHFLY. Hardy annual, growing about one foot high and bearing small, attractive flowers in various colors. Of easy culture and valuable for bedding. Mixed. Pkt. 5c. 
SMILAX. A climbing perennial, with beautiful, bright-green, glossy leares, much esteemed for its long, delicate sprays of foliage. Largely used for decorating. Start seed under glass and transplant six inches apart. It requires strings or wires to climb on when very young. Pkt. 5c; 0z. 50c.

SNAPDRAGON (Antirrhinum): A half hardy perennial, growing from six inches to two feet tall. Flowers are oddly shaped and apparently closed, but by pressing the sides together can be made to open like a dog's mouth. The newer strains are large flowered and contained in a great number of shades and colors. Fine Mixed. Pkt. 5c.

Giant Varieties. Mixed. Pkt. 10c.
SNAPDRAGON.-Continued.

Tom Thumb, or Dwarf Varieties. Six inches tall. Mixed. Pkt. 5c.

Queen of the North. Pure white. Pkt. 10c.

Firefly. Scarlet, white throat. Pkt. 10c.

Niobe. Maroon, white throat. Pkt. 10c.

Picturatum. Blotched varieties. Mixed. Pkt. 10c. Queen Victoria. New white. Pkt. 10c.

SOLANOM (Jerusalem Cherry). Very ornamental plant for house or garden culture; the flowers being followed by small brightly colored fruit or berries, which almost completely cover the plants. Flowering and fruiting the first season from seed. Pkt. 10c.

STATICE (Sea Lavender). A class of everlastings, of various colors, beautiful for winter bouquets. Pkt. 5c.

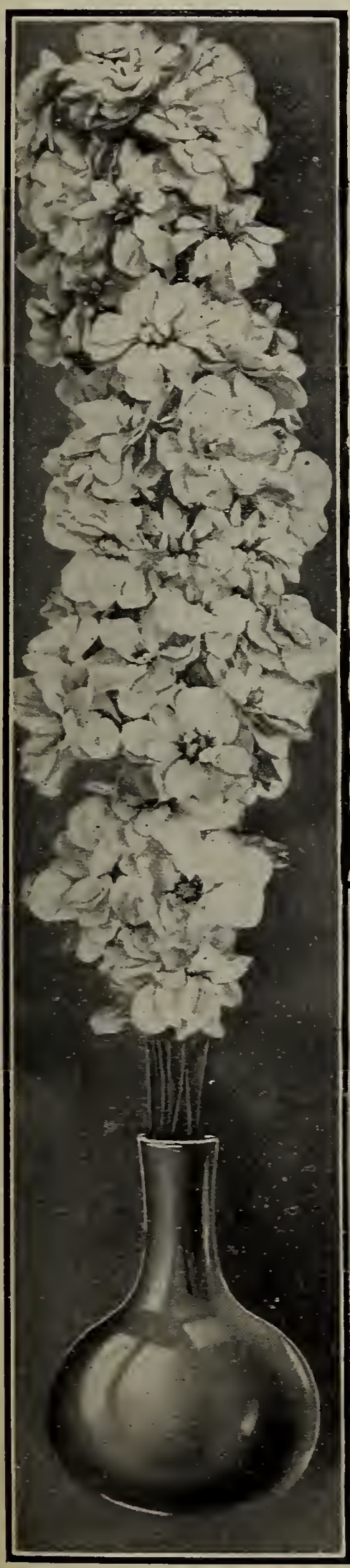

Stocks-Beauty of Nice
Spider Plant. See Cleome Pungens.

STEVIA. A tender perennial, one and one-half feet high and bearing clusters of small white, fragrant blossoms. Suitable for summer or winter blooming, and for pot culture or open air. Serrata. Pkt. 10c.

STOCKS (Ten Weeks' Stocks, or Gilliflowers). Hardy annuals, two feet high, with spikes densely covered with beautiful, double flowerets. The flowers come in many colors and tints and are fragrant and very valuable for bedding and cut flowers. The flowerseed growers have devoted a great deal of attention and care to this flower, and have developed a large number of varieties, and have so improved the double varieties that they will come fully eighty per cent double, where they formerly would not come fifty per cent so. Of easy culture. Sow seed in hotbeds or boxes and transplant.

STOCKS. Cut and Come Again. White. Princess Alice or White Perpetual. Best for cutting. Pkt. 15c.

Emperor, or Perpetual. A biennial double variety, the plants sometimes lasting many years if protected.

White, for florists. Pkt. 10c.

Mixed. Pkt. 10c.

German Double. A very good double strain. White, pkt. 10c. Mixed, pkt. 10c.

Early Large Flowering Winter. Almond Blossom, pkt. 25c.

Beauty of Nice. A beautiful flesh pink with very large spikes. It is of the cut and come again type, bearing continuously throughout the season. Very large handsome spikes. Pkt. 15c; 1/4 oz. $\$ 1.00$.

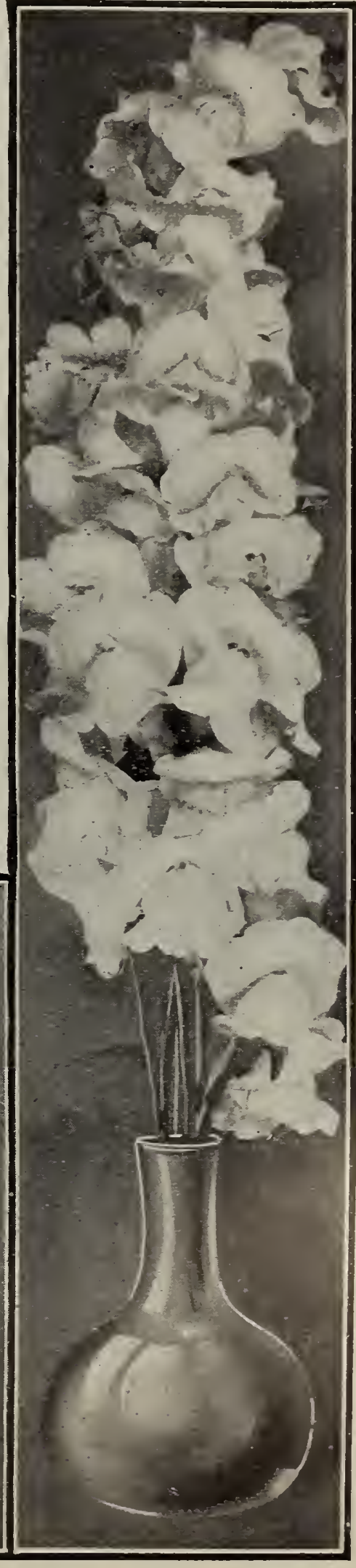

Snapdragon-Oueen Victoria 


\section{ST OCKS-Continued}

Dwarf Large Flowering Ten Weeks.

Mixed. Pkt. 10c.

Blood Red. Pkt. 10c.

Pink. Pkt. 10c.

Canary Yellow. Pkt. 10c.

White. Pkt. 10c.

Lavender. Pkt. 10c.

Purple. Pkt. 10c.

Giant Perfection. Finest mixed. Pkt. 10c.

Winter or Perennial Brompton. Pkt. 10c.

Dresden or Perpetual. Mixed. Pkt. 10c.

STOKESIA, or CORNFLOWER ASTER. A hardy perennial, two feet high, and bearing large blue flowers on long stems. Blooms freely all summer and fall, and is of easy culture, but is hard to start from seed. Cyanea. Pkt. 10c.

STRAW FLOWERS. See Australian Star Flower; Gomphrena; Helichrysum; Xeranthemum; Rhodanthe.

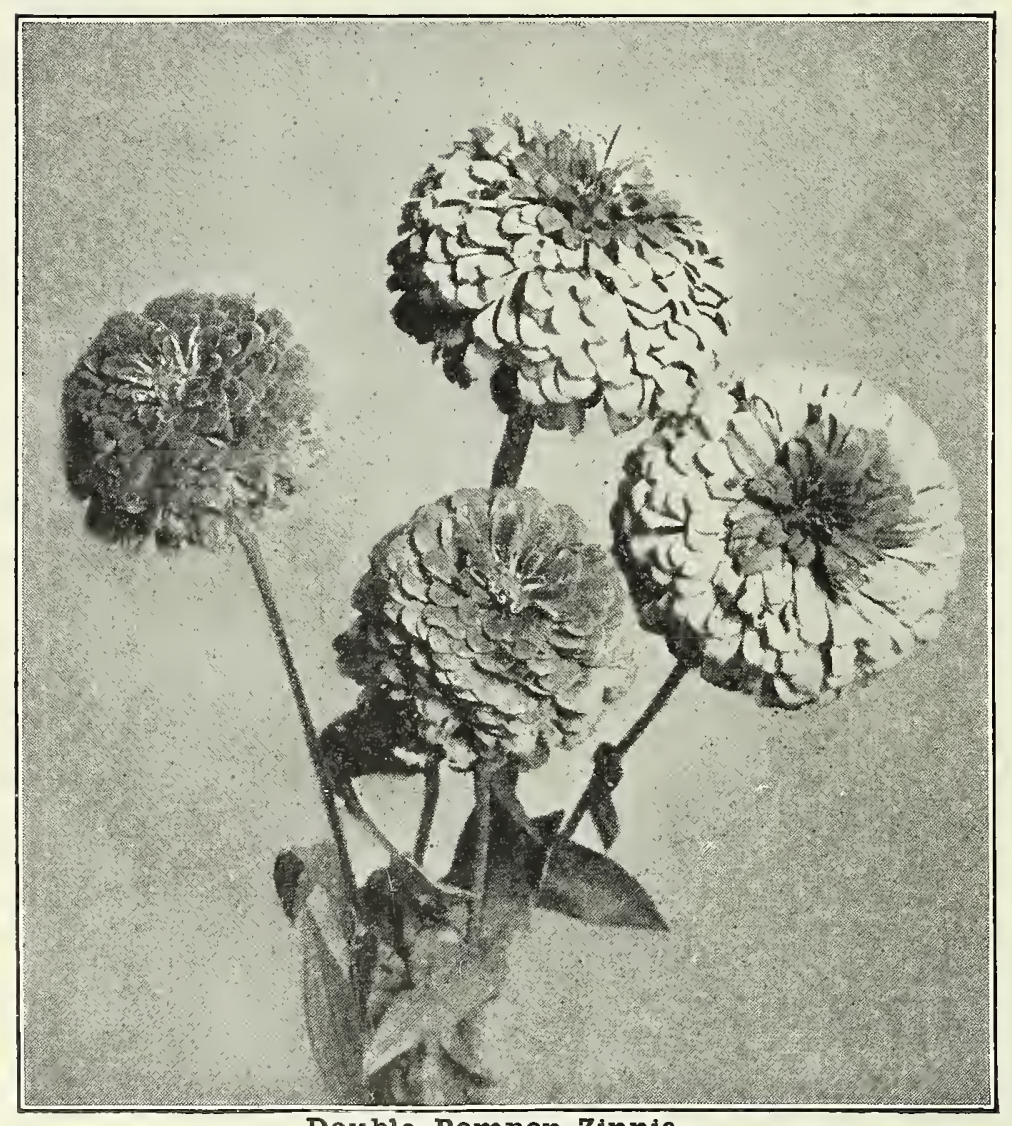

Double Pompon Zinnia

SUNFLOWER (Helianthus). Hardy annuals, growing from three to six feet high. Of the easiest culture and suitable for a stately row or background, or even for bedding.

Chrysanthemum Flowered. Large, densely double, bright golden flowers. The plant branches and affords fine, long stout stems for cutting. This is the best variety in existence. Pkt. 5c; oz. 25c.

Russian. The common, large flowering variety, with great brown centers and an edge of yellow petals. The seed is used for chicken feed. Pkt. 5c.

Stella. The shorter, smooth-leaved, small-flowered variety, growing wild in many States. Pkt. 5c; oz. $25 \mathrm{c}$.

Sweet Alyssum. See Alyssum.

SWEET ROCKET (Hesperis). A hardy perennial, growing two to three feet high. An old-fashioned, fragrant flower, of the easiest culture, and bearing clusters of white and purple blossoms.
Mixed. Pkt. 5c.

Sweet Sultan. See Centaurea Moschata.
SWEET WILLIAM. (Dianthus Barbatus). A hardy perennial, blooming the second year from seed. Grows one to two feet high and bears its flowers in clusters at the end of a stiff stem. The individual flowerets are handsomely. colored and marked. It makes a beautiful bedding plant, and is of easy culture.

Single Varieties. Mixed. More attractive than the double. Pkt. 5c.

Double Varieties. Mixed. Pkt. 5c.

THUNBERGIA, OR BLACK-EYED SUSAN. A hardy annual climber, growing about four feet long, and valuable for low fences or hanging baskets. Prefers a sunny situation. Blossoms are buff, orange, or white, with dark centers. Mixed, pkt. 5c.

TORENIA. A hardy annual, with trumpet-shaped flowers, and growing four to six inches, high. Good for hanging baskets or borders.

Fournieri. Velvety blue, with three dark spots of indigo and a bright yellow throat. Pkt. 5c.

Alba. Pkt. 5c.

White Wings. Dainty, white flowers, tinted with rose at throat. Pkt. 10c.

VALERIAN. Showy plants for mixed borders or shrubberies; bearing large corymbs of bright flowers; bears shade and moisture well. Hardy perennial. Flowers bright red and white. Mixed, pkt. 5c.

VERBENA. A half hardy trailing perennial of easy culture. While it grows readily from division of the root or from cuttings, it does best from seed. It is well known as a bedding or border plant, and the improved large flowered and fragrant strains make it a handsome cut flower for low vases.

Mammoth Auricula Flowered. Various colors, with large white center. Pkt. $10 c ; 1 / 4$ oz. 50c; 0z. $\$ 1.50$.

Mammoth Flowered. Mixed. Pkt. 10c; $1 / 4$ oz. 35c; oz. $\$ 1.25$.

Mayflower. Delicate white, edged with rose. Pkt. $10 \mathrm{c} ; 1 / 4$ oz. 35c; 0z. $\$ 1.25$.

Pink Shades. Mammoth strains of rose and pink shades. Pkt. 10c; $1 / 4$ oz. 35c; 0z. $\$ 1.25$.

Pure White. Mammoth strain. Pkt. 10c; $1 / 4$ oz. 35c; oz. $\$ 1.25$.

Purple and Blue Shades. Mammoth strains. Pkt. $10 \mathrm{c} ; 1 / 4$ oz. 35c; oz. $\$ 1.25$.

Scarlet Defiance. Brilliant scarlet. Pkt. 10c; $1 / 4$ oz. $35 \mathrm{c}$; oz. $\$ 1.25$.

Striped Varieties. Mixed. Pkt. 10c.

Morse's Extra Selected Mammoth Strain. Mixed. Pkt. 15c.

VINCA, OR PERIWINKLE. A tender perennial, with ornamental foliage, useful for bedding in summer and for the greenhouse in winter. Blooms freely the first year from seed.

Mixed. Rose, crimson, white, etc. Pkt. 10c.

VIOLAS. A hardy perennial, blooming freely throughout the summer and autumn. Of easy culture, and seed may be sown out of doors, where the plants are to remain.

Mixed. All varieties. Pkt. 10c.

Cornuta, Purple Queen. Pkt. 10c.

White. Pkt. 10c.

Yellow. Pkt. 10c.

VIOLET, OR VIOLA ODORATA. Although these flowers do best propagated from the cuttings, they grow readily from seed, and propagated from the cuttings, they grow readily from seed, and
produce a very fragrant blossom. We offer the large flowerproduce a very variety. Single, Sweet-scented. Pkt. 10c.

VIRGINIA STOCKS. A hardy annual, growing about nine inches high and blooming profusely. Of easy culture, and can be had in continuous bloom by sowing the seed at frequent intervals during spring and summer. Red and White Mixed. Pkt. sc. 


\section{SAN FRANCISCO CALIFORNIA U.S.A.}

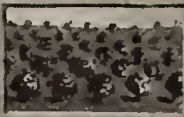

VISCARIA (Rose of Heaven). Pretty, profuse flowering plants; adapted for beds, edgings, or clumps, growing readily in any garden soil: flowers pink and white; annual. Pkt. 10c.

WALLFLOWER. Half hardy perennial blooming the first year from seed. Grows one to two feet high and bears long stems of fragrant flowers. It is best to renew the plants every two or three years by resowing the seed. An oldfashioned flower, which is always popular. Sow early in the year in boxes and transplant.

Fine German. Double. Tall. Mixed. Pkt. 10c.

Fine Single. Mixed. Pkt. 5c. Tom Thumb Golden. Small, compact plant, single blossoms. Pkt. 10c.

Dwarf German Double. Pkt. 10c.

WHITLAVIA. An easily grown, hardy annual, bearing small violet-blue, cup-shaped blossoms. Plants one foot high. Sow seed in open ground in spring and thin the young plants. Pkt. 10c.

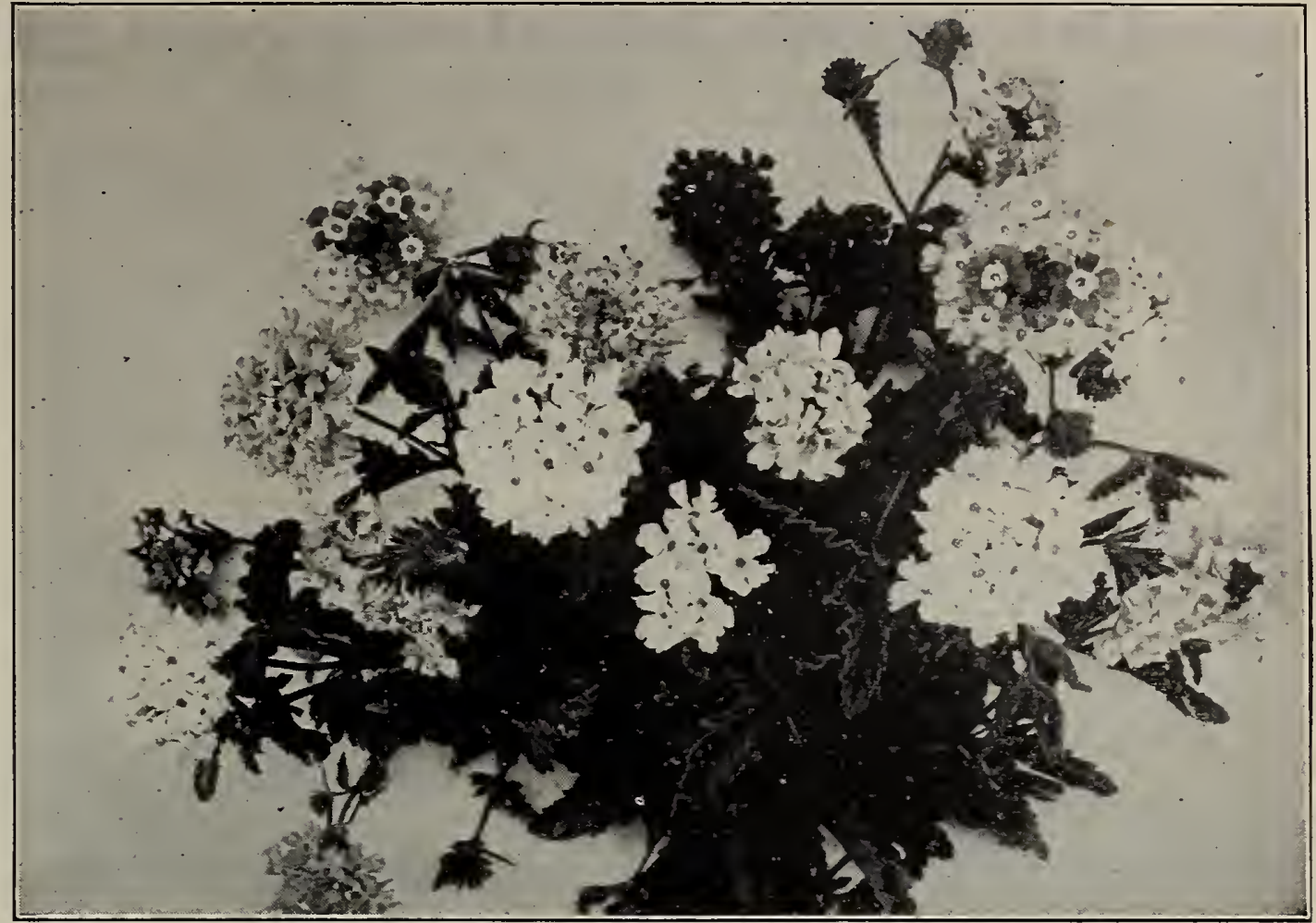

Pkt. 10c.

XERANTHEMUM (Everlasting Flower). A hardy annual, about one foot high, and bearing white, purple, or yellow blossoms. The leaves are hairy or covered with a silvery down. A very

ZINNIA. A half hardy annual, growing from one to two feet high. Blossoms are very double, and while the stems are stiff, they make an excellent bouquet flower. Probably no flower has such an assortment of shades, tints, and colors; no bedding plant is more effective for a brilliant show. Sow in boxes early and transplant. Mammoth Double.

Orange. Pkt: 10c. Scarlet. Pkt. 10c.

Yellow. Pkt. 10c. Deep Red. Pkt. 10c.

Mammoth Flowered Verbena

ZINNIA-Continued

Magenta. Pkt. 10c. White. Pkt. 10c.

Dark Crimson. Pkt. 10c.

Double Lilliput. A dwarf plant, one foot high, bearing rather small, very double flowers. Mixed. Pkt. 5c.

Grandiflora Robusta. The largest and finest variety in existence. The blossoms are globe-shaped, very large, and in numerous colors. Mixed. Pkt. 10c.

Pompon Mixed. A fine mixture of globe-shaped flowers Pkt. 5c.

Elegans. Tall, double. Mixed. Pkt. 5c.

Striped, or Zebra. Mixed. Pkt. 5c.

\section{SUMMER FLOWERING BULBS}

GLADIOLUS These fine summer and fall flowering bulbs of color and produce blooms which embrace every shade culture and arem the first beauty. They are of the easiest warm and dry make plantings every two weeks during the spring if succession of bloom is wanted. Take up bulbs in the fall.

America. A beautiful soft pink almost a tinted white in color: spikes long and with flowers large and all facing one way. The handsomest gladiolus we know. Each 15c; doz. \$1.50.

Princeps. A rich crimson scarlet variety having blotches or white on the throat and lower petals. The flower is fine and large, 5 to 6 inches across, and wide open like an am
often 18 to 20 flowers. Each 25 c; doz. $\$ 2.50$.

Groff's Hybrid Seedlings. Mixed. First size bulbs. Doz. 50c. $100 \$ 3.00$.

Lemoine's Extra Fine Mixture. One of the very best strains, in splendid shades and colors. Doz. 50c; $100 \$ 3.50$.

Fine Mixed. All colors. Doz. 40c; $100 \$ 2.50$.

Extra White and very light shades. Doz. 50c; $100 \$ 3.50$.

Fine Pink and Rose shades. Doz. 50c; $\$ 100 \$ 3.50$.

Brilliant Scarlet and Red Shades. Doz. 50c; $100 \$ 3.50$.
Extra Orange and Yellow shades. Doz. $\$ 1.00 ; 100 \$ 7.00$. Striped and Variegated. Doz. 50c; $100 \$ 3.50$.

GLADIOLUS. THE CHILDSI TYPE. Mixed. This type has mammoth petals, T"

TUBEROSES. For early flowers they can be started in February or March in the greenhouse or hotbed; and for a succession they can be planted at intervals as late as August. For fiowering in the open border plant about the middle of May.

Excelsior Double Pearl. Extra large bulbs. 3 for 15c; Doz. $50 \mathrm{c} ; 100 \$ 3.00$. If wanted by mail, add $10 \mathrm{c}$ per dozen extra.

THE YELLOW CALLA LILY (Calla Elliottiana) is the only true vellow flowered calla in existence and on account of its marvelous beauty has created a sensation wherever exhibited. It is a summer flowering variety, with the same habit of growth as the well-known common White Calla, with flowers of the same size
and shape, but of a rich, clear, golden vellow. The foliage is dark green, with a number of white spots, which greatly add to the beauty of the plant-so much so that when not in flower the plant at once arrests the attention and is ever an object of enthusiastic admiration. Fine large roots, 35c each; Doz. $\$ 3.50$.

\section{THREE SPLENDID JAPANESE LILIES}

The bulbs are ready for delivery in January and February, but not later

AURATUM. The grandest of all hardy Lilies, with large, graceful flowers of a delicate ivory white color, thickly studded with chocolate crimson spots, and a bright golden band through the center of each petal. Each 15c-25c; doz. \$1.50-\$2.50, according to size of bulb.

SPECIOSUM ALBUM. Beautiful pure white flowers of large size.
One of the handsomest and easiest grown Lilies we have. Each $20 \mathrm{c}$; doz. $\$ 2.00$.

SPECIOSUM RUBRUM. White, shaded rose and spotted deep red. One of the most beautiful. Is hardy and can be grown $\$ 1.50$. 


\section{C.C.MORSE \& CO. FLOWER SEEDS R.}

\section{THE BEST SWEET PEAS IN THE WORLD}

We are unquestionably the largest growers of Sweet Pea seed in the world, and our immense seed farms about Gilroy in the South Santa Clara Valley are now world renowned.

This popular flower, which is so easily grown anywhere is especially adapted to California, and most of the seed for the world's supply is

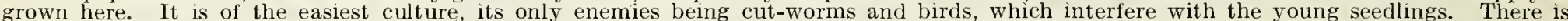

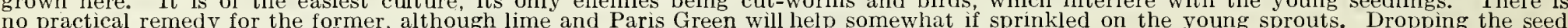
in red lead before planting will sometimes protect them from being eaten by the birds.

The seed should be sown in the fall or before February 1st, if possible, in a row, dropping two or three seeds every four inches and covering one or two inches deep. While the growth is very slow in the winter it is very rapid in the spring, and the plants are in full bloom in May, before the dry, hot summer sets in. The seed, however, can be planted any time until April 1, especially near the sea coast where the weather is cool and where fog is prevalent.

Sweet Peas require an abundance of water and an open location. The water, if possible, should be applied at the roots, and the vines

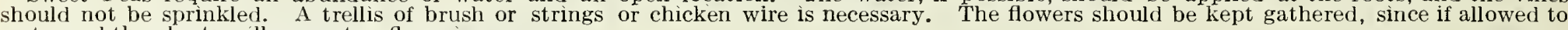
go to seed the plants will soon stop flowering.

The Sweet Pea is a climbing annual and hardy. The early flowering varieties are generally used for forcing under glass, but they are very desirable also in the garden, and will bloom in February if seed is sown in November.

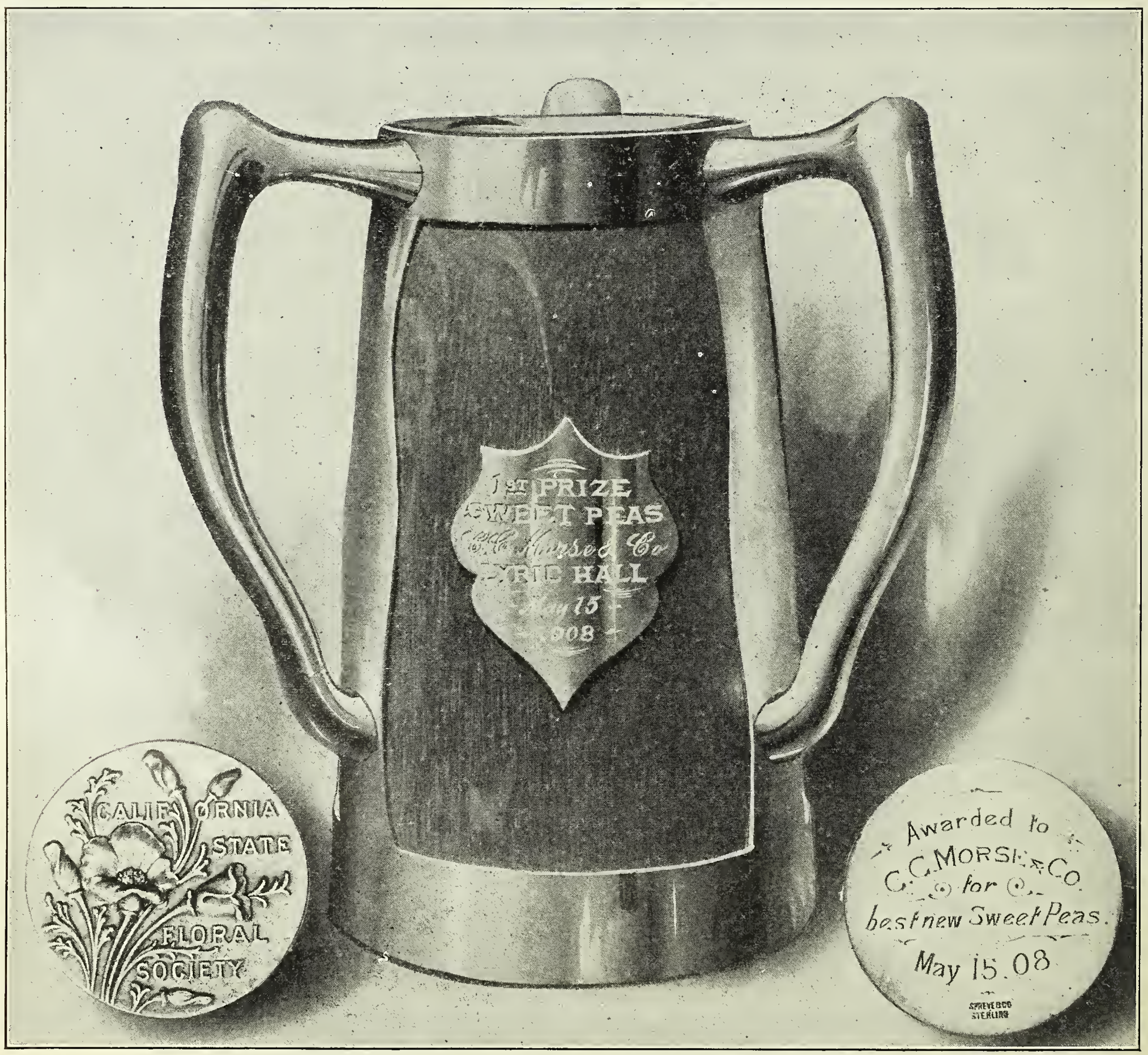

Sweet Pea Medals and Loving Cup, awarded to us in May, 1908

These beautiful testimonials speak for themselves. They were awarded to us on account of our elaborate display of Sweet Pea blossoms in vases at the great Flower Show held by the California State Floral Society and the Pacific Coast Horticulture Association at Lyric Hall in May, 1908. Our display consisted of one hundred vases of Sweet Peas, about twenty-five of which were new and unnamed novelties of the Countess Spencer Type. 


\section{NOVELTIES IN SWEET PEAS}

We offer for the first time Sweet Peas of the Countess Spencer type in many new colors. We have originated these on our own farms and unhesitatingly recommend them as the best Sweet Peas in existence. They were awarded the silver cup shown on the preceding page in San Francisco this last spring at the Flower Show. The stems are longer and have four flowers each, which are of a much larger size than are the ordinary sorts of Sweet Peas. Every person should plant some of these Novelties, so as to have some of the largest and best Sweet Peas there are in his garden.

\section{BEATRICE SPENCER}

As the name implies, this variety resembles in color and markings the old favorite Princess Beatrice. It is fully as large as Countess Spencer, with wavy standard and large wings. The ground is white, tinted with soft pink and buff on the standard, while each wing has a blotch of brighter pink near the base. One of the most delicate and dainty varieties we have. Per pkt. of 10 seeds $15 \mathrm{c}$; per pkt. of 25 seeds $25 \mathrm{c}$.

\section{MRS. SANKEY SPENCER}

Any one familiar with the old favorite, Mrs. Sankey, will at once recognize this as a "Black Seeded White" Spencer. It is fully as large as White Spencer and of equally perfect form. Being black seeded it is easy to germinate. Like all other black seeded White Sreet Peas, there is a faint tint of pink in bud, but the fully expanded flower is clear, pure white. Per pkt. of 10 seeds $15 \mathrm{c}$; per pkt. of 25 seeds $25 \mathrm{c}$.

\section{TENNANT SPENCER}

A beautiful purple mauve self-color, clear and distinct. It is a splendid accessory to any collection, being very harmonious with other light shades. It is large, of the true Spencer form, and comes daintily poised on long, stout stems. Per pkt. of 10 seeds 15c; 25 seeds $25 \mathrm{c}$.

\section{LOVELY SPENCER}

Like its predecessor, "Lovely," this selection is all its name describes it. The color is bright pink at the throat, or rather the base of both standard and wings, and shades to soft blush and almost white at the edges. Of the true Spencer type, large and wary. Per pkt. of 10 seeds $15 \mathrm{c}$; per pkt. of 25 seeds 25 c.

\section{CAPTAIN OF THE BLUES SPENCER}

The name we have adopted fully describes this variety. It is even larger than Countess Spencer and of fully as perfect form; standard, purple; wings, bright blue. A bright, striking variety, and decidedly new in Spencers. Per pkt. of 10 seeds $15 \mathrm{c}$; per pkt. of 25 seeds 25 c.

\section{HENRY'S SPENCER NOVELTIES MIXED}

We do not believe it possible for any other seed establishment in the world to offer a Sweet Pea mixture so unique as this one. In it are a great many absolutely new selections which have not yet been named and introduced. Of course, these new selections will probably follow along next year after their formal christening but by planting some of these this season it will be possible to see and judge the merits of some of our best next season's novelties. The seed is in very limited supply and will be sold only in sealed packets, the same as our other standard novelties. Pkt. of 10 seeds, 15c; 25 seeds, $25 \mathrm{c}$.

\section{MRS. ROUTZAHN SPENCER}

Our work-shop name for this charming selection was "Apricot and Straw" but we have dropped this pseudonym to avoid a complication of names, since one of our best friends in the seed trade was introducing the same variety from another source, we determined to adopt this name. It is a beautiful blending of soft straw color, tinted with blush pink and shading to apricot and rose at the edges, with quite a distinct rose margin. It is of immense size, wavy edges and its long, stout stems bear uniformly four blossoms. Per pkt. of 10 seeds $15 \mathrm{c}$; per pkt. of 25 seeds $25 \mathrm{c}$.

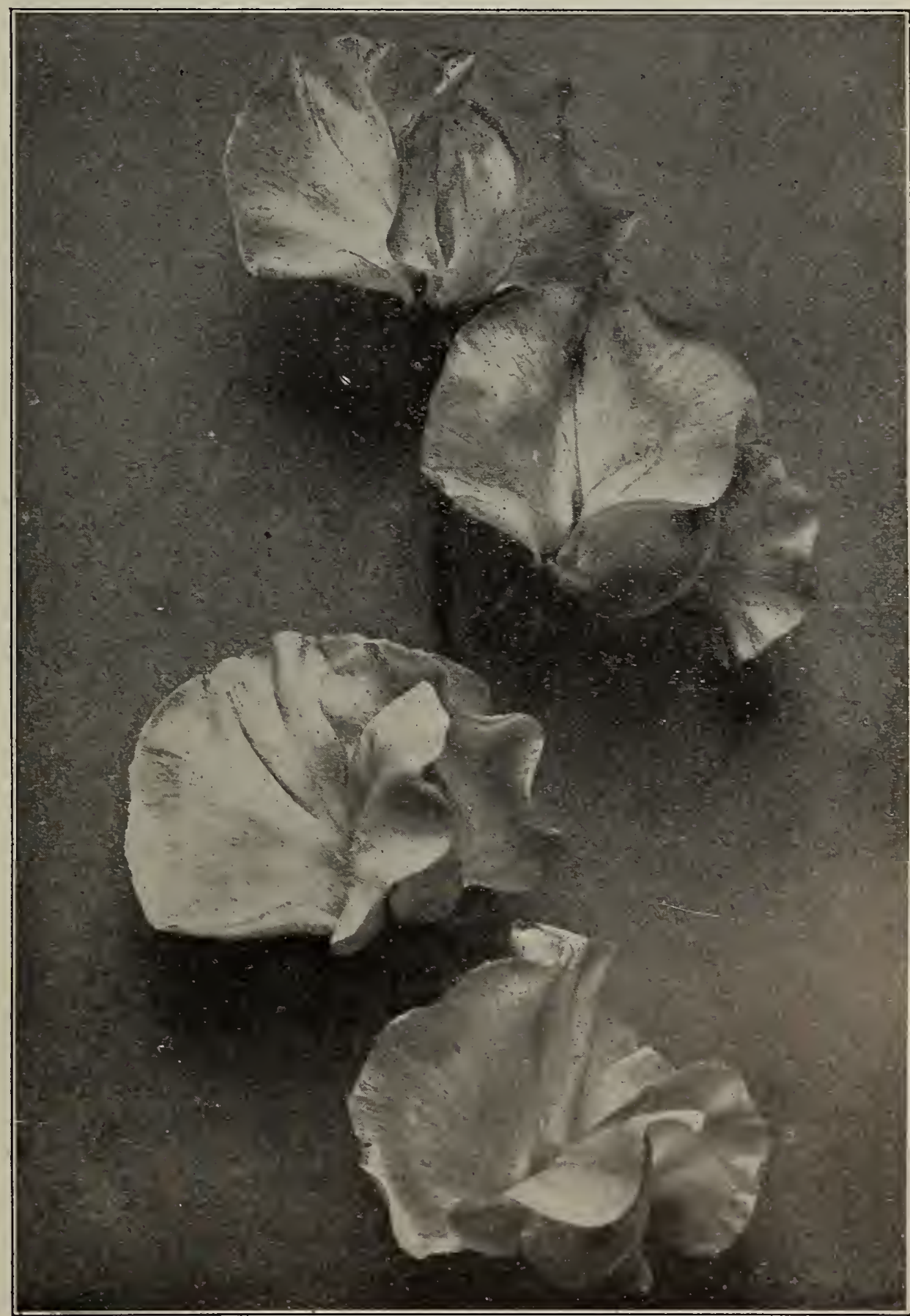




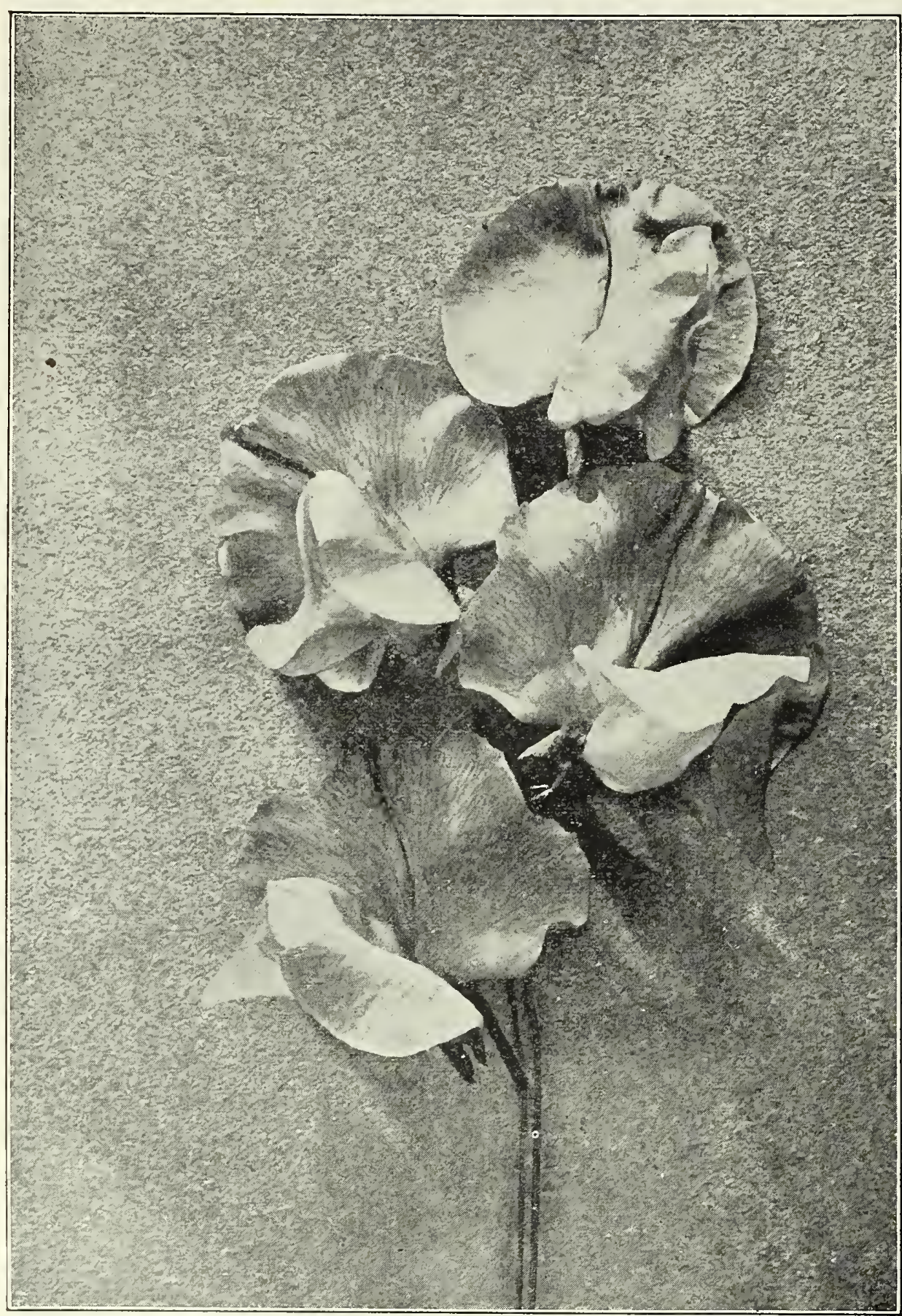

Flora Norton Spencer (A little under natural size)

\section{FLORA NORTON SPENCER}

This is a bright blue with a little tint of purple, perhaps a little more than the original Flora Norton. It is much larger, however, and has the wavy standard and wings of the true Spencers. The standard is rather heavier and more sturdy than usual in Spencer and it stands out bolder. It is a grand flower and fitting companion to the others in this set of novelties. Per pkt. of 10 seeds $15 \mathrm{c}$; per pkt. of 25 seeds $25 \mathrm{c}$.

\section{RAMONA SPENCER}

\section{See illustration on page 78}

Like our well-known Ramona, this variety is clear white, with soft delicate lines and flakes of blush pink. It is of the very finest form and immense size. Both standard and wings are wavy and fluffy. One seldom finds a stem with less than four blossoms, all beautifully poised. Delicate and beautiful. Per pkt. of 10 seeds 15c; pkt. of 25 seeds 25 c.

\section{SPECIAL COLLECTIONS OF SWEET PEAS}

Our "INCOMPARABLE" 25C COLLECTION of Sweet Peas. This package contains one packet each of the following 7 varieties:

King Edward VII Miss Willmott

Dorothy Eckford $\quad$ Hon. Mrs. E. Kenyon

Prima Donna

Lady Grisel Hamilton

Our "EXCELLENT" 50c COLLECTION of Sweet Peas. This package contains one packet each of the following 12 varieties:

Countess Spencer Helen Pierce

Queen Alexandra Hon. Mrs. E. Kenyon

Dorothy Eckford

King Edward VII $\quad$ Earliest of All

Our "SPLENDID" $\$ 1.00$ COLLECTION of the best Sweet Peas. This package contains one packet each of the following 26 varieties pare newest and best-and 1 packet of Morse's Superb Mixture:

King Edward VII

Dorothy Eckford

Countess Spencer

Lady Grisel Ha milton

.Miss Willmott

Hon. Mrs. E. Kenyon

Phenomenal

Helen Pierce

Aurora

Queen Alexandra

Helen Lewis

Shasta

Romolo Piazanni

Janet Scott

Othello

Na.j Blue
Zottie Eckford
Earliest of All
Stella Morse
Mrs. George Higgin-
son, Jr.
Morse's Superb Mix-
ture
Lovely
Golden Rose
Apple Blossom
Lord Roseberry
FI or e c e M o r s e
Spencer
White Spencer

OUY "EXTRAORDINARY SPENCER COLLECTION," Price \$3.00. This collection is composed of one packet each of the following nineteen new varieties. which includes all our novelties of Giant Spencer Type Sweet Peas, the combined value of which is $\$ 4.10$ :

Aurora Spencer

Asta Ohn

Beatrice Spencer Capt. of the Blues Spencer

Countess Spencer

Flora Norton Spencer Florence Morse spencer

Geor Herbert

Geo. Herber

Helen Lewis

Mrs. Routzahn spencer
Queen Victoria spencer

Othello Spencer

Ramona Spencer

Mrs. Sankey Spencer

Tennant spencer

White Spencer

King Edward Spencer

Henry's Spencer Nov elties $M i x e d-$ mixture of unnamed Spencer Types not yet introduced.

\section{KING EDWARD SPENCER}

As the name implies, this is a Spencer form of the bright crimson scarlet of the famous Sweet Pea, King Edward VII. Until the advent of this discovery, King Edward VII was indeed the king of all red Sweet Peas. The color is the gorgeous and brilliant red, of our old fashioned Firefly and is the most popular of all shades of red for florist's use. The seed we offer this year is not our own growing but we have secured it direct from the introducer and can recommend it as truly the grandest red Sweet Pea in existence today. Pkt. of 25 seeds, 25c; pkt. of 10 seeds, $15 \mathrm{c}$.

\section{QUEEN VICTORIA SPENCER}

A superb black seeded Primrose Sweet Pea. Soft, light and delicate and of immense size. It seems more yellow than the other Primrose varieties and being black seeded is far more hardy. It is a fitting addition to the list and should be planted by all who have Sweet Peas. Pkt. of 25 seeds, 25c; pkt. of 10 seeds, 15c. 


\section{PREFERRED LIST OF SWEET PEAS}

(Price per packet of each of the following is 5c, except where noted otherwise)

WHITE.

\section{A GRAND NEW WHITE SWEET PEA WHITE SPENCER}

Fine Re-selected True Strain. Although this Sweet Pea did not originate with us, it has our unqualified endorsement.

It is unquestionably the finest White Sweet Pea in existence.

It is beautiful and graceful with large fluted and wavy petals, long stout stems, bearing uniformly four well-poised dignified blossoms of delightful fragrance. Per pkt. 25c; oz. $75 \mathrm{c}$.

\section{BURPEE'S EARLIEST WHITE}

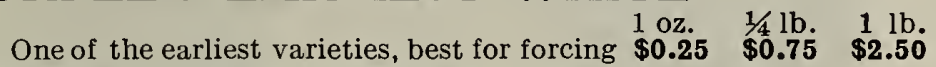

DOROTHY ECKFORD. The new white of

the largest and best type $\ldots \ldots \ldots \ldots \ldots$..........

Emily Henderson. A very hardy and free

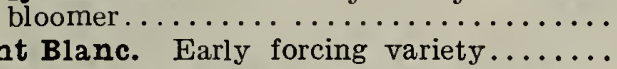

$.10 \quad .25 \quad .75$

$.10 \quad .20 \quad .50$

$\begin{array}{lllll}\text { Mont Blanc. Early forcing variety........ } & .10 & .25 & .75\end{array}$ Mrs. Sankey Spencer. Novelty, see page 75
Pkts.25c. and 15c.

Nora Unwin. New large wavy-edged white Pkt. 10c .......................... Sadie Burpee. Black seeded, clear, white opening $\mathbf{A}$. Our new large white ..............

White Wonder. A large double variety....

\begin{tabular}{|rrr}
.25 & .75 & 2.50 \\
\hline 10 & .20 & .60 \\
.10 & .25 & .60 \\
.10 & .25 & .60
\end{tabular}

\section{PALE YELLOW, OR PRIMROSE}

PRIMROSE SPENCER

Fine Selected True Strain. Almost as large as the White Spencer and a fitting companion to it.

It has the size and form of the improved Spencer typevery large petals which are wavy and fluted at the edges, giving the blossom a very graceful and pleasing appearance.

The color is a clear distinct primrose color without the least trace of pink. This shade is very much desired and is the nearest approach to clear yellow we have. This variety is the best Primrose Sweet Pea in existence to date. Per pkt. 25c; oz. 75c.

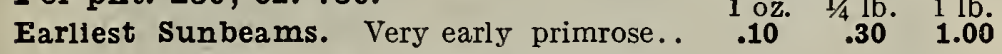
HON. MRS. E. KENYON

A fine, large, clear primrose...........

Mrs. Collier. A large, very light variety $\ldots$ Queen Victoria. Opens with a faint tint of pink, turns clear primrose .............

VERY LIGHT PINK, ALMOST WHITE

MODESTY. A very soft and delicate pale pink NYMPHAEA. Opens white but turns pink. Sensation. Opening light pink and buff, with white wings .........................

\section{VERY LIGHT PINK AND PRIMROSE}

Agnes Eckford. Buff and light pink Pkt. 10c. GOLDEN ROSE. Clear primrose, lightly striped with light soft pink.................

Marchioness of Cholmondeley. Buff and light pink, hooded and large ........... STELLA MORSE. Buff suffused with tint

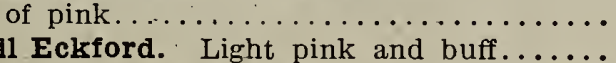

Sybll Eckford. Light pink and buff.......
Mrs. Routzahn Spencer. Novelty-see page 75 LIGHT PINK SHADES

Agnes Johnson. Light pink, buff and cream. COUNTESS OF LATHOM. Creamy pink, self color

GLADYS UNWIN. Large and wavy; a light delicate pink, a little deeper at the edges.

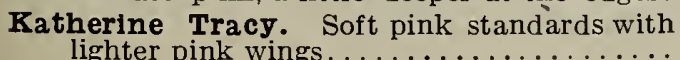

$.10 \quad .20 \quad .60$

$\begin{array}{lll}.25 & .75 & 2.50\end{array}$

$.10 \quad .20 \quad .60$

$\begin{array}{lll}.10 \quad .20 & .60\end{array}$

$.10 \quad .20 \quad .60$

$.10 \quad .20 \quad .60$

$.25 \quad .75$

$.10 \quad .20$

2.50

.10 .20

$.10 \quad .20$

$.10 \quad .20$

.10 .20

$.10 \quad .20$

.60

$10 \quad 30 \quad 1.00$

.10

LIGHT PINK SHADES-Continued

\section{FLORENCE MORSE SPENCER}

Our last season's sensational novelty, blush with pink edge..Pkt. 10c

1 oz. $1 / 4 \mathrm{lb} .1 \mathrm{lb}$.

Mrs. A. Watkins. Pink shading, light pink, wavy.................. Pkt. 10c.

PRIMA DONNA The most popular

$\begin{array}{lll}.25 & .75 & 2.50\end{array}$
of all the light pink varieties. soft pink self color, with shell-shaped standard of good size, strong and vigorous

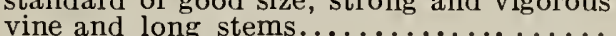
QUEEN OF SPAIN. Buff pink, or creamy
rose.....................

Venus. Opens a beautiful buff pink and turns a little deeper at full maturity DEEPER PINK SHADES

Beatrice Spencer. Novelty-see page 75

COUNTESS SPENCER The flowered type with wavy edges, bright pink JANET SCOTT. Clear pink at the base and shading to buff at the edges............. Paradise or Enchantress. A little deeper pink than Countess Spencer, otherwise same ROSE AND VERY LIGHT PINK SHADES

Apple Blossom. Crimson-pink, sh a d ing lighter; wings white, tinted pink........ EARLIEST OF ALL, or EXTRA EARLY
BLANCHE FERRY. The earliest variety grown. Comes into bloom in eight or ten weeks after sowing the seed. Bright rose standard with white wings.............

ROSE AND PINK SHADES

JEANNIE GORDON. Bright rose standard, showing veins of deeper rose; wings, primrose tinted with light rose..............

Royal Rose. Crimson-pink standard, lighter
at edges; wings, pink................. LIGHT PINK SHADED

DAINTY. Clear white, shaded lightly with blush pink and having distinct edgings of bright but soft pink................

LOVELY Both standard and wings at the base. which shades a lighter pink at the base, which shades a lighter pink

Hon. F. Bouverie. Deep pink shading, light pink, buff ground...

ORANGE PINK SHADES

AURORA. White, with stripes and flakes of orange pink ............ Brilliant pink

BOLTON'S PINK Brilliant pink salmon

Evelyn Byatt. A crimson-orange self colored Gorgeous. Orange and scarlet, brilliant..... HELEN LEWIS L Large wavy orange Spencer type ...............

Henry Eckford. Almost true orange self colored

MISS WILLMOTT $\underset{\text { pink } \text { bright } \text { showing }}{\text { and }}$ veins of a deeper tint $\ldots . . . \ldots \ldots \ldots . . . . .$. Aurora Spencer. Novelty-see 2nd page of cover.

BRIGHT RED SHADES

America. White, with stripes and flakes of brilliant red. The brightest striped variety Coccinea. Cherry or pure cerise. .

Scarlet Gem. Almost pure scarlet .......... KING EDWARD VII (Improved The new red which is taking precedence over all other red shades.

.10 .20

.60

.10

.25

.75

$.10 \quad .20$

.60

$.10 \quad .20$

.60

.10

.20

.60

$.10 \quad .20$

.60

$.10 \quad .20$

.60

$.10 \quad .20$

.60

.15

.35

1.00

$\begin{array}{lll}10 & .20 & .60\end{array}$

.25

.75

2.00

$.15 \quad .45$

1.50

$.10 \quad .25$

.75

QUEEN ALEXANDRA $\underset{\text { proved }}{(\text { I m - }}$ Scarlet Gem). Almost a true scarlet, new SALOPIAN. A fine, deep rich red variety of shell shaped form....
60

.60 


\section{ROSE CRIMSON SHADES}

Earl Cromer. Claret magenta, a new shade, 1 oz. $1 / 4 \mathbf{l b} .1 \mathbf{l b}$.

$\begin{array}{llll}\text { Pkt. 10c } & .15 & .45 & 1.50\end{array}$

$\begin{array}{lllll}\text { E. J. Castle. Carmine rose, Unwin ty pe, wavy } & \mathbf{. 1 5} & \mathbf{4 5} & \mathbf{1 . 5 0}\end{array}$

GEO. HERBFRT Rose crimson and type ............... magenta JOHN INGMAN. Large wavy type of rose
crimson ................. 10c LORD ROSEBERY. Bright rose suffused with magenta and showing veins of rose... Mrs. Jos. Chamberlain. White with rose stripes.

PRINCE OF WALES. A clear rose crimson self color, large and shell-shaped ......... Phyllis Unwin, rose crimson, wavy. . Pkt. 10c

IAVENDER, MAUVE, AND PURPLE SHADES.

Admiration. Purplish, mauve, or pinkish lavender...

Dorothy Tennant. Rosy purple, self colored.

Emily Eckford. Rose purple, turning to clear blue.

Frank Dolby. Fine lavender of Unwin type

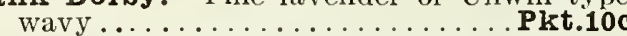

MRS. WALTER WRIGHT. Light rosy purple, turning blue when fully matured.

Romolo Piazanni. Rosy purple, turning blue with age. A fine, large variety.

Tennant Spencer. Novelty-see page 75 .

\section{LAVENDER SHADES}

Countess of Radnor or Celestial. Soft lavnder tinted with mauve.

FLORA NORTON. A new variety, bright sky blue..

Asta Ohn. Novelty-see page 2 of cover.

HELEN PIERCE Our own introAwarded first class certificate by National Sweet Pea Society of England. Bright

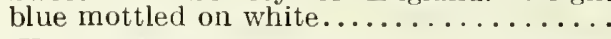

LADY GRISEL HAMILTON. Soft lavender.

MRS. GEO. HIGGINSON, JR. A clear azure

IAVENDER AND MAUVE SHADED, PICOTEE OR EDGED LOTIEE ECKFORD W White, with lilac, with a deeper border at the edges.

Mald of Honor. White with blue edge......

PHENOMENAL. Blue and lavender shaded on white; called the orchid flowering type Pkt. 10c

$\begin{array}{lll}.10 & .20 & .60 \\ .10 & .20 & .60 \\ .10 & .20 & .60 \\ .25 & .75 & 2.00 \\ .10 & .20 & .60 \\ .10 & .20 & .60\end{array}$

$\begin{array}{lll}.10 & .20 & .60 \\ .10 & .20 & .60\end{array}$

$\begin{array}{lll}.20 & .60 & 2.00\end{array}$

$.10 \quad .20 \quad .60$

$10 \quad .25 \quad .75$

$.10 \quad .20 \quad .60$ $.10 \quad .20 \quad .60$

$.20 \quad .60 \quad 2.00$

BLUE AND PURPLE SHADES

Captain of the Blues Spencer. Noveltysee page 75

Captain of the Blues. Purple and blue hoodCOUNTESS OF CADÖGÄ Purple standar with clear blue wings.................

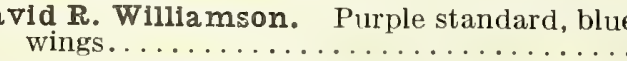
DUKE OF WESTMINSTER. Almost a clear purple................................. Pure white, striped and flaked with maroon and violet...

\section{DEEP MAROON SHADES}

Black Michael. Deep wine color or light

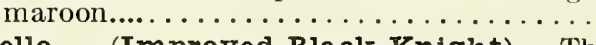

Othello. (Improved Black Knight). The best of the dark varieties, being very large and of the finest type. It is a deep maroon

and particularly of rich velvet effect.....
thello Spencer. Novelty-see page 2 of cover.

DARK IIAROON AND VIOLET SHADES.

Horace J. Wright. A violet and maroon.... "navy blue", Blue. A deep Navy Blue. Indigo and violet, wings violet

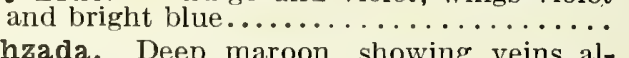
most black, wings dark violet.

$\begin{array}{rrr}.10 & .20 & .60 \\ .10 & .20 & .60 \\ .15 & .35 & .75 \\ .10 & .20 & .60 \\ .10 & .20 & .60\end{array}$

A GRAND SWEET PEA MIXTURE

MORSE'S SUPERB MIXTURE A mixture of

colors, all of the new giant Spencer type of Sweet Peas, with immense wavy petals. Pkt. 10c; oz. 50c

\section{MIXTURES}

Best Large Flowering Mixture. This is the $1 \mathbf{~ o z} .1 / 4 \mathbf{l b}, 1 \mathbf{l b}$. best mixture that can be made from existing varieties. The colors are well proportioned, and the amount of each is determined by a well-studied and carefully arranged formula, which has been tried and corrected for many years. All the newer and best for many years. All the newer and best

striped Varieties Mixed. A beautiful mixture made up exclusively of striped, mot-

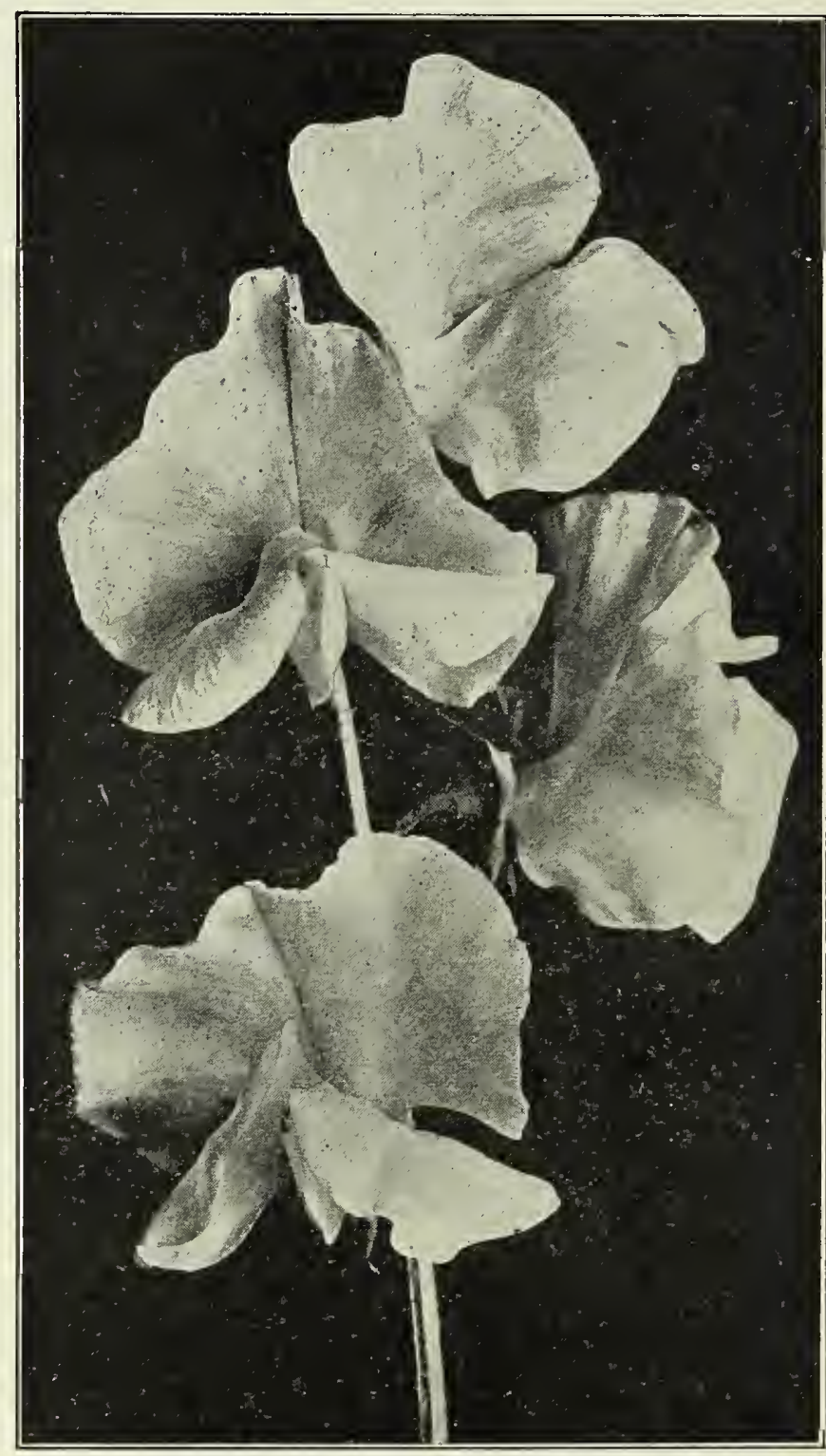

Ramona spencer, $3 / 4$ Natural Size

\section{CUPID SWEET PEAS}

These are low-growing or dwarf sweet peas, about one foot ligh and spreading to about two feet in diameter. The foliage is dark green and the stems are short, usually from three to six inches long. The blossoms, however, are larger than those of the tall varieties.

They are recommended for a border, especially along a drive or walk, and while the early buds drop off, the whole plant finally comes into blom niche early buds drop off, the whole plant finally comes Cupids exist in all the colors and shades found in the tall varieties, we have listed only the best ones and those that are freest flowering. We have listed only the best ones and those that are freest
The descriptions are the same as those of the tall varieties.

$10 z .1 / 41 b .11 b$

White. Pure White.

Pink. Color of Earliest of all

of all ....... Pkt. 5c $\$$.15

Prima Donna. Pink. Lavender.....Pkt. 5c $\mathbf{. 1 5}$

Mixture of all varieties, including those listed and many more besides.........Pkt.5c

$\begin{array}{rrr}\text { Z. } & 1 / 4 \text { lb. } & 11 \mathrm{lb} \\ 15 & \$ 0.40 & \$ 1.00 \\ 15 & .40 & 1.00 \\ 15 & .40 & 1.00 \\ 15 & .40 & 1.00 \\ 10 & .25 & .75\end{array}$




\section{SAN FRANCISCO CALIFORNIA U.S.A.}

\section{TREE AND PLANT DEPARTMENT}

"See to it that these trees are preserved. You can never replace them. Preserve and keep what nature has done." -PRESIDENT ROOSEVELT, at Big Trees, Felton, California, May, 1903.

SACRAMENTO, April 19.-An appeal from President Roosevelt to the school children of the state for the observanee of Arbor Day has been transmitted to State Superintendent of Publie Schools Hyatt. The President says:

"We ought to eelebrate this day thoughtfully, for within our life the nation's need of trees will become assured. In your full manhood and womanhood you will want what nature so bountifully supplies, and man so thoughtlessly destroys, and because of that you will reproach us, not for what we have used, but for what we have wasted. A country without trees is almost as hopeless as a people without children. The value of forestry therefore should be taught in the public schools."

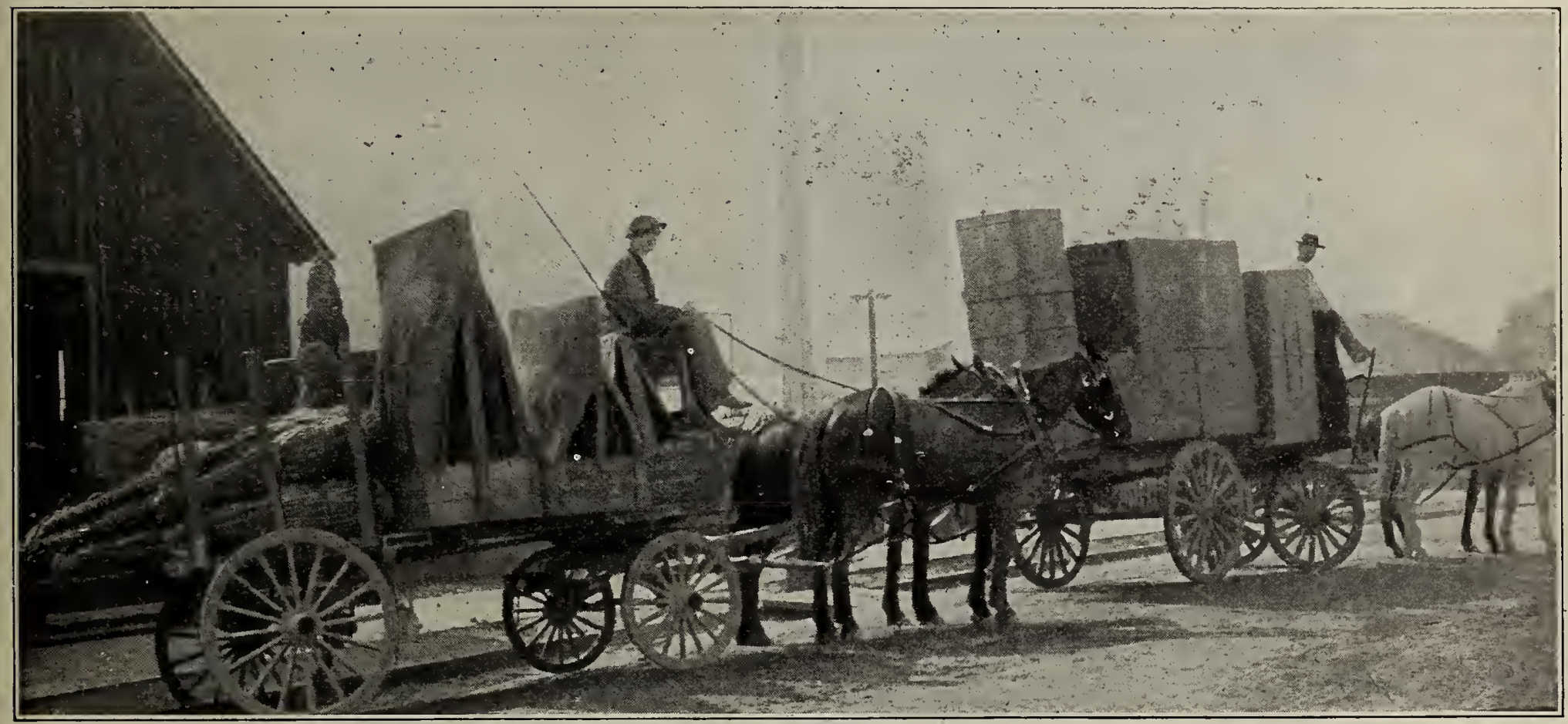

Scene at our Oakland Nurseries-Shipping Season

OUR GREENHOUSES AND SALES YARD are situated on GLEN AVENUE, off Piedmont Avenue, OAKLAND, CAL Visitors from San Francisco can reach there by taking the new Key Route Ferry (foot of Market Street) to PIEDMONT STATION; those from Oakland, by taking the Piedmont Avenue cars on Broadway to Glen Avenue. NURSERY TELEPHONE, PIEDMONT 30.

INTENDING PURCHASERS will do well to view our stock, as it is large, varied, and free from all sorts of seale and insect pests. Visitors are always welcome, whether they buy or not.

Our stock of ornamental trees, shrubs and palms, grown at our LIVER MORE NURSERIES, free from disease and insect pests, is large and varied and intending purchasers would do well to write us for special prices.

Customers will please remember that when our busy season commences we are rushed with orders, and it may be a few days before their orders receive attention; but they may rest assured that there will be no unnecessary delay in shipping. Prices quoted herein are f. o. b. cars, Nurseries, and cancel all previous quotations.

PACKING. Sufficient money should be added to remittance to eover cost of boxing, ete. Say ten per cent of purchase.

GUARANTEE. We do not guarantee stock to live, nor will we replace free of eost that which dies or fails to grow; nor can we, in view of the various incidents that the stock is subject to, as the success or failure depends largely upon climatic conditions, manner of planting, after care, etc. We do guarantee, however, that our stock will be in a good, live and healthy condition upon departure from our nurseries.

CERTIFICATE OF INSPECTION will be furnished with each shipment, when desired.

SUBSTITUTION. Where particular varieties are ordered, and particular ages and sizes of trees, kinds of stock, etc., it should be stated whether and to what extent substitution will be allowed in case the order cannot be filled to the letter. Where no instructions in this respect accompany the order, we shall feel at liberty to substitute other varieties as nearly similar as possible. If the selection of varieties is left entirely to us, we shall endeavor to send only such sorts as are acknowledged to give general satisfaction.

AS USUAL, 5 will be furnished at 10 rates; 50 at 100 rates; 500 at 1,000 rates.

CLAIMS. Should any errors occur we desire to be informed upon receipt of goods, in order that we may reetify them without delay. All claims must be filed within ten days after the arrival of the shipments. 


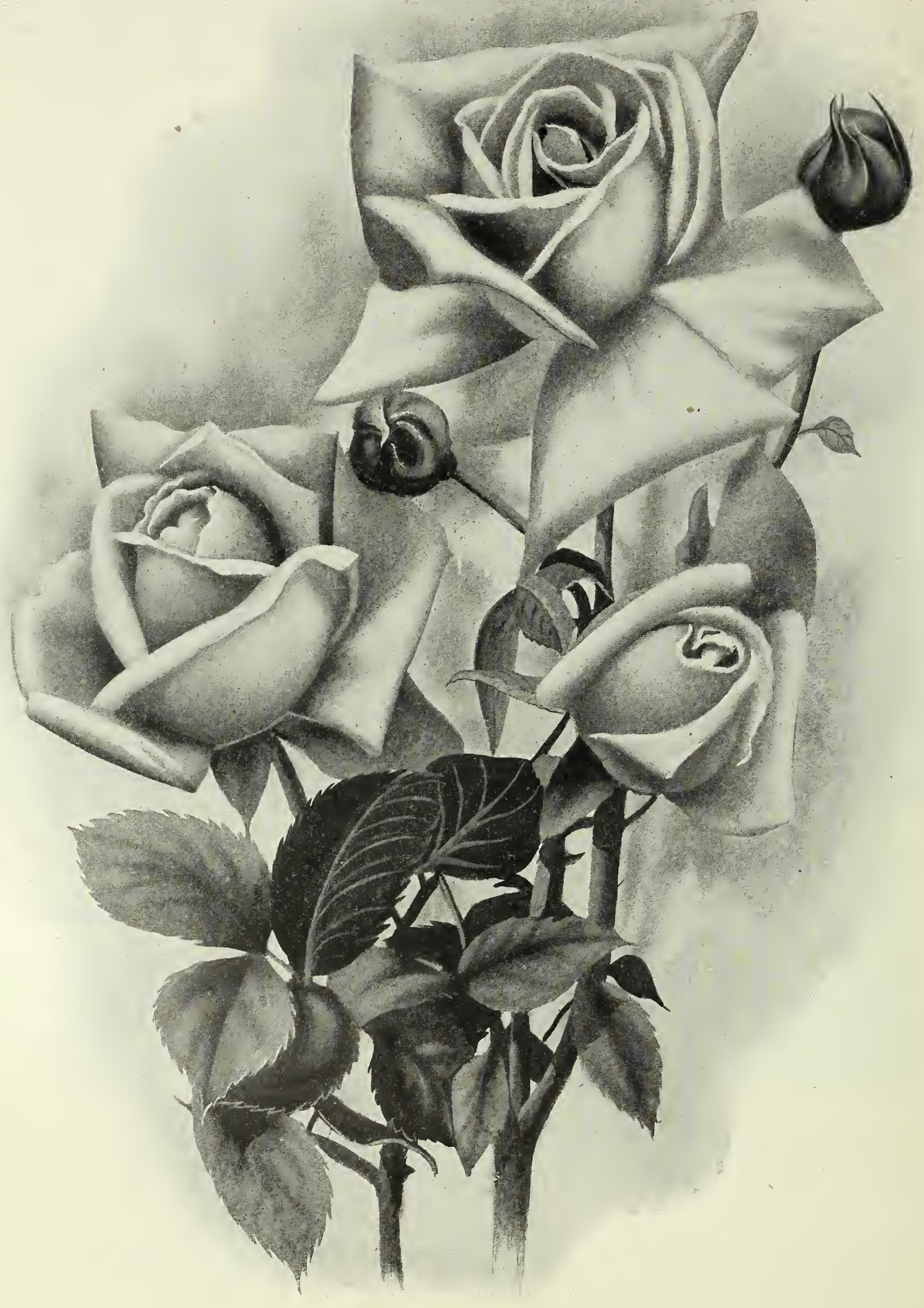

THE LYON ROSE

Gold Medal-Sensational Novelty from France

For description see opposite page 


\section{THE ROSE}

Perhaps there is no flower grown in California that more interest is taken in than the Rose. This State is fanous the world over for its

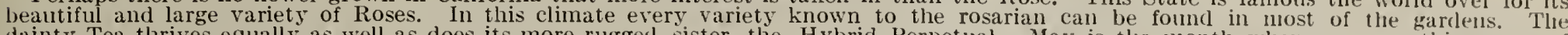

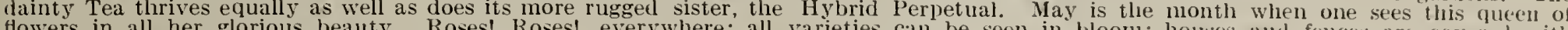

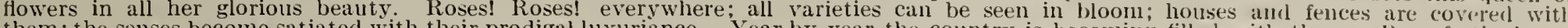

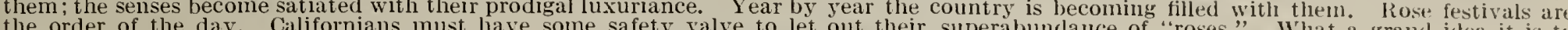

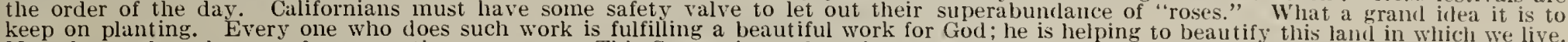

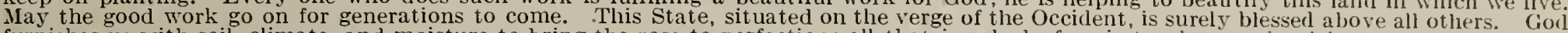
furnishes us with soil, climate, and moisture to bring the rose to perfection; all that is asked of us is to plant and cultivate, ancl nature wil do the rest.

To help the busy city man who delights "rus in urbe" we will specially appeal; to help him in simplifying tle culture of the rose will bc

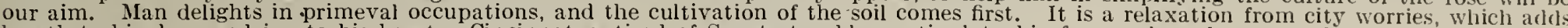

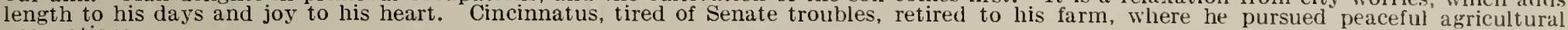
occupations.

\section{PLANTING SEASON}

First of all, let us tell you WHEN to plant. December, January, February, and March are the best months, but should the season be farorable, and with a little extra care, you can still plant during the early part of April. The plants sent during those nonths are, what we call, dormant two-year-old plants, and a verage from one and a half feet to two and a half feet in height, and are taken up without soil
around the roots, and are packed in damp moss. Should the purchaser be unable to plant them immediately, they will take no harm to remain around the roots, and are packed in damp moss. Should the purchaser be unable to plant them immediately", they will take no harm to remain
in the packing for a few days, or they can be opened up and "heeled" in the ground until ready to set out. The bushes sent out are already" pruned.

Roses give the best results when planted in good heavy sediment soil, to which may be added some good old stable manure, but remeinber that it ought to be well decayed. Under no circumstances use FRESH or new manure. After the hole is about three-quarters filled with soil, give some water to settle the earth around the roots; then put the remaining soil into the hole. This is usually enough water to give during the winter, provided we have not a long, dry period; in that case the plants should get another watering at regular intervals. Thiey will commence to bloom the first season after planting, in May and June, and if properly treated will give an abundance of flowers the first season. After the blooms are past, we advise you to cut the old flowers off; this treatment induces them to make new growth, from which
you will obtain your next crop. To aid them at that time, keep them freely watered, and by so doing Jou can have flowers away into December.

\section{PRUNING}

A few remarks on this important point is now necessary. This should be done during the months of January and February; at that time the bushes are in a dormant condition. The "Teas," or Ever-blooming Varieties, require to be more severely pruned than any other sort, a

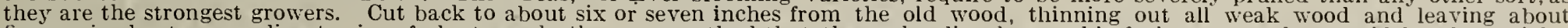

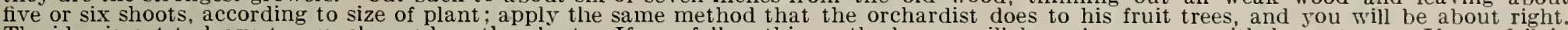

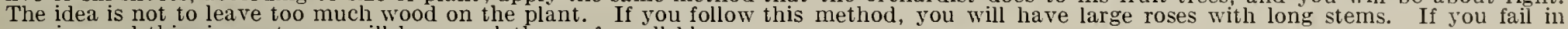
pruning and thinning out, you will have a plethora of small blooms.

THE HYBRID TEAS should have almost as much pruning done to them as the Teas.

HYBRID PERPETUAL sorts, not being such strong growers nor making so much wood as the preceding, do not require so much work done on them.

NOISETTE or CHAMPNEY varieties, being all climbers and strong, rampant growers, are not usually pruned, as their duties are to cover certain objects. They should, however, be periodically thinned out.

BOURBON sorts should be pruned according to the growth they have made.

MOSS ROSES require very little pruning, as they usually make only a few shoots in the season.

\section{VARIETIES OF ROSES}

We do not .intend to enumerate all known sorts to the rosarian, but confine our remarks to such sorts as succeed best in California.

First of all come the TEAS, or EVER-BLOOMING. These are more generally planted in this State than any other variety, for the reason that they are the most profuse and longest bloomers. If properly treated, flowers can be had from them nine months in the year. The first crop appears in April, May, and part of June.

The "Tea" is perfectly at home in this State, and this is the only State in the Union, perhaps, where they can remain out all winter without

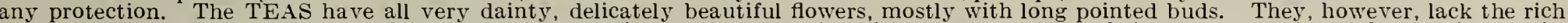

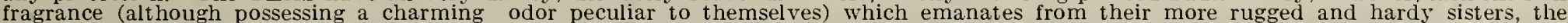
Hybrid Perpetuals; this, however, is amply offset bv their multitude of bloom

HYBRID TEAS are produced from crossing TEAS with Hybrid PERPETUALS, and partake of the rich fragrance of the Hybrids and the florification of the Teas. "La France," known to every one, is in this class. They are a most desirable class.

HYBRID PERPETUAL sorts produce much larger and more durable flowers than either of the two preceding hinds, and have a strong,

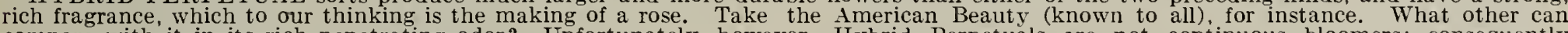

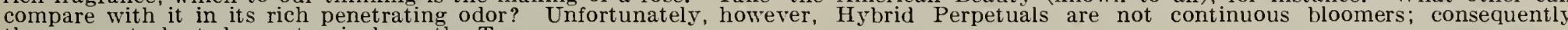
thev are not planted so extensively as the Teas.

THE NOISETTE or CHAMPNEY varieties are all strong, rampant growers, and are used as climbers, and include such sorts as the old favorite "Marechal Niel," so universally esteemed, "Cloth of Gold" and "William Allen Richardson."

POLYANTHA, or BABY ROSES. The blossoms of these are small miniature blooms, appearing in clusters and are great favorites.

They are free bloomers.

Besides the above varieties, we have the BOURBON, BANKSIA, MOSS, JAPAN, and SWEETBRIARS.

\section{LYON ROSE \\ NEWEST GOLD MEDAL ROSE}

In introducing this splendid novelty, we feel confident that we have a rare treat in store for all "Rose Lorers." Not for many years has such a novelty been sent out. Many so-called "novelties," that really have no true or uncommon merits, are being continually introduced, and we do not wonder at the public being somewhat skeptical on this point.
In the Lyon Rose will be found no disappointment, We have grown it and were greatly pleased with its wonderful beauty. We can truly say that it has the most distinct and novel color yet found in a rose; a shade that has long been sought after by the rosarian.

The Lyon Rose is a Hybrid Tea, thus insuring good blooming qualities. It was raised by Pernet-Ducher, and was awarded a Gold Medal at Lyons, France, in 1907. This triumph alone brands it a variety of the greatest merit. One of the judges who awarded the Gold Medal to this rose says, "I have no hesitation in recommending it as the most wonderful color yet obtained among roses. This may be best compared to the intense flame color seen in a glowing coke furnace."

A more detailed description is as follows: Shrimp pink at edges of petals, center of flower intense coral red, shaded chrome yellow. Flowers are large, fairly full, with smooth petals and long pointed buds. It is a free grower and abundant bloomer.

We believe that we are the only house in this country who has this grand novelty for sale.

Field grown plants, $\$ 1.50$ each. 


\section{THE ROSE \\ SOIL AND POSITION}

Again California is ahead in regard to soils and sunlight. There are very few places in the garden where the rose will not succeed. Our soil is pre-eminently adapted for the health of the rose, and sunlight we have to our heart's content; only, bear in inind, do not plant your roses in a too shady place, and if your soil is sandy, add a quantity of loam and old manure to enrich it, as the rose delights in good heavy rich soil.

\section{WATERING}

The best way to do this is to dig a ditch around your bushes and run the water into it, afterwards putting back the dry soil; by this means the water gets to the roots. Avoid surface watering, which in a great many cases never reaches the roots and only tends to bake and harden gicht to keep the foliage free from dust. You oun also give them during the summer months liquid cow manure every two or thrce weeks.

\section{DISEASES}

You must not expect in the genial climate of California to have your roses entirely free from insects, but they are few and easily controlled. APHIS, or GREEN FLY, is a small green louse, appearing on the young, tender shoots and buds. They are very prolific in breeding. Through their tender beak they suck the juices of the plants, always working at the tender shoots, and will in a short time, if unmolested, destroy the vigor and vitality of any plant they infest. REMEDIES: Tobacco in any form is fatal to them; sprinkle powdered tobacco on the bushes. The best time to do this is in the morning when there is moisture on the foilage; or soak tobacco stems in water till it is about the color of weak tea and apply with a syringe. When possible fumigate the plants with tobacco smoke. Another remedy: One pound Quassia (Quassia Armara) Chips, which can be obtained at any drug store, and put in four gallons of water and boil for ten ininutes; after Quassia (Quassia Arins ad one pound soft soap The solution is to be applied with a syringe.

MIILDEW When your plants become covered with a whitish-looking mould or dust, the disease is Mildew. Unless a very severe attack, it will probably not kill them, but retard their growth. It is caused by sudden atmospheric changes, and is generally worse in the spring when
the nights are cold and the days are warm. Some varieties are more susceptible to this than others. The best plan is NOT to wait until the disease appears, but "taking time by the forelock" dust them in the morning with powdered sulphur, or if the disease has made its appearance, syringe with a solution of sulphide of potassium.

ROSE SLUG. About the size of the common house fly and comes from the ground in early spring. The best remedies are powdered white hellebore or a solution of whale oil soap.

ROSE BUG. Is of a grayish color and about half an inch in length. It appears suddenly in.early spring, and feeds upon the opening buds and flowers, which it prefers to the foliage, and seems to be more fond of white and light colored flowers than of the darker colored ones. The best and really only cure is handpicking.

From the above, it will be noticed that the enemies of the rose are few, and really the only one which is at all troublesome is the Green Fly

\section{FORMS OF ROSES}

In California there are only two forms of roses grown-the BUSH and TREE or STANDARD ROSE. The former is (as the name indicates) of bush form, branching from the ground; the Tree Rose is budded on a stem of the wild rose, which has been trained up for this purpose three, four and sometimes five feet from the ground. The latter are usually preferred for planting on the lawn, as they are out of the way of the lawn-mower for one reason, and are certainly more showy for such places than the Bush rose. To grow a standard to saleable size usually takes three or four years; hence the dlfference in price Bush Roses are grown from slips or cuttings, or they are budded on some strong-growing sort. Some varieties being of weakly growth require to be worked in this style. There is really, however, not much difference in the quality or quantity of the blossoms.

\section{CATALOGUE OF VARIETIES}

Our list embraccs the most desirable roses for thís Coast. It is by no means a full list. Ellwanger in his "Treatise of the Rose" catalogues 1,086 sorts, and some French works describe over two thousand, but for the average amateur the following varieties are all that is necessary.

T. for Teas.

H. P. " Hybrid Perpetuals.

ABBREVIATIONS:

H. T. for Hybrid Teas.

N. for Noisette, or Champney.
P. for Polyantha, or Baby Roses. B. for Bourborn.

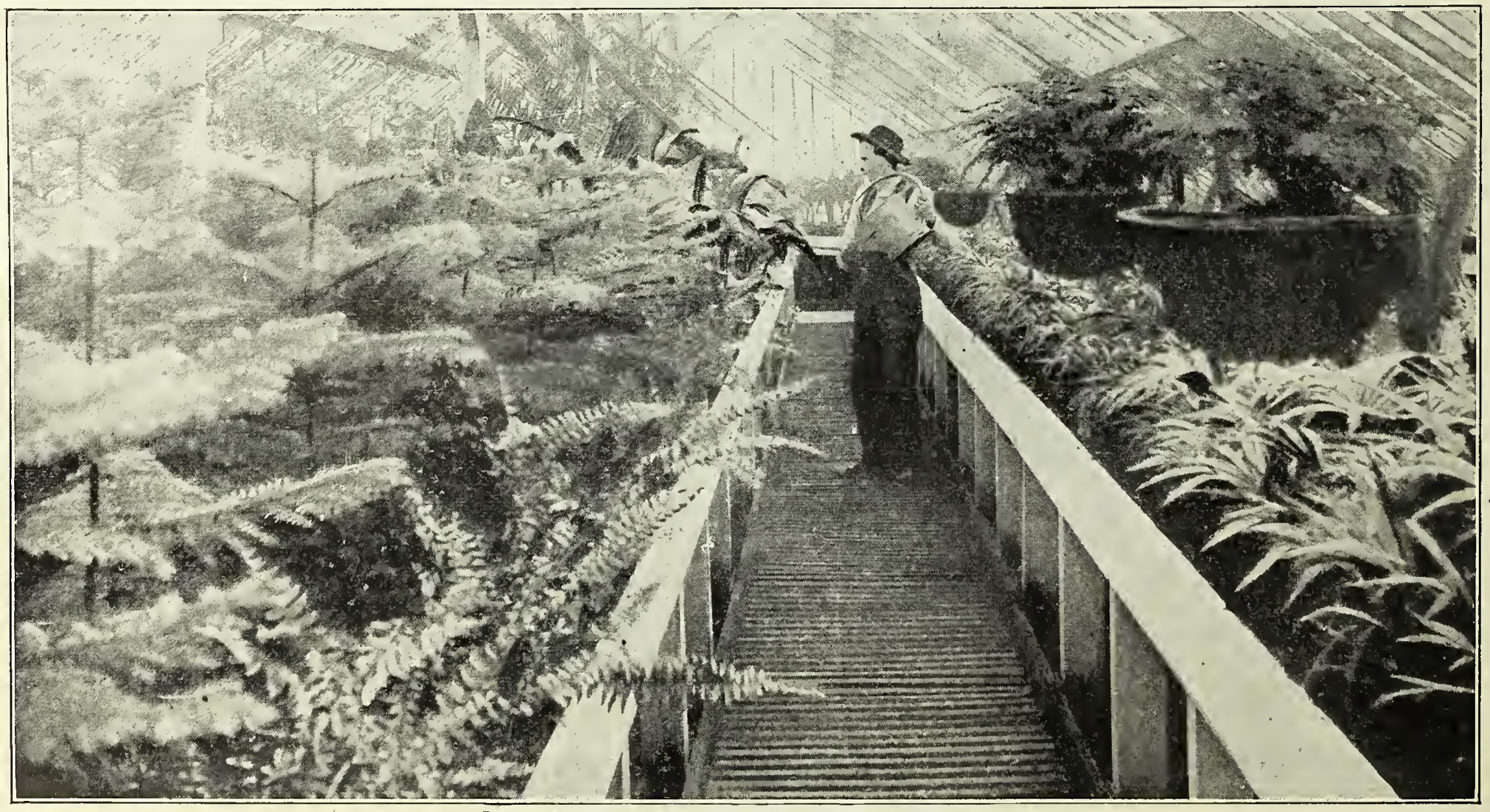

View in one of our oakland Conservatories 


\section{SAN FRANCISCO CALIFORNIA U.S.A.}

\section{ROSES \\ NEWEST INTRODUCTIONS \\ Price, Field Grown, 50c each}

\section{INTRODUCER'S DESCRIPTIONS}

ALICE GRAHAME (H. T.) Ivory white, tinted sal-

BETTY (H. T.) Ruddy gold (a coppery rose overspread with grower and of good habit. Said to be one of the best introducgrower and of good hab
tions of recent years.

CHARLES J. GRAHAME (H. T.) Dazzling ordid form. A grand rose.

COUNTESS OF DERBY (H. T.) Center salmon and fine, of good vigorous growth.

DEAN HOLE (H. T.) Silvery carmine, shaded salmon one of the best. Awarded gold medal.

EARL OF WARWICK $\underset{\text { pink, }}{(\mathrm{H} .} \underset{\text { vermilion }}{\mathrm{T}}$ salmonlarge and full.

HONORABLE IDA BINGHAM (H. T.) Pure veined; large petals, semi double, quite distinct; of strong habit. HUGH WATSON $\begin{aligned} & \text { (H.P.) } \\ & \text { shape, crimson shaded carmine. }\end{aligned}$
HUGH DICKSON (H. P.) Brilliant crimson, shaded high pointed center, opening up well. Sweetly scented. A warded gold medal.

IRISH ELEGANCE Apricot, slared coppery bronze This interesting rose is a new type sent out by Dickson \& C $C$ Newtonards, Ireland (distributers of so many fine roses) most unique variety. Should be in every collection. "Maharajah" for another of this style.

LADY BATTERSEA ${ }_{\text {crimson, }}^{\text {H. }}$, Beautiful cherry dium size, long stems; very attractive, splendid for massing, vigorous grower.

LADY WENLOCK (H.T.) China pink, suffuserl large and full, very healthy in growth.

LADY ASHTOWN $\underset{\text { pointed bud, large full flowers. }}{\stackrel{(\mathrm{H} . \mathrm{T} \text { T.) }}{\text { yel at }} \text { at }} \begin{aligned} & \text { Pale rose, shading to } \\ & \text { base of petals, long }\end{aligned}$

MAHARAJAH Deep velvety crimson, with prominent other very interesting single rose.

\section{NEWER ROSES}

\section{Field grown, 35c each; $\$ 3.50$ per dozen}

Customers serecting their own roses are respectfully requested to add to their orders a few supplementary sorts, lest by previous orders the stock of any particular variety should be exhausted.

CLIMBING CAROLINE TESTOUT. In this beautiful new introduction we have an exact counterpart in color and shape of that duction we have an exact counterpart in color and shape of that unfamiliar with that , Carietr, we would unfamifiar with that variety, we would say that the color is a most freely for a pink; the blooms are large and produced most freely for a long period; the growth is rapid, and it very quickly assumes large proportions; so that those wishing a desirable, free, quick-growing, pink rose can make no mistake in ordering the Climbing Caroline Testout.

CLIMBING BELLE SIEBRECHT. It is with real pleasure that we introduce this lovely new climbing rose. It is identical with the older bush form; color a most rare shade of pink; the buds are long and pointed; wonderfully profuse in bloom.

CLIMBING BRIDESMAID. We have a climbing sort of the wellknown favorite Bridesmaid to offer, which should be good nervs to those who are looking for sterling new introductions. The color is a rich shade of velvety pink; the buds are exquisite and the full blown roses equally so, being large and full; the stems are long and stiff, thus making it a valuable rose for cutting purposes. The plant is a strong climber.

CLIMBING CECILE BRUNER. It will no doubt come as a surprise, a pleasant surprise, to the lover of the rose, to learn that there is at last introduced a climbing sort of this ever popular "Baby" Rose. In its bush form Mademoiselle Cecile Bruner is well known; the blooms come in clusters and bloom for a long period. color, beautiful salmon-pink, with and bloom for a long period; color in center. Habit of growth very strong and vigorous.

CLIMBING SOUVENIR DE MALMAISON. The bush form of this variety is one of the best of its kind, and in this new climbing sort we have an exact counterpart in color and shape. A beautiful shade of flesh color, deeper towards the center of the petals.

CLIMBING PAPA GONTIER. The bush form of this old favorite red Tea Rose is known to all, so that a climbing sort of it will be a welcome acquisition to the list of roses. The buds are long and pointed and of deep-red color. It is a free and continuous bloomer, like its parent. Habit of growth, strong and free.

FRAU KARL DRUSCHKI (Hybrid Perpetual). Pure snow-white very long buds; shell-shaped petals, opening to very large flowers; has been well shown and is the finest white rose in cultivation; extra fine; superb.

This is the description of the introducer, Mr. Lambert of Germany, and we can fully corrobate all he has said about this magnificent rose. It has been well tested in this state during the last two vears and we send it out to the general public, knowing that it will give the best of satisfaction.
GRUSS AN TEPLETZ CLIMBING HERMOSA. There has always been a scarcity of good dark, climbing everblooming, red roses, so the rose-loving public will be pleased to learn that we have one to offer in Gruss an Tepletz. The color is velvety scarlet; and it is continually in bloom. It is of fast growth and very soon attains large size.

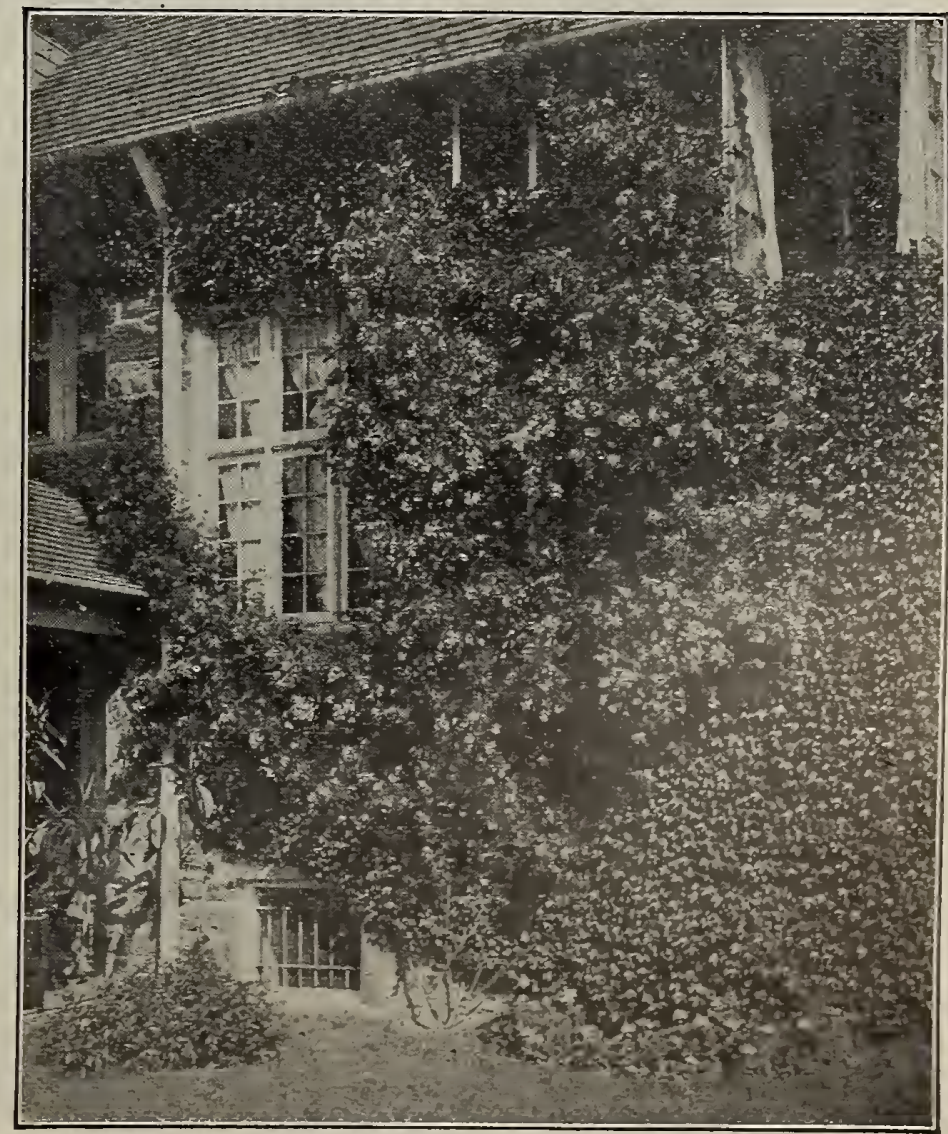


MILDRED GRANT. Ivory white, with a beautiful flush of pale peach bordering the petals; high pointed center, with unusually large and massive petals, opening to perfectly formed flowers of Medal of the English National Rose Society. This triumph alone brands it a variety of the greatest merit.
ROSE OF KILLARNEY. This grand new rose was raised by Dickson \& Co., of Belfast, Ireland, who have sent out so many sterling novelties in the rose line. The color is a glistening, soft silvery pink, the petals being waxy in appearance; the buds are long and pointed, slightly reflexed at the ends; the rose when full blown being fairly double. In continuity of bloom the Rose of Killarney is unsurpassed.

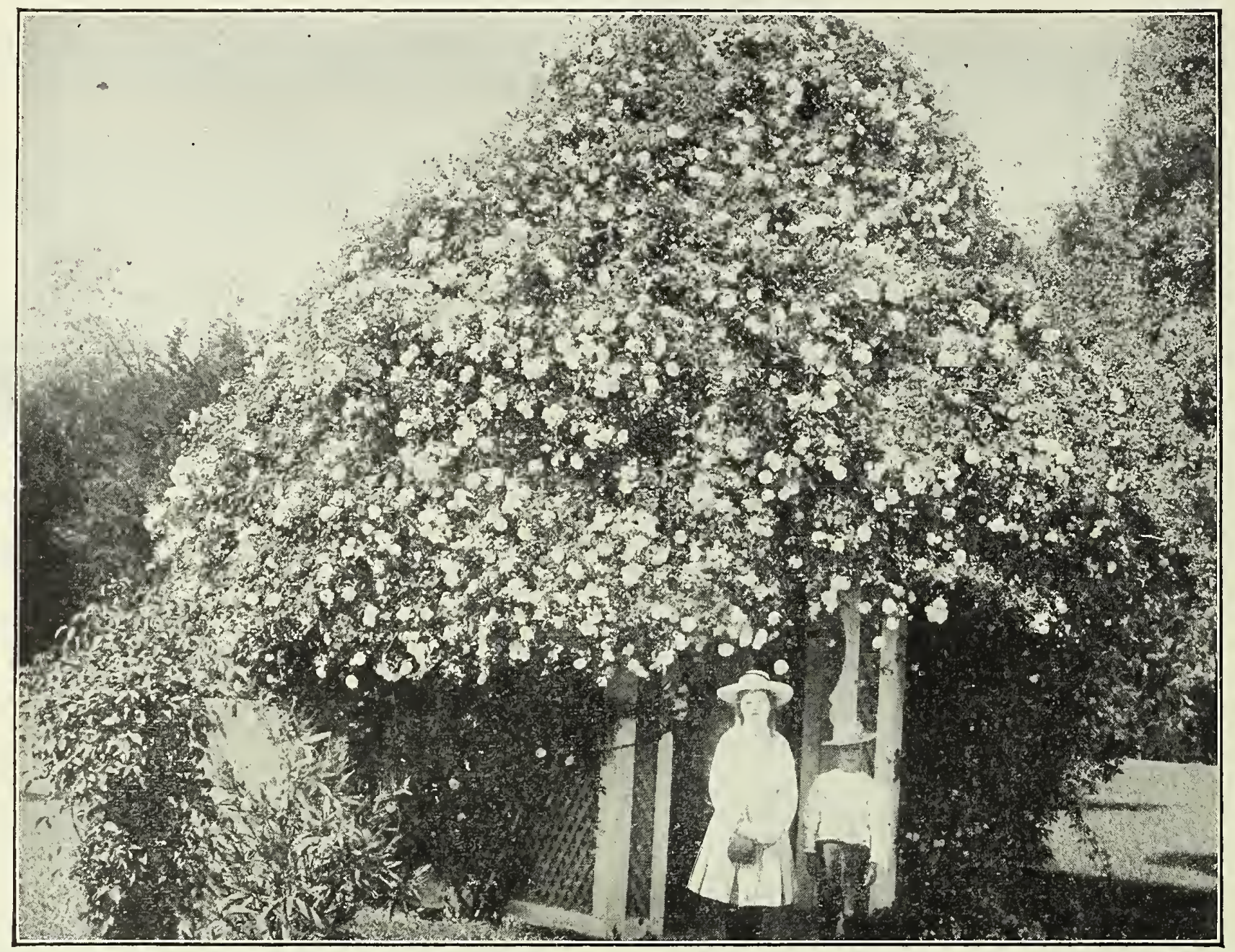

Beauty of Glazenwood

\section{ROSES-CHOICE ASSORTMENT}

In this list will be found nothing but the very best sorts

These roses that we offer are thrifty, well-developed two-year-old plants, and are shipped in a dormant condition from about December 15th to about April 1st.

Price. 25c each; $\$ 2.50$ per dozen. Extra Selected large plants, 35c each; $\$ 3.50$ per dozen.

We will not supply less than six of a kind at dozen rates; if one of a sort is ordered single rates will be charged.

AGRIPPINA. (B.) Rich velvety crimson; flowers come in clusters; very floriferous. This is the sort that is so much used for hedges.

ADIMIR AL DEWEY. (H. T.) Delicate light blush (a sport from Caroline Testout), with large, well formed flowers.

AMERICAN BEAUTY: (H. P.) Large, globular, deep pink, shaded carmine, delicious odor; a fine variety for forcing.

ANNA DE DIESB ACH. (H. P.) Brilliant crimson, shaded with maroon. Long-pointed buds and large compact flowers.

ARD'S ROVER. (H. P.) Crimson shaded maroon, flowers large, foliage handsome; a great acquisition to climbing sorts.

AUGUSTINE GUINOISSEAU (White La France). (H. T.) This beautiful variety with flowers of pure white, shading to a center of light rose, is a great favorite on account of its great freedom of bloom, fragrance, and large flowers. A vigorous grower, producing a great number ố buds and flowers.

AVOCAT DUVIVIER. (H. P.) Crimson, large, full, well formed and fragrant; a fine rose.

BANKSIA, White and Yellow. These are the well-known thornless climbing roses. The flowers are small, but bloom in great profusion in spring and early summer.

BARDOU JOB. The color of this beautiful rose is rich velvety (cimson, with yellow stamens. A grand climber.
BARONESS ROTHSCHILD. (H. P.) Very large flowers, sheil pink, exquisite shape and fragrance.

BARON DE B ONSTETTEN. (H. P.) Splendid large flowers; very double and full; color, a rich dark red, passing to a velvety maroon. Highly scented and very beautiful.

BEAUTY OF GLAZENWOOD. Variously known as San Rafael Rose, Hester Rose, Fortune's Yellow, and erroneously named Gold of Ophir in Southern California. (Banksia.) A combination of copper, carmine, and salmon-yellow. A strong fast climber. This is the rose that blooms so bounteously in springtime and which is admired wherever seen.

BELLE SIEBRECHT. (H. T.) A superb pink rose of recent introduction. The buds are long and pointed, and when halfblown the petals reflex in a graceful manner. The flowers have great substance and the petals are of heavy texture.

BEAUTE INCONSTANT. (T.) Flowers are pink, blotched white; a constant and profuse bloomer. Much admired.

BELLE LYONNAISE. (T.) Yellow, tinted pink; buds and open flower, very fine; a long and continuous bloomer.

BLACK PRINCE. (H. P.) Crimson, shaded with purple; medium size. A good dark rose.

BON SIIENE. (T.) Buds of beautiful form; an unusually free bloomer; color, deep rose-shaded carmine. 
BRIDE. An ever-blooming pure white Tea Rose, of large size and most perfect form. The buds are pointed, and the ends of the petals are slightly recurved. It is a very free-blooming variety, and has a most delicious tea fragrance. One of the best white roses.

BRIDESMAID. In this exquisite Tea Rose we have an improved Catherine Mermet, from which it is a sport. Mermet, on account of its exquisite shape, large, solid, firm buds, with long stiff stems, has long been considered one of the best cut-flower varieties. Bridesmaid at all seasons is a clear, delicate pink, in all respects a counterpart of Mermet, with large, handsome, pointed buds on long stiff stems.

CAROLINE TESTOUT. A grand perpetual blooming Hybrid Tea of La France type but much larger and of better color, being a bright, clear, delicate pink, retaining its color at all seasons.

CAPTAIN CHRISTY. (H. P.) Of delicate flesh color, rosy center. Flowers extra large, double, full, and sweetly scented.

CECILE BRUNER. (P.) A charming "Baby" variety of sweet, delicate fragrance. Color, salmon-pink, with deep salmon center.

CHEROKEE, Single. One of the finest pillar roses in cultivation; large, clear, white, single flowers, full of bright yellow stamens, which give it a most unique appearance; foliage, dark, rich green. A most vigorous grower.

CHEROKEE, Dov:ble White. A rampant climber.

CEESHUNT HYBRID. (H. T.) Cherry carmine; large and full flowers of strong habit; constantly in bloom; good pillar rose.

CIAIRE CARNOT. (N.) Color, fine coppery rose, shaded with amber at base of petals; bordered with white and rosy carmine.

CEIMBING CAPTAIN CBRISTY. (H. P.) Those who know the old bush form of Captain Christy will be pleased to learn that we now have a climbing variety of this old favorite; delicate flesh color.

CLIMBING DEVONIENSIS. (T.) Large, creamy-white, shell-like petals of great substance; large, full and very fragrant.

CLIMBING KAISERIN AUGUSTA VICTORIA. (T.) Buds long and pointed; pure white, of superb substance and texture; a strong and rapid grower.

CLIMBING IA FRANCE. A strong climbing sort of the old favorite La France.

CLIMBING NIPHETOS. (T.) A splendid companion to the Climbing Perle des Jardins, Color, pure white, with pale lemon center; beautiful long pointed buds; very fragrant.

CLIMBING PERLE DES JARDINS. (T.) Habit of growth is vigorous, young plants often sending up shoots six to eight feet in one season, with rich, glossy foliage, and bright red stems. The flowers are produced in profusion and are deep canaryyellow.

CIIMBING SAFRANO.' See Reve d'Or.

CLIMBING SOUVENIR DE WOOTON. (H. P.) Deep red, large; produced very freely. Strong grower.

CIIO. (H. P.) A really grand rose; on the order of Baroness Rothschild; recommended by expert growers as the finest rose of this type; strong, vigorous grower; handsome foliage; flowers are fiesh color, shaded in the center with rosy pink; large, of fine globular form; freely produced.

CLOTH OF GOLD. (N.) Deep yellow center, with sulphur-colored edges. A good climber.

CORNELIA COOK. (T.) Beautiful creamy white; petals of strong texture; free and continuous bloomer.

COUNTESS RIZA DU PARC. (T.) Bronzed rose; flowers medium size, moderately full; highly perfumed; very vigorous; large and full.

CRIMSON RAMBLER. (P.) Of remarkably vigorous growth, making shoots from eight to ten feet high in one season; flowers of brightest crimson, and produced in great pyramidal panicles, each having thirty to forty blooms.

DUCHESS d'AUERSTADT. (T.) Coppery-red, blended pink; a most lovely and unique variety.

DUCBESS DE BRABANT. (T.) Soft, rosy flesh, changing to deep rose color, edged with silver. Beautiful in bud, and highly fragrant.

DR. GRILL. (T.) Clear buff pink, passing to a clear rose and fawn, elegantly suffused with pale canary yellow. A most profuse and regular bloomer.

EMPEROR OF MOROCCO. (H. P.) An intensely dark rose, of velvety maroon.

ETOILE DE LYON. (T.) Orange yellow; very large and good.

FLORA McIVOR (Sweet Briar). White, tinged rose.

GENERAL JACQUEMINOT. (H. P.) Rich velvety crimson, changing to scarlet crimson. A magnificent rose, beautiful in the changing to scarlet crimson. A magnificent rose, beautiful in the
bud or open. Is without a rival in fragrance and richness of color.
GLOIRE DE DIJON. (T.) A combination of rosc, salmon and yellow; flowers very large and full. A good climber.

GLOIRE LYONNAISE. (H. P.) Whitc, tinted yellow; large, very showy and nicely perfumed.

GLOIRE DE MARGOTTIN. (H. T.) The most bcautiful of all red climbing roses. Specially arlapted for planting against fences and houses. Can also be grown on a trellis. Color, a most brilliant shade of red; buds large, long and pointed.

GLOIRE DE BOURG LA REINE. Vivid red, a very striking color; flowers large and double; a good bloomer.

GLORY OF ROSAMOND. Flowers brilliant scarlct; single; very free in bloom. Desirable for hedges.

GOLDEN GATE. (T.) Canary-yellow flowers of delicate appearance; highly commendable in all respects.

GOLD OF OPHIR. (T.) Salmon yellow, shaded with bright deep rose. Climber.

GRACE DARLING. (T.) Lovely pink tinted white, a great favorite.

HELEN KELLER. (H. P.) Brilliant rosy cerise; flowers large of most perfect form; sweetly perfumed; a vigorous strong grower.

HELEN GOULD. (T.) Lovely shade of pink, buds fine.

HERMOSA. (B.) Bright rose, a most constant bloomer.

HEINRICH SCHULTHEIS. (H. P.) Splendid large flowers, very double and sweet; color, delicate pinkish rose, wax-like substance; very beautiful.

ISABELLA SPRUNT. (T.) Beautiful canary-yellow; buds long and pointed.

KAISERIN AUGUSTA VICTORIA. (T.) Full flowers; magnificent in bud; stems long, and bearing large, strong canes, with handsome foliage; flowers pure white. A grand sort.

LA FRANCE. (H. T.) Delicate silvery rose, shaded with cerise pink, often silvery pink, with peach shading; very large, very double; of superb form.

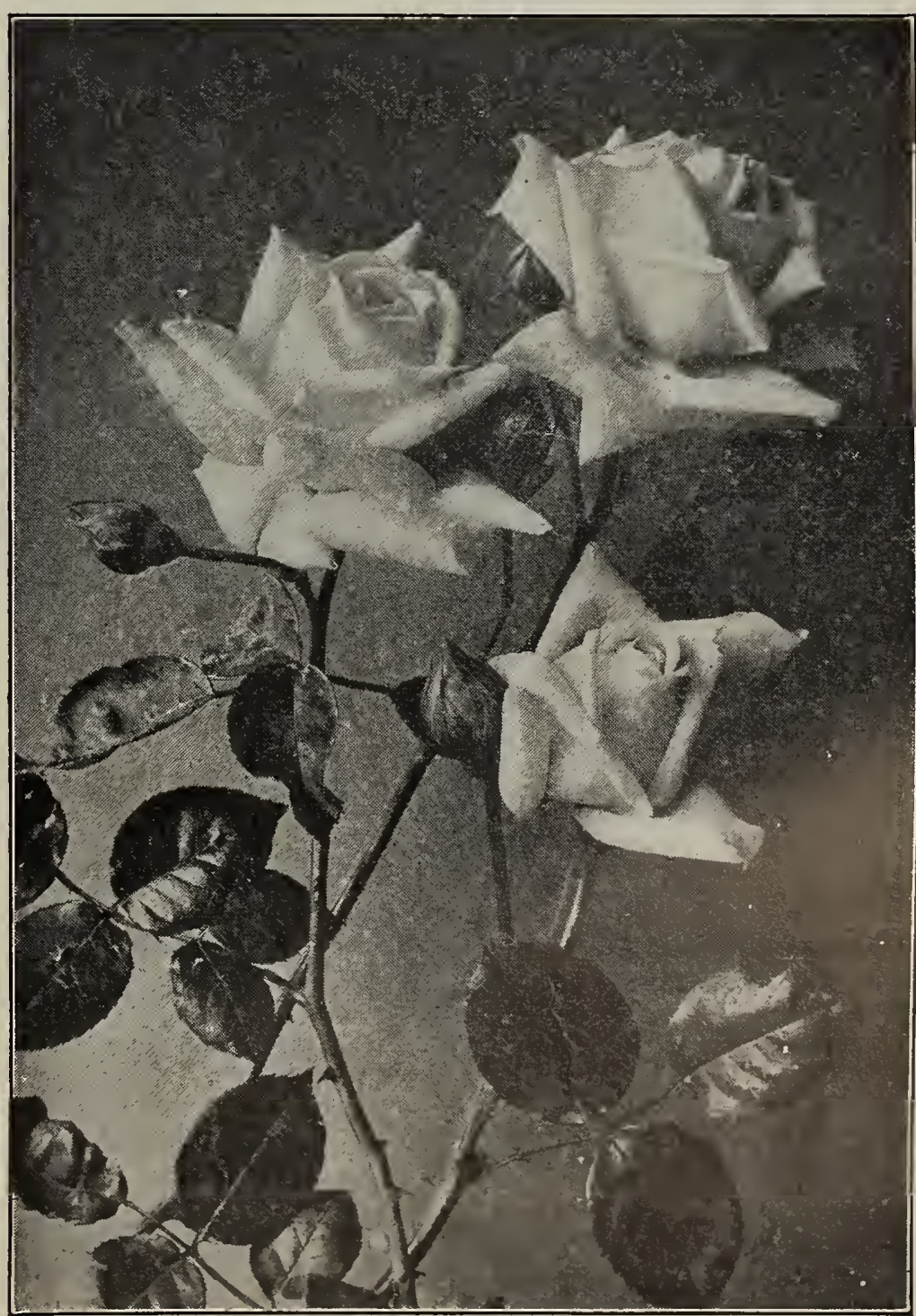

Kaiserin Augusta Victoria 
LA FRANCE OF '89. (H. T.) Long, elegant buds, approaching scarlet; of sweet fragrance; a long and continuous bloomer; very desirable in every way.

LA IMARQUE. (N.) Pure white buds, open flower tinged light canary-yellow; large and full. A grand climber.

LIBERTY (The New Century Meteor). (H. T.) Color, pure crimson-scarlet, of most intense hue; velvety in texture, cupshaped; of delicious fragrance; constant bloomer.

L'IDEAL. (T.) Coppery-yellow, blended pink; exquisite in every. particular.

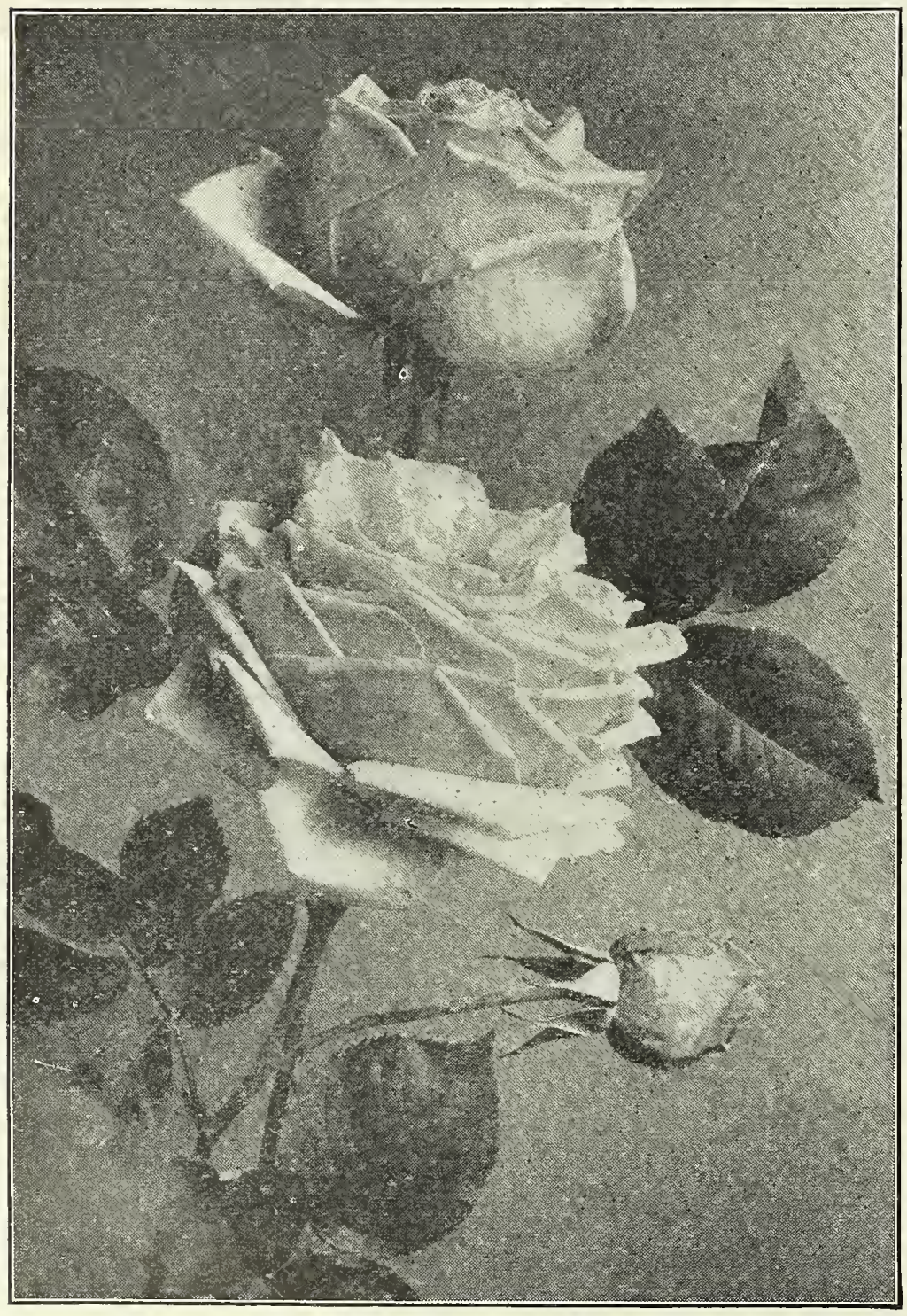

La France of ' 89

MADAME ALFRED CARRIERE. (N.) Creamy white, free bloomer, a strong and vigorous climber. One of the best for exposed cold situations.

MADAME C. GUINOISSEAU. (T.) Beautiful shade of canaryyellow; long pointed buds; very free.

MADAME CAROLINE TESTOUT. See Caroline Testout.

MADAME DE WATTEVILLE. (T.) A lovely blended sort; white tinged bronzy yellow.

IMADAME FALCOT. (T.) Deep apricot, shaded buff.

MADAME GABRIEL IUIZET. (H. T.) Beautiful shade of coral pink; sweetly fragrant; strong grower.

MADAME HOSTE. (T.) Canary-yellow; buds long and pointed when full blown; very double; very free.

MADAME LAMBARD. (T.) A grand rose; silvery pink; very free in bloom, and double at all times.

MADAME CLAIRE JAUBERT. (T.) Salmon-pink; the blooms come in clusters in great profusion; a desirable sort.

MADAME EUGENE VERDIER. (H. P.) Mottled rose color; very large, full and globular.

M'LLE C. BRUNER. See Cecile Bruner.
MAGNA CHARTA. (H. P.) Bright, clear pink, flushed with violet crimson; flowers large, fine form, very double and full.

IMAMAN COCEET PINK. (T.) Deep pink; buds long and pointed; of great substance; a continuous bloomer.

MARCHIONESS OF LORNE. (H. P.) Deep pink; flowers full and double; of exquisite fragrance.

MARECHAL NIEL. (N.) Beautiful deep yellow; large, full, and of globular form. A good pillar rose.

MARIE VAN HOUTTE. (T.) White, slightly tinged with yellow; free grower and fine bloomer. Exquisite.

MARSHALL P. WILDER. (H. P.) Cherry-carmine; very vigorous in growth, strongly perfumed, one of our best dark red "perpetuals."

MABEL MORRISON. (H. P.) Pure white, large flowers and very free in bloom.

MRS. JOHN LAING. Soft pink; large and of fine form, produced on strong stems; exceedingly fragrant.

MRS. R. G. SHARMAN CRAWFORD. (H. P.) Color, deep rosy pink. Flowers large, of perfect imbricated form.

NIPHETOS. (T.) An elegant white rose. The buds are long and pointed.

PAPA GONTIER. (T.) A splendid variety, valuable both for open ground and greenhouse culture; it is a strong, vigorous grower and free bloomer; the buds are extra large, finely formed and very beautiful; flowers double and full, and exceedingly sweet; color bright cherry red, passing to rich, glowing crimson, petals shaded with yellow; very striking and handsome.

PAUL NEYRON. (H. P.) Extra large and full; fine form; deep carmine color; very fragrant; free bloomer; an excellent rose.

PAUL VERDIER. (H. P.) Carmine red; flowers large and of fine shape, sweetly perfumed.

PAUL'S EARLY BLUSH. (H. P.) A superb rose in every respect; color, light silvery blush; large, fine, bold shape, producing its flowers among the first and continuing throughout the season.

PERLE DES JARDINS. (T.) Fine straw yellow; sometimes deep canary yellow; very large and full, and of the most perfect form; one of the finest roses grown; steps at once into fame as the finest yellow rose we have.

PINK RAMBLER. Flowers pink; produces in great profusion, small, a most vigorous climber.

PIERRE NOTTING. (H. P.) Deep maroon, tinted crimson, of velvety texture, fine pointed buds, a superb dark red.

PRINCE.SS ADELAIDE. (Moss.) Pale rose, good in bud and flower; very sweet.

PERLE D'OR. (P.) Coppery gold changing to fawn and salmon; charming and very distinct and one of the prettiest of the Fairy or Baby lioses.

PAUL'S CARIMINE PILLAR. Flowers very large; single; bright rosy crimson; produced with great freedom along the branches. Very vigorous grower.

PRINCE CAMILE DE ROHAN. (H. P.) Rich, dark, velvety crimson, changing to scarlet maroon; full, double and sweet.

RAINBOW. (T.) The color is a lovely shade of deep coral pink, beautifully striped and mottled in the most unique manner with beautifully striped and mottled in the most unique manner with intense glowing crimson, elegantly colored at center with rich
golden amber; makes beautiful buds, and the flowers are extra large, very sweet, and of great depth and substance.

REINE MARIE HENRIETTA. An extra fine climbing variety; flowers large, full, and handsome; color, clear cherry red; a grand acquisition to climbing roses.

REINE OLGA DE WURTEMBERG. A lovely bright red; semidouble. A strong rampant grower.

REVE D'OR. (Climbing Safrano-N.) Deep yellow, sometimes coppery yellow or rosy buff; large, full, and sweet. A beautiful climber.

ROBERT DUNCAN. (H. P.) Bright rosy lake, of perfect form; vigorous grower and good bloomer.

SHIRLEY HEBBARD. (T.) Deep saffron yellow; buds very beautiful.

SAFRANO. (T.) Buff apricot; a constant and profuse bloomer; one of the old favorites.

SOLEIL D'OR. "Golden Sun." A grand new yellow rose. The color in bud is a rich chrome yellow tinted with coppery rose, and on expanding becomes a beautiful orange-yellow, shaded with copper and red; a very free bloomer and one of the best and most distinct roses of recent introduction. 


\section{SAN FRANCISCO CALIFORNIA U.S.A.}

SOUVENIR DE PRESIDENT CARNOT. (H. T.) A continuous and free bloomer, with most delightful fragrance; extremely large, both in bud and flower, retaining its full shape even when full blown; long and pointed; color delicate rosy flesh, shaded to pink.

SOUVENIR DE MALMAISON. (B.) Free blooming, of beautiful, clear, flesh color, edges blush.

SOUVENIR DE WOOTTON. (H. T.) One of our-best red, everblooming, highly fragrant sorts. Flower is large and full; color beautiful shade of carmine crimson; strong grower.

SUNSET. (T.) Identical in every respect with Perle des Jardins, except that its color is that of rich saffron and orange.

THE QUEEN. (T.) Pure glistening white; buds full and double; very free in bloom.

ULRICH BRUNER. (H. P.) This we consider one of the most satisfactory of all the Hybrids. Flowers large, full and sweet; color, bright, clear red; a profuse bloomer and hardy grower.

WHITE IA FRANCE. (See Augustine Guinoisseau.)

WHITE RAMBLER. Creamy white, produced in great profusion; a strong vigorous climber.

WHITE MAMAN COCHET. (T.) This American sport of the grand Frencli variety, Maman Cochet, is one of the best whites of recent introduction; the buds are solid long and pointed faintly suffused pink on outside petals, and borne very freely: foliage glossy; plant strong, vigorous and healthy; highly comfoliage glos
mended.

WILLIAM ALLEN RICHARDSON. (N) Fine orange yellow, apricot center; medium size; full, very showy and distinct. A apricot center; $m$
beautiful climber.

YELLOW RAMBLER. This variety will be found a grand companion to "Crimson Rambler." "The flowers are borne in large clusters, very profusely; color canary-yellow.

XAVIER OLIBO. One of the darkest roses; very sweet and a free bloomer.

We can supply the following roses in standard or tree form, that is, they are budded on Single Stems, three to four feet from the ground. $\$ 1.25$ each. $\$ 10$ per 10 .

Descriptions of the following sorts will be found in preceding list, except as noted.

Belle Siebrecht.

Captain Christy.

Celine Forestier. Straw color. Very free in bloom.

General Jacqueminot.

Gruss an Tepletz.

Hugh Dickson. Brilliant crimson. Beautiful form. A Gold Medal Rose.

İaiserin Augusta Victoria.

Killarney.

La France.

L'Innocence. Pure white, carried on erect, strong stems; very free.

Mad. A. Chatenay. Carmine rose, shaded salmon.

Mad. Jules Grolez. Beautiful bright china rose color; large and full; very free in bloom.

Magna Charta.

Marechal Niel.

R. M. Henrietta.

Soleil d'Or.

Souv. de Malmaison.

Souv. de Pres. Carnot.

Ulrich Bruner.

For convenience sake we give below a list of those Roses that climb:

Banksia - White and Yellow.

Bardou Job

Beauty of Glazenwood.

Cherokee.

Climbing Belle Siebrecht.

Climbing Bridesmaid.

Climbing Malmaison.

Climbing Cecile Bruner.

Cheshunt Hybrid.

Climbing Cap. Christy.

Climbing C. Testout.

Climbing Devoniensis.

Climbing La France.

Climbing Papa Gontier.

Climbing Niphetos.

Climoing P. des Jardins.

Climbing Kaiserin.

Climbing S, de Wootton.

Cloth of Gold.

Gloire de Margottin.

Gloire de Dijon.

Gruss an Tepletz.

La Marque.

Marechal Niel.

Mad. A. Carriere.

Reine Marie Henrietta.

R. O. de Wurtemberg.

Reve d'Or

W. A. Richardson.

Yellow Rambler.

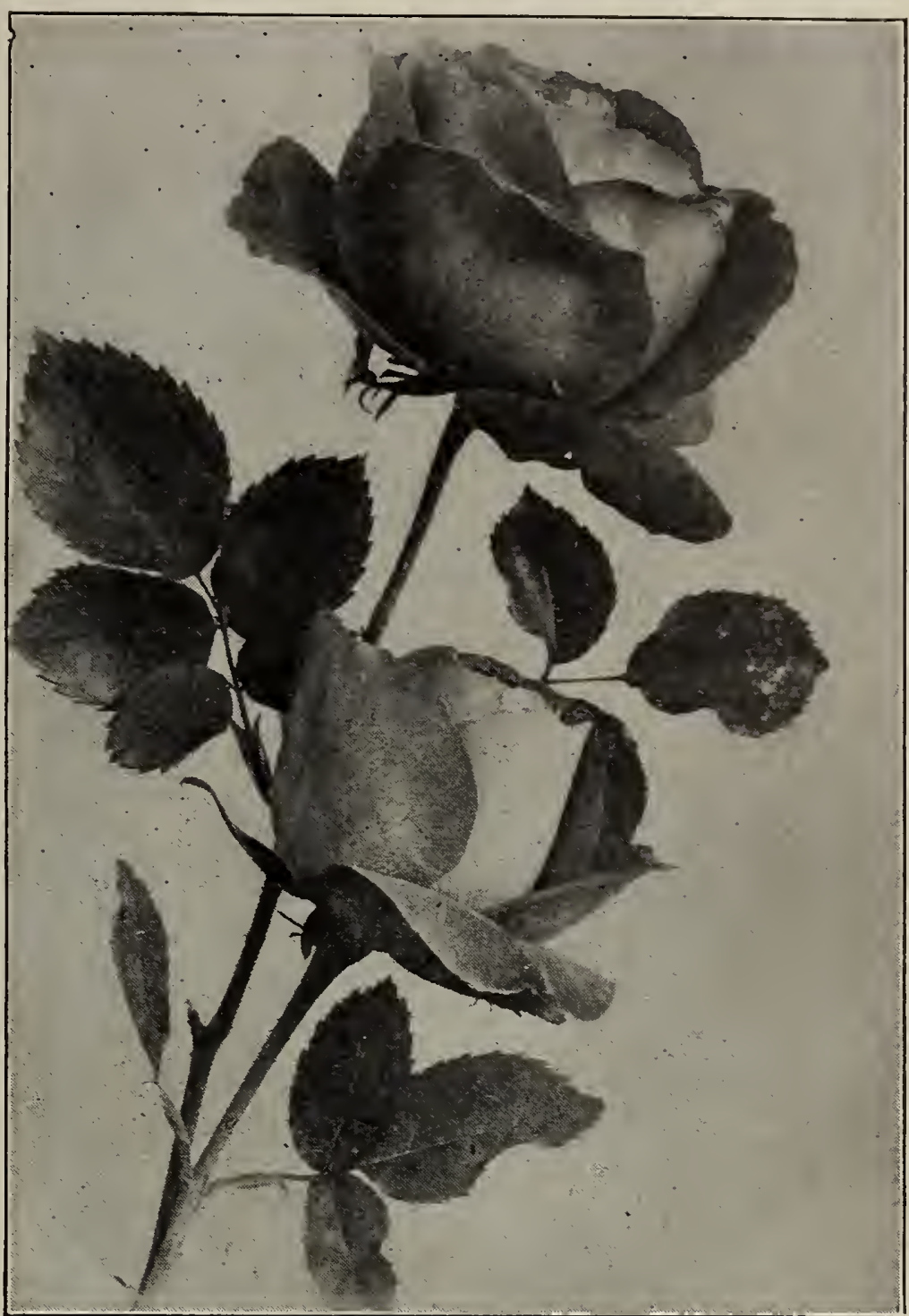

Ulrich Bruner

\section{ROSES ARRANGED IN COLOR CLASSES}

WHITE. Augustine Guinoisseau, Bride, Cherokee, Cornelia Cook, Gloire Lyonnaise, Kaiserin Augusta Victoria, La Marque, Madame A. Carriere, Maman Cochet, The Queen.

YELLOW. Cloth of Gold, Gloire de Dijon, Golden Gate, Isabella Sprunt, Madame C. Guinoisseau, Madame Falcot, Madame Hoste, Marechal Niel, Perle des Jardins, Reve d'Or, Safrano Sunset, W. A. Richardson, Yellow Rambler.

BRONZE YELLOW. Beauty of Glazenwood, Claire Carnot, Dr. Grill, Gold of Ophir, L'Ideal, Soleil d'Or.

PINK AND ROSE SHADES. American Beauty, Belle Siebrecht, Bon Silene, Bridesmaid, Caroline Testout, Killarney, La France Madame G. Luizet, Magna Charta, Mrs. John Laing, Mrs. J. S. Crawford, Madame Lambard, Pink Maman Cochet, Paul Neyron.

SCARLET CRIMSON AND SHADES. Agrippina, Anna de Diesbach, Bardou Job, Cheshunt Hybrid, Crimson Rambler, General Jacqueminot, Gloire de Margottin, Liberty, Marchioness of Lorne, Papa Gontier, Reine Marie Henrietta, Reine O. de Wurtemberg, Ulrich Bruner.

VERY DARK REDS. Baron de Bonstetten, Black Prince, Emperor of Morocco, M. P. Wilder, Prince C. de Rohan.

Crimson Rambler.

Paul's Carmine Pillar.

White Rambler.

SALMON SHADES. Captain Christy, M'lle C. Bruner, Souvenir de President Carnot.

BLENDED AND VARIEGATED SORTS. Beaute Inconstant Countess R. du Parc, L'Ideal, Madame de Watteville, Marie Van Houtte, Rainbow.

N. B.-We grow the leading sorts of roses in pots, so that if any of our customers are unable to get their planting done during the dormant months, they can purchase potted plants that can be set out at any time, without danger of their dying. $35 \mathrm{c}$ each; $\$ 3.50$ per

dozen. 
CX C.C.MORSE \& CO. PLANTS \& TREES

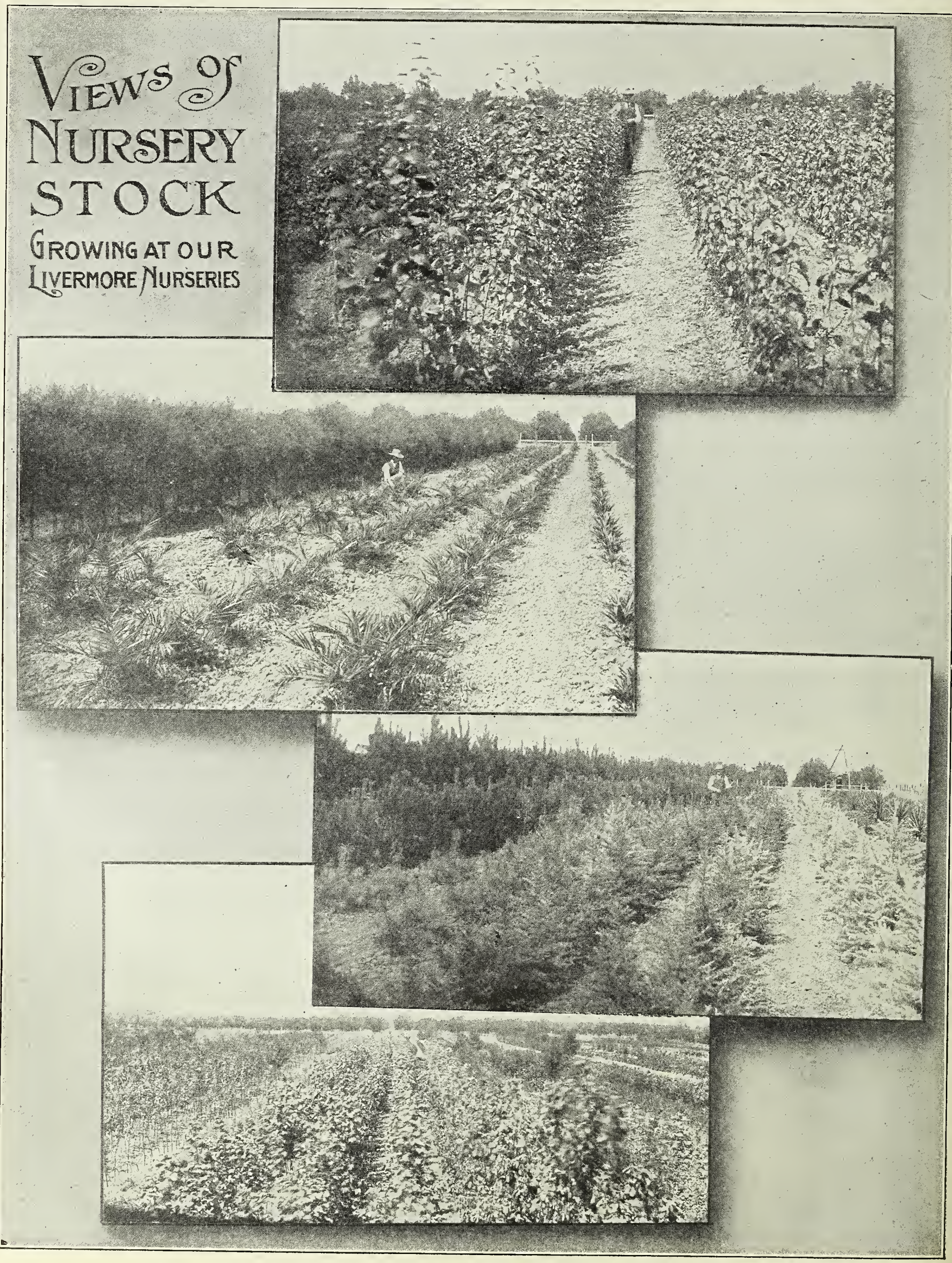




\section{HARDY EVERGREEN TREES AND SHRUBS}

\section{ABIES-SPRUCE, FIR AND HEMLOCK}

Among these will be found some of the grandest coniferous trees in existence. For reforesting they are unequaled and for home beautifying find no rivals; all of fairly rapid growth.

AJANENSIS. A choice variety, with deep sea-green foliage and of most symmetrical growth. The plants we offer have all been grafted. Balled, 1 foot, 50c each; $\$ 4.00$ per 10.

Balsamea (Balsam Fir). A rather slender, tall growing variety, taking the pyramidal shape in its habit of growth. This is one of the most rapid growing trees forming the Conifer group. Foliage very dark green, with soft needles, which have a very pleasant odor. This tree grows to a height of 40 to 60 feet, and does well on a variety of soils; is extremely hardy, and
thrives where other evergeens would fail. Boxed, 2 to $2 \frac{1}{2}$ thrives where oth $\$ 1.50$ each.

Concolor. The color of the foliage of this choice sort is a beautiful bluish green; the needles are long and soft and have a fine fir odor; very hardy in all northern parts of this State. Boxed, 2 to $21 / 2$ feet, $\$ 1.25$ each.

COERULEA HUDSONII. Deep sea-green foliage. Most desirable. Balled, $11 / 2$ feet, $\$ 1.00$ each.

CILICIA (Cillcian Silver Fir). A distinct and beautiful species from the mountains of Asia Minor. It is a compact grower, the branches being thickly set on the stems; foliage dark green; quite hardy. One of the best of the Silver Firs; $4-1$ nch pots, 50c each; $\$ 4.00$ per 10 ; balled, 1 foot, $60 \mathrm{c}$ each; $\$ 5.00$ per 10 ; balled, 2 feet, $\$ 1.50$ each.

CEPHALONICA (Cephalonian Silver Fir). From Europe. A remarkable and beautiful species; very broad for its height; leaves silvery and dagger-shaped with a spine on the point; quite hardy and rigorous. 4-inch pots, 50c each; $\$ 4.00$ per 10; balled, $11 / 2$ to 2 feet, $\$ 1.00$ each; $\$ 8.00$ per 10 .

\section{ABIES DOUGLASII-Douglas Spruce}

Red Fir. Yellow Fir. Oregon Pine. This rariety grows to a height of 300 feet; abounds in the Rocky Mountains. Accommodates itself to many soils, but prefers a deep, moist, cool and well-drained one; succeeds well on a dry, slaty soil and on sand dunes and exposed situations. Surpasses almost all of the Conifers in the rapidity of its growth, and endures much drought. One of the largest and most important forest trees 作 $\$ 5.00$ per $10 ; \$ 35.00$ per 100

ENGELMANNI. This fine new Conifer is found on the higher parts of the Rocky Mountains. In its most favorable localities this species makes a stately tree, 60 to 100 feet high forming a narrow tapering spire of a rather dark hue A suitable tree for reforesting mountain slopes. As a specimen on a lawn it has few equals. Balled, 1 to $11 / 2$ feet; 75 c each; $\$ 6.00$ per 10 ; balled, $21 / 2$ feet, $\$ 2.00$ each.

\section{ABIES EXCELSA-Norway Spruce}

Perhaps one of the best known spruces. It is of rapid growth, attaining large size; habit of growth most symmetrical. In England and Germany this is the sort that is used for Christmas trees. 5-inch pots, 35c each; $\$ 3.00$ per 10; balled, $11 / 2$ to 2 feet, 50 c each; $\$ 4.00$ per 10.

EXCELSA AUREA. The foliage on the upper side golden yellow in color. $1 \frac{1}{2}$ feet, $50 \mathrm{c}$.

FIRMA. A stately tree, attaining in farorable localities a height of 150 feet; branches horizontal. leares deep glossv green above, paler beneath. A native of Japan. Boxed, 2 to $21 \frac{1}{2}$ feet, $\$ 1.50$ each.

GRANDIS. A majestic and graceful tree, towering to a height of 200 feet; leaves arranged in double rows on the branches, apple green above, silvery beneath: very distinct and beautiful. 3-inch pots, 30c each; $\$ 2.50$ per 10 ; balled, 2 to $2 \frac{1}{2}$ feet, $\$ 1.00$ each.

Lasiacarpa. Native of Northern California and Southern Oregon; foliage, sea green; form of tree, most graceful; of quite rapid growth. Balled, 2 feet, 50c each; $\$ 4.00$ per 10.

\section{ABIES MENZĖISII}

A native of Alaska and Northwestern coast; thrives in low elevation, moist soil and climate, and is found in shady places. Beautiful as single speciniens on lawn, or very fine as an arenue tree. $21 / 2$ feet, $\$ 1.50$ each.

Maxwelli. One of the choicer sorts, of most beautiful growth and habit. Grafted plants, balled, 50c each;

MAXIMOWCZI. Grafted plants, 50c each.
MERTENSIANA (California Hemlock Spruce). Branches slen der, drooping and vert uumerous. It grows froul 100 to 150 feet high, forming a roundish conical liead. An exceedingly rapid grower. 5-inch pots, $60 \mathrm{c}$ each.

ABIES NORDMANIANA (Nordmann's Silver Fir) This majestic Fir, from the Crimean Mountains, is of symmetrical dark green, shining above, and slightly glaucous below, rendering and in Europe as one of the finest of the silver Firs. Balled, 10 to 12 inches, 50c each; $\$ 4.00$ per $10 ; 6-1$ inch pots, $60 \mathrm{c}$ each $\$ 5.00$ per $10 ;$ balled, 1 foot, strong plants, $75 \mathrm{c}$ әach; $\$ 6.00$ per 10.

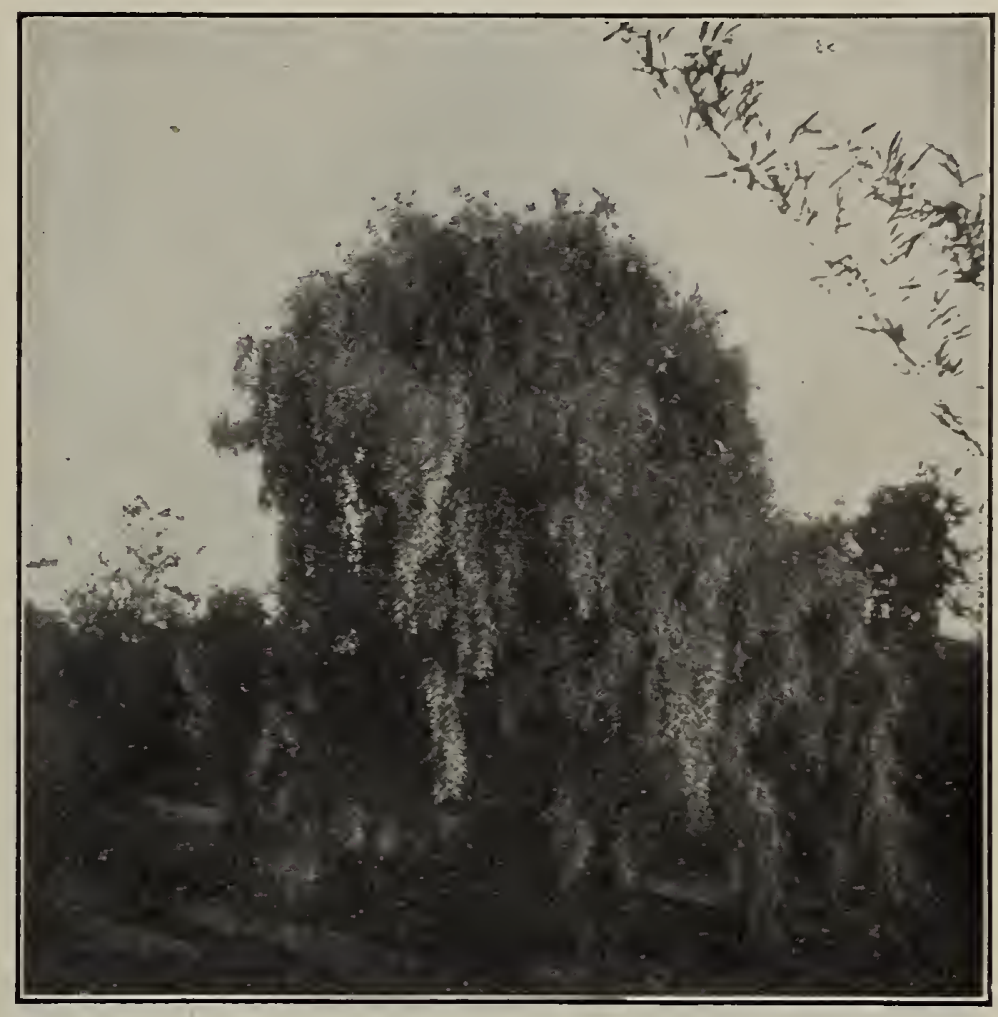

Acacia Retinoldes Florabunda

PARRYANA GLAUCA. A beautiful sort, with lovely sea-green foliage. Balled, 1 to $1 \frac{1}{2}$ feet, $\$ 1.00$ each; $\$ 8.00$ per 10 .

ABIES PINSAPO-(Spanish Silver Fir)

A beautiful tree; its compact growth and unique appearance renders it worthy of a place in the garden. One of the handsomest in this class, Balled. 10 to 12 inches, $40 \mathrm{c}$ each; $\$ 3.00$ per 10 ; balled, $11 / 2$ feet, $\$ 1.00$ each; $\$ 8.00$ per $10 ;$ balled, 2 to $2 \frac{1}{2}$ feet, $\$ 3.00$ each.

PINSAPO GIAUCA. A form of the preceding; the foliage is distinct and beautiful, being of a lorely sea green color. Grafted plants, 35c each; $\$ 3.00$ per 10 .

POLITA (Tiger's Tail Spruce). A distinct Japanese species. It is of erect habit and has rigid sharply pointed leares of a bright green color. Balled, $75 \mathrm{c} \mathrm{each}$.

\section{ACACIA}

The Acacias are all natives of Australia and Tasmania. The wood is valuable and the bark

tanning purposes. They are all of rapid growth and produce their various shades of yellow flowers in great profusion. For quick growth and shade-affording pur-
poses we know of no better tree. We offer the following varieties, all pot grown:

BAILEYANA. One of the most ornamental; foliage beautiful se green, flowers to 2 feet, 35 c each; $\$ 3.00$ per 10.

CULTRIFORMIS. Foliage of this variety is triangular in form; color beautiful sea-green; profuse in bloom; of medium-sized $\$ 3.00$ per 10 . 
ACACIA-Continued

IMPERIALIS. Leaves round, olive-shaped. 2 to $2 \frac{1}{2}$ feet, 25c each; \$2.00 per 10.

LATIF OLIA. Resembles the "Melanoxylon" variety, but leaves are longer and tree more floriferous. 2 to 3 feet, $30 \mathrm{c} \mathrm{each}$ $\$ 2.50$ per $10 ; 5$ to 6 feet, 60 c each; $\$ 5.00$ per 10 .

LOPTHANTHA. Of very rapid growth; very nice when young, but rather coarse as it glows older; where a quick growth is desired this tree will be found desirable. 2 to 3 feet, 25 c each; $\$ 2.00$ per 10.

LINEARIS. Long feathery foliage, very beautiful. 3 to 4 feet, 50c each; $\$ 4.00$ per 10.

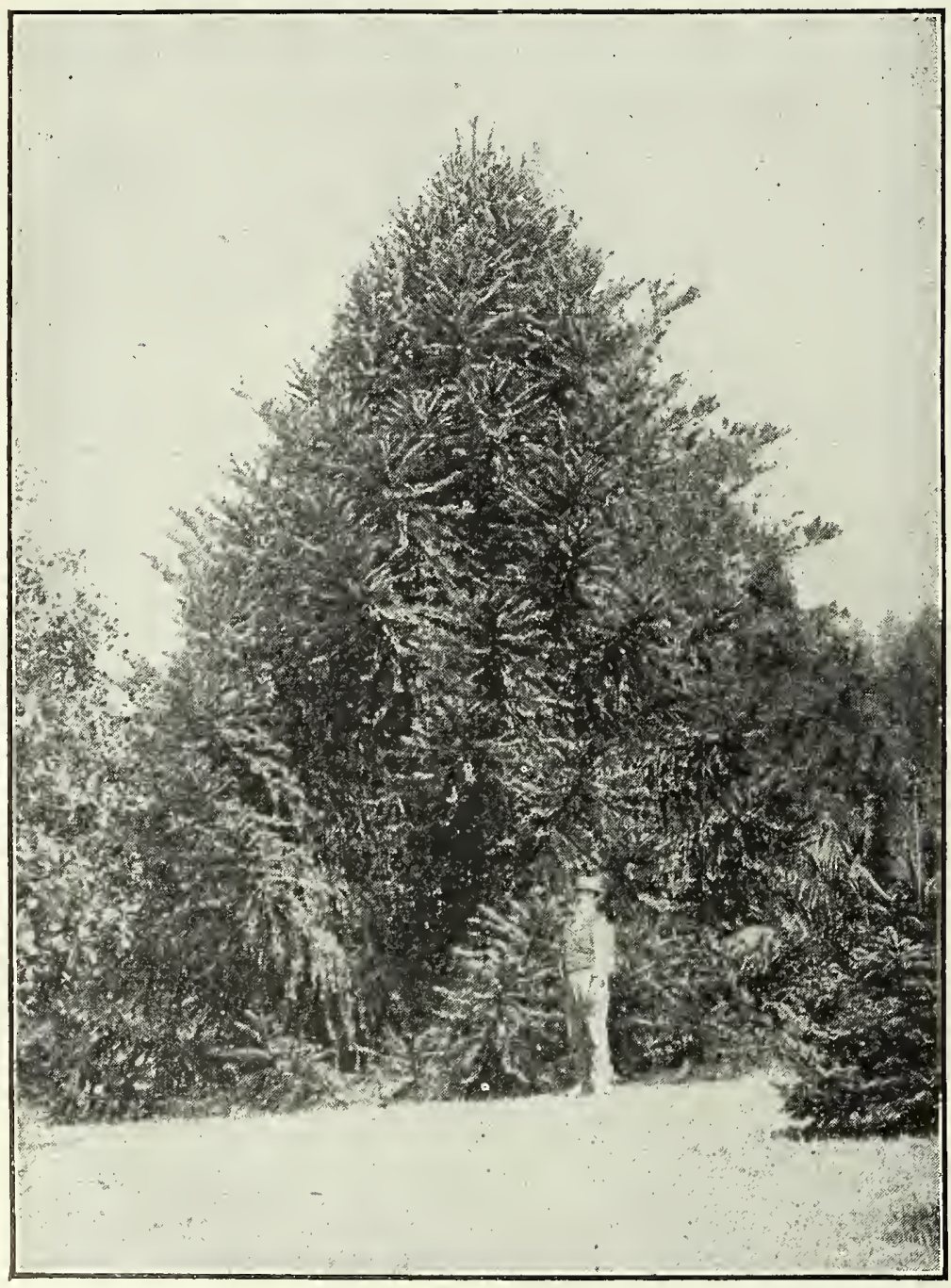

Araucaria Bidwelli-A Majestic Tree

ACACIA MELANOXYION-(Blackwood Tree)

Baron Von Mueller, in his "Select Extra-tropical Plants," writes of this tree: "This well-known Blackwood of our river flats and moist forest valleys. In irrigated glens of deep soil, the tree will at tain a height of 80 feet, with a stem several feet in diameter. The wood is most valuable for furniture, railway and other carriages, boatbuilding (stem and stern post, ribs, rudder), for tool-handles, crutches, some portions of the work of organ-builders, casks, billiard-tables, pianofortes (for sound boards and actions), and numerous other purposes. The fine grained wood is cut into veneers. It takes a polish, and is almost equal to walnut our veneers. It takes a polish, and is almost equal to walnut . Our The great billiard-table firm of Alcock \& Co., in Sydney and Melbourne, have been making tables from it for the last eight years, and at the exhibition of 1888 , there was a piano cased with it which was as handsome a piece of parlor furniture as one could wish to own. The Martini-Henry Rifle Co., have been using it for gun stocks for the last fifteen years because they could get it much cheaper than the French walnut hitherto used by them." Have you any vacant land suitable for the growth of this tree? If so, plant out a grove of them.

ot only is the "Melanoxylon" valuable as above, but for sidewalk or avenue trees it has few equals, being of very rapid growth and it can be trimmed so as to make beautiful specimens. We have $21 \frac{2}{2}$ years ago, and they are now 8 feet high and are trimmed in $21 / 2$ years ago, and they are now 8 feet high and are trimmed in standard form, many people mistaking them for "Bay Trees"
(so much in use for porch decoration). Some of these planterl at same time, and which have not been cut back are now 20 feet high, and have never received a drop of water excepting what they received during the rainy season.

3-inch pots, 2 to 3 feet, 25c each; $\$ 2.00$ per 10.

4 -inch pots, 3 to 4 feet, $40 \mathrm{c}$ each; $\$ 3.50$ per 10

5-inch pots, 5 to 6 feet, 50c each; $\$ 4.00$ per 10 .

6 and 7-1nch pots, 6 to 7 feet, 75c each, $\$ 6.00$ per 10 .

Special quotations on large lots.

MOLLISSIMA. A fine, erect-growing tree, with glaucous green, feathery foliage; flowers yellow, produced in early spring in great profusion. A rapid-growing tree. 2 feet, $35 \mathrm{c}$ each $\$ 3.00$ per $10 ; 3$ feet, 50 c each; $\$ 4.00$ per $10 ; 4$ to $41 / 2$ feet, 75c each.

PYCNANTHA (Golden Wattle). Leaves long and narrow, flowers in long solitary auxiliary spikes.

RETINOIDES FLORABUNDA. Pendulous hábit; sea-green foc each; $\$ 2.50$ per $10 ; 4$ to 5 feet, $50 \mathrm{coc}$ each; $\$ 4.00$ per $10 ;$ $30 \mathrm{c}$ each; $\$ 2.50$ per $10 ; 4$ to 5 feet
6 to 7 feet, $75 \mathrm{c}$ each; $\$ 6.00$ per 10 .

REASIANA. A variety with small, heath-like foliage; of small growth; very free flowering. Makes a lovely lawn tree. 4 feet, 50c each; $\$ 4.00$ per 10 .

SALIGNA. Leaves long and narrow; sea-green in color; very floriferous. 3 to 4 feet, $35 \mathrm{c}$ each; $\$ 3.00$ per $10 ; 5$ to 6 feet, 50 e each; $\$ 4.00$ per 10 .

\section{ARAUCARIA}

Named from Auracanos, the native Chilean name for this tree. We list three varieties, one from Chili, one from Australia, and one from Norfolk Island. Which is the handsomest it is hard for us to say. They are all grand, majestic, noble trees, attaining in time immense proportions.

BIDWELLI. Branches in regular whorls; closely set 'with spiny shining deep-green leaves. Very handsome. Pot grown, $11 / 2$ feet. $\$ 1.00$ each; balled, 2 feet, $\$ 1.50$.

EXCELSA (Norfolk Island Pine). One of the handsomest of all trees; pyramidal in form and very symmetrical; hardy in progrown, 2 feet (very fine), $\$ 3.00$ each; 3 feet, $\$ 4.00$ each.

IMBRICATA (Chili Pine, or Monkey Tree). A fine tree, of regular pvramidal form; leaves bright green, broad, thick,
pointed, overlapping each other. Balled, $\mathbf{2}$ feet, $\$ \mathbf{3} .00$ each.

\section{ARBOR VITAE (See Under Thuja).}

ARDISIA CRISPA. This Japanese shrub is prized chiefly on account of the fine clusters of red berries which it bears at Christmas time in great profusion. 5-inch pots, 50c each.

\section{AUCUBA}

JAPONICA. This shrub is sometimes called the "Gold-Dust Tree," on account of its large, glossy foliage being marked with yellow spots. It is an extremely beautiful plant, and is of slow, spread-
ing growth. In the warmer sections it should have partial shade. Balled, 1 to $11 / 2$ feet, 50c each; $\$ 4.00$ per 10 .

LATIFOLIA VIRIDIS. This variety has dark-green shining foliage; in winter time it is covered with red berries, which greatly enhance its beauty. Balled, $1 \frac{1}{2}$ feet, 50c each; $\$ 4.00$ per 10 .

DENTATA. Leaves deeply cut, glossy and green. Balled, $11 / 2$ feet, $50 \mathrm{c}$ each; $\$ 4.00$ per 10 .

LONGIFOLIA PICTA. Large leaves, beautifully spotted. Balled, $11 / 2$ feet, 50c each; $\$ 4.00$ per 10 .

SPLENDIDA. This variety has beautifully mottled golden foliage. Balled, $1 \frac{1}{2}$ feet, 50c each; $\$ 4.00$ per 10 .

\section{AZALEA INDICA}

'These beautiful plants are becoming more popular every year for forcing, window, store, and conservatory decorations. They are also adapted for outdoor planting. The Azaleas which we offer are all grafted and have bushy crowns, and are well set with flower buds.

We can supply the following named sorts at $\$ 1.50$ each:

APOLLO. Semi-double, dark scarlet.

BERNHARD ANDREAS ALBA. Double, pure white.

CHICAGO. Double, salmon, white margin. 
DE SCHRYVERIANA. Rich rose, shaded vermilion rerl, white margin, dark red blotch.

DEUTSCHE PERLE. Double pure white.

DR. MOORE. Double deep rose.

EMPEROR OF BRAZIL. Double soft rose; extra fine.

EMPRESS OF INDIA. Double, rich rosy salmon.

JOHN LLEWELLYN。 Double soft rose, white margin.

MADAME VAN DER CRUYSSEN. Semi-double crimson.

NIOBE. Double white; very fine.

SIMON MARDNER. Clear pink.

PROFESSOR WOLTERS. Single pink, white margin; undulated. VERVAENEANA. Double, rosy salmon, white margin.

AZARA MICROPHYLLA. A handsome shrub, having small, glossy leaves; orange-yeHow flowers. Pot grown, $1 \frac{1}{2}$ to 2 feet, $50 \mathrm{c}$ each.

\section{BAMBOOS}

Of late years the Bamboos have been receiving quite a lot of attention from the Californians who are interested in the horticultural development of their State. There are great possibilities in Bamboo culture; the Bamboo pole is useful for many purposes, and there are many places in this State where it can be grown successfully and profitably. The San Joaquin Valley, where there is irrigation, would be a good locality for its culture; it needs lots of water, but it must have good drainage. KUMASASA. Small, slender, grassy foliage. Clumps, 2 feet, $50 \mathrm{c}$ each.

MITIS. One of the largest bamboos; it attains a height of 28 to 38 feet. The canes are used extensively for furniture work, water-pipes, etc. Clumps, 50c each.

BLACK. This variety attains a height of 30 feet. The canes are black, used for making walking sticks, umbrella handles, etc. Clumps, 50c each.

QUILIOI. A very large-growing sort, attaining a height of 40 feet. Clumps, 50c each.

BERBERIS DARWINII. This is the finest of all berberis. Foliage thick and leathery; flowers orange-yellow, and deliciously fragrant. Pot grown, 50c each.

\section{THE BOX}

These are useful-some for bordering, some for hedging, and others as single specimens on the lawn. They are all of slow growth, and never attain very large dimensions. None of them produce flowers, but the foliage is handsome.

ARGENTEA. Balled, 1 to $1 \frac{1}{2}$ feet, 35c each. JAPONICA A UREA. Balled, 1 to $1 \frac{1}{2}$ feet, 35c each.

LACROPHYLLA. Balled, 1 to $1 \frac{1}{2}$ feet, 35c each.

NARICULARIS. Balled, 1 to $1 \frac{1}{2}$ feet, $35 \mathrm{c} \mathrm{each}$. PYRAMIDALIS VARIEGATA. Balled, 1 to $1 \frac{1}{2}$ feet, $35 \mathrm{c}$ each.

BOX DWARF (Suffruticosa). A fine small bush, with glossy, roundish leaves. The variety so extensirely used for edging. Strong plants for edging, $75 \mathrm{c}$ dozen, $\$ 5.00$ per 100 .

\section{BREATH OF HEAVEN. See Diosma.}

\section{THE BROOMS}

ANDREANA. The flowers of this variety are yellow and brown; they are not produced for such a long period as those of the Spanish rariety, but on account of their oddity and beauty they are much in demand. 12 to 15 beauty they are mu.
inches, 50c each.

SCOTCH, YELLOW. A very handsome shrub, with drooping branches, covered in the spring rith bright yellow pe a - sh a p ed flowers. Very effective for grouping. 3 feet, 50c each; \$i.00 per 10.
SPANISH. An upright growing slirub. Flowers yellow, procluced very freely in the spring and summer, on long, pendulou

WHITE. 12 to 15 inches, 50c each; $\$ 4.00$ per 10 .

\section{CALIFORNIA NATIVE TREES}

Under this caption will be found trees indigenous to this State. We adrocate strongly the systematic planting of these, so that they be not lost to future generations, as will undoubtedly be the case if some radical change be not effected in forest preservation and forest planting. Why there should be in this country such a lax method of caring for our forests is a wonder to us. In no other country are such methods permitted. As individuals, therefore, it behooves us that we do our very utmost toward reforesting. We head the list with the world famous

\section{CALIFORNIA BIG TREE-(Sequoia Gigantea)}

This is the largest tree known to exist on the American continent. The bark is from one to two feet thick. One of the largest trees (the so-called Grizzly Giant of the Mariposa Grove) is 93 feet in circumference at the ground. 4-inch pots, 30c each; $\$ 2.50$ per
10 ; balled, (fine specimens), $21 / 2$ to 3 feet, $75 \mathrm{c}$ each; $\$ 6.00$ per 10 ; balled, 5 feet, $\$ 4.00$ each.

CALIFORNIA REDWOOD (Sequoia sempervirens). From this tree is obtained the most valuable timber of the California forests. It attains a height of 200 to 250 feet, and from 8 to 12 feet in diameter. The wood is of a rich brownish red, strong anrl diameter. The wood is of a rich brownish red, strong ach; $\$ 2.50$ per 10 ; balled, 2 to 3 feet, $75 \mathrm{c}$ each; $\$ 6.00$ per 10 .

CALIFORNIA LIVE OAK (Quercus agrifolia). A familiar sight in our California landscapes, which adds so much to its beauty. Bailed, 2 feet, $50 \mathrm{c}$

CYPRESS MONTEREY. See page 92.

DOUGLAS SPRUCE. See Abies Douglasii, page 89.

LAWSON CYPRESS. See page 92.

PINE, MONTEREY. See page 96.

PINE, PONDEROSA. See page 96.

THUJA GIGANTEA. See page 96.

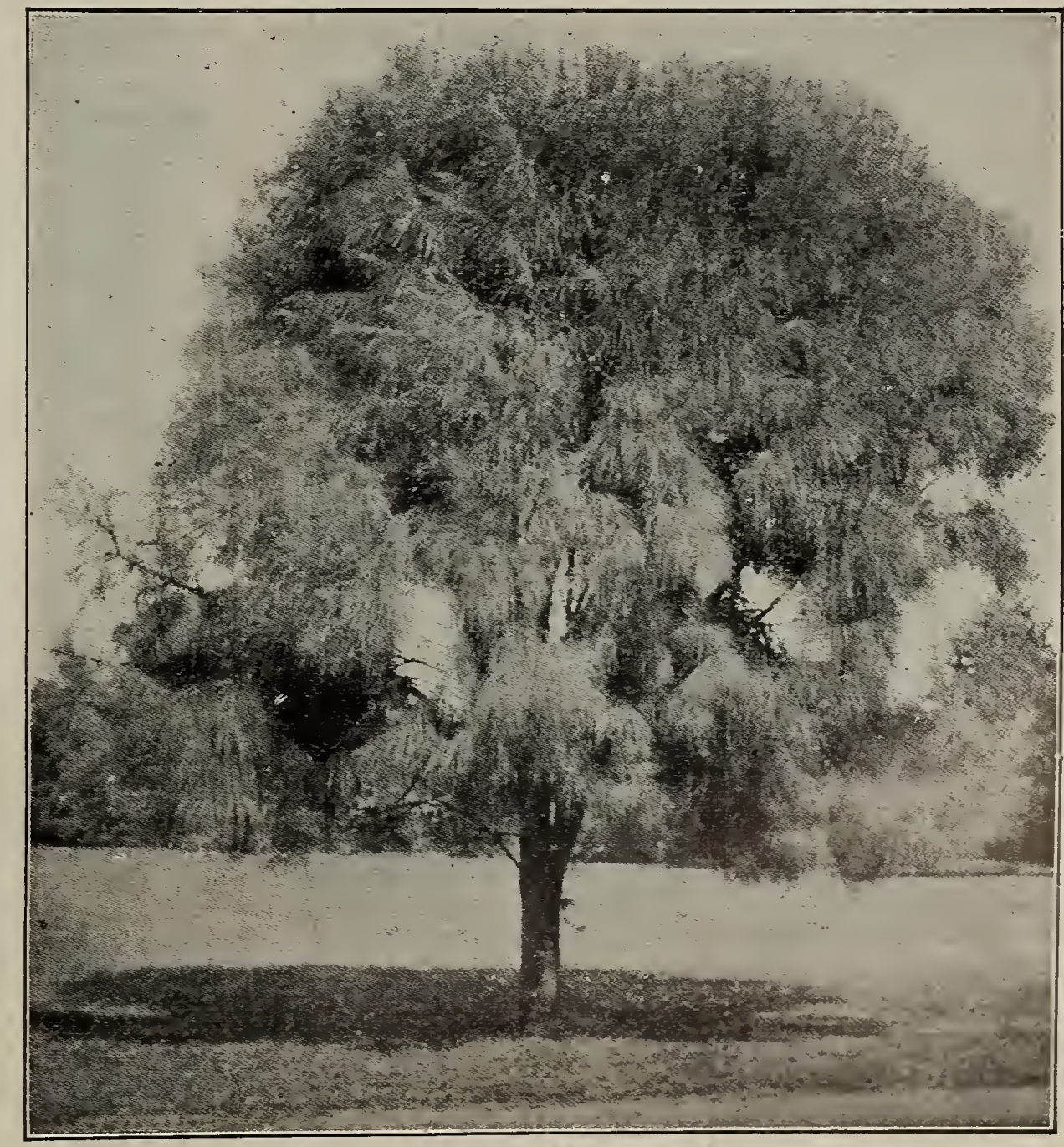

Casuarina Stricta. Reef Wood of Australia Read description, it will pay you 
CAMELLIAS. These showy Japanese shrubs are familiar to nearly every one. They bloom early in springtime, and are a great acquisition to the garden. The waxy odorless flowers are produced very freely. We offer the Double White, $80 \mathrm{c}$ to $\$ 1.00$ each; Double Pink, $80 \mathrm{c}$ to $\$ 1.00$ each; Double Red, 80c to $\$ 1.00$ each.

CAMPHOR TREE (Laurus Camphora). A fast-growing, very symmetrical, ornamental tree, thriving in the very poorest soil. A native of Japan. Bright green foliage; well adapted for lawn
purposes. 5 -inch pots, 2 feet, 40 each; 5 -inch pots, 3 feet, 60 c each; balled, $2 \frac{1}{2}$ to 3 feet, $\$ 1.50$ each.

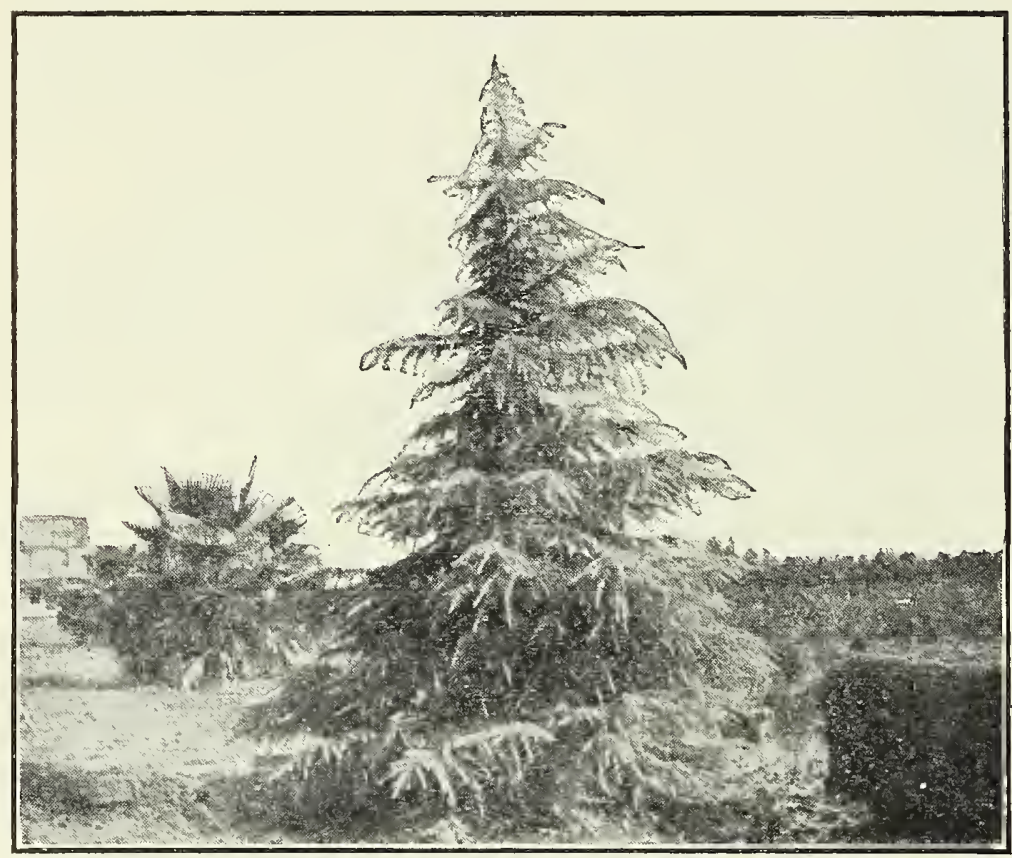

Cedrus Deodora. The Queen of Evergreens

\section{CASUARINA}

(Beef Wood, She Oak)

The picture of the Casuarina gives us a good idea of the habit of this beautiful tree. The Casuarina is supposed to be named after the Cassowary, a native bird of Australia (akin to the ostrich and emu) on account of its long plume-like foliage, which somewhat resembles the plumage of that bird. The leafless branches are long and pendulous and dark green in color. They are eminently adapted for forest planting in California. The Casuarinas are of very rapid growth and suit themselves alike to the cold bleak winds of the ocean or the hot interior valleys. The wood is very hard and can be advantageously used for many mechanical purposes. As an ornamental tree, we consider the Casuarina one of our best evergreen trees and as a tree for making windbreaks or hedges we consider it has no equal, being of such rapid growth and standing pruning so well. The more it is pruned the denser it becomes. They are indigenous to tropical Australia, and some are found in New Caledonia and India. We offer the following varieties: EQUISETIFOLIA. 5-inch pots, $2 \frac{1}{2}$ to 3 feet, 35c each; $\$ 3.00$
per 10.

STRICTA. 5-inch pots, 2 to 3 feet, 35c each; $\$ 3.00$ per 10.

STRICTA. Balled, $2 \frac{1}{2}$ to 3 feet; 50c each; $\$ 3.50$ per $10 ; \$ 30.00$ per 100.

STRICTA. Balled, 5 to 6 feet, $60 \mathrm{c}$ each; $\$ 5.00$ per 10 .

STRICTA. Transplanted in boxes, $\$ 5.00$ per 100 .

SUBEROSA. 5-inch pots, 3 feet, 35c each; $\$ 3.00$ per 10 .

\section{CEDAR OF LEBANON}

This grand old historic tree, old as it is, has always retained a warm spot in the hearts of tree lovers. It is possessed of much grandeur and for lawn or park adornment it is peculiarly adapted. 5-inch pots, $40 \mathrm{c}$ each; $\$ 3.50$ per $10 ;$ balled, 2
feet, $75 \mathrm{c}$ each; $\$ 6.00$ per $10 ; 3$ feet, $\$ 1.00$ each; $\$ 8.00$ per 10 .
CEDRUS DEODORA (Indian or Himalayan Cedar.) If we were asked to name the handsomest coniferous tree, we would, we think, be compelled to say that the Indian Cedar came as near being perfect as it were possible. The majesty and grandeur of this native of the Himalayan mountains is soul inspiring. To view its gräceful proportions, its lovely sea-green drooping branches, is certainly a treat that all must appreciate. It is perfectly at home in this State, growing rapidly; it grows in the hot valleys to perfection, in fact that is where one sees the finest specimens. As an avenue tree (where it can have plenty of space), it is unsurpassed and alternating it with a
Phoenix Canariensis the two make a grand combination. We have a fine stock of these to offer. The plants are finely shaped and beautifully colored. 5-inch, pots, $50 \mathrm{c}$ each; $\$ 4.00$ per 10; balled, 2 feet, $75 \mathrm{c}$ each; $\$ 6.00$ per 10 ; balled, 3 feet, $\$ 1.25$ each; $\$ 10.00$ per $10 ;$ balled, 4 feet, $\$ 1.75$ each; $\$ 15.00$ per 10.

THE ATLANTIC CEDAR. Another very fine sort, with very dark green foliage and of upright rapid growth. Balled, 2 feet, $75 \mathrm{c}$ each; $\$ 6.00$ per $10 ;$ balled, 3 feet, $\$ 1.00$ each; $\$ 8.00$ per 10 ; balled, 4 feet, $\$ 1.50$ each; $\$ 12.50$ per 10 .

CEANOTHUS. Known as Callfornia Lilac. It is an evergreen shrub of great beauty, having beautiful blue fluffy flowers borne in great profusion. 15 to 18 inches, $50 \mathrm{c}$ each.

COTONEASTER. A small growing evergreen of low-spreading habit; small round foliage; producing red berries along its branches, very showy. 5-inch pots, 50c each.

CRATAEGUS CUNEATUM. An evergreen species of the Hawthorn family. It is of dwarfish habit with glossy foliage, and has pots, 15 to 18 inches, $35 \mathrm{c}$ each.

\section{CYPRESS}

GLAUCOUS. A species that is very handsome. The foliage is beautiful sea-green, and the habit of growth is spreading; of very rapid growth. 3-inch pots, $25 \mathrm{c}$ each; $\$ 2.00$ per 10 ; balled, 3 to 4 feet, $35 \mathrm{c} \mathrm{each} ; \$ 3.00$ per 10 .

LAWSON. This California species has great beauty. It is of rather an upright growth; the branclies droop gracefully and the foliage is of a lovely sea-green color. 4 -inch pots, 5oc each; $\$ 4.00$ per 10 ; balled, $2 \frac{1}{2}$ to 3 feet, $75 \mathrm{c}$ each; $\$ 6.00$ per 10 .

LAWSON SILVER. In all respects, save color, this Cypress resembles the preceding. The foliage is indescribably lovely, being of a rich shade of silvery gray, which is not found in many trees. 4 -inch pots, 50c each; $\$ 4.00$ per 10; balled, $2 \frac{1}{2}$ to 3 feet $75 \mathrm{c}$ each; $\$ 6.00$ per 10 .

MONTEREY. A native of California, and one of the most desirable of evergreens; stands pruning well; very extensively planted for hedges. Transplanted in boxes. 2 years, $\$ 3.00$ per box, $(90$ to 100 in box). 1 year, $\$ 2.50$ per $100 ; \$ 20.00$ per 1000 ; pot grown, $1 \frac{1}{2}$ feet, 20c each; $\$ 1.50$ per $10 ; \$ 12.50$ per 100 2 feet, $25 \mathrm{c}$ each; $\$ 2.00$ per $10 ; \$ 15.00$ per $100 ;$ balleã, 2 to feet, $35 \mathrm{c}$ each; $\$ 3.00$ per $10 ; \$ 25.00$ per $100 ;$ balled, 3 to 4 feet, 40 c each; $\$ 3.50$ per $10 ; \$ 30.00$ per 100 .

ITALIAN. Of upright pyramidal growth. Balled, 3 to 4 feet, 75c each.

INTERTEXTA. Foliage dark green, of drooping habit; a fine variety for lawn purposes. Balled, 3 feet, $75 \mathrm{c}$ each.

FRASERII. In this variety, perhaps, we have one of the handsomest of its class; foliage lovely sea-green, much flattened, rendering it a grand lawn tree. Balled, 1 foot, $50 \mathrm{c}$ each.

LAWSONIANA NIFIFERA NANUS. As the name implies, this rare sort is of dwarf habit; the foliage is dark green and "fern like" in appearance. When a dwarf growing evergreen is wanted this variety will be found suitable. Balled, 1 to $11 / 2$ feet, $75 \mathrm{c}$ each.

LUTESCENS. Another rare sort, rarely found in collections, foliage beautiful golden yellow. Balled, fine bushy plants, $1 \frac{1}{2}$ feet, $75 \mathrm{c}$ each.

FUNEBRIS. An old favorite, much used for cemetery work; the foliage assumes a drooping habit; color pleasing green. A very lovely sort. Balled, 2 to $2 \frac{1}{2}$ feet, 50 each.

WOORLEYII. Another of the Lawson type of Cypress. Resembles somewhat in appearance the well known Italian Cypress. Balled. 2 feet, 50c each.

\section{CRYPTOMERIA JAPONICA}

The following extract taken from the "Florists' Exchange" issue of July 15, 1905, and to which we are indebted for the accompanying photograph, may be of interest to our readers:

"Here in Japan the timber of 'sugi' (Cryptomeria Japonica) is the most highly valued of all for general building purposes. Trees of 20 feet circumference are not rare in the temple groves around Nikko, and single specimens of larger proportions have been found. The 


\section{SAN FRANCISCO CALIFORNIA U.S.A.}

trees always grow as straight as an arrow, without any knots, to the height of over 100 feet. Sugi lias been much used in temple building, and there has shown its marvelous resisting power.

"The illustration shows an avenue which has evidently been planted, but your correspondent has seen the trees grow in natural groves as close together as the picture shows them, one tall shaft next to the other, all of even height, branchless to a height of 100 feet or more, as straight as trees can be, shooting perpendicularly out of the fertile soil. Imagine large tracts of hundreds of acres planted with this tree where they would grow as fast as here, attaining a diameter of one foot in 25 to 30 years; a more profitable tree could hardly be thought of.'

The Cryptomeria thrives well in a dry, hot climate; therefore it is just the tree for this State. It is of rapid growth, and is very ornamental as a young tree. 4 and 5 -inch pots, 2 to $21 / 2$ feet, $60 \mathrm{c}$ each; $\$ 4.00$ per $10 ; \$ 30.00$ per 100. Balled, 3 to 4 feet, $\$ 1.00$ each; $\$ 8.00$ per 10 .

\section{DAPHNES}

The Daphnes are, we think, very familiar to most of our readers. To those who do not know them we will try and describe them. They are evergreens; the leaves are very pretty; but it is the flowers that attract attention when they are in blossom in early spring; they are small, sweetly scented, and appear in great profusion. They come in two separate colors. White, $11 / 2$ feet, $\$ 1.00$ each; $35 / 8$ eet, $\$ 2.50$ each; Pink, $1 \frac{1}{2}$ feet, $\$ 1.00$ each.

DIOSMA ALBA (Breath of Heaven). This shrub never attains large proportions. It produces small white star-shaped flowers in great numbers. The 10 to 12 inches, $30 \mathrm{~cm}$ ea ${ }^{2}$ balled. 1 foot, $50 \mathrm{c}$ each; 1 1/2 feet, bushy, $75 \mathrm{c} \mathrm{each}$. $\$ 6.00$ per 10.

EUGENIA APICULATA. A very pretty shrub, of small growth, with pretty sweet smelling white flowers, something like the myrtle. 4-inch pots, $35 \mathrm{c}$ each.

\section{EUCALYPTI}

(Ecualyptus means "Well concealed" refering to the complete manner in which the essential organs of the flowers are concealed.)

There is no doubt in our mind but that the Eucalypti are destined to become the forest tree for this State, just as the Redwood and Big Tree have been in the past. They are all natives of Australia, the climate of which in many respects is similar to our own. The rapidity of growth, the durability of the timber and adaptability to almost any California climate or soil are recommendations which appeal very forcibly to us.

AMYGDALINA, Pepper Gum. Belonging to this variety are the tallest trees in the world. In Gippsland, Australia, are trees over 500 feet in height; makes first-class timber for flooring, boards, scantling, etc., and is well suited for avenue planting; yields more essential oil than any other variety. Pot grown, 2 feet, $25 \mathrm{c}$ each; $\$ 2.00$ per 10 .

CREBRA, Ironbark. A moderate sized tree. Timber red, very valuable, hard, tough, inlocked and strong; much esteemed by coach-builders and wheelwrights for poles and shafts of carriages, and spokes and naves of wheels; also for piles and railway sleepers, and in the construction of bridges. Thrives well inland in open forests and on gravelly ridges. Endures minimum temperatures of 18 to 20 degrees and maximum of 110 to 118 degrees. Pot grown, 2 to 3 feet, $25 \mathrm{c} \mathrm{each; \$ 2.00} \mathrm{per} 10$

CAMB AGEII. A tree about 80 to 100 feet high and 3 to 4 feet diameter. Grows well in hilly or mountainous country. Timber hard and close grained; used for fencing material, building purposes and makes good fuel. Transplanted in boxes, 2 years, $\$ 2.50$ per 100 .

CITRIODORA, Lemon-Scented Gum. A unique varietr; leaves highly perfumed, like Lemon Verbena. Pot grown, 25c each.

CORIACEA, White Gum. A tree of 80 to 100 feet in height and 4 feet diameter, of handsome appearance, with drooping branches. The foliage is eaten by cattle and sheep in dry seasons. It is a very hardy Eucalypt, and grows well in swampy lowlands, and very hardy Eucalypt, and grows well in swampy lowlands, and thrives in cold climates, and is not affected by snow, but will not
stand a hot, dry atmosphere. Timber used for building and stand a hot, dry atmosphere. Timber used for building and per 100.

CORYNOCALYX, Sugar Gum. Very ornamental; rapid growing with dark green leaves; timber verv durable and used for railroad ties. This gum will grow in a variety of climates; it thrives near the coast and will grow in a variety of climates; it thrives near the coast and grows equally well in parts of Southern Arizona.
It is of course benefited by moisture, but endures a great amount of drourht; stands intense heat of summer 115 degrees $F$ and a minimum of 20 degrees to 25 degrees. Transplanted in boxes, $\$ 2.50$ per $100 ;$
pot grown, 1 to $1 \frac{1}{2}$ feet, $20 \mathrm{c}$ each; $\$ 1.50$ per 10.00 .

FICIFOLIA, Scarlet-flowering Gum. A beautiful sort, bearing lovely scarlet flowers, thick leathery leaves; hardy only in
warmer sections. Pot grown, 1 1 2 feet, $50 \mathrm{c}$ each; $\$ 4.00$ per 10 .

GLOBULUS, Tasmanian Blue Gum. One of the most useful of all and of very rapid growth. Adapts itself to a variety of climatic conditions. It thrives in moist, warm regions and liot, dry ones; it succeeds in moist lowlands and dry stony uplands. Excellent for removing stagnant water. Resistant to both quite high and low temperatures. Great extremes always injury to young growth, but not permanent, as it rapidly outgrows this. Iost extensively planted of any sort. Transgrows this. Mlost extensively planted of any sort. Transplanted in boxes, $\$ 2.25$ per box (averaging 85 to 90 in box); $\$ 20.00$ per $1000 ;$ pot grown, $11 / 2$ to 2 leet, $15 \mathrm{c}$ each; $\$ 1.25$ per $10 ; \$ 10.00$ per $100 ;$ pot grown, $21 / 2$ to 3 feet, $25 \mathrm{c}$ each;
$\$ 2.00$ per $10 ; \$ 15.00$ per $100 ;$ pot grown, 3 to 4 feet,

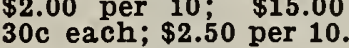

N. B.-Pot grown plants we can recommend for various reasons. For shipping they are knocked out of the pots, without disturbing or injuring the roots, hence no loss ensues in transplanting. They are light and cost of transportation is therefore low.

HEMIPHLOIA, Gray Box. Wood very hard, strong and durable above ground; also makes a first class fuel. At Santa Barbara this variety has attained a height of 80 feet and a diameter of 18 inches in 20 years. This Eucalyptus thrives near the coast and in the hot dry valleys of the interior. Endures a maximum temperature of 110 to 115 degrees and a minimum of 15 degrees to 20 degrees. Transplanted in boxes, 2 years, $\$ 2.50$ per
100 .

MARGINATA, The Jarrah of West Australia. Famed for its indestructibility; used largely for shipbuilding, railway sleepers, piles for jetties, and all purposes where strength and durability are required. This variety does not thrive near the coast and
only fairly well in the valley. Pot grown, $11 / 2$ to 2 feet, $20 \mathrm{c}$ each; $\$ 1.50$ per 10 .

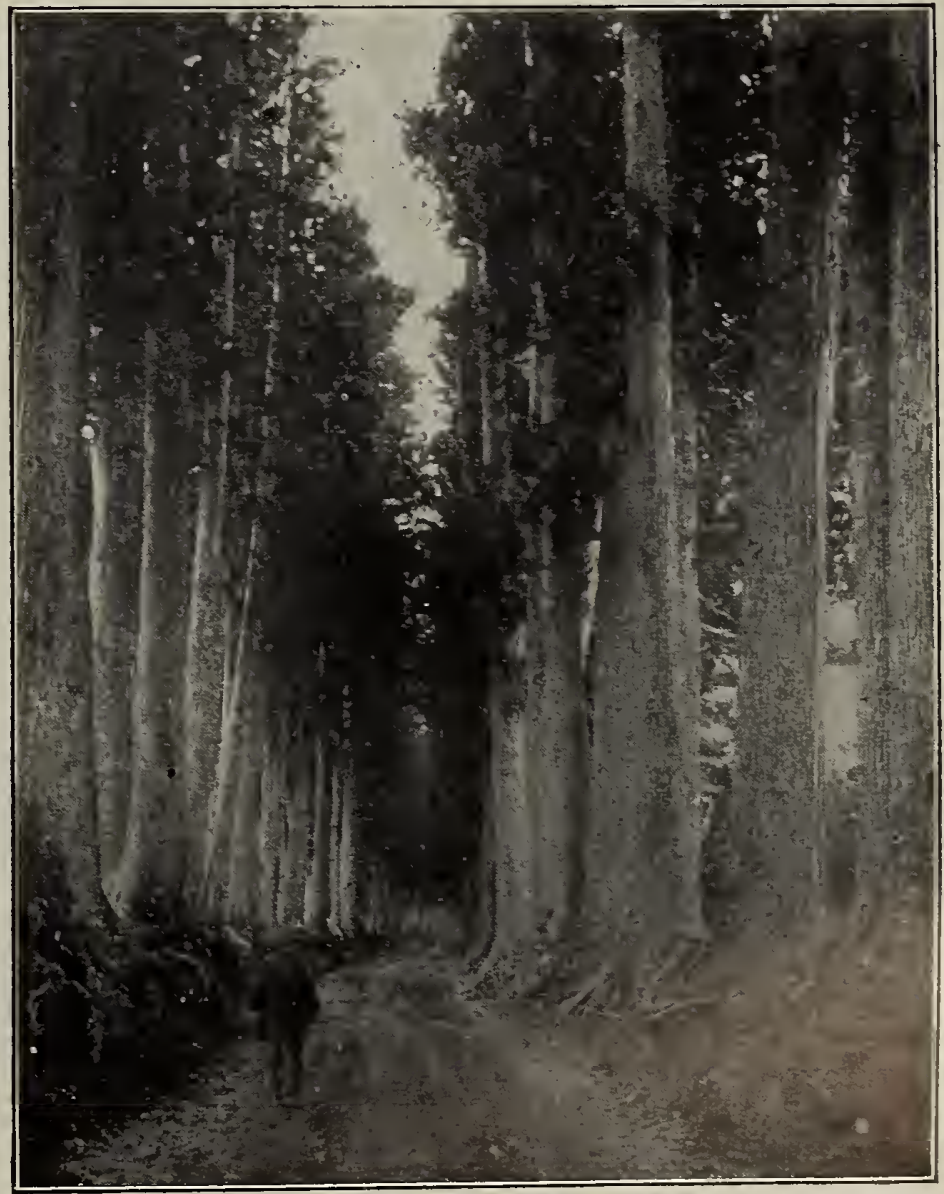

A Forest in Japan of Cryptomeria Japonica

OBLIQUA (Stringy. Bark). Produces good wood for flooring. scantling and shingles; also used in the manufacture of paper, Inferior as fuel, but makes the best charcoal for the forge. Grows not endure extremes. Transplanted in boxes, 2 years, $\$ 2.50$ per 100 . 


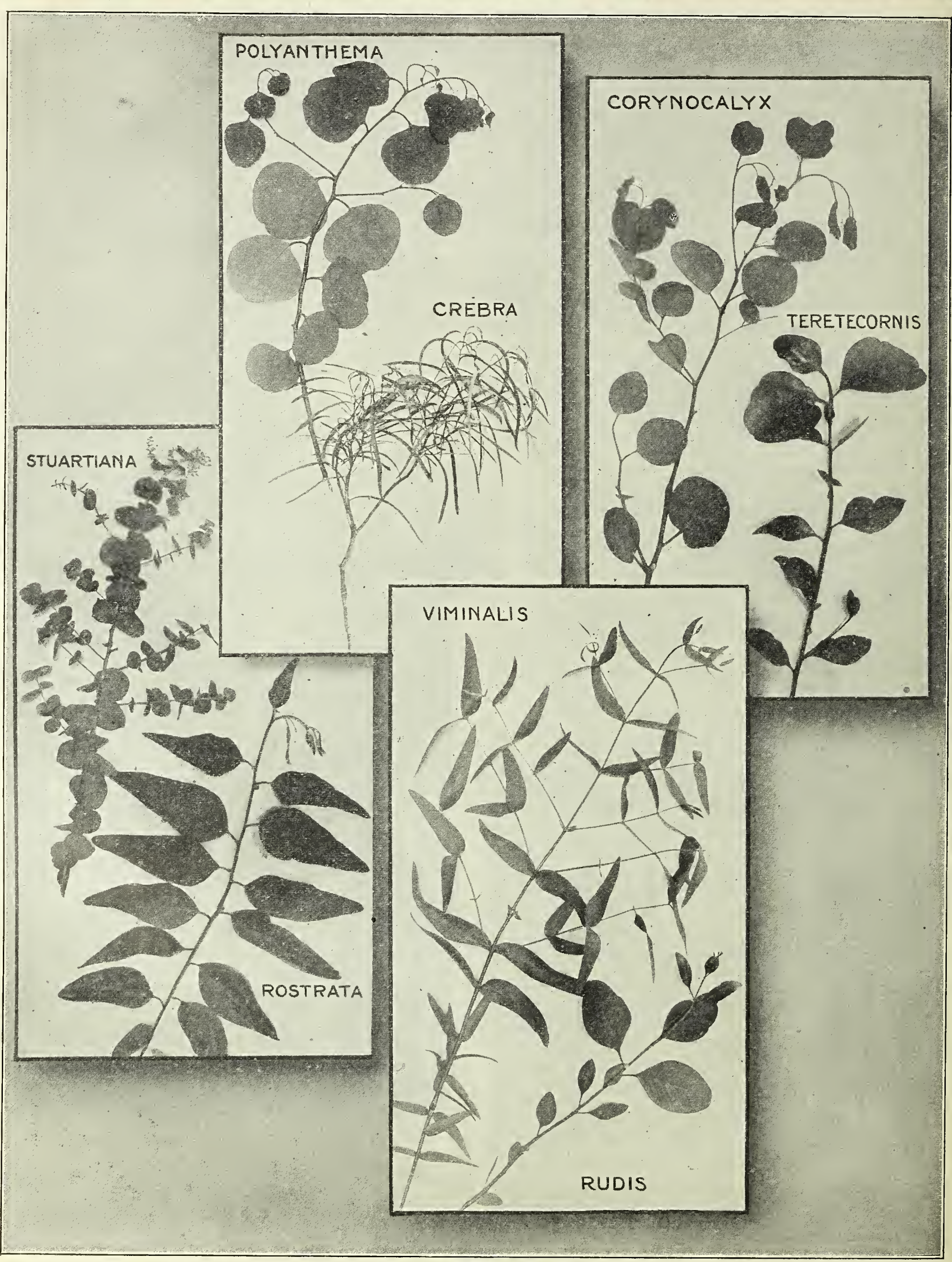


PIPERITA (Peppermint Gum). Timber valuable for fence rails, shingles, etc.; yields a greater quantity of oil than any other boxes, 2 years, $\$ 2.50$ per 100 .

POLYANTHEMA, Red Box. A moderate grower; timber valuable for underground work, being remarkably hard and durable. Endures extremes from the coast to the hot interior valleys and foothills. Maximum temperature 110 to 118 degrees. minimum 15 to 20 degrees. One of the handsomest of the family; very $21 / 2$ feet, $20 \mathrm{c}$ each; $\$ 1.50$ per $10 ; 3$ feet, $25 \mathrm{c}$ each; $\$ 2.00$ per 10.

ROBUSTA, Swamp-Mahogany Gum. Best adapted to a moist, warm climate. Very symmetrical while young; quite brittle as it grows older; branches directly opposite in regular whorls; foliage large, of a deep, glossy green color; flowers large, creamyTransplanted in boxes, 2 years, $\$ 2.50$ per 100

ROSTRATA, Red Gum. Said to attain to a height of 200 feet; a rapid grower, coming second to "Globulus," more frost resistant than it and said to thrive in alkali soil. Adapted to the coast and hot interior valleys. Maximum temperature 110 to 115 degrees, minimum 15 to 20 degrees. The wood takes on an exceptionally high polish, suitable for interior finish. For this purpose the wood will be of value; it is extremely durable. The purpose the wood will be of value; it is extremely durable. The
growth is not always straight, but when the first growth is cut growth is not always straight, but when the first growth is cut
down and the second grows up they appear to grow much straighter; close planting will in a measure help to make them grow more erect. Pot grown, 2 feet, $15 \mathrm{c}$ each; $\$ 1.25$ per 10;
3 feet, 25c each; $\$ 2.00$ per 10. Transplanted in boxes, one year, $\$ 2.50$ per $100 ; \$ 18.00$ per 1000 .

RUDIS. This has been grown very extensively around Fresno, where it has been found to make an excellent avenue tree and also to be of very rapid growth. It withstands both. heat and cold and in Arizona its suitability to conditions there has been fully established. It is a very rapid grower and the wood is quite hard and tenacious. The practical uses of this variety have not been fully demonstrated. Maximum temperature 110 have not been fuly demonstrated. Maximum temperature 110 to 118 degrees, minimum 15 to 18 degrees. Pot grown, 2 to 3
feet, 25c each; $\$ 2.00$ per 10 . Transplanted in boxes, $\$ 2.50$ per 100 .

SALIGNA. Has not been extensively planted, so no data are forthcoming as to its requirements. In Australia it is said to grow to a height of 100 to 200 feet and is confined to the warmest coast regions, hence it cannot be expected to endure very severe extremes. Transplanted in boxes, 2 years, $\$ 2.50$ per 100 .

SIDEROPHLOIA. Broad Leaved, Iron Bark. This variety, in Australia, attains a height of 100 feet or more, with a trunk in diameter of 3 to 4 feet; grows fairly well in quite a variety of situations in the Coast range of California, but will not thrive in
the dry, hot valleys. The timber is strong and durable. Pot grown, 2 to 3 feet, $20 \mathrm{c}$ each; $\$ 1.50$ per 10.

TERETECORNIS, Forest Red Gum. This variety has been receiving much attention of late years. At Mr. Cooper's ranch, Santa Barbara, their rate of growth has been about two-thirds that of the Globulus. It grows best near the coast. but endures the dry heat of the interior valleys. Maximum temperature 110 to 115 degrees, minimum 15 to 20 degrees. The wood is red. each; $\$ 1.50$ per 10 .

STUARTIANA, Apple-scented Gum. Of medium growth, quite erect and stocky; a great resister of frost, enduring temperatures as low as 10 to 18 degrees $F$. Valuable for wind-breaks; timber useful for fence posts and for fuel. Transplanted in boxes, $\$ 3.50$ per 100 .

VIMINALIS, Manna Gum. A rapid-growing variety and very hardy; on rich soil it grows to a gigantic size; the young bark and leaves yield Australian manna-a hard, opaque, sweet
substance. Pot grown, $1 \frac{1}{2}$ to 2 feet, 25c each; $\$ 2.00$ per 10.

ESCALONIA ROSEA. A beautiful low growing shrub, producing lovely pink blossoms. 3-inch pots, 25c each; $\$ 2.00$ per 10.

EUONYMUS, SILVER VARIEGATED. A very pretty ornamental shrub; the foliage is silvery yellow. Balled, 3 to 4 feet, $75 \mathrm{c}$ each.

EUONYMUS, DUC D'ANJOU. Golden blotch in center of leaf. Balled, 1 to $1 \frac{1}{2}$ feet, $35 \mathrm{c} \mathrm{each} ; \$ 3.00$ per 10 .

FABIANA IMBRICATA. A very pretty heath-like shrub of erect growth, producing pure white tube-shaped flowers in great pro-
fusion. When in bloom it is a most lovely shrub. 4-inch pots, $25 \mathrm{c}$ each.

GREVILLEA ROBUSTA (Australian Silk Oak). A splendid fern-leaved evergreen tree, which makes a magnificent pot plant for all sorts of decorative purposes; flowers golden yellow; planted out in this State, it soon forms a magnificent lawn or shade tree. 3-inch pots
60c each.

HABROTHAMNUS ELEGANS. A strong-growing shrub, bearing panicles of small trumpet-shaped, purplish red flowers; makes a grand showing on a lawn or trained against a wall or porch. Pot grown, 2 feet, 25c each.
HEATH, MEDiTERRANEAN. This variety is most desirable it produces its small wax-like pink flowers in wonderful profusion.

HEATH, WHITE. A beautiful sort; white flowers. 5-inch pots, 12 to 15 inches, 50 each.

HEATH, RED. This variety has red flowers. 4-inch pots, 12 to 15 inches, 500 each.

HOLLY, EUROPEAN. A small tree, with shining dark-green thorny leaves, somewhat resembling the oak in form. In w11ter $75 \mathrm{c}$ each. Balled, 2 to $21 / 2$ feet, $\$ 1.50$ each.

HOLLY, SILVER. Variegated. Balled, 15 to 18 inches, 50c each.

JACARANDA MIMOSIFOLIA. A beautiful evergreen sliade tree, with fine acacia-like foliage; it produces a handsome, showy blue flower. Much used in the soutlern part of the
State as a sidewalk tree; not hardy in colder sections. Pot grown, 15 to 18 inches, 35c each; $\$ 3.00$ per 10.

JUNIPER, IRISH. A distinct and beautiful sort, of erect, dense, conical outline and upright growth; short glaucous-green foliage.
Fine for planting in cemeteries. Balled, 2 to 3 feet, 75c; $\$ 6.00$ per 10.

LAUREL, ENGLISH. A fine evergreen, with broad shining green leaves, produces large panicles of creamy-white flowers, followed
by purple berries. Balled, 2 to $2 \frac{1}{2}$ feet, $60 \mathrm{c}$ each.

LAUREL, PORTUGAL. Balled, 2 feet, $60 \mathrm{c} \mathrm{each}$.

LAUREL, SWEET BAY. A very ornamental, upright growing slirub, with deep, dark-green, fragrant leaves, and covered in the fall with berries. If properly pruned, one of the handsomest of decorative plants, The leaves are placed between the layers fruit. 5-inch pots, $11 / 2$ feet, 50c each; balled, 3 feet, $75 \mathrm{c}$ each; 4 feet, $\$ 1.50$ each.

IA URUSTINUS, VARIEGATED FOLIAGE. 4-inch pots, 25c each; $\$ 2.00$ per 10 .

LAURUSTINUS. A well-known winter flowering shrub, of great beauty, producing an abundance of white flowers; well adapted $11 / 2$ to 2 feet, $50 c$ each; balled, $11 / 2$ feet, 35 c each; $\$ 3.00$ per 10.

LIB OCEDRUS CHILENSIS. One of our beautiful coniferous trees; of low compact growth; foliage, pleasing green and crimpled in appearance. Balled, 15 to 18 inches, $50 \mathrm{c}$ each;

IIGUSTRUM JAPONICUM. (Japanese Privet). Produces large clusters of white flowers, slightly fragrant, followed by purge-growing shrub (or small tree). Makes an excellent hedge; stands trimming well. It also makes a very handsome sidewalk tree when trimmed up. Balled, 2 to 3 feet, $35 \mathrm{c}$ each;
$\$ 3.00$ per 10; balled, 4 to 5 feet, 60c each; $\$ 5.00$ per 10; special prices on large lots.

LIGUSTRUM OVALIFOLIUM (California Privet). A valuable hedge plant; stands pruning well, and is of rapi
$21 / 2$ feet, 15 c each; $\$ 1.00$ per $10 ; \$ 8.00$ per 100 .

LIGUSTRUM ELEGANTISSIMA AUREA. A variety with beautiful golden foliage. 3 feet, $50 \mathrm{c}$ each; $\$ 4.00$ per 10.

LOQUAT. This tree produces a very delicious fruit, which ripens in early summer; it comes in clusters, and is yellow in color. It is also valuable as an ornamental tree; the leaves are large,
crumpled and olive-green in color. Pot grown, 2 to $2 \frac{1}{2}$ feet, 50c each.

MAGNOLIA GRANDIFLORA OXONIENSIS. A lovely evergreen species, with large, leathery, bright green leaves that look as if made of wax, a foot or eighteen inches long and four inches fragrant white flowers. Very choice. Pot grown plants, 2 feet, $\$ 1.50$ each.

MAGNOLIA GRANDIFLORA. Pot grown, 12 to 15 inches, $35 \mathrm{c}$ each; $\$ 3.00$ per 10 .

\section{METROSIDEROS SEMPERFLORENS.}

"Bottle Brush." "Produces curiously shape

shape of a bottle brush;
grown, $1 \frac{1 / 2}{2}$ feet, 50 e each.

MYRTLE, COMMON. and fragrant white flowers. Pot grown, 2 feet, 50 oc each.

NEW ZEALAND FLAX. Has large sword-like leaves, of a deep ricl green color. From this plant flax is
Very ornamental. 50c and $\$ 1.00$ each.

NANDINA DOMESTICA. A beautiful, upright-growing plant of dwarf habit, with a number of reed-like stems, growing fronl the same root, crowned wikes of white flowers. The young growth is prettily tinged white berries. $75 \mathrm{c}$ each. 


\section{THE OLEANDER}

Best suited for the warmer sections, where, if given plenty of water, it thrives to perfection. The flowers are produced very freely for a long period. One of the showiest of ever-blooming evergreens.

MADAIME SARAH BERNHARDT. Beautiful rose color, center feet, $50 \mathrm{c}$ each; $\$ 4.00$ per 10 .

NANKIN. Single, salmon. Balled, $1 \frac{1}{2}$ to 2 feet, 50c each; $\$ 4.00$ per 10

MADAME PEYRE. Changes from pure ivory to bright straw color. Balled, $1 \frac{1 / 2}{2}$ to 2 feet, $50 \mathrm{c}$ each; $\$ 4.00$ per 10

MRS. F. ROEDING. Double pink very fine. Balled, $11 / 2$ to 2 feet, 50c each; $\$ 4.00$ per 10 ; balled, 3 to $3 \frac{1}{2} \mathrm{feet,} \$ 1.00$ each. MADONNA GRANDIFLORA. Double white. Balled, 11/2 to 2 feet, $50 \mathrm{c}$ each; $\$ 4.00$ per 10 ; balled, 3 to $31 / 2$ feet, $\$ 1.00$ each.

PEPPER TREE. A most popular shade and ornamental tree, with fine feathery foliage; producing clusters of reddish berries in autumn. 4-inch pots, $1 \frac{1 / 2}{2}$ to 2 feet, 3

\section{PINES}

For reforesting, windbreaks, shelter and shade affording purposes, pines have few equals; all being of rapid growth. Take some of our barren hills and plant them to pines; In a few years what a different appearance the country will have. In the past few years millions of these have been set out in the Piedmont and Berkeley hills and today that section is assuming a different look. What effect will these have? They will add much beauty to the landscape, attract more "rain, and retain the moisture in the ground and preserve the rainfall. Write us if interested in large numbers and we will make special prices.

EXCELSA. Bhotan Pine. A native of the mountains of Northern India. A graceful and elegant tree, with drooping silvery pendulous. Hardy and vigorous. Balled, 3 to 4 feet, 50c each. MONTEREY. The most desirable pine for shade, and more extensively planted than any other variety in this State. 4-inch pots, 2 to $21 / 2$ feet, $30 \mathrm{c}$ each; $\$ 2.50$ per 10.4 4-inch pots, each; $\$ 5.00$ per 10 . 6 to 7 feet, 75 c each; $\$ 7.00$ per 10 .

SCOTCH. A fine, robust, rapid-growing tree, with stout, erect shoots and silvery-green foliage. Pot grown, $1 \frac{1}{2}$ to 2 feet, $25 \mathrm{c}$ each; $\$ 2.00$ per 10 . Balled, 2 to 3 feet, $35 \mathrm{c} \mathrm{each;} \$ 3.00$ per $10 ; 4$ to 5 feet, $60 \mathrm{c}$ each; $\$ 5.00$ per 10 .

CANARIENSIS. A quick growing pine with beautiful glaucous foliage when young, changing to dark-green when older. Balled, foliage when young, changing to dark-gr

PONDEROSA ("Yellow Pine"). Very rapid grower; one of the great timber trees of California. 3-inch pots, 12 to 15 inches, $25 \mathrm{c}$ each; $\$ 2.00$ per 10 .

PINEA (Parasol, or Stone Pine). This very picturesque tree thrives best in a sandy soil in a sheltered situation, branches spreading like a parasol and usually confined to the top of the
tree. A feature of the landscape in Southern Italy. Balled, 5 to 6 feet, $50 \mathrm{c}$ each; $\$ 4.00$ per 10 .

PIMELIA DECUSSATA. A very attractive shrub of dwarf compact growth, dense light-green foliage; the flowers are soft pink, appearing in clusters very profusely. A rare and choice plant. Fine plants in 5 -inch pots, $50 \mathrm{c}$ each.

\section{PITTOSPORUM}

NIGRICANS. A very handsome, upright growing shrub, with silvery light green leaves and black stems. A good hedge plant, and very ornamental as an individual. Pot grown,
$11 / 2$ feet, 25 c each; $\$ 2.00$ per 10 .

EUGENOIDES. A large, upright growing shrub, with glossy yellowish green leaves; a very effective shrub, and excellent for hedges. Pot grown, 12 to 15 inches, $25 \mathrm{c}$ each; $\$ 2.00$ per 10 . $21 / 2$ feet, 35c each; $\$ 3.00$ per 10 .

TOBIRA. A very desirable sort; the foliage and stems are very stiff; flowers pure white, sweetly scented; of dwarf habit. Balled, $11 \frac{2}{2}$ feet, 35c each; $\$ 3.00$ per 10 .

UNDULATUM. Flowers sweetly: scented; very desirable. Pot grown, 2 feet, $30 \mathrm{c}$ each; balled, $2 \frac{1}{2}$ to 3 feet, $50 \mathrm{c}$ each.

POLYGALA DALIMATIANA. A profuse flowering shrub, with purple pea-blossom-shaped flowers, and pretty light green foliage.
Pot grown, $1 \frac{1}{2}$ feet, 35c each.

PRIVET. See Ligustrum. Page 95.

REDWOOD. See page 91 .
RETINOSPORA OBTUSA. A new and rare sort; leaves very much flattened, coral-like in appearance, and of a lovely dark-green Balled grafted plants, 15 to 18 inches, $50 \mathrm{c}$ each; $\$ 4.00$ per 10 .

RETINOSPORA PLUMOSA. Foliage "plume like", a lovely species. Balled, $1 \frac{1}{2}$ to 2 feet, $75 \mathrm{c}$ each.

\section{RHODODENDRONS}

These are among the grandest of our hardy flowering shrubs, and cannot be surpassed for lawn decoration. The flowers range through shades of rose, pink, crimson, white, etc. Should be planted in partial shade. We have a magnificent European collection to offer. Price, $\$ 2.00$ and $\$ 2.50$ each.

BOULE DE NEIGE. Pure white; fine large truss.

CARACTACUS. Rich purplish-crimson; very large truss.

JACKSONII. Light rose, with dark spots; free bloomer.

KATE WATERER. Clear rosy crimson.

IMRS. FITZGERALD. Bright rosy scarlet; exceedingly fine.

MAD. WAGNER. Scarlet; dark spots on petals.

MLLE. MASON. Pure white; yellow stripes.

PURITY. White, faintly suffused with yellow.

SPRUCE. See Abies.

SKIMMIA JAPONICA. Flowers white, quite fragrant, leaves rich glossy green. Pot grown, 2 feet, $50 \mathrm{c}$ each.

SWAINSONA GREYANA (Darling River Pea). Flowers rose colored, produced in sprays of trom twelve to twenty flowers each the individual blooms resembling the flowers of a sweet pea. Leaves small; acacia-like. A most desirable ever-blooming plant. Native of New South Wales. 4-inch pots, 35c each.

SWAINSONA GALEGIFOLIA ALBA. This variety has delicate white flowers. 4-inch pots, $35 \mathrm{c}$ each.

SWEET BAY. See Laurel.

\section{THUJA-ARBOR VITAE}

A class of evergreen trees and shrubs; among the latter will be found some of our handsomest specimens for lawn adornment. They are of dwarf round neat habit.

GOLDEN. Of slow compact growth, foliage beautiful bright green, changing at certain periods of the year to golden yellow. Balled, 1 foot, $50 \mathrm{c}$ each; $\$ 4.00$ per 10 ; balled, 2 to $2 \frac{1}{2}$ feet, $\$ 1.00$ each.

GIGANTEA. A Californian Arbor Vitae attaining great height in time; the foliage is pleasing green, and the individual branchlets time; the foliage is pleasing green, and the individual branchlets of a book; it is a most graceful tree in all respects. 4-inch pots, $35 \mathrm{c}$ each; $\$ 3.00$ per 10 ; boxed, 4 feet, $\$ 2.50$ each.

GIGANTEA LUTEA. Of dwarf, compact habit. Balled, 1 foot, $50 \mathrm{c}$ each.

FILIFORMIS. The foliage of this variety is like "whip cord," a most beautiful and uncommon species, of dense compact growth. We recommend this variety very highly. Balled, $\mathbf{2}$ feet, $\mathbf{\$ 1 . 5 0}$ each.

LOBBII AUREA. Of upright growth, with beautiful golden foliage. A choice and rare sort. Balled, $1 \frac{1}{2}$ feet, $60 \mathrm{ceach}$.

MINIMA GLAUCA. The beauties of this choice Arbor Vitae are hard to describe; they must be seen to be appreciated; habit of growth unsurpassed. We take pleasure in recommending this variety, as we know they will give the best of satisfaction. Balled, $1 \frac{1}{2}$ to 2 feet, $\$ 1.00$ each. Stock limited.

THUJOPSIS DOLOBRATA. Leaves shining green above, silvery white beneath; of pendulous and dwarfish habit; branchlets coral-like in appearance; very handsome. Pot grown, 2 to 3 feet, $\$ 1.00$ each.

VERONICA IMPERIALIS. The finest of the species. Flowers amaranth. 2 feet, 50c each.

VERONICA TRAVERSII. A most desirable sort; of dwarf habit; flowers pure white; excellent for hedge purposes. 4-inch pots, $30 c$ each; $\$ 2.50$ per 10 ; balled, 2 feet, 50 each; $\$ 4.00$ per 10 .

\section{YEW}

ENGLISH. A densely branched, spreading tree; foliage dark and somber; a good sort for clipping into artificial forms, 5 -inch pots, 35c each; $\$ 3.00$ per 10 ; balled, 15 to 18 inches, $50 \mathrm{c}$ each; $\$ 4.00$ per 10 .

ENGLISH GOLDEN. A golden, variegated kind of the preceding. Balled, 15 to 18 inches, 50c each; $\$ 4.00$ per 10.

IRISH. An upright growing variety, with deep dark green foliage; branches erect, closely compressed, forming a pyramidal shaped head; a very distinct and beautiful variety. Balled, 12 to 15 inches, $50 \mathrm{c}$ each; $\$ 4.00$ per $10 ; 11 / 2$ to 2 feet; $75 \mathrm{c}$ each; $\$ 6.00$ per 10. 


\section{DECIDUOUS TREES AND FLOWERING SHRUBS}

In California, where there is such a scarcity of native trees, especially in the middle and southern parts, it is incumbent on all that they plant some shade trees. The first cost of these is not great, and the after attention, until they are old enough to care for themselves, should be a pleasure to, those who may have planted them. For roadside planting we particularly recommend the following:

Black Walnut, Catalpa, Elm, Linden, Locust, Maple, Poplar, and Sycamores.

These are all very desirable, fast-growing trees, adapted to California conditions.

A good assortment of flowering trees and shrubs adds greatly to the beauty of all places, and is a source of continuous pleasure. Among the earliest of these to bloom is the Japanese Scarlet Quince, which commences to bloom early in February. It is a very showy shrub and blooms at a time when flowers are at a premium. It is much valued. The flowering Peaches next attract attention; when in bloom the tree is one mass of flowers; there are the double pink and the double white; the blooms resemble small roses. Corchorus Japonicus is a very nice flowering shrub. The flowers are of a deep orange shade, double; appearing among the branches for a long period. Crape Myrtles are among our prettiest shrubs; they bloom in summer and autumn; there are various shades, among the best being red and white. Mock Orange, Deutzias, Spiraeas, and Weigileas are also to be commended as being highly ornamental; these all bloom in springtime. The Lilacs are known to all; their sweet fragrance adds greatly to the charm of the garden. Hydrangea Hortensis bears immense white ball-shaped flowers, changing to pink. Hydrangea Paniculata bears pure white flowers, spike-shaped, and are very floriferous. A most beautiful flowering tree is the Crabapple-pink and white. The Brooms (Scotch and Spanish) come under this class; they both bear pea-shaped yellow flowers. The Spanish variety we prefer, being the longest bloomer. The Snowballs, which bear immense ball-shaped white flowers, are great favorites. Those who have seen the Japanese Magnolias bloom in early spring will agree with us that once seen they will never be forgotten. The blossoms appear before the leaves, and come in various colors-cup-shaped in appearance; in time they become quite large trees, but are of rather slow growth. Calycanthus Floridus (Sweet Shrub) is much thought of on account of the delightful odor emitted from the foliage. The Hawthorns are old-fashioned favorites.

ALTHEA. One of our showy ever-blooming deciduous shrubs. Lavender. 3 feet, $35 \mathrm{c}$ each; $\$ 3.00$ per 10.

ASH, AMERICAN. 4 to 5 feet, $40 \mathrm{c}$ each; $\$ 3.50$ per 10.

ASH, EUROPEAN. A lofty tree of rapid growth, with spreading head and giay bark; pinnate leaves and black buds. 4 to 5 feet, $40 \mathrm{c}$ each; $\$ 3.50$ per 10 .

AZALEA MOLLIS. A native of Japan, and undoubtedly one of the most beautiful shrubs for forcing or planting in groups or borders in parks and gardens. The flowers are larger and of more perfect form than those of Azalea Pontica, and resemble in form and size the flowers of the Azalea Indica. Their gorgeous colors vary from yellowish white, rose, all shades of yellow to richest orange. Large, strong and bushy named plants. $75 \mathrm{c}$ and $\$ 1.00$ each.

AZALEA PONTICA. This is one of the most beautiful varieties of hardy shrubs. Their flowers vary from the purest white to the most gorgeous scarlet and crimison; sweetly fragrant. Our list embraces all the most distinct and handsome named varieties. The plants we offer are strong and well set with buds. $\$ \mathbf{1 1 . 0 0}$ each; $\$ 8.00$ per 10 .

BIRCE, EUROPEAN WHITE. Remarkable for its elegance; very graceful, with silvery bark and slender branches. 3 to 4 feet, $50 \mathrm{c}$ each; $\$ 4.00$ per $10 ; 4$ to 6 feet, $75 \mathrm{c}$ each; $\$ 6.00$ per 10 ; 7 to 8 feet, $\$ 1.00$ each.

BIRCH, CUT-LEAVED WEEPING. A charming tree with deeply lacinated foliage. Its tall, slender, yet vigorous growth, graceful, lacinated foliage. Its tall, slender, yet vigorous growth, graceiul, drooping branches, silvery-white bark, and delicately cut foliage, with in one tree. 6 to 8 feet, $\$ \mathbf{1 . 2 5}$ each.

BOX ELDER. See under Maple.

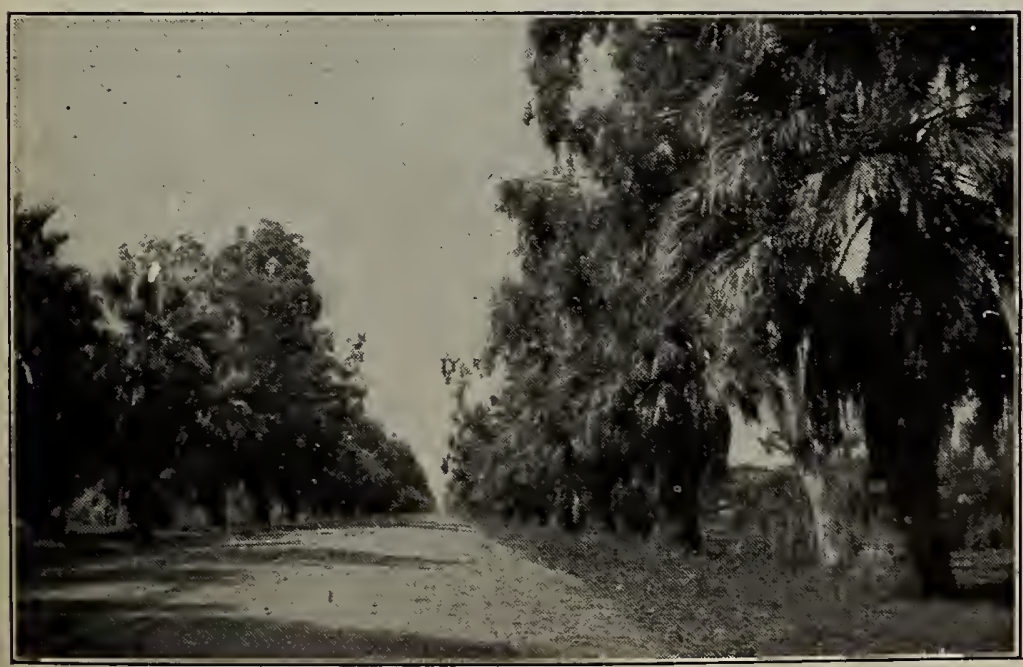

A California Road Beautified with the Planting of Trees; contrast this with one unplanted
CALYCANTHUS FLORIDUS (Sweet Shrub). A very desirable shrub, with fragrant wood and foliage; flowers of a rare chocolate color. 2 to 3 feet, $50 \mathrm{c}$ each.

CATALPA SPECIOSA (Western Catalpa). Leaves large, heartshaped; of rapid growth; flowers come in long grape-like clusters of white and purple; very fragrant. The timber obtained from 7 feet, $60 \mathrm{c}$ each; $\$ 5.00$ per 10.

CATALPA B UNGEI (Chinese Catalpa). Of dwarf habit, growing only four to five feet high; foliage large and glossy; eminently adapted for lawn planting, where it makes a lovely specimen, as it is of very bushy habit and shows off to great advantage. 3 to $31 / 2$ feet, 50 e each; $\$ 4.00$ per 10 .

CERCIS CANADENSIS (Judas Tree, or Red Bud). A very ornamental native tree, of medium size, irregular rounded form, with perfect heart-shaped leaves of a pure green color, glossy surface above, and grayish green beneath. The tree derives the name of Red Bud from the profusion of delicate reddish purple flowers with which it is covered before the foliage appears. Flowering with which it is covered before the foliage appears. Flowering among them in groups with fine effect. Grown as single specimens they are also beautiful and attractive, and deserve to be classed among our finest ornamental trees. 4 to 6 feet, 50c each.

CHERRY, JAPANESE DOUBLE FLOWERING. A very ornamental family of trees; they produce their flowers in great masses, and when in blossom they present a glorious sight. We can $50 \mathrm{c}$ each; $\$ 4.00$ per 10 .

CRAB APPLE, Betchell's Double Flowering. One of the most beautiful of the many fine varieties of flowering Crabs. Tree of medium size, covered in early spring with large, beautiful double fragrant flowers of a delicate pink color. From a distance the flowers have the appearance of small roses. A great acquisiBlooms when quite young. 4 to 5 feet, $60 \mathrm{c}$ each; $\$ 5.00$ per 10.

CRAB APPLE, Parkmanil. This sort has single pink blossoms. 2 feet, $50 \mathrm{c}$ each; $\$ 4.00$ per 10.

CHESTNUT, AMERICAN. A noble large-growing tree, at first of slow growth, but eventually growing with fair rapidity. 4 to 5 feet, 50c each; $\$ 4.00$ per 10 .

CHIONANTHUS VIRGINICUS (White Fringe) tree or shrub, of roundish form, with larg drooping racemes of pure white flowers, having narrow, fringelike petals; blossoms in May or June. A superb lawn tree. 3 feet, $50 \mathrm{c}$ each.

CORCHORUS JAPONICUS. Produces globular-shaped deep yellow flower

CRAPE MYRTLE. Words fail to convey an adequate idea of the beauty of this shrub. They succeed best in a warm section and
blossom for a long period; the flowers have curiously crimpled petals. We can supply the Red and White varieties. 3 feet, 50c each.

CURRANT, FLOWERING. Produces pink flowers very early in spring; much admired. 2 to 3 feet, $25 \mathrm{c} \mathrm{each}$. 
DEUTZIA GRACILIS. A charming species of dwarf habit : flowers pure white; produced in great masses in spring time. Excellent for pot culture. $1 \frac{1}{2}$ feet, $30 \mathrm{c} \mathrm{each}$.

DEUTZIA LEMOINEII. Flowers pure white, borne on stout branches, which are of upright growth; free flowering. 2 to $2 \frac{1}{2}$ feet, 35c each.

DOGWOOD (Red Siberian). A valuable shrub; branches bright red. 2 to 3 feet, 30c each.

\section{THE ELIM}

Is considered our handsomest and quickest growing shade tree, making excellent shade. One of the best trees for country road planting.

AMERICAN BLACK. A magnificent large tree, with drooping, spreading branches; one of the grandest of our native forest trees. per 10; $\$ 35.00$ per 100

ENGLISH OR FRENCH. An erect, lofty growing tree, of rapid, compact growth, with smaller and more regularly cut leaves than $10 ; \$ 35.00$ per 100 .

BROAD-LEA VED ENGLISH (Latifolia). 6 to 7 feet, 50c each; $\$ 4.00$ per 10 .

CORK BARKED. 4 to 6 feet, 35c each; $\$ 3.00$ per 10 .

EUSCAPLIES STAPHYLEOIDES. Produces white or yellowish flowers, borne in terminal panicles, succeeded by red, bladdery fruit, remaining on the bush till late in winter. This plant is properties. 2 to $2 \frac{1}{2}$ feet, $50 \mathrm{c}$ each.

FORSYTHIA SUSPENSA (Golden Bell). One of the earliest of spring flowering shrubs, being completely covered with tufts of rather large, pendulous bright, yellow flowers, which grow two or three together from all parts of the rod-like branches. 2 to 3 feet, $35 \mathrm{c}$ each.

HAWTHORN. See Thorn.

HORSE CHESTNUT, EUROPEAN. White Flowering. Of majestic appearance, bearing large clusters of beautiful white flowers, succeeded by mahogany-colored nuts, inclosed in burrs; the leaves are palmate-shaped. 3 feet, 50c each.

HYDRANGEA PANICULATA GRANDIFLORA. This is one of the finest of all hardy shrubs for the lawn or border. The flowers are white, spiked-shaped, and are produced for a long period HYPERICUM MOSERIANUM. It produces long, slender, muchbranched stems. It is marvelously free-flowering; of large size; a rich golden-yellow, which is rendered still more effective by the numerous yellow stamens and crimson anthers, and blooms con-
tinuously the entire season. Strong plants, 35c each; $\$ 3.00$ timuously

HYPERICUM PATULUM (St. John's Wort). A most desirable shrub. It has single flowers of a buttercup-yellow, produced ground. 2 feet, $25 \mathrm{c}$ each; $\$ 2.00$ per 10 .

KOLREUTARIA PANICULATA. A hardy, small, round-headed tree, with fine lobed leaves and large panicles of showy golden yellow flowers, in the latter end of July; leaves change in autumn to a fine yellow. One of the most desirable trees, particularly valuable for its brilliant, golden blossoms, which are produced so late in the season, when few
feet, 400 each; $\$ 3.50$ per 10 .
LABURNUM, or GOLDEN CHAIN, A beautiful small-growing tree, with long drooping racemes of fragrant yellow flowers. 4 to 5 feet, $50 \mathrm{c}$ each; 6 to 8 feet, $75 \mathrm{c}$ each.

LARCH, EUROPEAN. A valuable timber tree; very ornamental for lawn purposes; of rapid growth. 3 to 4 feet, $50 \mathrm{c}$ each.

LEMON VERBENA. The fragrance from the foliage of this old favorite is delightfully refreshing. 2 to 3 feet, $50 \mathrm{c}$ each.

\section{LILAC}

CHARIES X. Reddish purple. $21 / 2$ feet, 50c each; $\$ 4.00$ per 10.

LA TOUR D'AUVERGNE. Double. Violet purple. $21 / 2$ feet, 50c each; $\$ 4.00$ per 10 .

MADAME LEMOINE. Double. White. $21 / 2$ feet, 50c each; $\$ 4.00$ per 10 .

MATTHEW DE DOMBASLE. Double. Mauve. $21 / 2$ feet, 50c each; $\$ 4.00$ per 10.

COMMON WHITE. $21 / 2$ to 3 feet, 35c each; $\$ 3.00$ per 10.

COMMON PURPLE. $2 \frac{1}{2}$ to 3 feet, $35 \mathrm{c}$ each; $\$ 3.00$ per 10.

LINDEN, BROAD-LEAVED AMERICAN. The Linden is a magnificent tree; the leaves are beautiful, thus making a very handsome tree. They produce small, white flowers, very sweetly scented indeed. 4 feet, $50 \mathrm{c}$ each; $\$ 4.00$ per 10 .

LINDEN. EUROPEAN. 4 feet, 50c each; \$4.00 per 10.

LOCUST, THORNLESS (Bessoniana), A very ornamental variety; it makes a beautiful umbrella-like head, and is free from thorns. Of rapid growth. 3 to 4 feet, 40c each; $\$ 3.50$ per 10. 5 to 6 feet, $60 \mathrm{c}$ each; $\$ 5.00$ per 10 .

LOCUST, COMMON OR BLACK. A rapid-growing tree, with spreading branches. A valuable timber tree, and used for per 10 . 6 to 8 feet, 50 e each; $\$ 4.00$ per $10 ; \$ 30.00$ per $100 ;$ 6 to 8 feet, $75 \mathrm{c}$ each; $\$ 6.00$ per $10 ; \$ 40.00$ per 100 .

LOCUST, PINK FLOWERING (Decnaisneana). This grand flowering deciduous shade tree produces beautiful coral-pink flowers in long grape-like clusters for a long period and is one each; $\$ 5.00$ per 10 . 5 to 6 feet, $75 \mathrm{c}$ each. $\$ 6.00$ per 10 .

MAIDEN HAIR TREE (Salisburia). A remarkable tree from Japan, combining in its habit characteristics of the conifer and deciduous tree. The tree is of medium size and rapid growth; beautiful fern-like foliage, in shape resembles somewhat a Maiden each.

\section{MAPLE}

A valuable and highly ornamental family of trees. The Maples are regular in outline, beautiful in foliage, vigorous growers, free from all diseases, and adapted to all soils, merits, which deservedly render them universally popular.

BOX ELDER. A large-growing, handsome tree, of rapid growth: foliage ash-like; a fine avenue tree. 8 to 10 feet, $60 \mathrm{cech}$ $\$ 5.00$ per $10 ; \$ 40.00$ per 100

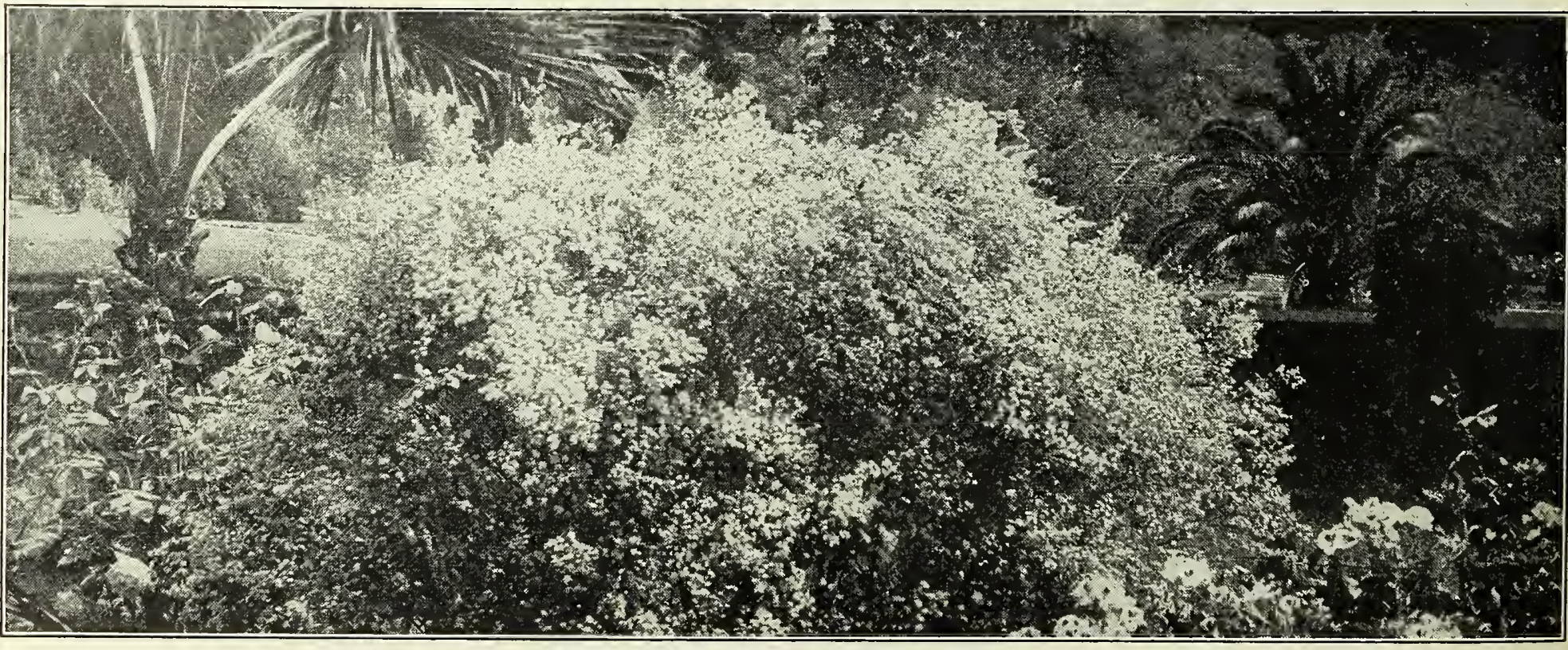

Breath of Heaven. (Diosma Alba)

This "Fairy-like" Scene was photographed by us on the grounds of the Claremont Hotel, Berkeley 
ENGLISH, or CORK-BARKED. A native of Europe attaining a height of sixty feet; a stocky tree, of compact, roundish habit, with rough corky bark full of deep fissures. An excellent variety in the interior as it does not sunburn. 5 to 6 feet, $40 \mathrm{c}$ each: $\$ 3.50$ per 10 .

NORWAY. A large, handsome tree, with broad, deep green foliage, and of very compact growth, rendering it one of the most desirable varieties for the street park or garden. A valuable variety in the interior valleys. 8 to 10 feet, $60 \mathrm{c}$ each; $\$ 5.00$ per $10 ; \$ 40.00$ per 100.

SILVER, or SOFT. A rapid-growing tree of large size; irregular rounded form; foliage bright green above, silvery beneath; a favorite street and park tree. A very promising and distinct tree; should be extensively planted. 5 to 6 feet, $50 \mathrm{c} \mathrm{each}$; $\$ 4.00$ per $10 ; \$ 30.00$ per 100 .

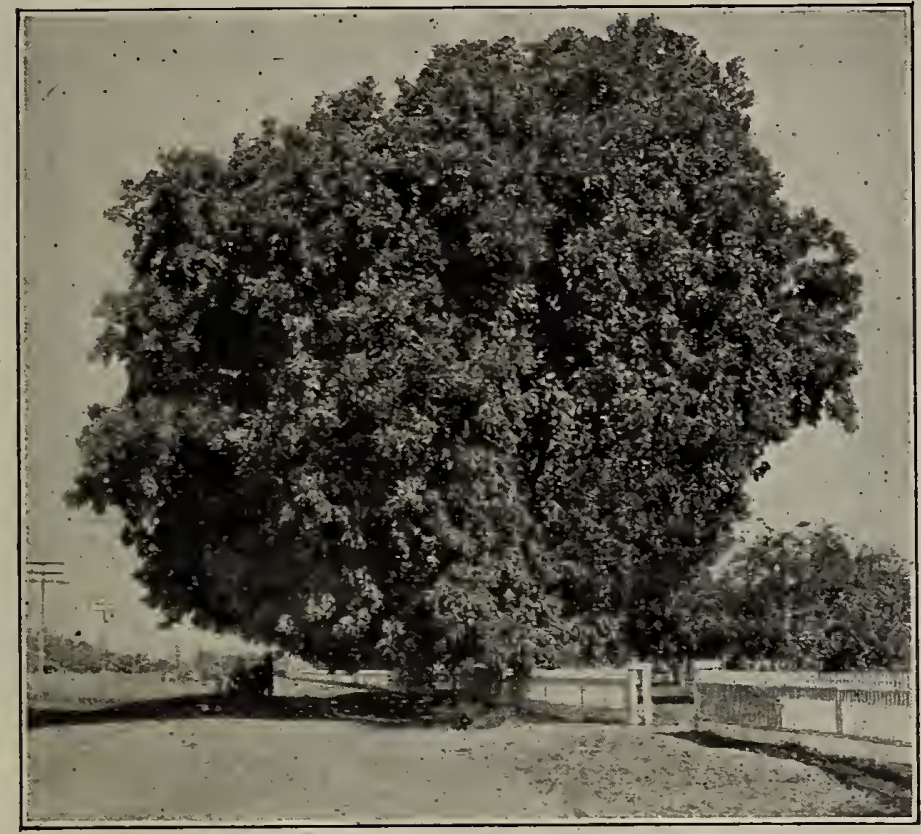

Black Walnut. One of the largest trees of its kind to be found in California

JAPANESE. None of our autumnal trees can excel these in gorgeousness of coloring; they include yellow, blood-red, green and variegated. The uniqueness of the shape of the leaves is also wonderful, some as delicate as the finest lace. Plant in shady place. 2 to 3 feet, $60 \mathrm{c}$ each; $\$ 5.00$ per 10 .

PLANE TREE (American Sycamore). A tree of great beauty leaves large, producing ideal shade; of rapid growth. 5 to 7 feet, $40 \mathrm{c}$ each; $\$ 3.50$ per $10 ; \$ 30.00$ per 100 .

RUBRUM. Produces deep red blossoms, which appear before the leaves. The foliage changes to brilliant scarlet in autumn. A tree of very neat and rounded form. conspicuously so when planted in a lawn. 4 feet, $50 \mathrm{c}$ each; $\$ 4.00$ per 10.

\section{MAGNOLIA, JAPANESE}

These highly ornamental medium sized trees with their lavish display of fragrant, many hued flowers, are worthy of a place in every garden of any size. Planted in groups, their effect in the early spring with their brilliant colorings and their rich fragrance is grand beyond description.

CONSPICUA. Flowers large, pure white, cup-shaped, very sweet. $21 / 2$ to 3 feet, $50 \mathrm{c}$ each.

OBOVATA. Purple flowers. 2 to 3 feet, $50 \mathrm{ceach}$.

MOCK ORANGE, or SYRINGA. An invaluable shrub, of vigorous habit, very hardy, with large, handsome foliage and beautiful white flowers, produced in the greatest profusion. $\mathbf{3}$ feet, $\mathbf{3 5 c}$ each.

MOUNTAIN ASE, EUROPEAN (Rowan Tree). Flowers creamy white; foliage somewhat like the Pepper Tree; covered from August to November with large clusters of orange colored berries. 5 to 6 feet, $60 \mathrm{c}$ each; $\$ 5.00$ per 10 .

MULBERRY, DOWNING'S EVERBEARING. A very rapid grower. A valuable shade tree; produces a good fruit. 5 to 6 frower, $60 \mathrm{c}$ each.

MULBERR Y, WHTTE. A quick-growing tree. Suitable for producing quick shade, 4 to 5 feet, $30 \mathrm{c}$ each; $\$ 2.50$ per $10 ; \$ 20.00$ per 100.
OAK, ENGLISH. We take pleasure in recommending this listorical tree to our customers as one of the most desirable for Califormia. It is of fairly rapid growth; it makes a dense head and the leaves are a dark glossy green, to which dust does not adhere; it letains its foliage till late in the season, and sheds at a time whell we do not want shade. 3 feet, $35 \mathrm{c}$ each; $\$ 3.00$ per 10.

OAK, SCARLET. Perhaps there is no tree that appeals to us more forcibly than those producing scarlet foliage in tall. Just as we remember "snow at Christmas," so do we think of "Autumn leaves." It has a place in our hearts tliat call never be forgottell as it brings back to us days of long ago. In this variety we liave such an ideal tree; the foliage changes to a bright scarlet and roc each; $\$ 4.00$ per 10 .

PEACH, FLOWERING. The double flowering varieties are distinguished for their showy and beautiful bloom. At the bloseouling season in April, erery branclulet is corered At the blosrombeautifully formed, highly colored flowers, rendering the trees supply the Double White and Double Pink. 4 to 5 feet, $50 \mathrm{c}$ each.

PAULOWNIA IMPERIALIS. Known as "Empress Tree." A magnificent tropical looking tree from Japan; of extremely rapid growth, and surpassing all others in the size of its leaves, which are twelve to fourteen inches in diameter. Blossoms trumpetcolor a beautiful shade of lavender. 8 to 10 feet, $\$ 1.00 \mathrm{each}$.

PLUM, PURPLE-LEAVED (Pissardi). The young branches are very dark purple; the leaves when young are lustrous crimson, changing to a dark purple, and retain this beautiful tint till they drop late in autumn. No other purple-leaved tree or shrub 4 feet, $50 \mathrm{c}$ each.

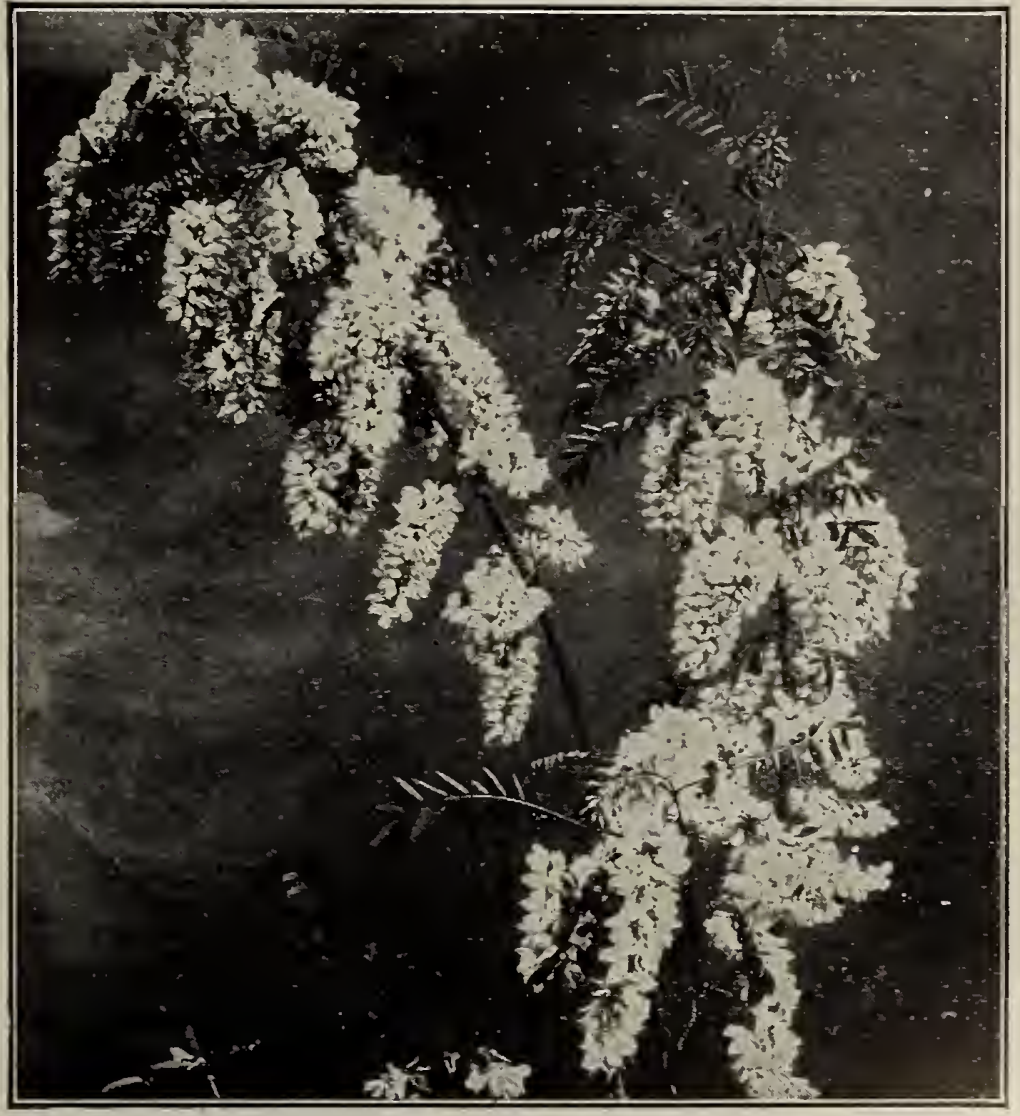

Pink Flowering L ocust

POPLAR

Poplars are very rapid growing trees and thrive under a great variety of conditions as regards soil, but do best in damp situations and along watercourses. Their leares are bright among other trees, of heavier foliage and give to a group a sprightly air. They are well adapted for windbreaks and are very effective when planted in groups by themselves.

"BALM OF GILEAD." Of remarkably rapid and luxuriant growth, with large glossy

CAROLINA. A very distinct tree, making a large, spreading head. Excellent for arenue planting. 5 to 6 feet, $35 \mathrm{c} \mathrm{each;} \$ 3.00$ per $10 ; \$ 27.50$ per 100 . 


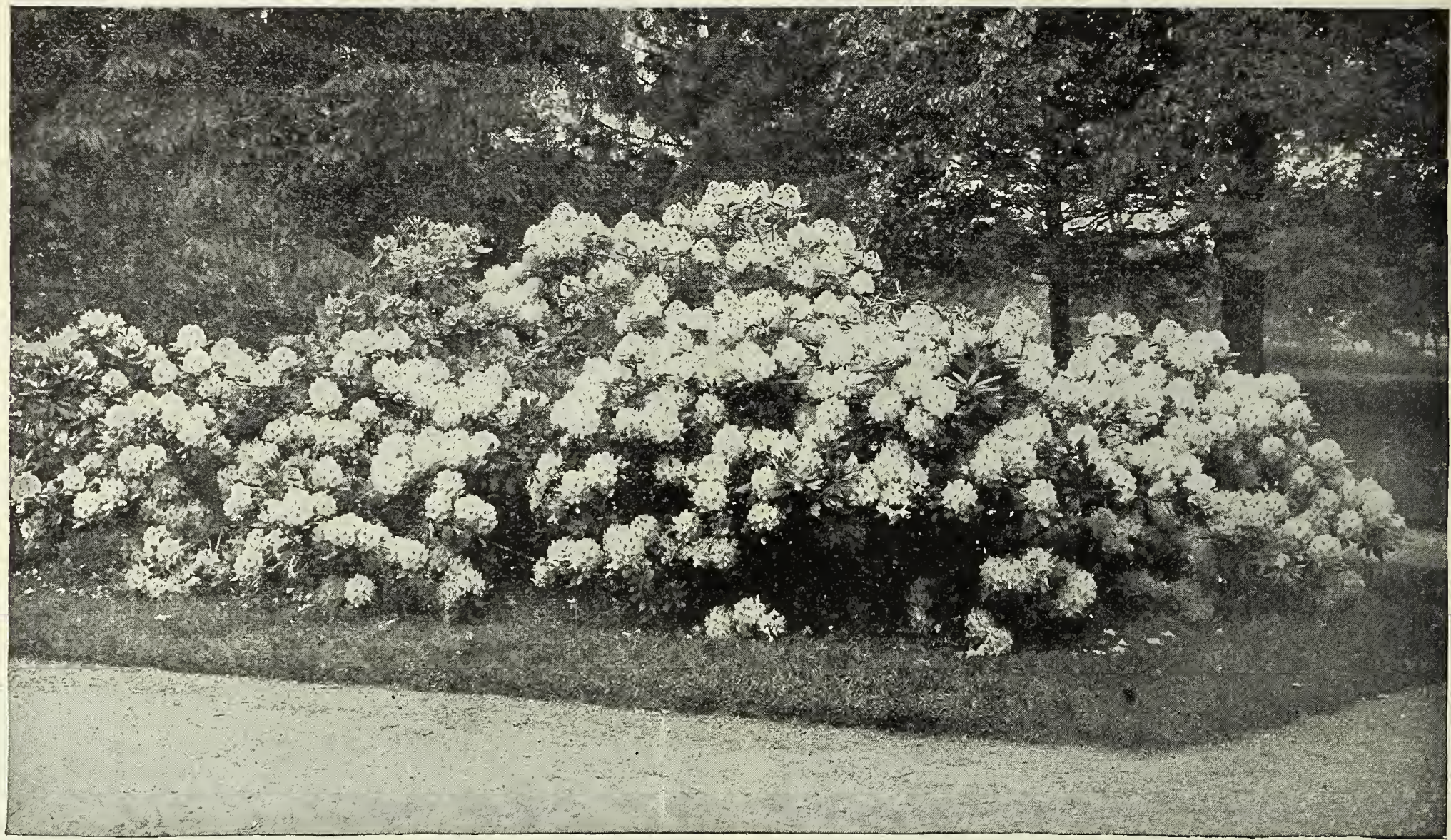

Group of Rhododendrons-Unsurpassed for such purposes

POPLAR-Continued

B OLLEANA. Silver Leaved Poplar. Foliage silvery green above; snow white underneath. Adds great beauty to landscape work. 4 to 5 feet, 25 c each; $\$ 2.00$ per 10 .

LOMBARDY. This is one of the characteristic trees of parts of Italy and it is from the Italian province, Lombardy, that its com-
mon name is derived. Probably a native of Asia. A very rapid, mon name is derived. Probably a native of Asia. A very rapid, erect growing tree with a tall spiry form and particularly striking 30c each; $\$ 2.50$ per $10 ; \$ 18.00$ per 100 .

POMEGRANATE, DOUBLE SCARLET. As an ornamental shrub or small tree, it is much prized in the South of Europe.
This fine shrub does particularly well in California. The flowers measure two inches across, are very double and appear for a long period. This shrub makes a very pretty hedge. 3 feet, 35c each; $\$ 3.00$ per 10 .

POIMEGRANATE. SINGLE SCARLET. 3 feet, $35 \mathrm{c}$ each; $\$ 3.00$ per 10 .

QUINCE (Japanese Scarlet Flowering). This is the first shrub to bloom in spring and the blossoms appear in great profusion, the leaves. 2 to 3 feet, $35 \mathrm{c}$ each; $\$ 3.00$ per 10.

ROWAN TREE. See under Mountain Ash.

RHUS COTINUS ("Mist or Smoke Tree"). A low-growing, shrubby tree, covered in midsummer with large clusters of feathery flowers, giving the appearance of a cloud of smoke or mist. 3 to 4 feet, $35 \mathrm{c}$ each; $\$ 3.00$ per 10 .

RHUS GLABRA LASCINIATA ("Cut-leaved Sumach"). A very showy plant; leaves very large, deeply cut and drooping 2 to $2 \frac{1}{2}$ feet, $35 \mathrm{c}$ each; $\$ 3.00$ per 10 .

SNOWBALL. This well-known shrub is known to nearly everyone; they produce immense ball-shaped, white flowers in great profusion in May and June. Should be in every collection. 3 feet, $40 \mathrm{c}$ each; $\$ 3.50$ per 10 .

\section{SPIRAEA}

A. WATERER ("Crimson Spiraea"). A valuable addition to our shrubs; the flowers are crimson, appearing in great masses. This 3 feet, 30c each; $\$ 2.50$ per 10 .

DOUGLASII ROSEA. This variety has spikes of beautiful deep rose-colored flowers. 2 to 3 feet, 30c each; $\$ 2.50$ per 10 .

PRUNIFOLIA ("Bridal Wreath"). A beautiful sort from Japan, with pure white flowers like white daisies, produced the entire length of the branches. Certainly a magnificent sight when in bloom. 2 feet, 25c each; $\$ 2.00$ per 10.
THUNBERGII. Of dwarf habit and rounded, graceful form; branches slender and somewhat drooping; foliage narrow and being one of the first Spiraeas to flower. 2 to 3 feet, 35c each; $\$ 3.00$ per 10 .

TAMARIX AFRICAN. An elegant and handsome flowering small tree, thriving in all soils and locations, whether by the seashore or hot interior valleys. The flowers are pink, appearing all along the branches; foliage feathery and graceful. 5 to 6 feet, $35 \mathrm{c}$ each; $\$ 3.00$ per 10 .

TEXAS UMBRELLA TREE. This is one of the handsomest of deciduous shade trees, and is adapted particularly to the warm parts of this State, where, when sufficient water is supplied, it assumes a grand umbrella-shaped head, affording delightful shade in the hot summer days. 5 to 6 feet, strong, 75c each; $\$ 6.00$ per 10 .

THORN, DOUBLE WHITE. Has small double white flowers. A highly ornamental variety, on account of both foliage and flowers. 4 to 5 feet, $60 \mathrm{c}$ each; $\$ 5.00$ per 10 .

THORN, DOUBLE PINK. Similar to the preceding in all respects but color, which is pink or rose. 4 to 5 feet, $60 \mathrm{c}$ each; $\$ 5.00$ per 10.

THORN, PAUL'S DOUBLE SCARLET. 4 to 5 feet, 60c each; $\$ 5.00$ per 10 .

TULIP TREE. A magnificent rapid growing tree of tall pyramidal habit, with light green, glossy, fiddle-shaped leaves, and greenish yellow tulip-like flowers. Known to lumbermen as Poplar and Whitewood. 3 to 4 feet, 50c each.

WALNUT, AMERICAN BLACK. One of the best shade trees for California; of rapid growth. 3 feet, $30 \mathrm{c}$ each; $\$ 2.50$ per 10 ; $\$ 18.00$ per 100 .

WEIGELIA A. CARRIERE. Bright rose; a choice sort. 2 to $21 / 2$ feet, 35c each; $\$ 3.00$ per 10 .

WEIGELIA CANDIDA ("White Flowered Weigelia"). A very free flowering variety. One of the best. 2 to $2 \frac{1}{2}$ feet $35 \mathrm{c}$ each; $\$ 3.00$ per 10 .

WEIGELIA ROSEA. An elegant shrub, from Japan. They produce superb, large, trumpet-shaped flowers of a fine rose color. 2 to $2 \frac{1}{2}$ feet, 35c each; $\$ 3.00$ per 10 .

WILLOW, BAB YLONIAN. This is the willow we see so many of in this State and known as "Common Willow," or Weeping Willow. It is best suited to plant in wet land, where it makes rapid growth and affords grateful shade for stock, which browse lazily of the lower branches, and when so pruned add picturesque-
ness to our landscapes. 3 to 4 feet, $35 \mathrm{c}$ each; $\$ 3.00$ per 10 .

WILLOW, ASIA MINOR. Foliage narrower than the Babylonian. 4 to 5 feet, 35c each; $\$ 3.00$ per 10 . 


\section{CLIMBING AND TRAILING PLANTS}

Some nice, rapid-growing, climbing plants planted round our dwelling houscs add considerably to the bcauty thercof, be it the mansion of the opulent or the dwelling of the artisan. What dear memories chuster around the names "Honeysuckle" and "Sweet Briar." Who does not remember the sweet fragrance of these old, old favorites, friends of long ago?

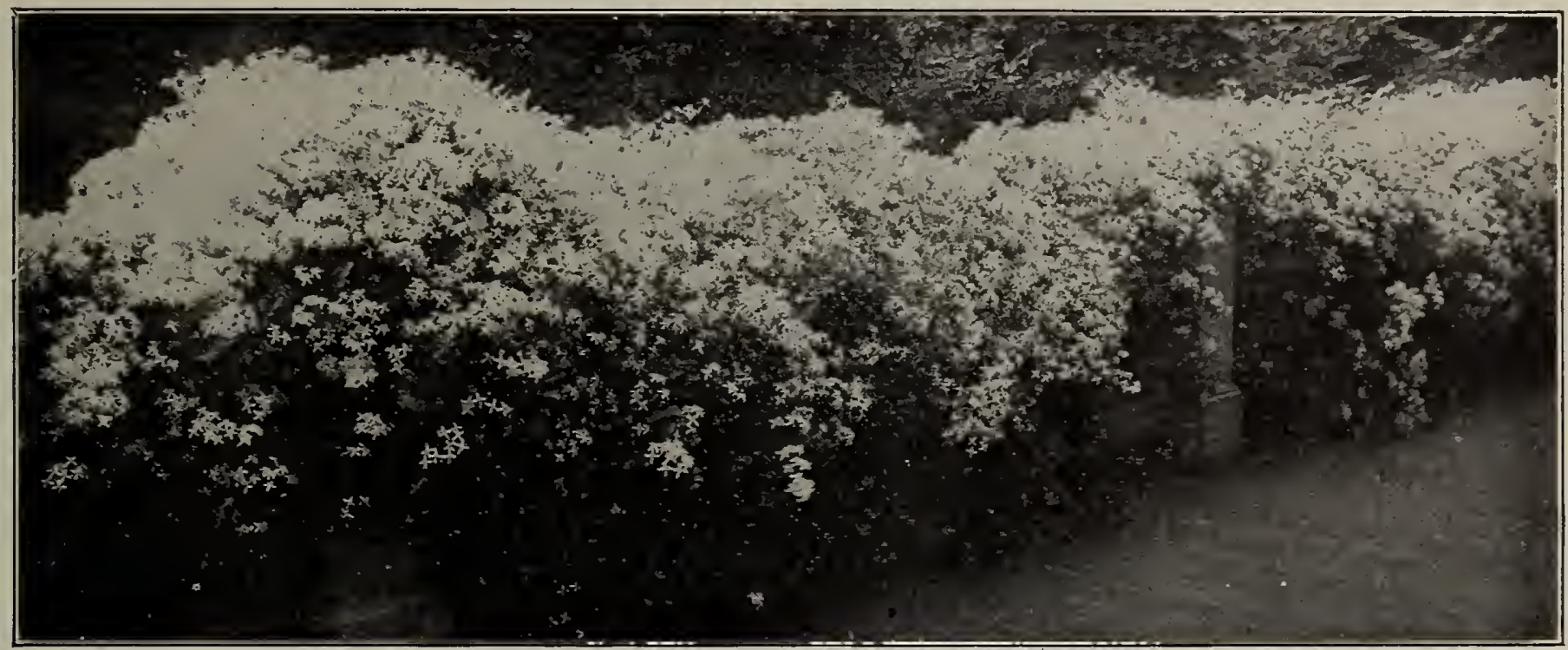

Clematis Paniculata. Note the wealth of bloom

AKEBIA QUINATA. A very distinct and pretty climber from Japan. Foliage clover-like in appearance, semi-evergreen; flowers chocolate-colored, appearing in early spring. Very sweet. $50 \mathrm{c}$ each.

AMPELOPSIS ENGELMANNI. Shorter jointed than quinquefolia. Strong grower. 2-year-old plants, 50c each, $\$ 4.00$ per 10.

AMPELOPSIS MURALIIS. Resembles the quinquefolia, but is more slender in growth and shorter jointed, with smaller foliage. 2-year-old plants, 50c each; $\$ 4.00$ per 10.

AMPELOPSIS QUINQUEFOLIA (Virginia Creeper). The leaves are palmate, handsome and luxuriant, assuming in autumn a gorgeous bronzy hue. Strong, 50c each; $\$ 4.00$ per 10 .

AMPELOPSIS VEITCHII (Boston or Japan IVy). This variety clings closely without any assistance to a stone wall or brick flue or a wooden surface. It is widely planted in California, where it succeeds admirably, and is much admired. Strong plants, 50c each; $\$ 4.00$ per 10 .

AUSTRALIAN PEA VINE. Pink flowers; fast growing. $30 \mathrm{ceach}$.

\section{CLEMATIS}

The Clematis are elegant, slender-branched climbers of rapid growth, with fine foliage and beautiful, large flowers of various colors; they are perfectly hardy, and cannot be excelled as climbing plants in any situation; they are very particular as to soil, that of a loamy texture being the most suitable; thorough drainage is indispensable to good, healthy growth; large, deep holes should be dug, and if the soil is heavy it must be replaced; in planting, the roots should all be spread out, and plants pruned down to one-half their height; they should never be allowed to get very dry; an annual manuring should be given, and tops pruned off in December. 75c each, except where noted.

DUCHESS OF EDINB URGH. Fine large double white; sweetly cented.

JACKMANII. Deep purple violet, produced in masses; one of the best; large single. 50c each.

HER R YII. Large, single white.

MAD AM E. ANDRE. Large, single red.

MONTANA. In this variety we have the ideal Clematis for this State. The flowers are produced in spring in -wonderful profusion (as will be seen from the picture which we have the fusion (as will be seen trom the picture which of a dollar and pleasure in presenting); they are about the size of a dollar and plants, $60 \mathrm{c}$ each.
PANICULATA. A Japanese climber, recently introduced into this country of unusual and attractive merits; rapid grower; foliage of a glossy rich green; the flowers are of medium size, pure white, and of most delicious fragrance. Strong plants, 50c each.

B OUGAINVILLEA SPECTABALIS. These climbers are becoming greater favorites every year. They have peculiarly shaped fowers, somewhat resembling the leaves in shape, the color being of a rosy lake, and produced at the end of the branches in wonderful profusion. They are indispensable for the greenhouse and do remarkably well in many protected situations out of doors. Strong plants, 60c each.

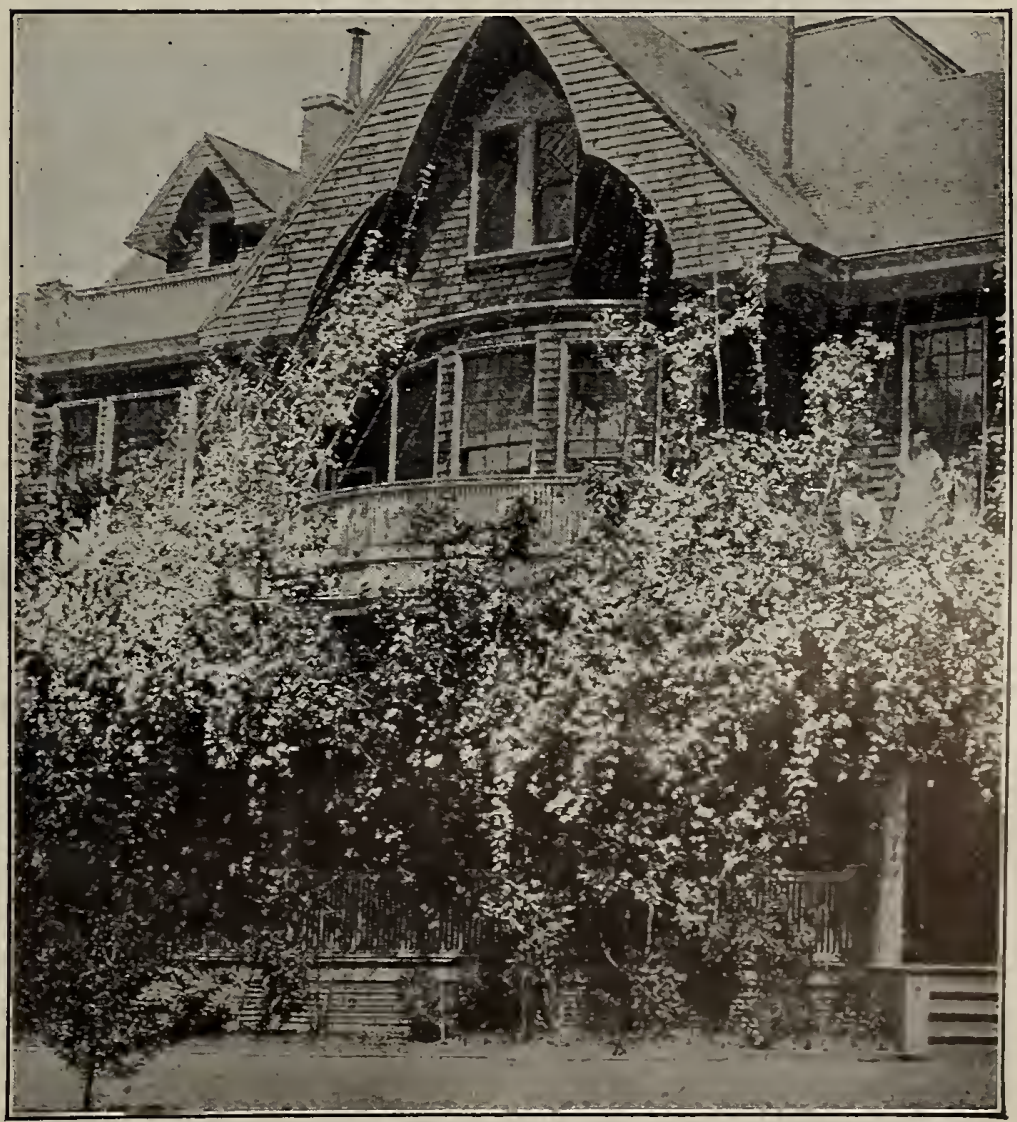

Clematis Montana 
CLIMBING AND TRAILING PLANTS-Continued

BIGNONIA GRANDIFLORA (Trumpet Vine). Rapid-growing climber, bearing large orange-yellow trumpet-shaped flowers in great profusion. Strong plants, $50 \mathrm{c}$ each.

BIGNONIA RADICANS. Scarlet trumpet flowers; exceedingly showy. 50c each.

BIGNONIA VENUSTA. A vigorous grower, producing large, deep, orange-colored flowers. 35c each.

FICUS REPENS. A very pretty useful climber; clings to stone, brick or wood; like the Boston Ivy. Evergreen. $25 \mathrm{c}$ and $35 \mathrm{c}$ each.

HONEYSUCKLE, BEI G I A N O R E N G L I S H. Red and yellow flowers; long bloomer; very fragrant. 40c each.

HONEYSUCKLE, HALLEANA, HALL'S J A P AN HONEY'SUCKLE. A strong, vigorous, almost evergreen sort, with pure white flowers, changing to yellow; very fragrant; a long and continuous bloomer. 40c each.

HONEYSUCKLE PUNICEA.A most beautiful sort; having scarlet trumpet shaped flowers. 50c each.

HOPS (Humulus Lupulus). One of the very best climbers for covering unsightly places. It is a rapid grower, and bears a profusion of seed-pods suitable for inany domestic purposes. March deliv. ery 50c per dozen (60c postpaid).

IVY, ENGLISH, LARGE-LEAVED. $25 c$ and 35c each.

IVY, ENGLISH, SMALI-LEAVED. Large plants, 50c each.

IVY, VAR I E G A T E D, SILVERLEAVED. Large plants, $50 \mathrm{c}$ each.

JASMINE GRANDIFLORUM (Catalonian Jasmine). Plant is of shrubby, half-climbing habit, with very delicate foliage, and its small, white, star-shaped, fragrant flowers are produced in the greatest profusion all the year round. 60c each.

JASMINE REVOLUTUM (Yellow-Flowering Jasmine). Produces fragrant yellow flowers. $\mathbf{3 5 c}$ each.

JASIMINE OFFICINALIS. Flowers pure white, sweetly-scented, produced in early spring. 35c each.

MANDEVILLEA SUAVEOLENS (Chili Jasmine). Flowers very fragrant; star shaped; strong climber. 25c each.

MUEHLENBECKIA COMPLEXA (New Zealand Mattress Vine). This pretty, strong-growing climber and trailer is very desirable for covering old stumps of trees, rockwork, etc. The foliage is small, dense and graceful. 40c each.

PASSION VINE (Passiflora)。 These well-known hardy climbers are familiar to and appreciated by all. They are of rapid growth, are familiar to and appreciated by all. They are of rapid growth, and very

PINK. 25c and $35 \mathrm{c}$ each.

SCARLET. 35c and 50c each.
PLUMBaGo CAPENSIS. Can be trained as a bush or climber. Flowers light sky-blue, verbena-shaped, produced throughout the entire summer; stands drought and water and the brightest sunshine. 35c each.

SMILAX. 20c each; 3 for 50c.

SOLANUM JASMINOIDES GRANDIFLORA. A most beautiful climber. Its flowers are star-shaped, and borne in good-sized panicles or clusters. $25 \mathrm{c}$ each.

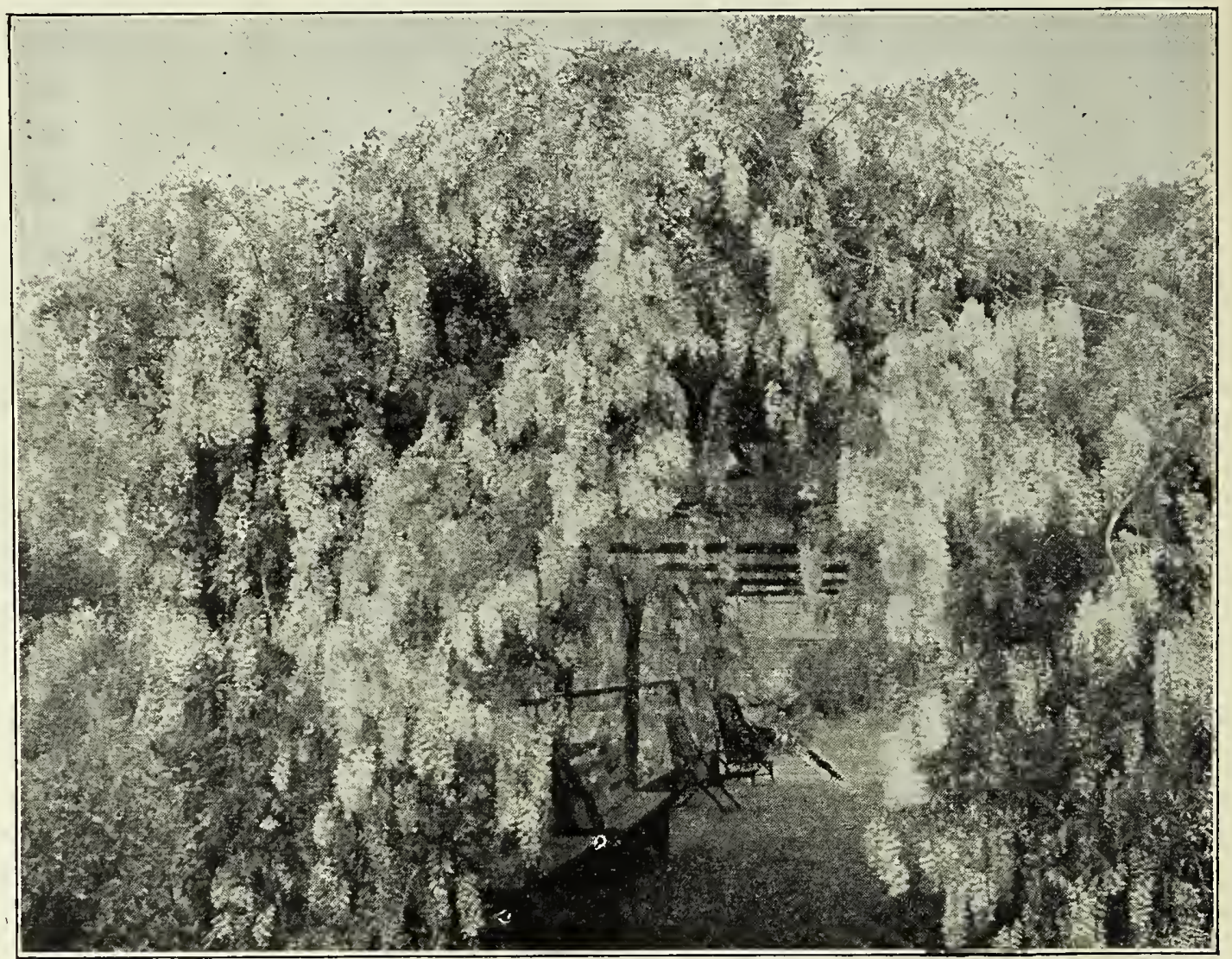

Pale Blue Wistaria, Truly Suggestive

TECOMA JASMINOIDES. An evergreen climber with bright glossy foliage; flowers white, with beautiful blotch of lavender flowers large, bell-shaped, appearing in clusters. Hardy only in sheltered situations. 4-inch pots, 50c each.

WISTARIA SINENSIS (Chinese Wistaria). One of the most elegant and rapid growing of all climbing plants; attains an immense size, growing at the rate of 15 to 20 feet in a season. Has long, pendulous clusters of pale blue flowers in May. Strong plants, 75ceach.

WISTARIA SINENSIS ALBA (Chinese White Wistaria). Pure white flowers. Introduced by Mr. Fortune, from China, and regarded as one of his greatest acquisitions. Strong plants, $75 \mathrm{c}$ each.

WISTARIA SINENSIS ROSEA. A fine new ivariety with clusters of pink flowers. $\$ 1.25$ each.

\section{PALMS, DRACAENAS, ETC.}

* Marked thus are for indoor, conservatory decoration, or warmer sections only.

BRAHEA EDULIS. Unsurpassed, whether grown outside (it is very hardy) or as a pot plant. It has very large fan-shaped Plants in 4-inch pots, 50c each; 5-inch pots, $75 \mathrm{c} \mathrm{each}$ Balled, 2 feet, $\$ 1.50$ each. Boxed, 4 feet, strong plants, $\$ 4.50$ each.

CALIFORNIA FAN PALM (Pritchardia filifera). The wellknown native palm. Leaf stalks very long; at the edge of the 4-inch pots, 25ceach, $\$ 2.00$ per $10 ; 6$-inch pots, 75 c each; $\$ 6.00$ per $10 ;$ balled, $1 \frac{1}{2}$ feet, $\$ 1.00$ each; $2 \frac{1}{2}$ feet, $\$ 1.50$ each; balled, 3 feet, $\$ 2.00$ each.

CHAMAEROPS EXCELSA (Japanese Fan Palm). One of the hardiest of the Fan Palms. Foliage dark green; the segments of the fan-shaped leaves deeply cut, the edges covered with tooth- like spines. Grows from 15 to 20 feet high; very desirable for sidewalk decoration. Balled, $11 / 2$ feet, 75c each; $\$ 6.00$ per decoration or transplanting in the ground. 2 feet, $\$ 3.00$ each; 3 feet, $\$ 3.50$ each.

*CORPYHA AUSTRALIS (Livistonia). An Australian palm. Foliage dark green; very symmetrically and regularly slit, the segments partially doubled from base of petioles or leaf stalk which is thickly armed with crooked spines. Used chiefly for house decoration, though hardy in some locations. 4-inch pots, 50c each; 5-inch pots, $75 \mathrm{c}$ each.

cocos PLUMOSUS. Hardy in some localities, and when grown outside is of rapid growth. No handsomer palm can be found than this. 5-inch pots, $75 \mathrm{c}$ each. 


\section{- S. SAN FIRANCISCO CALIFORNIA U.S.A. W.}

*CYCAS REVOLUTA. The well-known "Sago Palm" so much in demand for inside decoration. The stems are cylindrical terminating in a crown of handsome, feather-shaped leaves of thick, leathery texture. In the southern part of this State this variety grows to perfection out of doors. $75 \mathrm{c}, \$ 1.00, \$ 1.50$,

DRACAENA INDIVISA. A fine plant for outdoor planting in California, and much in use for lawns, avenues and parks. The each; $\$ 3.00$ per $10 ;$ balled, $11 / 2$ to 2 feet, $75 \mathrm{c}$ each; $\$ 6.00$ per 10 ; balled, 3 feet, $\$ 1.50$ each; 4 feet, $\$ 2.00$ each.

ERYTHEA ARMATA (Blue Palm). A variety with deep seagreen leaves; of slow growth. Boxed, 3 feet, $\$ 10.00$ each.

EULALIA GRACILIMA. The foliage is narrow, long and graceful; much used on lawns, where, when supplied liberally with water, it produces a grand effect. $60 \mathrm{c}$ each.

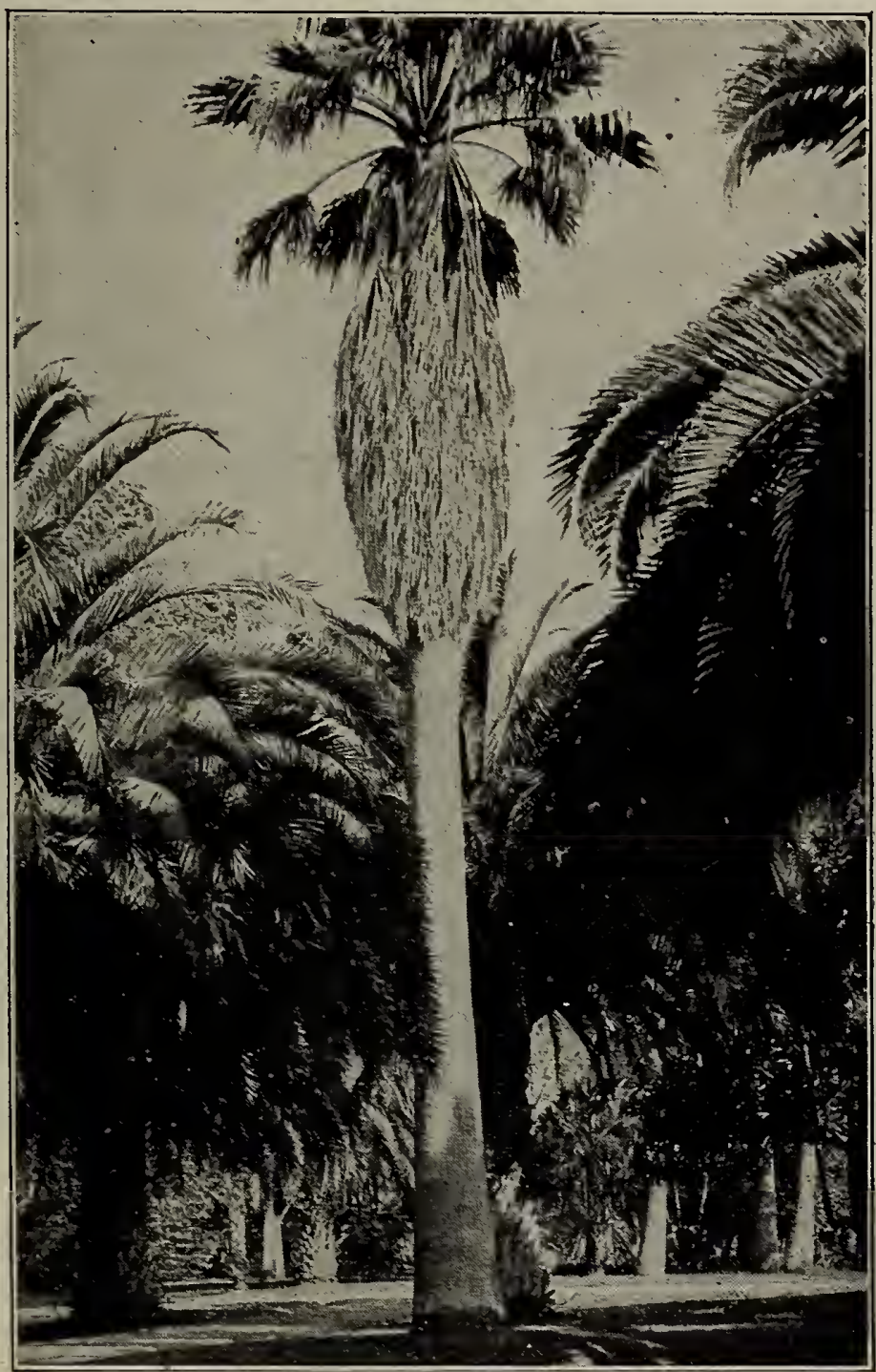

California Fan Palm-Growing in Alameda County

* KENTIA BELMOREANA. This fine palm is a valuable addition to our collection. Its leaves are pinnate, dark green, and so beautifully crisp as to gain for it the name of "Curly Palm." It is very elegant and graceful in habit. $A$ native of Lord Howe's Island, where it attains a height of 40 feet. Plants in 3-inch pots, 35c each; in 4-inch pots, 50c each; in 5-inch pots, $75 \mathrm{c}$ and $\$ 1.00 \mathrm{each} ; 6-1 \mathrm{nch}$ pots, $\$ 1.50 \mathrm{each}$.

* KENTIA FOSTERIANA. One of the finest of the Kentias, with graceful, bright green foliage. Plants in 3-inch pots, 35c each; in 4-inch pots, 50c each; in 5-inch pots, 75c and $\$ 1.00$ each; in $6-i n c h$ pots, $\$ 1.50$.

*IATANIA BORBONICA. Leaves large, fan-shaped, of a very cheerful green color; plant of hardy construction, and adapted to all decorative purposes within doors. Appreciated by all the plant-loving community. Nice young plants, 35c and $50 \mathrm{c}$ each; larger plants, $\$ 1.00$ each.

MUSA ENSETE (Abyssinian Banana). The noblest of all plants is the great Abyssinian Banana. The fruit of this variety is not edible, but the leaves are magnificent, long, broad, and massive, of a beautiful green, with a broad crimson midrib. The plant grows luxuriantly, from 8 to 20 feet high; it grows rapidly and attains season. $75 \mathrm{c}, \$ 1.00$ and $\$ 1.50 \mathrm{each}$.

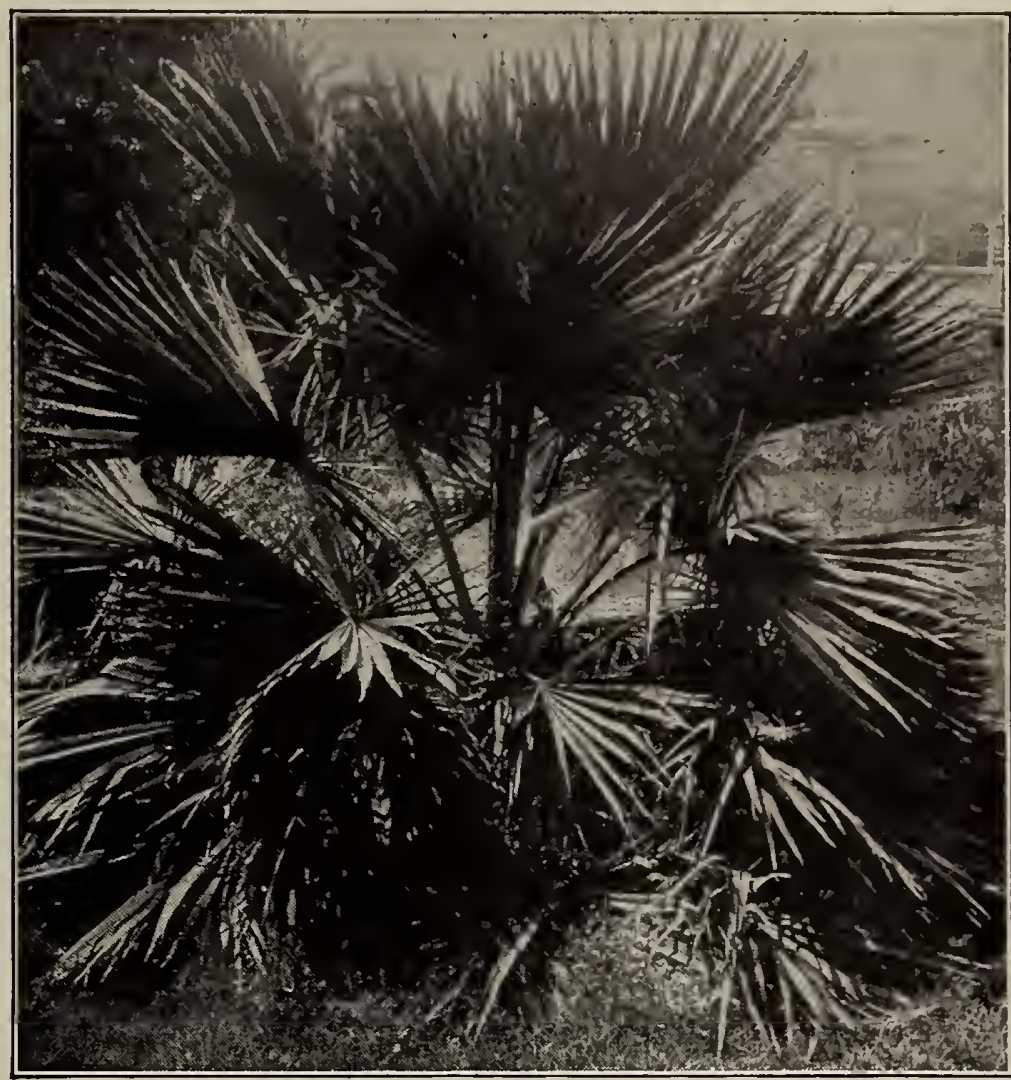

Brahea Edulis - A noble variety

PHOENIX CANARIENSIS (The Canary Island Date). The handsomest and hardiest species of the date palm family. Being a rapid grower, it soon develops into beautiful specimens, with pinnate, dark green leaves, from 6 to 21 feet long, the divisions linear, lance-shaped, very much pointed. It is fully as hardy as the native Fan Palm and differing so widely from that variety in its habit of growth, color, and style of foliage, a finer contrast cannot readily be imagined when the two are planted, either opposite or alternately in rows. Balled, $1 \frac{1}{2}$ feet, $\$ 1.00$ each; balled, 2 to $21 / 2$ feet, $\$ 2.00$ each; boxed, $\$ 2.50, \$ 3.50, \$ 5.00$ and $\$ 6.00$ each, according to size.

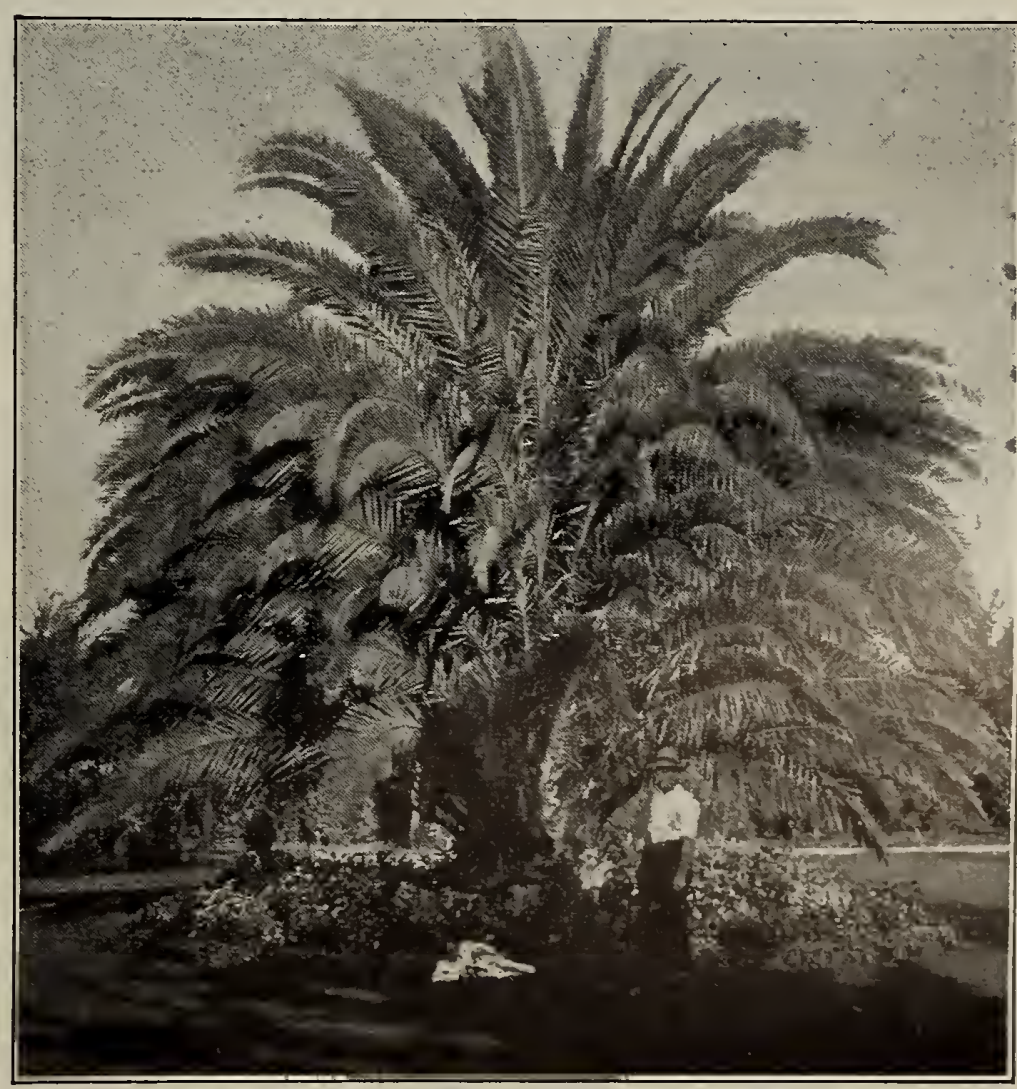

Phoenix Canariensis-Unsurpassed for grandeur 
PALMS, DRACAENAS, ETC.-Continued

PHOENIX DACTYIIFERA. Produces the date of commerce. Boxed, 3 feet, $\$ 4.00$ each.

PAMPAS GRASS. Strong clumps, 60c each.

TRITOMA UVARIA (Red-Hot Poker Plant). So called on account of its scarlet flowers resembling that household article They are borne on long stiff stems during summer months, and are very effective. clumps, 50c each.
* APHIS HUMILIS. China and Japan. A hardy little cane palm, which suckers from the roots like the bamboo and forms a dense clump of canes. A delicate and graceful little plant only 3 to 4 feet in height when full grown. Strong plants in 8-inch pots, $\$ 4.00$ each.

WASHINGTONIA ROBUSTA. One of the hardiest and most beautiful of palms; in habit of growth resembling our well-known California Fan Palm, but more symmetrical and spreading eaves fan-shaped, medium size, retaining their dark-green color during the winter months; stems short, thorny; of upright, compact growth. Boxed, $31 / 2$ feet, $\$ 4.00$ each.

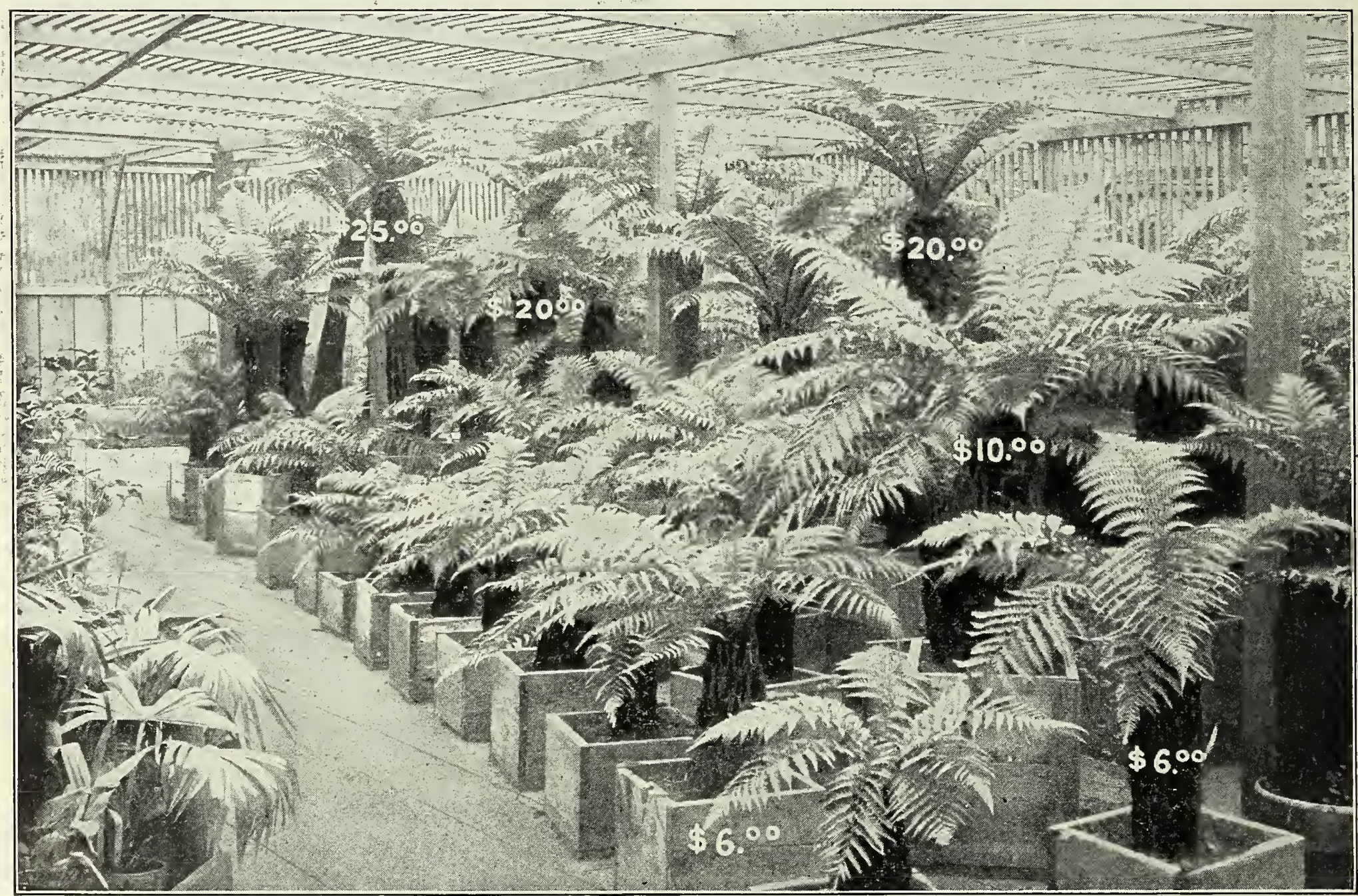

A View in one of our Lath Houses in Oakland, showing some of these magnificient Tree Ferns (Dicksonia Antartica). Natives of New Zealand.

\section{CONSERVATORY AND PARLOR DECORATIVE PLANTS}

Under this heading we have included such plants as flourish in the parlor, hall, greenhouse, and some in protected situations out of doors.

ASPARAGUS PLUMOSUS. The leaves are a bright green, are gracefully arched, and are as finely woven as the finest silken
mesh, surpassing Maiden-Hair Ferns in grace, fineness of texture, and richness of color. $25 \mathrm{c}, 35 \mathrm{c}$ and $50 \mathrm{c}$, according to size.

ASPARAGUS SPRENGERII. A variety of recent introduction. It is as a basket plant that this will prove most valuable. In 6-Inch pots, 60c each; in hanging baskets, $\$ 1.50$ each.

ANTHERICUM, VARIEGATUM. Foliage beautifully striped esteemed as a basket plant. 4-inch pots, 35c each.

ASPIDISTRA LURIDA. This is the plant one sees so many of in windows, halls, and stores. The foliage is large, lily like in appearance, of a dark green color. It is of rugged constitution and will stand in locations that would kill most plants. 75c $\$ 2.00$ and $\$ 3.00$ each, according to size.
ASPIDISTRA IURIDA $\nabla$ ARIEGATA. A variegated form of the preceding. Large plants, in 7 and $8-1$ nch pots, $\$ 2.50$ and $\$ 3.50$ each.

COLEUS. Ready in April. 15c and 25c each.

CYCLAMEN. Charming plants, with beautiful foliage and richlycolored fragrant flowers. Universal favorites for winter and spring blooming. Pot prown plants, in leaf and bloom, $35 \mathrm{c}$ each; smaller plants, $15 \mathrm{c}$ each; $\$ 1.25$ per 10.

FICUS ELASTICA (India Rubber Plant). Very large, smooth leathery leaves, evergreen foliage; generally esteemed one of the finest house plants grown, the plant attaining a large size. $\mathbf{7 5 c}$ $\$ 1.00, \$ 1.50$ each.

ISOLEPIS GRACILIS. A pretty grass-like plant, valuable for hanging-baskets and decorating the edges of benches in greenhouses. 4-inch pots, $25 \mathrm{c}$ each.

Note-Testimonial from an English customer:

Dear Sirs-The first consignment of Loganberries are to hand today, and have arrived in excellent condition. I hope that you have sent the remainder. The packing of this consignment is excellent and cannot be improved on. Please keep this for future reference and pack all future consignments the same way. $\quad$ Yours faithfully,

W. C. S., Woking, Surrey, England. 


\section{SAN FRANCISCO CALIFORNIA U.S.A.}

\section{SELECT LIST OF FERNS}

ADIANTUM CUNEATUM (Maiden-Hair Fern). This fine variety is more generally grown than any of the other sorts; for cutting, greenhouse, and parlor decoration. 5-inch pots, 50c each; 6 and 7-inch pots, 75c each; in hanging baskets, $\$ 1.50, \$ 2.50$ and $\$ 3.50$ each.

ADIANTUM GRACILIMUM. A variety that has finer and more graceful foliage than the preceding; a most lovely sort. 5-inch pots, 50c each; in hanging baskets, $\$ 2.00$ and $\$ 2.50$ each.

ASPLENIUM FALCATUM (Holly Fern). A favorite variety for house culture; the leaves are dark and very glossy and the fronds beautifully arched. 3-inch pots, 25 c each.

ASPLENIUM NIDUS AVIS (Bird's-Nest Fern). The fronds of these curious looking ferns are long and broad, with a dark these curious looking ferns are long and broad, with a dark very dense, and in the center there is a hairy growth, and as one looks down into it it resembles a bird's nest; hence the name. 3-inch pots, 50c each.

ALSOPHYLLA AUSTRALIS (Australian Tree Fern). A most useful fern for house decoration; of easy culture; a most graceful sort. 6-inch pots, $75 \mathrm{c}$ each.

JAPANESE FERN HANGING BALLS. 50c each.

NEPHROLEPIS BOSTONIENSIS (Boston Fern). Is one of the very few plants that will thrive under ordinary house care. It grows well, and improves in size where most all other ferns fail. The fronds droop and arch gracefully over the edge of a pot or basket, and, as it is a very rapid grower it is not long before they reach the floor from an ordinary parlor table. $35 \mathrm{c} \mathrm{each}$.

NEPHROLEPIS EXALTATA (Sword Fern). Splendid extra hardy sort, well adapted for house culture, succeeding, with ordinary care, with every one who tries it. $50 \mathrm{c}$ and $75 \mathrm{c}$ each.
NEPHROLEPIS AMERPHLOIA. The latest introduction of the crested foliaged ferns. 4-inch pots, 50c each.

NEPHR OLEPIS ELEGANTISSIMA. This fern has lovely plumelike foliage and is in mucl demand for house or greenhouse decoration; of recent introduction. 4-inch pots, $50 \mathrm{c}$ each.

NEPHROLEPIS WHITMANII. This is one of the newest introductions to the "plume foliage" varieties and it is certainly very fine; must be seen to be appreciated. Does beautifully in hanging baskets. 4-inch pots, 35c each; in hanging baskets, $\$ 1.50 \mathrm{each}$

NEW ZEALAND TREE FERN (Dicksonia antartica). We have always been large importers of this truly grand Tree Fern and the ever-increasing demand has compelled us to keep up with the times; so we have a good assortment of well-established plants to offer from $\$ 5.00$ to $\$ 25.00$, according to size. For green-house decoration the New Zealand tree fern cannot be beaten; or for outside work, when planted in a sheltered location, they are also very suitable. (See cut opposite page).

POLYSTICHUM SETOSUM. 50c each.

PTERIS ARGYREA. Fronds prettily striped silvery white. 5inch pots, 35c each.

PTERIS ADIANTOIDES. Fronds similar to those of the MaidenHair Fern, only larger; very nice. 5-inch pots, 35c each.

PTERIS DRINKWATERII. Silvery green foliage; very choice. 5 -inch pots, $35 \mathrm{c}$ each.

PTERIS TREMULA. A favorite house fern; fronds long and arching. 5-inch pots, $35 \mathrm{c}$ each.

PTERIS WINSETTI. A beautiful sort, with lovely crested foliage. 5 -inch pots, $35 \mathrm{c}$ each.

\section{THE DAHLIA}

Of late years these have sprung into wonderful prominence, and are becoming more and more popular every year. This is not to be wondered at, considering how they have been improved upon. The Cactus Dahlia of today is much superior to the old "show" round, stiff sorts (though still admired by many) of old. The Cactus varieties have long twisted petals, resembling in many cases chrysanthemums.

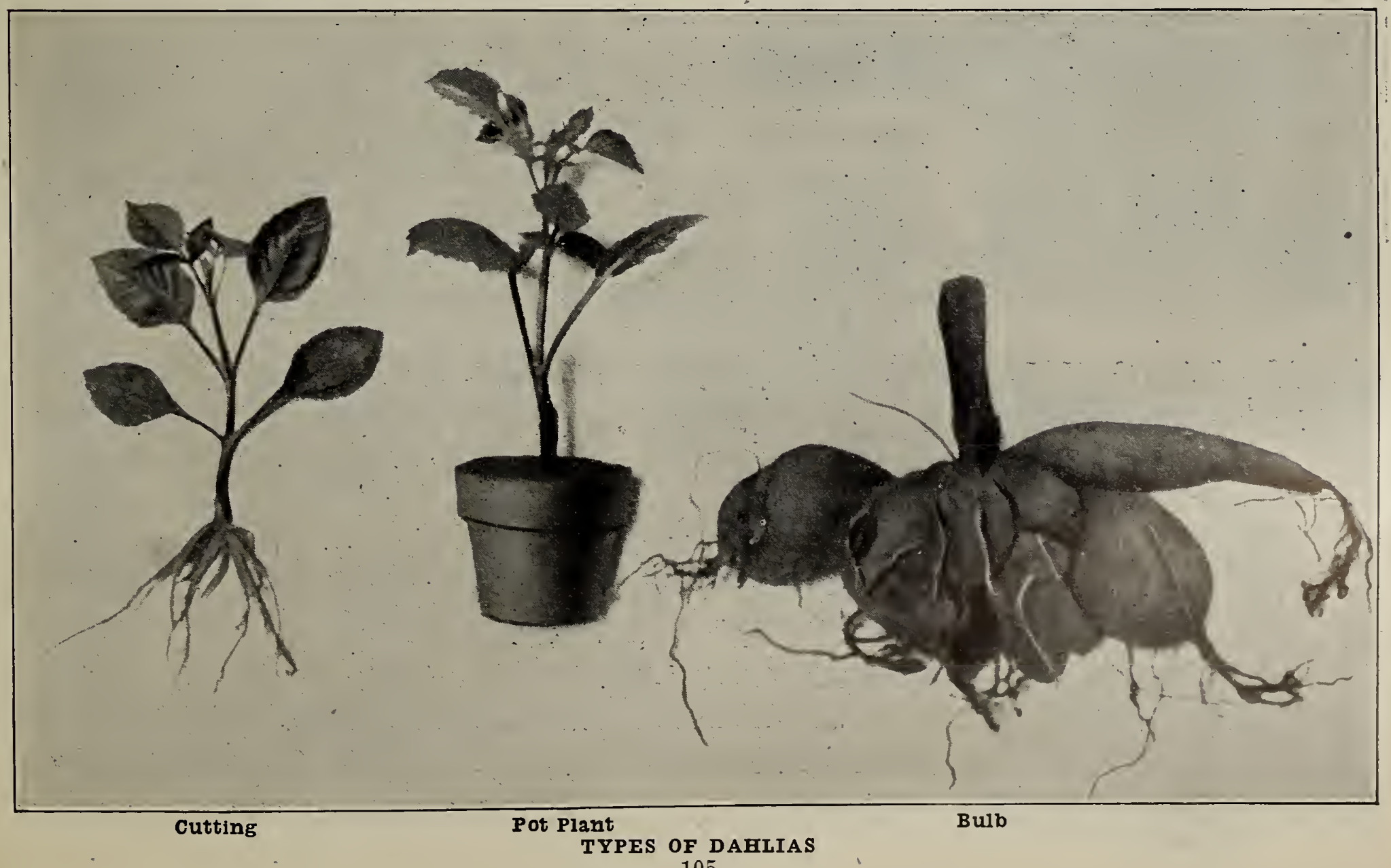




\section{C.C.MORSE \& CO. PLANTS \& TREES}

\section{DAHLIAS}

CULTIVATION.-While the Dahlia is one of the easiest of all flowers to cultivate, it by no means follows that it requires no attention. In fact, no flower that we have ever cultivated will give such a generous response to good cultivation as the Dahlia. Deep and thorough stirring of the soil during the early growth of the plant is indispensable to success. With poor cultivation or neglect, the flower will rapidly degenerate-becoming semi-double and faded in color. The Dahlia, with but few exceptions, should be given an open, sunny situation for at least a portion of each day. It is a rank feeder and should be given rich soil and kept free from weeds. We are in favor of taking up the roots every year, as soon as the tops are cut down by the frost, and laid away in sawdust or in a dry place. Plant them out again in MAY OR THEY CAN BE PLANTED AS LATE AS THE END OF JUNE. We strongly advise our customers not to be in a hurry about setting the Dahlia out, as it is essentially a fall flower, and when planted early they bloom in the hot summer months, and the flowers are very inferior, and at that season they are generally infected with an insect called "Diabrotica," resembling a lady bug, which does much damage to the flower of the dahlia. This insect disappears later on; hence our reason for advising late planting. So many of our customers have been disappointed in this respect just through early planting. Continuing with our remarks about cultivating-as soon as the plants are about two feet high, they should be staked, care being taken that the stake is driven far enough away from the root, so that it may not be injured. Mulch heavily with old, well-rotted manure, and give the plants a thorough soaking once in ten days or two weeks. Frequent syringing adds greatly to the health and vigor of the plant. Disbudding or picking off some of the flower buds and leaving only a few on one bush adds greatly to the size of the bloom. Dahlias can be set out from two kinds of roots, viz., DRY ROOTS and GREEN POT PIANTS. The former can be obtained as soon as we dig them, in December, and can be kept in sawdust, as above described, till planting time. It is better to order early or when you are getting your other stock.

GREEN POT PLANTS will be ready for delivery during May; they are grown in pots and raised from a cutting. There are some of the newer sorts which we can supply in green plants only. These-green plants-you will please remember, will all bloom the first season after planting, and at the same time they are forming a bulb, which will do for planting out next season. THE DAHLIA KEEPS ON MULTIPLYING YEAR AFTER YEAR.

\section{NEWEST INTRODUCTIONS}

We can supply Green Plants only of the following choice sorts. Ready April and May. 35c, $\$ 3.50$ per dozen.

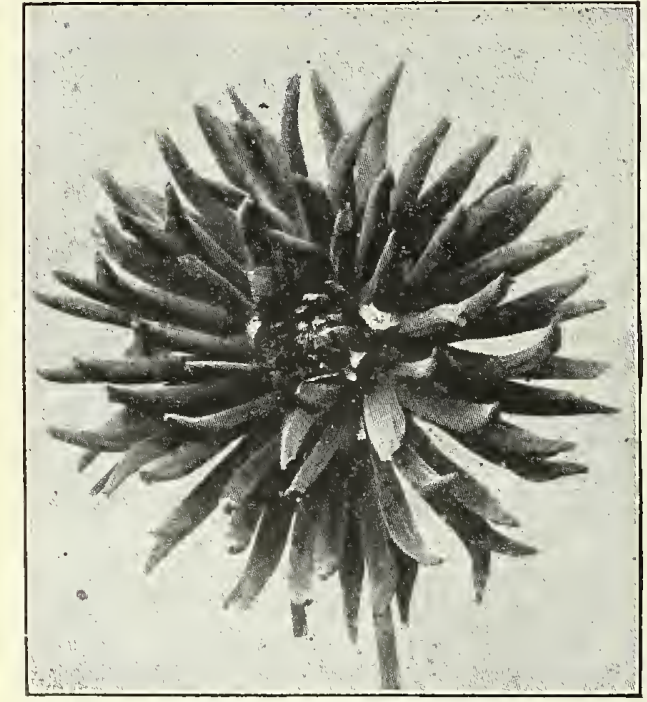

Countess of Lonsdale

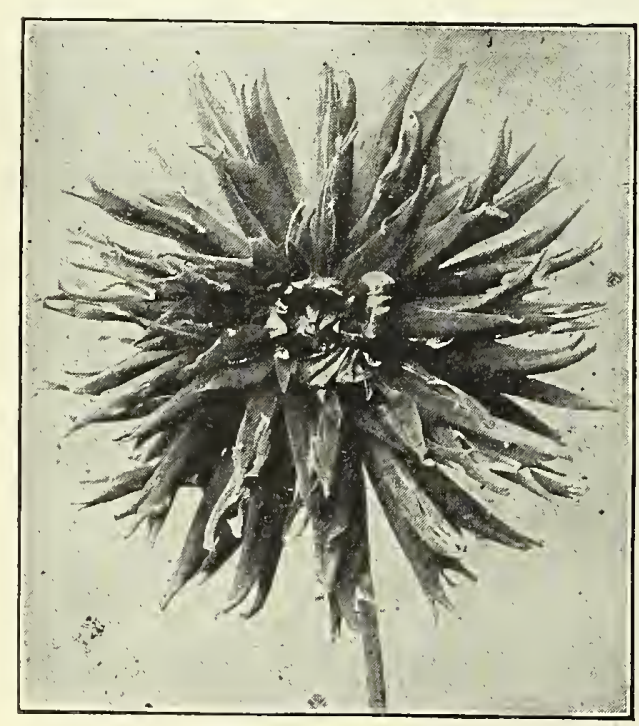

Progeniture

MRS. MORSE This variety is one of our own introductions. It is a sport from Mad. H. Chanet. Color, beautiful pure snow-white, showing no yellow shading, whatever. It is a decorative Dahlia, flowers large, borne very freely on long stems, throwing the flowers well above the foliage, thus rendering it very valuable for cutting purposes. It is a fine keeper lasting fortseveral days after cutting. Those who have seen this Dahlia at our nurseries all say that it is the purest and best white they have ever seen. Mr. George C. Roeding says: "When on a visit to your nurseries in Oakland a few days ago, I was shown through your nursrey of Dahlias. I want to take this opportunity of complimenting you on your magnificent collection. Among the numerous varieties which impressed me was the 'Mrs. Morse'. It is certainly one of the finest white Dahlias I have ever seen. I am of the opinion that it is a very valuable variety and is sure to meet the delighted approval of all that it is a very valuable variety

DAYBREAK A very rare shade of burnished copper; true cactus sort; stems good, DOROTHY VERNON A very pleasing cactus Dahlia of exquisite shape. COLUMBIA A fancy cactus sort; red; petals long and narrow, beautifully CLOWN

GOLD MEDAL Bright canary yellow, regularly marked with fine stripes and markably fine fancy Dahlia.
mings of deep red; flowers very large; easy grower. A re-

GETTYSBURG An exceedingly large decorative Dahlia; full, round, high center GETIYSBRG Bright rich scarlet. An early and extrenely profuse bloomer.

J. SEULBERGER A fancy cactus Dahlia. Pink ground, beautifully variegater SEULBERCER with yellow. A decidedly fine new introduction.

LADY COLIN CAMPBELL A fine yellow. shaded orange, cactus Dahlia : LUCIFER A true cactus, petals long and narrow, twisted; flowers borne very proMRS. ALEXANDER A very large, double rose colored, show variety.

MISS HARMON A magnificent red cactus Dahlia; flowers very large and full MADAME VAN DEN DAEL A grand decorative variety of immense white. Shading shell pink on outer end of petals. This variety attracted much attention when on exhibition at our store and nurseries last season.

SAILOR PRINCE A superb rich crimson cactus, long narrow petals, finest THOMPSON very dark-red; a large double show variety. 


\section{CHOICE CACTUS DAHLIAS}

Including all of the best of the newer and older sorts.

We will supply dry roots of the following varieties, as long as they last; after they are sold out we will supply green plants; those are ready during April and May:

Price of Roots and Plants, 25c each; $\$ 2.50$ per dozen.

BEAUTY OF NIGET. An intense dark, velvety black. The petals are long, pointed and twisted; stems long and stiff, holding the flowers well above the foliage; very free in bloom.

BRITANNIA. Delicate shade of soft salmon pink, blended with apricot. Petals long and twisted. Very full in bloom; stems long and stiff. Superb.

COUNTESS OF LONSDALE. A most bèautiful Cactus Dahlia of true type. Color rich salmon tinted with apricot at the base of the petals, carmine pink towards the tips; stems long and stiff; very free in bloom. Hard to beat.

CBARM. The base of the petals yellow, varying to red, with white tips and edges; very full in bloom. Distinct and charming.

COMET. A grand "fancy cactus," which has proven most satisfactory with us. The ground color is silvery rose, speckled and striped crimson. The stems are long and stiff and the flowers are borne well above the foliage; a good bloomer and keeper.

EVA. Pure white; petals incurved; an exceedingly free bloomer; flowers of medium size and fine form; of dwarf habit.

FLAMINGO. Very bright scarlet; flowers large, long pointed petals; stems strong, throwing the flowers well above the foliage; extremely profuse in bloom.

FLORENCE. A charming shade of yellowish orange. The flowers last well, and always come good from early to late. The pointed petals are arranged neatly; very free in bloom.

F. H. CBAPMAN. Yellow overlaid with deep orange; very bright and effective. A flower of grand form and largest size, with narrow, beautifully incurved petals.

FLORADORA. Dark velvety crimson. Plant of medium height, branching in habit and an exceedingly early and profuse bloomer; continually in bloom. Fine for cutting, as the flowers are borne on long, erect stems, and keep for a long time.

GENERAL BULLER. Rich velvety crimson, nearly black at the base, each floret having a pure white tip, those in the extreme center showing a tinge of plum color. A very remarkable and perfectly distinct flower. Long erect stems, very free.

GENESTA. The ground color is amber, passing towards the center to golden-yellow; the florets are beautifully arranged. Good free bloomer; stems long and erect.

GOLDFINCB. Clear bright cinnamon; the best of this shade; petals gracefully incurved.

INNOVATION. Reddish scarlet, ends of petals distinctly tipped with white. Very fine and much admired.

J. W. BAGGE. Color bright radiant orange, with a tint of shining vermilion, an indescribably beautiful shade; flowers extremely large; stems long; blooming qualities unexcelled.

J. C. JACKSON. The deepest, darkest velvety maroon-black; of true cactus form; fine stems; grand bloomer. Nothing to equal it in its color. Perfection.

KREMHILDE. Delicate shell-pink with white at center; of good cactus form; a free and long bloomer.

MAID OF HONOR. Rosy pink. A magnificent large flower with long narrow petals; exceedingly free in bloom. The stems are all that can be desired.

MATCBLESS. Dark purple maroon; almost same shade as the "Black Prince" rose. In form, color, size, and growth this variety is perfect. Blooms for a long period.

MONARCH. The color is a rich glowing velvety crimson; stems very long and stout, and hold the flowers well above the foliage. Very floriferous indeed.

MONARCE II. This is a sport of the preceding; the plant is of dwarf habit, and is somewhat on the decorative type; color dazzling magenta; very free in bloom.

MRS. MAWLEY. The finest yellow Cactus Dahlia of largest size, coming on strong stems; fine form and shape; every bloom coming perfect; deep canary-yellow. Superior to all other yellow sorts.

MRS. SANDERS. A beautiful deep golden-yellow; grand flowers, borne well above rich foliage, on long stiff stems.

MAJOR TUPPENNY. Center of the petals yellow-tipped and bordered with dark buff, beautifully blended; stems long and strong, carried well above the foliage; a good keeper. A novel color.
MAD. H. CHANET Pure snow-white; flowers of uncommon shape, being somewhat on the decorative type, looks more like a white water lily than a clalia. Of free growth and prolific in bloom and of very large size.

MRS. H. J. JONES. Scarlet edged cream and heavily tipped with white, very large and perfect; fine erect habit, blooms well above parti-colored varieties.

ocTopUs. White, tinted blush, very large; good shape, free bloomer; good stems and an excellent keeper.

PRINCE OF YELLOWS. Another grand yellow Cactus; not as many-petaled as Mrs. Mawley; stems long and stout; a grand keeper.

PROGENITURE. Intense dark, cardinal-red; large size; heavy flowers, coming perfect, and so free flowering that the whole plant is covered with blooms; petals are beautifully quilled ends cleft or prettily fimbriated. A unique variety that should

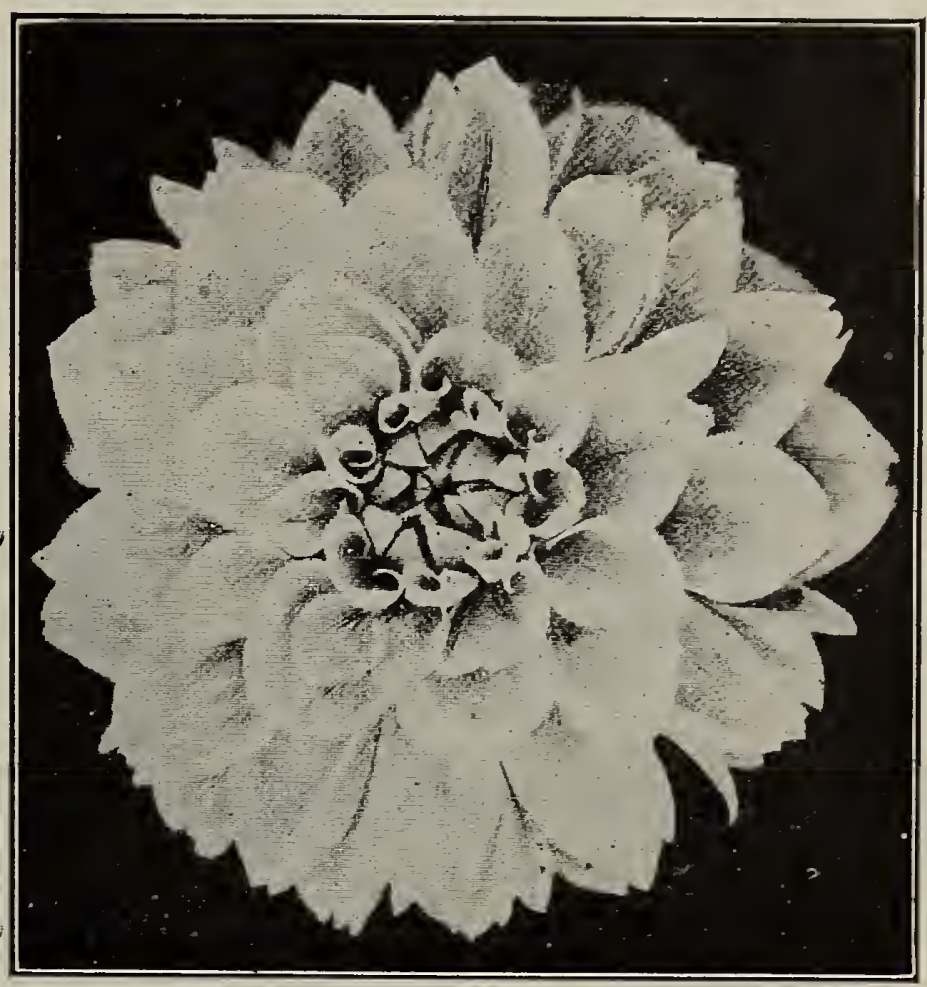

Dahlia-Mrs. Roosevelt Much reduced

PROFESSOR ZACHARIAS. Canary yellow; long pointed petals; very free in bloom, the bushes being literally covered with a mass of Howers.

RICHARD DEAN. One of the most striking novelties of recent years Vermilion scarlet, with distinct white tips. The habit will please the most exacting. It is upright, and has flower stems of great length. Flowers are of good size and splendid form.

RADIANCE. Soft vermilion-scarlet; shining with a gloss that illuminates the blooms. A brilliant variety that must be seen to be appreciated.

RUBY. Intense ruby-red; tip of petals touched with magenta; petals quilled and pointed; the blossoms come on good stout stems, holding them well above the foliage.

SPOTLESS QUEEN. A grand Cactus Dahlia, pure white; stems long and stiff.

SERIUS. A true cactus; perfect in every particular; yellow, beautifully penciled scarlet.

VESUVIUS. A fancy cactus sort, much admired; the ground coloring is cinnamon-yellow, and penciled scarlet; petals long and full to center.

VICTOR VON SCBEFFEL. In this new soft pink cactus Dahlia, we have a decided acquisition; petals narrow and pointed.
It is a strong vigorous grower, extremely profuse bloomer with long, erect stems.

WM. JowETT. Deep cardinal red; perfect cactus form, every petal quilled, very large; stems all that can be desired; very free in bloom.

WINSOME. A very fine white cactus dahlia; flowers very large, beautiful cactus form, with twisted, incurved petals, and borne on long, erect stems, holding the flowers well above the foliage, 


\section{DECORATIVE DAHLIAS}

$25 \mathrm{c}$ each; $\$ 2.50$ per dozen.

AMERICAN FLAG. Bright orange, sometimes tipped white. Much admired. Free bloomer.

COUNTESS OF PEMBROKE. Perfect form and double to the center. Color rosy lavender, beautiful shade. A magnificent sort.

FRANK L. BASSETT. Bright royal purple, shading to blue. The nearest approach to a blue Dahlia yet produced; the flowers are large, of fine form, and, although such a profuse bloomer, they are perfectly full to the center until the last.

MRS. ROOSEVELT. One of the finest novelties that has been offered in years. It is of immense size, 6 to 7 inches in diameter something of the form of Grand Duke Alexis but not so stiff and heavy, The color is a delicate blush pink. The plant is very strong, vigorous, growing about 5 feet high; of branching habit, and for such a large flower an extremely profuse bloomer.

IMRS. WINTERS. Color pure waxy white. It blooms very freely, producing flowers from 5 to 7 inches in diameter.

PATRICK HENRY. Pure white; of good decorative shape; stems long and stout; very full in bloom.

SANTA CRUZ. Straw color petals, beautifully tipped rosy-red; elegant shape; good free early bloomer; fine stems; one of the best of its class.

\section{SHOW AND FANCY DAHLIAS}

These are the old style of Double Dahlias much improved. Shape of the flowers in this class is mostly ball-shaped. All of them of wonderful formation.

\section{ALBERT ELDRED}

It gives us much pleasure to offer this grand, new acquisition. This variety was raised by Wm. Eldred, Burlingame, California. The ground coloring is a most lovely shade of orange-pink, the ends of the petals are beautifully tipped with white, altogether a most wondrous color, which we are unable to adequately describe as it should be; suffice it to say that those ordering this variety cannot but be delighted with it. The formation of the flower is also very fine, being absolutely faultless. Flower, very large.

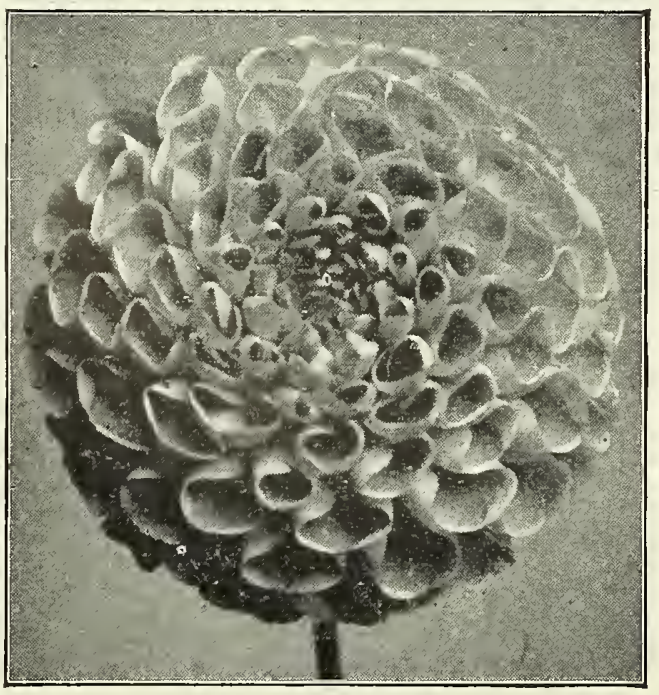

A. D. Livonil

A. D. LIVONII. A clear deep rose. The flower is well built up in the center; petals beautifully quilled.

ADMIRAL SCHLEY. A seedling of American Flag and a great improvement on that popular variety. It is of same color and marking-bright crimson with a broad white stripe through the center of each petal-but much larger and fully as profuse a bloomer

BLACK DIAMOND. The color is dark, jet-black when the flower first expands, and gradually changing to a deep velvety maroonblack. The flowers are large, of regular form, and good substance.
FRANK SMITH. Deep" maroon, tipped white; large and full to the center; petals beautifully quilled. One of the best "Fancies."

GERIMANIA. A novel variety that has attracted great attention; bright deep pink; petals reflexed and serrated.

GRAND DUKE ALEXIS. A magnificent flower of large size and distinctly unique; petals are rolled up so that the edges overlap; color pure white.

JUDAH. The color varies-sometimes solid primrose yellow; sometimes primrose-yellow shaded and suffused old gold, sometimes striped and penciled crimson, sometimes the flowers are solid crimson. All these types often appear on the same plant.

LOTTIE ECKFORD. This is a "Fancy Dahlia." The ground is white, spotted and striped with pink and crimson.

IMAID OF KENT. Another "Fancy Sort." Scarlet-crimson at base of petals, point of each being white.

OLYMPIA. The flowers are of immense size, measuring 6 to 7 inches across, with full high center and, owing to the great length of the petals when opening, there is never a green center showing, even when the buds are first expanding. 'The color is deep rose-pink, striped and penciled with rich crimson.

RED HUSSAR. The flowers are large, of regular form, with a full high center and good texture. The color is purest cardinal-red. without trace of purple or crimson.

STORIM KING. Pure white; perfect form: An extremely profuse bloomer. Dwarf habit. Fine for bedding.

\section{SINGLE DAHLIAS}

All these are of dwarf, bushy growth, and need but little staking, unless in very exposed situations. Many people prefer single Dahlias. They are like most single

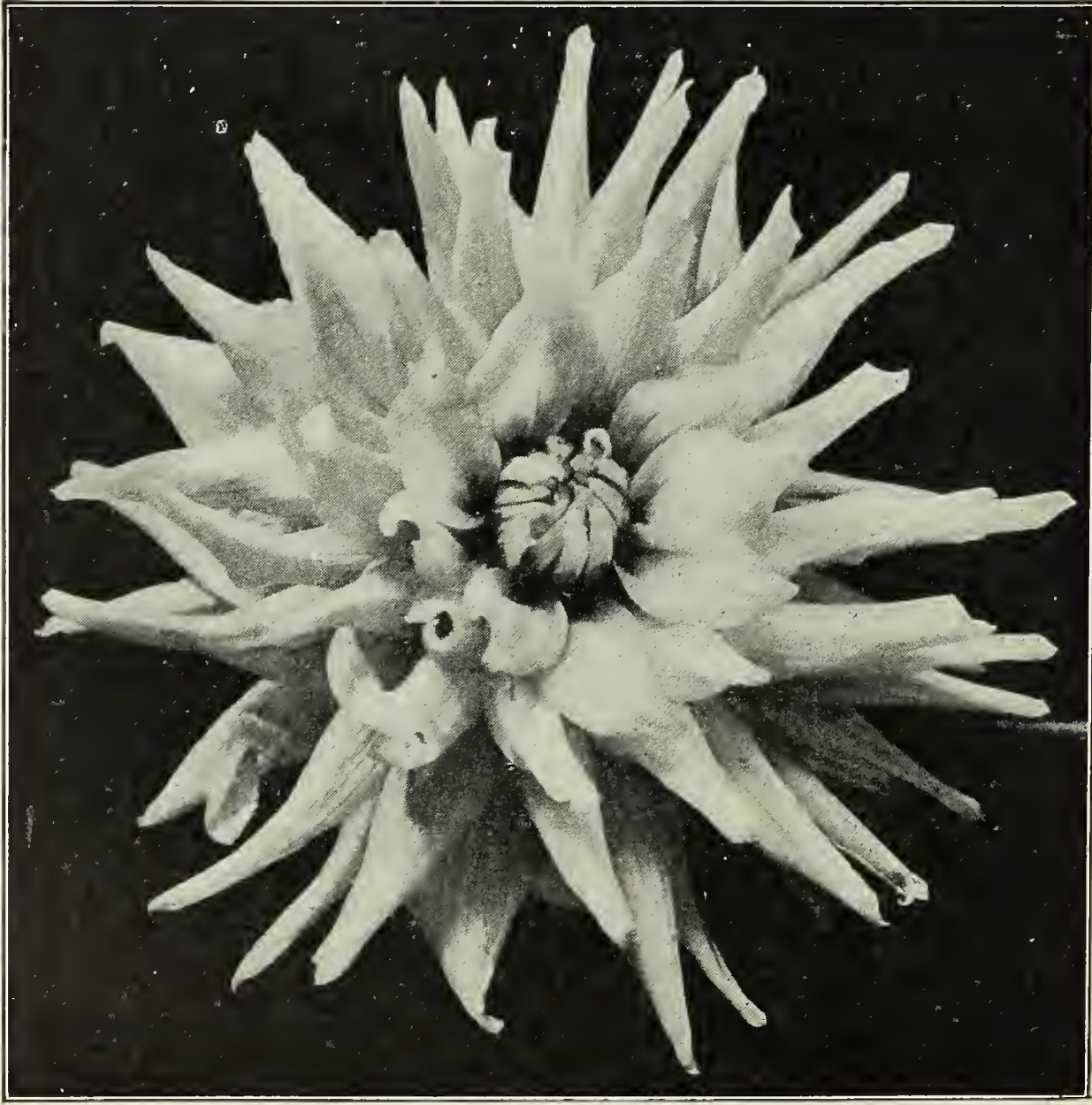

Cactus Dahlia. Winsome

flowers, more esthetic and graceful than the double. The coloring is equally vivid and brilliant, and they bloom even more abundantly. A few plants will give quantities of cut flowers from early June to the middle of November, if old blooms are kept picked off.

25c each; $\$ 2.50$ per dozen.

BRILLIANT. Deep, rich, vivid, velvety scarlet; sometimes the flowers eome striped yellow instead of solid color; medium sized, produced on good stems; good keeper; exceedingly free flowering. A mass of bright color throughout the entire season. 
BLACKBIRD. Black, changing to rich, velvety maroon with a bright red spot at the base of each petal; the flowers are large, regular in form and of fine texture and finish.

GRACILIS. White, tinted blush; dashed, splashed, streaked, and spotted with crimson and dark red in a beautiful manner. Of the hundreds of blooms covering a single bush scarcely two are marked alike. Very fine.

GAILLARDIA. Golden-yellow, with a broad band or disc of red around the yellow center; named from its striking resemblance to Gaillardia Grandiflora. A distinct type that will become a popular favorite.

LEONE. A very lovely variety; flowers exceedingly large; white overlaid with soft pink. A rare combination. It blooms very freely for a lengthened period; the stems are long and stiff, thus making it a very valuable variety for cutting purposes. A vase making it a very valuable variety for cutting purposes. A vase the electric light showing up the flowers to the greatest possible advartage.

LAWRENCE KRAMER. The color is a deep, bright rosy pink of the richest, brightest shade, without tint or blemish, in marked
contrast with so many of the so-called pink singles, which are contrast with so many of the so-calle
shaded crimson, violet or lavender.

RAINBOW. Intensely bright crimson, shaded cerise and tipped with pink. The blending and shading of these colors is indescribable; it fairly shines with a metallic luster that no words can do justice to. One of the very best.

ST. GEORGE. Pure yellow, without spot or shading; long stems; free bloomer.

\section{COLLARETTE DAHLIAS}

An entirely new type of single Dahlia, which has produced a great sensation the past three years wherever shown, and which has been awarded highest honors. The peculiarity of the type lies in the development of the four stamens into short rays or petals at the base of the petal, which form a frill or collar around the center. As the collar is entirely distinct in color from the rest of the flower, it is most unique and striking. We offer two of the most distinct varieties. We were pleasantly surprised and delighted with the habits of both these varieties, as they are of dwarf, branching habit and extremely profuse bloomers, starting with the earliest and continuing in full bloom until frost. 25c each.

JOSEPH GOUJON. The flowers are quite large, orange-red shading to deep red, with light canary-yellow collar. This variety has ten to twelve petals instead of the regulation eight.

PRESIDENT VIGER. The most beautiful and striking of the two varieties. Rich, deep blood-red, shading darker toward the base of the petals, with pure white collar, occasionally suffused with rosy carmine. The flowers are always perfect, with eight petals; it is an extremely early and profuse bloomer.

\section{CARNATIONS}

In the following list will be found none but the newest and choicest varieties. Ready $\mathbf{M a r c h}$ and April.

NOTE.-Customers selecting their own Carnations are respectfully requested to add to their orders a few suppiementary sorts, lest by previous orders the stock of any particular variety should be exhausted; this being especially necessary late in the season. $\quad$ Plants from $21 / 2$ inch pots, $15 \mathrm{c}$ each; $\$ 1.50$ per dozen.

ENCHANTRESS. Of recent introduction. A very pleasing shade of light pink, deepening toward the center; borne on long stiff stems; habit of plant strong and vigorous.

ESTELLE. A standard scarlet carnation, in much esteem on account of its all round good qualities.

GLENDALE. Variegated; similar to that old favorite, Mrs. Bradt, but freer in bloom and larger flowers; flowers borne on long stems continuously.

HARRY FENN. A very large, extremely full flower, deeply fringed and very fragrant. In color, a fine crimson, a little lighter in color than Governor Roosevelt and much freer in bloom than that variety. Stems long, and stiff enough to carry the flowers very nicely.

JOHN CARBONE. A much admired variety; color brilliant rich shade of gold flaked with light carmine; flowers large and produced very freely on strong stems.

MRS. THOMAS W. IAWSON. A grand deep pink carnation of very large size; blooms carried very erect on strong heavy stems; unusually free in growth and bloom. No carnation to date has created such a sensation as this variety, thirty thousand dollars having been paid for the original stock.

MARIAN. A good pure white carnation; flowers of good size, borne on good stems; fragrance good.

MRS. PATTON. A beautiful variegated carnation; sent out by the originator of Lawson. Flowers very large and full; carried on long wiry stems; ground color pure glistening white delicately striped with fine pink stripes. Very free in growth and bloom. It is with pleasure that we call the attention of all lovers of It is with pleasure that we call th

NELSON FISHER. A very deep pink in color, deeper than Lawson; flowers finely formed, with fringed edges. We can recommend this variety very highly for out-door planting. To say that this variety originated with the same grower that sent out Mrs. Lawson and Mrs. Patton, should be a guarantee for its sterling qualities.

PINK ENCHANTRESS. A bright rose colored sport of Enchantress; already as popular as its parent; it has all of the latter's good qualities.

PROSPERITY. One of the most remarkable Carnations yet originated, producing probably the largest average size blooms of any variety known, the flowers a veraging from $3 \frac{3}{4}$ to 4 inches. of any variety known, the flowers averaging from $33 / 4$ to 4 inches. The plant is extremely healthy in growth and a continuous
bloomer. It is a first-class keeper in every respect and a splendid shipper. The color is distinct from any other variety, the ground color being pure white overlaid with pink mottles, deepening toward the center, the color scheme reminding one of the beautiful tints often seen in azaleas and rhododendrons.

VICTORY. Brilliant scarlet; flowers very large, borne on long stems; vigorous in habit and very free in bloom. Considered stems; vigorous in habit and very
the best Scarlet ever introduced.

WHITE PERFECTION. This is now conceded to be the best white in cultivation; stems good, fine keeper and with a pleasing clove fragrance.

\section{CHOICE NEWER SORTS}

ARISTOCRAT. Deep pink, brighter than Lawson; flower very full and built high, perfect in form, splendid stem and calyx; good keeper and continuously in bloom.

EL DORADO. One of the best yellow sorts.

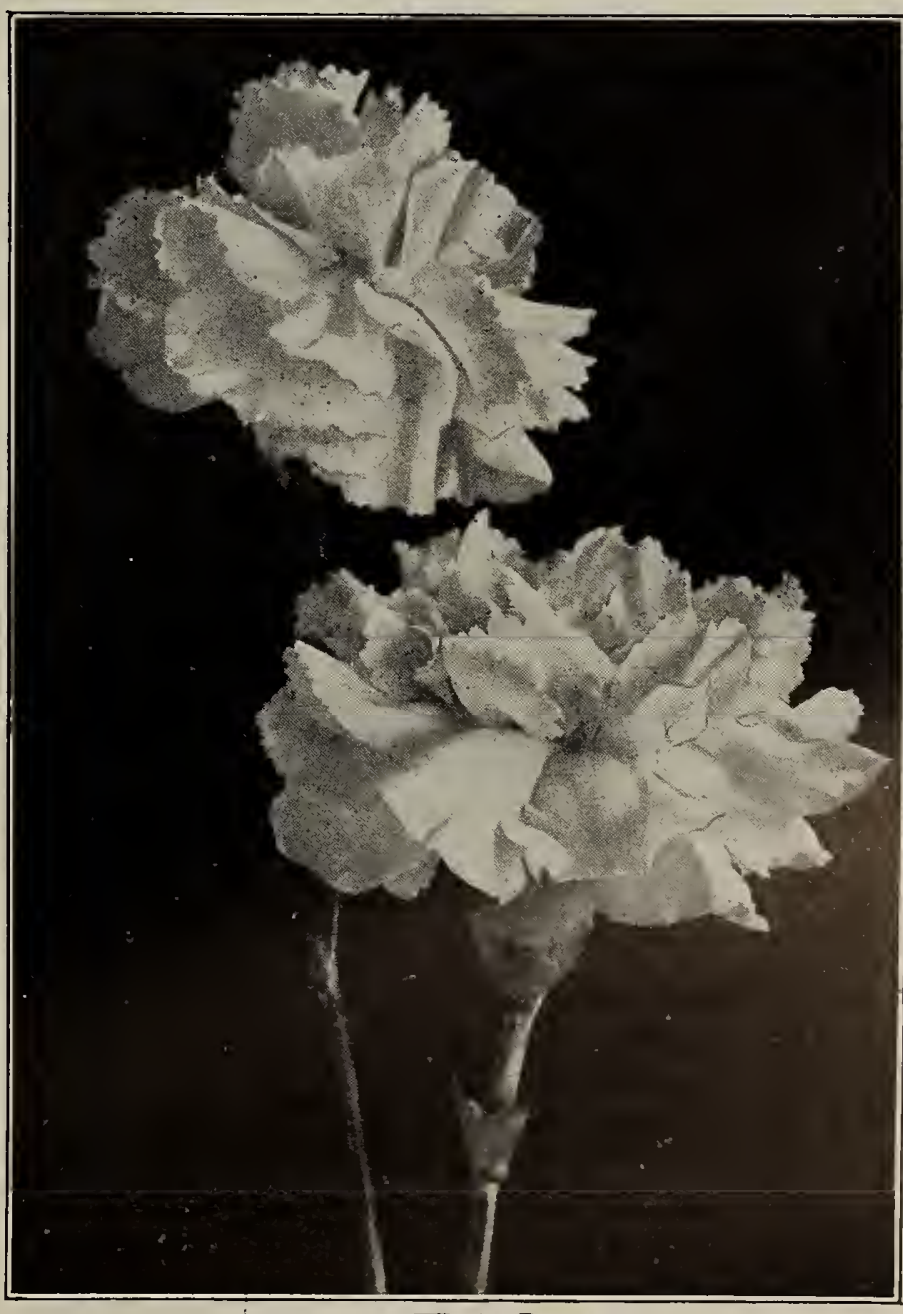

Carnation-White Perfection 


\section{C.C.MORSE \& CO. PLANTS \& TREES}

\section{GERANIUMS}

\section{Price of plants in 31/2-inch pots, 20c each; $\$ 2.00$ per dozen}

Smaller plants, $15 \mathrm{c}$ each; $\$ 1.50$ per dozen

ALICE OF VINCENNES. Border of intense scarlet, forming band around the body, color a rosy-pink, heavily veined with
scarlet, center white; a very brilliant combination of colors. scarlet,

COUNTESS OF HARCOURT. Pure double snow white. A grand bedder. Florets large and beautifully formed.

GENERAL GRANT. A fine scarlet; good bedder.

JEAN VIAUD. Soft, pure pink, with two white blotches; dwarf, stocky grower, rigid stems, large trusses, perfect florets.

M. P. MORLAN. Large flowers of rosy salmon, center white, surrounded by a halo of bright salmon. Single.

MARQUIS CASTELLANE. Immense flowers about $2 \frac{1}{2}$ inches in diameter; two beautiful shades of red; petals undulating on the edges.

MADAME LANDRY. Double; very free and constantly in bloom throughout the season; trusses large, and florets of the finest size and circular in form; color clear salmon; center shading to copper with a white eye.

MADAME L. ABBEMA. This lovely variety has large, round double florets of an exquisite shade of blush pink, mottled, and shading into white; nicely filled with petals.

MRS. GAER. Fine velvety pure white; single
S. A. NUTT. The very best of the dark crimson scarlet bedders.

TAMATAVE. Large, round, full flower; clear bright red shading to orange.

THE SWAN. A grand double white variety, constantly in bloom.

\section{IVY-I.EAVED GERANIUMS}

Are indispensable for covering banks, fences, etc. They are almost continuously in bloom, and require very little water.

CHAS. TURNER. The handsomest Ivy Geranium ever introduced; flowers $2 \frac{1}{2}$ inches, trusses 6 inches across. The color is a bright pink,. Quite double. Very useful for window boxes and rockeries.

CHER R RED. A very fine double variety.

FLOURENS. Large irregular flowers, salmon shaded with rose, large petals.

P. CROzY. A grand hybrid between the zonales and ivies, having the foliage of the former, while the forms of truss and florets are found only among the ivies. The color is soft bright scarlet, with veinings of maroon. A grand bedder. Profuse in bloom.

\section{PELARGONIUMS}

\section{(Lady Washington Geraniums)-Regal, Fringed, and Decorative Varieties}

This magnificent group includes those varieties whose habit is more robust, and the flowers much larger than those of the Show Pelargoniums. Their petals are either frilled or fringed, and overlap each other in such a manner that they present the appearance of being double. Several of the varieties display a warmth and richness of coloring not found in any other class. Plants in 4-inch pots, 25c each; $\$ 2.50$ per dozen. Ssmaller plants, $15 \mathrm{c}$ each; $\$ 1.50$ per dozen.

Please state if we can substitute, if necessary.

ANITA. A most charming flower of extraordinary size, combining with it great freedom of bloom; of a lovely shade of brightest pink; upper petals grandly feathered with dark, velvety crimson, with an almost white center.

DOKOTHY. Soft shade carmine rose; white center, surrounded with lilac shade; all the petals margined white; upper petals blotched maroon.

DUKE OF ALBANY. Deep, rich crimson maroon, margined with rosy lake; light center, surrounded with violet, rose shading. A grand, dark variety, having a very full appearance.
DUCHESS OF TECK. Very large trusses of extra large semidouble white flowers; petals undulated and frilled.

E. G. HILL. Brilliant dark maroon, shaded scarlet, lower petals, lighter shade, with white center; very large.

GOLDEN GATE. Large flowers, with elegantly fringed margins of a beautiful orange-scarlet color; center light maroon; upper petals blotched with intense black.

MABEL. Upper petals brilliant dark maroon, under petals soft rosy pink; large white center.

MADAME THIEBAUD. Blotched and marbled rose and white ground; upper petals marked with crimson maroon; large white center, and edges of petals also white.

MILTON. Upper petals grandly blotched dark maroon, surrounded with bright crimson and edged with rose. lower petals soft pink, feathered with crimson; light center. Light trusses of fine. elegantly fringed flowers.

PRINCE GEORGE. Large trusses of finely fringed white flowers faintly suffused with blush; all petals spotted with purplish lake; two upper petals more marked than the others.

\section{CHRYSANTHEMUMS}

Chrysanthemums should not be planted out earlier than March 30th. At that time we can supply plants from 3-inch pots. at $15 \mathrm{c}$ each, $\$ 1.50$ per dozen, of the following choice sorts:

A. J. BALFOUR. A grand Japanese incurved. Color, rose-pink, broad petals of great substance. Fast gaining a first place, for there is nothing to touch it in color; a pink that is dazzling.

COLONEL APPLETON. Large yellow; late; fine incurved.

CONVENTION HALL. Very large pure incurved white. Flowers mid-season.

GOLDEN DOME. A large bright yellow incurved variety; very easy to grow; rather late blooming.

HELEN FRICK. A fine late blooming dark pink; produces fine incurved Japanese blooms, of good form.

LAVENDER QUEEN. A fine lavender pink variety; very pretty.

LILY MOUNTFORD. A beautiful variety with outer rows of petals pure pink; center salmon; very large and fine.

MAJOR BONNAFFON. The most widely grown of yellow sorts for commercial purposes.

MOUNIER. Very large deep yellow; form broad, reflexed petals twisting; extra good late sort.
MRS. COOMBS. Bright rose color. In heavy demand on account of the record it has made. The flower is immense, with broad, slightly reflexing petals; dwarf, and with elegant foliage. One purposes. Very early mid-season.

MRS. NATHAN SMITH. Pure snow-white, very large; incurved blooms mid-season.

MONROVIA. One of the best early yellow varieties; flowers very large and full.

OCTOBER FROST. The best early white sort; full and double.

ONGAWA. Golden amber; an excellent variety.

ROBT. HALLIDAY. Is still near the top of the list of early yellows it has taken several years to show its possibilities, but this it has taken several years to show its possibilities, but this variety has attained wide popularity and

ZANOMA. A fine late white variety; deep reflexed blooms, with good stem and foliage.

Morse \& Co.

Kukaian, Hamakua, Haawii, Oct. 29th, 1908

Dear Sirs:-

The roses arrived in perfect condition; looking as fresh as the day they were shipped. I am delighted with them and hall be sending for more soon.

Mrs. E. Madden. 


\section{ABUTILONS}

$15 \mathrm{c}$ and $25 \mathrm{c}$ each

BOULE DE NEIGE. The best pure white, up to date.

GOLDEN FLEECE, OR GOLDEN BELLS. A bright golden-yellow abutilon, of strong, vigorous habit.

SCARLET GEM. A rich bright scarlet.

THOMPSONII PLENA. Has perfectly double flowers, that resemble in form a double hollyliock. Color a deep orange, shaded and streaked with crimson; the foliage is beautifully variegated.

\section{VIOLETS}

CALIFORNIA. Large, single blue. 60c per dozen.

MARIE LOUISE. The well-known double light purple variet $y^{\circ}$ 75c per dozen.

PRINCESS OF WALES. This grand variety is of French origin; produces grand single flowers of a beautiful violet blue color in great abundance, and after years of trial has been found to be the best single blue. 60c per dozen.

SWANLEY WHITE. Double white. $75 \mathrm{c}$ per dozen.

\section{HELIOTROPE}

15c each, \$1.50 per dozen. Strong plants (ready April), 20c QUEEN. Very dark.

SAPPHIRE. Purple, white center.

SNOW WREATH. White.

\section{FUCHSIAS}

In 4-in pots, $25 \mathrm{c}$ each; $\$ 2.50$ per dozen.

smaller plants $15 \mathrm{c}$ each; $\$ 1.50$ per dozen.

BISMARCK. Sepals bright red, eorolla double, dark plume. One o the best. Constant blooiner.

BERLINER KINE. A large, double white Fuchsia. One of the very best

MRS. E. G. HILL. Best and largest; double white.

PHENOMENAL. The largest double Fuchsia of dark color; tube and sepals scarlet carmine, corolla measuring $2 \frac{1}{2}$ inches in diameter, of a rich dark-blue color.

PROCUMBENS, TRAILING. As a Fuchsia, this is an interesting sort, and of value for hanging pots and baskets. Covered with
pretty leaves, bright flowers, and red berries. The flowers are pretty leaves, bright flowers, and red berries. The
small and show several colors, the anthers being blue.

STORM KING. A perfect gem. Dwarf habit; sepals dark carmine corolla white, shaded rose. A magnificent large, double variet

\section{HARDY AND HERBACEOUS PERENNIALS}

For many purposes hardy perennial plants are indispensable. To fill vacant spaces among shrubbery, under trees, etc., they occupy a place in gardening that annuals cannot supply. Once planted they need very little attention, and can be left from year to year only thinning out now and then. By judicious selection they can be had in bloom throughout the whole year.

ANEMONE JAPONICA (Wind Flower). One of the most desirable of hardy herbaceous plants. As a cut-flower we consider the Anemone invaluable. We offer the White and Pink. 25c each; $\$ 2.00$ per 10 .

CLEMATIS DAVIDIANA. A herbaceous variety of the Clematis; the flowers are blue and come in large clusters; very fragrant. $35 \mathrm{c} \mathrm{each}$.

COREOPSIS LANCEOLATA. This handsome perennial is now probably the most popular perennial plant in cultivation. It is continually one mass of golden yellow. The flowers, which are of graceful form, are invaluable for cutting for decorative purposes. 15c each; $\$ 1.25$ per 10.

DELPHINUM-(LARKSPUR). A remarkably showy"class of tall growing plants, producing magnificent spikes of blue flowers in summer. Extremely satisfactory. 25c each.

GAILIARDIA GRANDIFLORA. The brightest of all Gaillardias. Flowers bronze scarlet, bordered with golden yellow, three inches in diameter, produced on long stems. $15 \mathrm{c}$ each; $\$ 1.25$ per 10 .

HELIANTHUS MAXIMILLIANA (Single Sunflower). A most graceful single-flowered variety, growing from five to seven feet high, continuing in bloom very late in the season. The flowers are produced in long graceful sprays, which make it invaluable for cutting purposes. 15c each.

HEUCHERA SANGUINEA. A desirable hardy herbaceous plant, growing one and a half feet high. The flowers are produced in loose graceful spikes and come in great profusion. In color it varies from coral-red to crimson, and when in perfection dazzles the eye with its brilliancy. It blooms all summer. 25c each; $\$ 2.00$ per 10 .

IRIS KAEMPFERII (Japanese Iris). The newer varieties of this King of Iris, introduced from Japan, are marvels of beauty and stateliness. Many of the varieties rival the orchid in point of beauty and fantastic shapes. They commence blooming in June and continue in bloom for 5 or 6 weeks. Many of the colors, blue, lavender, white. 20c each; $\$ 2.00$ per dozen.

\section{PHLOX-PERENNIAL}

One of the finest of summer and autumn flowers; of easy culture and they produce in great profusion for a long period, flowers of fine form and substance and of bright and various colors; the flowers come in large trusses and are really a most desirable plant for garden decoration. $25 \mathrm{c}$ each; $\$ 2.00$ per 10 .

PENTSTEMON. Very ornamental plants, producing long spikes of showy flowers in great abundance. We have a fine assortment of colors. 20c each; $\$ 1.50$ per 10 .

SHASTA DAISY (Alaska). An improvement on Mr. Burbank's original Shasta Daisy. The flowers are rery large, borne on long stems and rery free in bloom. Single white, with yellow
A most satisfactory perennial. 25c each; $\$ 2.00$ per 10 .

RUDBECKIA ("Golden Glow"). Produces masses of double golden-yellow flowers in great profusion. Very effective in the border. 25c each; $\$ 2.00$ per $\mathbf{1 0}$.

\section{MISCELLANEOUS FLOWERING AND BEDDING PLANTS}

Bedding and Border Plants should not be set out much before April 15th, when all danger from frost is over.

ACHANIA MALVAVISCUS. ("Turk's Cap"). Flowers vivid scarlet; produced nearly all the year. 25c each; $\$ 2.00$ per 10 .

ALTERNANTHERA. Much used for bedding purposes; of low growth; stands clipping well. Ready about April 15th. Yellow and Red Varieties, $50 \mathrm{c}$ per dozen; $\$ 3.00$ per 100 .

ASTER, SEMPLE'S NEW BRANCHING. Crimson, lavender, pink, and white. Ready about April 15th. 35c per dozen;
$\$ 2.00$ per 100 .

BEGONIA VERNON. This variety grows about eighteen inches high. The foliage, in the sun, turns deep olive green, shaded and edged with bronze purple; the flowers are bright red in color: magnificently set off by abundant dark foliage. $15 \mathrm{c}$ each; $\$ 1.50$ per dozen.

BEGONIA ERFORDII (Beauty of Erford). It is more dwarf and spreading than Vernon and bears three times as many flowers. The color is a lovely soft pink throughout, which does not fade in the hottest sun. It blooms ten months in the year; grows about twelve inches high, and makes a most beautiful border for 15 th. $15 \mathrm{c}$ each; $\$ 1.50$ per dozen.
BEGONIA. TUBEROUS-ROOTED. Double varieties, separ colors, 20c each. Single varieties, $15 \mathrm{c} \mathrm{each}$.

BOUVARDIA JASMINOIDES. In this plant qualities; the flowers come in clusters; pure fragrance emitting therefrom is of sweet, subte for cutting. The plant grows from three
should be in every collection. 50c each.

CINERARIA. As a winter blooming plant for hous for use for bedding under the shade of large trees, these are
invaluable. We offer a fine strain. 25c each; $\$ 2.50$ per dozen. cosmos. Crimson, pink, white and yellow. Ready about April 15 th. 25c per dozen; $\$ 1.50$ per 100 .

DAISIES. Double, all colors. 35c per dozen; $\$ 2.50$ per 100 .

ECHEVERIA (Hen and Chickens). 50c per dozen.

GAZANIA SPLENDENS. Flowers orange-yellow, produced in the greatest abundance in the spring and early summer. For inakin borders, where there is a lack of water, this plant cannot be beat $50 c$ per dozen. 
GOLDEN FEATHER. Ready April. 35c per dozen; \$2.50 per 100.

HYDRANGEA HORTENSIS. This plant is a most satisfactory one, blooming as it does for such a long period; they succeed admirably when planted in a shady place in the garden. Large plants, $50 \mathrm{c}$ each.

HYDRANGEA. NEW PINK. 50c each.

HYDRANGEA. INDIGO B L U E . $50 \mathrm{c}$ each.

IMANTOPHYLLUM MINIATUM. Flowers bright brick-red produced in clusters on long stems. 50c each.

LIPPIA REPENS. Used in place of grass for lawns; it does not require much water and makes a fairly $\$ 25.00$ per 1000 .

LOBEIIA. Dwarf blue. Ready April 15 th. 35c per dozen; $\$ 3.00$ per

MESEMBRYANTHEMUIM. The se are much used for bedding purposes and planting on banks and hillsides where there is a scarcity of water. They make a gorgeous sight when massed.

Perhaps the showiest of them all is the one which produces the large, single, pink flowers. We can also supply plants of the small, lavendercolored one at 50c per dozen; $\$ 3.50$ per 100 .

MARGUERITE, WHITE. 15c each; $\$ 1.25$ per dozen.

MAR GUERITE, Y E L L O W. $15 \mathrm{c}$ each; $\$ 1.25$ per dozen.

P ANSIES (Morse's Prize Strain). The plants we offer are grown from seed, obtained from a noted grower in Germany, and include quisitely spotted and blotched, veined, mottled, and margined. 50c per dozen. Ready February. Best time to transplant.

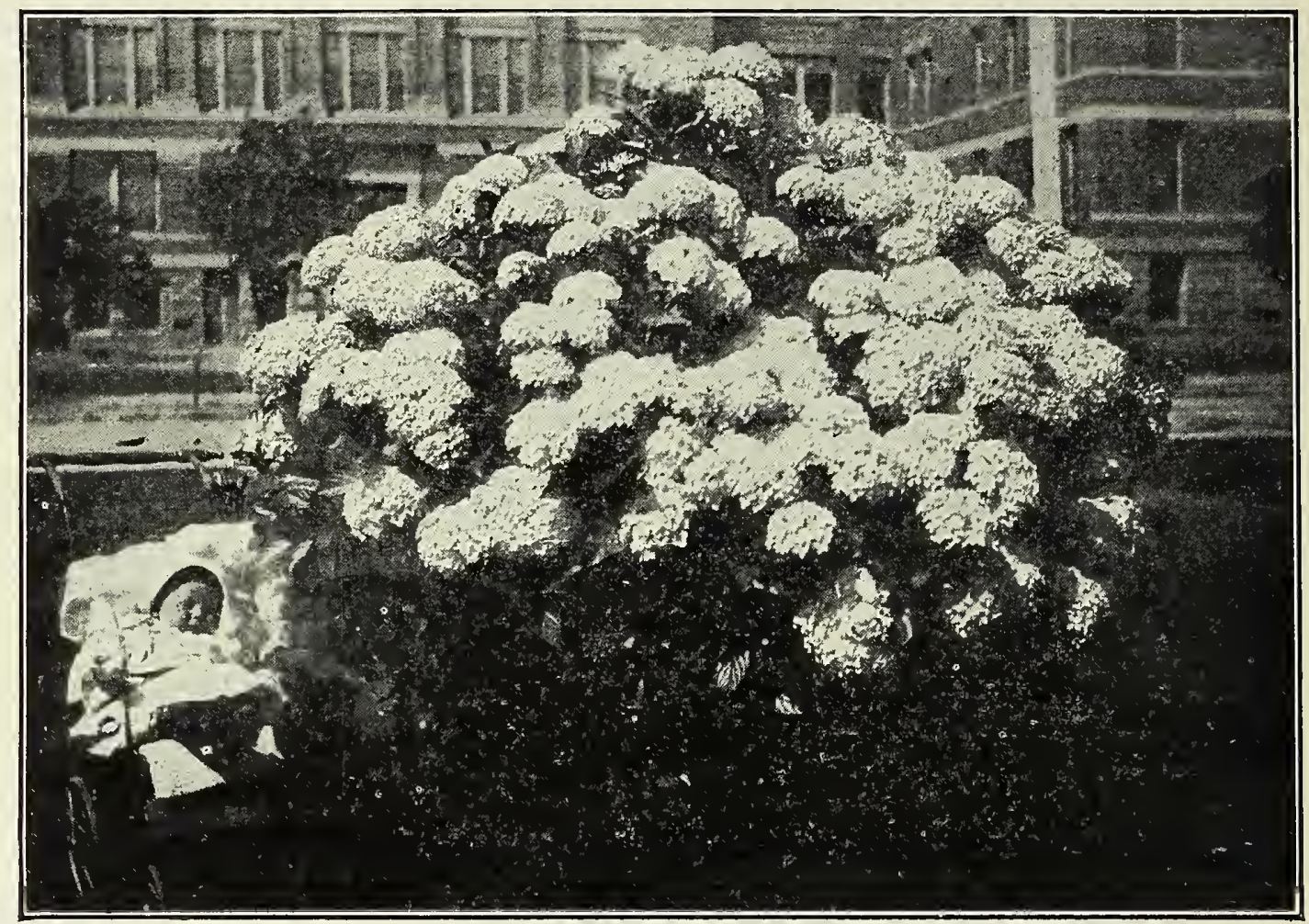

Hydrangea Hortensis

PINKS, BORDER. Pure white; delightful clove fragrance; excellent for borders. 50c per dozen; $\$ 3.00$ per 100 .

PETUNIA, SINGLE. Ready April 15th. 15c each; $\$ 1.50$ per dozen.

PRIMULA, CHINESE. Invaluable for winter and early spring flowering. 25c each.

SALVIA SPLENDENS. Scarlet flowers continuous bloomers. Ready April. 10c each; $\$ 1.00$ per dozen.

SEA PINK (Armeria). Very dwarf, requiring no trimming. Flowers rose pink. 50c per dozen; $\$ 3.00$ per 100.

SPERGULA. Very dwarf; splendid for edging. Square foot, 50c. One square foot would make an edging 25 feet long.

STOCKS. In fine assortment. Ready April. 25c per dozen; $\$ 2.00$ per 100 .

STREPTSOLON JAMESONII (The "Yellow Heliotrope")。A very useful garden plant, producing masses of showy yellow flowers. $20 \mathrm{c}$ each; $\$ 1.50$ per 10.

VERBENA. MISS WILLMOTT. Color, dark pink; very large truss; stems long, thus making it valuable for cutting; a long and continuous bloomer. An excellent novelty and one which dozen.

\section{CANNAS}

These are, without doubt, the most useful and ornamental plants we have. Their blooms are very showy and continue for a long period; the shades are very brilliant and they are peculiarly adapted for grouping or edging lawns and when supplied plentifully with water they are a mass of magnificent flowers. If you wish a bed of yellow colors you can have it, or scarlet or pink, or spotted. The foliage is also very handsome, being "banana-like" in appearance and when once planted they are there for all time. They are a perennial plant, that is they die down in the winter and start again in the spring. We grow the following newest and choice varieties. Price, 20c each; $\$ 2.00$ per dozen.

ATLANTA. Bronzy pink; good; large flower.

ALLEMANNIA. Orange red, petals edged yellow; very large. AUSTRIA. Canary yellow; very good.

BEAUTY DES MARCHES. Flowers salmon pink; very fine.

BRAND YWINE. Wine-red flowers, dappled with deep crimson, and sometimes edged with yellow.

C. HENDERSON. Deep crimson.

CORONET. A very fine yellow flowering variety.

EASTERN BEAUTY. Light salmon; dark foliage.
J. C. VAUGHAN. Vermilion-orange; large size.

J. AYMAND. Scarlet; large; good.

LOUISE. Rich velvety crimson; very good; tall growing.

MUSAFOIIA. A tall-growing sort, with banana-like foliage, excellent for planting in background or center of beds; flowers red.

MARTHA WASHINGTON. Red, shading to magenta.

MAD. C. DUBROST. Salmon, flowers beautifully spotted.

PANSY STRAIN. Vivid scarlet.

SOUV. DE PRES. CARNOT. An uncommon shade of salmon pink. 


\section{FRUIT TREES AND SMALL FRUITS}

"Every land owner should be a fruit grower. The symbol of civilization has all along been the orchard, and the evolution of better fruits has been a distinctive feature of the highest progress made by man during the last two centuries."-Extract from "The Orchard and Fruit Garden."

When ordering, please state whether substitution will be permitted, as, when no instructions accompany the order, we feel at liberty to substitute similar sorts.

Articles mentioned in our price-list will be furnished at prices named only when the number specified be taken, except that 5 will be furnished at 10 rates and 50 at 100 rates. We will not, however, furnish long lists of one of a kind at OTHER THAN SINGLE RATES.

We will charge for packing sufficient to cover actual cost of same; so when ordering add 10 per cent of order.

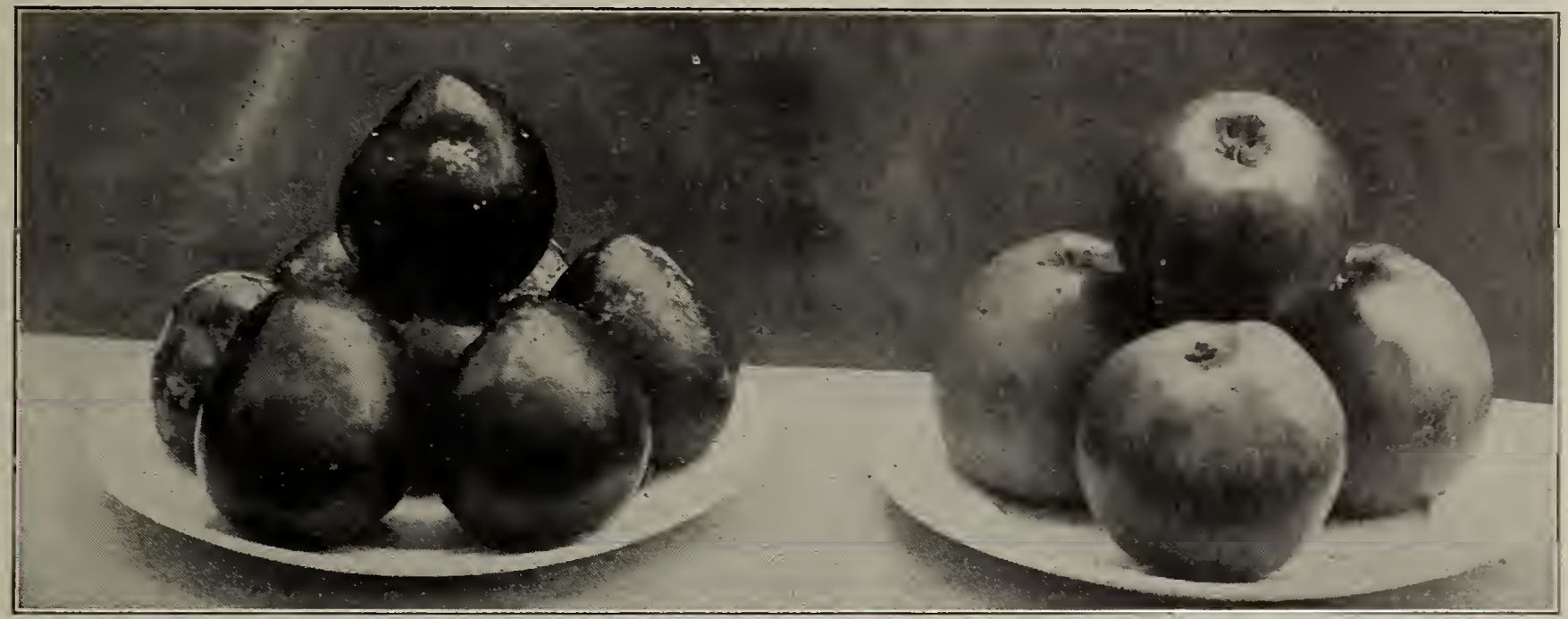

Kelsey Japan Plum

Gravenstein Apple

\section{HINTS ON TRANSPLANTING}

PRUNING. All fruit trees must be pruned after setting out, so as to shape them from their infancy, and this kept up each year. All of the long branches should be cut off, and where there are too many side branches thin out to a few of the strongest; when the tree has only one growth, cut back to $21 / 2$ or 3 feet from the ground.

Some attention should also be given to the roots. Sometimes the tree may have a few broken roots; these should be cut a way and when any of the roots are long a little clipping will do them no harm.

PLANTING. Successful planters always dig good large holes for the roots. A little extra labor at this time will be amply repaid in the more rapid growth of the tree, and should the ground be at all heavy or sandy, add some welldecayed manure. Of course, in large plantings this cannot always be done, but we are speaking more particularly to the "home planter." After the tree is set in the hole properly, commence to throw in the soil gently, and see that it is well pulverized, and work all in round the roots $\pi$ ell. After the hole is half filled up, press down gently with the foot; then fill in the remainder, also going through the same process, leaving the last spadeful or two untrodden. Never, especially in soils that are apt to run together, or adobe, try to plant when the ground is wet. Wait until the ground dries; otherwise your trees will not grow so well.

Planting can be done from December to March, according to the season, but orders should be placed early with us, so as to obtain desired selections.

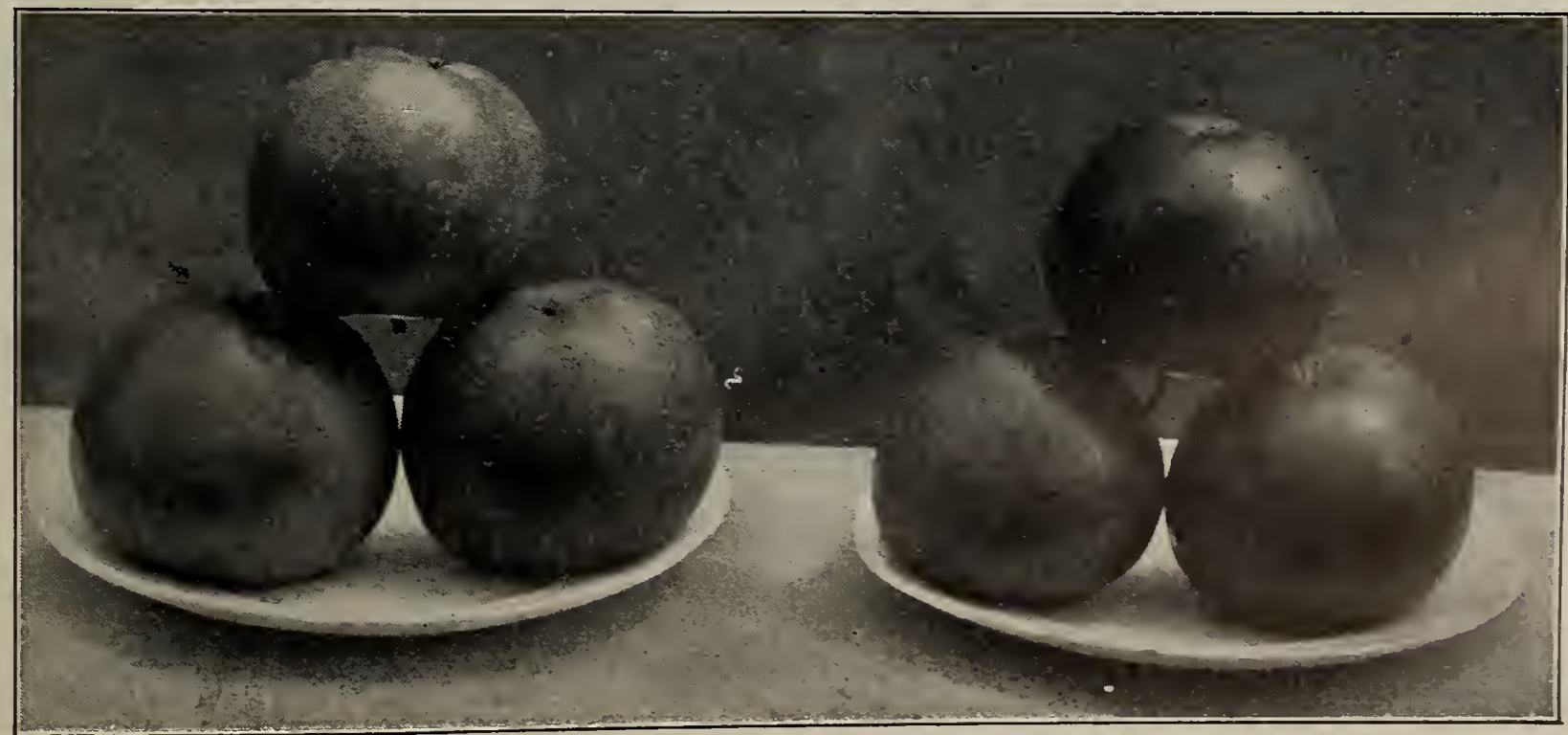


Frequent cultivating is necessary, as there is no better way of keeping the moisture near the surface.

Our list of fruit trees has been cut down to the very best, so that intending planters may depend upon them as being the best. We do not believe in cataloging long lists. Our customers, therefore, will have no experimenting. We do that.

While we aim to have all our fruit trees true to name, and hold ourselves ready, on proper proof, to replace, free of charge, all stock that may prove untrue to label, or to refund amount originally paid by the customer, it is mutually understood and agreed between the purchaser and ourselves that our guarantee of genuineness shall not make us liable for any sum greater than that originally paid us for such stock as may prove untrue.

We have an unusually fine lot of trees to offer for this coming planting season, and planters will do well to write us for prices on large lots.

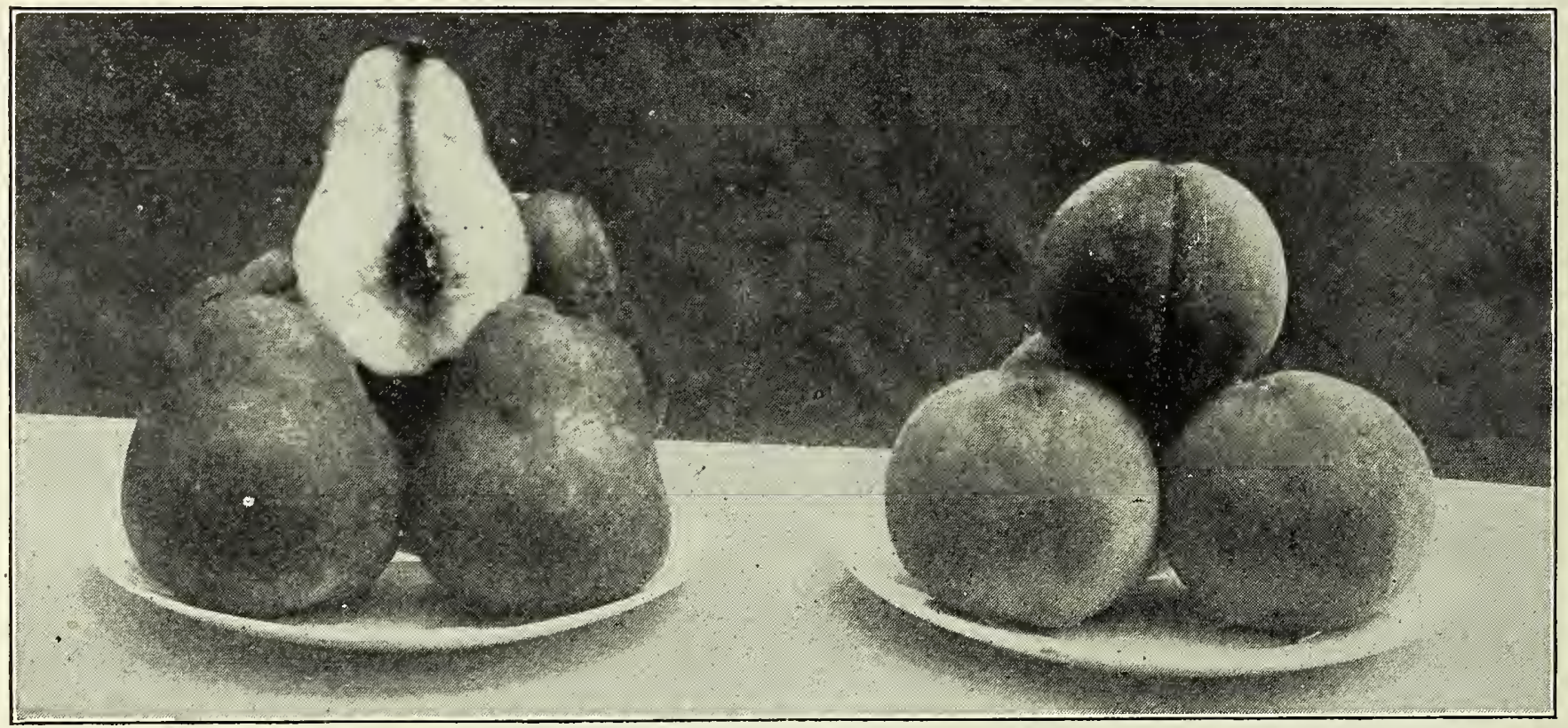

Bartlett Pear

\section{APPLES}

The first fruit in importance is the apple. Its period of ripening, unlike that of other fruits, extends nearly or quite through the year. By making judicious selections of Summer, Autumn and Winter sorts, a constant succession can easily be obtained of this indispensable fruit. Price, 4 to 5 feet high, $25 \mathrm{c}$ each; $\$ 2.00$ per 10 ; $\$ 18.00$ per 100 . Special price on large lots.

ALEXANDER. Yellow, streaked with red; brighter red in the sun flesh yellowish white; crisp, tender and juicy. A very fine marke variety. Ripe in September and October.

RISMARCK. Introduced from New Zealand and said to be one of the most promising of recent introductions; a tremendous beare and one of the very best apples for hot climates. Fruit is of a beautiful golden-yellow color, of the largest size; very highly flavored and as a dessert apple said to have no equal; also suit able for cooking purposes. Ripens early and is a good keeper

BALDWIN. Large, roundish, deep bright red over a yellow ground; flesh yellowish white, crisp, juicy, sub-acid. Ripe in November and December. An excellent market sort.

BEN DAVIS. Large and handsome; striped; of good quality; very productive. Ripe in November and December.

EARLY HARVEST. Yellow, excellent for cooking or dessert. July.

ESOPUS-SPITZENBERG. Large, light red, rich. Sprightly vinous flavor. One of the best. November to January.

GRAVENSTEIN. A large, striped, beautiful, roundish apple; of excellent quality, juicy, high flavored. A good grower and prolific bearer. Ripe in August. A good market sort.

NORTHERN SPY. Greenish-yellow, striped purplish red; flesh white and juicy. A fine, late keeper.

RED ASTRACHAN. Large, roundish, skin deep red; flesh white juicy and crisp, though rather acid. A hardy, vigorous and early bearer. The best early apple. Ripe in June and July.

RHODE ISL AND GREENING. Large, greenish yellow. A constant heavy bearer. Ripe in October and December.

WHITE WINTER PEARMAIN. Another sort that bears well in this State. Large, roundish, oblong, and pale yellow, dotted with brown; flesh yellowish, delicate, crisp, juicy, sub-acid; extra fine flavor. A general favorite. Late keeper. A strons and healthy grower Ripe December to February.

\section{Early Crawford Peach}

WINESAP. Yellow, ground streaked with red; flesh yellow, with rich flavor; excellent for table. Ripens November to January.

YELLOW BELLFLOWER. Very large, oblong, irregular and tapering toward the eye; skin smooth and of pale lemon color flesh firm but tender, juicy and sub-acid. One of the standard apples of California. A good grower and very productive. Ripens November to February.

YELLOW NEWTOWN PIPPIN. Another variety very successfully grown in California. Large; flesh yellow, firm, crisp, juicy, of exceedingly rich flavor. The best winter apple. Ripe juicy, of exceeding
January to March.

\section{CRAB APPIFS}

\section{Price same as Apples}

RED SIBERIAN. Fruit about an inch in diameter. Yellow with a scarlet cheek. An erect, free grower. Bears very young.

WHITNEY. Glossy green, striped and splashed carmine; flesh firm, juicy and very pleasant flavor.

YELLOW SIBERIAN (Golden Beauty). Large, color beautiful golden yellow.

\section{PEARS}

The Pear does well in all soils, but succeeds best on a heavy loam. Summer and Autumn pears should be gathered at least ten days before they are ripe, and the fruit placed in a dark, cool place, where it will ripen, acquiring a delicious aroma and fine flavor.

Price, 4 to 5 feet, 35c each; $\$ 3.00$ per $10 ; \$ 25.00$ per 100 .

BARTLETT. There is no occasion to describe this variety, so well known is it. A vigorous and strong grower. Bears heavily known is it. A vigorous and strong grower.
good for shipping and canning. Ripe in August.

BEURRE CLAIRGEAU. Very large; red cheek with russet ground. Bears very heavily and when quite young. Flesh rather coarse at the core. Fine shipper to Eastern markets. Ripe in October.

BEURRE HARDY. This autumn pear is very desirable on account of its fine flavor and good bearing qualities.

CLAPP'S FAVORITE. A splendid sort; resembles the Bartlett ripens a few days earlier; fine, melting, with a sweet vinous flavor. Ripens August. 
P. BARRY. This pear was raised by the late B. S. Fox of San Jose The tree is a good grower, bears immensely and when quite young. The color of fruit is deep yellow, nearly covered with rich golden russet: very large. A splendid shipper and late rich golden russet; very large. A splendid shipp
keeper. Best of all late pears. January to March.

SECKEL. Quite small; rich, yellowish brown; very sweet and productive. Good only for local markets. Ripe in September.

WINTER BARTLETT. Fruit large, closely resembling the famous Bartlett, but ripening four months later.

WINTER NELIS. Medium size, roundish, yellowish green, dotted with russet. Fine flavor. November to January.

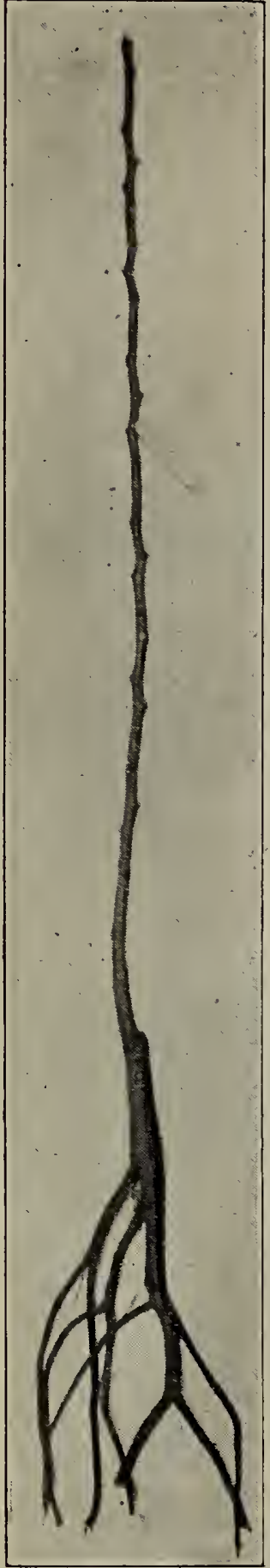

One year old B artlett Pear pruned, ready for planting

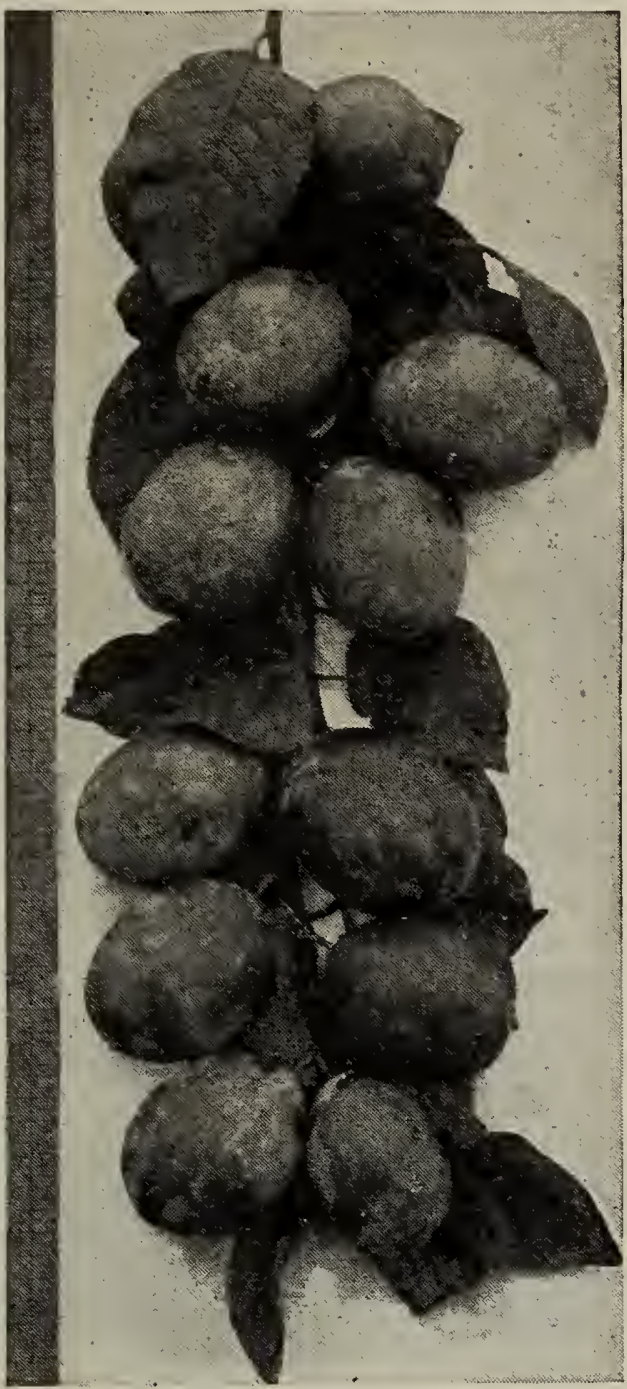

Hungarian Prune

\section{CHERRIES}

Cherries thrive in almost any well-drained soil. It is one of the most ornamental of all fruit trees, and very desirable for planting, where beauty and shade as well as fruit are desired.

Price, 4 to 6 feet, 35c each; $\$ 3.00$ per $10 ; \$ 20.00$ per 100 .

BING. Fruit large, dark brown or black; very fine; late. A good shipping variet $\%$.

BLACK TART ARIAN. Very large, bright black. The favorite.

ENGLISH MORELI0. Large deep red, juicy and acid. A sour sort.

LAMBERT. Very large; bright rich red color; an excellent sort. Ripens two weeks later than the Royal Ann.

LEWELLING (Black Republican). Large size; a cross between Black Tartarian and Napoleon Bigarreau, having the size and color of the former and the solid flesh of the latter. Late and good.
MAY DUKE. One of the sour sorts, excellent for tarts; rich, dark red, when fully ripe; quite early.

NAPOLEON BIGARREAU (Royal Ann). Very large; amber in color. The favorite white cherry.

\section{PLUMS}

The Plum tree attains its greatest perfection on our heavy soils, being entirely free from disease. Plums are very hardy and grow vigorously in all sections.

Price, 4 to 5 feet, 35c each; $\$ 2.50$ per $10 ; \$ 20.00$ per 100 .

ABUNDANCE An extremely early and profuse bearer and strong grower. Fruit large, showy and beautiful, briglit cherry red, with white bloom; flesh yellow, exceedingly juicy, tender and sweet. Ripens July and August.

BARTLETT. One of the best of Burbank's recent introductions. Said to be wonderfully productive; a very ornamental tree witli glossy green leaves, resembling closely the famous Bartlett Pear in habit of growth, flavor and fragrance. Fruit oval, yellow colored, firm and juicy. Ripens before Burbank.

BURB ANK (Japanese). Large, yellowish ground, with red cheeks; flesh yellow: firm.

ClIMAX. (A New Early Plum). Cross of Simoni and Botan. Very large, measuring $63 / 4$ by $11 / 2$ inches in circumference; heartshaped. A superbly rich plum; extremely early. Ripens in the coast counties early in July, before any other good plun.

GREEN GAGE. Small, but of the highest excellence; rounct greenish yellow, with brown dots; very juicy and sweet. August.

KELSEY (Japan). Very large, heart-shaped, greenish yellow, red cheek on sunny side; flesh verv solid and firm, juicy, and with a rich vinous flavor; small pit. September.

WASHINGTON. A magnificent large plum, roundish; deep yellow, with pale crimson blush; flesh yellow, firm, very sweet and luscious, separating from the stone. July and August.

YELLOW EGG. Very large and beautiful; egg-shaped; flesh yellow, rather acid until fully ripe, when it sweetens. Clingstone.

\section{PRUNES}

By the term "Prune" is signified a plum that dries suecessfully, without the removal of the pit, and produces a sweet dried fruit.

Price, 4 to 6 feet, 35 c each; $\$ 3.00$ per $10 ; \$ 25.00$ per 100 , except where noted.

FRENCH (Petite d'Agen). This is the prune now grown so extensively and successfully in California for drying purposes; medium-sized; egg-shaped, violet purple; very rich and sugary. The best prune; prolific bearer. Can supply this variety on Myrobolan Plum and Almond root. $\$ 24.50$ per 100 .

GERMAN. Long, oval, and swollen on one side; skin purple, with a thick blue bloom; flesh firm, green, sweet with a peculiasly pleasant flavor. Separates readily from the stone. September.

HUNGARIAN. Fruit very large, with tendency to come double: reddish violet, covered with a handsome bloom. Very juicy and sweet. Good shipper.

IMPERIAL EPINEOSE. Large and uniform in size. Very sweet and of high flavor; the skin is thin and of a reddish purple when green; when dried coal black.

SUGAR. An extremely early prune. Very large. Ripens August 1st. Skin very tender, at first of a light purple, tinted with green, changing at maturity to dark purple, covered with a thich green, changing at maturity to dark purple, covered with a thick
white bloom. Valuable in localities where the French prune ripens too late for sun-drying.

SILVER. Very large, oval; skin yellow. Makes a very attractive dried fruit, besides being a good shipper and canner. Bears heavily.

TRAGEDY. This is the earliest of all prunes, and earlier than any plum. Good size, dark purple skin, yellowish-green flesh. Sweet and very rich.

\section{PEACHES}

The Peach tree requires a well drained, moderately rich soil, warm sandy loam is probably the best. In order to preserve the continued healthy growth of the tree and the fine quality of the fruit, the peach should have the shoots and branches cut back to one-half the preceding season's growth every year, so as to preserve a round, vigorous head; this should be done the last of February or as early in the spring as practicable.

Price, 1 year, 4 to 5 feet on peach root, $35 \mathrm{c}$ each; $\$ 3.00$ per $10 ; \$ 25.00$ per 100 . 
ALEXANDER. Very early; medium to large; greenish-white, nearly covered with deep red; flesh firm, juicy and sweet.

CROSBY. Fruit medium size; roundish, slightly flattened; bright orange-yellow, splashed with carmine on sunny side; of good quality. Ripens between early and late Crawfords.

ELBERTA. Very large; bright yellow with a beautiful red mottled cheek; juicy and sweet; regular bearer. Ripens about end of July.

EARLY CRAWFORD. This is probably the most extensively grown of all peaches. Very large; color yellow, red cheek flesh yellow, rich, excellent. Very productive. Ripens about middle of July.

FOSTER. Large yellow; resembles Early Crawford, ripening a little earlier; an excellent sort.

FITZGERALD. Very large; pleasant sub-acid flavor; excellent; a regular and heavy bearer.

HALE'S EARLY. Medium size, nearly round; skin greenish-white, red cheek; very rich and juicy. Ripens early in July.

LATE CRAWFORD. Very large; yellow with dark red cheek; flesh deep yellow, juicy and melting; of exquisite fla vor; valuable for canning and drying. Ripens niddle to end of August.

LEMON CLING. A fine clingstone variety; large, yellow, fine cropper. An excellent variety.

MUIR. The best of all peaches for drying, because it loses less than any other in the process. Has a delicious, rich, buttery, sweet flavor. The fruit is large to very large; skin pure yellow; flesh yellow. Excellent for canning. Ripens end of August.

ORANGE CLING. Very large, yellow with dark crimson cheek; flesh golden-yellow; rich and sugary; a heavy and regular bearer.

SALWAY. A large, yellow English peach, with deep yellow flesh; very juicy, melting and rich. The most valuable late market

SUSQUEHANNA. Large, globular; skin yellow, nearly covered with red; flesh yellow, sweet, juicy and rich. Tree strong grower, bearing heavy and regular crops.

WHITE HEATH CLING. A most delicious cling; very large; skin downy, creamy white, with slight tinge of red; flesh white, very tender, juicy and sweet. Valuable for canning. Ripens September.

WHEATLAND. A very large round freestone; skin yellow, shaded red; flesh yellow, firm, melting and sweet. Tree a rapid grower and heavy bearer. An excellent variety.

\section{- APRICOTS}

Beautiful and delicious fruit. In quality and appearance is between the plum and the peach, combining quality of both. Ripening early, together with its delightful flavor, makes it one of the most valuable fruits. Requires about the same cultivation as the peach or plum. For drying and canning it has no superior.

Price, 4 to 5 feet, $35 \mathrm{c}$ each; $\$ 3.00$ per $10 ; \$ 25.00$ per 100 .

BLENHEIM. An excellent variety and in great demand. The trees are early and regular bearers and have an abundance of oval; orange color, with deep yellow; juicy and rich flesh; July.

HEMSKIRKE. Large, roundish; flesh bright orange, tender and juicy, with a rich plum like flavor; fruit not quite as large as the Moorpark, but ripening more evenly. August.

MOORPARK. Very large, yellowish-green, brownish-red on the sunny side, marked with numerous dark specks and dots; flesh bright orange, parts freely from the stone.

PEACH. Very large, handsome, and of a delicious flavor; skin deep orange, mottled with dark brown. Flesh of a fine saffron-yellow color, juicy, rich and highly flavored.

\section{NECTARINES}

The habit and growth of the Nectarine resembles the peach. The fruit has the distinction of a smooth skin, and is of most delightful flavor.

Price, 3 to 5 feet, 35c each; $\$ 3.00$ per 10 .

BOSTON. Large, deep yellow, with a bright blush and deep mottlings of red; flesh yellow, without any red at the stone. Sweet though not rich, with a pleasant and peculiar flavor.

LORD NAPIER. Large, cream color, dark red cheek; flesh white; EW WHITE. Large; skin white; flesh white, tender and rery juicy, of rich vinous flavor, pit small and free. Easy to grow wherever nectarines thrive.

\section{ALMONDS}

The Almond prefers a loose, light, warm soil. It makes quite a large tree, and should have plenty of room. Trees should be headed low and pruned during the first three years.

Price, 4 to 5 feet, $35 \mathrm{c}$ each; $\$ 3.00$ per $10 ; \$ 20.00$ per 100 .

DRAKE'S SEEDLING. Originated with Mr. Drake, of Suisun, California, of the Languedoc class; bears abundantly and regularly where the Languedoc is a total failure.

I. X. L. Tree a sturdy, upright grower, with large leaves; nuts large shells easily, no machine being needed, nor is any bleaching necessary; shell soft but perfect. It bears heavily and regularly.

JORDAN. The nuts are long and hard-shell; the kernels are single, narrow, long and plump; the kernel is always removed from the nut proper when exported.

NE PLUS ULTRA. Introduced by Mr. A. T. Hatch. Tree a rapid grower; leaves rather large; a heavy and regular bearer; nuts large and very long in shape; soft shell; hulls freely.

NONPAREIL. First called Extra. Of a weeping style of growth smaller foliage than the I. $\mathrm{X}$. L., but still forms a beautiful tree an extraordinarily heavy and regular bearer, with very thin shell, of the Paper Shell type.

\section{QUINCES}

Price, 4 to 5 feet, 35c each; $\$ 3.00$ per 10 .

APPLE, or ORANGE. Large, bright yellow. The best. Ripe August and September.

CHAMPION. Very large; flesh cooks as tenderly as an apple, not having hard spots or cores; flavor delicate, imparting an exquisite quince taste and odor to any fruit with which it is cooked. Highly productive, especially so while young.

\section{OLIVE TREES}

Price, 4 to 5 feet, 60c each; $\$ 5.00$ per 10.

MANZANILLO. Among the olives of Southern Spain, especially around Seville, the Manzanillo is highly prized both for pickling
and oil. The fruit is very large. One of the best olives. Very hardy, prolific, and a regular bearer. Makes a fine pickle, and produces oil of a high grade.

MIssION. The variety found at the Old Missions, introduced by the Spanish Padres, and until recently the only sort cultivated in California. It still ranks as one of the most vigorous, productive, hardy and long-lived varieties. It is the most extensively cultivated sort in California, and can be found in almost every county of the State. It is thrifty and vigorous, and yields a fine oil. Can be used for pickling. Ripens late.

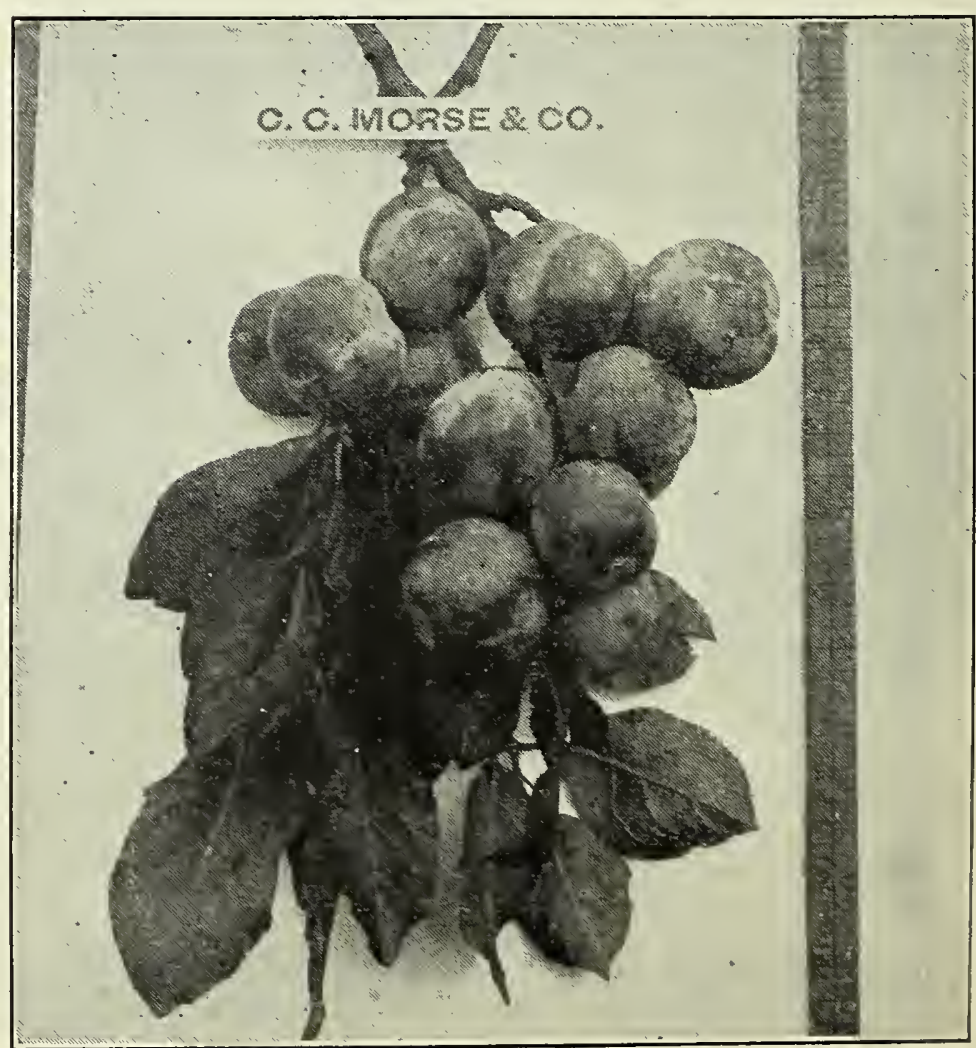

Green Gage Plum 
NEVADILLO BLANCO. Medium size, well set on, and its numerous branchlets usually bend with the reight of the fruit. It is for oil only, of which it yields an abundant supply of finest grade. Ripens early.

RUBRA. The tree is a very vigorous, upright grower; succeeds in dry, hilly soils. Fruit of medium size, bears heavy and regular crops. November.

SEVILLANO. The tree is a strong grower; leaves green, greenishwhite on the under side. The largest of olives, and the variety exported from Spain under the name of "Queen Olive." When ripe, of a bluish-black color; flesh adheres to the pit. A regular fine flavor, and the fact that it pickles easily, is sure to cause it to be in demand.

\section{FIGS}

CALIFORNIA BLACK. A well-know local variety. Large, dark purple, almost black when fully ripe. Makes a good dried fig. Tree grows to a very large size, and gives immense yield. 3 to 5 feet, $40 \mathrm{c}$ each; $\$ 3.50$ per 10 .

CALIMYRNA. The genuine Smyrna Fig packed under the name of "Erbeyli" (signifying fine fig) in Asia Minor, and known in Turkish as "Lop"" and in Greek as "Lopia," Large to rery large; t urbinate, pyriform; very short, stalk short; ribs distinct, orifice large, of pale ocher color and widely open when the fig is mature and before shriveling; skin lemon yellow; pulp reddish amber, sometimes pale amber, turning to dark amber just before falling; seeds large, vellow, fertile, overspread with a clear, white syrup, giving the fruit a richness and meatiness surpassed by no syrup, giving the fruit a richness and meatiness surpassed by no other fig. Tree of spreading habit; leaves medium to large, and is $11 / 2$ per cent more sugar than found in the imported Smyrna is $11 / 2$ per cent more sugar than found in the imported Smyrna fig. Dries readily and with less trouble and expense than any other fig, dropping to the ground of its own accord, being practically dry when it falls, requiring when placed on trays only from two to three days' exposure to the sun. This is the Roeding, of Fresno. 3 to 5 feet, $50 \mathrm{c} \mathrm{each;} \$ 4.00$ per 10 .

WHITE ADRIATIC. Fruít large; skin greenish-yellow color pulp carnation red. Ripens from August to October. 3 to 5 feet, $40 \mathrm{c}$ each; $\$ 3.50$ per 10 .

WILD, or CAPRI. Must be grown in connection with every Calimyrna Fig orchard. 3 to 5 feet, $60 \mathrm{c}$ each.

\section{ORANGES}

Price, lifted with balls of soil, 4 to 5 feet, $\$ 2.00$ each; $\$ 17.50$ per 10 .

MALTESE BLOOD. Fruit below medium, nearly round; skin rery thin and smooth; pulp ruby-red.
MEDTTERRANEAN SWEET. Fruit medium to large; pulp solid, with few seeds; ripens late. A very popular sort.

RIVERSIDE WASHINGTON NAVEL. Fruit first-class in every respect; size medium to large, oval, sinooth, symmetrical, seed-

VALENCIA LATE, OR HART'S TARDIFF An orange remarkilbly stroug-groving habit, and it to be a which it resembles very much.

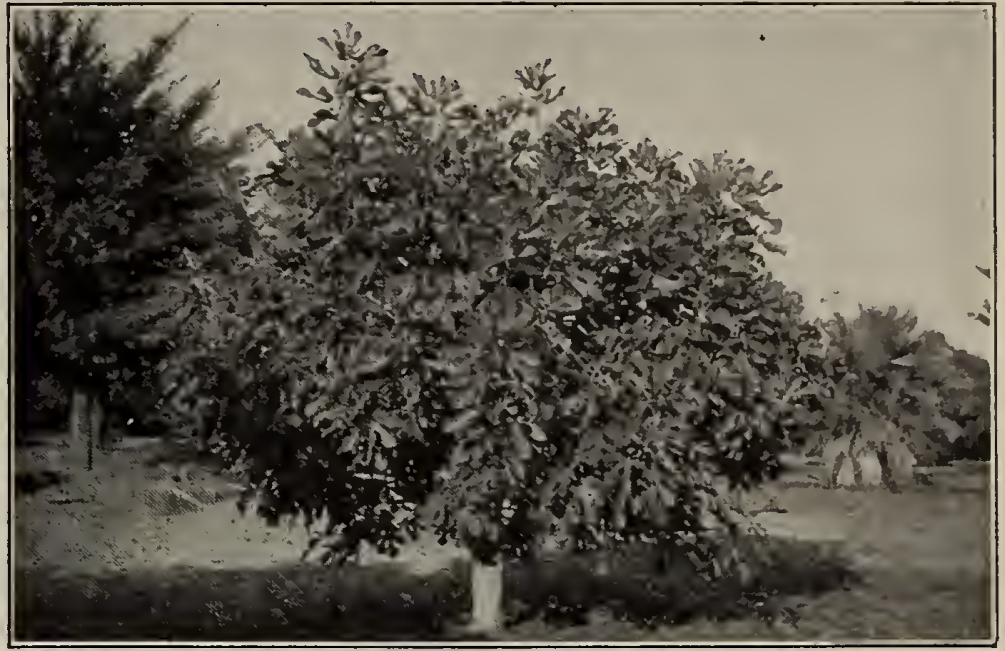

A Calimyrna Fig Tree Showing habit of Growth

\section{LEMONS}

Price, lifted with balls of soil, 4 to 5 feet, $\$ 2.00$ each; $\$ 17.50$ per 10 .

EUREKA. Tree nearly thornless, of rapid growth, and prolific bearer; fruit of the best quality. A general favorite.

LISBON. Medium size; sweet rind; very strong in acid; very few seeds; tree a rapid grower and very productive.

VILLA FRANCA. Fruit uniformly medium size, fine grained, sweet rind; very few seeds; good keeper; tree strong grower.

\section{POMELOS, (Grape Fruit)}

This fruit is becoming one of the most popular of the citrus fruits in the Eastern States, and the demand for it thus far has exceeded the supply. The name of "Grape Fruit," by which it is often called, due to its growing in clusters on the tree, is a misnomer. The growing popularity of this fruit is probably due to its medicinal qualities, particularly for correcting stomach troubles. The tree is fully as hardy as the orange and is a vigorous grower.

Price, lifted with balls of soil, 4 to 5 feet, $\$ 2.00$ each.

MARSH'S SEEDLESS. Medium, practically seedless; skin thin and smooth; pulp juicy; o superior flavor. Keeps late. valuable acquisition; its delicious flavor and having no seeds should cause it to take the precedence

T R I U M P H. Medium size; skin I grained, juicy and well flavored. No bitter in the juice, flesh or membranes surrounding the cells and diriding the segments, and rery little in the white inner lining of the peel. Tree of the imported varieties. 


\section{C.C.MORSE \& CO. PLANTS \& TREES}

\section{LIME-MEXICAN}

Balled, 3 feet, $\$ 1.50$ each.

\section{JAPANESE PERSIMMONS}

A magnificent fruit from Japan. Tree highly ornamental. Fruit beautiful in appearance and excellent in quality. 35c each; $\$ 3.00$ per 10 .

\section{MULBERRY}

DOWNING. Tree of rapid growth; very good as a shade tree, as the leaves are very large; deep green in color; fruit similar in shape to a blackberry; very sweet and aromatic. 5 to 6 feet, $60 \mathrm{c} \mathrm{each}$.

\section{IOQUAT GIANT}

The fruit of this Japanese tree is very nice. In this State it ripens in April and May, and is about the size of small plums, and comes in clusters; very sweet and refreshing. The plant itself is very ornamental, having large, crimpled foliage of an olive-green color of spreading, dense growth. $21 / 2$ to 3 feet, $75 \mathrm{c} \mathrm{each}$

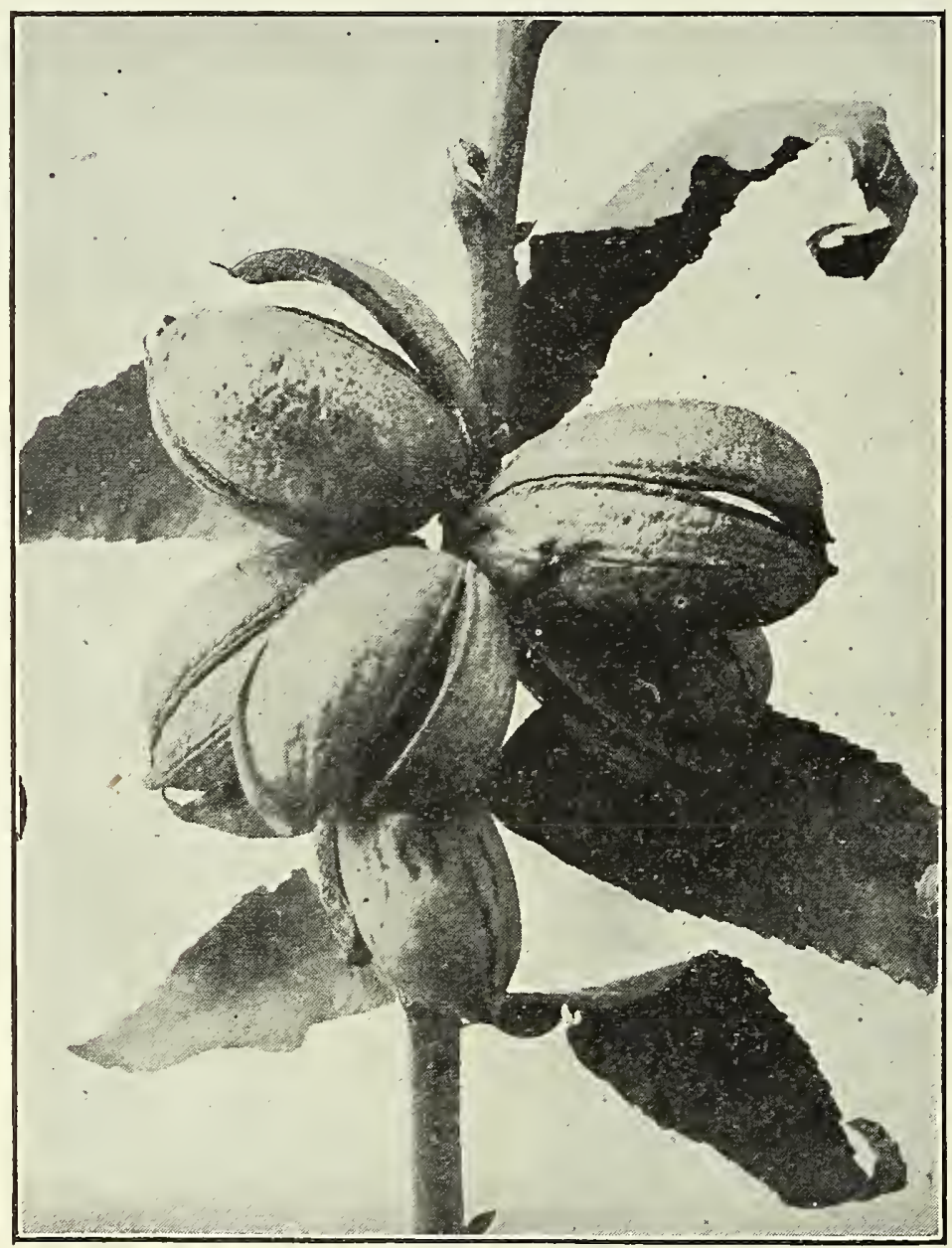

Pecan Nut

\section{STRAWBERRY GUAVA}

The Guava is an ornamental evergreen shrub with pink, shining foliage, and bears when only 2 feet in height. The fruit is smaller than an English walnut, of a fine claret color, and with a flavor resembling that of a strawberry. Makes an excellent jelly. 2 feet, 35c each.

\section{CHESTNUTS}

AMERICAN SWEET. A valuable native tree, both useful and ornamental; timber is very durable, and possesses a fine grain for oil finish. Nuts sweet, of delicate flavor, and are a valuable article of commerce. No farm should be without its grove of nut-bearing trees, and the chestnut should be foremost wherever the soil is adapted to its growth. Price, 3 to 4 feet, $35 \mathrm{c} \mathrm{each}$ $\$ 3.00$ per 10 .

JAPANESE MAIMMOTH. Is remarkable for its great size and fine flavor-in these respects being superior to the European varieties. The tree is similar in habit and growth to the Italian Chestnut; it is a handsome, sturdy, healthy tree; it grows in Northern Japan, and has proved to be sufficiently hardy almost anywhere in the United States. Bears fruit at three or four years of age. 3 to 4 feet, $35 \mathrm{c}$ each; $\$ 3.00$ per 10 .

\section{BUTTERNUTS}

A native of the Eastern States, of vigorous growth, spreading head, grayish colored bark, and foliage resembling that of the Ailanthus; produces a large, longish nut, prized for its sweet, oily, nutritious kernel. 4 to 6 feet, $50 \mathrm{c}$ each; $\$ 4.00$ per 10 .

\section{WALNUTS}

AMERICAN BLACK. One of the largest and lhandsomest of American forest trees; grows freely on this coast, stands transplanting well, bears early, and ought to be extensively cultivated, not alone for the nuts, but also for the valuable wood it produces. 3 feet, 30c each; $\$ 2.50$ per $10 ; \$ 17.50$ per 100 .

SANTA BARBARA SOFT SHELL. Tree a vigorous grower, early and abundant bearer. The nut is large; kernel white, sweet and readily extracted; shell thin, easily broken. One of the favorites in Southern California. On own roots, 2 to 3 feet, $25 \mathrm{c} \mathrm{each}$; $\$ 2.00$ per $10 ; \$ 17.50$ per 100 . 4 to 6 feet, 50c each; $\$ 4.00$ per 10.

FRANQUETTE. Nut is quite large, of an elongated oval shape and very attractive; kernel full sweet and of a rich nutty flavor: a late bloomer. On own roots, 2 to $21 / 2$ feet, $25 \mathrm{c}$ each; $\$ 2.00$ per $10 ; \$ 17.50$ per 100 .

SANTA BARBARA SOFT SHELI. Grafted on California Black root. 4 to 6 feet, $\$ 1.25$ each; $\$ 10.00$ per 10 .

PARISIENNE. A beautiful nut with full fledged kernel. Blooms late. 2 to $2 \frac{1}{2}$ feet, $25 \mathrm{c}$ each; $\$ 2.00$ per $10 ; \$ 17.50$ per 100 .

\section{THE PECAN}

A rapid-growing tree, attaining a height of 170 feet in its natural habitat. In form and contour conspicuous and attractive, producing valuable timber, and a great abundance of smooth oblong nuts with sweet and delicious kernels. We offer named grafted sorts: 3 to 4 feet, $\$ 1.50$ each.

\section{GRAPES}

\section{FOR TABLE AND RAISINS}

Price, 20c each; $\$ 1.50$ per $10 ; \$ 5.00$ per 100 .

BLACK HAIMBUR. Bunches and berries large; black, very ugary and rich.

CALIF ORNIA BLACK. The well-known Mission Grape.

CORNICHON, BLACK. Berries very large, oblong; covered with beautiful bloom; skin rather thick and dark. A good shipping sort.

FLAME TOKAY. A magnificent, large, red grape.

MUSCAT OF ALEXANDRIA. Bunches and berries large, pale amber. One of the best for raisins. $\$ 18.00$ per $\mathbf{1 , 0 0 0}$.

ROSE OF PERU. Very large bunches; berries rounding, brownish black. One of the best for table.

SUITANA. Bunches long and very compact; berries small, amber colored, seedless; make fine seedless raisins; vine an immense bearer. Grows on sandy soils, producing large crops. $\$ \mathbf{\$ 1 8 . 0 0}$ per 1,000.

SWEETWATER. Bunches good size; berries medium size, round fruit.

THOMPSON'S SEEDLESS. Vine an enormous bearer and very rapid grower; bunches very large; berries greenish-yellow, firm rapid grower; bunches very large; berries greenish-yellow, frm, raisins are of a very superior quality, and are in good demand. A valuable shipping grape, ripening in July. $\$ 18.00$ per $\mathbf{1 , 0 0 0}$.

\section{FOREIGN WINE GRAPES}

BEST ASSORTED. $\$ 5.00$ per $100 ; \$ 18.00$ per 1,000 .

\section{RESISTANT GRAPES}

LENOIR, RIPARIA, RUPESTRIS ST. GEORGE. $\$ \$ 4.00$ per 100 $\$ 20.00$ per 1,000 .

Write for prices and varieties of Grapes Grafted on Phylloxera Resistant Roots.

\section{AMERICAN GRAPES}

Price, 2 years old, 20c each; $\$ 1.50$ per 10 .

This class of grapes is useful in localities where the more tender foreign varieties will not succeed on account of the severe winters. They are also the best for arbor and trellis covering.

AGAWAM. One of the best of red varieties; bunches good size; berry tender and juicy.

CoNCORD. Bunches large, compact; berries large, round, light, red, sweet.

DELAWARE. One of the most desirable garden varieties. Ripen with the Concord; bunches small and very compact, berries small, violet-red, sweet and highly flavored. 


\section{GRAPES-Continued}

ISABELIA. Our inost extensively planted Eastern grape; bunches long, large and loose; berries black, oval, juicy and sweet, with distinct musky flavor: an immense bearer; a valuable market variety.

NIAGARA. Bunch large, uniform, very compact; berry large, mostly round, light greenish white, slightly ambered in the sun; mostly round, light greenish white, slightly ambered
peculiar flavor and aroma. Enormously productive.

THE PIERCE. A sport from the Isabella. It is an immense bearer and strong grower.

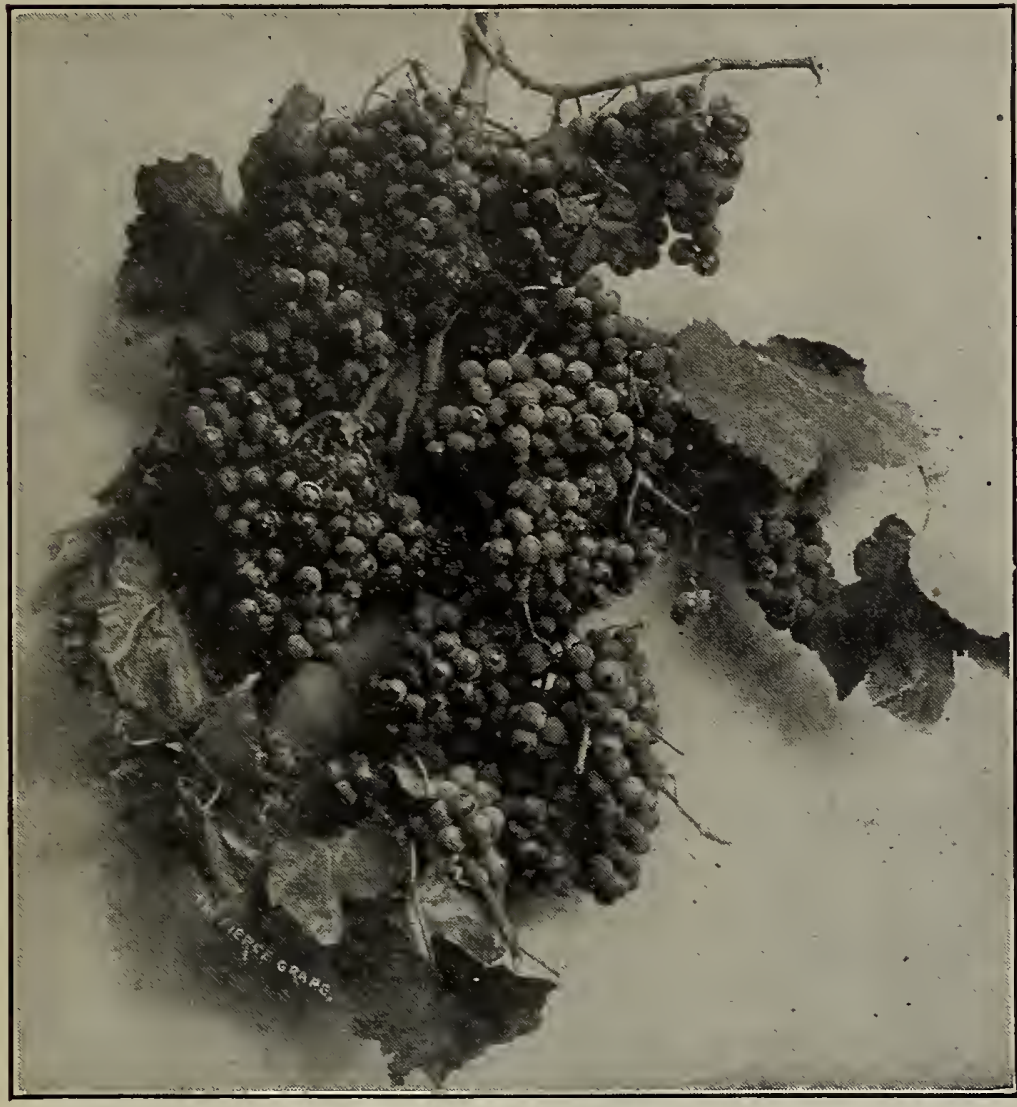

The Plerce Grape

\section{CURRANTS}

Currants and Gooseberries should be planted in good soil, which must be kept rich and well worked. Trim out the old wood as soon as it begins to decline, and shorten all the young shoots, to keep the bushes in good shape. Sprinkle ashes around the roots occasionally, to keep the borers away.

Strong, 2 years old, 20c each; $\$ 1.75$ per 10.

BLACK NAPLES. Berries large and black.

CHERRY CURRANT. Very large, deep red. One of the best.

LONDON MARKET. Very productive, with long branches covered with large, rich, red-colored fruit.

WHITE DUTCH. Bunch and berry large, with fine transparent

\section{GOOSEBERRIES}

We can supply the following English sorts. Large fruiting, and of delicious flavor. 2-year-old plants, 25c each; $\$ 2.00$ per 10

CROWN BOB. Large roundish, oval, red, hairy; of first quality.

INDUSTRY. Immensely prolific; large and handsome; ripens very early; color, dark red.

LANCASHIRE LAD. This splendid sort is of superior quality, almost as large as Industry, having a rich pleasant flavor when ripe; color, rich dark red; a vigorous grower.

WHITESMITH. Large, oval shaped; yellowish white, slightly downy; of first quality.

OREGON CHAMPION. An American variety, berries large, brownish-red; very sweet and fine. 15c each; \$1.25 per 10.

\section{RASPBERRIES}

Plant in rows 5 to 6 feet apart 2 to 4 feet in the row. Cut the tops off within a few inches of the ground when planted. After the fruit season, cut out all the old wood which bore the last crop of fruit. Pinch the vigorous young shoots several times during the summer. They will then grow stout enough to stand without staking.

\section{Price, 60c per $10 ; \$ 4.00$ per 100 .}

CUTHBERT (Queen of the Market). The largest, handsomest and best red Raspberry cultivated. Bears transportation well. Very productive.

TURNER RED. Of rich flavor and very good quality. Time of ripening is with the earliest and continued until the end of the raspberry season.

\section{BLACKBERRIES}

Plant in good soil, in rows 5 to 6 feet apart, and 3 to 4 feet apart in the row. After the fruiting season, or in early spring, cut out all the dead wood. Blackberries should be planted early, before the buds start. A good top dressing of stable manure, applied annually, will be conducive to large crops. Keep the ground clean.

Price, 60c per 10; $\$ 4.00$ per 100 , except where noted otherwise.

RITTATINNY. Fruit large, roundish conical, rich glossy black; firm, juicy, sweet and excellent.

LAWTON. Fruit large; very productive and late.

HIMALA Y A GIANT. A late Blackberry coming after the other berries are gone, ripening over a period of several weeks, making it especially desirable for family use. In Northern California they are seldom injured by frost, as they blossom after all frosts are over. Like the Loganberry, it must be grown on a trellisthe vines under favorable conditions growing 15 to 20 feet. The berries grow in bunches; are of excellent flavor and the yield The berries grow in bunches; are of excellent fiavor and the yield surpasses any berry ever introduced. One year old plants, $15 \mathrm{c} \mathrm{each} ; \$ 1.00$ per $10 ; \$ 6.00$ per 100 .

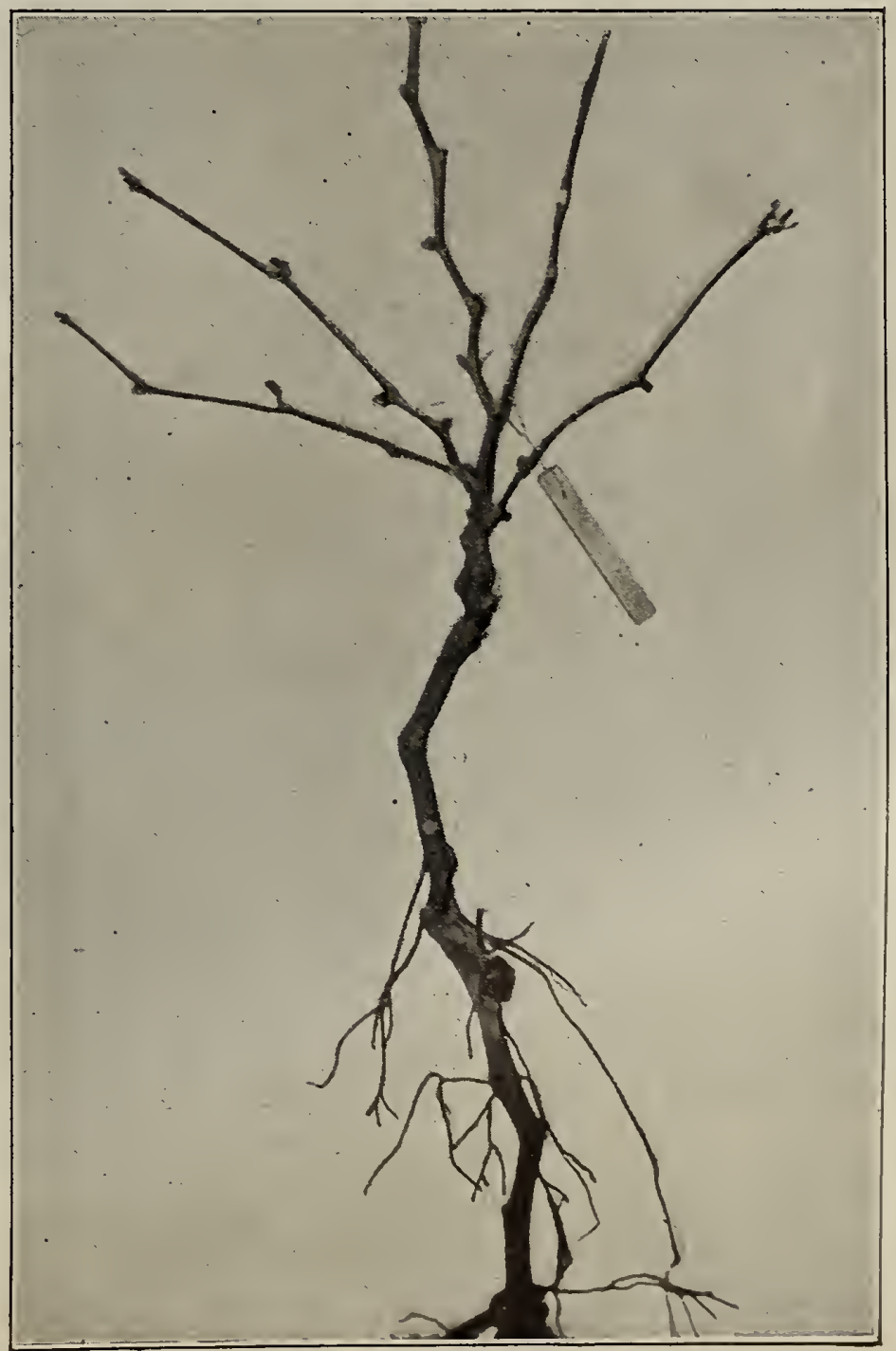

One year old Grape Vine 


\section{OH C.C.MORSE \& CO. PLANTS \& TREES}

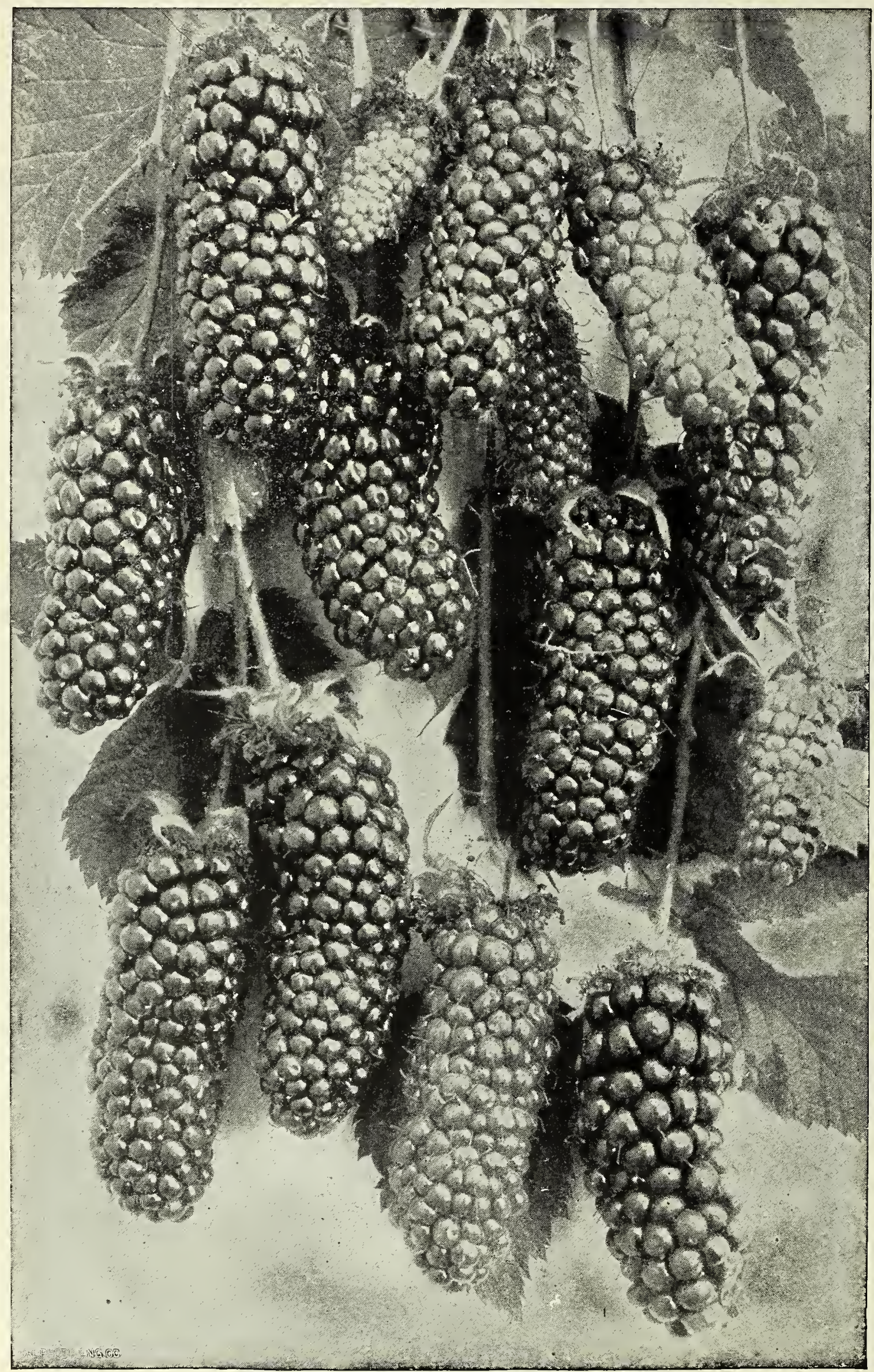

Mammoth Blackberry-Actual size, not exaggerated

\section{MAMMOTH BLACKBERRY}

Named by some "The Black Loganberry"

The fruit is enormously large, some specimens measuring from $21 / 4$ to $21 / 2$ inches long; the very largest blackberry known to the world. The globules are large, seed small, soft and not very abundant; core quite small and very soft. The flavor is a decided improvement on any known variety of blackberry, the acid flavor so pronounced in all other kinds is very mild and pleasant, and when fully ripe is quite sweet. This berry in size and delicious flavor will eclipse any blackberry heretofore produced.

It is advisable in planting the Mammoth Blackberry plants that they be given plenty of room. If grown upon a trellis, which is by far the best way, the rows should not be less than 9 feet apart and the plants 6 to 8 feet in the rows.

One year old plants (stock limited), $15 \mathrm{c}$ each; $\$ 1.25$ per 10 .

Tip rooted, ready February. 10c each; 75c per $10 ; \$ 4.00$ per 100 .

\section{STRAWBERRIES}

To cultivate the Strawberry for family use we recommend planting in beds four feet wide, with an alley two feet wide between the beds. These beds will accommodate three rows of plants, which may stand fifteen inches apart each way, and the outside row nine inches from the alley. Ground should be well prepared by digging or plowing at least ten or twelve inches deep, and be enriched with well rotted manure, ground bone, wood ashes or any other good fertilizer.

Price, 25c per dozen. $\$ 1.50$ per $100 ; \$ 8.00$ per 1,000 .

Varieties marked (Imp.) are imperfect in blossom and need at least every third or fourth row to be planted with some perfect or stam-

EXCELSIOR. (Per.) Berries large, long, conical or pointed and a bright scarlet in color. The flesh is bright, juicy, of fair quality, and firm. Plants vigorous and healthy in growth and foliage. Ripens early and is very productive.

ENHANCE. (Per.) Deep red in color, inside of berry being a beautiful wine color; a wonderful heavy cropper. inate sort. Those marked (Per) are especially good to use as staminates or to be grown alone.

LONGWORTH. (Imp.) An old popular variety. Fruit small, very sweet. Requires to have a perfect variety to be planted in 
STRAWBERRIES-Continued

BRANDYWINE. (Per.) Plant a luxuriant grower, healthy and hardy, and very productive; blossoms perfect; fruit very large, of good form, bright red all over and of good quality. Season, medium to very late. It succeeds on any soil.

JESSIE. (Per.) Large, handsome, roundish conical, dark red, firm and of good quality.

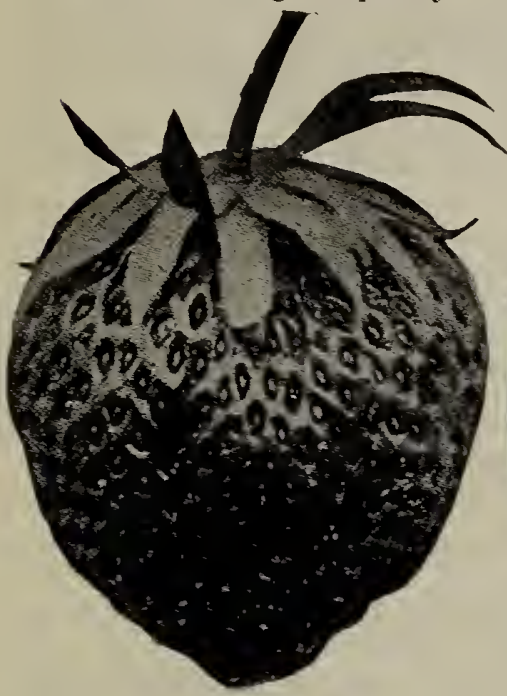

Brandywine

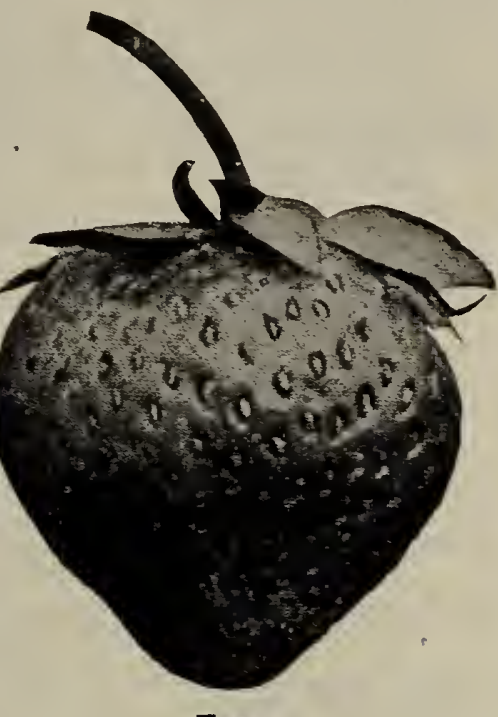

Texas
KLONDYKE. (Per.) Color of berry rich red, extending to center of mild flavor, quite juicy; of great productiveness. A fine shipping sort and grown extensively for market as it is an excellent shipper.

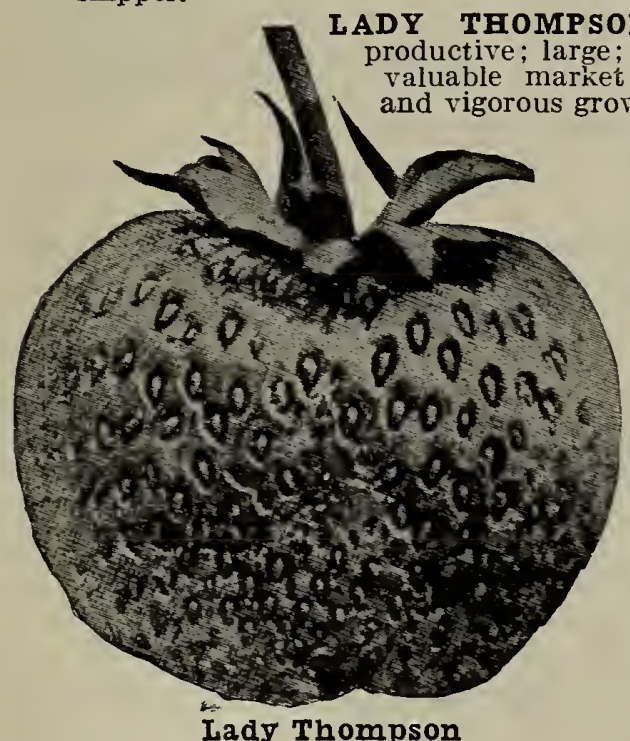

(Per.) Early; very firm and fine flavor. A
variety. Plant, strong

MARSHALL (Per.) Very large; blood red color $\mathrm{ich}$ aromatic flavor. A good old stand-by.

PRIDE OF MICHIGAN (Per) The berries are wonderfully large: bright scarlet with blood-red cheeks; one of the highest colored and $\mathrm{richest}$ flavored berries grown.

TEXAS. Produces handsome crimson berries with dark red cheeks medium size; firm and solid; fine flavor; good folid; fine flavor; good for c anning an

\section{SPRAYING}

BORDEAUX MIXTURE. Copper sulphate, 6 pounds; quicklime, 4 pounds; water, 40 gallons. Dissolve the copper sulphate by putting it in a bag of coarse cloth and hanging this in a vessel holding at least 4 gallons, so that it is just covered by the water. Use an earthern or wooden vessel. Slake the lime in an equal amount of water. Then mix the two and add enough water to make $\mathbf{4 0}$ gallons. It is then ready for immediate use. If the mixture is to be used on peach foliage it is advisable to add an extra pound of lime to the above formula. When applied to such plants as carnations or cabbages it will adhere better if about a pound of hard soap be dissolved bages it will adhere better if about a pound of hard soap be dissolved fungous diseases.

AMMONIACAL COPPER CARB ONATE. Copper carbonate, 1 ounce; ammonia ( 1 volume 26 per cent Beaume, $7 / 8$ volume of water). enough to dissolve the copper; water, 9 gallons. The copper carenough to dissolve the copper; water, 9 gallons. bonate is best dissolved in large bottles where it will keep inderinitely. poses as Bordeaux Mixture.

PARIS GREEN. Paris green, 1 pound; water, 200-300 gallons. If this mixture is to be used upon peach trees, 1 pound of quicklime should be added. Repeated applications will injure most foliage, unless lime is added. Paris green and Bordeaux mixture can be applied together with perfect safety. Use at the rate of four ounces applied together with perfect safety. Use at the rate of four ounces is weakened, and the Paris green loses all caustic properties.

\section{THE LOGANBERRY}

(Raspberry-Blackberry)

The fruit is as large as the largest-sized blackberry; is of the same shape, with globules similar to that fruit Color, when fully ripc, a dark rich red. It partakes of both flavors of the raspberry and blackberry, being a combination of the two mixcd; a very pleasant, mild, vinous flavor, delightful to the taste, not found in any other fruit, but peculiar to this alone. It is exccllent for the table, eaten fresh or cooked, and for jellies or jams without an equal. The vines are enormous bcarers. One year old plants (stock limited), 15c each; $\$ 1.25$ per 10. Tip rooted, ready February. 10c each; $75 \mathrm{c}$ per 10 $\$ 4.00$ per 100 .

\section{THE PHENOMENAL BERRY}

Is the result of a cross between the Improved California Dewberry and the Cuthbert Raspberry. Mr. Burbank (the introducer) describes it as larger than the largest berry ever before known; bright crimson raspberry color productive as could be desired. Tip rooted, ready February. $15 \mathrm{c}$ each; $\$ 1.00$ per 10.

\section{NEW DEWBERRY-GARDENA}

The Gardena has proven itself a most valuable fruit for Southern California. It is remarkably early, ripening its fruit in April and May, and in productiveness is a surprise to fruit-growers, having the past season far exceeded that of any other variety of its class. The fruit is large, firm, of superior flavor, and very attractive in its appearance. Grow them upon a low trellis, not over 2 feet high; plant the rows 5 feet apart; plants 3 feet apart; put up two wires, one a foot from the ground the other not over 2 feet-better 20 inches. 15c each; $\$ 1.00$ per $10 ; \$ 6.00$ per 100 .

\section{HORSERADISH}

Strong plants, 15c each; $\$ 1.00$ per 10.

\section{RHUBARB}

LORENZO AND LINNAEUS. Strong roots, $15 \mathrm{c}$ each; $\$ 1.50$ per dozen.

\section{AUSTRALIAN CRIMSON WINTER}

The great value of Rhubarb as a vegetable has always been its earliness, and a vast amount of time and labor has been spent in efforts to originate a variety which would produce stalks even a day or two in advance of other early varieties. Australian "Crimson Winter" Rhubarb will produce marketable stalks abundantly, fully six weeks earlier than any other Rhubarb. Price, $25 \mathrm{c}$ each; $\$ 2.00$ per 10.

\section{FORMULAS}

COPPER SULPHATE SOLUTION. Copper sulphate, 1 pound water, 15 gallons. Dissolve the copper sulphate in the water, when it is ready for use. This should never be applied to foliage, but must be used before the buds break. For peaches and nectarines use 25 gallons of water. For fungous diseases.

LONDON PURPLE. This is used in the same proportion as Paris green, but as it is more caustic it should be applied times its weight of lime, or with the Bordeaux mix sition of London purple is exceedingly variable, and unless good reasons exist for supposing that it contains as much on peach or green, use the latter poison. Do not use Lon
plum trees unless considerable lime is added.

HELLEB ORE. Fresh white hellebore, 1 ounce; water, 3 gallons, Apply when thoroughly mixed. This poison is not so energetic as the arsenites and may be used a short time before the sprased portions mature.

KEROSENE EMULSION. Hard soap, 1/2 pound; boiling water 1 gallon; kerosene, 2 gallons. Dissolve the soap in th kerosene, and churn with a pump for 5 to 10 ininutes. Dilut 25 times before applying. Use strong emulsion for all scale insects. For insects which suck, as plant lice, mealy bugs, red spider, thrips, which have soft bodies can also be successfully treated. 


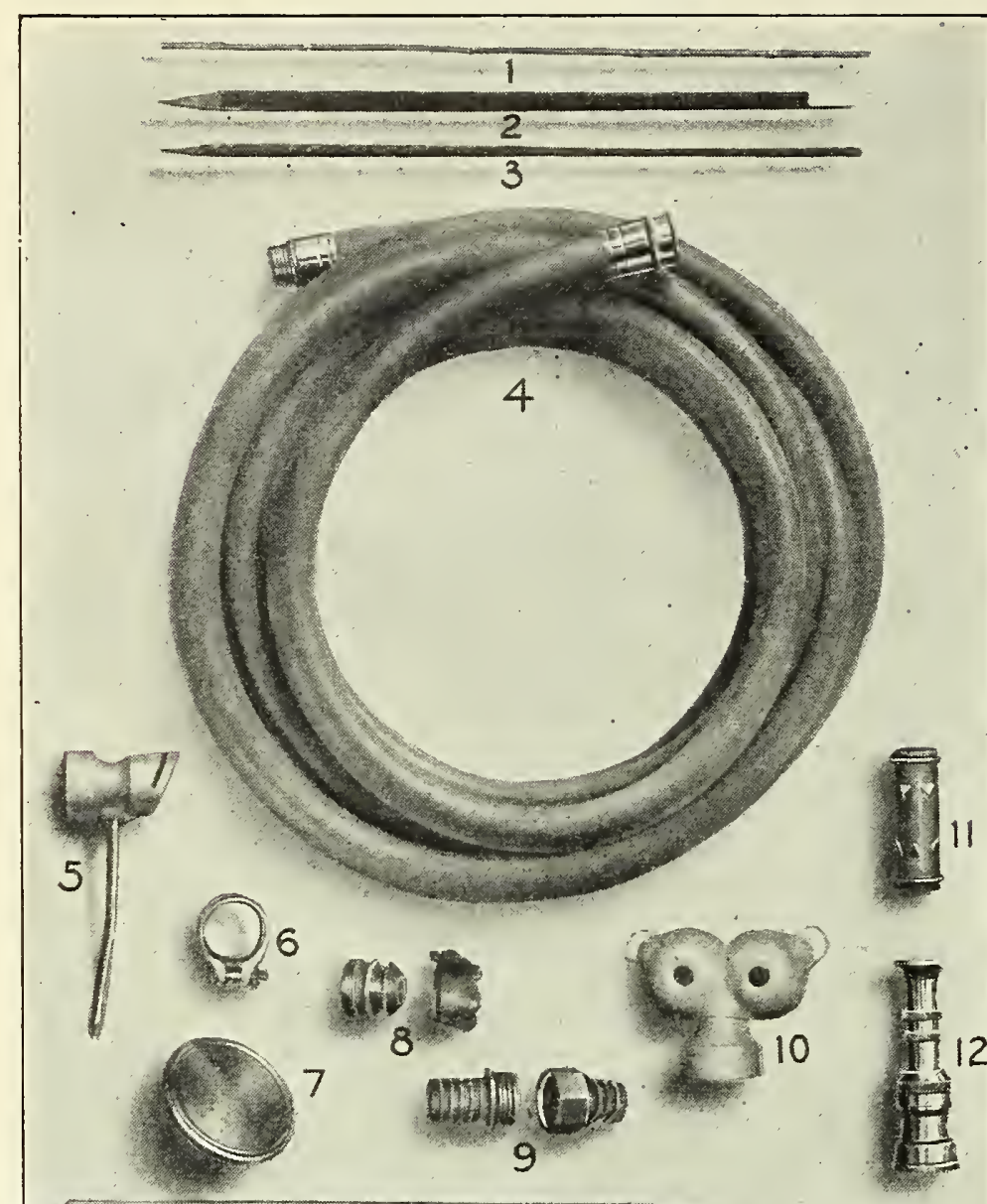

\section{HORTICULTURAL TOOLS AND REQUISITES}

Bamboo Canes.-Fig. 1. Dozen, 4 feet, 20c; 5 feet, 25c; 6 feet, 30c; 7 feet, 35c.

Garden Stakes.-Fig. 2. Heavy, square, painted green. White tipped, made of Redwood and impossible to rot. 3 feet, $\$ 1.25$; 4 feet, $\$ 1.50 ; 5$ feet, $\$ 1.75 ; 6$ feet, $\$ 2.15 ; 7$ feet, $\$ 2.75$.

Garden Stakes.-Fig. 3. Heavy, round, painted green, pointed. 5 feet, $\$ 1.50$ per dozen; 4 feet, $\$ 1.25$ per dozen; 3 feet, $90 \mathrm{c}$ per dozen.

\section{HOSE AND HOSE ACCESSORIES}

REVERO-Fig. 4. Best grade of heavy, pliable rubber hose made. Will outwear and outlast the ordinary kinds many times. The Revero is many times the cheapest hose to buy.

For Spraying Hose there is none so good as, $1 / 2$-inch Revero Hose. Will stand the chemicals and the rough use.

$1 / 2-1$ ch, in 25 feet, at $18 \mathrm{c}$; in 50 feet, at $17 \mathrm{c}$.

$3 / 4$-inch, in 25 feet, at $20 \mathrm{c}$; in 50 feet, at $19 \mathrm{c}$. $1-1 \mathrm{nch}$, in 25 feet, at $30 \mathrm{c}$; in 50 feet, at $28 \mathrm{c}$.

Concord. A 5-ply hose good for ordinary garden use. $3 / 4$-inch, 25 feet, $15 \mathrm{c} ; 50$ feet, $12 \frac{1}{2} \mathrm{c}$.

Hose Bands.-Fig. 6. Double wire with key to tighten that may be turned by a nail. $1 / 2,3 / 4$ or $1-1$ nch, 30c dozen.

Hose Couplings.-Fig. 9. 25c per pair. Tin plated and polished, 35c.

Hose Mender. The "Cooper" Brass.-Fig. 11. Made of thin brass tubing; will not rust or wear out; scarcely decreases the flow of water. Easy to apply and a good mender. Will not leak. For $1 / 2$-inch and $3 / 4$-inch hose.

Price, 10c each; $\$ 1.00$ per dozen. Postage, 15c per dozen. For 1 inch hose $15 \mathrm{c}$ each.

Hose Snap Couplings.-Fig. 8. Fit into ordinary coupling, and allow hose to be disconnected instantly, saving time and patience. Pair, 40c.

\section{HOSE NOZZLES}

Brass Rose-Fig. 7. for spraying either greenhouse or garden. $\mathrm{Each}, 65 \mathrm{c}$.

Gem Hose-Nozzle.-Fig. 12. Adjustable, coarse or fine spray. 50c.

\section{WOODEN LABELS \\ For trees, pots and gardens}

Unpainted Painted

15

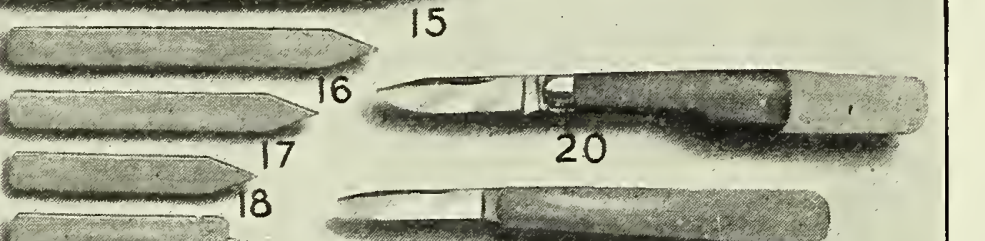

$31 / 2$-inch iron wire, Fig. $19 \ldots \ldots \ldots \ldots \ldots \$ 0.20 \quad \$ 1.25 \$ \$ 1.50$

$31 / 2$-inch copper wire, Fig. 19........ . $30 \quad 1.75 \quad 2.00$

4 -inch Pot Labels, Fig. 18............15 $\quad .75 \quad 1.00$

5 -inch Pot Labels, Fig. 17.......... .20 $\quad 1.00 \quad 1.35$

6 -inch Pot Labels, Fig. 16.......... . .20 $1.20 \quad 1.65$

8 -inch Pot Labels, Fig. 15.......... .50 4.00

10 -inch Garden Labels, Fig. 14........ .75 6.25

12 -inch Garden Labels, Fig. 13...... $1.00 \quad 8.50$

\section{KNIVES}

Propagating Knife.-Fig. 20. Pointed blade, ebony handle, ivory wedge. $\$ 1.00$ each.

Budding Knife.-Fig. 21. Small size, ivory handle. $\$ 1.00$ each.

Pruning Knife.-Fig. 22. Medium size, black handle, best American steel. $80 \mathrm{c}$ each.

Budding Knife.-Fig. 23. Large size, long ivory handle, best English steel. $\$ \mathbf{1 . 5 0} \mathrm{each}$.

Pruning Knife.-Fig. 24. Large size, ebony handle, metal tipped. $\$ 1.25$ each.
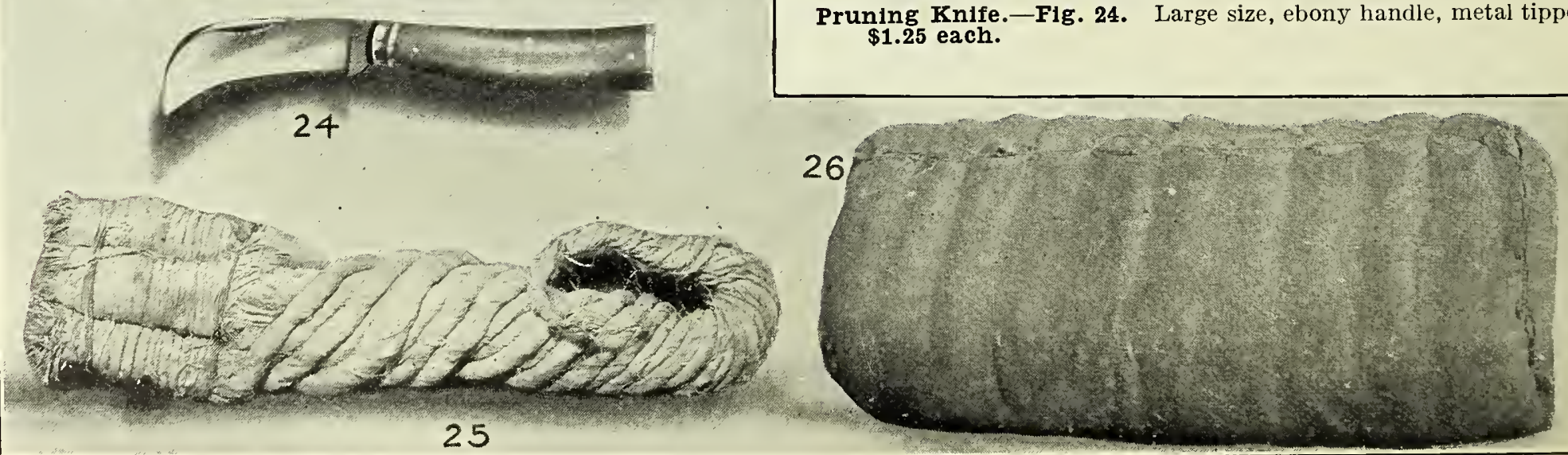


\section{HORTICULTURAL TOOLS AND REQUISITES}

Raffia.-Fig. 25. Largely used by nurserymen and others and considered the best and cheapest material for tying known. Lb. 20c; in $10 \mathrm{lb}$. lots, 15c per $1 \mathrm{~b}$.

In bale lots ( 224 lbs.) write for special eastern prices.

Moss.-Fig. 26. Selected Oregon ..........Lb. 10c; 100 lbs. $\$ 5.00$ Selected Sphagnum.......Lb. 15c;100 lbs. \$6.00

Peat. Best imported peat for growing orchids, bulbs, etc. Use to mix in the soil to start flower seeds. This peat is equivalent and better than "leaf mould," recommended for garden work. per 1b. 10c; 100 lbs. $\$ 6.00$

Grafting Wax.-Fig. 27. $1 / 4$ 1b. 10c; $1 / 21 b .15 c ; 1 b .25 c$

Trowels.-Fig. 34. Solid shank, cast steel. 50c each. Riveted Shank. 25c each.

Rubber Plant Sprinklers.-Fig. 35. For indoor watering, straightneck. $\$ 1.00$ each.

Rubber Plant Sprinklers, for indoor watering, angleneck. $\$ \mathbf{\$ 1 . 0 0}$ each.

\section{LAWN SPRINKIERS}

Meyer's Lawn Sprinkler. Consists of a tin pipe about 4 feet long, mounted and perforated with fine holes which throw a spray in all directions. Has brass connection and is durable. Each \$1.25.

"Twin" Sprinkler.-Fig. 10. Made of zinc metal and cannot rust. Will cover the lawn evenly for 16 feet radius. Very popular. Each 35c.

Fan Sprinkler.-Fig. 5. Made of zinc metal and shaped so that it will water:a bed on one side only. Very convenient to use from a cement walk. Each $\mathbf{3 5 c}$.

\section{GOPHER AND MOLE TRAPS}

"Novelty" Gopher Trap.-Fig. 33. Without doubt the best trap made; never fails to catch them. 30c each.

Mole Trap.-Fig. 32. Reddick, is all right. $\$ 1.00 \mathbf{~ e a c h}$.

\section{LAWN MOWERS}

We ship these all carefully boxed to any point, delivered free to the railroad.

Philadelphia, Style A.-Fig. 31. Solid steel throughout, ball bearings highly geared; will clip closely and well. Used by the Golden all parts tested. 15-inch, \$14.00; 17-inch, \$15.00; 19-inch, $\$ 16.00$.

Philadelphia, Style K.-Fig. 30. Has 5 blades, part steel, single pinion; a good high class mower. 14-inch, $\$ 8.75 ; 16-1 n c h$, $\$ 9.75 ; 18$-inch, $\$ 10.75$.

old Style Philadelphia-Fig. 28. Solid blade and wheel. Impossible to get out of order; will last a life time; does good work. There is no mower just like this and none other so popular. 10 -inch, $\$ 5.00 ; 12$-inch, $\$ 6.00 ; 14-$ inch, $\$ 7.00 ; 16-$ inch, $\$ 8.00$.

The Dewey.-Fig. 29. A good mower, 4 blades, solid wheels, 12-inch, $\$ 5.00 ; \$ 14-i n c h, \$ 5.25 ; 16-i n c h, \$ 6.50$.

New Mower.-Fig. 29. A cheap mower to compete in price with any made, but this is far ahead of them in workmanship and ease of running. 10-inch, $\$ 3.50 ; 12-1 n c h, \$ 3.75 ; 14-1 n c h, \$ 4.25$; 16-inch, $\$ 4.75$.

Grass Collectors. All metal. $\$ 1.50$ to $\$ 1.75$ each.

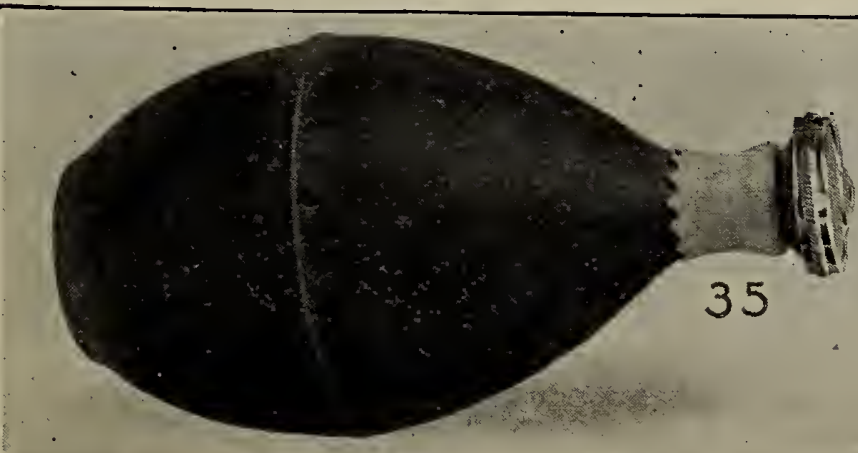

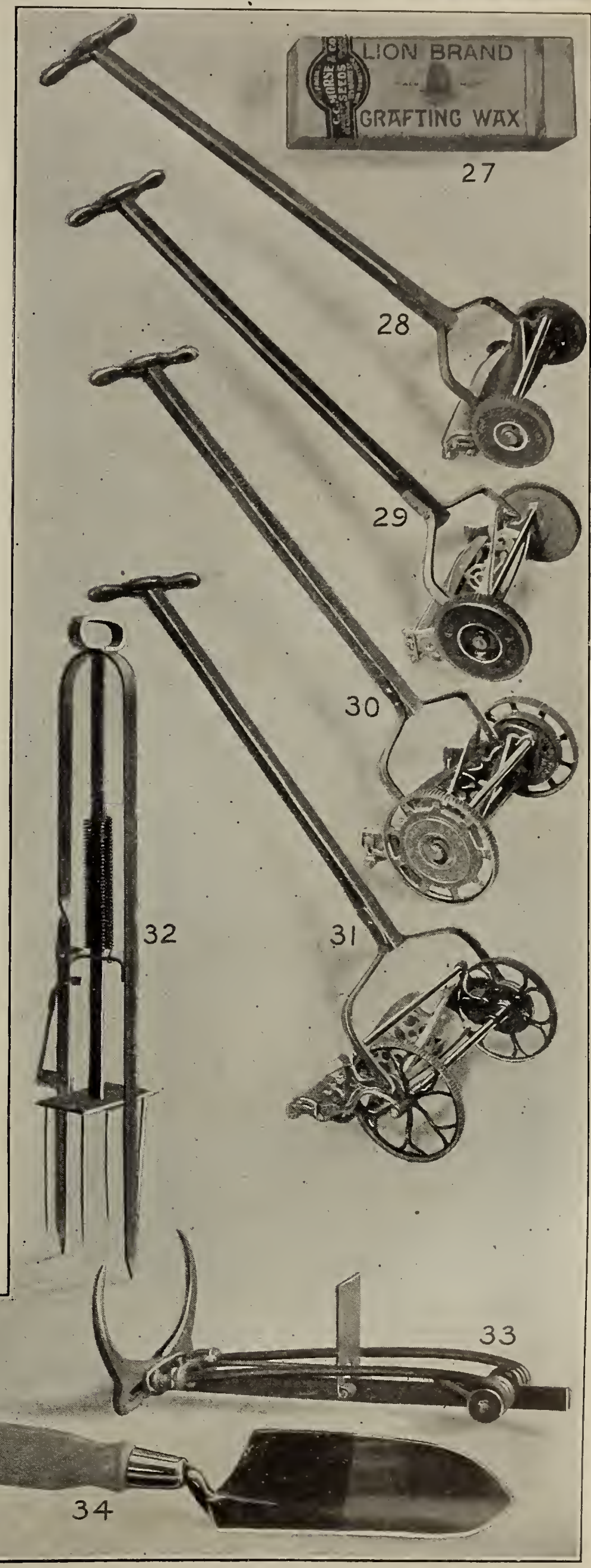




\section{E. C.C.MORSE \& CO. GARDEN REQUISITES WH}
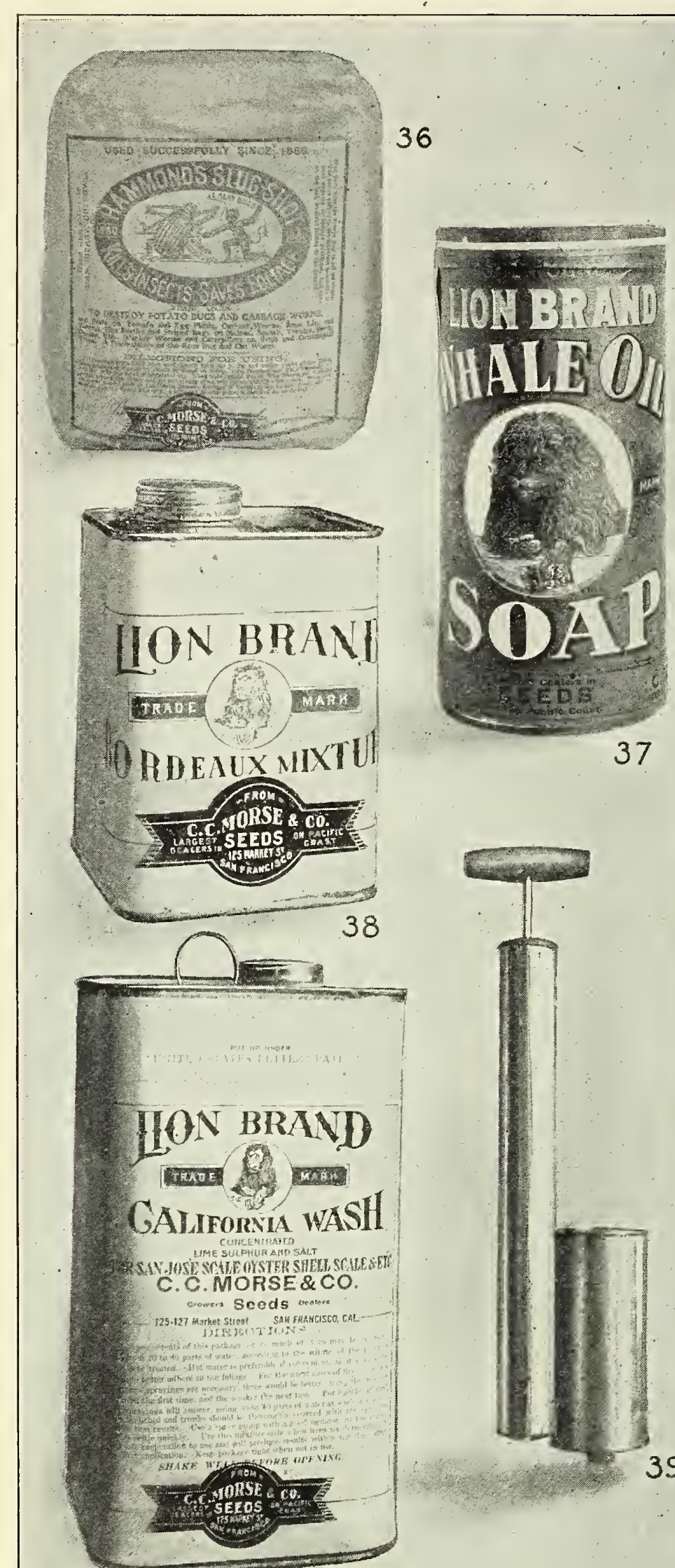

36
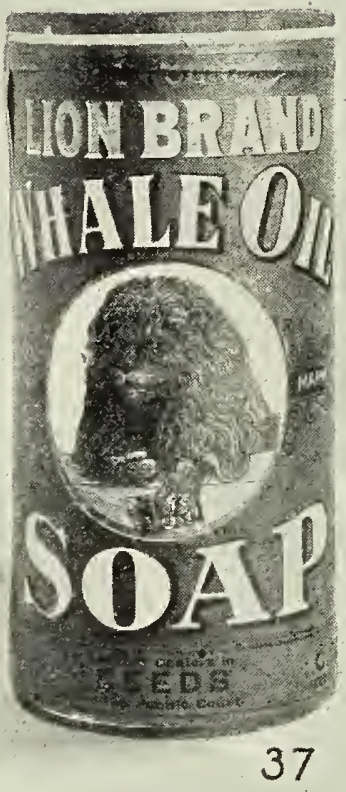

39

\section{INSECT DESTROYERS}

The following can not be sent by mail, except where noted, but must go by express or freight:

Arsenate of Lead. A new arsenic spray for caterpillars, codlin moth, etc. This is preferred by many to Paris Green, as it can be readily seen when applying; sticks to the leaves and does not burn the foliage. Recommended by the Department of Agriculture. 2 lb. can, 50c; $10 \mathrm{lbs}, \$ 1.75 ; 25 \mathrm{lbs} ., \$ 4.00 ; 100 \mathrm{lbs}$.,
$\$ 14.00$.

Bordeaux Mixture-Fig. 38. The best and most generally used spray for blight, mildew, curled leaf, pear scab, etc. All prepared and rearly for use. Dilute 50 times. 50 -gallon bbl. enough for 10-gal. keg, 70c: 50-gal. bbl., 50c gal.

California Wash.-Fig. 40. Lime, sulphur, and salt. Makes 30 to 40 gallons of spray. The only effective spray for San Jose scale; apply when leaves are off the trees. 1-quart can, 65c; 1-gallon can, $\$ 1.50$.

Grape Dust. A non-poisonous powder for the remedy and control of mildew and rot on grapes, roses, etc. 5-lb. package, 50c.

Hellebore. For killing caterpillars and other pests of this nature. Is a poison and very deadly to insects but not to people. $1 / 2$ 1b. package, 20c; 1-1b. package, 35c.

Kerosene Emulsion. Ready to use; will kill scale, green lice and other pests that suck; makes 25 gallons of spray. 1-quart cans, 65c; 1-gallon cans, $\$ 1.50$.

Nico-Fume Liquid. Contains $40 \%$ nicotine. Place a hot iron in $11 / 2$ pints of water to which a scant table spoonful of Nico-Fume has been added. This will kill greenhouse pests over 600 square feet. 1/4-pint can, 65c; 1-pint can, $\$ 1.85$.

Nico-Fume Tobacco Paper. Strongly saturated with nicotine. Merely suspend from bench and light lower end. One sheet is destructive to 2000 cubic feet. Air-tight can 2 dozen sheets, 85c; postpaid, 95c; air-tight can of 144 sheets, $\$ 3.85$.

Paris Green. In cans, pure, poisonous. Kills caterpillars, potato bugs and all bugs which chew the leaves. $1 / 21$ b., 30c; 1 1b., 50c.

"Rose-Leaf" Extract of Tobacco. Most effectual for the destruction of insects on plants. Dilute with 65 parts of water. This spray will kill the thrip that is so destructive to the orchards. Spray early when the buds begin to swell and again orchards. Spray early when the buds begin to swell and again scab on animals. 1 pint, 55c; 1 quart, 75c; 1 gallon, \$2.50.

Slug-Shot.-Fig. 36. Destroys all insects injurious to house and garden plants, vegetables, and fruits of all kinds, also poultry lice; as effective as Paris green without the danger from poison. 1-1b. cartons with perforated top for applying, 20c each; if by mail, 20c extra; 5-lb. package, 40c; 10-lb. package, 75c. Tin Dusters for applying Slug-Shot, 40c each.

Tobacco Dust. The most economical form to use tobacco as an insecticide; fatal to green and black fly and similar garden pests, by simply dusting over the plants. If dug around the roots will keep away all pests below ground and insure health to the plants. 10c per $1 \mathrm{~b}$.; if by mail, 15c extra.

Whale Oll Soap.-Fig. 37. Dissolved in water makes an excellent spray for scale on palms, etc. $1 / 2-1 \mathbf{b}$. package, $15 \mathrm{c} ; 1-1 \mathrm{~b}$. package, 25c; postage, 16c per $1 \mathrm{~b} . ; 10 \mathrm{lbs}$. in bullk, $\$ 1.00$.

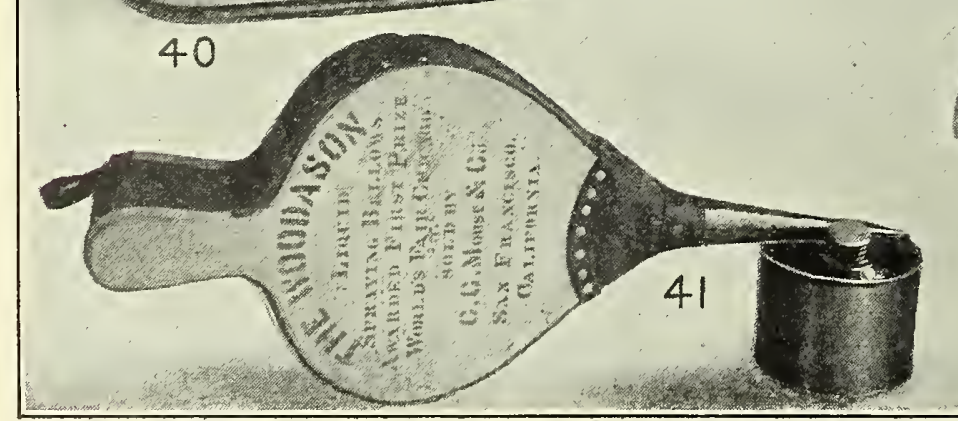




\section{SAN FRANCISCO CALIFORNIA U.S.A.}

\section{INSECT DESTROYERS}

Morse's Burning Brand of Tobacco Dust. The best and cheapest nicotine fumigator. It will kill all insect life in greenlouse without the slightest injury to flower or leaf. Give it a trial is all we ask. Write us for a free sample and directions. 5 lbs. covers a house $100 \times 25$. 10c per 1 b.; $\$ 6.00$ per $100 \mathrm{lb}$. sack.

Sulpho-Tobacco Soap.-Fig. 46. A wonderful insect and bug exterminator. 3-oz. cake (makes $1 \frac{1}{2}$ gallons prepared solution), 10c; mailed, postpaid, 13c; 8-oz. cake (makes 4 gallons prepared solution), 20c; mailed, postpaid, $28 \mathrm{c}$.

Tobacco stems. In bales of about $50 \mathrm{lbs}$. at $3 \frac{1}{2} \mathrm{c}$ per $1 \mathrm{~b}$.

\section{APPLIANCES FOR INSECTIDES}

\section{WOODASON BEILOWS AND ATOMIZERS}

These are the best made bellows; will last a long time and are very effective:

Bellows, Double Cone ...$\ldots \ldots \ldots \ldots$

Bellows, Large Single Cone, with spreader.-Fig. 52... . . 2.50

Bellows, Small Single Cone. ...............................

Liquid Atomizer, large.-Fig. $41 \ldots \ldots \ldots \ldots \ldots \ldots \ldots \ldots . \ldots \ldots$

Liquid Atomizer, small. ..................... 1.50

The Morse Garden Syringe.-Fig. 45. Polished brass, 18x1 1/2 inches, fitted with adjustable plunger; one coarse rose, one fine rose, and one jet spray. $\$ 5.00 \mathbf{e a c h}$.

Ladies' Garden Syringe.-Fig. 45. Polished brass, $16 \times 1 \frac{1}{4}$ inches, coarse and fine spray and jet. $\$ 4.00$ each.

Morse's Tin Sprayer.-Fig. 39. For spraying liquid insecticides of all kinds on plants, kerosene in chicken houses, etc. An all-round useful instrument and at a low price. $65 \mathrm{ceach} ; \$ 1.50$ for three; with galvanized can, 75c each.

Eouchin Powder Belllows.-Fig - 42. In three sizes. $\$ 1.00, \$ 1.25$ and $\$ 1.50$ each.

Lawn Force Pump.-Fig. 44. Good for whitewash, bailing boats and general spraying. $\$ 1.00$ each.

White Wash Pump.-Fig. 43. Galvanized iron, fine for chicken houses, fences, etc. $\$ 2.00$ each.

Lightning Tin Sprayer.-Fig. 47. With glass jar for holding the liquid. $\$ 1.00$ each.

Meyers Bucket Pump.-Fig. 48. A standard force pump of heavy brass. $\$ 3.25$ each.

Large Floradora Powder Gun.-Fig. 49. Holds 1/2-lb. of powder. $40 \mathrm{c}$ each, postpaid.

Watering Pot.-Fig. 50. Galvanized iron, with brass fittings and two brass roses, one tine and one coarse, with each pot. 6-quart, $\$ 2.50 ; 8$-quart, $\$ 2.75 ; 10$-quart, $\$ 3.25$.

Jumbo Powder Gun.-Fig. 51. $30 \mathrm{c}$ each, postpaid.

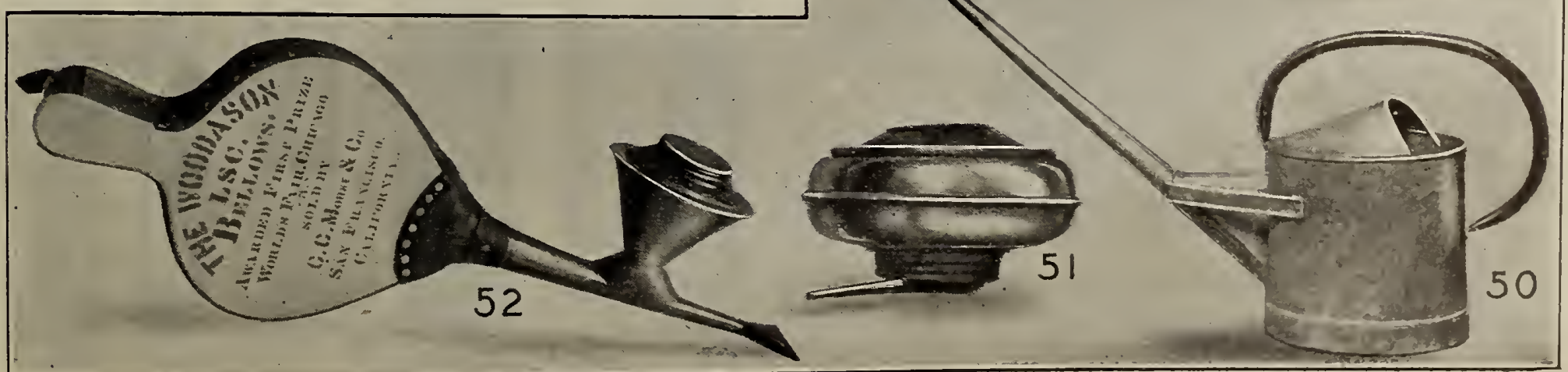

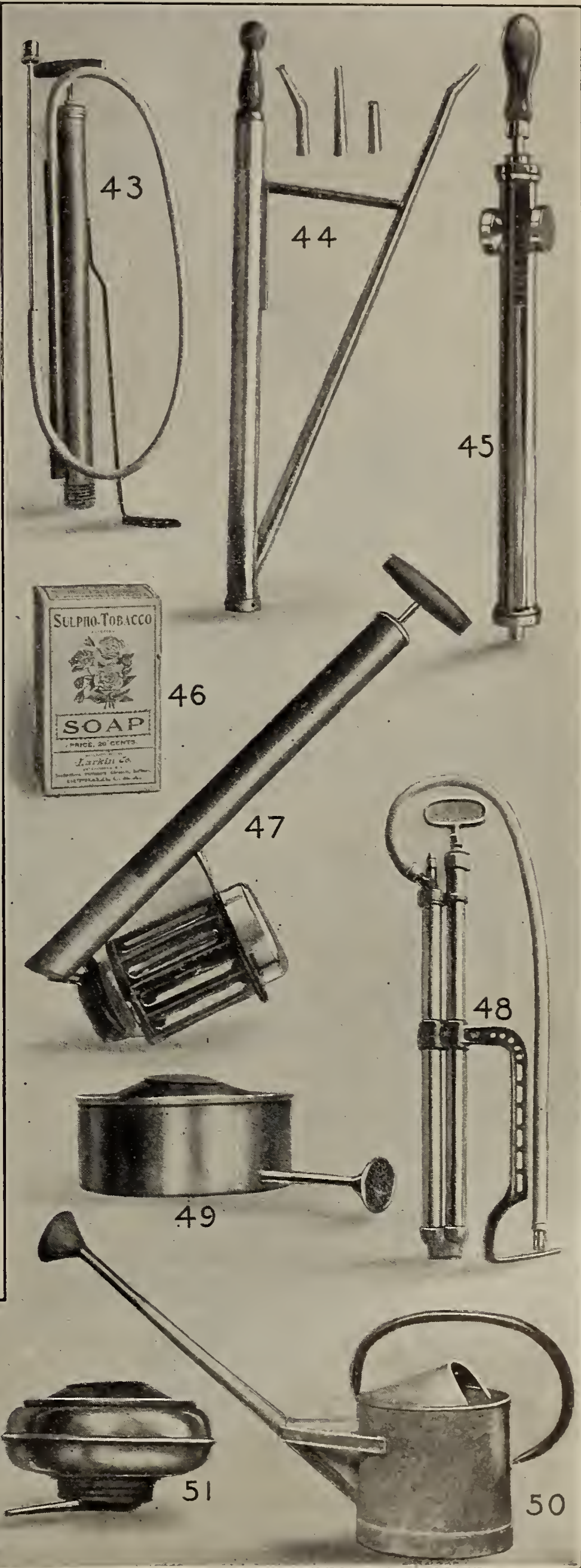




\section{AGRICULTURAL AND HORTICULTURAL IMPLEMENTS}

A drayage charge of 25 cents must be added to the price of the tools unless they are sent by express.

"NEW MODEL" SEED DRILL

Weight, packed, 50 pounds, price $\$ 12.00$

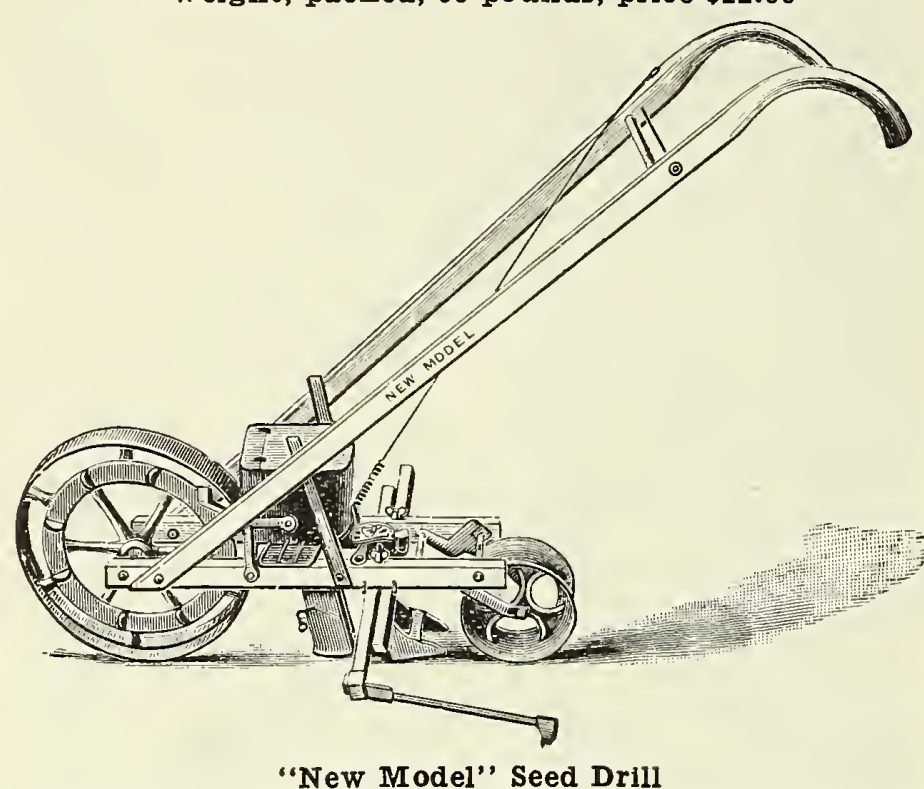

On our own extensive seed farms which are illustrated in the first few pages of this catalogue, we use the new Model Seed Drill exclusive1y. We have found by trying the different makes that this one is the best. The following are reasons which we ask you to consider:

1st. The New Model will sow in rough, lumpy ground without getting clogged. Many of the light Eastern seeders are inefficient on hedvy California soils, but not so with the New Model.

2nd. Can be perfectly adjusted to the finest difference in size between the different seeds.

3rd. New Model seeds evenly and cut off Is quickly and easily handled; is economical.

4th. Main wheel is of large size and width, so will not sink in soft earth. Handles are well bolted and adjustable in height machine is easy to work.

5th. Opening plow is of steel, adjustable in depth; index shows a. a glance how to set for the ordinary seeds. A well made and a. a glance how to set for the ordinary seeds. A well made and
satisfactory seeder. It will save much labor and give a better stand than other methods of seeding.

\section{IRON AGE TOOLS}

We are agents for these celebrated garden implements, and shall be glad to send complete catalogue to intending purchasers. The tools have the best of workmanship and of material. By having the right tool much labor may be saved.

No. 1. Double Wheel Hoe. (Fig. 75.) $\$ 9.00$.

No. 3. Double Wheel Hoe (Side Hoes only). \$6.00.

No. 4. Combined Double Wheel Hoe and Drill Seeder. (Fig. 83.) $\$ 13.50$.

No. 4. Drill Seeder Attachment. (Fig. 133.) \$4.50.

No. 6. Combined Double Wheel Hoe, Hill and Drill Seeder. (Fig. 114.) \$14.75.

No. 6. Hill and Drill Seeder Attachment. (Fig. 134.) \$6.00.

No. 9. Single Wheel Hoe, complete. (Fig. 78.) \$7.35.

No. 12. Wheel Plow and Cultivator. (Fig. 120.) \$4.50.

No. 13. Double Wheel Hoe (Side Hoes and Teeth only). $\$ \mathbf{\$ 7 . 1 5}$.

No. 19. Wheel Plow and Cultivator. \$4.25.

No. 20. Single Wheel Hoe, complete. (Fig. 135.) \$7.35.

No. 8. Hill and Drill Seeder. (Fig. 95.) \$15.00.

\section{"PLANET JR. TOOLS"}

We offer the following, which can be recommended for all who desire good tools:

No. 4. Hill and Drill Seeder and Single Wheel

Packed Price

No. 4.

Hoe....................................

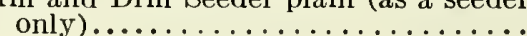

47 lbs. $\$ \mathbf{\$ 1 2 . 0 0}$

38 lbs. 10.00

No. 25. No. 6 .

No. 6.

No. 36 .

No. 3.

No. 5 .

No. 1.

No. 2.

No. 11.

No. 12.

No. 13.

No. 16.

No. 17.

No. 171

No. 18.

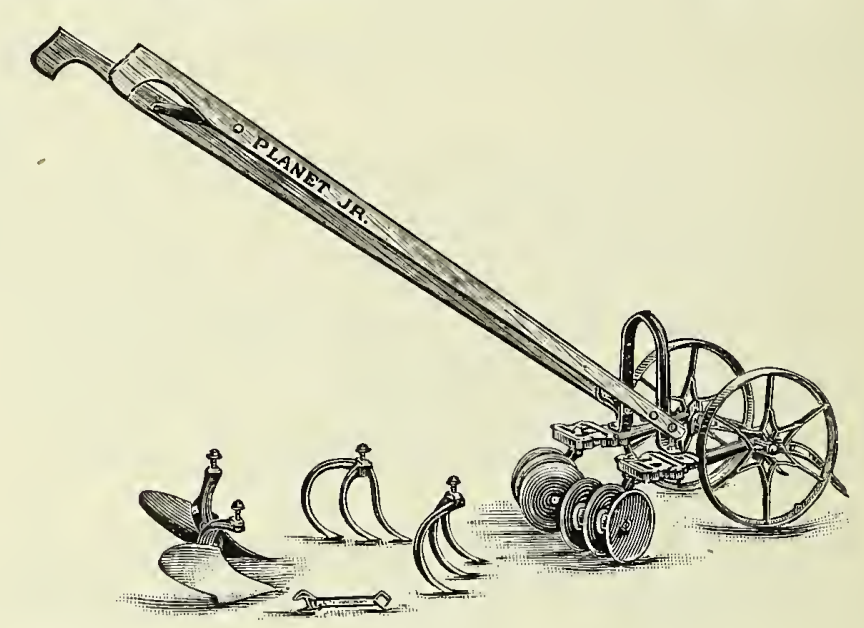

\section{THERMOMETERS}

Japanned greenhouse, 8-inch scale. Fig. E, 20c each; 6 for 90c. Japanned greenhouse, 10-inch scale. Fig. E, 25c each; 6 for $\$ 1.30$. Japanned tin, black oxydized scale, a better thermometer than the above. We recommend this as a good all round thermometer. Fig. D, 50c each.

Spirit Thermometer, accurate, easy to read. $\$ 2.00$ each.

Maximum and minimum thermometer, records each day the extreme heat and cold, porcelain scale, has a magnet to set the little steel stops which are left at the highest point each afternoon and at the lowest point each night, thus telling the range of temperature for the day. Fig. $\mathbf{A}, \$ 3.75$ each.

Maximum and minimum thermometer, records each day the extreme heat and cold, wood scale. Fig. C, $\$ 1.75$ each.

Mushroom and hot bed, brass point. Fig. B, \$1.25 each.

Mushroom and hot bed, extra fine, heavy brass. Fig. B, \$2.25 each.

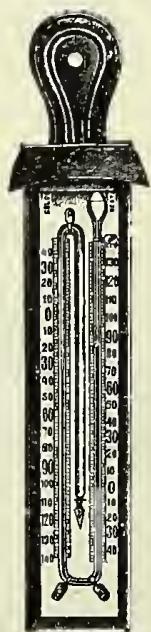

Fig. A
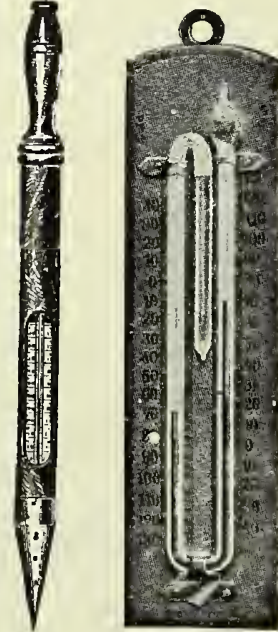

Fig. B. Fig. C

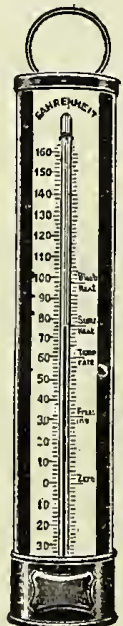

Fig. D

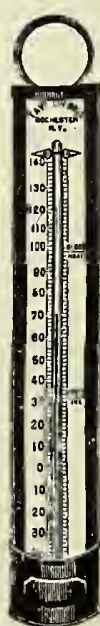

Fig. E

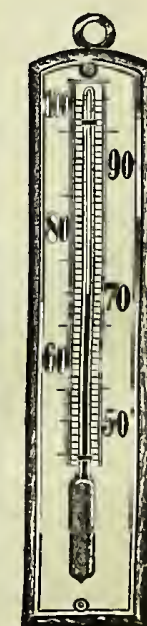

Fig. F 


\section{FOREIGN NAMES OF VEGETABLES}

English

Artichoke.

Asparagus......

Beans Dwarf.

Beet.

Broccoli

Brocsels Sprouts

Cabbage.

Cabbage Savoy.

Carrot

Cauliflower.........

Celery

Celeriac.

Chicory.

Collards...........

Corn Salad

Corn.

Cress, Water.

Cucumber.

Dandelion......

Egg-plant.

Endive

Kohl Rabi...

Leek..... .

Mettuce Mius

Melon, Water

Mushroom.

Mustard....

Nasturtium.......

Okra..

Onion.....

Parsnip...

Peas.....

Pumpki

Radish...

Rhubarb.

Salsify....

Sqinach

Tomato
Turnip.

\section{German}

Artischo

Krupp-Bohnen.

Stangen-Bolinen.

Salatruben.

Spargelkohi...

Kosenkohl ........

Kopfkohl

Carotten, Moliren

Blumenkohl...

Sellerie.

Knoll-seilerie.....
Kerbel...........

Blarienwurze.

Feldsalat.

Mais.

Garten-Kresse

Brunnenkresse...

Gurken

Lowenzahn

Eierpflanze

Blat terkohl.

Kohlrabi.

Porree Lauch.

Lattich, Kopfsalat...

Ielone.

Wasser-ielone

Champignonbrut

Senf ..........

Kapuciner-Kresse

Zwiebel

Petersilie...

Pastinake.

Erbsen.

Kurbiss.

Radies....

Rhabarber.

Haferwurzel.

Spinat.

Kulchen-Kürbiss

Liebesapfel, Tomate.

\section{French}

Artichaut.

Asperge

Haricot Nains....

Betterave.

Chou Brocoli.

Chou de Bruxelles

Chou pomme...

Carot te............

Carot te.......

Celeri

Celem-rail

Chicoree sauva....

Chou cabu...

Mache.

Mais.

Cresson alenois

Cresson de fontaine.

Concombenlit

Pissenlit...

Aubergine

Chicoree Endive.

Chou frise.

Chou-rave.

Poireau.

Laitue .........

Melon d'Eau...

Champignon

Moutarde.

Gombaud

Gombaud.....

Persil.

Panais.

Pois.

Piment

Radis.

Rhubarbe.

Salsifis blanc.

Epinard.

Pomme dimour

Navet
Spanisb

Alcachofa....

Frijole nano.

Habichuelas enridaderas

Remolach

Broculi. .

Berza de Brusels.

Col repollo...

Zanahoria...

Zanahoria

Apio.

Apio-nabo.

Perifollo...

Achicoria

Canonigos (macha valer-

Maiz

Maiz .......

Berro.

Pepino

Diente de leon (Amargon)

Berengena.

Endivi

Breton Col

Colinabo

Puerro.

Muscate.

Zandia

Seta...

Mostaza....

Capuchina.

Cuimbom

Perejil.

Chirivia

Chicaroso Guisantes

Pimiento.

Calabaza totanera.

Rabanito.

Ruibarbo....

Salsifi bla

Calabaza...

Tomate.

Nabo...
Itallan

Articiocca.

Faginolo nani.

Faginolo rampicant

Barbabietola.

Brocoli.

Cavolo di Brusselles.

Cavolo cappuccio

Cavolo di Milano

Carota

Cavoloflo

Sedano.

sedano-rapa.

Cerfoglio

Cicoria selvatica.

Valeriana.

Mais

Agretto.

Nasturzio aquatico.

Cetriolo

Dente di leone.

Petronciand

Indivia.

Cavolo verde.

Porro.

Lattuga.

Popone.

Melone d'aqua

Fungo pratajolo.

Nasturzio..

Ocra...

Cipollo....

Pastinaca...

Pisello......

Peperone.

Zucca.

Ravanello...

Sassefrica...

Spinace.

Zucca.

Pomo d'ore...
Navone.......

\section{INDEX}

\section{GARDEN SEEDS, CLOVERS, GRASSES, TOO}

Acacia See Tree Alfalfa. See Clovers. 45 Artichoke.

Asparagus.

Australian Salt Bush... 46

Beans.

Beets.

Broccoli.....

Broom Corn...

Brussels Sprouts

rabbage

Canary

Canary...

Cauliflower

Celeriac

Celery.

Chervil.

Chicory...

Chives....

Collards...
Commission Bage

Commission Box.... 49

Corn, Egyptian, Kaffir 46

Corn Salad......... 24

Cress.

Cucumber............ 24

Dandelion.

. 25

Egg-Plant........ 25

Endive....... Se Tree

Seeds...........4 47

Field Seeds......... 46

Flax Seed.

Foregin Names........ 127

Grass Seeds..

. 45

Herbs............ 43

Homp. Radish Roots.. ${ }_{23}^{46}$

Hot Beds........... 53

Hose ............ 122
Implements... . . . . P. 126 Insecticides....... 124, 125 Kale. .

Kentucky Biue Grass 26 Kohl Rabi......... 26

Labels, Wooden....... 122 Lawn Grasses....... . 44 Lawn Mowers......... 122 Lettuce.............27, 28 Mangels. See Beets.. 17 $\begin{array}{lll}\text { Martynia ........... } 26 & 26 \\ \text { Mushroom Spawn... } & 31\end{array}$ Mushroom Spawn.... 31 Muskmelon, Fordhook 8 Mustard............ 31

Okra............. 31

Onion................

Onion Sets........ 34

Parsnip.............. 34

\section{INDEX OF FLOWER SEEDS}

Classification........ 50

Abronia.......... 53 


\section{INDEX OF FLOWER SEEDS-Continued}

Diantlus ( or Pinks) 60

Dolichos, (Hyacinth

Bean) Dolichos-Iridescent

(New) ${ }_{\text {usty Miller. See Cen- } 51}$

taurea Candidisima 60

Echinocystis, Wild

Cucumber Vine. . 60

Eschscholtzia.....60,61

Euphorbia............ 61

Everlasting Pea. See
Lathryrus Latifolius $\mathbf{6 4}$

Evening Primrose. See

Oellothera..........

Feverfew. See MatriFlax. See Iinum.... 64

$\begin{array}{lll}\text { Forget-me-not........ } & 61 \\ \text { Four O'clock......... } & 61\end{array}$ Fuchsia.

Gaillardia

Geranium

Gilia

Gilliflower. See Stocks

Gloxinia.

Godetia .....

Gomphrena (or Globe
Digitalis, Foxglove... 60

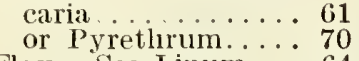

Fourglove. See Digitalis 60

Gladiolus Seed.....662

Gladiolus Bulbs...... 73
Glaucum Luteum... 62

Amaranth).
Grasses, Ornamental 62

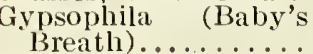

Helichrysum.

Heliotrope..... Satio

Flower).

ese Hop)......... 63

Ice Plant.......... 63

Impatiens Sultani.... 63

Japanese Hop(Humu-

lus $\ldots \ldots \ldots \ldots . \ldots 6$

Job's Tears.......... 62

Kennilworth Ivy .... 64

Kochia.........6 64

Lantana.

Lathyrus Latifolius... 64

Lavatera.

Lavender.

Leptosine Densifioris 64

Lilies ..... . . . . . . . 73

Lobelia . . . . . . . . . 64

Lophospermum

Lychnis.

\section{Gourds...........62 62}

Humulus, (or Japan- 62

Lavend Verben......64

Scandens......... 64

\section{Page}

Marigold (Calendula). 56

Marguerite. See Chrysanthemum, Frute- 58

Marvel of Perui. See

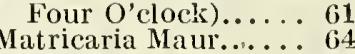

Maurandia...........6. 64

Mignonette........ 65

Mimulus

Momordica (Balsam)

Apple, Balsam Pear) 65

Ioonflower. See Ipo-

moea Alba.......6 63

Mourning Bride. 'See 70

Musk Plant. See Mim- 70

ulus Moschatus..... 65

Nasturtium. . . . 6 65, 60

Nasturtium (New)...5

Nemophila, or Love
Grass........... 66

Nicotiana, or Flower-

ing Tobacco....... 66

Nicotiana. New Affinis 51
Nigella............ 66

Oenothera.........66 6

Oxalis ................ 60

Pampas Grass........ 62

Passion Flower.......... 68

Pelargonium. See

Geranium.......662 Sunflower.

Scabiosa

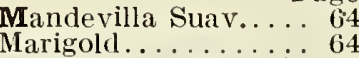

Mina Lobata.

Morning Glory . . . . 65

Pentstemon....... Page 68

Perilla............. 68

Petunia, Baby Bìe... 51

Phlox ..... 69

Physalis Francheti... 69

Pinks. See Dianthus 60

Platycodon......... 69

Poppy..........68, 69

Primula or Primrose 69,70

Pyrethrum........70

Rhodanthe.

(Castor Beans) 70

Romneya Coulteri or

Matilija Poppy..... 70

Salpiglossis........ 70

Salvia or Flowering

Sage.......... 70

Santolina......... 70

Schizanthus. ........ 70

Senecio (Tall Jacobea) 70

Silene, or Catchfly... 70

Smilax............. 71

Solanum, (or Jerusa-

olanum, (or Jerusa- 71

Statice. See Lavender 7

$.71,72$

\section{INDEX OF PLANTS AND TREES}

Abies.............8 89

Abutilon .......... . 111

Achillea.............. 111

Adiantum..............

Almonds...............116

Alternanthera...........111

Althea ............9.94

Ampelopsis...........101

Anthericuin.............104

Apples............114

Apple, Crab, Flowering 97

Araucarias, Assorted . 90

Arbor Vitae....... 90

Ardisia............ 90

Asparagus Fern....... 104

Aspidistra..........104

Aster..............111

Aucuba.......... 90

Australian Pea Vine . 101

Azalea.

Bamboo.

91

Banana, Abyssinian. 103

Begonias, Bedding..... 111

Begonias, Tub. Rooted 111

Berberry

Bigno
Birch

91
97

Blackberry .............. 119

Box Elder. See Maple 98

Bougainvillea.........101

Brahea...

Breath of Heaven....991

Broom...

California Big Tree... 91 91

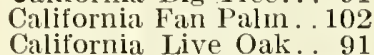

California Native Trees 91

Calycanthus.

Camellias.

Camphor Tree.

Cannas.

Casuarina...

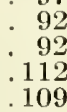

92
112
109

99

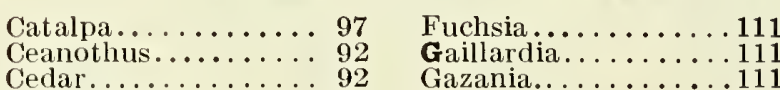

Cedar.

Geranium

Cherries

Cherry, Flowering. ... 97

Chionanthis........997

Chrysanthemum.........110

Cineraria..........111

Clematis, Assorted....101

Clematis, Assorted....101
Climbing Plants......101

Coleus

Cory pha.

Cotoneaster...

Corchorus

Coreopsi

Crape Myrtile

Crataegus.

Cryptomer

Currant Flowering...119

Currant, Flowering... 97 97

Cyclamen

Cypress.

Dahlias.

106 to 109

Daisies.

Gooseberries..............11

Gloxinia........... 112

Golden Feather......112

Grapes............. 118
Grevillea..........

Guava...............118

Habrothamnus..... . . 95

Hawthorn. See Thorn 100

Heath

Helianthus.

Heliot rope...

Heucher

Honeysuckle. . . ..... 95

Hop Vine..........102

Horse Chestnut...... 98

Hydrangea.....98 to 112

Imantophyllum........

Iris, Japanese... . .

Isolepis.

Jacaranda.

Jasmine..

Juniper . .

Kentia..

Kolreutaria......... 103

Daphne............ 93

Deutzia...

Dogwood.

Dracaena.............. 98

Echeveria..........111

Elm

Erythea...

Escalonia..

Euscaplies........... 98

Eucalyptus, Assorted 93

Eulalia..............

Eunoynus............99 95

Fabiana.......... 95

Ferns ...............

Figs.............117

Fruit Trees and Smail

Fruits......113 to 121
Deutziam...........111

Ficus, Elastica..... . 104
Ficus, Repens . . . . 102

Marguerite.......... 112

Mesembryanthemum..112

Metrosideros........ 95

Mountain Ash......... 99

Muehlenbeckia....... 102

Mulberry.

Myrtle.

Nandina

New Roses.

New Zealand Flax....99 95

Nectarines.......

New Zealand Tree

Fern............105

oak............. 99

Oleander...........969

Olives................116

Palms.............102

Pampas Grass.......... 104

Pansy... Pane...........1102

Paulownia ..........999

Peach, Flowering..... 99

Peaches............115

Pears...

Pecan...............118

Pentstemon.............11

Peonies...............112

Peonies................118

Pepper Tree.......... 96

Petunia........... 112

Phlox............... 111

Pink Border......... 112

Pine.

Pittosporum ........ 96

Pimelia............ 96

Plums and Prunes....115

Plumbago......... 102

Polystichunı.

Polygala.

Pomelos.............117

Pomegranate........ 100

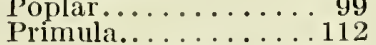

Privet. See Ligustrum 95

Pteris..............105

Quince, Flowering....100

Quince, Fruiting......116 


\section{SELECT LIST OF BOOKS}

\section{BY THE BEST AUTHORS}

Treating on the Cultivation of Flowers, Trees, Shrubs, Fruits and Vegetables, the Study of Botany, and Horticulture in General.

Postage must be added as follows: $5 \mathrm{c}$ for books priced at $50 \mathrm{c}$ and under; $10 \mathrm{c}$ for books priced over $50 \mathrm{c}$. to $\$ 1.50$; $20 \mathrm{c}$ for others.

A Woman's Hardy Garden. By Mrs. Ely.

Alfalfa. By F. D. Coburn

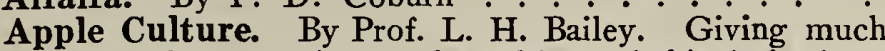
valuable instruction on the subject of this fruit, from planting to picking .

Asparagus Culture. By. Wm. Robinson. Gives the best methods of cultivation by experienced growers .

Asparagus. By. F. M. Hexamer

Barn Plans and Outbuildings. A valuable work ; full of ideas, hints, suggestions, plans, etc., for the construction of barns and outbuildings, by practical writers.

Botany, the Treasury of. A popular dictionary of the Vegetable Kingdom, giving a concise account of all known plants in language devoid of all dry technical terms ; of much interest to the professional, and as a work of reference for the amateur student it stands unrivaled. Two volumes, beautifully illustrated with numerous steel plate engravings.

Broom Corn and Brooms. A treatise on raising broom corn and making brooms on a small or large scale.

California Vegetables in Garden and Field. By Prof. E. J. Wickson. A manual of practice with and without irrigation ; beautifully illustrated

California Fruits and How to Grow Them. By Prof. E. J. Wickson .

Carrots, Mangelwurzels, Etc. $\dot{B} \dot{J}$ J. J. H. Gregory. How to raise them, how to keep them and how to feed them.

Farm Appliances. Describing numerous useful and labor-saving appliances which will be found of great value in every department of farm work.

Farm Drainage. By Judge French. Describes the principle, process, and effects of draining land, and other valuable information

Fences, Gates and Bridges. $\dot{A}$ much-needed and valuable work, abundantly illustrated .

Fertilizers. By J. J. H. Gregory. Tells how and where to obtain in cheapest form; how to compound formulas, etc.

Fertilizers. By Voorhies.

Flowers, and How to Grow Them. By E. E. Rexford. This little work, intended for the amateur, gives some very good instructions regarding the selection of plants for the house or garden and how to care for them .

Forage Plants Other Than Grasses. By Thomas Shaw. 287 pages scientific, accurate information on this subject

Forestry, Practical. By A. S. Fuller. A treatise on the propagation, planting and cultivation, with a description and botanical and popular names of all the indigenous trees of the United States .

Forcing Book. By L. H. Bailey.

Fumugation Methods. By Willis J. Johnscn. Showing simple and effective means of exterminating insect pests and vermin, being the outcome of practical tests of the author and others ............

Gardening for Pleasure. By Peter Henderson. Tells how to grow flowers, vegetables and small fruits in the garden and greenhouse ; also treats fully on window and house plants .

Gardening for Profit. By Peter Henderson. A guide to the successful culture of the market and family garden .

Garden Making. By Prof. L. H. Bailey. Instructions for beginners and for the skillful gardener. Covers the whole subject, laying out and planning small city yards and large suburban grounds, plants, trees, bedding, pruning, vegetables, fruits ; scientific truths in simple language
Grape Culturist. By A. S. Fuller. One of the best works on the cultivation and management of hardy grape

Grasses and Forage Plants. By Charles L. Flint. Varieties, nutritive values, culture, curing, management of grass lands, etc. Accurately described in a work of 400 pages, containing nearly 200 illustrations of our most common grasses and a large number of others not so well known

Handbook of Plants. By Peter Henderson. A concise and comprehensive dictionary of plants, with instructions on propagation and culture

Horticulturist Rule Book. By Prof. L. $\dot{H}$. Bailey. Full of useful information for fruit grower, truck gardeners, florists and others.

Irrigation Farming. By Lucius Wilcox. The application of water in the production of crops, appliances, principles, and advantages .

4.50 Irrigation for Farm, Garden and Orchard. By Henry Stewart. Methods and management to secure water for critical periods

King's Irrigation and Drainage

Making Manures. Boomer's Methods. A practical and comprehensive guide for making manures on the farm

Mushroon Culture. By Wm. Robinson. A practical guide to successful production of this crop

Nursery Book. By Prof. L. H. Bailey. This is a complete handbook of propagation of plants. Tells in plain language what every one who sows a seed, makes a cutting, or sets a graft wants to know

Onion Culture. By T. Greiner. For the home garden or the market; new and highly valuable methods are described

Peanut Plant. By $\mathrm{W} . \mathrm{B}$. Jones. Instructs the beginner on how to raise good crops

Plant Breeding. By L. H. Bailey

1.50

1.00

1.00

ractical Floriculture. By Peter Henderson. As a guide to the successful propagation and cultivation of florists' plants nothing has been left unsaid on the subject

Practical Garden Book. By L. H. Bailey .

Principles of Agriculture. By L. H. Bailey

Principles of Vegetable Gardening. By L. H. Bailey

Pruning Book. By Prof L. H. Bailey. Where, how and when to prune fruit and ornamental trees and shrubs .

Rose, The. By H. B. Ellwanger. Contains full direction for planting, pruning, propagating, and valuable in many ways to lovers of this flower

Silos, Silage and Ensilage. By Manley Miles. Practical treatise on ensilage of fodder, corn, etc.

Small Fruit Culturist. By A. S. Fuller. Rewritten, enlarged, and up to date; propagation, culture, varieties, marketing, etc.

Spraying of Plants. By Prof. Lodeman. Insects and fungi ; liquids and powders ; application and apparatus

Strawberry Culturist. By A. S. Fuller. Full directions for field and garden culture, forcing or pot culture, etc.

Sweet Potato Culture. By James Fitz. Full directions from starting the plants to harvesting and storing

Swine Husbandry. By F. D. Coburn. Breeding, rearing, and management treatment, and preservation from disease

The Garden Book of California. By Belle Sumner Angier. Beautifully illustrated

The New Rhubarb Culture. By J. E. Morse .

Tobacco Culture. Full practical details by fourteen experienced growers in different sections of the country and Margaret W. Buck. 


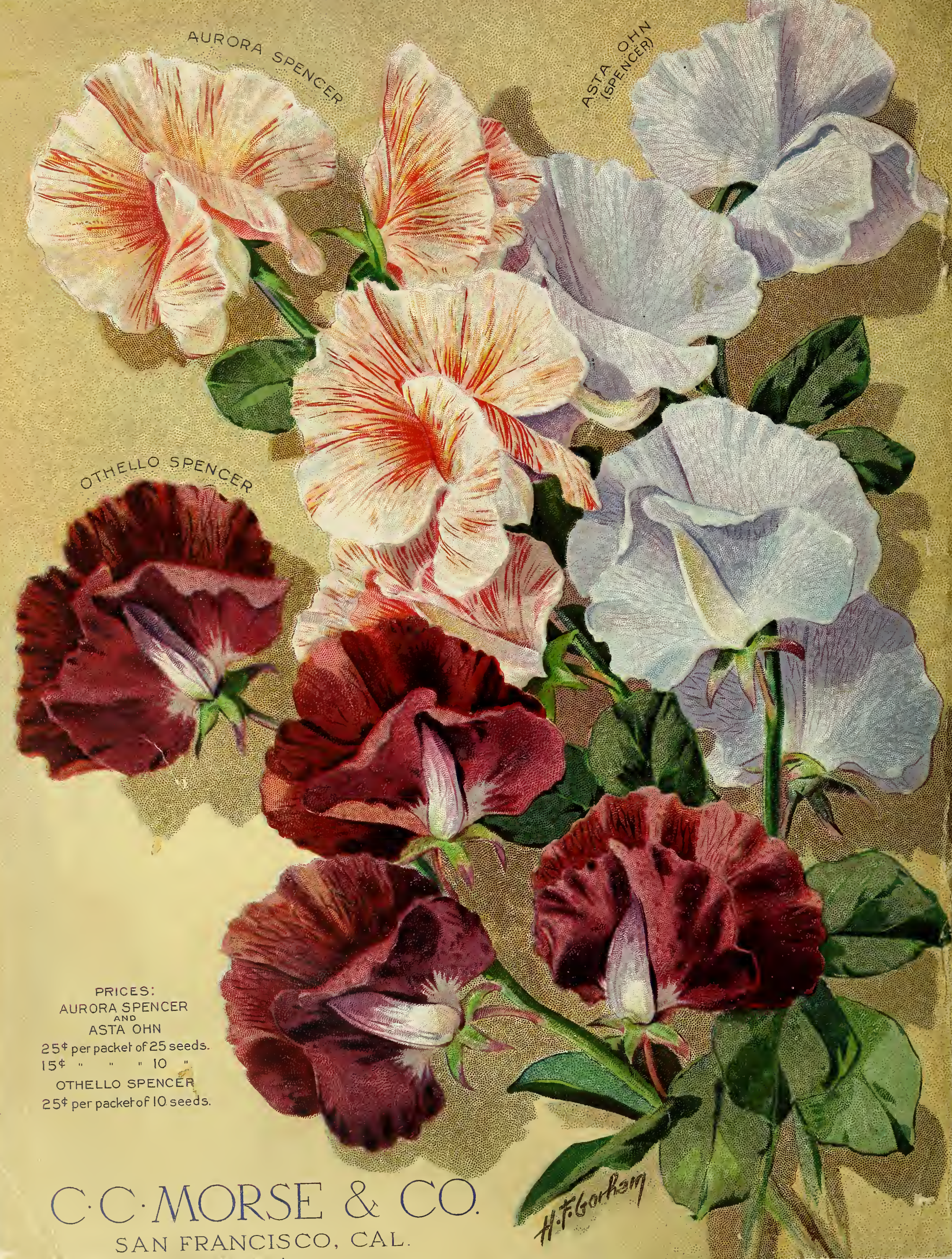

